UNIVERSIDADE DE SÃO PAULO

FACULDADE DE FILOSOFIA LETRAS E CIÊNCIAS HUMANAS DEPARTAMENTO DE LETRAS MODERNAS ESTUDOS LINGUÍSTICOS E LITERÁRIOS DE INGLÊS

EDISON GOMES JUNIOR

A adaptação cinematográfica do romance Paranoid Park:

Uma visada semiodiscursiva

VERSÃO CORRIGIDA 
EDISON GOMES JUNIOR

edigomes2000@uol.com.br

\title{
A adaptação cinematográfica do romance Paranoid Park: Uma visada semiodiscursiva
}

\author{
VERSÃO CORRIGIDA
}

Tese de Doutorado a ser apresentada ao Programa do Departamento de Letras Modernas na área de Estudos Linguísticos e Literários de Inglês da Faculdade de Filosofia, Letras e Ciências Humanas da Universidade de São Paulo.

Orientadora: Profa. Dra. Elizabeth Harkot de La Taille

São Paulo 
Autorizo a reprodução e divulgação total ou parcial deste trabalho, por qualquer meio convencional ou eletrônico, para fins de estudo e pesquisa, desde que citada a fonte.

Catalogação na Publicação

Serviço de Biblioteca e Documentação

Faculdade de Filosofia, Letras e Ciências Humanas da Universidade de São Paulo

$33 a$

Gomes Junior, Edison

A adaptação cinematográfica do romance Paranoid

Park: Uma visada semiodiscursiva / Edison Gomes Junior ; orientadora

Elizabeth Harkot de la Taille. São Paulo, 2019.

$363 \mathrm{f}$.

Tese (Doutorado)- Faculdade de Filosofia, Letras e Ciências Humanas da Universidade de São Paulo. Departamento de Letras Modernas. Área de concentração: Estudos Linguísticos e Literários em Inglês.

1. ADAPTAÇÃO PARA CINEMA. 2. SEMIOLOGIA DO CINEMA. 3. SEMIOLOGIA DA LITERATURA. 4. AUTORIA (CINEMA). I. Harkot de la Taille, Elizabeth, orient. II. Título. 


\section{ENTREGA DO EXEMPLAR CORRIGIDO DA DISSERTAÇÃO/TESE \\ Termo de Ciência e Concordância do (a) orientador (a)}

Nome do (a) aluno (a): EDISON GOMES JUNIOR

Data da defesa: 21/10/2019

Nome do Prof. (a) orientador (a): Elizabeth Harkot de la Taille

Nos termos da legislação vigente, declaro ESTAR CIENTE do conteúdo deste EXEMPLAR CORRIGIDO elaborado em atenção às sugestões dos membros da comissão Julgadora na sessão de defesa do trabalho, manifestando-me plenamente favorável ao seu encaminhamento e publicação no Portal Digital de Teses da USP.

São Paulo, 21/11/2019

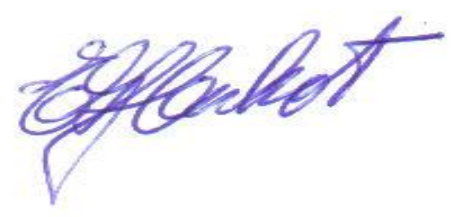

(Assinatura do (a) orientador (a) 
Nome: GOMES JUNIOR, Edison

Título: A adaptação cinematográfica do romance Paranoid Park: uma visada semiodiscursiva

Tese de Doutorado apresentada ao Programa do Departamento de Letras Modernas na área de Estudos Linguísticos e Literários de Inglês da Faculdade de Filosofia, Letras e Ciências Humanas da Universidade de São Paulo.

Aprovada em: $/ 2019$

\section{Banca examinadora:}

Prof. Dr.:

Instituição:

Julgamento:

Assinatura:

Prof. Dr.:

Instituição:

Julgamento:

Assinatura:

Prof. Dr.:

Instituição:

Julgamento:

Assinatura: 


\section{AGRADECIMENTOS}

À minha orientadora, Elizabeth Harkot-de-La-Taille, por ter acreditado no projeto e me orientado com paciência e sabedoria, a partir de uma leitura atenta e estimulante do trabalho.

À minha esposa, por seu amor, companheirismo, paciência e incentivo.

Aos meus pais e irmã pelo carinho e ajuda em todos os momentos da pesquisa.

Aos professores Luiz Tatit, John Corbett e Renata Mancini pelas valiosas contribuições ao projeto.

Aos professores Ivã Carlos Lopes, José Luiz Fiorin, Diana Luz de Barros, Irene Machado e Daniela Nery Bracchi pelas sugestões.

Aos professores e colegas de pós-graduação da Universidade de São Paulo envolvidos na pesquisa semiótica, que me ajudaram de forma mais direta e indireta durante a tese, sendo sempre atenciosos.

À Universidade de São Paulo e aos seus funcionários, que ajudaram a tornar este projeto possível.

À Fundação Capes, que me proporcionou uma bolsa de estudos e contribuiu para que eu pudesse pesquisar e desenvolver atividades acadêmicas que contribuíram não apenas para a tese, mas com meu crescimento profissional.

A George Lucas, que me maravilhou com o filme Guerra nas Estrelas, há muito tempo atrás, em uma galáxia muito, muito distante... 


\section{RESUMO}

GOMES JUNIOR, Edison. A adaptação cinematográfica do romance Paranoid Park: uma visada semiodiscursiva. 2019. XXX fls. Tese (Doutorado em Estudos Linguísticos e Literários de Inglês) - Faculdade de Filosofia, Letras e Ciências Humanas da Universidade de São Paulo, São Paulo, 2019.

O objetivo do trabalho é o de analisar a adaptação fílmica do romance Paranoid Park a partir da teoria semiótica francesa, utilizando as noções do percurso gerativo, tensividade e práxis enunciativa, que não apenas oferecem um vasto arsenal analítico do texto e do discurso, mas também refletem sobre a fabricação discursiva do sentido como modo de interação humana, prática de conjuntos significantes, que podem ser mais utilitários ou mitopoéticos, conteúdos expressivos gerados a partir de vários tipos de relação com o mundo natural. De maneira geral, através do percurso gerativo, comparamos as estruturas semionarrativas e discursivas de ambos os textos envolvidos na adaptação, o texto fonte e o texto alvo (a quo e ad quem respectivamente, uma instância textual inferior e abstrata e uma superior e concreta), observando também as relações inter e intratextuais entre seus planos da expressão e do conteúdo, e operações de figurativização. A partir da tensividade, discutem-se os modos e as sintaxes tensivas dos textos, a noção de campo de presença, e operações de intensidade e extensidade. Do ponto de vista da práxis enunciativa, os textos são observados como atualizações de outros discursos, literários e fílmicos, sendo objetos compostos em relações de ascendências e decadências discursivas, mais ou menos assumidas ou reconhecidas por um sujeito da enunciação. Além da análise da adaptação, propriamente dita, tratamos de questões pertinentes à linguagem verbal, ao texto literário, sua expressão tipológica / topológica, e à linguagem audiovisual, entendidas como conjuntos significantes compostos a partir de uma macrossemiótica formada de línguas naturais e mundo natural. Por causa da diferença entre nossos objetos e a base teórica utilizada, não apenas procuramos entender a linguagem cinematográfica semiodiscursivamente, mas também tratamos da arbitrariedade e motivação entre os planos do sentido do texto verbal e plástico, questões figurativas do espaço e do movimento, e do actante observador, elemento importante para a enunciação verbal e não verbal. Em relação ao texto fílmico, que proporciona a ilusão de movimento, o observador será considerado a partir de semióticas proxêmicas, gestuais e plásticas, e a distância entre esse actante e o mundo diegético do filme será concebida como graduação tensiva e semântica que oscila entre enunciador, narrador e ator interlocutor, criando diferente subjetividades, inclusive a de um autor, e também diferentes afetos. A análise da adaptação mostra que enquanto a adaptação pode ser considerada fiel, e ambos os textos propõe um engajamento sensível com o enunciatário, o ator da enunciação Gus Vas Sant, que não apenas transpõe o texto fonte, mas cria novos sentidos no texto alvo, imprimindo-o com novos ritmos, revela um projeto enunciativo de tradução intersemiótica que recicla, ou atualiza, gêneros fílmicos relacionados à impressão subjetiva, propondo um texto-acontecimento audiovisual.

Palavras-chave: adaptação fílmica; tradução intersemiótica; semiótica narrativo-discursiva; o actante observador; práxis enunciativa; discurso verbovisual e audiovisual; o cinema de Gus Van Sant. 


\begin{abstract}
GOMES JUNIOR, Edison. The film adaptation of the novel Paranoid Park: a semiodiscursive point of view. 2019. XXX f. Tese (Doutorado) - Faculdade de Filosofia, Letras e Ciências Humanas da Universidade de São Paulo, São Paulo, 2019.
\end{abstract}

The aim of this paper is to analyze the filmic adaptation of the novel Paranoid Park departing from the French semiotic theory, and its notions of generative path, tensivity and enunciative praxis, which not only are powerful analytical text-tools, but also reflect on the discursive fabrication of meaning as a mode of human interaction, the practice of meaningful sets which may be more utilitarian or mitopoetic, and seen as expressive contents generated in the various types of relationship with the natural world. Through the greimasian generative path, we compare the semionarrative and discursive structures of both texts involved in the adaptation, the source text and the target text ( $а$ quo and ad quem respectively), paying attention to inter / intratextual relations between planes of expression and content, and figurative operations. From the tensive semiotics point of view, we discuss modes and syntaxes of both texts, the notion of presence field, and operations of intensity and extensity. Based on the enunciative praxis, both texts are observed as dynamic update operations of other discourses, literary and filmic, more or less assumed or recognized by a subject of enunciation. In addition to the adaptation analysis itself, issues pertaining to the verbal language, the literary text, its typological / topological expression, and the audiovisual language, understood as significant sets composed differently, are discussed. Because of the difference between the objects and the theoretical frame employed in the analysis, cinematographic language is treated semiotically, and questions about the arbitrariness and motivation of language, figurative issues of space and movement, and the observer, an important narrative actant in verbal and nonverbal enunciation, are investigated. Regarding the filmic text, which provides the plastic illusion of movement, the observer is considered from the proxemic, gestural and plastic semiotics, and the distance between this type of actant and the diegetic world of the film is conceived as a tensive and semantic gradation that oscillates between enunciator, narrator and interlocutor, creating not only different subjectivities, including that of an author, but also different affects. The analysis of the adaptation shows that while the target text can be considered faithful to the source text, and both propose a sensible engagement with the enunciator, the enunciation actor Gus Vas Sant creates new meanings in the target text, revealing an enunciative project of intersemiotic translation that recycles, or updates, filmic genres related to the subjective impression, proposing an audiovisual event text.

Keywords: film adaptation; intersemiotic translation; narrative-discursive semiotics; the actant observer; enunciative praxis; verbovisual and audiovisual discourse; the cinema of Gus Van Sant. 


\section{SUMÁRIO}

INTRODUÇÃO: QUESTÕES INTERSEMIÓTICAS E ADAPTAÇÃO ........................ 17

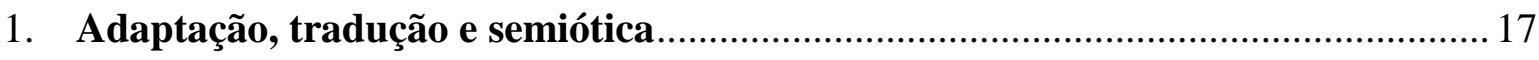

2. A semiótica narrativo-discursiva: uma abordagem geral ................................. 22

3. Questões teóricas: semiótica greimasiana e pós-greimasiana ............................. 27

4. Metodologia de análise: sequência e objetivos da pesquisa ................................. 40

1. MANIFESTAÇÃO DO SENTIDO E ADAPTAÇÃO ...........................................43

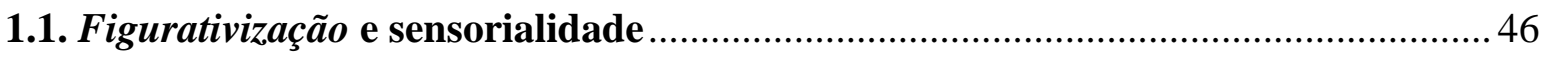

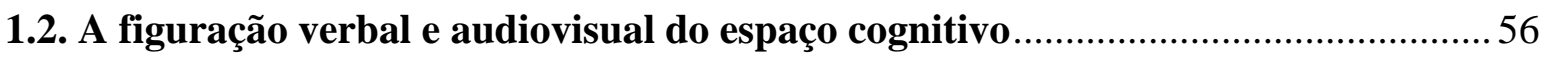

1.3. Operações plásticas do sentido fílmico: imagem, plano e decupagem................... 62

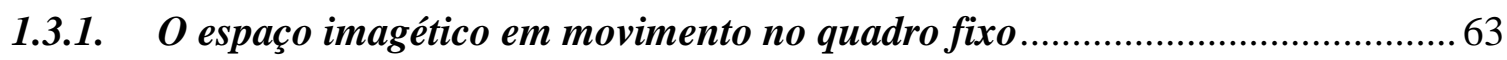

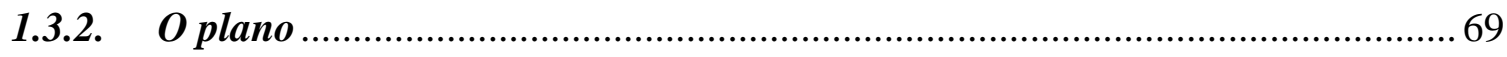

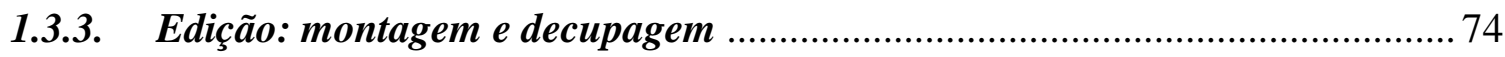

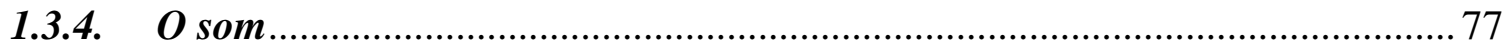

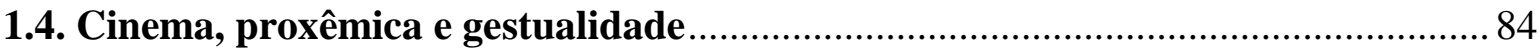

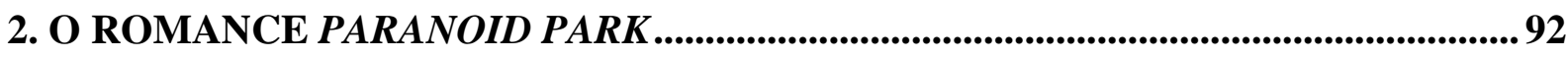

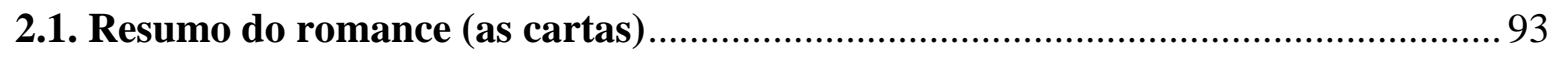

2.2. A construção discursiva do acontecimento e do sobrevir: memória e

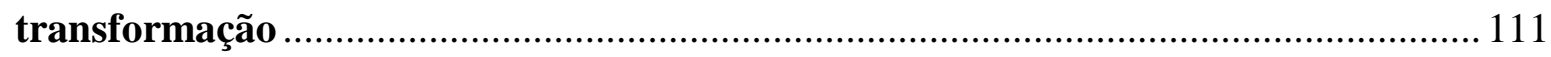

2.3. O percurso do sentido de Paranoid Park .................................................. 122

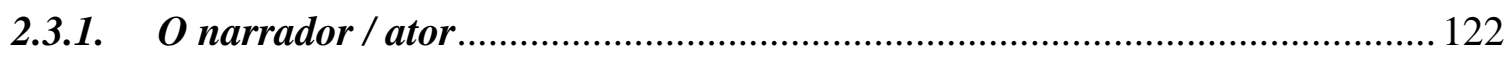

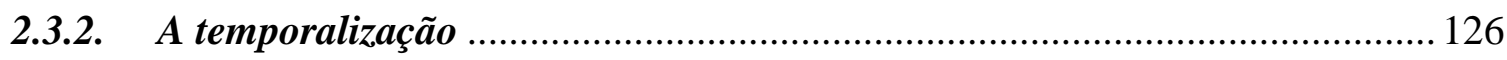

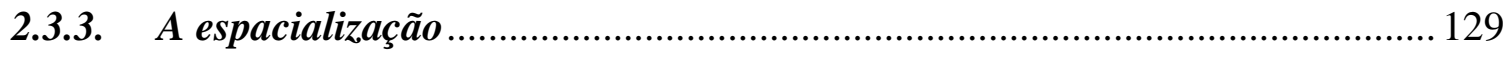

2.3.4. A actorialização (destinadores, sujeitos e paixões) .................................... 133 
2.3.5. Tematização, figurativização e manifestações do sensível.

2.3.6. O nível fundamental do sentido

2.4. Resumo das estratégias de produção do sentido do romance 157

3. O FILME

3.1. Os primeiros 13 minutos de Paranoid Park

3.1.1. Comentário sobre os primeiros minutos do filme:

3.2. Adaptando o acontecimento e o sobrevir: estudo do espaço topológico verbal e audiovisual e figurações do espaço.

3.2.1. Parte 2 do acontecimento: Na casa de Jared

3.3. A actorialização: adaptando Alex

3.4. Os outros atores

3.5. Tempo e espaço

3.6. A semiose proxêmica e gestual do observador

3.7. A trilha sonora

3.8. Falas e diálogos

4. ADAPTAÇÃO: SUJEITO DA ENUNCIAÇÃO, ATOR DA ENUNCIAÇÃO E PRÁXIS ENUNCIATIVA

4.1. O ator da enunciação e seu projeto enunciativo

4.2. Atualizando temas e figuras do romance

4.3. A práxis enunciativa e PP

4.4. Resumo do projeto enunciativo: do texto ab quo ao texto a quem

CONCLUSÃO.

REFERÊNCIAS BIBLIOGRÁFICAS 346

ANEXOS 362 



\section{LISTA DE FIGURAS}

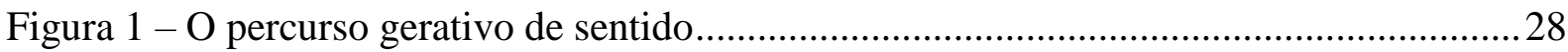

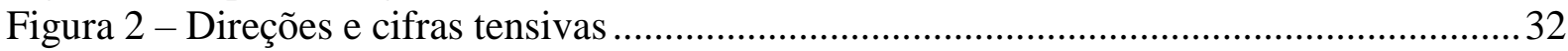

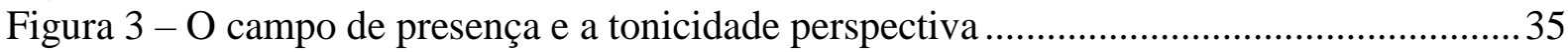

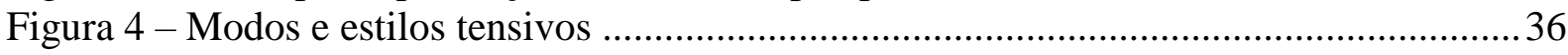

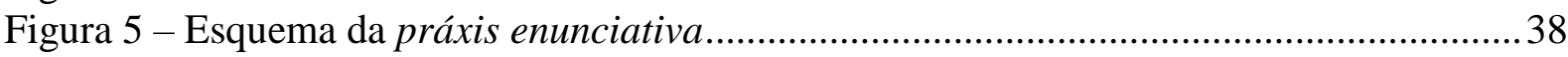

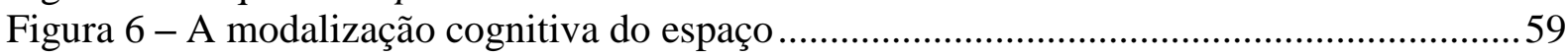

Figura 7 - Regimes intersubjetivos da relação observador/informante .................................59

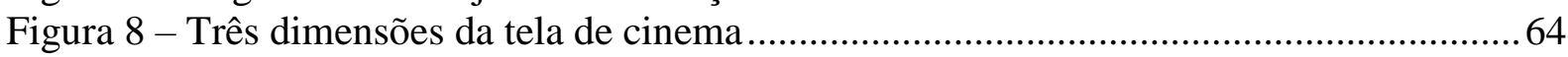

Figura 9 - Relações centrípetas e centrifugas entre quadro e imagem: "fora e dentro" do

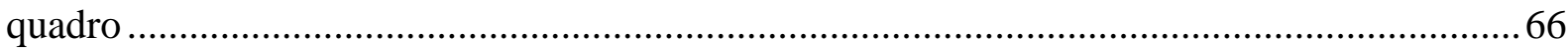

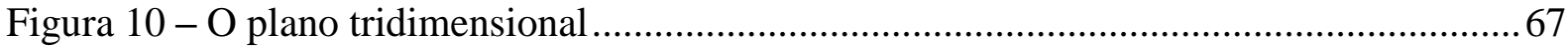

Figura 11 - A tela dividida em quatro planos e em enunciados simultâneos idênticos,

diferentes e multifocais

Figura 12 - Expressão acústica de estados emocionais de acordo com Friederich Marpurg

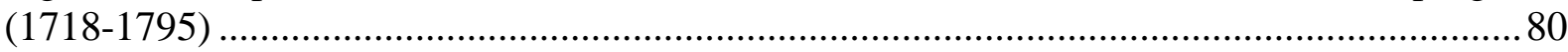

Figura 13 - Impacto físico, mental e emocional dos gêneros musicais .................................. 81

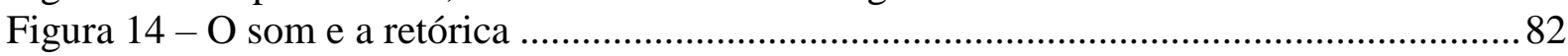

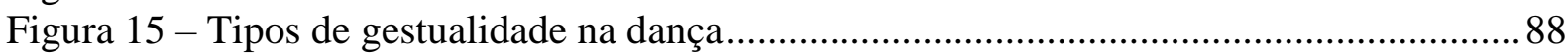

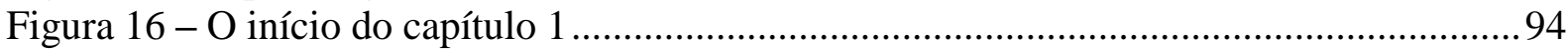

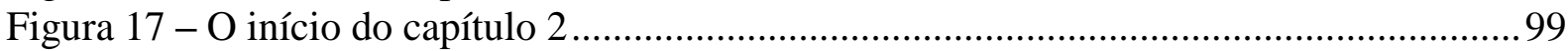

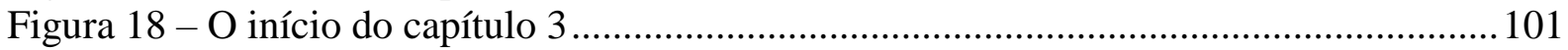

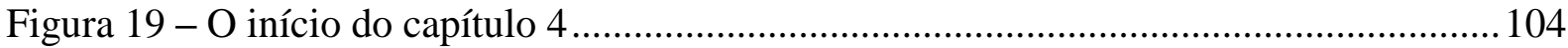

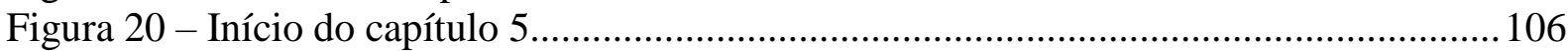

Figura 21 - Início do capítulo 6 ( a primeira carta do dia) ....................................................... 108

Figura 22 - Início do último capítulo (a segunda carta do dia) ........................................... 110

Figura 23 - O campo de presença e a tonicidade perspectiva .............................................. 113

Figura 24 - Modos de existência do sujeito Alex no romance ............................................. 118

Figura 25 - As cartas e as emoções do protagonista ............................................................. 119

Figura 26 - A densidade da presença do acontecimento-objeto no campo de presença do

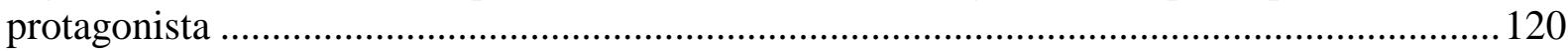

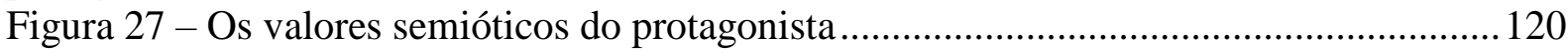

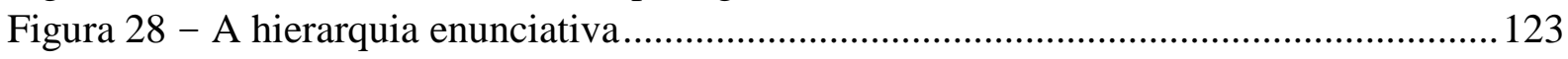

Figura 29 - Alex como dois tipos de sujeito da enunciação no romance ............................. 124

Figura 30 - As categorias aspectuais do discurso ........................................................... 127

Figura 31 - A temporalização em Paranoid Park .............................................................. 128

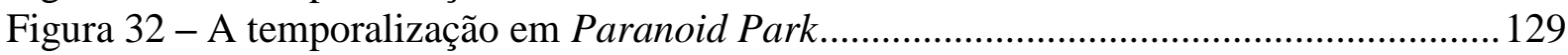

Figura 33 - Programação Espacial de Paranoid Park …......................................................... 129

Figura 34 - Presença dos objetos, tempos e espaços na memória do ator Alex..................... 136

Figura 35 - O percurso passional do ator no romance .......................................................... 138

Figura 36 - O pôster da polícia (imaginado pelo jovem); e o cartão do detetive entregue ao

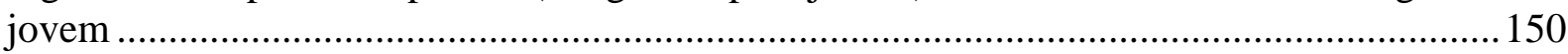

Figura 37 - Tipos na capa e na contracapa do romance .............................................. 150

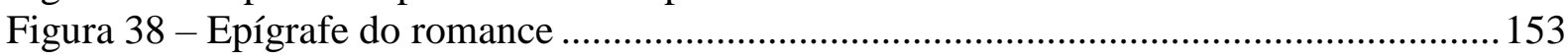

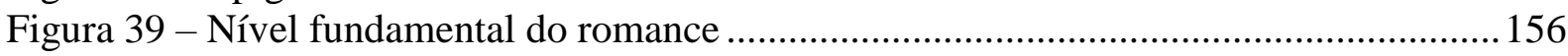

Figura 40 - Análise do continuum tensivo do romance .................................................... 157

Figura 41 - A transformação do protagonista .................................................................... 157

Figura 42 - Abertura do filme e créditos. A cidade esmagada pelo céu ................................ 162 
Figura 43 - O título do filme é reescrito pelo ator Alex................................................... 162

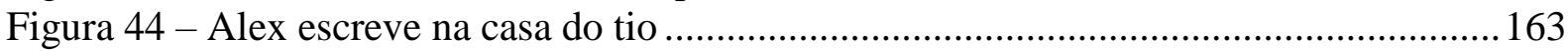

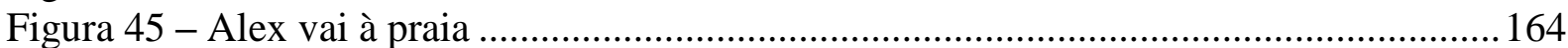

Figura 46 - a primeira visita a Paranoid Park: manhã .................................................... 165

Figura 47 - Alex vai à praia (imagem granulada e fora de foco; aproximação do ator) ........ 166

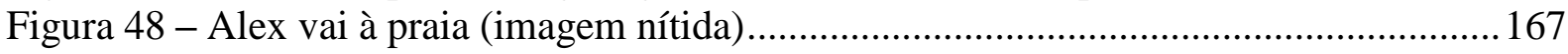

Figura 49 - A praia é um dos lugares onde Alex escreve suas cartas .................................. 168

Figura 50 - Alex e Jared falam sobre Paranoid Park no passado ......................................... 170

Figura 51 - Alex pela primeira vez em Paranoid Park .................................................... 171

Figura 52 - Alex observa alguns usuários de Paranoid Park (em câmera lenta, um skatista

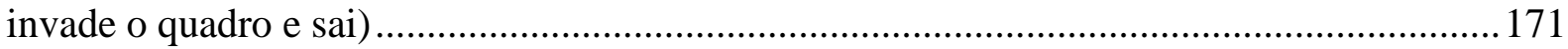

Figura 53 - Paranoid Park e Alex andando de costas ....................................................... 171

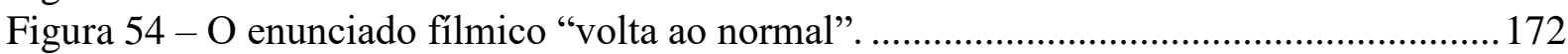

Figura 55 - Alex escreve na praia. Há alterações cromáticas na imagem, que fica

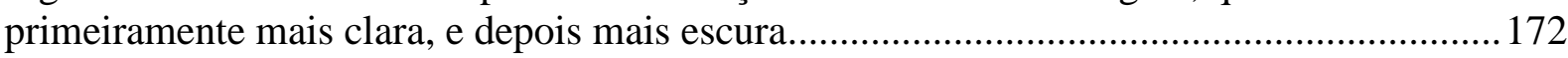

Figura 56 - A imagem do planeta Terra em um retroprojetor............................................ 173

Figura 57 - Alex na escola, em sala de aula................................................................. 173

Figura 58 - Alex andando pelo corredor da escola depois de ser chamado .......................... 174

Figura 59 - Alex chega na sala e é interrogado pela polícia ................................................ 174

Figura 60 - Durante o depoimento do jovem, ouve-se o grito de um homem que começa em

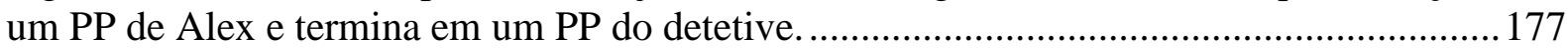

Figura 61 - O detetive entrega o seu cartão a Alex ........................................................ 178

Figura 62 - Alex escreve suas cartas e explica que suas lembranças estão fora de ordem (13'

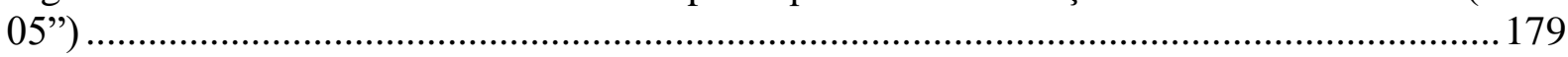

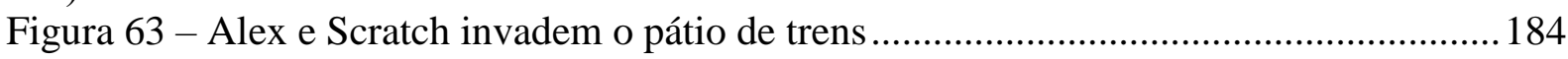

Figura 64 - Os jovens correm em direção ao trem e ouve-se um apito. ............................... 184

Figura 65 - Alex e Scratch preparam-se para trepar em um vagão..................................... 185

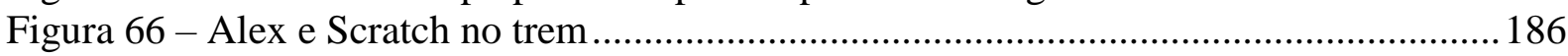

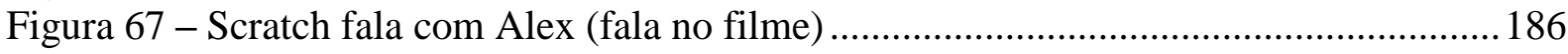

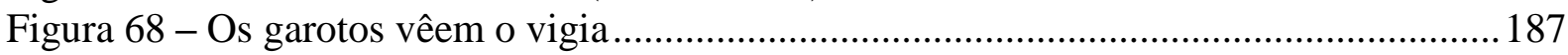

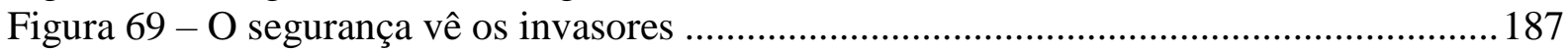

Figura 70 - O vigia do pátio de trens ataca os jovens e é derrubado por Alex ..................... 188

Figura 71 - O vigia cai nos trilhos de um trem que se aproxima .......................................... 189

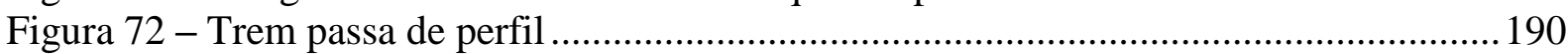

Figura 73 - Garotos aproximam-se e observam o corpo do vigia atropelado ........................ 190

Figura 74 - O trem passa e revela o vigia e o protagonista juntos ....................................... 191

Figura 75 - A cena do acidente é interligada por três faces ............................................... 191

Figura 76 - Alex, olha fixamente para o vigia no chão, em choque ......................................192

Figura 77 - Alex pensa em pedir ajuda no rádio do carro do segurança, mas foge ................194

Figura 78 - Chuva e relâmpagos que não existem no texto original, mas figuram a ideia de

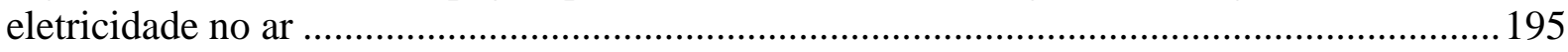

Figura 79 - Alex foge perdido em pensamentos (falas no filme sobrepostas) ........................196

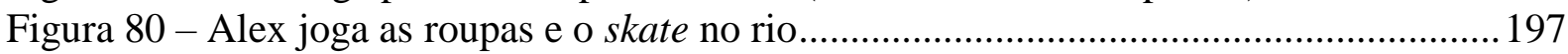

Figura 81 - Na cozinha da casa do amigo, Alex põe as suas roupas sujas em um saco plástico

Figura 82 - Alex percebe que pode ser observado do lado de fora, agacha-se, e atravessa a

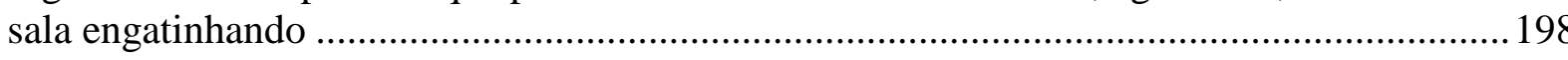

Figura 83 - Alex no chuveiro, chora e se desespera, em uma imagem que vai da figura ao

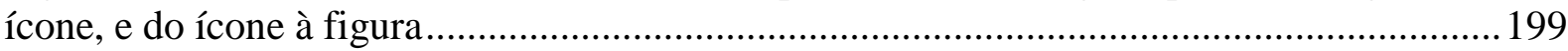

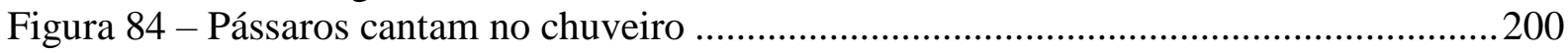




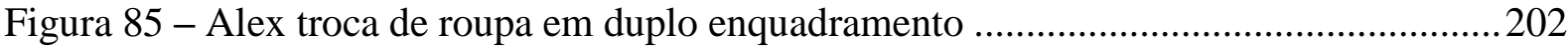

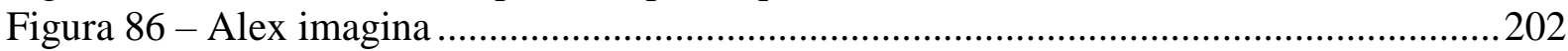

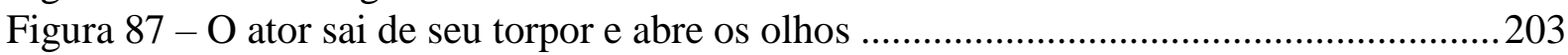

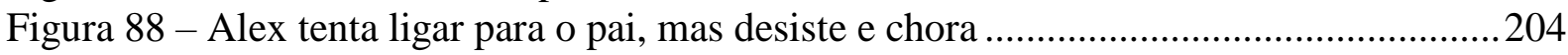

Figura 89 - Exausto, Alex dorme, e no dia seguinte vai para a casa ..................................204

Figura 90 - Alex coloca o saco de lixo com suas roupas sujas no carro e dirige para a casa 205

Figura 91 - Figura de uma exposição inesperada...............................................................211

Figura 92 - Tipos de planos e suas durações na sequência do acontecimento.......................214

Figura 93 - Manifestações de categorias expressivas .....................................................217

Figura 94 - Cenas fragmentadas do acontecimento, que serão repetidas posteriormente na

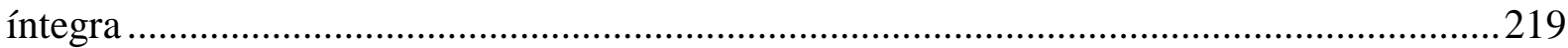

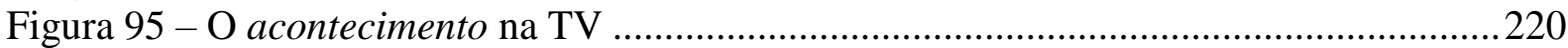

Figura 96 - O acontecimento em um jornal da biblioteca da escola ....................................221

Figura 97 - Foto do acidente no pátio de trens distribuída pelo detetive Lu aos alunos ........221

Figura 98 - Esquemas tensivos do romance e do filme .....................................................222

Figura 99 - A ascendência e a decadência da tensão no filme ............................................223

Figura 100 - O rosto do ator como expressão da interioridade ............................................224

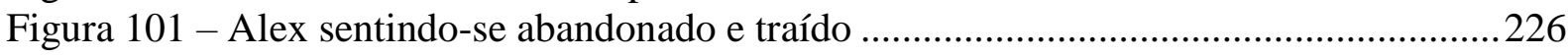

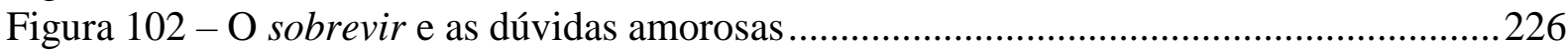

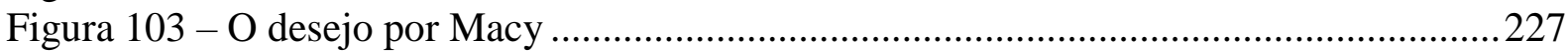

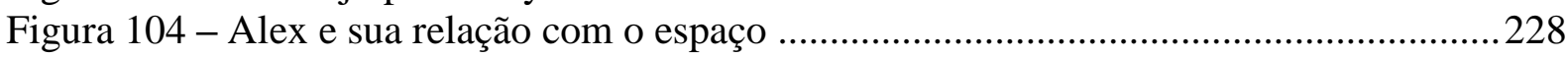

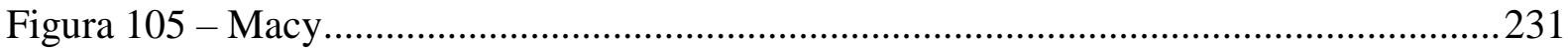

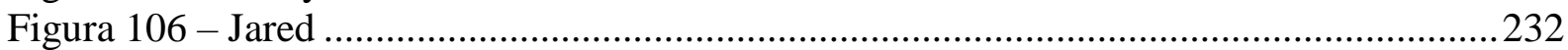

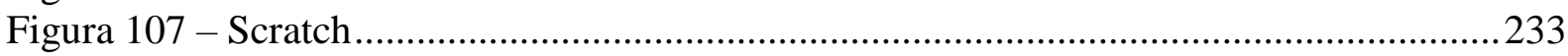

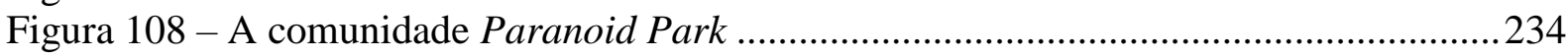

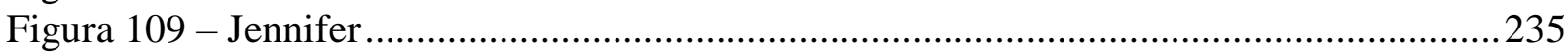

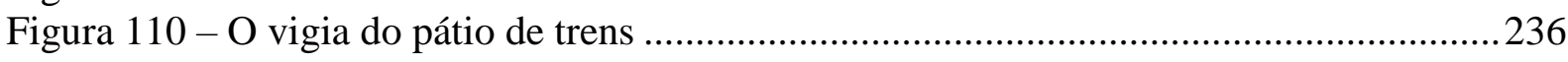

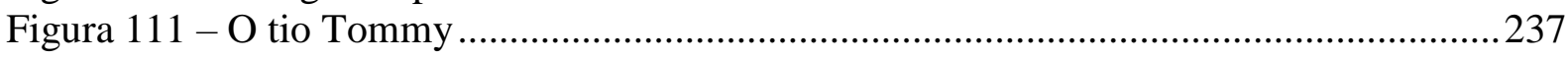

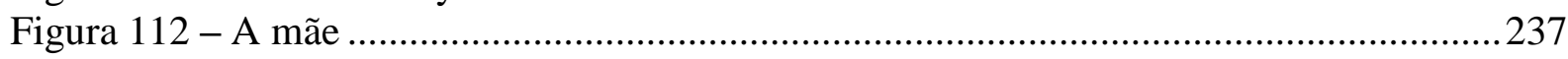

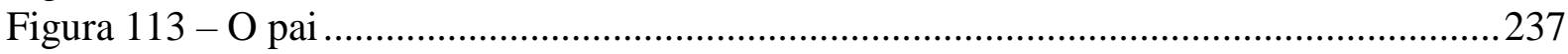

Figura 114 - O inspetor de polícia Richard Lu. Diferença étnica não existente no romance 238

Figura 115 - Alternando entre presente e passado ..........................................................241

Figura 116 - O passado fora de ordem e a incerteza das datas da narração e do narrado......244

Figura 117 - Entre o presente e o passado (flashback sonoro) …..........................................24

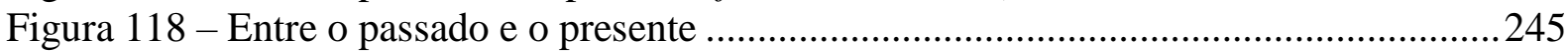

Figura 119 - Paranoid Park como lugar fechado e subterrâneo, onde Alex desce ................246

Figura 120 - $\mathrm{O}$ interior da casa do tio figurado por cores quentes........................................246

Figura 121 - O exterior da casa do tio figurado por cores frias (inverno) ............................. 247

Figura 122 - Alex em casa: desorganização, mudança e outro espaço subterrâneo ...............248

Figura 123 - Tabela 1 (planos: 1 - 58; tempo fílmico: 0 - 16' $57^{\prime \prime}$ ) .......................................250

Figura 124 - Tabela 2 (planos: 59 - 116; tempo fílmico: 16'57' - 32'08'”)........................251

Figura 125 - Tabela 3 (planos: 117 - 174; tempo fílmico: 32'08" - 45'20") ........................251

Figura 126 - Tabela 4 (planos: 175 - 232; tempo fílmico: 45'20" - 1h2'29") ......................252

Figura 127 - Tabela 5 (planos: 233 - 281; 1h2'29" - 1h21'16") .........................................252

Figura 128 - Alex termina a última carta e queima tudo o que escreveu: cortes do mais

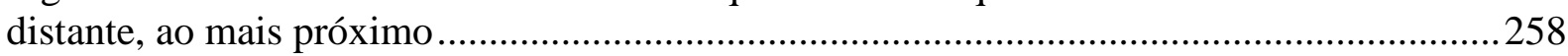

Figura 129 - Planos classificados pela duração em segundos.............................................260

Figura 130 - A quantidade de 7 tipos de plano em tabela e gráfico......................................260

Figura 131 - Um grito de horror é ouvido no meio da conversa entre o jovem e o investigador do crime. O corte entre eles se dá durante o grito, que ressoa nas duas imagens...................263 
Figura 132 - Alex chora no chuveiro ao som de pássaros. Nos azulejos do banheiro há pássaros pintados

Figura 133 - A canção Angeles é executada quando Alex termina as cartas e as queima na

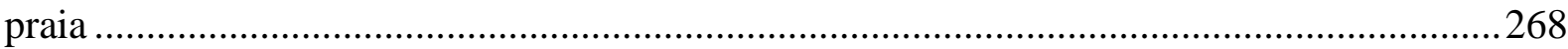

Figura 134 - Imagens mostradas durante a canção The white lady loves you more ..............269

Figura 135 - Imagens da canção I can help (Alex é chamado para encontrar o detetive) .....271

Figura 136 - No final do filme, a canção Outlaw e cenas de jovens andando de skate na rua

Figura 137 - Jared percebe que Alex tem um novo skate e reclama....

Figura 138 - O punk rock toca sobre o rosto de Jared, depois de uma discussão envolvendo homofobia.....

Figura 139 - A Nona Sinfonia liga breves momentos do passado (a morte do vigia e a conversa com o detetive), e do presente, na praia (sequência de imagens do filme)

Figura 140 - A música de Rota é utilizada na imagem inicial do filme, nas cenas entre Alex, Jennifer e Macy (românticas e tensas), e quando ele passeia pelo shopping, faz compras e anda pela rua.

Figura 141 - Alex ouve hip-hop, música clássica e country no carro (reações ao ritmo).....286 Figura 142 - Na loja de discos e CDs, enquanto Alex e Jared olham as novidades uma música eletrônica pode ser ouvida brevemente 287

Figura 143 - Na loja de roupas usadas onde Alex e Jennifer divertem-se, a música de fundo é

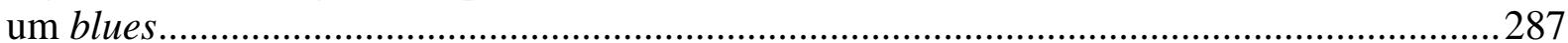

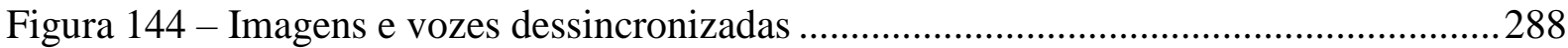

Figura 145 - Voz-over e corpo do narrador /ator unidos no final da narrativa ......................290

Figura 146 - O enunciador e o sujeito da enunciação em relação ao percurso gerativo .........294

Figura 147 - O produtor, o sujeito da enunciação e o interpretante m relação ao percurso gerativo

Figura 148 - O título da obra escrito duas vezes e nos dois níveis do discurso: o da enunciação e o do enunciado

Figura 149 - $\mathrm{O}$ final do filme

Figura 150 - O fogo (a cena da queima no romance é apenas sugerida e potencializada; no filme é realizada)

Figura 151 - Os elementos naturais no filme. Céu, terra, água e fogo .................................305

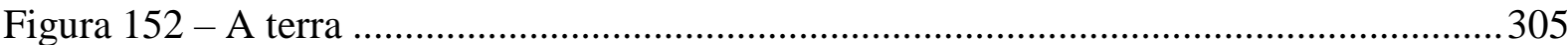

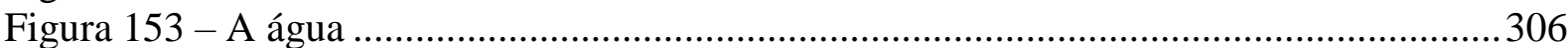

Figura 154 - A cena de sexo entre os jovens, depois da aula, é trocada por uma visita a uma

loja de roupas, mas mantém a tensa relação entre eles, preservando suas personalidades. ...308

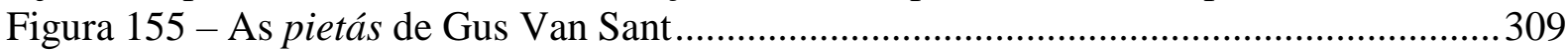

Figura 156 - Macy / pietá como entidade superior e salvadora .............................................310

Figura 157 - Alex, pesaroso ao ser comunicado que ele e o amigo não ficarão juntos no fim

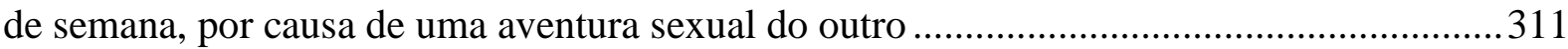

Figura 158 - Homoafetividade entre Scratch e Alex na pista de skate .................................312

Figura 159 - Jovem é escoltado na escola por posse de maconha .........................................313

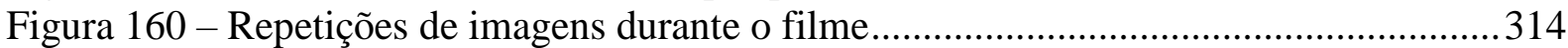

Figura 161 - Elementos estranhos à narrativa proposta pelo romance ……...........................315

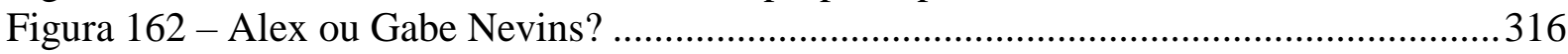

Figura 163 - Dimensão tensiva da práxis enunciativa ......................................................... 318

Figura 164 - Transformações da existência de enunciados dinamizados pela práxis............319

Figura 165 - Operações da práxis do ponto de vista do devir dos sujeitos.............................321

Figura 166 - Transposição fiel de elementos do enunciado literário .....................................332

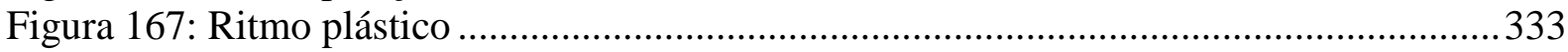


Figura 168 - Características discursivas gerais da enunciação literária e fílmica...................335 Figura 169 - Elementos do plano da expressão e do conteudo fílmico ..................................336 


\section{INTRODUÇÃO: QUESTÕES INTERSEMIÓTICAS E ADAPTAÇÃO}

\section{Adaptação, tradução e semiótica}

De maneira geral as teorias sobre adaptação que discutem as dinâmicas de transposição de narrativas de obras literárias para o cinema possuem pontos de vista de ordem prescritiva, descritiva e comparativa, ou intertextual e cultural. Se os discursos seminais sobre o tema parecem trair certos preconceitos em relação à sétima arte, julgando-a inferior à literatura por limitações expressivas, e incapaz de retratar e discutir o homem em sua complexidade e profundidade, gerações posteriores de teóricos e pesquisadores, revendo a linguagem cinematográfica e suas teorias, se dão conta de que o cinema possui um saber-fazer próprio, que é tão complexo e poético quanto o da literatura.

Desenvolvido desde os seus primórdios, assim que começa a contar as suas primeiras histórias, esse saber é distinto do saber literário, mas possui relações com as línguas naturais, sendo de ordem narrativo-discursiva. Com o passar do tempo, o cinema não só se torna mais complexo e persuasivo como o romance, mas a adaptação fílmica passa a ser reconhecida menos como obra literária adaptada, do que um discurso audiovisual autônomo, e que pode ser mais ou menos apoiado no discurso literário. A partir da ideia de discursos cruzados, abre-se a questão da adaptação inter e intratextual, relativas a pontos de vistas culturais, autorais, receptivos, históricos e sociais, que também são assuntos da semiótica.

Atualmente, as teorias da adaptação, inúmeras e conscientes das capacidades retóricas da linguagem fílmica, aceitam o fazer adaptativo como operações de tradução, recriação, transposição, transdução etc, respeitando a autonomia de ambos os meios de comunicação, e o momento histórico-social de ambos os textos envolvidos nessa prática, as fontes e alvos. Os vários sinônimos do termo já apontam para um problema na definição exata do fenômeno, pois obras podem ser mais ou menos livremente adaptadas, e filmes têm a liberdade de se apresentarem como adaptações, inspirações, ou obras livremente baseadas, de modo que podem alterar elementos do texto original, em uma prática descrita passionalmente, nas teorias tradulógicas, como "traição".

No impasse de definição preciso de adaptação, e devido à diferença entre a linguagem verbal e fílmica, em sua historiografia há teóricos que defendem a ideia um tanto abstrata de tradução do "espírito" ou do "valor literário" da obra adaptada (MCFARLANE, 1996), que procuram criar uma diferenciação entre tradução literal, tradicional e radical, concebendo uma diferenciação entre adaptar e transpor (CAHIR, 2006). Segundo McFarlane (1996) os teóricos 
de adaptação que são amantes da sétima arte preferem, acreditando que o cinema seja uma forma de expressão independente da literatura, o termo releitura ao invés de adaptação.

Os pesquisadores que entendem a adaptação a partir das ciências sociais, teorias da recepção e da intertextualidade, afirmam que tanto o romance quanto o filme podem ser observados a partir de outros textos que os integram, em maior ou menor grau. Os adeptos da visão pós-modernista da arte, como Hutcheon (2006), por exemplo, acreditam na adaptação como um processo amplo e irrestrito, uma mescla intensa de formas artísticas e culturais realizadas conjuntamente por atores sociais, produtores e consumidores, tais como diretores, produtores, escritores, artistas e espectadores. Elliot (2004), por exemplo, sustenta que o romance vitoriano, sendo composto não só de textos verbais, mas de imagens, e sendo frequentemente adaptado desde os primórdios do cinema (e da televisão), seria um dos principais responsáveis pela evolução da linguagem fílmica. Francesco Casetti (2004), que igualmente adota a pós-modernidade como momento histórico diferenciado, entende o filme como discurso e desenvolve questões relacionadas à recepção e ao espectador pós-moderno.

Partindo diretamente da teoria literária e cinematográfica, os próprios especialistas em cada área tentaram dar sua contribuição, tímida, para a discussão, comparando menos as obras literárias e audiovisuais do que as capacidades de produção de sentido da literatura e do cinema: aproximamo-nos da linguística e da semiótica. Eisenstein (1990), cineasta russo que revolucionou a montagem, explica que tanto ele quanto Griffith, o inventor do close (ou primeiro plano) e da ação paralela, percebiam na literatura uma verdadeira fonte de imagens e possibilidades expressivas audiovisuais, já contendo visualidade e sonoridade. O teórico de cinema François Jost (2004) transfere a noção de narrador-observador de Genette para a câmera fílmica, desenvolvendo a noção de ocularização, a relação entre o que câmera mostra e o que os atores presumidamente vêem, e focalização, o ponto de vista cognitivo adotado pela narrativa (p. 74). Christian Metz também compara o cinema à linguagem escrita e teoriza um narrador/enunciador que pode existir como verbo e imagem. Seymor Chatman, denominando o filme de discurso mimético, igualmente entende que existe um narrador audiovisual responsável por operações retóricas, que respeitando o seu meio, realiza as mesmas operações de mostrar e contar, a partir de um narrador implícito que tudo organiza $(1978,1990)$.

A partir desse breve panorama epistemológico sobre a adaptação, que envolve a linguagem, verbo e imagem, discursos verbais e audiovisuais, a ideia de fidelidade e a constatação de diversos agentes que integram esse processo, pode-se perceber a complexidade da discussão. No entanto observa-se que, mesmo identificando-se diversas linhas de pensamento sobre o tema, parte-se do princípio geral de que há uma transposição ou tradução 
mínima de certas ideias e conteúdos de um texto de origem, que podem ser reconhecidos no texto adaptado, mesmo sendo expressos de maneira diferente, por imagens, por exemplo; ao mesmo tempo, aceita-se que essa transposição de ideias é original, devido às várias coerções de caráter social e linguístico de cada linguagem, de modo que o texto alvo não apenas possui autonomia e liberdade para ir além do texto fonte, mas dificilmente poderia ser idêntico a ele. Ademais, entende-se que ambos os tipos de textos, os originais e os adaptados, são executados e consumidos por agentes sociais, que dialogam e se influenciam na adaptação: o extremo desse pensamento seria admitir que, pelo fato de um texto nunca ser igual a outro, a adaptação não existiria, e estudos tradulógicos seriam inúteis.

Assim, enquanto se discute a fidelidade, acreditando que a adaptação deva primar pela transposição de ideias, personagens e eventos do texto original (MCFARLANE, 1996), percebe-se que tal operação é de caráter semio-linguístico, sendo estrutural e poética, alicerçada em simbolismos, metáforas e novas axiologias veiculadas em discursos. Ela ocorre dentro de coerções históricas que são da ordem das crenças e dos saberes sancionados e partilhados por um conjunto social em dado momento de sua existência material, sendo relacionada ao relatar novamente, ao enunciar um conjunto significante de outra forma.

As questões abordadas acima, sem dúvida, encontram eco na semiótica, que se debruça sobre o estudo da construção do sentido, e entendem a adaptação como uma operação mais geral de tradução, presente na própria semiose, indo além da linguagem verbal. Jakobson (2010), em um texto que estipula uma posição mais semiótica do assunto, propõe três tipos gerais de tradução: a intralingual, ou reformulação, que consiste na interpretação dos signos verbais por meio de outros signos da mesma língua; a interlingual, ou tradução propriamente dita, que consiste na interpretação dos signos verbais por meio de signos verbais de outra língua; e a tradução intersemiótica, ou transmutação, que consiste na interpretação de signos verbais por meio de sistemas de signos não-verbais (p. 79-90). A ideia de tradução intersemiótica, ao propor a existência de signos não verbais, é abraçada principalmente por semioticistas cognitivistas e sociais.

A partir da semiótica de cunho mais cognitivo, a tradução é vista como operação de apoio à própria sobrevivência dos seres vivos. Segundo Petrilli (2016), que adota uma visão ampla da significação, revendo Pierce, Sebeok e Lotman e a semiótica social, o estudo da tradução não pode limitar-se à relação entre diferentes linguagens naturais históricas, concernindo o próprio conceito de signo e suas relações, uma vez que o sentido de um signo não está nele, mas em outro signo, e a tradução estaria relacionada à identificação de certas relações, sendo a base da construção do sentido (p. 23). A semioticista entende que sentido, 
tradução e vida são atividades complementares, pois “onde há vida, há semiose, há signos sendo processados, há tradução" (PETRILLI, 2016, p. 23-56).

Desse ponto de vista a tradução pode ser entendida dentro de um processo maior de adaptação, que é inerente à natureza e está presente em todos os seres vivos. Ela seria espécieespecífica e natural, em uma dinâmica de sentido na qual "corpos, signos e valores são interconectados e desenvolvem-se com base em um ininterrupto processo translativo" (p. 46). Uma vez que vida e semiose convergem, a tradução seria condição necessária para a renovação e regeneração da vida em todas as suas expressões, humana e não humana, verbal e não-verbal, natural e cultural, planetária e local, em termos que adquirem consistência e significado na rede do signo global de nossa semiobiosfera como parte de um processo semiósico contínuo, interconectado e nunca isolado

Vislumbrando a tradução como condição da existência dos signos, gerados e multiplicados por operações de inter-relação, interpretação, transposição ou tradução, Petrilli descreve a capacidade humana de significação em termos de "pensamento translativo", um processo automático no qual tudo sugere ou lembra outra coisa, dentro de diferentes sistemas sígnicos que se relacionam ou diferenciam-se nas dinâmicas da significação, e onde "um signo é mais desenvolvido que outro, sendo enriquecido, criticado, afastado, desconstruído ou reconstruído, colocado em aspas, parodiado ou simplesmente imitado, mas sempre interpretado nos termos de outro" (p. 33). Da mesma forma, Plaza (2010) entende a tradução intersemiótica em termos de pensamento intersemiótico, um processo de transmutação de signos, pois pensar é traduzir o que está presente na consciência, imagens, sentimentos ou concepções em outras representações, que também são signo, de modo que "todo pensamento é a tradução de outro pensamento, pois qualquer pensamento requer ter havido outro pensamento para o qual ele funciona como interpretante" (p. 18).

Em termos sociais, Petrilli, ainda apoiada na concepção semio-cognitiva, acredita que a tradução pressupõe uma relação dialógica, de hospitalidade e de escuta, condição de abertura sem limites, propensão para o encontro, que ocorre também com o estrangeiro, o estranho. Desse modo, um dos aspectos desse fenômeno estaria relacionado ao diálogo, ao envolvimento, à participação e ao comprometimento com o outro. Plaza (2010) acredita que a tradução:

Implica um encontro entre diferentes linguagens, textos verbais e culturas. No nível das relações interculturais, a condição de intersemioticidade translacional, ou transsemioticidade revelam processos de compromisso, hibridização e negociação que necessariamente formam diferença e identidade em todos os aspectos e dimensões da cultura. Processos translacionais são a condição para a formação de diferenças e identidades, mas também para a 
relação ilusória de independência mútua e indiferença, oposição e conflito (p. 48).

Segundo Massia (2016) Humboldt, descrevendo a linguagem como uma energia (energeia) que formata o mundo e a mente humana, sugere que o papel da tradução no desenvolvimento humano não é acidental, mas determinado pelo valor da linguagem como componente constitutivo da cultura humana e da identidade. Por essa razão, "o processo de conhecer o outro e ganhar consciência pode ser definido como translacional em natureza, e a tradução definida como um paradigma de conhecimento antropológico e troca intercultural"1.

A partir dessa visão geral da tradução, que conjunge diferentes formas de significação, pensa-se em uma prática de sentido que mescla diferentes tipos de signos, mais naturais e mais artificiais, mais arbitrários ou motivados. Assim, a ideia de tradução intersemiótica aponta para além da linguagem verbal, entendendo que o significado desse signo não é se dá apenas nos limites do sistema da linguagem, desenvolvendo-se em trajetórias interpretativas que transcendem os limites de seu sistema (p.36). Petrilli e Massia, combinando semióticas cognitivas e sócioculturais, e entendendo a linguagem verbal humana como apenas um tipo, entre outros, de construção de sentido, e a tradução como operação que ocorre em um nível sócio-biológico, revelam a importância da questão, no que tange o estudo da produção de sentido dos seres vivos, assim como das relações de convivência entre eles.

Enquanto as contribuições de Jakobson, assim como de outros semioticistas cognitivos explicitam a importância da tradução para o ser vivo e para a cultura, há outra abordagem semiótica, nascida das ciências linguísticas, mas não limitada a ela, que não descarta a ideia de mundo e corpo, mas entende a significação como um processo de ordem principalmente linguística e discursiva, de modo que as línguas naturais seriam não apenas os primeiros conjuntos significantes aprendidos e compartilhados pela espécie humana para fazer referência ao mundo natural e a si mesmo, mas a base própria da cognição e percepção. A semiótica de base discursiva, que veremos a seguir, engloba questões de formas e conteúdos, sintaxes e semânticas, ritmos e práticas, e sempre entende a linguagem verbal como fonte direta ou indireta do sentido, em uma compreensão que se à ideia de tradução intersemiótica como produção básica de sentido.

Se na discussão sobre adaptação / tradução fazemos uma pequena distinção entre dois tipos de semiótica, apresentando uma mais voltada para o corpo e a cognição, as coerções

\footnotetext{
1 "For this reason, the process of both getting acquainted with the other and of gaining self-awareness can be defined as translational in nature. Therefore, translation can be deemed as a paradigm of anthropological knowledge and of intercultural exchange" (MASSIA, 2016, p. 128, tradução nossa).
} 
materiais no sentido, a emissão e a recepção de informação; e outra mais voltada para o texto verbal e a língua natural, procuramos delimitar minimamente dois conjuntos epistemológicos diferentes, em uma abordagem que merece ser investigada com mais profundidade, e foge ao escopo da tese. No entanto propomos, por questões científicas e pedagógicas, e para delimitar com mais precisão as nossas ferramentas teóricas de trabalho, ao menos dois tipos de semiótica, uma de base informativa / comunicativa, e outra de base discursiva. O foco neste tipo de semiótica, de ordem mais verbal e semântica, e não naquele, servirá como ponto de vista para as nossas abordagens sobre a adaptação e os objetos analisados. O ponto de vista teórico escolhido, porém, em nenhum momento nega produtivas intersecções teóricas entre as semióticas, mas elege a linguagem e o discurso verbal como ponto de partida para as nossas argumentações.

\section{A semiótica narrativo-discursiva: uma abordagem geral}

Sem negar a cognição ou a evolução biológica, a semiótica de linha francesa, de um lado deposita a construção do sentido em uma atividade narrativa sempre textualizada, que existe enquanto conjunto significante estruturado, no sentido de que práticas humanas e narrativas são quase sinônimas, possuindo início, duratividade, fim, ou seja, transformação e movimento, atores sociais que interagem e são manipulados para entrarem em conjunção com objetos-valor em diferentes espaços e tempos. A partir do texto narrativo enunciado em discurso, esse tipo de semiótica trata o sentido como uma construção sintático semântica fórica tanto do mundo inteligível como do mundo sensível.

Em sua versão mais moderna, a semiótica de linha pós-greimasiana debruça-se sobre a tensividade e o discurso como prática, estabelecendo a produção de sentido sob pontos de vista a princípio menos semânticos e sintáticos do que prático-tensivos, feito de ascendências e descendências, e andamentos e tonicidades dentro de uma construção discursiva da significação. Os dois tipos de semiótica também imaginam um corpo com campo de presença, no qual forças tensivas interagem: de certa forma enfatiza-se a importância do enunciador como corpo discursivo que reconstrói o sentido a partir de outros sentidos estocados em um sistema. A partir desses dois pontos de vista, um mais estrutural e um mais tensivo, a ideia de tradução / adaptação ganha ferramentas semióticas de ordem lógica e prática, mas também sensíveis e graduais, e sempre relacionadas na tensão eu / outro, o individual e o social. Os termos narrativo-discursivo que utilizamos procuram englobar essas duas semióticas, ou vetores de análise, vendo-as como complementares: combinados, tratam o estudo da produção de sentido 
de práticas verbais e não verbais fórico-tensivas que formam um sistema praticado por um enunciador e um enunciatário. Do ponto de vista do discurso como prática, a semiótica pósgreimasiana propõe a ideia de práxis enunciativa, que pode ser entendida como prática recicladora do sentido, a partir de enunciados realizados e potencializados, e reutilizados ou estocados em um sistema virtualizado.

Segundo Greimas e Courtés (2011 [1979]) a possibilidade de tradução, a traduzibilidade, é uma das propriedades fundamentais das linguagens, ou seja, dos sistemas semióticos e da abordagem semântica, de modo que é uma operação que possibilita falar do sentido: “entre o juízo de existência 'há sentido' e a possibilidade de dizer alguma coisa a seu respeito intercala-se, com efeito, a tradução; 'falar do sentido' é ao mesmo tempo traduzir e produzir a significação" (p. 508; verbete: tradução). Desse ponto de vista, assim como na semiótica cognitiva, a discursiva vislumbra a tradução como condição sine qua non para a sobrevivência e a vida social humana, sendo que o corpo interessa menos como fonte biológica do que como ferramenta humana, objeto flexível capaz de significar a intencionalidade do sujeito através de capacidades não apenas cognitivas, mas motoras e cinéticas recortadas culturalmente por um grupo social.

A semiótica narrativo-discursiva também propõe um mundo natural e um sujeito inserido nesse mundo, mas aquele será sempre expressivo, uma série de estímulos visuais, acústicos, olfativos, táteis e olfativos, que para serem discriminados e compreendidos, deverão passar por uma estrutura narrativo-discursiva fórica, gradual, de aumentos e diminuições, continuidades e descontinuidades de formas e conteúdos que possibilitam a semiose. O mundo natural sensível, assim, torna-se a partir do discurso, sendo criado em vários tipos de conjuntos significantes realizados pelos homens em contato com esse mundo. Os autores do Dicionário de Semiótica (doravante DS) entendem o mundo natural como o parecer segundo o qual o universo se apresenta ao homem como um conjunto de qualidades sensíveis, dotado de certa organização, muitas vezes designado como "mundo do senso comum". Esse mundo "é uma estrutura discursiva, pois se apresenta no quadro da relação sujeito / objeto: é o enunciado construído pelo sujeito humano e decifrável por ele" (p. 324; verbete: mundo natural). Do ponto de vista gestual, o mundo comum é também tocado, penetrado, atuado.

Como as relações entre os mundos naturais (os vários criados, sem distinção entre os "reais" e os "fantásticos") e as línguas naturais são estreitas, de modo que estas enformam e categorizam aqueles, o mundo natural traduz-se em linguagem figurativa, cujas figuras, encontradas no plano do conteúdo das línguas naturais são feitas de 'qualidades sensíveis' do mundo e agem diretamente, sem mediação linguística, sobre o homem” (p. 325): assim, 
enquanto Greimas e Courtés admitem um mundo natural sensível, no qual o homem está inserido, eles rechaçam a ideia de que as linguagens humanas sejam sua extensão natural, mas criadas culturalmente à medida que o homem se mescla naquilo que entende como natureza. $\mathrm{O}$ mundo natural, da mesma forma que as línguas naturais, não deve ser confundido com uma semiótica particular, mas um lugar de elaboração e exercício de várias semióticas que supondo possuírem propriedades comuns, podem ser tratadas como uma macrossemiótica. Assim, comprova-se que a atividade humana sobre o mundo, o que a biologia denomina adaptação, pode ser vista como uma capacidade de tradução intersemiótica possibilitada pelas línguas naturais, mediando expressão natural e conteúdo cultural.

Dentro dessa macrossemiótica, o homem opera sentidos. Greimas e Courtés vislumbram significações humanas que falam do mundo tal como ele aparece, as visões significativas, e as significações que se referem ao homem tal como ele se comporta e se significa para si e para os outros, as práticas significantes. Ao primeiro grupo pertenceriam as etnotaxionomias, as semióticas dos objetos, dos processos naturais e do espaço; ao segundo, a gestualidade, a proxêmica e os comportamentos humanos programados orientados para um fim, estereotipados, analisáveis como discursos do mundo natural. A partir das práticas significantes, parece haver um primeiro impulso dos semioticistas para se pensar a práxis enunciativa.

Como a semiótica cognitiva, a semiótica narrativo-discursiva entende as línguas naturais como um tipo de sentido, não sendo o único. Assim, se de um lado o mundo natural é discursivo, isso não implica que ele seja simplesmente falado, e mesmo que a língua verbal seja capaz de explicitar categorias semânticas abstratas (universais), o homem produz inúmeros tipos de conjuntos significantes, de modo que "as organizações semióticas reconhecidas no mundo natural são determinadas pelo caráter implícito dessas categorias" (GREIMAS; COURTÉS, 2011 [1979], p. 325). Vimos que Jakobson, ao propor a ideia de tradução intersemiótica, baseada na ideia de signo, sugere o desaparecimento do signo verbal na tradução intersemiótica. Segundo a semiótica narrativo-discursiva, no entanto, a linguagem verbal poderia ser vista como sistema que explica os sistemas não-verbais.

Assim, deve-se ter cautela em não se confundir a capacidade humana de explicar o mundo verbalmente, com os diversos tipos de conjuntos significantes produzidos pelo homem, sejam eles verbais, não verbais e complexos, ou sincréticos. Enquanto a semiótica de linha francesa reconhece nas linguagens verbais um estatuto privilegiado em relação às outras, pelo fato de serem línguas de chegada, no processo de tradução, a todas as outras semióticas, apresentando-se como macrossemióticas que traduzem outras macrossemióticas, ou "semióticas construídas a partir de mundos naturais, ela igualmente entende que, por haver 
textos compostos por línguas não-naturais (a música, a pintura, o cinema, a arquitetura, as línguas de sinais etc.), o reconhecimento privilegiado dessas línguas "não autoriza sua reificação como lugares do 'sentido construído': a significação é primeiramente uma atividade antes de ser seu resultado" (GREIMAS; COURTÉS, 2011 [1979], p. 509; verbete: tradução).

Entendida pela semiótica discursiva como atividade cognitiva que opera a passagem de um enunciado dado em outro enunciado considerado como equivalente (p. 508), a tradução pressupõe uma enunciação e um enunciador, um discurso e uma narrativa mínima, e sendo baseada em outro conjunto de enunciados, o texto alvo opera uma "equivalência de sentido". Segundo Greimas e Courtés, na qualidade de atividade semiótica, a tradução pode ser decomposta em um fazer interpretativo do texto a quo, de um lado, que é o texto fonte imaginado como o início do sentido do texto adaptado, e em um fazer produtor do texto ad quem, do outro, o texto alvo, visto como o resultado do fazer interpretativo. A distinção permite entender o texto fonte, a adaptação propriamente dita, como mais superficial e concreto, e alicerçado sobre um texto fonte, mais fundamental e abstrato, o texto ab quo. Ao mesmo tempo, o enunciador do texto ad quem é enunciatário do texto a quo.

A partir dessas considerações, podemos argumentar que esse tipo de semiótica prevê um sujeito inserido em um mundo natural e sensível onde várias semióticas ocorrem concomitantemente, suportadas por operações de tradução. Porém, diferentemente da semiótica cognitiva, prefere debruçar-se sobre o discurso verbal e não-verbal como "homologador" do real, entendido aqui como conjuntos de formas discursivas, ou conjuntos significantes que constroem o inteligível, o perceptível e o sensível a partir de um enunciador minimamente coagido. Ao mesmo tempo, cada conjunto significante deixa uma pista no mundo natural, marcando-o como traço e impressão de ordem cultural.

Segundo Mancini (2018), uma adaptação é um projeto enunciativo, um conjunto de escolhas e estratégias das quais um enunciador lança mão, no processo de textualização, visando a otimizar seu fazer persuasivo em relação ao fazer interpretativo de um enunciatário previsto no próprio modo de enunciar. A semiótica acredita que a discussão sobre a fidelidade é fundada pelas modalidades de ser e parecer, usadas para construir discursos veridictórios, que podem ser mais ou menos tonificadas. Mancini (2018) lembra que:

A discussão da fidelidade, ou aqui do efeito de fidelidade, retoma o problema da gradação das modalidades veridictórias, uma vez que notamos que algumas estratégias do tradutor na concepção da obra traduzida / adaptada criam um parecer mais facilmente detectável de identidade com a obra de partida. A manutenção figurativa, por exemplo, faz com que a obra de chegada pareça mais próxima à obra de partida e é comumente tratada como "mais fiel", 
mesmo que, na verdade, outros elementos da estratégia do original, como foco narrativo, jogo de vozes e principalmente modos de engajamento sensorial, sejam desfeitos (p. 25).

A discussão da fidelidade na adaptação desperta interesse para a semiótica, pois é uma atividade de reformular categorias do plano do conteúdo em diferentes linguagens, que podem ser naturais ou artificiais, como o cinema. No nosso caso, entre a linguagem verbal e a audiovisual, podemos pensar na ideia de um tipo muito peculiar de práxis enunciativa, que deve manipular conteúdos realizados em discursos verbais e não verbais para compor outro discursos mais ou menos equivalentes ao primeiro, em uma atividade que deve se ajustar a coerções não apenas da linguagem e as ideologias que transmite, mas também a suportes materiais. Podemos dizer que a adaptação atualiza um texto literário e o realiza em outro enunciado.

Do ponto de vista modal, as coerções semióticas não dependem nem do querer-fazer, e nem do dever-fazer do sujeito, mas de um querer-dever-ser (GREIMAS; COURTÉS, 2011 [1979], p. 63), o que demonstra a tradução como uma imbricação das modalidades veridictória volitiva e alética. Mancini (2018) entende que as coerções podem ser relativas "às características de um modo prototípico de dispor o conteúdo em diferentes linguagens, as potencialidades sensoriais distintas dos planos de expressão envolvidos, no caso dos objetos sincréticos, e relativas a um novo perfil de enunciatário buscado na obra de chegada" (p. 25): são de ordem discursivo narrativa, ética e estética.

A partir da ideia de tensividade e práxis de conjuntos significantes, a semiótica de linha francesa contemporânea estabelece um modelo que possa dar conta da produção geral do sentido de todos os textos, inclusive dos textos traduzidos, tanto a partir de um ponto de vista narrativo como de um ponto de vista tensivo. De um lado, o sentido é entendido como formado em camadas, com estruturas semionarrativas e discursivas que devem ser mais ou menos gradualmente descontinuadas; de outro, é atualizado no discurso de outros enunciadores para realizar outros sentidos que coloquem o homem em conjunção com o "real". Da ideia de texto biplanar e estruturado em movimento no discurso, produz-se a ideia de gradação tensiva narrativo-discursiva, que também anima a ideia de subjetividade, de modo que longe de imaginar um texto "frio" e estático, a semiótica contemporânea faz justamente o contrário, supondo nele uma série de tensões que o animam, confirmando o seu pertencimento legítimo ao ritmo do mundo humano, natural e sensível.

É justamente porque todo o texto é uma estrutura inteligível e sensível, que o enunciador consegue fabricar um corpo imerso no "real" do mundo textual, em um tipo de pulsação discursiva que projetas acelerações e desacelerações, continuidades e descontinuidades no 
tempo e no espaço, projetando emoções e sinestesias de todas as ordens, em um conjunto de sentido igualmente sócio-simbólico, que constrói conteúdos que podem ser mais ou menos esperados ou surpreendentes. Do ponto de vista do sentido como elaboração discursiva e narrativa do mundo natural e cultural, organizador de comportamentos e práticas sociais, a semiótica narrativo-discursiva permite observar a sua produção, e consequentemente sua tradução, como narrativas mitopóeticas "vividas", ou seja, relacionadas a ações, crenças e saberes compartilhados e praticados em comunidade, e que possuem um caráter menos lógico e científico do que sublógico ${ }^{2}$ e metafórico, admitindo mudanças e redefinições constantes, ou seja, adaptações de sentido em novas formas e conteúdos.

\section{Questões teóricas: semiótica greimasiana e pós-greimasiana}

Depois de termos explanado o motivo da denominação semiótica "narrativodiscursiva", que associamos à uma lógica semântica e à uma prática tensiva do discurso, convém elucidarmos alguns pontos sobre o uso desses termos em nossa discussão, que podem ser consideradas antagônicos e excludentes, por serem vistos como mais "racionais" e mais "sensíveis", de modo que pareceriam incompatíveis dentro de uma mesma análise. Como o nosso ponto de vista é integrador, no sentido de acreditarmos que os dois tipos de semióticas não apenas convergem, mas contribuem para uma observação mais apurada da construção do sentido, discutiremos brevemente possibilidades de interação entre a semiótica greimasiana e a pós-greimasiana, que juntas são os pressupostos teóricos para as nossas análises.

A semiótica greimasiana explica a construção de sentido a partir de uma ferramenta epistêmica denominada percurso gerativo, um caminho abstrato do sentido que pretende ser ideal e aplicável a qualquer texto, e que é independente das línguas naturais, sendo "anterior a elas, ou dos mundos naturais em que esta ou aquela semiótica pode a seguir investir-se par manifestar-se" (GREIMAS; COURTÉS, 2011 [1979], p. 235; verbete: gerativo), e aplicável a todo o tipo de conjunto significante humano. O percurso é formado de duas estruturas, as semionarrativas e as discursivas: as primeiras constituem o nível mais abstrato do percurso ( $a$ quo), e apresentam-se sob a forma de uma gramática semiótica e narrativa, que comportam dois componentes - sintático e semântico, e dois níveis de profundidade: uma sintaxe e uma

\footnotetext{
2 Tatit (2007) explica que a sublógica da linguagem consiste em que ela dispõe de recursos que englobam elementos que deveriam ficar separados, diferentemente do que acontece no pensamento estritamente lógico, que seleciona uma ou outra coisa. No pensamento sublógico pode-se ter, de um lado, um elemento mais destacado, e do outro, todos juntos. Essa triagem sublógica é de caráter tensivo: a concentração seria um termo intensivo, uma disjunção; e a propagação um termo extensivo, uma conjunção (p. 359).
} 
semântica fundamental (no nível profundo), e uma sintaxe e semântica narrativa (no nível de superfície); as segundas, menos profundas, são encarregadas de retomar as estruturas semióticas de superfície e colocá-las em discurso, fazendo-as passar pela instância da enunciação. O componente sintático dessa estrutura, ou sintaxe discursiva, é encarregado da discursivização das estruturas narrativas, que comporta os subcomponentes actorialiação, temporalização $e$ espacialização, utilizados para produzir discursos abstratos e figurativos. No componente semântico operam tematizações e figurativizações, que completam o sentido do texto. Assim:

Figura 1 - O percurso gerativo de sentido

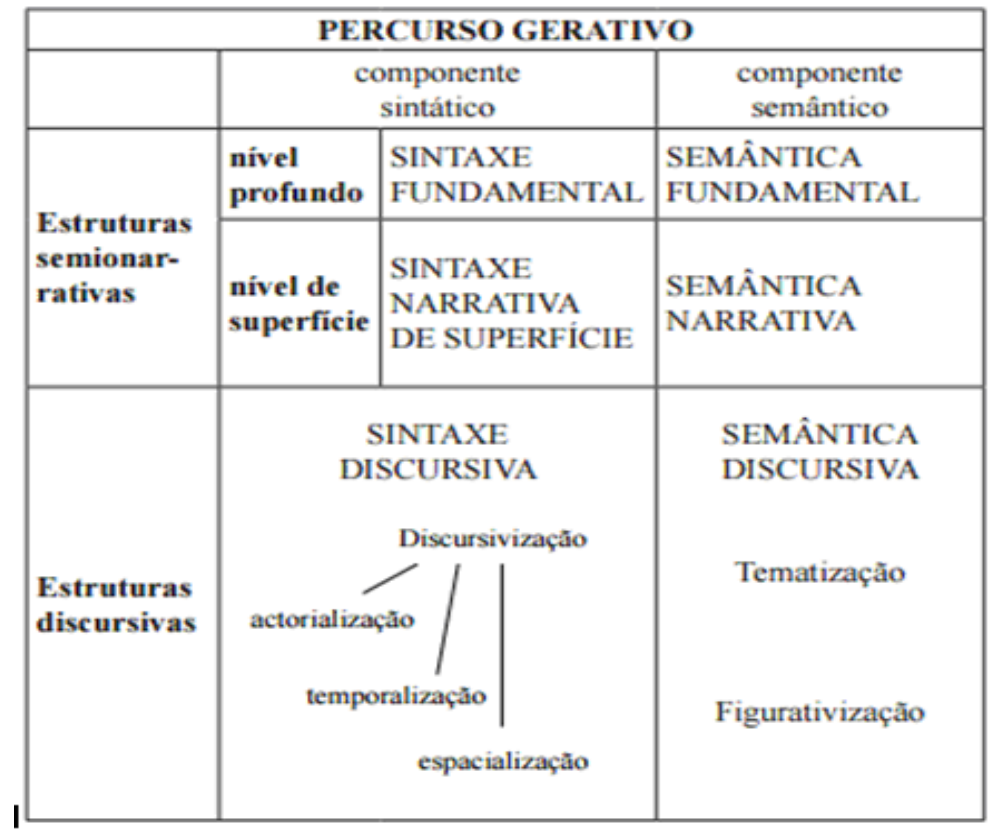

Fonte: Greimas e Courtés (2011, p. 235).

O percurso gerativo foi pensado, entre outras coisas, como uma maneira de observar a construção de sentido do homem linguageiro, ativo e passional no mundo, a partir de um sistema fixo e mais abstrato de categorias semânticas: as estruturas semionarrativas são compostas de um nível fundamental formado de semas linguísticos universais mínimos que entram em relação de afirmação e negação, contrariedade e contradição (S1 e S2 e não-S1 e não-S2) e que, em chave antropológica estrutural, uma das vertentes da semiótica greimasiana, são relacionados a noções abstratas, primitivas e universais da espécie humana, tais como vida, natureza, liberdade, identidade etc, e suas ideias contrárias e contraditórias (não-vida, nãomorte etc.), e também aos quatro elementos naturais (e ligados à dualidade vida / morte e natureza / cultura), que são o ar, a terra, a água e o fogo. Tal estrutura operatória elementar do 
sentido, segundo Greimas ${ }^{3}$, é apenas uma de suas possibilidades (1976 apud LEITE, 2019, p. 30).

A estrutura semionarrativa superficial compõe um nível com actantes destinadores que manipula sujeitos e os modaliza através de combinações de semas modais relacionados ao querer, dever, poder, saber, ser e fazer, para atingirem a conjunção com objetos-valor, em uma busca que é ativa e passional e será posteriormente sancionada. Na estrutura discursiva projetam-se atores, que não precisam ser necessariamente humanos, mas podem ser personificados, e espaços, tempos, temas e figuras são desenvolvidos para completar a encenação do ser no mundo.

As estruturas discursivas, como articulam operações de actorialiação, temporalização e espacialização, também concentram operações retóricas e sintáticas relacionadas à construção dessas categorias em todas as linguagens, abrangendo as projeções da instância da enunciação no enunciado, controladas pela breagem, e as relações entre enunciador e enunciatário, ou seja, a argumentação. Na sintaxe discursiva a oposição entre enunciado e enunciação são expressas nos usos retóricos da linguagem, tais como a ironia, o lítote, a preterição, a reticência, o eufemismo e a hipérbole presentes em todos os conjuntos significantes, os verbais e os não verbais. Da mesma maneira, do ponto de vista da semântica discursiva, relacionada à tematização e à figurativização, operações retóricas como a metáfora, a metonímia e a antítese são ativadas, além das operações isotópicas relacionadas à manutenção de percursos temáticos e figurativos que dão coesão ao discurso.

Dessa maneira observamos, de um lado, como o percurso prevê a construção de sentido a partir de um nível fundamental e mínimo, sintático e semântico, que opera negações e afirmações ao qual outras formas sintáticas e semânticas mais complexas são adicionadas, até que se completam na figurativização discursiva para produzirem um texto coerente e pleno de sentido; de outro, como esse mesmo sentido semântico é imaginado a partir de uma operação semântico-narrativa de caráter mitológico, comum a todos os grupos humanos, sendo relativa à noção de sobrevivência e cultura. Greimas e Courtés, discutindo a relação entre o percurso gerativo e a mitologia, entendem a última como um conjunto de "pré-ocupações" humanas básicas que são constantes em todos os discursos, ou seja, um componente abstrato e gerador do sentido praticado de diferentes maneiras por macro e micro sociedades. Silva (1995) entende que, segundo Greimas, o estudo da mitologia insere-se nos quadros das pesquisas sobre o "ça

\footnotetext{
${ }^{3}$ GREIMAS, Algirdas Julien. Entretien avec A. J. Greimas sur les structures élémentaires de signification. In: F. Nef, Structures elementaires de la signification, p. 18-26. Bruxelles: Editions Complexe, 1976.
} 
symbolise", o que implica reconhecer, como organização semiótica profunda, um nível mítico do discurso, cujas estruturas são comparáveis às que regem os discursos poéticos e oníricos (p. $56)$.

A semiótica pós-greimasiana produz duas vertentes, uma de ordem tensiva e o outro de ordem mais prática, que dialogam e procuram entender o sentido de outra maneira. De modo geral, a tensiva recorta o texto do ponto de vista temporal, das continuidades e descontinuidades dos elementos que participam do sentido daquele conjunto significante. Como todo o texto produz tempo e espaço, tanto enquanto enunciado como enunciação, é o andamento e a tonicidade do discurso que os controlam. Ao mesmo tempo, como a noção de tempo e espaço pode ser adotada para qualquer texto, seja ele verbal e não-verbal, sonoro ou plástico, e fixo e em movimento, pode-se afirmar que todo conjunto significante é tensivo, ou seja, suas unidades constitutivas desenvolvem-se no tempo, entre oscilações de continuidades e descontinuidades.

Do ponto de vista pós-greimasiano o sentido é visto como operação menos polarizada, mais dinâmica e de maneira mais ou menos gradual, na qual combinam-se elementos de sentido de maneira mais ou menos intensa e continua, e que lida não apenas com os contrários que possibilitam o sentido, mas os contrários de contrários. Como prática, ou práxis, o discurso é construído e desconstruído continuamente, em estratégias que são intertextuais, "bricoladas", e igualmente sensíveis, pois articulam elementos de outros discursos de maneira mais ou menos intensa e contínua.

Assim, à semiótica greimasiana, que lida com descontinuidades, valores, oposições e diferenças do sentido, acrescenta-se a pós-greimasiana, que se debruça sobre as continuidades, gradações, valências, complexidades e dependências do texto, procurando analisar o sentido a partir de entidades dinâmicas e instáveis, em um projeto no qual a observação de direções vetoriais em termos de aumentos, diminuições tornam-se essenciais para a construção "do devir da intensidade, ascendente ou declinante" (ZILBERBERG, 2006, p. 167). Como o encadeamento de estados contínuos e descontínuos de elementos evocam a noção de transformação, e uma vez que a semiótica narrativa preocupa-se primordialmente com a ação do sujeito (manipulação, busca e conjunção), pode-se presumir que a ideia de transformação é um fator preponderante para a construção do sentido, existindo tanto como mais e menos do mesmo, assim como narratividade.

Apesar de a semiótica tensiva ser associada ao "sensível" e ao "corpo do sujeito" que enuncia, convém entendermos que tais noções não devem ser vinculadas às ciências psicológicas ou biológicas, mantendo-se estritamente dentro do campo da linguagem, do texto e do discurso, entendido como um conjunto de articulações de sentido arquitetadas nos mais 
diferentes conjuntos significantes imaginados pelo homem. Assim, a tensividade deve ser tomada como operação discursiva e temporal que articula intencionalmente as continuações e paradas dos vários elementos que compõem o sentido, em seu plano do conteúdo e expressão, de modo que o "sensível" se torna uma construção figurada e balizada socialmente, não existindo em uma "realidade crua" desprovida de uma leitura cultural condicionante, e nem antes da linguagem, sendo experimentando enquanto é significado no texto-discurso. Segundo Tatit (2007), uma forma de se entender a afetividade é o andamento, pois nele estão as variações de velocidade, aceleração e desaceleração, os retardos e as antecipações, ou seja, categorias temporais que se relacionam com o conteúdo, e tem a ver com questões de espera e surpresa (p. 376).

Segundo Leite (2019), as operações tensivas de aumentos e diminuições de intensidades e extensões que controlam os elementos significantes do discurso ocorrem em outro nível do sentido, mais englobante e superior, o que corrobora a ideia da existência de um percurso composto em camadas mais abstratas e profundas, de modo que as fronteiras tensivas entre esses elementos do sentido não se auto-delimitam, mas são delimitadas, sendo razoável supor uma descontinuização do descontínuo, "em que unidades graduais surgem pela aplicação de uma diferença de outro nível, que promove a coalescência de fronteiras entre unidades discretas” (p. 29). Dessa maneira, a tensão torna-se menos a aplicação do gradual sobre a oposição do que uma graduação da diferença por outra diferença, em uma questão a ser resolvida num nível de transposição metalinguística, e não em um nível substancial ou sensível propriamente dito: assim o "sensível" passa a ser da ordem do inteligível, e sua existência é afirmada minimamente pelo quadrado semiótico, que representa apenas um tipo de figuração do sentido, mas pode ser ampliado ou alterado.

Apresentando-se como forma dinâmica de exploração do texto, a semiótica tensiva discute a foria como energia que rege a extensidade do sentido, transformado-o em operações discursivas graduais tônicas e átonas, de aumentos e diminuições de intensidades, e possuidor de forças sobre e subcontrárias: ela seria a base da aspectualização, tendo precedência lógica em relação aos níveis do percurso gerativo; a continuidade fórica seria concebida como uma sequência entoativa ora destinada à tensão, ora ao relaxamento, semelhante à cadencia rítmicomelódica da frase, e também homologável às noções de intenso e extenso (TATIT, 2016, p. 20). Podendo ser associada às operações de afirmações e negações de continuidades, a semiótica tensiva dialoga com o percurso gerativo, que propõe semas de caráter eufóricos e disfóricos, e seus negativos e subcontrários, sugerindo uma operação de graduação semântica mais fina, que também afeta a organização expressiva do texto. 
O ponto de vista tensivo emerge do modelo da silabação comentado por Saussure, a partir da observação de que a consecução silábica se dá pela alternância de seus constituintes fundamentais de implosão e explosão ao longo da cadeia falada. A passagem da implosão a explosão provoca o efeito de fronteira silábica, de fechamento seguido de abertura de sonoridade, que pode ser cifrado em quantificações de somente menos ao menos menos ou diretamente ao mais mais. A passagem da explosão à implosão representa a transição do somente mais ao menos mais ou diretamente ao mais menos.

Zilberberg conceberá essa dinâmica como aspectualização profunda, mas também como expressão prosódica do que ocorre nas alternâncias direcionais do conteúdo, formuladas como esquemas ascendentes e descendentes, e nas correlações inversas entre intensidade e extensidade, perfazendo uma dinâmica tensiva que vai da saturação à extinção e vice-versa (TATIT, 2016, p. 22). Assim:

Figura 2 - Direções e cifras tensivas

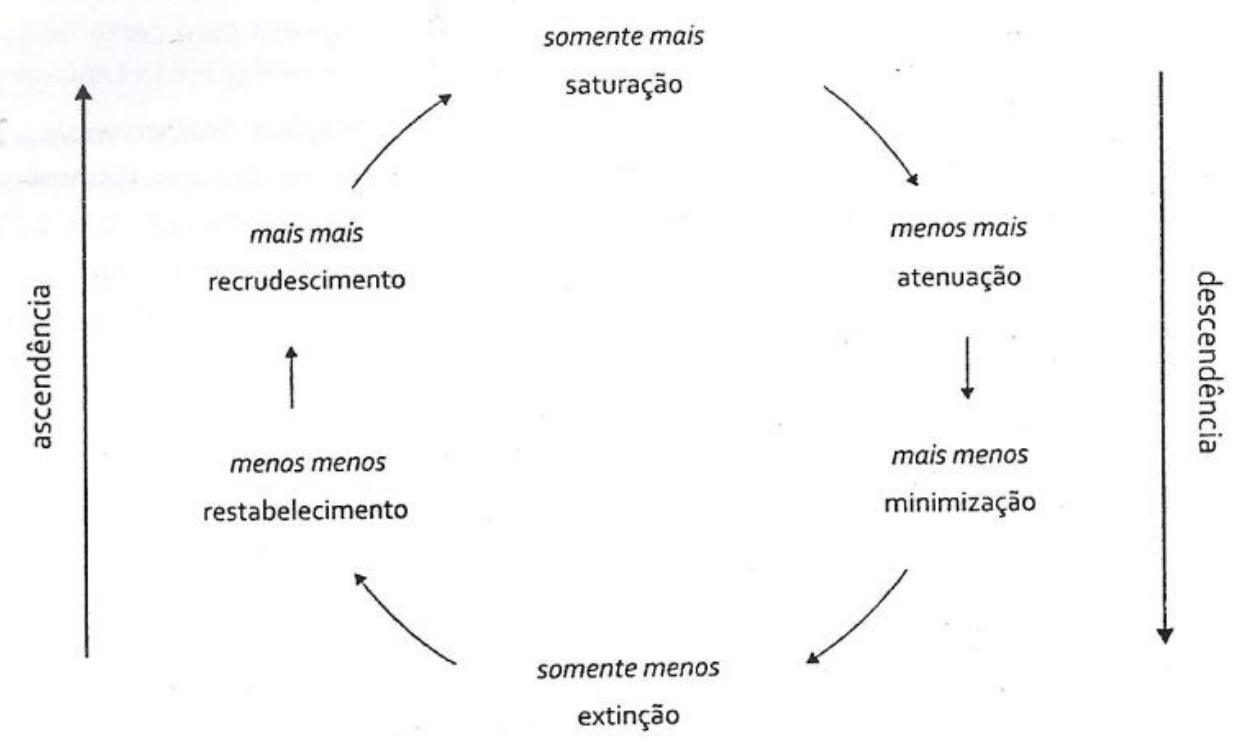

Fonte: Tatit (2016, p. 29).

O plano da expressão, de acordo com as regras da silabação, corresponderia à fase explosiva, em que ocorre a abertura da sonoridade. Do ponto de vista prosódico ocorreria a modulação. Tais processos descreveriam o esquema descendente, cujas operações extensivas contribuiriam para diluir o choque provocado pelo acontecimento que irrompe com relevância na vida do sujeito. As relações de acento e modulação corresponderiam ao assomo e à resolução, e a complexidade tensiva da silabação revelaria que a implosão (acento ou assomo) caracterizar-se-ia por concentrar a extensidade e aumentar a intensidade, enquanto a explosão (modulação ou resolução) retrataria a expansão da extensidade como forma de diluição da 
rapidez da tonicidade. Enquanto a prosódia regularia o ritmo entre acento e modulação, a consistência regularia a sintaxe entre intensidade e extensidade (p. 23-24).

A partir da ideia das dinâmicas entre implosão e explosão imagina-se que a primeira prevê a parada, definindo na expressão o acento, e no conteúdo os valores de absoluto, e também o ápice da direção ascendente em ambos os planos; e a segunda a parada da parada, definindo na expressão a resolução, e no conteúdo os valores de universo. Assim, esse tipo de semiótica preocupa-se menos com os contrários do que com suas relações, ou seja, as transformações graduais que os geram e revelam continuações estruturais mais ou menos descontinuadas. Sendo definida dentro de um recorte semiótico que tenta entender a construção cognitiva do evento, ou acontecimento, ou seja, um fato significado pelo discurso como surpreendente e inesperado, a semiótica tensiva mostra o papel relevante do tempo, a partir do qual todos os elementos de sentido de um texto são analisados em termos das intensidades e extensidades de seus vetores, relacionados também a aumentos, diminuições e descontinuações de um caráter de "existência" como forma estável, ou seja, como "estado tensivo no tempo".

Em outro nível teórico, mais antropológico e sócio-discursivo, a semiótica pósgreimasiana entende a tensividade como categoria que engloba a interação de duas dimensões humanas vistas como universais e gerais, e que são detectáveis a partir do discurso: a da afetividade, dos estados de sentimento e da sensibilidade; e a dos estados de coisas, da inteligibilidade (ZILBERBERG, 2006, p. 167). Tais articulações tensivas são valências, e a associação entre elas produz um valor. A intensidade, relacionada ao "sensível", é articulada em duas subdimensões, a tonicidade e o andamento; e a extensidade, controlada pela intensidade e associada ao inteligível, subdivide-se em espaço e tempo.

Fiorin (2016) vê na semiótica tensiva um novo ponto de vista sobre a retórica, criadora de tropos intensos e tônicos, de maneira que tanto na atenuação como na minimização (decadência), como no restabelecimento e recrudescimento (ascendência), mecanismos escalares, tais como lítotes, eufemismo, ironia e hipérbole, ou processos, tais como o anacronismo, a inércia, a desaceleração, a extenução, a obsolescência, a efemeridade, a ubiquidade etc. poderiam ser descritos com mais eficiência a partir das cifras tensivas de mais e menos (p. 160). Desse ponto de vista, a tensividade interessa como discriminação de operações discursivas, a partir do qual o homem social e linguageiro estabelece modos de junção, existência e eficiência com um mundo expressivo.

Utilizando a perspectiva tensiva, Zilberberg formula um quadrado semiótico fórico que articula no nível fundamental os termos contrários continuação e parada, e os subcontrários parada da continuação e parada da parada (ZILBERBERG, 2006, p. 161), propondo um nível 
na produção gerativa de sentido reservado ao fazer missivo, onde "teríamos as escolhas missivas do enunciador, contemplando tanto o fazer remissivo, com suas paradas, concentrações e consciência temporal (espera ou reminiscência), quanto o fazer emissivo, com suas difusões, retomadas do curso narrativo e ocupações espaciais" (p. 20). Dessa maneira, os fazeres emissivos e remissivos se encarregariam dos aspectos incoativos, durativos e terminativos das modalidades de base, do percurso dos vários actantes assim como dos processos discursivos ${ }^{4}$. Do ponto de vista tensivo da narrativa, se o antissujeito cria uma parada para o sujeito da busca, o destinador vai estabelecer a parada da parada. Ao mesmo tempo, o destinador só tem o sentimento de progresso a partir do antissujeito, senão parece que o sujeito nada conquistou. Necessitando da descontinuidade imposta pelo antissujeito para construir sua continuidade (TATIT, 2007, p. 369), o destinador existe em relação fórica com aquele.

A partir do discurso "sensível" o sujeito adquire um campo de presença tensivo, sendo fruto de uma dicotomia relacionada à tensão da inteligibilidade do acontecimento vs. rotina: a primeira aponta para o discurso da surpresa e da intensidade (relacionada aos valores de absoluto), e a segunda para o discurso da espera, do exercício ou do estado, e coloca-se dentro da extensidade (relacionada a valores do universo) ${ }^{5}$. O campo de presença discursivo é construído a partir das modalizações de existência, categorizadas em virtualização, aspectualização, realização e potencialização, que corresponderão a uma maneira de o discurso controlar a "foria", cujo devir será modulado pelas variações de tonicidade discursiva.

Os modos de existência fornecem uma sintaxe canônica que cruza dois percursos: a inanidade (a potencialização) constitui uma perda de densidade existencial, provocada pela anulação do foco, que conduz da presença (realizante) à ausência (virtualizante); inversamente, a perda (atualizante) proporciona um ganho de densidade existencial, devido à intensidade do foco, no caminho que leva da ausência à presença. Os dois percursos podem ser representados, respectivamente, como a saída e a entrada em relação ao domínio perceptivo, podendo ser vistos como cíclicos, intensos e extensos. Assim:

\footnotetext{
${ }^{4}$ Da mesma forma Tatit (2016) lembra que os trechos literários descritos por Greimas no Da Imperfeição retratam o momento implosivo, o assomo, que fratura o cotidiano do sujeito realizando uma parada e pede imediata resolução cognitiva, administrada por uma parada da parada.

${ }^{5}$ Apesar de os teóricos terem desenvolvido essas noções conjuntamente no livro Tensão e Significação (2001) suas abordagens e nomenclaturas diferem quando tratadas separadamente. Para a nossa discussão, e sempre que podemos, compomos as duas.
} 
Figura 3 - O campo de presença e a tonicidade perspectiva
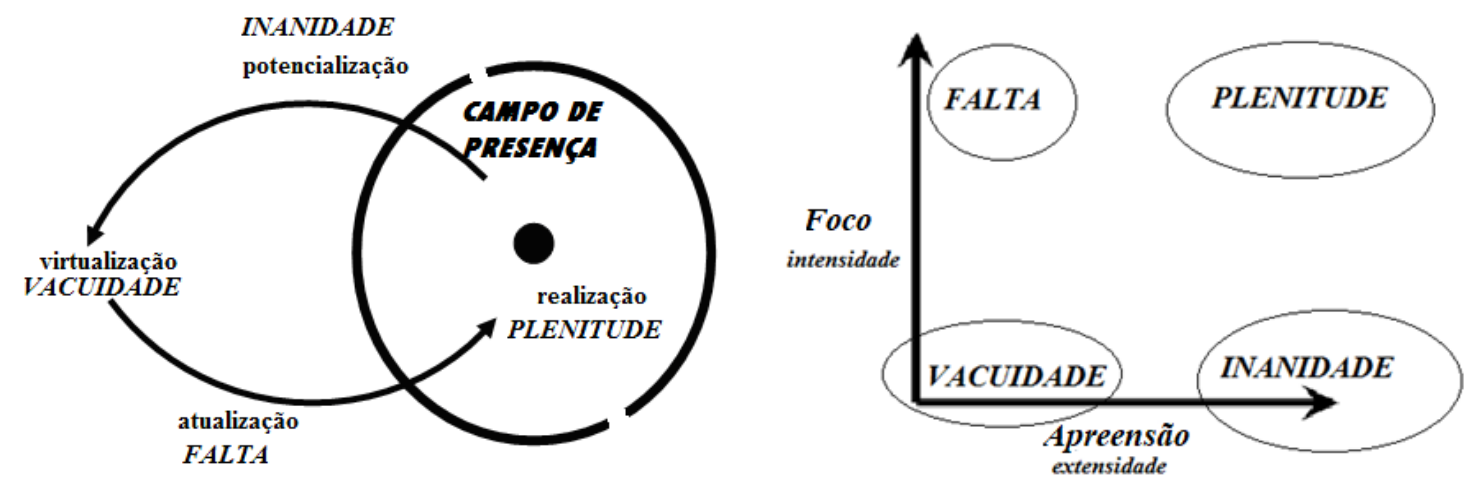

Fonte: Fontanille, Zilberberg (2001, p. 135 - 196).

Partindo da noção discursiva de campo de presença e da ideia de sujeito da surpresa e da espera, Zilberberg (2011) imagina dois modos semióticos básicos de discurso, dois regimes gerais de sentido, equivalentes a dois estilos enunciativos elementares à produção e à assimilação de sentido: um de natureza concessiva, o acontecimento; e outro de natureza implicativa, o pervir. O primeiro é relacionado ao inesperado, à surpresa, ao que sobrevém ao sujeito, que apenas foca um objeto sem estar pronto ou preparado para apreendê-lo, sendo que sua rotina, marcada por valores já discriminados e aceitos, é ameaçada; o segundo relacionado ao que o sujeito espera ou pode controlar e apreender (a apreensão): no primeiro a significação se impõe subitamente, na ordem da exceção, adquirindo o efeito de impacto; no segundo ela se configura progressivamente, respondendo às expectativas do sujeito. A partir daí o acontecimento e a rotina serão modos discursivos de junção do sujeito com o mundo, complementados por modos de eficiência e de existência: o primeiro com o foco e o sobrevir; e o segundo com a apreensão e o pervir.

O modo de eficiência administra a tensão entre o pervir e o sobrevir; o esperado e o inesperado; o de existência, entre o foco e a apreensão, gerenciando as especificidades do ato de percepção instaurado, mais ou menos intensas, ou inversas ou conversas; o de junção, submetido à tensão entre acontecimento e rotina, caracteriza-se pela discursivização da interação acionada, pela lógica que a dirige. Cada modo será organizado por um estilo sintático tensivo: uma sintaxe intensiva, de aumentos e / ou de diminuições da tensão, para o modo de eficiência, fazendo emergir o sobrevir ou o pervir, conforme a variação tensiva atualizada pelo andamento e pela tonicidade; uma sintaxe extensiva, de triagens e / ou misturas dos valores percebidos, para o modo de existência, convocando o sujeito por meio do foco ou da apreensão, segundo a variação tensiva atualizada pela espacialidade e pela temporalidade; e uma sintaxe juntiva, de concessões ou implicações, para o modo de junção, própria à lógica que determina 
a constituição do campo de presença, da interação perceptiva. Na sintaxe juntiva implicativa há uma causa e uma consequência (se a então b); na concessiva, mesmo sem elos implicativos e casuais causados pelo acontecimento, a concessão opera uma junção resistente (apesar de a, não b). Assim:

Figura 4 - Modos e estilos tensivos

\begin{tabular}{|c|c|}
\hline Modos semióticos & Estilos sintáticos \\
\hline $\begin{array}{l}\text { Modos de eficiência } \\
\text { (sobrevir e pervir) }\end{array}$ & $\begin{array}{l}\text { Sintaxe intensiva } \\
\text { Ascendência e Descendência } \\
\text { (mais ou menos) } \\
\text { (intensidade: andamento e tonicidade) }\end{array}$ \\
\hline $\begin{array}{l}\text { Modos de existência } \\
\text { (foco e apreensão) }\end{array}$ & $\begin{array}{l}\text { Sintaxe extensiva } \\
\text { Triagens e Misturas } \\
\text { (mais e menos) } \\
\text { (extensidade: espaço e tempo) }\end{array}$ \\
\hline $\begin{array}{l}\text { Modos de junção } \\
\text { (acontecimento e rotina) }\end{array}$ & $\begin{array}{l}\text { Sintaxe Juntiva } \\
\text { (concessão e implicação) }\end{array}$ \\
\hline
\end{tabular}

Fonte Adaptação de Zilberberg (2012, p. 8).

Cada uma dessas orientações discursivas é dirigida por uma dinâmica tensiva distinta responsável pela determinação de diferentes modos de interação gerados no campo de presença do sujeito. No estilo enunciativo concessivo, do qual resulta o efeito de acontecimento, o sobrevir é constituído por um alto grau de intensidade, próprio a concentração da extensidade do campo de presença no qual atua a percepção do sujeito, acelerando a velocidade de inserção da grandeza semântica em questão, do objeto percebido, que é tonificado ao máximo, causando o efeito de impacto sensível. No estilo implicativo, do qual procede o efeito de rotina, o pervir delineia-se com intensidade compatível à difusão da extensidade do campo de interação, o que desacelera a inserção da grandeza e, consequentemente, sua tonicidade, causando o efeito de estabilidade inteligível, de regra, que rege a atividade perceptiva do sujeito.

Segundo Tatit a ideia de concessão ou pensamento concessivo abre a possibilidade concreta para a gramaticalização do acontecimento, tratado como objeto acidental e inapreensível por leis que estabelecem previsibilidade: o discurso concessivo propõe uma junção 'de fato' nos contextos em que ‘de direito', ela não existe (ZILBERBERG, 2011, p. 27). 
A lógica da concessão permite que as fronteiras do mais e do menos possam ser sempre aumentadas: pode-se recrudescer o recrudescimento e minimizar uma minimização; as combinações menos...mais e mais...menos podem dar origem a formas hiperbólicas e aceleradas de adição e de subtração; pode-se triar uma triagem e misturar uma mistura. A relação entre acontecimento $($ intensidade $=$ sobrevir, foco e concessão) e rotina $($ extensão $=$ pervir, apreensão e implicação) pode ser conversa (quanto mais intensidade mais extensidade, e viceversa) ou inversa (quanto mais intensidade menos extensidade, ou vice-versa).

Vista por Greimas e Courtés em relação ao percurso gerativo (operações entre as estruturas semionarrativas e discursivas), a noção de práxis é revitalizada por Fontanille e Zilberberg, que a relacionam ao aparecimento e desaparecimento dos enunciados e das formas semióticas no campo do discurso ou no acontecimento que constitui o encontro entre o enunciado e a instância que lhe assume. Em Tensão e Significação os semioticistas rediscutem o problema da enunciação a partir da ideia de campo de presença tensivo e da dicotomia presença / ausência e aparecimento / desaparecimento, mostrando que as importâncias para a semiótica dessa visão são sua formulação dêitica e a ideia de que a presença seria o primeiro modo de existência da significação. Do ponto de vista do discurso tensivo praticado, os modos de existência virtualizado, atualizado, realizado e potencializado transformam-se em estágios da dinâmica da práxis enunciativa, que ao realizar o discurso, fornece certo estatuto de realidade aos produtos da atividade da linguagem: "a língua se destaca do mundo natural, mas a práxis enunciativa a reincorpora nele, sem o que os atos de linguagem não teriam qualquer eficiência nesse mundo" (FONTANILLE; ZILBERBERG, 2001, p. 123).

Segundo Fontanille (2008) a práxis administra a presença de grandezas no campo realizado do discurso, convocando ou invocando nele os enunciados que o compõem, assumindo-os mais ou menos e atribuindo-lhes graus de intensidade e certa quantidade; recupera formas esquematizadas pelo uso ou estereótipos e estruturas cristalizadas, reproduzindo-as ou desvirtuando-as, fornecendo-lhes novas significações; e apresenta outras formas e estruturas, inovando de forma explosiva, assumindo-as como singulares ou propondoas para um uso mais amplamente difundido (p. 271). Dessa forma, enquanto o percurso gerativo pode ser visto como um simulacro idealizado da competência enunciativa, permitindo a organização de estruturas virtuais de que a instância de discurso dispõe no momento de enunciar, ele não indica como a enunciação atua, sendo "o simulacro do modo de estocagem dos componentes do sistema e dos produtos de uso, e não o simulacro de sua manifestação" (p. 272). 
A práxis enunciativa é proposta pela semiótica pós-greimasiana como cíclica e interativa, pois extrai formas de um espaço de esquematização para modificá-las e alimentálas; ultrapassa a oposição entre sincronia e diacronia mantendo a ligação entre um determinado estado sincrônico e todos os estados sincrônicos anteriores e posteriores (pancronismo); administra, em termos de presença, o modo de existência das grandezas e dos enunciados que compõem o discurso, apreendendo-os no estágio virtual (enquanto entidades pertencentes a um sistema, e dormentes), atualizando-os (enquanto seres de linguagem e de discurso), realizandoos (enquanto expressões) e potencializando-os (enquanto produtos de uso). Assim, para que em um mesmo discurso coabitem grandezas de estatutos diferentes, elas devem derivar de modos de existência igualmente diferentes, que convertem a co-presença em uma espessura discursiva e projetam articulações modais sobre o campo discursivo. Assim, a práxis pode ser esquematizada da seguinte maneira:

Figura 5 - Esquema da práxis enunciativa

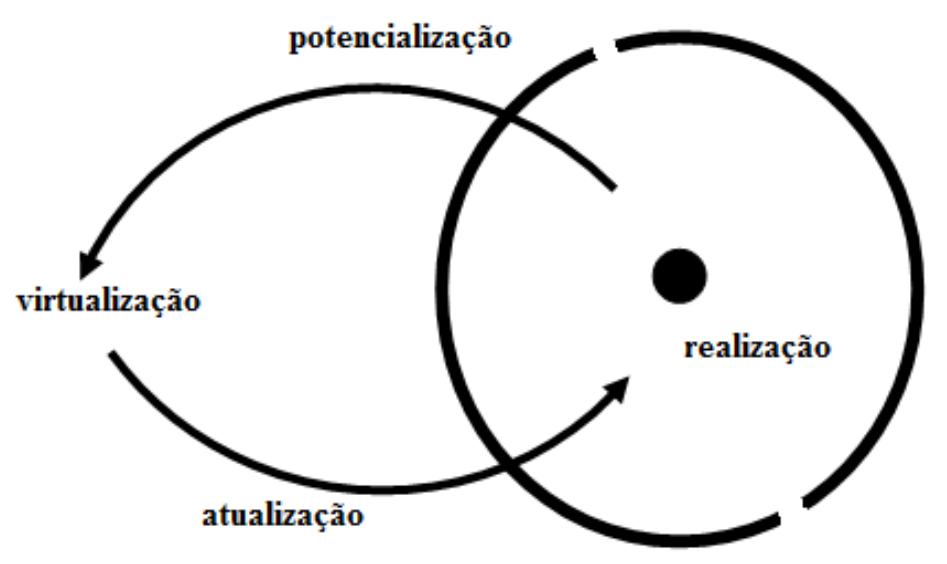

Fonte: Fontanille (2008, p. 275).

O ato produtor do discurso de significação apresenta-se, em princípio, como uma tensão entre o virtual (o que está fora do campo do discurso), e o realizado (o centro do campo do discurso), passando pela mediação do modo atualizado. Outra tensão leva do modo realizado ao potencializado (a passagem da fronteira no sentido contrário). O modo virtual corresponde ao das estruturas de um sistema subjacente, da competência formal disponível no momento da produção do sentido; o atualizado é o das formas que advém no discurso e das condições para que elas advenham; o realizado é o modo pelo qual a enunciação faz as formas do discurso encontrarem-se com a realidade material do plano da expressão (coerção), realidade do mundo natural e do mundo sensível no caso do plano do conteúdo. Inversamente, dá-se a dimensão retórica dos atos do discurso: 
Uma forma é considerada potencializada quando sua difusão ou reconhecimento são tais que ela pode figurar como tópos do discurso (lugar comum ou motivo, disponíveis para outras convocações); o modo virtualizado é o das grandezas que servem de segundo plano ao funcionamento das figuras do discurso: o ato semiótico consiste em realizar uma figura, em remeter uma outra figura ao estado virtualizado e em colocá-las em interação de modo que, no momento da interpretação, o enunciatário seja conduzido a ir e vir de uma figura à outra (FONTANILLE, 2008, p. 276).

Segundo Fiorin (2010), a partir da ideia do percurso e da práxis a enunciação é determinada por dois tipos de coerção: a do sistema de linguagem e o das fronteiras de natureza sóciocultural impostas por hábitos, ritualizações, esquemas, gêneros, fraseologia, discursos sociais, etc, de modo que a enunciação individual não é independente de enunciados coletivos que a precederam e a tornaram possível, e que os usos sedimentados da linguagem, como resultado da história, determinam todo ato linguístico. Quando a enunciação ocorre, o sujeito da enunciação convoca, atualiza, repete, reitera algo "já dado" (discursos, gêneros, modos de falar, etc.), mas também revoga, recusa, renova e transforma. Apesar de existir um domínio impessoal que governa a enunciação individual, ela rompe qualquer sedimentação de sentido, criando práticas inovativas. De acordo com a semiótica discursiva, os sujeitos manipulam os enunciados a partir da amplificação, desdobramento, somação e atenuação; os objetos, por sua vez, ou discursos, são transformados e atingem o seu devir como distorções, flutações, remanejamentos e revoluções.

As discussões geradas por ambas as semióticas em relação ao texto, que são de ordem cognitiva, tensiva e prática, podem ser reconhecidas em teorias estéticas, narratológicas, literárias e linguísticas, que tratam do ritmo e da intertextualidade e revelam que essas categorias estão presentes em todos os textos. A contribuição da semiótica narrativo-discursiva, nessa discussão, é o de observar as relações semânticas básicas de todos os conjuntos significantes, fornecendo categorias metalinguísticas que discriminem, como almeja as ciências linguísticas, categorias textuais e discursivas mais gerais e universais, e relativas ao sentido textualizado em qualquer linguagem. Procurando desvendar, via observação das articulações semânticas do texto-discurso, como se dá a referencialização do mundo viabilizada por uma ideia de subjetividade sensível linguageira que possui um corpo discursivo e mitopoético, e projeta discursos a partir de atualizações de outros discursos.

Considerando-se a operação de figurativização do percurso gerativo, podemos igualmente supor que, de um lado, o texto fechado e figurado é equivalente ao estágio de realização da práxis, e a estrutura discursiva é reconhecida como prática e em transformação, 
encontrando-se como um todo realizado no mundo natural e "real". Em relação à práxis, devese lembrar que se o homem usa e se apropria de outros discursos, praticando-os, é preciso antes haver um processo de reconhecimento que é discursivo e enunciado, e figurado de alguma maneira. Assim, calcula-se que às estruturas semionarrativas e discursivas do percurso articulados na figurativização, somam-se os produtos de sentido das operações tensivas, figuradas verbal ou não-verbalmente, e previstas no percurso como operações semânticas mínimas de mais e menos, menos mais e menos menos, que podem ser ainda mais discretizadas e complexas. A partir daí o percurso gerativo elaborado pela semiótica greimasiana torna-se perfeitamente compatível com as semióticas pós-greimasianas, tanto no que tange o seu nível semionarrativo quanto o discursivo, que prevê tempo, espaço e movimento. Combinadas, a semiótica greimasiana e pós-greimasiana criam uma ferramenta epistemológica mais avançada e completa para a observação dos processos de significação do texto realizado na enunciação.

\section{Metodologia de análise: sequência e objetivos da pesquisa}

A partir da semiótica discursiva discutiremos, de um lado, o texto fonte, o romance, e o texto alvo, o filme; e de outro a sua relação, ou seja, a adaptação / tradução entendida como discurso que atualiza e realiza outro discurso já figurado e textualizado, de modo que tanto as categorias semionarrativas e discursivas, assim como as categorias tensivas e os modos de existência da práxis serão utilizadas para examinar ambos os objetos em diferentes momentos.

Paranoid Park (Blake Nelson, 2006), cujo gênero é a novela teen mesclada ao thriller psicológico, é sobre um garoto de dezesseis anos que se envolve acidentalmente em um evento traumático que o marca para sempre, atormentando-o durante meses e alterando completamente o seu cotidiano, em um processo que o faz crescer e se transformar. O protagonista, que narra a sua história em sete cartas, revive emoções, repensa a vida e amadurece, encontrando na escrita uma maneira de controlar a sensação disfórica que o invade. Para figurar tal narrativa, o discurso literário adota a forma de romance epistolar, sendo enunciado a partir de estratégias de sentido que procuram construir uma subjetividade jovem, "surpresa", angustiada, fragmentada e passionalmente confusa.

Observaremos, também, como ambos os discursos, o literário e o fílmico, são modalizados semioticamente em termos de eficiência, existência e junção, e suas respectivas sintaxes. Do percurso gerativo, utilizaremos as categorias semionarrativas e discursivas para analisar o seu conteúdo semântico e sintático, observando os textos tanto a partir de sua discursivização, tematização e figurativização, assim como de seus destinadores, sujeitos e 
objetos-valor disseminados na narrativa a partir de semas fundamentais relacionados ao relato mitopoético, que gera operações simbólicas e semissimbólicas.

Uma vez que ambos os textos são considerados sincréticos, verbo visuais e audiovisuais, abordaremos questões relacionadas aos seus planos de expressão e dinâmicas de manifestação de sentido, a partir da ideia da arbitrariedade da língua verbal e da motivação da língua fílmica. Sendo motivado, veremos como o filme transforma espaços linguísticos e tópicos verbais em espaços tópicos audiovisuais. Assim, relações entre conteúdos verbais, gráficos e plásticofigurativos serão examinadas. Em relação à linguagem fílmica, e a partir da ideia de semiose proxêmico-gestual fórica, analisaremos a decupagem dos planos do filme, suas relações de aproximação e distância, movimentos e duração temporal, e como o discurso se manifesta a partir de um plano de expressão plástico e cinemático.

As diferenças da tradução também serão tratadas, e apontaremos inserções de cenas e sequências originais do filme, assim como cenas alteradas e descartadas pelo enunciador, que refletem de um lado a reconfiguração de percursos temáticos e figurativos e suas isotopias; e de outro, estão dentro de certos projetos enunciativos. Como a obra original e a adaptada não são temporalmente distantes, e o filme foi feito um ano após a publicação do livro, discutiremos como as diferenças entre esses dois textos contemporâneos e escritos quase em uníssono podem ser explicados, e como tais mudanças elaboram, cada um, seu próprio arco tensivo.

Antes da análise das obras, porém, como nosso tópico é a adaptação da linguagem verbal para a audiovisual, abordaremos pontos de vista teóricos sobre a produção semiodiscursiva do sentido visual e verbal, a construção do espaço e do movimento na literatura e no cinema, e analisaremos algumas questões sobre a construção fílmica do sentido em relação à gestualidade e a proxêmica, que nos parecem pertinentes para a discussão, pois no cinema os enunciadores relacionam-se em um espaço plástico, visual e sonoro.

Assim, no Capítulo 1, trataremos questões da manifestação do sentido e da biplanaridade do texto, cujo plano do conteúdo é convertido em sentido apenas a partir de suas relações com o plano de expressão e um suporte coercitivo. Discutiremos também a figuratividade e a ilusão referencial, existentes tanto no texto verbal como no audiovisual, mas expressas diferentemente. Em nossa discussão, tentaremos redimensionar o conceito de figurativização, para que possamos tratar de questões semióticas de ordem narrativo-discursiva. Depois disso, abordaremos algumas características de sentido pertinentes ao conjunto significante cinematográfico, como a imagem planar, o plano e a montagem, relacionados à discursivização do espaço e do tempo no filme, tentando oferecer um aporte semionarrativo discursivo para a questão. Dentro da ideia de espaço visual e sonoro plástico em movimento, 
projetado no texto pelo percurso gerativo, a noção de observador e informador será retomada, assim como discussões sobre a aspectualização, modalização e figuração do espaço cognitivo. Como prática de sentido, e a partir da ideia de gestualidade plástica, discutiremos o cinema como discurso gestual e proxêmico capaz de simular aspectos cinéticos e cinemáticos do corpo humano.

No capítulo 2, o romance será analisado a partir das categorias do percurso gerativo tensivo e observaremos como são construídas as categorias do conteúdo, do ponto de vista de suas estruturas discursivas e semionarrativas. Avaliaremos a estrutura discursiva e suas categorias, sua discursivização, tematização e figurativização, além de particularidades da manifestação do sentido, relacionada ao seu plano de expressão. Assim, prestaremos atenção em relações sincréticas, simbólicas e semissimbólicas. Utilizaremos a ferramenta de análise linguística Antconc ${ }^{6}$, para que possamos investigar algumas peculiaridades do discurso verbal que possam jogar luz sobre o romance e a operação de adaptação.

Em relação ao filme, que será abordado no capítulo 3 serão analisados com mais cuidado os seus primeiros minutos e a cena do evento traumático, o acontecimento, e igualmente observaremos a estrutura discursiva e semionarrativa de seu conteúdo, prestando atenção na figurativização audiovisual de atores, espaços, tempos e temas. Em relação ao som, que completa a noção de espaço e movimento e também figura temas da narrativa, veremos como o ele, tripartido no plano do conteúdo em la, ruído e música, é utilizado para construir sentido e contar a história de um jovem que sofre, lembra um evento traumático, e se transforma. A partir da ideia de distância tensiva e tempo de cada plano, imaginados como sílabas tensivas de uma semântica proxêmica que graduam a distância, analisaremos tanto a cena do acontecimento, como do filme de maneira geral, e sua temporalidade, tentando compreender as relações entre distância, tempo do plano e a narrativa. A análise fílmica das imagens também será apoiada nas modalidades de construção do espaço executadas por um observador, uma entidade discursiva que oscila entre ator em enunciador, e auxilia a enunciação da narrativa. Elementos significantes da montagem, sons e imagens serão tratados discursivamente, a partir de questões tensivas de inter-relação e graduação mais ou menos tônica.

\footnotetext{
${ }^{6}$ Antconc é um concordanciador, um programa de computador que constrói concordâncias automaticamente. $\mathrm{Na}$ linguística de corpus, os concordanciadores são utilizados para listar as ocorrências de uma determinada palavra ou frase, a qual fica centralizada, com uma quantidade definida de contextos, tanto da esquerda como da direita, fornecendo uma visualização privilegiada do item. De forma geral, muitos concordanciadores, além de produzirem concordâncias, também executam outras funções, como listar a frequência de palavras em um texto ou corpus, extrair palavras-chave e colocados. CONCORDANCIADOR. In: WIKIPÉDIA, a enciclopédia livre. Flórida: Wikimedia Foundation, 2019. Disponível em: $\langle$ https://pt.wikipedia.org/w/index.php?title=Concordanciador\&oldid=54730889 $>$. Acesso em 07 / 07 / 2109. A versão utilizada foi a AntConc 3.5.7 (2018).
} 
Como nosso foco é a adaptação como enunciação também singular e única, no capítulo 4 o sujeito da enunciação será discutido a partir da abordagem narrativo-discursiva, sendo que algumas diferenças de conteúdo entre texto alvo e texto fonte serão apontadas em relação à noção de "autor", que na semiótica insere-se na questão do ator da enunciação, caracterizado através de operações intertextuais, e é um importante elemento para se compreender, a partir das categorias da práxis enunciativa, como o objeto semiótico romance foi adaptado pelo sujeito em relação ao sistema linguístico cinematográfico e outros discursos fílmicos. Finalmente, faremos um resumo geral das operações de tradução do texto fonte, tanto do ponto de vista da enunciação como do enunciado, e concluiremos nossa análise.

O nosso estudo sobre a adaptação de Paranoid Park, apesar de lidar com temas já tratados pela semiótica, pretende ser inédito no que trata a questão tanto da tradução intersemiótica, como dos estudos semióticos propriamente ditos, pois: procura aumentar o escopo da semiótica narrativo-discursiva, expandido seu alcance para os estudos da adaptação; propõe novos pontos de vista para os estudos tradulógicos e intersemióticos, e uma metodologia semiótica de análise para o estudo da tradução, baseada principalmente em uma nova visão do percurso gerativo e da figurativização; propõe maneiras diferentes de se abordar aspectos do discurso fílmico, a partir das discussões semióticas sobre tensão, motivação, distância, observador e gesto; e procura observar como a macrossemiótica das línguas naturais integra-se à macrossemiótica da língua artificial cinematográfica, auxiliando poeticamente na composição de cenas audiovisuais.

Esperamos também, que como analisamos a transposição de literatura para o cinema, nossas discussões possam interessar, além dos estudos intersemióticos e tradulógicos, áreas paralelas tais como criação e análise de textos literários e audiovisuais, letramento audiovisual, e o estudo e a produção de fanfics, que mostram uma interessante relação enunciador / enunciatário, e destinador / destinatário que é bem própria das práticas adaptativas tradutórias.

\section{MANIFESTAÇÃO DO SENTIDO E ADAPTAÇÃO}

Segundo Beividas (2015), pode-se considerar a instância da manifestação não apenas como a entrada da forma da expressão no jogo da significação, mas também como lugar onde um texto toma sua existência concreta e material (p. 82). Resulta daí a percepção de que a experiência da leitura de um texto verbal seja bem diferente da leitura de um texto fílmico. Ao adotar diferentes formas de expressão, o texto é coagido por ordens expressivas materiais e 
linguísticas de semióticas do mundo, e projetará maneiras diferentes de se apreender o mesmo conteúdo semântico, de ordem mitopoética,

No texto escrito, mergulha-se em um universo feito de palavras grafadas em uma página, cuja direção de leitura varia entre as culturas, e de efeitos gráficos e plásticos; no filme, a diegese da narrativa se dá por meio de sons e imagens exibidas em uma tela. Apesar de serem manifestadas por sistemas de construção de sentido diferenciados, vale a pena observar que filme e literatura impressa dividem o mesmo tipo de espaço topológico, que é planar (assim como o quadrinho, a pintura, a fotografia etc.). Além disso, existem dentro de práticas linguísticas não-naturais e tecnológicas: não só a literatura impressa, e todas as outras artes, requerem "instrumentos naturais de enunciação", como o próprio alfabeto escrito é considerado uma tecnologia. Como podemos observar, a similaridade de algumas características enunciativas na literatura e no cinema indica categorias expressivas que interagem e manifestam-se no sentido, tais como a planaridade, a plasticidade e a visualidade.

Partimos do princípio que ambos os textos que estudamos são sincréticos. Greimas e Courtés consideram semióticas sincréticas aquelas que "como a ópera ou o cinema, acionam várias linguagens de manifestação; da mesma forma, a comunicação verbal não é somente de tipo linguístico: inclui igualmente elementos paralinguísticos (como a gestualidade ou a proxêmica), sociolinguísticos etc.” (GREIMAS; COURTÉS, 2011 [1979], p. 476; verbete: sincretismo). A definição é interessante e sugestiva, ao comparar o cinema e ópera, à comunicação verbal entre duas pessoas, sugerindo ambas como espetáculos audiovisuais.

No caso do texto literário, além do uso de categorias expressivas do sistema plástico gráfico, tais como negritos, espaços, itálicos, tipos de fonte, é possível observar a utilização de textos visuais para construir sentido, além da própria capa, entendida como paratexto. Oliveira (2009), seguindo Floch, considera a página impressa como um sistema sincrético (gráfico)visual-espacial materializada pelas opções da construção enunciativa do enunciador no seu orientar o percurso do enunciatário em direção à significação (p. 88). Da mesma maneira, e de forma mais fácil de entender, o cinema é uma linguagem composta por música, diálogo, ruído gesto, cor, arquitetura, moda etc., mas que se articula como um todo único de sentido.

Pietroforte (2012) sugere que as linguagens se organizam, em sua forma de expressão, de duas maneiras distintas, em sequência ou em paralelo, que correspondem ao tempo e ao espaço, ao texto verbal oral, por exemplo, cuja entonação o aproxima da música, e ao texto visual, que é plástico e é construído em um espaço. Assim, "há semióticas manifestadas cronologicamente, como a música e as línguas naturais, ou manifestadas topologicamente, como a pintura, a escultura e a fotografia. Há ainda as complexas, como a história em 
quadrinhos, a ópera, o cinema (falado ou mudo) e a escrita (pois dispõe, no espaço, uma semiótica própria do tempo)” (p. 106). A discretização é engenhosa, mas admite-se que todos os textos sejam cronológicos e topológicos, uma vez que o percurso assume uma estrutura discursiva que constrói espaço e tempo não apenas como enunciado, mas como ato da enunciação, que ocupa tempo e espaço, possuindo uma figurativização enunciativa. Assim, todo o texto, ou conjunto significante, seria crono-topológico.

Como o percurso gerativo trata apenas do conteúdo do texto, é preciso lembrar que o sentido nele constituído une-se a um plano de expressão para manifestar-se, pois não há conteúdo sem expressão. Dessa forma, existindo como inteligível, e construído por várias linguagens, verbais e não-verbais, o sentido possui um plano expressivo que vai além do percurso gerativo, sendo entendido como "sensível” (vazio e sem conteúdo), e formado de microestruturas que se ordenam e se complexificam até tornarem-se inteligíveis: as relações entre expressão e conteúdo de todos os textos, que são relacionadas às línguas naturais, são fundamentais para os estudos intersemióticos.

Para falar do plano expressivo da linguagem, Hjelmslev utiliza o termo sentido da expressão, que pode ser visto como instaurador de um semantismo próprio. Segundo Beividas (2015) o plano da expressão "não cria o sentido, mas é o único a consignar a significação do plano do conteúdo, dando-lhe uma marca expressiva que torna sua possível manifestação à percepção (aos sentidos)” (p. 128), servindo como teste de controle, garantia e legitimação. A expressão, assim, seria um percurso de consignação.

Diferencia-se o plano do conteúdo (o percurso gerativo) do plano da expressão, pois um mesmo sentido pode ser expresso de diferentes maneiras, em diferentes tipos de conteúdos, verbais e não-verbais: no caso da adaptação cinematográfica literária, o texto fonte, cujo plano de expressão é verbal e gráfico, será reconstruído em texto fílmico cujo plano de expressão é audiovisual, plástico, sonoro e cinético. Ao ser transportado para outro conjunto significante, o percurso ganha feições semânticas da ordem do mundo natural. Segundo Fiorin (2008), a relação entre os planos funda tipos diferentes de discursos: os utilitários, em que o plano de expressão apenas veicula o conteúdo; e estéticos, ou poéticos, tipos de discurso em que a expressão patenteia o conteúdo, ou seja, em que certas categorias da expressão são homólogas a determinadas categorias do conteúdo (FIORIN, 2008, p. 57). Neste segundo tipo, no qual existe uma correlação entre as categorias dos dois planos, operam sistemas semissimbólicos. ${ }^{7}$

\footnotetext{
${ }^{7}$ Fiorin (2008) explica que a semiótica acolheu a partir da distinção entre semióticas monoplanas e biplanas (Hjelmslev) a diferença entre sistemas simbólicos e sistemas semióticos. Nos primeiros há uma correspondência termo a termo entre o plano de expressão e o plano do conteúdo, uma conformidade entre os dois planos: a foice
} 
A partir de uma visão sincrética de sentido, da ideia de manifestação coagida e de discurso utilitário e poético, algumas operações de sentido nos interessam mais profundamente, tais como a figurativização como ilusão referencial; a construção do espaço cognitivo pelo discurso verbal e não-verbal, e quatro operações significantes da linguagem cinematográfica, que são a imagem em movimento, o quadro, a decupagem e o som, que serão discutidas e relacionadas a questões semióticas.

\subsection{Figurativização e sensorialidade}

Uma interessante dinâmica na relação entre expressão, conteúdo e manifestação passa pela figurativização, que segundo Fiorin (2011) é um dos níveis de concretização do sentido (p. 90), e remete a figuras que podem ser reconhecidas como elementos do mundo natural. Greimas e Courtés (2011 [1979]) comentam que o estudo da figuratividade está apenas no início, e sua principal dificuldade reside no apriorismo implícito, segundo o qual todo o sistema semiótico é uma representação do mundo e comporta a iconicidade como dado primeiro, imagens do mundo já acabadas (p. 212; verbete: figurativização).

Bertrand (2003) demonstra como a ideia de figuratividade é ampla e procura abarcar o discurso da vida não apenas cognitiva, mas sensível, sendo concebida como: conteúdo dado de uma língua, quando esta tem correspondente no nível da expressão da semiótica (ou mundo) natural; conteúdo de uma língua natural ou de qualquer sistema de representação (visual, musical, pictórica) que tenha um correspondente no plano do significante (ou da expressão) do mundo natural da realidade perceptível, sendo considerado em um determinado universo discursivo, verbal e não-verbal, e referindo-se aos cinco sentidos tradicionais e à percepção; conteúdo de um sistema de representação, ou conjunto significante, verbal, visual, auditivo ou misto, cujo discursivo constrói uma figura significante do mundo percebido; ato semiótico visual moldado por um crivo cultural, que reconhece formas figurativas na imagem; signoobjeto visual dotado de significado a partir de um crivo de leitura de natureza semântica, que solicita um significante planar, e assume feixes de traços visuais de densidade variável, aos quais constitui formantes figurativos que serão apreendidos, dentro de unidades significantes reconhecidas pelo crivo do significado, como representações parciais de um objeto do mundo

(o campesinato) e o martelo (o proletariado) como o símbolo do comunismo. Nos segundos não há conformidade entre o plano da expressão e o plano do conteúdo, ou seja, não há correspondência entre as unidades menores da expressão e as do conteúdo, nem entre as unidades maiores do sistema (p. 58). 
natural (BERTRAND, 2003, p. 156-158). Segundo Barros (2002), discutir as figuras discursivas é retomar a questão da relação entre língua (ou discurso) e realidade (p. 117).

Procurando abarcar a expressão e o sensível da expressão, a figurativização oscila entre a veridicção de um mundo expressivo e tenso, relacionando-se à construção discursiva da "realidade sensível", articulada por unidades menores, não sendo "imagens do mundo", mas criando signos delas a partir da semiose entre expressão e conteúdo dentro de um sistema de linguagem que produzem carregam efeitos "realistas". Tais efeitos são, de um lado sociais e mitopoéticos, e de outro, extratextuais, visão de uma realidade diegética e intrínseca a um mundo representado, mas que existe a partir da percepção de uma realidade extrínseca a ela, em outra macrossemiótica natural de caráter igualmente discursivo e ficcional.

Greimas, que utiliza uma metáfora cinematográfica para descrever a figurativização, entende-a como tela do parecer, "cuja virtude consiste em deixar entreabrir, em deixar entrever, em razão de sua imperfeição ou por culpa dela, como que uma possibilidade do além-sentido, onde os humores do sujeito reencontram, então, a imanência do sensível" (1987 apud BERTRAND, p. 158): mergulhamos, a partir da figurativização do texto, não apenas no real, mas no real como dado sensível para o corpo no mundo natural macrossemiótico. Como construção narrativo-discursiva, "o real”, assim como a literatura e o cinema, é organizado por um conjunto significante, de modo que linguagem, narrativa mitopoética e "realidade sensível" interpenetram-se no discurso, que transforma o mundo natural sensível em expressão e impressão figurativa.

Segundo Bertrand (2003), a discussão entre figuratividade e realidade nasce na teoria estética, que opõe arte figurativa e não figurativa, ou abstrata, sugerindo a semelhança, a representação, a imitação do mundo pelas disposições das formas em uma superfície. A semiótica, ultrapassando a arte pictórica, ou visual, estende o conceito aos vários conjuntos significantes, designando a propriedade de produzir e restituir parcialmente significações análogas às de nossas experiências perceptivas mais concretas (BERTRAND, 2003, p. 154) ${ }^{8}$.

Ligada inicialmente às categorias da psicologia da percepção, que são a exteroceptividade (o mundo exterior), a interoceptividade (o mundo interior) e a proprioceptividade (a interface entre ambas), a semiótica cria o conceito discursivo de figuratividade, indicando a transcodificação das figuras da expressão do mundo natural em figuras do conteúdo das línguas naturais, substituindo as propriedades exteroceptivas; para as

\footnotetext{
${ }^{8}$ Bertrand entende que a figuratividade rege em boa medida muitas outras formas e gêneros discursivos: a narrativa mítica, o conto popular, o provérbio, o texto religioso, o discurso jornalístico ou publicitário, e os episódios da troca cotidiana etc.
} 
categorias que não permitem semelhante codificação, o conceito de abstração substitui o de interoceptividade, e o conceito de foria, com sua dupla polaridade euforia /disforia, dá conta da incorporação do sentido, substituindo a proprioceptividade (BERTRAND, 2003). Assim, entende-se que todos os conjuntos significantes são figurativos, e a figuratividade "localiza no discurso o efeito de sentido particular que consiste em tornar sensível a realidade sensível” (p. 154). Como textos figurativos possuem uma racionalidade particular, sendo analógicos e não dedutivos (p. 155), eles são estruturados por sublógicas mais mitopoéticas, que existem "naturalizadas" e atonizadas nos textos dedutivos e lógicos.

Como maneira de construir o "real", o discurso figurativo envolve a composição de ações, paixões, qualidades, objetos naturais, gestos, emoções, sentidos e sensações, que podem ser expressas verbal e não-verbalmente, problematizando e potencializado referentes do mundo natural e o mundo natural como referente. Dentro dessa representação, a diferença semântica entre os pólos icônico e abstrato é interpretada pela semântica estrutural em termos de densidade sêmica, de modo que a iconização e a abstração, ou figuração, serão formadas a partir de traços de ordem verbal e não-verbal, cuja composição tensiva de qualidades e quantidades administram o sentido e criam inúmeras possibilidades de variações semêmicas se os contextos de uso forem muito abertos.

A partir da figurativização do "real", uma discussão que nos interessa com mais particularidade em relação à literatura e ao cinema é a da impressão, ou ilusão referencial textualizada, um subprograma gerativo da construção do mundo "real" e concreto, uma vez que mesmo as impressões objetivas carregam em si impressões discursivas de tipos de percepção e corpos no mundo, que por sua vez incidem sobre a construção da narrativa e seus vários programas. Assim, a figuratividade engloba também a construção da percepção, do acontecimento da apreensão e de sua existência estética, em uma relação entre figuras expressivas e o mundo expressivo apreendido pelo sujeito cognitivo sensível. A partir da observação da percepção figurada, a diegese torna-se carregada de "sensibilidade", e o discurso figurativo perceptivo mimetiza o sentido como devir e acontecimento, como gradação e continuidade de figuras, ou o seu oposto, como explosão e fragmentação surpreendente, em uma prática que vale tanto para o enunciado como para o enunciador.

Como formas discursivas figurativas e poéticas, filme e romance são discursos que se colocam em relação sensível com o mundo natural e suas semióticas, e onde formas desse mundo podem ser mais ou menos reconhecidos como verdadeiras e exatas, podendo ser copiadas, mimetizadas ou retorcidas. A partir da ideia de que o signo icônico seja gerado de partes menores, presentes também na expressão do texto, os não-signos, a semiótica discursiva 
entende a figurativização como um procedimento com dois patamares: o da figuração, que corresponde à instalação das figuras semióticas (espécie de nível fonológico, ou plástico) e o da iconização, que visa revestir exaustivamente as figuras, de forma a produzir a ilusão referencial, que as transformaria em imagens do mundo (GREIMAS; COURTÉS, 2011 [1979], p. 212; verbete: figurativização). Assim caracteriza-se a iconicidade, e o signo-icônico como ilusão referencial, resultado de um conjunto de procedimentos para produzir efeito de sentido "realidade", condicionada pela sua concepção culturalmente variável e pela ideologia realista assumida pelos produtores e usuários desta ou daquela semiótica. A partir da iconicidade, a iconização será a última etapa da figurativização do discurso (p. 251; verbete: iconização).

O discurso figurativo na literatura e no filme, a princípio, apresentam configurações bem diferenciadas, advindo de planos de expressão distintos, que serão adensados semanticamente, organizados e atualizados a partir de sistemas próprios em estados virtualizados. Enquanto o discurso verbal falado é gerado por elementos mínimos de sentido, categorias fonéticofonológicas, o audiovisual se dá a partir de categorias plásticas articuladas sobre um espaço visual e planar. De modo geral, no discurso verbal, que trabalha com conceitos lexicais, antropônimos, topônimos e cronônimos, palavras que fazem parte da onomástica, um subcomponente da figurativização, estabelecem nomes a sujeitos, locais e tempos, como datas, dias do mês e anos, sendo utilizadas para permitir "uma ancoragem histórica que visa a constituir o simulacro de um referente externo e a produzir o efeito de sentido "realidade" (p. 507; verbete: topônimo ). Substantivos concretos e abstratos revelam a oscilação entre iconização e figuração, mas também os tipos de descrição, de modo que um espaço ou objeto possa ser mais ou menos figurativizado ou tematizado: "a elasticidade semântica da figuratividade permite que se fale em uma profundidade do figurativo, que pode ser considerado em si mesmo, por meios dos raciocínios figurativos, por exemplo, como um dado primário da linguagem” (BERTRAND, 2003. p. 231).

Em relação à figuratividade do discurso visual, que propõe uma ancoragem imagética do real, a imagem pictórica serve como excelente base para discutirmos o cinema. Na pintura, por exemplo, a exploração do significante plástico planar pictórico começa pela constituição de um campo de problemas relativos às condições topológicas tanto na produção como da leitura do objeto "quadro", cuja definição passa por uma delimitação que o separa daquilo que não é. A tela instaura o fechamento do objeto, em uma operação ativa do produtor que, colocando-se no próprio espaço da enunciação "fora do quadro", instaura, por meio de uma debreagem, um espaço enunciado que comandará, e onde criará um universo utópico separado desse ato, garantindo ao objeto circunscrito o estatuto de um todo de significação. Dessa maneira o quadro 
apresenta-se primeiramente como um conjunto de categorias topológicas, que são retilínias (alto / baixo; direito / esquerdo), curvilíneas (periférico / central; circunscrevente / circunscrito), ou compostas, e estabelecem uma superfície traçada por eixos e / ou delimitações de regiões, segmentando o conjunto em partes discretas.

A partir da aplicação da categoria topológica, que permite empreender a análise da superfície enquadrada, é possível articular o significante visual em termos de outras categorias, depreendendo-se assim as unidades mínimas do significante, cujas combinações reencontrarão os subconjuntos reconhecidos no recorte espacial planar. Assim, dentro de uma categoria plástica, delimitada por cores e formas, distinguem-se categorias cromáticas, relativas a todas as cores do espectro, inclusive o branco e o preto, e que dão conta de cores produzidas por pigmentos ou luz; e categorias eidéticas, relativas a formas, uniformes, multiformes, homogêneas, heterogêneas, e aos vários traços e espaços que compõem tais formas: de certa maneira, toda forma ocupa um espaço e é espaço, sendo também topológica. Greimas lembra ainda, que a distinção entre o eidético e o cromático reside em sua apreensão relacional, na função atribuída pelo enunciatário de um termo com relação aos demais.

Entendendo que o caráter mínimo das unidades de expressão é relativo, Greimas prendese à semântica que, incapaz de estabelecer um inventário restrito de categorias sêmicas que englobe todo o universo cultural, limita-se a levar em conta apenas as categorias pertinentes da expressão para a análise de um microuniverso. Assim, a ausência de um conteúdo terminológico estrito ou mesmo divergências teóricas importam menos ao bom andamento da análise do que a determinação nítida e inequívoca da instância da apreensão dos fenômenos plásticos. Desse modo o reconhecimento de categorias plásticas "que constituem o nível da forma do significante (ou da expressão), não esgota sua articulação: são apenas as bases taxionômicas capazes de tornar operatória a análise desse plano da linguagem" (GREIMAS, 2004, p. 88)9

$\mathrm{Na}$ construção do mundo icônico plástico, o "real" é textualizado, de modo que a imagem precisa ser aprendida e reconhecida como um tipo de imitação reconhecível: "ao conceito de imitação que, na estrutura da comunicação, se situa no âmbito do enunciador, corresponde o de reconhecimento que é próprio do enunciatário (GREIMAS, 2004 [1984], p. 7). Baseado nesse fato, o que é "naturalmente" dado e é imediatamente legível são menos os

\footnotetext{
${ }^{9}$ Aumont (2006) explica que a operação de semantização operada por Greimas é uma operação de transcodificação entre traços pertinentes visuais e semânticos, a partir de uma seleção (p. 187). Essa operação, sendo semântica, é acompanhada de uma outra relação, qualificada de metacódiga por Metz, uma vez que a língua verbal é a única linguagem em posição de metalinguagem universal. No caso do cinema, ela produz um sentido denotado pela analogia figurativa que tenta explicar o material da base da imagem cinematográfica, aquele sobre o qual ela vem sobrepor seus arranjos, e organização típica.
} 
objetos "reais" do mundo do que as figuras que os constroem e foram ensinadas e naturalizadas socialmente. Tais figuras, "sendo constituídas por traços provenientes dos diferentes órgãos de sentido, só podem ser reconhecidas como objetos a partir do traço semântico "objeto", que se une à figura para transformá-la em objeto" (p. 79).

O encaminhamento da construção do objeto semiótico pictórico consiste em determinar combinações dessas unidades mínimas, plásticas, para se encontrar configurações mais complexas, os formantes plásticos, entendidos como organizações particulares do significante que se definem por sua capacidade de serem alcançados por significados e constituírem signos. Enquanto os formantes figurativos significam somente após a aplicação de um crivo de leitura natural, os plásticos servem de pretexto para outras significações, fato que sugere uma linguagem. A partir do reconhecimento das categorias e das figuras plásticas, que revela o modo de existência de uma forma, pode-se detectar a sua organização sintagmática, suas triagens no eixo paradigmático (relações ou...ou, norteadas por ausências de traços contrários ou contraditórios da mesma categoria) e mesclas no sintagmático (relações e...e, norteadas por dinâmicas de co-presença dos termos e figuras plásticas em uma mesma superfície-texto).

$\mathrm{Na}$ distinção entre as categorias cromáticas e eidéticas, as primeiras podem ser consideradas como constituintes (a superfície com cor é um território aberto de regiões indistintas), e as segundas constituídas (devido à sua contiguidade, as regiões delimitam-se entre si). Para poder afirmar a co-presença de unidades do significante, é preciso reconhecer seu caráter discreto: "as reflexões sobre a contiguidade, sobre os contornos (nítidos) e sobre os limites (fluidos) constituem o primeiro passo com vistas ao estabelecimento do texto plástico" (GREIMAS, 2004, p. 90) ${ }^{10}$.

Em termos de orientação de leitura da imagem plástica, a semiótica entende que não existe a necessidade de admitir apenas a existência de uma direção, a linear e contínua, como a utilizada no caso do discurso verbal, pois pode-se admitir que a imagem seja limitada por percursos parciais (impostos, por exemplo, por desvios de contrastes) prevendo-se, ao mesmo tempo, saltos anafóricos, cuja função seria a de conectar entre si diferentes percursos (percebe-

\footnotetext{
${ }^{10}$ Greimas observa que esse tipo de organização textual não existe apenas na linguagem plástica, embasando boa parte dos discursos narrativos: a falta assinalada no início da narrativa, existe à distância, constituindo assim uma mola dramática, a liquidação da falta que elimina a tensão narrativa. A recorrência da categoria plástica que se concretiza mediante a tomada de um termo categórico pelo seu contrário, ou contraditório, deve ser distinguida de outro tipo de recorrência discursiva, que consiste na iteração e retomada de um mesmo termo, mas empregado em um contexto diferente, ou configuração diferente. Tais recorrências entre semelhante e diferente constituem uma trama que cobre a superfície construída, sendo reconhecíveis sob a forma de eixos de tensão de isotopias de expectativas, elas predispõem para uma leitura globalizante.
} 
se que na literatura o modo linear de leitura se impõe, mas como a página é planar, outras direções de leitura estão previstas, como na poesia concreta).

Assim como o dispositivo topológico possui uma função de segmentação, um papel de orientação da leitura, os diferentes eixos que o ato da enunciação plástica projeta sobre a superfície enquadrada podem ser considerados como motivações para reunir as figuras neles constituídas em conjuntos significantes. Da mesma maneira, marcas de orientação podem ser reconhecidas em diferentes figuras plásticas, mesmo que tais marcas permaneçam como elementos inerentes à sua organização: isso vale tanto para as figuras eidéticas (onde a categoria pontudo / arrendondado, por exemplo, pode orientar a leitura) quanto para as figuras cromáticas (a categoria não-saturado / saturado, de caráter gradual, comporta uma intensidade orientada). As categorias e os formantes figurativos podem ser assumidos e explorados como indicadores de orientação do texto plástico.

Finalmente, e talvez o mais importante para a nossa discussão, é a diferenciação que Greimas faz da semiótica verbal e visual em relação à semiótica do mundo natural, e ao tipo de junção do plano do conteúdo com o plano de expressão, entendendo a primeira como mais arbitrária, fato que impacta diretamente a operação figurativa. Assim, enquanto no texto literário a iconicidade pertence a uma macrossemiótica verbal das línguas naturais, cujos signos não possuem nenhuma relação natural com o seu referente e sua expressão, o texto visual, não sendo uma linguagem natural, pertencerá a uma macrossemiótica plástica motivada pela expressão do mundo natural, percebido como um conjunto de linhas, cores, espaços, distâncias etc. Apesar da imagem ser compreendida como linguagem e dentro de um discurso, é interessante observar que enquanto uma palavra simples, como "cadeira", necessitará de uma tradução em diferentes idiomas para ser compreendida, sua imagem será mais amplamente reconhecida, independentemente do idioma falado pelo artista. Tal fato aponta para uma diferença na manifestação e reconhecimento das figuras verbais e visuais.

Segundo Greimas (2004), o mundo natural, que desperta uma riqueza de sentidos e emoções no homem, sendo apreendido pelos sentidos, constrói-se em um quadro pictórico menos como imitação do que como considerável redução de suas qualidades, pois, de um lado, nota-se que somente os seus traços visuais são imitáveis e, de outro, apenas as propriedades planares, bidimensionais são transponíveis e representáveis sobre superfícies artificiais; ao mesmo tempo, a extensão do mundo nos é dada em sua profundidade inteiramente cheia de volumes. A consequência disso é que a representação icônica atribuída à pintura não pode ser vista como uma relação de semelhança entre figuras visuais planares e configurações do mundo natural, mas que ocorre no nível das estruturas significantes ou expressivas entre natureza e 
figura, sendo comum a ambas (e por isso transferíveis). Assim, "os traços do mundo - e os traços e as regiões - selecionados nessa perspectiva e transpostos para uma tela são pouca coisa em relação à riqueza do mundo natural; são talvez identificáveis como figuras, mas não são reconhecíveis como objetos do mundo" (p. 78). Pode-se sugerir que Greimas entende a iconicidade visual em termos de intertextualidade entre semióticas construídas e semióticas naturais, um caso de adaptação intersemiótica entre formas plásticas da cultura e da natureza.

O que explanamos em relação à pintura e semiótica, ajusta-se com perfeição ao cinema, que a partir de um espaço topológico compõe suas imagens. No entanto, em relação ao discurso fílmico, duas diferenças figurativas são notáveis e precisam ser abordadas com mais extensão: a impressão de som e movimento, que parecem não existir na literatura e nem na pintura, mas são previstas na operação mais ampla de figurativização, que concretiza o inteligível e sensível em forma de espaço, tempo e movimento.

Greimas e Courtés entendem que o movimento é relacionado a enunciados de fazer e “interpretável como passagem de um espaço a outro, de um intervalo temporal a outro, articulado em função de uma direcionalidade, de movimentos de um espaço ou de um tempo de origem para um espaço ou tempo de destino (GREIMAS; COURTÉS, 2011 [1979], p. 324; verbete: movimento). Como é composto de espaço e tempo, ele pode ser entendido também como duração. Segundo a semiótica tensiva, espaços e tempos são criados por efeitos de velocidade e tonicidade, que controlam a composição de sons e imagens, e possibilitam a heterocategorização, ou seja, as medidas de tempo e espaço se descreverem mutuamente ${ }^{11}$. Do ponto de vista expressivo, porém, como a linguagem plástica é não-natural, e possui operações de figurativização motivadas, ou seja, apoiadas na expressão do mundo natural, a semiótica faz algumas considerações sobre textos fílmicos que são importantes para a abordagem da adaptação.

Por causa de uma maneira própria de exprimir som e movimento, e a partir da noção de categorias plásticas e da ideia de plano de expressão isomórfico ao plano do conteúdo, foram sugeridas para o cinema categorias expressivas cinéticas, (MÉDOLA, 2009, p. 404), sonoras e cronológicas (PIETROFORTE, 2008, p. 106). Assim, ao espaço movimentado e sonoro da diegese, abordado em uma duração temporal precisa, corresponderiam categorias de formantes diferenciadas das outras linguagens, que auxiliariam a figurativização do mundo sensível retratado: as categorias cinéticas seriam relativas à ideia de movimento; as sonoras às propriedades básicas do som, que são a altura, a intensidade, o timbre e a duração, ou

\footnotetext{
${ }^{11}$ Uma distância expressa em horas, ou o tempo em distância.
} 
sustentação no tempo; e as cronológicas, análogas à categorias topológicas, mas cumprindo a função de determinar como as demais categorias musicais são distribuídas ao longo do tempo da manifestação musical (p. 128).

Do ponto de vista tensivo, que não se opõe às categorias do plano de expressão greimasianas, mas entende o sentido como um conjunto de vetores de aumentos e diminuições de relações estruturais, imagina-se um nível profundo de células tensivas como categorias complexas que controlam a tensão (retensão / relaxamento), a junção (conjunção / disjunção), o espaço (fechado / aberto), o tempo (breve / longo), o andamento (aceleração / desaceleração) e a foria (euforia / disforia) (TATIT, 2007a, p. 382). De um lado, a ideia de categoria complexa pode ser traduzida pela concepção mais ou menos do mesmo elemento, ou processo; de outro, sejam células tensivas ou categorias expressivas, o fato que mais nos interessa é que o discurso é relacionado a um plano da expressão tensivamente estruturado, e que também se "movimenta", em relações mais ou menos graduais.

A partir dessas categoriais expressivas fílmicas, que indicam plasticidade (topografia, cromatismo e forma), velocidade, cronologia, sonoridade, espacialidade e duração, projetando conteúdos figurativos icônicos visuais e sonoros relativos a espaços, tempos e sujeitos, gostaríamos de sugerir uma categoria mais abrangente para o plano da expressão do texto cinematográfico, denominada cinemática, que do ponto de vista da física, seria diferente da cinética, observando não apenas as forças que movem um corpo, mas como esse corpo movese e se comporta no espaço e no tempo, combinando direção vetorial, velocidade, ângulo, distância e altura (equivalentes aos movimentos, velocidades, e posições dos corpos, tanto do enunciado como na enunciação fílmica, relacionados a atores e câmera, por exemplo, que corresponderão a enunciadores do texto em primeiro e segundo grau). Juntamente com a categoria plástica e sonora, a cinemática, que pode ser estendida ao som como movimento no espaço, discriminaria as categorias expressivas plásticas em transformação, que dariam conta da figurativização do conteúdo fílmico, seja ela mais icônica ou figurativa.

O sentido, sendo uma relação entre expressão e conteúdo figurado constrói, também, operações simbólicas, naturalizadas e relacionadas a um crer-saber. Fiorin (2008) explica que a semiótica acolhe, a partir da distinção entre semióticas monoplanas e biplanas, uma diferença entre sistemas simbólicos, e monoplanos, e sistemas semióticos, e biplanos. Nos primeiros há uma correspondência termo a termo entre o plano de expressão e o plano do conteúdo, uma conformidade $^{12}$. Nos segundos não há conformidade entre os planos, não há correspondência

\footnotetext{
${ }^{12}$ A foice (o campesinato) e o martelo (o proletariado) são símbolos do comunismo.
} 
entre as unidades menores da expressão e as do conteúdo, nem entre as unidades maiores do sistema (p. 58): a partir daí, tentam-se compreender as relações simbólicas entre as partes menores do sentido, as categorias que formam os textos, e a semiótica cria o conceito de sistemas semissimbólicos, "que são aqueles em que a conformidade entre os planos da expressão e do conteúdo não se estabelece a partir de unidades, como nos sistemas simbólicos, mas pela correlação entre categorias dos dois planos" (FIORIN, 2008, p. 58).

Assim, em dado texto audiovisual, por exemplo, uma cor pode ser relacionada a valores de vida; ou em um poema, os sons de fonemas oclusivos podem ser homologados à temática da tristeza e valores de morte. Tal ligação, porém, não é socialmente partilhada, e só ocorre articulada em dado texto. As relações semissimbólicas, explica Pietroforte (2008), “embora envolvam a figuratividade, pertencem aos níveis mais profundos de realização semiótica, tanto na forma do conteúdo quanto na da expressão" (p. 111). Greimas entende que a semiótica plástica pode ser definida como um caso particular de semiótica semissimbólica, induzindo o investigador a interrogar-se sobre o estatuto semiótico dos elementos do significado que são homologados às categorias do significante plástico. Assim, tudo passaria como

se a leitura do texto plástico consistisse em um duplo desvio: certos significados, que são postulados no momento da leitura figurativa, encontramse destacados de seus formantes figurativos para servir de significados aos formante plásticos em via de constituição; certos traços do significante plástico destacam-se, ao mesmo tempo, dos formantes figurativos aos quais se integram e, obedecendo aos princípios autônomos de organização do significante, constituem-se como formantes plásticos. Bem mais do que a uma subversão do figurativo existe um processo de auto-determinação, ao nascimento de uma linguagem segunda (GREIMAS, 2004, p. 94).

Apesar de a semiótica discursiva considerar o texto plástico como fundamentalmente semissimbólico, a afirmação esbarra em algumas questões que precisam ser consideradas: primeiramente, partindo-se da ideia de texto poético, que contrapõe o discurso semissimbólico, ao discurso simbólico e já aceito do texto utilitário, falta ainda esclarecer de que tipo de discurso seriam os documentários cinematográficos e transmissões televisivas de partidas esportivas, por exemplo. Se atentarmos para o fato de que, por causa do uso prático da linguagem, que é redutor, conciso, e tende à repetição, certas estruturas de sentido são hierarquizadas (tonificadas) e repetidas para construírem os mesmos efeitos semânticos, podemos entender que filmes repetem certas estruturas que se tornam simbólicas e monoplanas, e podem ser entendidas como representações da noite, do dia, do calor, do frio, da memória, do sonho etc. De maneira geral, a percepção de que nem todos os textos sejam semissimbólicos deve ser pensada para os vários gêneros fílmicos. Como meio tecnológico de comunicação e não tipo de 
arte (como pensava Bazin), pode-se argumentar que textos fílmicos possam ser utilitários e nãosemissimbólicos.

\subsection{A figuração verbal e audiovisual do espaço cognitivo}

Diante de um texto literário e um audiovisual icônico, a questão da construção do espaço do mundo natural é de extrema importância para a narrativa, que cria uma ambientação sensível onde sujeitos sensíveis operam. Enquanto o espaço faz parte do nível discursivo do sentido, e existe em todos os textos, já discutimos como a linguagem verbal e visual o expressam de diferentes maneiras. A questão é importante para o nosso projeto, uma vez que em ambas as linguagens o discurso espacial origina-se a partir de uma macrossemiótica natural interligada pela língua natural. Fiorin (2002) detecta três elementos importantes para caracterizar o espaço: é um objeto construído a partir da introdução de uma descontinuidade numa continuidade; possui relações simétricas e reversíveis em função do ponto em que é organizado; e é pluridimensional, podendo ser definido como tempo. As duas últimas características distinguem espacialização e temporalização (p. 260). Assim como as línguas expressam um tempo linguístico e um crônico, ou seja, um tempo direta ou indiretamente relacionado ao momento da enunciação, e um tempo que exprime as divisões do tempo físico, elas também conceituam dois tipos de espaço: o linguístico e o tópico, que concernem a um conjunto de coisas ordenadas pelas relações espaciais básicas, relativos à localização dos corpos no espaço, e são simétricos e reversíveis.

O espaço linguístico, assim como o tempo linguístico, é ligado ao exercício da fala, definindo-se e ordenando-se como função do discurso. Ele é erigido a partir do eu, aqui, agora, ou seja, do lugar do ego, de modo que todos os objetos são localizados menos a partir de seus lugares no mundo do que a partir de um enunciador, que os situa colocando-se como centro e ponto de referência da localização. Assim, nesse tipo de espaço, não se estabelecem nem posições determinadas, nem movimentos numa dada coordenada geométrica, mas apenas o espaço dos actantes da enunciação em relação aos do enunciado, de modo que ele não é uma posição fixa nem um movimento que se efetua sobre uma dada dimensão do espaço, sendo reinventado quando alguém toma a palavra. Sendo reversível, esse espaço funciona como fator de intersubjetividade, sendo aceito pelo interlocutor, que ao se transformar em enunciador, também converte a espacialidade (assim, todos os falantes, até em uma mesma interação, podem utilizar o eu, aqui e o agora, e automaticamente gerar por pressuposição o não-eu, o não-aqui 
e o não-agora): específico, o espaço linguístico comporta suas próprias demarcações e limites, independentes daqueles do espaço tópico (FIORIN, 2002, p. 263).

O espaço tópico marca a emergência da descontinuidade na continuidade, sendo estabelecido como uma posição fixa em relação a um ponto de referência, ou como um movimento em relação a uma referência. Da mesma forma que o tempo crônico pode ser assinalado a partir do momento da enunciação (ex: "há dois dias", "dentro de três semanas"), ou de um marco temporal instalado no enunciado (ex: "dois meses antes"), o espaço tópico pode ser determinado em relação ao enunciador (ex: "à minha esquerda") ou em relação a um ponto de vista de referência inscrito no enunciado (por exemplo, "na frente ou atrás da igreja"). Além disso, quando não há actantes presentes no enunciado para servir de ponto de referência, é preciso construir um: por exemplo, “à direita de quem sobe ou desce a rua”. No espaço tópico, os corpos são dispostos em relação ao ponto de referência, segundo um determinado ponto de vista, ou seja, uma dada categoria espacial, o que permite estabelecer a posição do corpo ou da direção de seu movimento com base em uma das dimensões do espaço: "temos então, uma espacialidade tópica estática e uma cinética que nos diz onde estamos e onde estão os corpos na vastidão do universo, para onde vamos ou vão os corpos” (FIORIN, 2002, p. 262): por isso, em nossa opinião, a espacialidade cinética é, na verdade, cinemática.

Esse tipo de espaço, diferentemente do linguístico, é pluridimensional, e suas categorias fundamentais em sua análise são a direcionalidade e o englobamento: a primeira, articulada em três dimensões do espaço, que são a altura, a largura e o comprimento, é determinada por um modelo que reproduz o corpo, sendo delimitada principalmente pelo olhar e articulando-se em verticalidade vs horizontalidade, que subsume lateralidade e perspectividade; a segunda é a colocação de um espaço considerado em sua bi / tridimensionalidade numa posição, articulando-se como englobante e englobado. A direcionalidade e o englobamento são dimensionadas por duas operações de movimento, expansão e condensação, que permitem descrever as mudanças de posição.

Uma vez que o espaço tópico, diferentemente do linguístico, é relacionado ao espaço físico geométrico bi e tridimensional, à visão e ao movimento, ele é, na narrativa, mediado por um observador, que pode pertencer ao nível da enunciação ou do enunciado. Relacionado à focalização, o observador pode ser mais ou menos implícito, sincretizado com actantes pragmáticos tais como narradores e personagens, operando a debreagem e construindo, dentro de um espaço, tanto o sujeito cognitivo que o habita, como aquele que o descreve: o observador "é encarregado de exercer o fazer receptivo (ativo: escutar, olhar) e passivo (ouvir e ver) e, eventualmente, o fazer interpretativo, que é uma das formas do fazer cognitivo, associado à 
instância da enunciação (tal tipo de fazer recai sobre outros actantes e programas narrativos, e não sobre ele mesmo ou seu próprio programa) (GREIMAS; COURTÉS, (2011 [1979], p. 348; verbete: observador ). Como sujeito cognitivo o observador mediatiza a comunicação do saber entre enunciador e o enunciatário sob formas variáveis (conforme se suponha que sabe ou ignora muita ou pouca coisa)" (p. 66; verbete: cognitivo).

No nível actorial o papel do sujeito cognitivo pode se manifestar em sincretismo com o do sujeito pragmático, ou pode ser diferente dele, possibilitando o aparecimento de um ator autônomo como o informante, que em certos casos "será simplesmente reconhecível como posição ao menos implícita, sob a forma de observador" (p. 66). Assim, o enunciador cria, para a aspectualização do espaço, um sujeito cognitivo observador que pode entrar em sincretismo com outro actante da comunicação (narrador ou narratário) ou da narração; e um informante, que representa um ator autônomo, um sujeito também cognitivo dotado de saber, parcial ou total, e colocado no discurso em posição de mediador em relação ao enunciatário (p. 265 e p. 348; verbetes: informador e observador ). Com base na ideia de sujeito da enunciação que é composto de enunciador e enunciatário, poderíamos sugerir, no caso do discurso fílmico, a existência de um sujeito da observação, composto de observador e observatário, e relacionado à relação motivada da linguagem plástica.

Com base na ideia de partilha entre os espaços cognitivos dos sujeitos enunciativos e dos sujeitos do enunciado, observadores $e$ informantes, Fontanille sugere um modo de aspectualização espacial a partir de categorias exclusivamente discursivas: a modalização cognitiva do espaço, a tradução figurativa dessa modalização, e a manifestação figurativa dessas categorias. Assim, do ponto de vista espacial cognitivo intersubjetivo, construído entre a produção de um observador enunciador e o reconhecimento de um observador enunciatário, as modalizações de saber e poder geram quatro aspectos diferentes do espaço observado, que pode ser exposto, obstruído, inacessível e acessível. A exposição caracteriza tudo que, no enunciado, se exibe ao observador como, por exemplo, a face ou corpo de um personagem inteiramente visto; a obstrução caracteriza tudo que é encoberto, de difícil acesso, incompleto, ou pouco reconhecível, agindo como a negação da exposição (objetos parcialmente encobertos, distantes ou vistos de costas); a inacessibilidade caracteriza a imagem que se recusa ao observador, como a que se encontra nos limites naturais do campo de visão, ou são totalmente cobertas; a acessibilidade caracteriza tudo que se deixa perceber, entrever (em espelhos, reflexos, atores enquadrados por portas, cortinas e persianas entreabertas etc.). Assim: 
Figura 6 - A modalização cognitiva do espaço

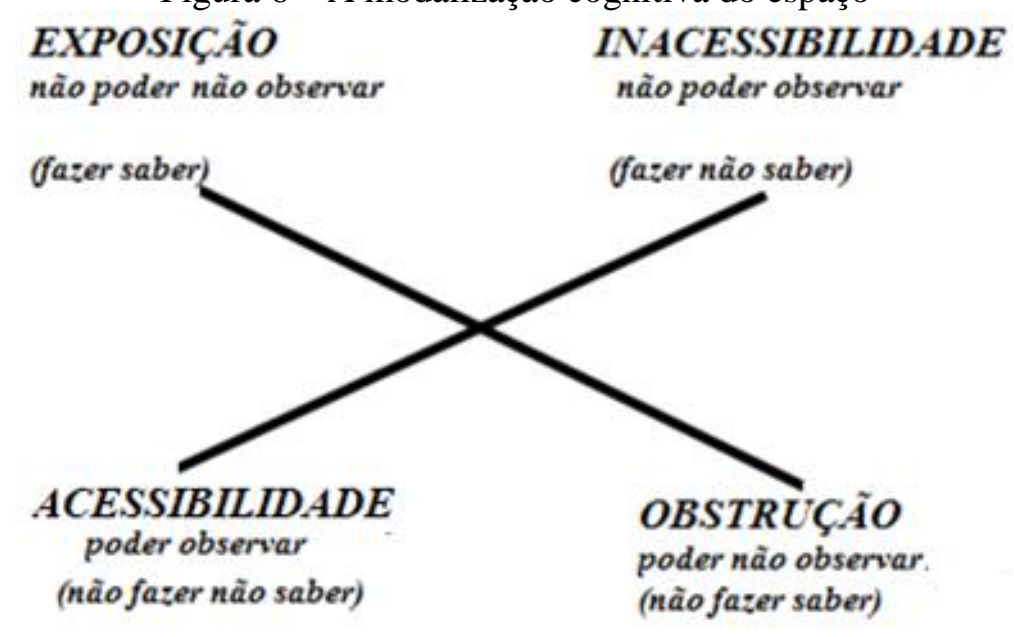

Fonte: gráfico adaptado de FONTANILLE (1989. p. 55).

Tal modelo pode ser visto como a manifestação dos regimes intersubjetivos que caracterizam a relação enunciador / enunciatário observador. Assim:

Figura 7 - Regimes intersubjetivos da relação observador/informante

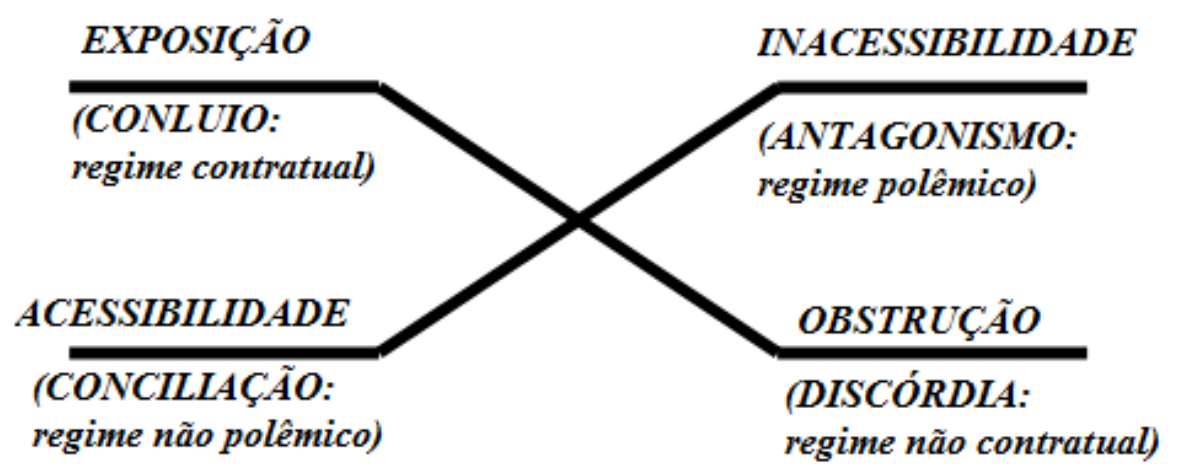

Fonte: FONTANILLE (1989, p.56).

Além da modalização cognitiva do espaço, Fontanille sugere categorias figurativas dessa modalização relacionadas ao movimento, que pode ser simples ou complexo, e são 
responsáveis pela aspectualização do espaço, cujas categorias são direcionalidade e englobamento. $\mathrm{O}$ movimento simples significa toda modificação elementar de uma relação espacial. Assim, em uma relação direcional, a expansão produzirá um afastamento e a contração produzirá uma aproximação (resultando em uma distância); em uma relação de englobamento, a expansão produzirá uma extensão do espaço, enquanto a contração produzirá uma concentração (resultando em uma ocupação). Essas duas categorias obtidas, distância e ocupação, podem ser definidas como a aplicação, a uma relação invariável de tipo dada, de um movimento variável do mesmo tipo: assim, a distância resultará da aplicação de um movimento variável direcional a uma relação invariável direcional; e a ocupação resultará da aplicação de um movimento variável de englobamento a uma relação invariável de englobamento. Assim, sendo C uma condensação (ou concentração) e E uma expansão, temos:

Movimento simples no espaço e suas categorias:

a. Distância $=$ movimento $($ variável) direcional + relação (invariável) direcional (aproximação - C vs. afastamento - E). Ex: a atividade de ir e voltar, ou subir e descer observada a partir de um ponto de vista fixo, ou invariável (exemplos nossos).

b. Ocupação = movimento (variável) de englobamento + relação (invariável) de englobamento (expansão - E vs. concentração - C). Ex: uma matilha de lobos que cerca uma presa dentro de uma forma circular (relação invariável), aproximando-se dela lentamente, formando uma concentração de elementos dentro dessa área, ou retrocedendo (relação variável): os resultados extremos da condensação seriam a nuclearização ou a pontualização.

Se o tipo figurativo do movimento difere do tipo de relação obtêm-se os movimentos complexos, definidos como a aplicação a uma relação de um tipo dado, de um movimento pertencente a outro tipo. Assim, um movimento direcional (variável), aplicado a uma relação de englobamento (invariável) produzirá "cruzamentos" ou "atravessamentos" do espaço: se o cruzamento se dá no sentido da expansão, tem-se uma saída, se no sentido da condensação, uma entrada. Da mesma maneira, um movimento de englobamento (variável) aplicado a uma relação direcional (invariável) produz efeitos de "difusão" no espaço: se a difusão é em expansão, produz-se uma dispersão; se ela é condensada, dá-se uma reunião. Assim:

Movimento complexo no espaço e suas categorias: 
a. Cruzamento $/$ travessia $=$ movimento $($ variável $)$ direcional + relação (invariável) de englobamento (entrada - C vs. saída - E). Ex: Fontanille exemplifica como a ultrapassagem de um limite, como o entrar ou sair de qualquer espaço delimitado (seja ele bi ou tridimensional); ou a visão de um espaço separado do observador por algum limite (porta, cortina, cerca etc) ${ }^{13}$ : no cinema, o enquadramento ou olhar de um personagem para além do quadro, um cruzamento do espaço, potencializa outro espaço.

b. Difusão $=$ movimento $($ variável) de englobamento + relação (invariável) direcional (reunião - C vs. dispersão - E). Ex: Fontanille (1989) comenta que se as figuras de um quadro tendem a se alinhar na direção de um olhar fixo, produzindo a impressão de reunião espacial, dá-se uma combinação de duas categorias: uma reunião produzida pelo espaço enunciado, regida por uma direção do olhar que observa. Este encontro é também a tradução figurativa do plano modal da obstrução (FONTANILLE, 1989, p.58). Pode-se pensar em "uma fila de pessoas vista de frente", onde um sujeito maior, ou em primeiro plano, pode esconder ou encobrir todos os demais atrás dele $\mathrm{e}^{14}$.

Para definir uma dada posição no espaço, a língua usa uma categoria espacial (a horizontalidade, por exemplo, que pertence à direcionalidade), sobre a qual aplica uma escala de avaliação homogênea, que pode ser medida pelo movimento (próximo ou distante), ou pode representar um ponto numa dada perspectiva espacial (superatividade e inferatividade). Como

\footnotetext{
${ }^{13}$ Fontanille fornece algumas ilustrações plásticas da categoria "cruzamento", que pode ser mais refinado, e a partir do qual se podem distinguir: no englobado (centro e periferia: mesotopo e peritopo); e no englobante (circundante e distante: paratopo e téletopo). Assim, o cruzamento apresentaria um percurso mínimo típico: da periferia (peritopo) ao distante (paratopo). O movimento direcional às vezes, pode encontrar um fechamento hermético do englobamento, tensão que se resolve de duas maneiras: por falta de movimento, ou por um movimento não direcional que se confina à periferia do local; se a saída é impossível, dá-se um movimento peritópico; se a entrada é impossível, paratópico (como a imagem de um leão circulando dentro de uma jaula, incapaz de sair; ou um gato circundado uma gaiola, e incapaz de entrar). No caso do espaço de observação, o "cruzamento impossível" produz dois efeitos particulares: na impossibilidade de avançar no espaço enunciado sem se tornar um ator como os outros, perdendo seu estatuto de observador único, o sujeito adota um movimento peritópico; da mesma maneira, na impossibilidade de recuar em relação ao espaço enunciado sem dele excluir-se, o observador adota movimentos paratópicos.

${ }^{14}$ Uma imagem mais comum no cinema, fotografia, pintura ou em espaços tridimensionais (um grupo de dançarinos, por exemplo, posiciona-se em fila, de frente para uma plateia, e ondula os braços para compor uma figura com cabeça, um par de pernas, mas vários pares de braços). Na literatura tal imagem é mais difícil de ser encontrada, mas não de ser descrita, como fizemos aqui, fato que demonstra certos "ganhos" visuais relativos a possibilidades expressivas de certas linguagens: nesse sentido as linguagens icônicas parecem ser mais interessantes para criar esse tipo de efeito do que as verbais. De toda maneira, a ideia de obstrução de uma imagem é mais comum na literatura do que a de difusão.
} 
explica Fontanille, tal escala é do âmbito da aspectualização do espaço, de modo que o espaço tópico é mais da ordem aspectual do que espacial. O que é mais propriamente espacial neste espaço é o ponto de referência: enunciativo (o enunciador ou o enunciatário) ou o enuncivo (ponto de referência inscrito no enunciado), que funciona como um especificador do espaço linguístico propriamente dito. Quando se usa um espaço tópico, ele estará sempre precisando um espaço linguístico explicitamente manifestado ou não, de modo que o conceito de debreagem só se aplica ao espaço linguístico e não a seu especificador: na debreagem enunciativa, o ponto de referência é o espaço do enunciador; na debreagem enunciva, o ponto de referência é o do enunciado (FIORIN, 2002, p. 265).

As questões sobre o espaço linguístico e topológico, a relação entre o observador e o informante, e a figuração de tipos de movimento são sugestivas e merecem destaque em uma teoria semiótica da adaptação fílmica, por poderem ser utilizadas tanto para a texto verbal como para o audiovisual. Uma vez que o espaço visual fílmico é também dotado de som, a modalização cognitiva do espaço também supõe a exposição, obstrução, inacessibilidade e acessibilidade não apenas visuais, mas sonoras, relacionadas à fala, à música e ao ruído, que podem ser claros e nítidos, negados no silêncio, abafados, cortados, difíceis de serem ouvidos ou entreouvidos: imagem e som dão conta do espaço cognitivo, inteligível e sensível. Da mesma forma, assim como a modalização cognitiva do espaço e a figuração do movimento é produzida em ambas as linguagens, é preciso ainda tenta explicar como cada uma realiza tais operações. Na linguagem verbal, por exemplo, pronomes demonstrativos, dêiticos, advérbios espaçoaspectuais e preposições sistematizam o espaço linguístico e topológico. Na linguagem fílmica, no entanto, distância, cruzamento, difusão e ocupação no espaço cognitivo bi-tridimensional é de ordem plástico-cinemática e sonora motivada, executada por um actante da enunciação. Assim, não podemos deixar de investigar alguns modos de manifestação do sentido fílmico, pertinentes à imagem enquadrada em movimento, para tratarmos de questões referentes a proxêmica e a gestualidade, características que o aproximam o cinema de textos gestuais, como a dança e o teatro. Por produzir um texto plástico que se expressa a partir do movimento, o cinema, além de um texto visual planar, torna-se proxêmico e gestual.

\subsection{Operações plásticas do sentido fílmico: imagem, plano e decupagem}

Dentro de nossa discussão sobre manifestação e textualização do percurso gerativo cabe ainda falar sobre como o conteúdo e suas categorias são realizadas a partir das coerções da linguagem cinematográfica, que não é uma linguagem natural, sendo construída historicamente 
a partir de práticas narrativo-discursivas de uma semiose audiovisual planar, que começa bem antes do cinema. Como o mesmo sentido pode ser expresso de maneiras diferentes, cumpre tecermos algumas considerações sobre o discurso fílmico a partir do quadro em movimento, do plano, da montagem, ou decupagem, e do som, que formarão unidades textuais e discursivas controladas por um enunciador que projeta de maneira bem particular, a partir de embreagens e debreagens, um discurso audiovisual diegético. Esse discurso, de um lado é inscrito de relações entre formas e volumes visuais e sonoras que pretendem a ilusão de mundo "real" cognitivo habitado por um sujeito sensível; e de outro, é o local onde se dão as relações entre o sujeito da enunciação e o do enunciado. Por ser um espaço cognitivo que pretende um mundo natural, o filme adota observadores audiovisuais, que oscilam entre enunciação e enunciado, e realizam o que chamaremos de linguagem proxêmica, relacionadas a gestos, movimentos e distâncias no espaço.

\subsubsection{O espaço imagético em movimento no quadro fixo}

A imagem, no cinema (a nossa discussão baseia-se principalmente no cinema analógico, filmado em película, que é o caso de nosso objeto, mas não exclui o cinema digital, cujos quadros são "tecidos" em linhas), é um fenômeno curioso, pois ela nada mais é (e vamos inicialmente abstrair o enquadramento e os movimentos da câmera), do que um conjunto de textos plásticos planares imóveis, os fotogramas, projetados em uma velocidade que pode ser alterada para satisfazer as demandas da narrativa e criar efeitos discursivos ${ }^{15}$. Assim, criando a captura menos do gesto e da pose, como a pintura ou a fotografia, do que de vários instantes do movimento espaçotemporal, o material bruto do cinema é formado de uma sequência de textos plásticos fixos relacionados minimamente ${ }^{16}$. Projetados em sucessão e rapidamente, dentro de uma dimensão espacial pré-estabelecida, o quadro, esse conjunto de fotogramas vai criar a ilusão de movimento e transformação da imagem, ou de sua inércia e permanência no tempo. O cinema capta movimento enquanto transformação espaçotemporal.

Como local da enunciação, a tela do filme, que não deve ser confundida com a tela das salas de cinema, é um espaço plano poligonal no qual a imagem é "acolhida" e pensada em

\footnotetext{
${ }^{15}$ A imagem como movimento plástico existe bem antes que o cinema.

${ }^{16}$ Segundo Deleuze (2018), o cinema vai além da fotografia clássica, conhecida como "posada" (provavelmente por causa da pintura), instituindo as fotos instantâneas e suas equidistâncias dentro do suporte "filme" (p. 18). O filósofo entende o fotograma menos como parte do discurso fotográfico do que como típico do cinema, como elemento genético da imagem, elemento diferencial do movimento, sendo término e princípio de sua aceleração, redução e variação. Do ponto de vista semiótico, a definição do filósofo conduz à ideia de fotograma como uma das unidades mínimas do plano da expressão fílmica, que não deve ser confundida com a expressão pictórica, pois é pensada cinéticamente.
} 
termos de composição, sendo projetada em uma velocidade considerada "normal e aceita socialmente como realista", e que será a medida para outras velocidades. Se o cinema começa a sua história projetando imagens em movimento dentro de um espaço visual quadrado, com sua evolução e novas tecnologias de exibição, ele altera o campo visual da enunciação, tornando-o mais retangular, mas não eliminando os tamanhos e formatos anteriores, que são decididos pelo enunciador por vários motivos, práticos e poéticos ${ }^{17}$.

Figura 8 - Três dimensões da tela de cinema

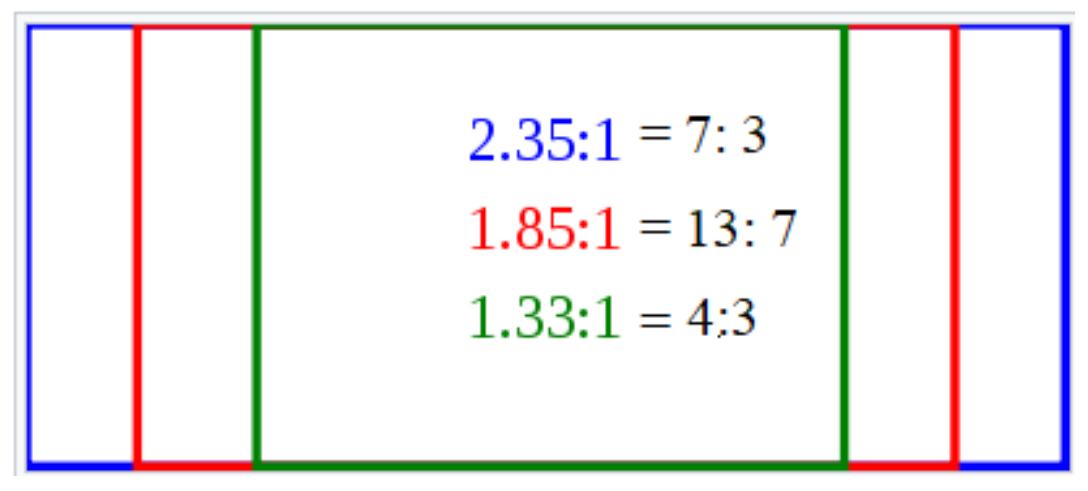

Fonte: Wikipedia ${ }^{18}$.

A partir da ideia de filme como texto plástico-cinemático construído a partir de um recorte-enquadramento, as discussões seminais de Greimas sobre a semiótica planar pictórica nos auxiliam a entender algumas das características desse tipo de texto. Como vimos mais acima, "os efeitos de quadro pensáveis são os mesmos em pintura e no cinema", sendo que sua diferença está nos "meios empregados para atingir tais efeitos e, por conseguinte, nos contextos estético-estilísticos nos quais são pensados" (AUMONT, 2004, p. 124): tais meios estéticoestilísticos podem ser pensados, a partir da semiótica, em diferentes tipos de coerções expressivas de cada linguagem, modalizados por um querer-dever-fazer. Ambos os teóricos, por exemplo, ao trabalharem a superfície da tela, tratam o quadro como um espaço que pode ser recortado de diversas vezes em outras figuras geométricas, e no qual formas e massas cromáticas mais ou menos figurativas são espalhadas topologicamente, criando pesos, densidades atrações e repulsões, equilíbrios e desequilíbrios, áreas mais vazias e cheias de cores e volumes, em uma operação tensiva de composição plástica.

Deleuze (2018) acredita que o quadro fílmico é geométrico e físico, possuindo dois tipos opostos de presença, relacionados à saturação e à rarefação de elementos visuais que o

\footnotetext{
${ }^{17}$ Como é o caso da pintura e da fotografia, no qual tamanhos e formatos de tela e negativo são determinados pelo artista e escolhidos para gerar um efeito de sentido.

${ }^{18}$ https://pt.wikipedia.org/wiki/Proporção_de tela. Acesso em 10/ 06 / 2019.
} 
preenchem ou o tornam uma área totalmente negra ou branca (p.30). Tal fato estético pode ser visto discursivamente como a negação da imagem, ou pelo menos um ou vários de seus formantes. Do ponto de vista tensivo, se no projeto plástico da imagem ela é composta por uma cor difusa e gradual, que vai desaparecendo, ou oposições bruscas de cores, teremos, no primeiro caso, um discurso baseado em escolhas emissivas, ou de continuidade; e no segundo, escolhas remissivas, de descontinuadas e paradas (TATIT, 2007a, p. 387).

Nesse sentido Aumont comenta que, apesar de serem confirmados de maneira diferente, é no quadro e na cenicidade, ou no jogo dos valores plásticos, que cinema e pintura mais se assemelham. Ademais, lembrando que na pintura figurativa clássica o arranjo de figuras, meio simbólicas, meio funcionais, é realizado a partir de um decorum, o teórico lembra como as imagens enquadradas são efeitos estéticos criados e sancionados a partir de valores sociais que fundam o quadro como local do discurso: ele e a superfície da tela "são investidos de um valor propriamente retórico e a tela 'fala', exibe o seu decorum, sua composição simbolicamente correta" (AUMONT, 2004, p. 113). Tal operação aciona, tanto na pintura como no cinema, a organização de formantes visuais nos eixos de seleção e contiguidade, e requisita da parte do enunciatário observador capacidade de interpretação de texto e reconhecimento do mundo natural construído no discurso pictórico motivado.

Quando Greimas discute o quadro, ou tela, em relação à pintura, explicando que é ela uma área plana capaz de expressar a profundidade do mundo, ou seja, de construir efeitos de tridimensionalidade, uma questão cara ao cinema é levantada, sendo relacionada à diferenciação entre a noção de quadro e campo, termos que não são sinônimos e apontam para dois pontos de vista em relação à imagem figurativa planar, que valem tanto para o cinema como para a pintura. Enquanto a ideia de quadro alude, como vimos, à figura geométrica de um polígono (o termo quadro vem do italiano quadro, palavra que deriva da palavra latina quadratto) dentro do qual a imagem é colocada, recortada e organizada, detida e tornada finita, a ideia de campo compreende o mundo retratado como "real", ou tridimensional. Segundo Deleuze (2018), por ser geométrico ou físico, o quadro torna-se sistema fechado no que diz respeito a coordenadas escolhidas ou variáveis selecionadas, e também no que se refere às partes do sistema que ele ao mesmo tempo tria e mescla (p. 30-31).

O campo, ao contrário, pertencendo aos efeitos de verdade figurativos do mundo natural tridimensional, torna-se uma "janela" onde o "planar" é reconstruído em “esférico", não apenas pelo uso da perspectiva, mas também por sobreposição de formas e cores e a criação de proporções e relações plásticas: fazer uma imagem, segundo Aumont (2004), é sempre “apresentar o equivalente de um certo campo, visual e fantasmático, e os dois a um só tempo, 
indivisivelmente" (p. 114). Aumont e Marie (2003) explicam que o campo vai além das bordas do quadro e determina um fora-de-campo (p. 42; verbete: campo). Desde que o mundo tridimensional emerge do mundo bidimensional, tais espaços logicamente dialogam e se confundem.

Sobre o fora de campo Deleuze (2014) é taxativo, entendendo-o como local que, apesar de estar presente, não pode ser ouvido ou visto: se num caso ele "designa o que existe alhures, ao lado ou em volta; noutro caso atesta uma presença mais inquietante, da qual nem se pode mais dizer que existe, mas antes que "insiste" ou "subsiste", um Alhures radical, fora do espaço e do tempo heterogêneo" (p. 35-37). Aproximando-se da categoria topológica da semiótica plástica, Aumont explica que a consideração do quadro-limite e o quadro-janela como um conjunto "é justificada por sua própria reversibilidade, que põe em evidência a escolha de duplas de termos - abertura / fechamento, centrípeto / centrifugo, avessos um do outro" (AUMONT, 2004, p. 120). Assim:

Figura 9 - Relações centrípetas e centrifugas entre quadro e imagem: "fora e dentro" do quadro

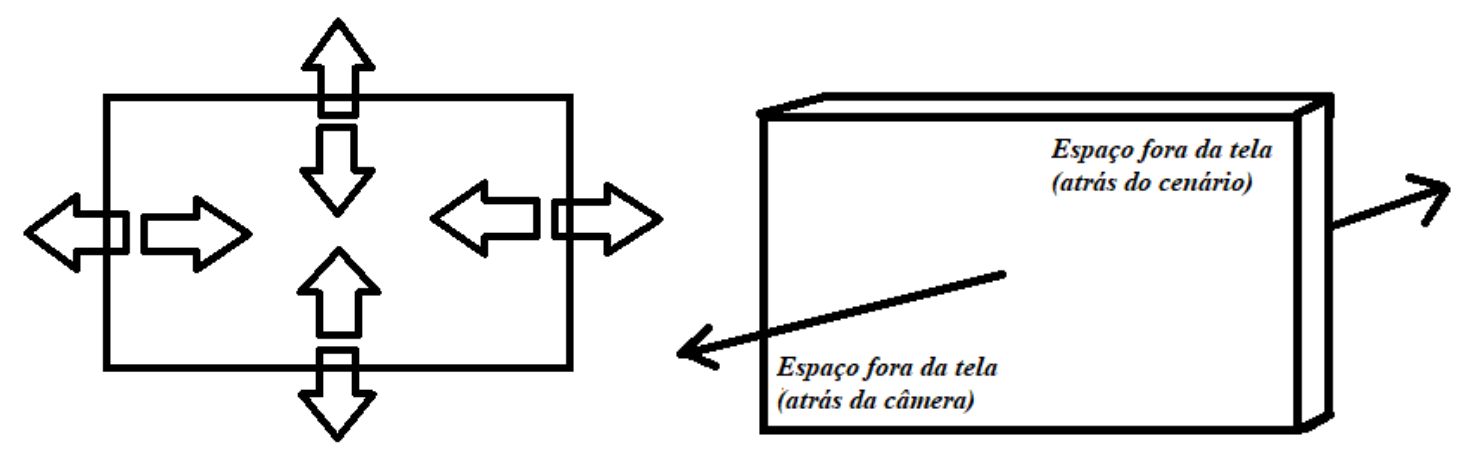

Fonte: autor.

A partir do momento que a profundidade do mundo é instaurada no quadro bidimensional, o campo, em sua tridimensionalidade, possibilita a ilusão de objetos visuais englobados e englobantes. Assim: 
Figura 10 - O plano tridimensional

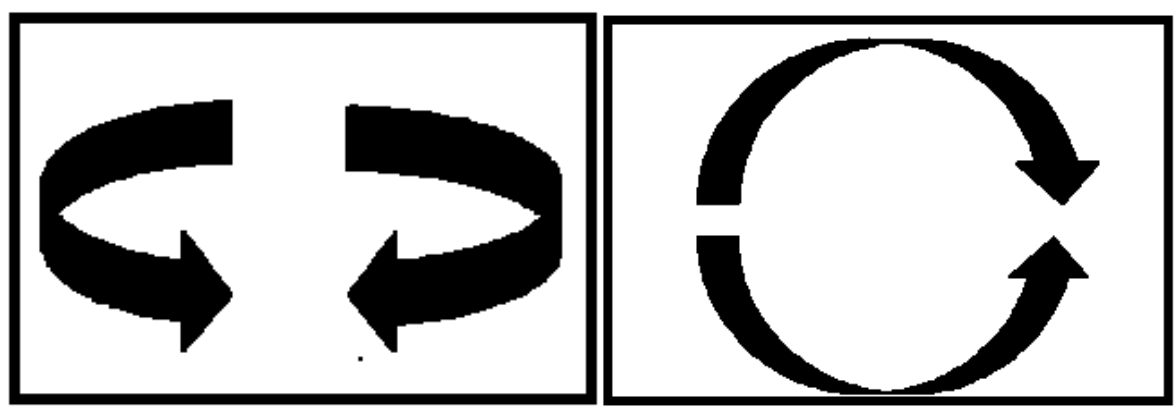

Figura: autor.

Considerando-se a imagem como conteúdos em movimento pode-se admitir que as figuras plásticas, controladas por categorias plástico-cinemáticas, de um lado alteram-se, sendo constantemente reformuladas, ou (re) formadas, e de outro são executadas, apesar de possuírem formas e cores, por outras práticas narrativas e coerções que diferem da pintura, envolvendo o recorte da luz e o uso de lentes, que podem manipular o espaço planar, tornando-o mais ou menos profundo. Se a pintura é um conjunto de manchas de tinta aplicadas sobre a tela, organizado em formantes pertinentes, figuras e ícones, o cinema é um conjunto de manchas de luz manipuladas por lentes e aplicadas em superfícies fotossensíveis, e que também geram topologias, cromatismos e formas ${ }^{19}$. Organizada por categorias cinemáticas, as figuras que compõem o quadro cinematográfico constroem a percepção de evolução e mudança gradual, alternando-se constantemente e provocando ajustes constantes em sombreamentos, sobreposições, direções, deslocamentos, distâncias, angulações etc. ${ }^{20}$ Sendo um texto sincrético formado de várias figuras expressivas a imagem fílmica firma um contrato veridictório mínimo a partir da mise-en-scène (cenários, figurinos, maquiagem, iluminação, encenação, movimento e intepretação dos atores), que estará a serviço de uma semiótica planar e significantes bidimensionais e audiovisuais.

Como em outros textos visuais planares e figurativos, uma imagem e suas figuras, dentro de um quadro fixo, podem ser observadas de vários ângulos, alturas e distâncias: de frente ou perfil, de cima para baixo e vice-versa, de modo mais aproximado ou distanciado, de cima, de

\footnotetext{
${ }^{19}$ É interessante observar que apesar de a cor é gerada ser diferentes no quadro pictórico e no cinema, de um lado pela tinta, formada de uma mistura de corantes, e de outro pela luz projetada em suporte fotoquímico sensível, tal diferença de qualidade cromática é anulada pelo próprio suporte de cada linguagem, cuja coerção possibilita uma paleta específica de cores próprias. A partir daí pode-se pensar que o vermelho, por exemplo, não é apenas gerado por outras cores que existem no texto e relacionam-se, mas também pelas coerções do suporte.

${ }^{20} \mathrm{Em}$ termos semissimbólicos, quanto mais uma figura cresce dentro do quadro, ocupando a sua totalidade, mais ela parece maior e próxima; quanto menos, menor e mais distante: o cinema pode desestabilizar essa semissimbologia, provocando surpresas.
} 
baixo, de uma altura "normal" (90 graus), etc. Em relação às bases inferiores e superiores da tela que recortam o texto visual e projetam a enunciação, sendo horizontais e verticais, a imagem também pode ser observada como "torta", ou "desnivelada", ou mesmo "de cabeça para baixo". Por causa disso, o reconhecimento da imagem, diferente do que acontece na literatura, está vinculado ao modo de como ela é observada e representada plasticamente, e também dentro de uma semiótica proxêmica e gestual simbólica, que elege o horizontal como posição humana natural.

No cinema, a tela, ou quadro, assim como no caso dos trípticos pictóricos (ou casos na pintura moderna, por exemplo), pode ser subdividida em vários outros quadros, textos visuais fixos ou móveis que se complementam de três maneiras: podem ser simultâneos e idênticos, simultâneos e diferentes, ou simultâneos e multifocais. Assim, a partir da subdivisão linear planar da tela em dois ou mais quadros, a ação que a imagem retrata pode ser narrada como um conjunto de textos visuais idênticos (a ação é repetida em todos os quadros); diferentes e autônomos, e mais ou menos complementares (ações diferentes que podem determinar causa e consequência em relação aos outros quadros); ou um conjunto de pontos de vista sobre a mesma ação (ação idêntica descrita de maneiras diferentes). Assim:

Figura 11 - A tela dividida em quatro planos e em enunciados simultâneos idênticos, diferentes e multifocais
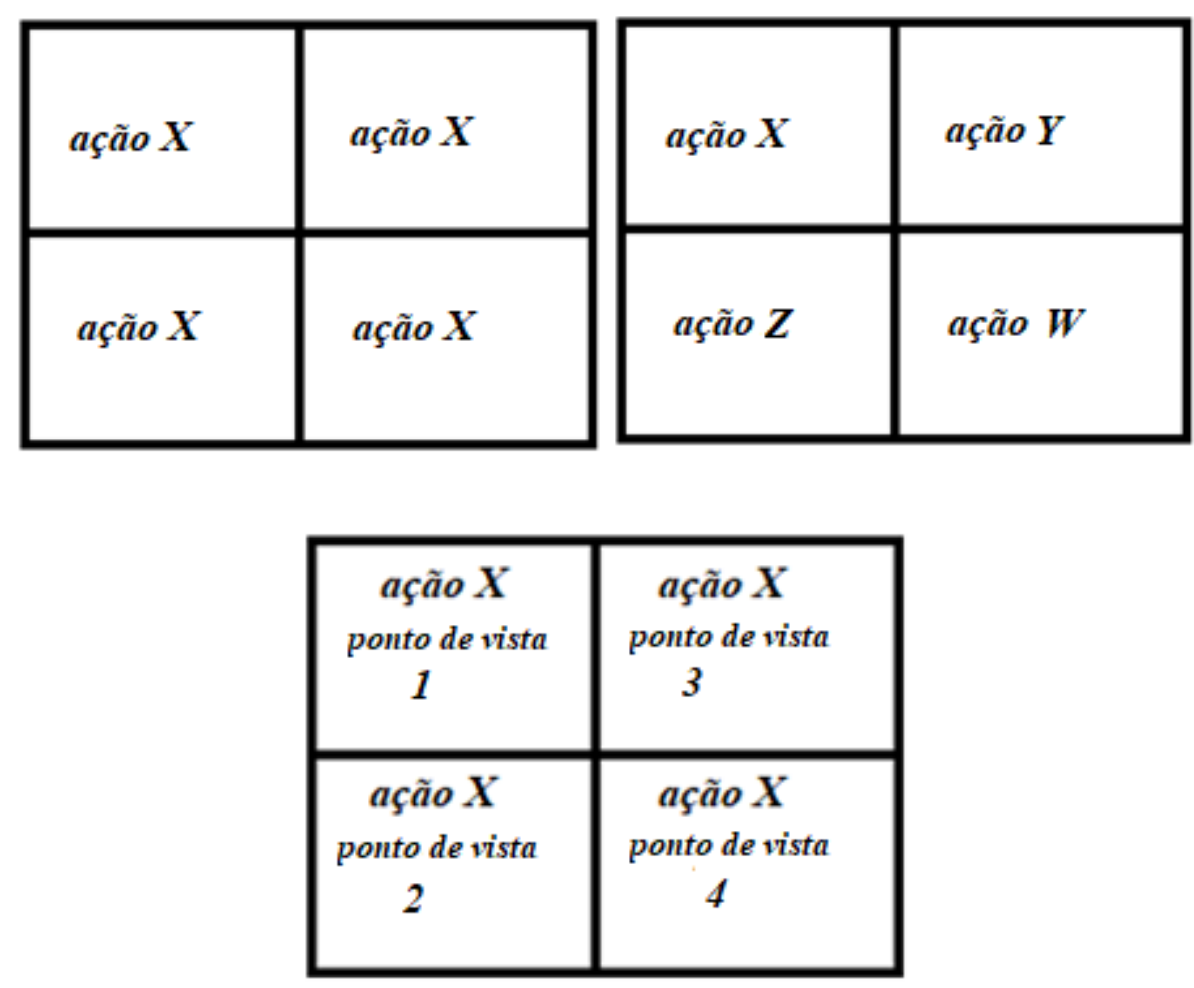

Fonte: autor. 


\subsubsection{O plano}

O quadro, que se inicia como apenas um campo fixo onde a imagem se movimenta, torna-se ele próprio um movimento, revelando outra capacidade da enunciação, e passa a criar o sentido a partir de relações de distância dentro dessa imagem. Assim se o quadro cinematográfico é, nos primórdios do cinema, um não quadro, ou seja, um espaço imóvel que revela uma mise-en-scène "viva", nos moldes de um proscênio teatral (os filmes de Méliès são um bom exemplo ${ }^{21}$ ) que possui um único ângulo de vista, ele logo adquire o poder de percorrer a imagem em dado tempo, potencializando a capacidade expressiva da linguagem cinematográfica.

Segundo Bonitzer (1982), é o plano que estabelece a linguagem fílmica e sua evolução (p.16). A partir do movimento, tanto interno, da cena, como externo, do quadro, Deleuze (2018) acredita que o cinema, mais diretamente do que a pintura, fornece relevo e perspectiva ao tempo (p. 46). Ao falar sobre o plano, o filósofo os compara à "imagem-movimento", o que pressupõe deslocamento espacial dentro de um tempo, mas também, segundo a semiótica, a construção do tempo. Como imagem-movimento o plano é o corte móvel da duração, possuindo dois aspetos: de um lado apresenta modificações de posição relativas ao conjunto ou conjuntos de elementos da composição do discurso fílmico, de outro exprime mudanças absolutas num todo apresentando enquadrado e topológico, de modo que articula conjuntos e modificações entre as partes, em totalidades que exprimem mudança.

De maneira geral, aceita-se que há sete tipos de plano fílmicos que operam a inserção do sujeito em espaço cognitivo discursivo. Bordwell (2013a) discrimina: o plano geral (PG), relacionado a grandes distâncias, e no qual o corpo humano é minimamente reconhecido, perdendo-se ou ficando minúsculo; o plano de conjunto $(\mathrm{PCj})$, no qual as figuras são mais proeminentes, mas o fundo ainda domina, e o corpos podem ser demonstrados em conjunto e de forma inteira; o plano americano (PA), que enquadra os corpos a partir da altura do joelho, sendo menos amplo que o $\mathrm{PCj}$, mas espaçoso o bastante para mostrar o fundo, sendo "planos comuns, já que permitem um bom equilibro entre figura e entorno; o plano médio (PM), que

\footnotetext{
${ }^{21}$ Bonitzer (1982) acredita que tanto em Méliès, como em muitos filmes de Chaplin, mais interessados em registrar a pantomima dentro de um cenário único filmado frontalmente por uma câmera fixa, ainda não existe a noção de plano, que será desenvolvida por Griffith, que deixa de regular a câmera em relação ao ponto de vista do público, e opõe visões aproximadas de visões distanciadas (p. 25-26). Não obstante, téoricos concordam em ver o cineasta francês como o pai da trucagem, e não da narrativa cinematográfica.
} 
corta os corpos na altura da cintura e limita mais o espaço ao seu redor, mas torna gestos e expressões do sujeito mais visíveis; o meio primeiro plano (1/2 PP), que enquadra o corpo do peito para cima, diminuindo assim o espaço; o primeiro plano (PP), que enquadra pescoço e a cabeça do ator, "enfatizando a expressão facial, os detalhes de um gesto ou um objeto significativo; e o detalhe, ou primeiríssimo plano (PPP), que isola e amplia um objeto, revelando partes menores do corpo do sujeito (p. 309).

Tal tipologia, porém, foi revisada várias vezes e novas surgiram, aumentando o leque de possibilidades discursivas do sujeito e do espaço. Na teoria cinematográfica há uma miríade de nomenclaturas de planos, tais como o plano de dois ou de três, o aberto, o fechado etc. Da mesma maneira, a profundidade de campo da imagem e os vários recortes que uma composição pode gerar dentro de um campo visual dificultam a clara delimitação dos planos. Tais dificuldades igualmente incidem sobre a descrição de ângulos, distâncias e alturas de objetos apreendidos e construídos na duração temporal da enunciação visual. Além da impossibilidade de fixar planos concretos, pois eles evoluem constantemente, há ainda a crítica de que a tipologia mais geral de Bordwell não se aplicaria a filmes feitos depois da era clássica e do controle dos estúdios, e gerados em uma linha de produção industrial, de modo que certos planos eram simplesmente repetidos a partir de relações de custo benefício da indústria de entretenimento: assim, a linguagem fílmica estaria mais à mercê de forças econômicas do que culturais, sendo um objeto simbólico fabricado. $\mathrm{O}$ mesmo, no entanto, pode ser dito de qualquer linguagem.

A questão de variação e repetição de planos interessa à semiótica por seu caráter significante, discursivo e até mítico, de modo que, sendo ou não repetido, os planos mais primitivos, de um lado indicavam preocupações básicas sobre a enunciação fílmica que ainda são pertinentes; de outro, sua atualização é relativamente rápida, e o cinema aprendeu a significar através de diferentes distancias e composições, que podem ser analisadas a partir das cifras tensivas de mais e menos distante, longo, ou acelerado. Bordwell lembra-nos a capacidade gradual de existência dos planos, o que nos remete a uma semiose tensiva própria de qualquer linguagem. Tatit (2007a) prefere pensar os planos (também no desenho e na pintura) como aberturas, e os seus limites como fechamentos, comparando-os a uma divisão silábica, de modo que possuem extensões, seus espaços, e limites, seus recortes (p. 387).

Além dos quadros fixos, ligados pela montagem, e suas inúmeras possibilidades de focalização, a câmera cinematográfica, construindo o quadro em movimento passa a ver menos passivamente do que ativamente, a partir de dois movimentos básicos que serão desenvolvidos e expressos de diferentes maneiras (em gruas, câmeras na mão, steadycams etc): os movimentos 
panorâmicos (a câmera, de um ponto fixo, registra imagens virando-se para todos os lados do espaço: para a esquerda e direita, para cima e para baixo, diagonalmente ou de cabeça para baixo, em direção ou ao lado oposto da figura que registra); e os travellings (o corpo da câmera move-se nos vários sentidos do espaço, realizando os mesmos movimentos da panorâmica, mas de maneira que as dimensões desse enquadramento móvel sejam mantidas), dos quais o zoom pertence como travelling ótico (e não mecânico).

Finalmente, e como mescla total de todos os planos do cinema há o plano-sequência, conhecido também como longo plano (PS), e cuja operação discursiva privilegia a identidade e a continuidade, de modo que é um movimento contínuo e sem cortes. O PS pode ser obtido travellings e panorâmicas, mas também pode ser mais ou menos fixo, de modo que incorpora o movimento e a fixidez, podendo variar de formas mais ou menos graduais e extensas a relação com um observador e a distância entre os elementos do mundo esférico, tornando as categorias topoógicas mais instáveis e abstratas. Sendo mais ou menos fluido, o PS pode ser expresso em apenas um plano, o de conjunto, por exemplo, ou um close, mas geralmente mescla distancias em sua duração cinemática. Deleuze (2018) acredita que antes de interiorizar a montagem, o PS coloca problemas específicos a esse tipo de operação discursiva (p. 53). O plano em movimento, gerenciado por panorâmicas e travellings, pode também apresentar direções e velocidades diferentes de seus movimentos internos, outro fato que dificulta a criação de tipologias. Fornecendo a ilusão de total fusão espaçotemporal o PS é negado por Mitry, que o vê menos como uma operação de enquadramento do que de montagem.

Os planos cinemáticos são capazes de não apenas construir o espaço e o sujeito, mas construi-los em uma duração temporal, relacionada ao movimento. Como pode mimetizar os percursos do olhar, os movimentos de uma "cabeça" que vê, ou de corpos-observadores em movimento, podem ser investidos de valores de subjetividade, tanto advindos de um sujeito da enunciação (em forma de estilo autoral) como do enunciado, que oscilam na narrativa. Como o sistema virtual do discurso engloba todos os tipos de enunciação sobre o espaço, feitas pelo cinema desde os seus tempos primevos, o PS nos ensina que o plano aprende a fazer gestos e a se mover, formando um sistema virtualizado proxêmico constantemente atualizado.

Capaz de enquadrar, ou seja, triar os limites do espaço, o plano em movimento adquire grande autonomia de edição, pois pode igualmente "cortar" partes do espaço e o que o integra, assim como sua manifestação, ou existência realizada no tempo. Operando um corte em movimento, ele "não se contenta em exprimir a duração de um todo que muda, mas faz incessantemente variarem os corpos, as partes, os aspectos, as dimensões, as distâncias, as posições respectivas dos corpos que compõem o conjunto da imagem” (DELEUZE, 2018, p. 
46). A partir daí Deleuze considera o plano como elemento com duplo aspecto: translação das partes de um conjunto que se estende no espaço, e mudança de um todo que se transforma na duração (DELEUZE, 2018 [1983], p. 39).

Dentro das tipologias dos planos, um plano se sobressai dos demais, sendo "um dos mais constantes objetos teóricos de qualquer reflexão sobre o cinema, por causa de sua expressividade, capacidade de extrema aproximação, aumento do poder de revelação, e consequente destruição momentânea do espaço diegético e sua profundidade: o close, ou PP, que pode estender-se ao PPP, que são distâncias capazes de dificultar a leitura da imagem ou a própria fluência da narrativa visual. Exibindo fenomenal força, a teoria cinematográfica entende o PP como existência individual com valores próprios, o plano da intensidade por excelência. Jean Epstein chama-o de "a alma do cinema" (apud AUMONT, p. 141) e Deleuze o descreve como a própria imagem-afecção, pois refere-se, ao mesmo tempo, a um tipo de imagem e a um componente de todas as imagens (DELEUZE, 2018 [1983], p. 141). Segundo o filósofo, ao determinar uma rostidade, que não precisa ser apenas humana, o PP retira o objeto de seu espaço, a parte do todo, abstraindo-o de todas as coordenadas espaciais.

Aumont (2006), resumindo algumas de suas características principais, explica que ambos o PP e mais intensamente o PPP produzem efeitos de "gulliverização" ou de "liliputização", tirando partido do tamanho relativo da imagem e do objeto representado, sendo muitas vezes utilizados devido a seus estranhos efeitos de ampliação; ele também transforma o sentido da distância, levando a uma proximidade psíquica e a uma intimidade; e materializa quase literalmente a metáfora do tato visual, ao acentuar ao mesmo tempo e contraditoriamente a superfície da imagem (uma vez que nela o grão está mais perceptível) e o volume imaginário do objeto filmado (extraído do espaço circundante, cuja profundidade é abolida. Dentro da concepção de descontinuidade do espaço, o PP arruína a concepção linear da montagem em benefício de uma concepção do plano como fragmento, tendo efeitos pulsionais e vertiginosos, que simultaneamente repelem e fascinam (p. 140-143).

Em relação à proximidade do rosto humano, parte do corpo mais expressiva por registrar a emoção, que está inserida na produção de figuras gestuais faciais socializadas, sancionados e praticadas culturalmente, o PP e a face interagem e confundem-se de tal maneira, que segundo Deleuze "não há primeiro plano de rosto, o rosto é em si mesmo primeiro plano, o primeiro plano é por si mesmo rosto, e ambos são o afeto, a imagem afecção (DELUZE, 2018 [1983], p. 142). A extrema importância do rosto e seus componentes é inegável, e provavelmente 
emergem de práticas sociais voltadas à sobrevivência tanto material quanto afetiva ${ }^{22}$. No ser humano, sabe-se que o rosto "é lugar de onde se vê e de onde se é visto, razão pela qual é lugar privilegiado das funções sociais - comunicativas, intersubjetivas, expressivas, linguísticas, servindo também como suporte ontológico: o rosto é do homem” (AUMONT, 1998, p.18), revelando os tormentos interiores provocados pela existência. Do ponto de vista semiótico discursivo, o rosto interessa de várias maneiras: primeiramente, e no âmbito social, fazendo parte de uma semiótica natural, ele é um dos mais importantes operadores da narrativa, sendo "puro operador de sentido, de relato e movimento, pivô da narratividade e o vínculo da diegese" (p. 53). Dentro de uma semiótica gestual e espacial do mundo natural, ao qual localizamos o plano, o ser humano também elabora uma gestualidade facial, que também é plástica e cinemática.

Do ponto de vista sócio-semiótico, o plano torna-se uma ferramenta de atualização da observação do sujeito na profundidade do espaço, iniciada nas artes mais primitivas. O plano fílmico enuncia a esferecidade do mundo a partir de um espaço planar, criando relações de profundidade dentro dessa esfera, e diferentes pontos de vista, que são expressos por distâncias, movimentos, velocidades, ângulos e alturas dentro de um espaço topológico cognitivo. A ideia de figura e fundo, tão cara à psicologia, na semiótica transforma-se na de sujeito e mundo esférico e sensível. Ao mesmo tempo, tais conteúdos expressivos são acionados por categorias tensivas que controlam as graduações de distâncias e movimentos operadas nesse espaço cognitivo, mesclando e triando suas partes. Sendo imagem-movimento que se aproxima e distancia-se de objetos do mundo, percorrendo um espaço esférico construindo de forma mais ou menos contínua de pedaços, o plano constrói também atores, que podem ser mais concretos ou abstratos, mas que não obstante vão adquirir um corpo que será composto em relação ao espaço circundante. Na narrativa fílmica, o ator e seu corpo, através de planos manipulados por enunciadores que controlam as breagens discursivas, significam o espaço transformando suas relações com ele e transformando-o cognitivamente. Como estratégia mais intensa de representação do sujeito no mundo, o PP e o PPP podem marcar tanto a identidade de um ator como provocar sua destruição.

\footnotetext{
${ }^{22}$ Indo além das práticas humanas, lembramos que há muitas espécies de seres vivos cujas manchas no corpo servem de proteção, pois mimetizam um olhar grande e ameaçador que afugenta o inimigo. Parece haver na natureza o reconhecimento do perigo do olho e de ser olhado.
} 


\subsubsection{Edição: montagem e decupagem ${ }^{23}$}

Os planos, porém, não existiriam sem uma edição que mesclam decupagens e montagens, organizando o discurso audiovisual icônico tanto em relação a distâncias do mundo natural representado, como em suas relações sintagmáticas simbólicas, que incluem distâncias. Selecionando e organizando planos, a edição faz o discurso audiovisual fluir em seu movimento plástico, adicionando a ele ritmo visua e sonoro, enquanto instaura enunciados mitopoéticos que precisam ser decifrados em sua extensão. Segundo Deleuze, a edição organiza a imagemmovimento dos quadros-partes em imagem-tempo de uma totalidade, encerrando a produção de sentido do texto fílmico, e tornando-o apto para a leitura e o reconhecimento. Ela fecha o ciclo discursivo e narrativo do texto audiovisual e estabele um tempo de vida e duração ao discurso: é "a composição, o agenciamento das imagens-movimento enquanto constituem uma imagem indireta do tempo" (DELEUZE, 2018, p. 56).

Mitry, apesar de discordar que a cadência fílmica possa ser equiparada a outros tipos de cadência, como a musical, entende que o ritmo pode ser para o tempo o que a simetria é para o espaço, ou ser ordem e proporção no espaço e no tempo. Segundo o teórico, o filme é uma arte dinâmica cujo papel é análogo ao da música, mas não idêntico a ela, pois nele o ritmo existe como sucessão, ou movimento, de quadros compostos visualmente e sonoramente, justapostos em uma ordem linear, mas com extensão variadas. O ritmo fílmico, como expressão de uma intencionalidade ou de um querer, é bem menos uma relação de quantidades do que de qualidades, sendo essencialmente dinâmico: relações de duração e intensidades que criam a ideia de movimento entre partes, períodos ou proporções consideradas (MITRY, 1963, p. 347). Como a imagem fílmica contém uma animação própria, interna e externa à diegese, a animação do enunciado e da enunciação (de um lado, o mundo natural dos atores, no qual pessoas e coisas se deslocam, e microrritmos visuais ${ }^{24}$; de outro, a imagem "escrita" pela câmera, variações do quadro e montagem), a temporalidade do som combina-se com a temporalidade já existente na imagem, quer para seguir o seu sentido, quer para o contrariar ligeiramente (CHION, 2008, p.19).

\footnotetext{
${ }^{23}$ Utilizamos o termo decupagem, para enfatizar o discurso ajustado por distâncias entre o observador e os objetos sonoros e visuais; o termo montagem, a partir da ideologia soviética, é utilizado para descrever o "choque de oposições" entre imagens e sons, ou seja, articulações metafóricas e simbólicas do discurso fílmico (na maioria das vezes, os termos são usados livremente e muitas vezes montagem, edição e decupagem são entendidos como sinômimos). A edição é a operação montagem / decupagem.

${ }^{24}$ Segundo Chion (2008) os microrritmos visuais são movimentos rápidos na superfície da imagem, causadas por coisas como volutas de fumaça, chuva, flocos de neve, ondulações na superfície da água e da areia e, no limite, pela agitação do próprio grão fotográfico. Tais fenômenos criam valores rítmicos rápidos e fluídos, instaurando na imagem uma temporalidade vibrante (p. 20).
} 
Eisenstein entendeu a montagem como fenômeno onipresente, na poesia, filme e artes plásticas, que repousa em um decalque formal do funcionamento do espírito humano, por análise e síntese (AUMONT, 2006, p.236). Da mesma forma, Leone e Mourão (1987) percebem que a ideia de estruturar ou dar forma total à narrativa audiovisual já está presente em outras práticas e processos utilizados no cinema, tais como o roteiro e a realização, depois na realização do filme, e finalmente na fase da montagem, propriamente dita, na qual diferentes planos e sons são organizados em uma sequência linear para estabelecer diferentes tipos de vista sobre sujeitos e espaços. Segundo esses teóricos, a montagem, elabora uma narrativa visual que pode apresentar-se de duas maneiras básicas: "como um processo de representação que quer passar despercebido; ou como um processo de representação que, contrariamente ao anterior, quer fazer-se descaradamente perceptível (LEONE; MOURÃO, 1987, p. 56). Assim, não se deve confundir linearidade com harmonia. Eisenstein, ao entender a montagem como ideia que nasce do choque de fragmentos menciona vários tipos de conflitos, elaborando um primeiro mapa tensivo da expressão: há o gráfico, o das superfícies e volumes, o espacial, o das iluminações e ritmos, o conflito entre o material e o enquadramento (deformação espacial pelo ponto de vista da câmera), entre o material e sua espacialidade (deformação ótica pela objetiva), entre o processo e sua temporalidade (câmera lenta, filmagem acelerada), entre o conjunto do complexo ótico e um domínio diferente (AUMONT, 2006, p. 84).

Bordwell (2013a) lembra que as junções da edição fílmica existem em diferentes tipos, em combinações de escurecimentos e clareamentos da imagem, fusões e sobreposições, transições ou cortinas (também chicotes), que dão a impressão de "página virada", pois um plano é gradualmente substituído por outro através de uma linha fronteiriça (p. 350). Do ponto de vista tensivo, se levarmos em conta o corte realizado pela câmera, os cortes óticos e os cortes secos, desenha-se uma tipologia tensiva de cortes, ou paradas da continuação, que podem ser mais ou menos intensos e extensos, tendo maior ou menor tempo e velocidade de presença na tela. Uma vez que o cinema possui uma linguagem que conjunge imagem e tempo de exibição (que também se aplica ao som), a edição oferece quatro áreas básicas de escolha e controle: relações gráficas, rítmicas, espaciais e temporais (BORDWELL, 2013a, p. 352).

Tudo somado podemos dizer que como imagem-tempo, a edição, como decupagem e montagem, pode combinar gradualmente (e abruptamente) categorias plásticas, cinemáticas e sonoras, que mediam expressão e conteúdo ao se manifestarem, e criam efeitos que confirmam ou desafiam crenças e saberes figurativos pré-estabelecidos. Enquanto encerra o último nível de sentido do discurso fílmico, a edição faz parte, de um lado, de operações de figurativização temporais, ajudando a compor a duração da imagem plástica de atores inseridos no mundo; de 
outro, é operada por um enunciador que controla a figurativização, sendo capaz de combinar vários formantes expressivos fílmicos para estabelecer harmonias e desarmonias entre os níveis de conteúdo e de expressão do texto. Tais harmonias e desarmonias de ordem estética provocam não apenas a sensação de consonâncias ou dissonâncias do mundo diegético, controlando o esperado e o inesperado, mas refletem na organização do próprio mundo natural, previamente simbolizado.

A partir dessas relações e de teorias narrativas, linguísticas, musicais e psicológicas, várias tipologias de edição foram propostas, na tentativa de pontuar tipos mais característicos de seus efeitos retóricos na organização discursiva: assim, na história do cinema, a edição já foi definida como ideológica, metafórica, poética, alegórica, intelectual, rítmica, normal, subjetiva, métrica, tonal, atonal, lírica, orgânico-ativa, dialética, quantitativo-psíquica, intensivoespiritual, narrativa, discursiva etc.

Aumont distingue três funções importantes dessa operação: sintáticas, que garantem efeitos de ligação ou disjunção (e mais amplamente todos os efeitos de pontuação e de demarcação), e efeitos de linearidade ou alternância; semânticas, a partir das quais distinguemse a produção de sentido denotados (essencialmente espaço-temporal) e conotados (relacionados a efeitos de causalidade, paralelismo, comparação etc.); e rítmicas, pois o filme se apresenta como a sobreposição e a combinação de ritmos visuais e sonoros.

A semiótica pode contribuir para a questão lembrando que a operação de segmentação, definida como um conjunto de procedimentos de divisão dos textos, ilumina a prática discursiva da edição fílmica, pois aponta para a existência de grandezas de sentido, unidades textuais que se distinguem por disjunções categoriais espaciais (aqui / lá), temporais (antes / depois), tímicas (euforia /disforia), tópicas (mesmo /outro), actoriais (eu / ele) etc. (GREIMAS; COURTÉS, 2011 [1979]. p.428; verbete: segmentação). Como prática de bricolagem de diferentes formas, a edição organiza linguagens visuais e sonoras, podendo construir objetos-texto harmônicos ou desarmônicos no que tange a relações biplanares e sincréticas, elaboradas a partir de diferenças que serão tonificadas ou atonificadas no discurso, e manifestando rotinas ou surpresas tanto da ordem da enunciação como do enunciado. Combinando a expressão e conteúdo do texto plástico audiovisual, ela articula simbolismos e semissimbolismos, sugerindo associações de sentido entre formantes e categorias semânticas, e organizando um discurso mais ou menos poético ou utilitário.

No discurso fílmico a edição, ao reunir diferentes linguagens, opera o encaixe, que existe tanto nos textos verbais como não-verbais, e é um procedimento complementar de localização temporal e espacial, fazendo parte da articulação da categoria concomitância (p.164; verbete: 
encaixe). No encaixe temporal, um período é incluído em outro período, e o programa narrativo torna-se duplamente localizado, podendo operar no passado e presente ou no presente e futuro, por exemplo: os flashbacks e flashforwards no cinema, e as analepses e catalepses na literatura ilustram esses encaixes. Do ponto de vista da edição, tais encaixes se dão, dentro do discurso audiovisual, como textos icônicos visuais e sonoros.

\subsubsection{O som}

Tanto a noção de imagem-movimento como imagem-tempo, que relacionamos ao plano e à edição são, na semiótica, uma questão de movimento, ferramenta da espacialização cognitiva no discurso, que é também de natureza sonora. Apesar de ser segmentado e montado como a imagem, e possuir plasticidade e movimento, o som possui um plano de expressão diferenciado, e merece algumas considerações sobre suas capacidades icônicas e discursivas. Como elemento figurativo, ele pode descrever e caracterizar atores, espaços e tempos e, ancorado a uma imagem, provocar uma ilusão audiovisual mais ou menos referencial e icônica, sendo um meio mais insidioso de manipulação afetiva e semântica do que ela, quer execute um trabalho apenas descritivo (os sons do mundo natural, inclusive os fisiológicos, tais como ruídos corporais: a respiração, os batimentos cardíacos, a mastigação, a digestão etc), quer interprete o sentido da imagem, acrescentando-lhe um valor, fazendo ver o que sem ele não seria visto ou visto de outra forma. Como elemento discursivo o som é capaz, como o quadro e o plano, de chamar a atenção para certos elementos da diegese, estabelecer um fora-de-campo, distâncias entre alvo e fonte e manipular perspectivas.

Vimos acima com Pietroforte, (2008), que de acordo com a tradição musical o som possui quatro propriedades básicas, relacionadas a categorias figurativas: a altura (frequências altas e baixas, graves e agudas), a intensidade (forte e fraco), o timbre (harmonioso e atonal, com altas ou baixas amplitude, vivo ou monótono) e a duração (breve e longo). Sonnenschein (2001), adiciona mais quatro, tais como ritmo (regular / irregular), velocidade (rápido / lento), forma (impulsiva: rápido e sem eco / reverberante) e organização (ordenada / caótica) (p. 65). Tais formantes são utilizados na constituição de figuras vocais, musicais e analógicas, que organizarão na substância do conteúdo falas e diálogos, músicas e espaços acústicos figurativos, e podem ser combinados para produzir vozes "como ruídos", falas "como canções", ruídos "musicais" e ritmados (sons contínuos de máquinas, "sinfonias" de buzinas, apitos ou de bebês chorando etc), ou músicas "barulhentas" e "cacofônicas". 
Apesar de a percepção sonora ser bem diferente da percepção visual, o contrato audiovisual faz com que tais percepções se influenciem mutuamente, emprestando uma a outra “por contaminação e projeção, as suas propriedades respectivas" (CHION, 2011, p. 15). Som e imagem, ocorrendo no mesmo plano de expressão do texto sincrético, têm seus formantes plásticos e sonoros triados, mesclados, tonificados e atonificados durante o discurso, de modo que seus valores plásticos e sonoros sejam redistribuídos em novas pertinências para orientar a construção do sentido.

Chion (2008) lembra que o andamento da imagem vai além de seu tempo de exibição, dependendo também do tipo de som colocado sobre ela, dando-lhe um ritmo mais ou menos forte: um som de sustentação lisa e contínua, por exemplo, é menos animador do que um som de sustentação acidentada e trêmula. Ao mesmo tempo, uma nota executada no violino, em trêmolo, e com pequenos saltos de arco, manipula o valor do que está sendo exibido visualmente. Da mesma forma, um som com ritmo regular, como um baixo contínuo ou um tique-taque mecânico e previsível, tende a criar uma animação temporal menor e mais desacelerada do que um som com estruturas irregulares e imprevisíveis (p.19).

O som também constrói tensões expressivas entre operações de sincronização e dessincronização com a imagem, uma vez que uma cena ou sequência audiovisual mais ou menos silenciosa ou sincronizada, pode criar tensões insuportáveis. Segundo Chion (2008), a sincronização do som dá ao cinema a capacidade de pontuação, uma vez que, dentro do campo, ou em off, podem sublinhar uma palavra, pontuar um diálogo, fechar uma cena (p. 44), valorizando a imagem em movimento e seus signos, com os quais ele pode entrar em harmonia ou desarmonia: "com a introdução do cinema sonoro, à infinidade de possibilidades visuais juntou-se a infinidade de acontecimentos acústicos” (BORDWELL, 2013a, p. 413).

Apesar de o cinema ser majoritariamente vococêntrico, ou verbocêntrico, o que significa que a voz humana, quando existir, será sempre favorecida, evidenciada e destacada de outros sons (AUMONT, 2008, p. 13), a música participa ativamente na emoção da cena, dando ritmos, tons e fraseados à imagem, em função dos códigos culturais de tristeza, alegria emoção e movimento. Dessa forma, ela pode ser empática, compartilhando o sentimento despertado pela imagem, ou anempática, manifestando uma indiferença ostensiva relativamente à situação ${ }^{25}: 0$ mesmo pode acontecer com os ruídos. A relação entre música e imagem é também de ordem

\footnotetext{
${ }^{25}$ Um exemplo muito explorado no cinema, considerada retoricamente como uma ironia, é uma cena violenta unida a uma música serena, a um jingle de comercial de televisão, ou melodia de caixa de música, que parece tocar mecanicamente e friamente em relação ao mostrado.
} 
simbólica, uma vez que ela existe a partir de gêneros sancionados, e ritmos, harmonias e melodias são utilizados para criar emoções e despertar sentimentos.

Coker (1972) observa que a música possui um sentido extragenérico (extrageneric musical meaning), resultante da interação entre ela e o ouvinte:

O significado musical extragenérico emerge quando o ouvinte responde a um gesto musical, ou a um conjunto de propriedades musicais como significando algo fora da própria obra ou, nesse sentido, qualquer outra obra do mesmo meio. A obra musical, como um todo ou parte dele, pode ser interpretada como referindo-se a, apontando, caracterizando, ou conectando objetos não musicais, tais como atitudes, pensamentos, estados afetivos e conativos, coisas físicas e eventos, ou valores e propriedades de tais objetos. Então a música pode afetar o ouvinte, dispondo-o a reagir de maneiras que normalmente ocorrem quando ele é estimulado por tais objetos não musicais. E as sequências de resposta obtidas de um ouvinte assim disposto são aquelas que são apropriadas para coisas normalmente consideradas extrínsecas a simples elementos musicais (p. 147. Tradução nossa) ${ }^{26}$.

Desse ponto de vista a trilha sonora musical, no discurso fílmico, assim como o discurso verbal, adquire um potencial semântico e simbólico para denotar e conotar conceitos abstratos e objetos do mundo natural e cultural, e figurar uma série de elementos relacionados a paixões e emoções, sendo também metafórica. A partir de uma visão semiótica discursiva da música, Monelle (2002) acredita que, ao invés de ser a expressão de um sentimento, ela é antes a sua apresentação, ou construção, podendo ser pensada não como incorporação da emoção, mas a expressão de uma ideia de emoção (p. 4).

Seguindo Greimas (e o percurso gerativo) e Levi-Strauss (antropologia estrutural), Tarasti (1979; 2002), acredita que a linguagem musical e a verbal possuem similaridades, tais como estrutura sônica e prosódica, padrões que se aproximam de semas e isotopias que geram redundâncias, e capacidade semântica de delimitar temas, tópicos e estilos ${ }^{27}$. No século 18, por exemplo, Friederich Marpurg tenta definir estados de humor e emoções de acordo com ritmos musicais específicos, progressões tonais e harmonias, em uma tipologia que pode ser percebida

\footnotetext{
26 "Extrageneric meaning emerges as the listener responds to musical gestures of a set of musical properties as signifying something outside the work proper or, for that matter, any other work in the same medium. The musical work as a whole or some part of it may be interpreted as referring to - pointing to, characterizing, or connected with - non-musical objects such as attitudes, thoughts, affective and conative states, physical things or events, or values and properties of such objects. Then music may affect the interpreter by disposing him to respond in ways that usually occur when he is stimulated by such non-musical objects. And the response sequences elicited by the music from an interpreter so disposed are those that are appropriate to things ordinarily regarded as extrinsic to bare musical elements".

${ }^{27}$ Tarasti (2002) explica que o Romantismo intensifica a relação entre música e as outras artes, e elabora os seus próprios tópicos: a questão faustiana do porquê e a busca de uma resposta, o pastoral, o panteísmo, a religiosidade, o sofrimento e a tristeza etc (p. 33).
} 
claramente nos dias atuais, sendo relacionadas a muito do que experimentamos nas trilhas sonoras dos filmes:

Figura 12 - Expressão acústica de estados emocionais de acordo com Friederich Marpurg (1718-1795)

\begin{tabular}{|c|c|}
\hline Emoção & Expressão \\
\hline Sofrimento, aflição & $\begin{array}{l}\text { Melodia lenta e lânguida; carícia de palavras soltas com material } \\
\text { tonal requintado; harmonia dissonante prevalecente }\end{array}$ \\
\hline Alegria & $\begin{array}{l}\text { Movimentos rápidos; melodia animado e triunfante; tom quente } \\
\text { de cor; harmonia mais consonante }\end{array}$ \\
\hline Contentamento & Melodia mais tranquila e estável que a da Alegria \\
\hline Arrependimento & $\begin{array}{l}\text { Os elementos do Sofrimento combinados com uma melodia mais } \\
\text { turbulenta e lamuriosa. }\end{array}$ \\
\hline Esperança & Uma melodia orgulhosa e exultante \\
\hline Medo & $\begin{array}{l}\text { Progressões descendentes, principalmente em registros menores } \\
\text { e inferiores }\end{array}$ \\
\hline Risada & Tons languidos, prolongados \\
\hline Inconstância & Expressões alternadas de Medo e Esperança \\
\hline Timidez & $\begin{array}{l}\text { Similar ao Medo, mas geralmente intensificada por uma } \\
\text { expressão de impaciência }\end{array}$ \\
\hline Amor & $\begin{array}{l}\text { Harmonia consoante; suave, melodia prazerosa em movimentos } \\
\text { amplos }\end{array}$ \\
\hline Ódio & Harmonia e melodia ásperas \\
\hline Inveja & Tons irritantes e hostis \\
\hline Compaixão & $\begin{array}{l}\text { Melodia lamuriosa, suave e lânguida; movimento vagaroso; } \\
\text { figuras repetidas no baixo }\end{array}$ \\
\hline Ciúme & $\begin{array}{l}\text { Introduzido por um tom suave e oscilante e, então, intenso e } \\
\text { nervoso. Finalmente um tom comovente e suspirado; } \\
\text { alternância de movimentos rápidos e lentos. }\end{array}$ \\
\hline Ira & $\begin{array}{l}\text { Expressão de ódio combinada com notas rápidas, mudanças } \\
\text { repentinas e frequentes no baixo; movimentos violentos e } \\
\text { agudos; dissonâncias estridentes }\end{array}$ \\
\hline Modéstia & Melodia hesitante e vacilante; paradas rápidas e curtas \\
\hline Ousadia & Melodia desafiadora e rápida \\
\hline
\end{tabular}




\begin{tabular}{|l|l|}
\hline Inocência & O estilo pastoral \\
\hline Impaciência & Mudança rápida; modulações irritantes \\
\hline
\end{tabular}

Fonte: Sonnenschein (2001, p. 108).

Da mesma forma Sonnenschein (2001) lembra que a terapia musical soube utilizar os vários gêneros musicais para alterar a energia do ouvinte, e explica que as mudanças físicas, mentais e emocionais podem também ser aplicadas aos elementos dramáticos do filme:

Figura 13 - Impacto físico, mental e emocional dos gêneros musicais

\begin{tabular}{|c|c|}
\hline Gênero & Impacto \\
\hline $\begin{array}{l}\text { Sagrado, hinos, música religiosa } \\
\text { (gospel) e shamânica. }\end{array}$ & $\begin{array}{l}\text { equilíbrio, paz profunda, consciência } \\
\text { espiritual, transcendência e alívio da dor }\end{array}$ \\
\hline Canto gregoriano & $\begin{array}{l}\text { Respiração regular, abertura, diminuição do } \\
\text { estresse, contemplação }\end{array}$ \\
\hline Música da Nova Era (New Age) & $\begin{array}{l}\text { Expansão do tempo e do espaço, calma } \\
\text { contemplação, desconexão com o corpo }\end{array}$ \\
\hline Barroco lento (Bach, Vivaldi) & Segurança, precisão, ordem \\
\hline Clássico (Mozart, Haydn) & $\begin{array}{l}\text { Leveza, visão, majestade, percepção } \\
\text { tridimensional }\end{array}$ \\
\hline $\begin{array}{l}\text { Clássico Romântico } \\
\text { (Tchaikovsky, Chopin e Beethoven) }\end{array}$ & $\begin{array}{l}\text { Emoção, calor, orgulho, romantismo, } \\
\text { patriotismo }\end{array}$ \\
\hline Impressionista (Debussy, Ravel) & Sensações, imagens oníricas, devaneio \\
\hline $\begin{array}{l}\text { Música afro-americana } \\
\text { (jazz, blues, Dixieland, reggae) }\end{array}$ & $\begin{array}{l}\text { Alegria, sensação de amizade, divertimento } \\
\text { esperteza, ironia }\end{array}$ \\
\hline Música latina: salsa, rumba, samba & Sensual, excitante, estimulação corporal \\
\hline Big band, pop, country /western & $\begin{array}{l}\text { concentração, sensação de bem-estar, } \\
\text { centramento }\end{array}$ \\
\hline Rock & $\begin{array}{l}\text { Movimento agressivo, aumento e liberação de } \\
\text { tensão }\end{array}$ \\
\hline Heavy metal, punk, rap, hip-hop, grunge & $\begin{array}{l}\text { Animação do sistema nervoso, comportamento } \\
\text { rebelde }\end{array}$ \\
\hline
\end{tabular}

Fonte: Sonnenschein (2001, p. 108). 
O som também é capaz de produzir efeitos retóricos e simbólicos:

Figura 14 - O som e a retórica

\begin{tabular}{|l|l|}
\hline Símile & $\begin{array}{l}\text { Similaridade acústica entre dois sons } \\
\text { (grito e sirene) }\end{array}$ \\
\hline Hipérbole & $\begin{array}{l}\text { Exageração óbvia e intencional } \\
\text { (grito com despertador de relógio) }\end{array}$ \\
\hline Metáfora & $\begin{array}{l}\text { Comparação sugerida de um som com uma ideia } \\
\text { (grito com uma luz vermelha piscando) }\end{array}$ \\
\hline Alegoria & $\begin{array}{l}\text { Representação do abstrato através do concreto } \\
\text { (grito contido misteriosamente até o clímax) }\end{array}$ \\
\hline Ironia & $\begin{array}{l}\text { Contraste de oposições que fogem à expectativa } \\
\text { (grito com sorriso) }\end{array}$ \\
\hline Paradoxo & $\begin{array}{l}\text { Contradição aparente que pode expressar uma verdade interna } \\
\text { (grito de um cigarro) }\end{array}$ \\
\hline Vivificação & $\begin{array}{l}\text { Traços de seres vivos em objetos inanimados (o grito de um tapete de } \\
\text { Porta sendo batido em uma parede) }\end{array}$ \\
\hline
\end{tabular}

Fonte: Sonnenschein (2001, p. 55).

Da mesma forma, os verbos modais dever, querer, poder, fazer, saber e ser igualmente podem existir como conteúdo narrativo musical, sendo relacionados a ideias, recursos técnicos e tendências de interpretação, estilos, momentos de repouso e consonância, dinamismo e dissonância etc. Tarasti (2002) acredita que a música, que geralmente escapa de definições lexicográficas, é semântica em virtude das modalidades, que "podem formar parte das qualidades intrínsecas da composição, ou podem ser ativadas externamente, a partir de como a música é executada" (p.15). Ademais, uma composição musical pode ser caracterizada por semas fundamentais, tais como euforia / disforia, vida / morte, e natureza / cultura. Além de estabelecer ritmos, intensidades e harmonias (e os seus contrários), a música vincula-se a formas de vida sociais, de modo que é, na linguagem de alguns semioticistas, codificada, ou seja, relacionada diretamente a grupos humanos e seus valores.

Gorbman (1987) acredita que a música, codificada pelo contexto, só assume sentido em relação a esse contexto, de modo que deve ser pensada em relação ao discurso onde é implicada (p.3). Nesse sentido, ela adquire as propriedades dos shifters, ou dêiticos, como o pronome em 
primeira pessoa, que pode ser usado por diferentes interlocutores, mudando assim de sentido ou referência, mas mantendo o seu significado (MONELLE, 2002, p. 16). A partir daí, mesmo tendo uma vida independente e deixando rastros próprios no enunciado, ela conforma-se à narrativa, fazendo parte de sua figurativização. No discurso fílmico, assumindo planos diegéticos e não-diegéticos, a música pode alternar-se entre o mundo fictício da obra e o mundo "não-fictício" da enunciação. Como faz parte do discurso e pode ser debreada, pode existir tanto no nível do enunciado como no da enunciação, em operação gradativa tensiva.

Duas músicas (ou canções), por exemplo, uma diegética e a outra não, podem ocorrer simultaneamente no mesmo texto audiovisual, ou se substituírem. Tal capacidade de cruzar "fronteiras narrativas", segundo Gorbman, põe a trilha musical a serviço não apenas da libertação do realismo da imagem (diríamos da construção do realismo, da iconicidade), mas o faz de forma não percebida conscientemente (GORBMAN, C., 1987, p. 64). Podendo verter a enunciação em ficção, ou enunciado, a música pode criar suturas entre o fora e o dentro da ficção e minimizar a consciência da natureza tecnológica do discurso fílmico (p. 5). Tais suturas, unidas a operações visuais, podem ter características temáticas, dramáticas, rítmicas e estruturais (p. 26). Sendo relacionada ao "realismo da imagem", e sendo parcialmente percebida (sendo menos intrusiva do que a voz-over, por exemplo), a trilha sonora musical é usada a serviço não apenas de uma maior ou menor iconização do conteúdo plástico fílmico, estabelecendo contratos fiduciários de ser e parecer entre enunciador e enunciatário, mas também assume, como ato comunicativo, a função poética, afetiva, referencial, fática, conativa etc., construindo tensões a partir de uma maior ou menor relação entre ela e o texto visual, e os ritmos e conteúdos da imagem em movimento. Com seus efeitos harmônicos, rítmicos, melódicos, sugestivos, e capacidade de figuração, ela é parte do leque de 'métodos indutivos' do cinema narrativo (GORBMAN, C.,1987, p. 6), que a utiliza de variadas formas para construir sujeitos, espaços, tempos, temas e figuras.

Segundo Gorbman, a música é capaz de reduzir o desprazer da incerteza da significação, pois pode apresentar valores conotativos intensamente codificados (o que gera o mesmo efeito da legenda na fotografia). As músicas standard do cinema, por exemplo, podem ajudar a intepretação da imagem, sugerir leituras e prevenir ambivalências no discurso. Por ser altamente codificada, tal tipo de texto estabelece configurações atmosféricas, históricas e geográficas. Sendo capaz de esconder as coerções tecnológicas do discurso fílmico, a trilha musical livra o espectador de um segundo desprazer: o do reconhecimento da construção formal da narrativa, da manipulação e a sensação de uma impressão de realidade incômoda, ou falsa (p. 58). Existindo entre a percepção consciente e inconsciente, entre os níveis ficcionais diegéticos e 
não-diegéticos, ritmos narrativos e formais, a música, como espécie de coesão nãorepresentativa (mas preferimos coesão sonora, motiva e plástica), media vários tipos de contradições textuais, enquanto delas participa (p. 91).

Diferentemente do que acontecia no filme silencioso, acredita-se que a música, com seu ritmo e cadência, imprime na ação editada do filme a sensação de duração temporal, menos sentida no silêncio, pois enquanto o advento do som diegético restringe as possibilidades da temporalidade, transformando-a em uma espécie de linearidade, ela se torna o único elemento sonoro capaz de libertar tal representação, acompanhando a edição, sequências mais ou menos lentas, flashbacks, flashforwards etc. (p. 38). Chion (2008) pensa que a música não-diegética não está submetida às barreiras de tempo e espaço (p. 68), de modo que é flexível, transformando-se em gel, espaço, linguagem, ritmo, sinal de profundidade e emoção interna, e enfatizando o movimento visual e a ideia de espetáculo (GORBMAN, C.,1987, p. 55).

Como a relação entre som e imagem constrói efeitos não apenas de harmonia, mas também de contraponto, Chion (2008) entende que ambos formam duas cadeias paralelas e livremente ligadas, e sem dependência horizontal. A partir dos conceitos da música clássica ocidental de contraponto e harmonia ${ }^{28}$, o som torna-se uma "voz sonora percebida horizontalmente como coordenada com a cadeia visual, mas individualizada e desenhada por si mesma" (CHION, 2008, p. 35). Do ponto de vista da semiótica, como o cinema é um texto sincrético, mesmo considerando a música como individualizada, podendo haver uma hierarquização de sentido na qual a trilha é mais importante do que a imagem, ou efeitos discordantes entre som e imagem, ela ainda pertence ao texto e é uma peça de seu sentido.

\subsection{Cinema, proxêmica e gestualidade}

Nessa abordagem sobre cinema, levaremos em conta o que foi discutido sobre figurativização, manifestação e biplanaridade do sentido no texto literário e fílmico, o espaço linguístico, topológico e cognitivo, e as unidades textuais e discursivas do filme, como a imagem e o plano em movimento, acionados por um observador. Uma vez que os planos podem mover-se, tanto no tempo como no espaço, formando diferentes graduações de distância, a ideia de filme como um conjunto de gestos no espaço natural parece ser frutífera para a discussão.

\footnotetext{
${ }^{28} \mathrm{O}$ primeiro designa um modo de escrita musical que pensa as diferentes vozes simultâneas como devendo ser seguidas, cada uma delas no seu desenrolar horizontal, coordenado com o das outras vozes, mas individualizado; o segundo adota um ponto de vista vertical em relação ao texto musical, o das relações de cada nota com as que se ouvem no mesmo momento, que juntas formam acordes.
} 
Assim, podemos entender a linguagem fílmica em relação à gestualidade e à proxêmica que, enquanto no texto literário ocorre verbalmente, arbitrariamente, e geralmente estende-se mais ao enunciado do que à enunciação, no texto fílmico se dá audiovisualmente a partir de uma relação motivada entre expressão e conteúdo, e de um enunciador que se move plasticamente e não conceitualmente dentro de um espaço esférico. Como não devemos associar a construção do espaço apenas à imagem, ou à câmera, pois vimos que a mise-en-scène fílmica também é sonora, nossa discussão sobre cinema, gestualidade e proxêmica, apesar de serem mais voltadas à plasticidade da imagem, deve também ser pensada em relação à plasticidade do som.

No DS, Greimas e Courtés não relacionam a proxêmica ao cinema, explicando que ela é uma disciplina semiótica que visa não apenas analisar a disposição dos sujeitos e dos objetos no espaço, mas também o uso que os sujeitos fazem dele para fins de significação, sendo um projeto abrangente que engloba a semiótica do espaço, a natural, a teatral, a discursiva etc. Assim, ela corresponde ao mundo natural e aos comportamentos das pessoas "reais" inseridas nele, às relações espaciais entre os sujeitos e às significações não verbalizadas, acionadas por gestos corporais em práticas gestuais. De outro lado, ao admitir semióticas artificiais que constroem gestos e movimentos, tais como o teatro, a dança, a liturgia, o ritual, o urbanismo, a ópera, o circo, etc, a semiótica discursiva entende que tanto a disposição dos objetos como a dos sujeitos articuladas nesses textos torna-se portadora de sentido. Como a proxêmica observa os movimentos dos sujeitos e os deslocamentos de objetos significativos, pois são representações espaçotemporais de transformações entre os estados, ela integra em seu campo de análise as linguagens gestuais e visuais (GREIMAS; COURTÉS, 2011, p. 396; verbete: proxêmica): assim, gestualidade e cinema tem muito em comum, tratando-se de expressões plásticas e cinemáticas ${ }^{29}$.

Dessa forma, a semiótica abre o caminho para a observação do espaço cognitivo e do gesto também do observador no texto fílmico. De um lado, a construção proxêmica do sentido pode ser observada na própria narrativa, e os atores, enquanto ocupam o mundo "real" enunciado, produzem espaços e gestos corporais; de outro, por causa das coerções da linguagem filmica, o enunciador projeta um narrador-observador no espaço audiovisual que está sempre em relação de contiguidade com o que mostra, ou relata, de modo que, diferentemente do narrador do texto literário, pertence ao mundo diegético como gradação de distâncias, direções e velocidades, podendo ser localizado no enunciado fílmico a partir da espacialidade

\footnotetext{
${ }^{29}$ Podemos pensar no gesto humano, quando imita formas do mundo natural expressivo, como uma semiótica visual motivada.
} 
perspectiva que constrói. Como no cinema o observador e o observado estão sempre relacionados audiovisualmente, é possível estabelecer as várias posições dos observadores no mundo topológico esférico da diegese. Revelando sua posição no enunciado audiovisual, o observador constrói a impressão de uma presença física, de um corpo que se move, vê e ouve. Muito além da câmera subjetiva, que "encarna" o olhar de um personagem-informante, o cinema revela a posição do narrador em relação ao que narra visualmente.

A partir dos atores do enunciado e da enunciação, que constroem e habitam o mundo discursivizado da narrativa, produzindo espaço e gesticulando, outra interessante questão entre cinema, gesto e proxêmica concerne os vários movimentos físicos e gestuais, visuais e plásticos, que se inserem-se na dicotomia arbitrariedade vs. motivação do sentido. O texto gestual humano, o plástico pictórico, e o plástico-proxêmico audiovisual entram em ressonância com a macrossemiótica do mundo natural, pois gestos e movimentos no espaço da ficção podem ser motivados por configurações encontradas no mundo "real", sendo parcialmente refeitas e expressas no texto fílmico pelos sujeitos da enunciação e do enunciado.

Greimas (1970) assim como faz no caso do texto pictórico, entende que em se postulando a existência e a possibilidade de uma semiótica do mundo natural, pode-se conceber a relação entre os signos e os sistemas linguísticos (naturais), e os signos e sistemas de significação desse mundo significante, "não como uma referência do simbólico ao natural, do variável ao invariante, mas como uma rede de correlações entre dois níveis de realidade significante" (p. 52). Assim, a partir das relações entre mundo natural e gestualidade pensadas conjuntamente, e a ideia de um narrador observador presente como instância perceptível realizada dentro do espaço tópico da diegese visual, outras questões sobre corpo e gesto podem ser derivadas para a enunciação fílmica, que serão importantes para a discussão da adaptação, também construída pelas mesmas macrossemióticas básicas que o filme, a das línguas e dos mundos naturais.

Ao discutir a gestualidade natural / cultural do corpo humano, Greimas acredita que este se move dentro de um contexto espacial que deve ser categorizado a partir de três critérios: deslocamento, orientação e apoio. Se o uso do espaço tridimensional para a descrição do volume humano parece evidente, ele implica pelo menos três sistemas diferentes: um sistema de coordenadas espaciais, que dá conta do volume humano; uma perspectiva espacial, pois o corpo humano, como objeto percebido, pressupõe um espectador situado em um espaço tridimensional englobante em relação ao corpo humano englobado; e uma topologia, ou seja, uma relativização do espaço que se torna necessária quando a forma ou formas humanas se 
movem em relação a um ponto no espaço, que pode ser fixo ou móvel, ou em relação a outras formas humanas.

O peso do corpo privilegia, de certa forma, dois eixos espaciais: o eixo vertical, na direção da gravidade, introduz a categoria do contato vs. não-contato do volume humano com relação a outros volumes, muitas vezes euforizando o não-contato para conotar a libertação do corpo com respeito à gravidade (Greimas pensa no ballet), e por vezes reforçando certas posturas por causa de seu desvio da norma (andar plantando bananeira); o eixo horizontal é, por sua vez, a superfície sólida (ou líquida, no caso da natação) que dá origem ao deslocamento "natural", opondo-se à postura "natural" que é a posição ereta. Embora sendo apenas parcialmente motivada, a articulação "terra horizontal" versus "homem vertical" é geralmente admitida como a posição incoativa, anterior à mobilidade; a oposição categorial entre imobilidade e mobilidade, entre posição e movimento, possui um caráter demarcativo e permite uma descrição aspectual.

O corpo humano, além de poder ser reconhecido como objeto da percepção, pode ser também observado como autor de sua motricidade, em uma abordagem mecanicista cinéticocinemática que permite circunscrever o campo da gesticulação e incluí-lo em uma esfera geométrica transparente, mas postula uma desarticulação morfológica, pois ele deixa de ser uma forma global para aparecer como um organismo de atores metonímicos (braços, pernas, cabeça, tronco, etc), cada um em seu espaço parcial em nome de um actante único. Tal ponto de vista permite reduzir a gestualidade humana a um modelo geral de virtualidades que engloba gesticulações e posturas, e traçar um limite entre a gestualidade normal e anormal, de modo que esta constitua uma diferença estilística, ou um lugar onde uma segunda língua gestual, de caráter lúdico, é construída. A motricidade humana, no entanto, não deve ser confundida com um fenômeno natural, e a gestualidade natural tem caráter social e cultural, sendo uma prática programada.

Dentro da atividade programada dos gestos e do uso do corpo, Greimas distingue uma gestualidade propriamente prática e uma mítica (ex: abaixar o corpo, como para se sentar = saudar), que podem ser graduais, mesclar-se, e são fundadas dentro da dicotomia fazer e querer. Toda a gestualidade programada superior às dimensões semema / fonema, na medida em que é posta a serviço da comunicação, é de origem mítica, sendo uma transposição, no eixo da comunicação, de enunciados e programas gestuais com conteúdo implicitamente mítico (GREIMAS, 1970, p. 79). Assim, transportando as categorias do sagrado, do lúdico e do estético, emprestadas dos discursos verbais, para o discurso da dança, o semioticista faz a seguinte classificação: 
Figura 15 - Tipos de gestualidade na dança

\begin{tabular}{|c|c|c|}
\hline Sagrado & Lúdico & Estético \\
\hline não comunicação & comunicação e & comunicação \\
& não comunicação & \\
\hline práxis mítica & ex: dança folclórica & ex: ballet \\
\hline
\end{tabular}

Fonte: Greimas (1970, p. 79).

Nessa classificação, o fundador da semiótica francesa acredita que a dança "arcaica" ou sagrada, que é uma práxis gestual sem intenção de comunicar, mas que transforma os conteúdos que são expressos em sagrados, opõe-se à dança-ballet, que é uma práxis que visa apenas comunicar, e não em transformar os conteúdos que recobre, não sendo sagrada; a dança folclórica, por sua vez, ocupa uma posição intermediária, na medida em que é ao mesmo tempo, de maneira explícita, uma comunicação para os espectadores e participantes, e de maneira implícita, um fazer apoiado na práxis mítica ${ }^{30}$.

Quando aproximamos as considerações de Greimas sobre espaço, corpo-objeto, corpomotriz e tipos de gestualidades bailarinísticas ao cinema, algumas considerações podem ser feitas em relação à gestualidade do enquadramento em movimento e a câmera, que tanto possui um corpo material capaz de motricidade, como age como suporte da linguagem fílmica, podendo ser vista como uma máquina que se acopla ao corpo humano e se torna sua extensão, coagindo e motivando a expressão: um actante destinador ajudante.

Dentro de uma prática proxêmica e gestual humana, a câmera cinematográfica mimetiza gestos e desenvolve movimentos no espaço: como o corpo humano, por exemplo, o seu estado "natural" é vertical (a câmera fica de pé), e dentro de um mundo planejado como horizontal; ao mesmo tempo, ela também pode "deitar-se", inclinar-se, ou virar de ponta cabeça, de modo que pode realizar gestos considerados normais e anormais. A câmera é capaz de produzir os movimentos do olhar e os deslocamentos do corpo, podendo ser fixa ou móvel, e é capaz de mimetizar a "cabeça" humana, produzindo gestos de afirmação e negação, a partir de movimentos em eixos verticais e horizontais que fazem a imagem oscilar de cima para baixo, ou de um lado para o outro; é igualmente capaz de compor relações entre "cabeça e tronco", ao ir para um lado, mas olhar para outro (ex: mover-se para a direita enquanto olha para a esquerda,

\footnotetext{
${ }^{30}$ Lembramos, no Brasil, dos movimentos da dança do boi-bumbá por exemplo, cuja história gira em torno da morte e ressurreição de um animal.
} 
ou mover-se para cima, enquanto mantém-se fixa em um ponto do espaço abaixo dela). A câmera em movimento pode também mimetizar, a partir do espaço visualizado, o movimento do corpo de um sujeito, desorientado, tonto, bêbado, etc, de modo que seu poder-fazer gestual reconstrói as gestualidades e somatismos do corpo natural. As figuras do movimento, relativas à distância, ocupação, cruzamento e dispersão podem ser traçados pelo corpo não apenas dos atores, como nos mostra Fontanille, mas com a câmera.

Esse objeto, portanto (e o seu conjunto de lentes, tripés, trilhos, apoio corporais etc), corporificado e flexível como o corpo humano, torna-se também um suporte significante capaz de gerar significados e práticas gestuais similares às práticas proxêmicas desenvolvidas no contato com o mundo natural: possui olhos, cabeça, tronco e membros que se ajustam aos do homem. Pode-se também sugerir, como Greimas faz nos três tipos de dança apresentados acima, que a gestualidade da câmera adota gestos mais ou menos sagrados, lúdicos ou simplesmente estéticos $^{31}$. Indo-se além da câmera, no entanto, que utilizamos apenas como exemplo de relação entre corpo humano, prótese, e suporte da linguagem, é a figura do observador fílmico que merece destaque, e que só pode ser localizado a partir do enunciado audiovisual, e nunca antes dele. Como reflexão sobre sentido e coerção, se todo o texto possui um observador, no texto fílmico ele será relacionado à câmera e suas potencialidades. Ao mesmo tempo, é na imagem plástica cinemática e perspectiva que se imprime sua proxêmica e gestualidade.

$\mathrm{O}$ ponto de vista cinemático da enunciação fílmica permite afirmar que o cinema constrói textos visuais de caráter gestual, no qual concebe-se o plano, relacionado ao movimento no espaço, e a montagem, ao tempo, dentro de uma nova perspectiva de análise que se ajusta ao meio de comunicação cinema (que pode ser extrapolado aos textos produzidos pela TV, o teatro e os quadrinhos): um tipo de ilusão referencial do mundo apoiado na gestualidade e na proxêmica, que podem ser vistas como linguagens ou paralinguagens, funções auxiliares no quadro da comunicação intersubjetiva ${ }^{32}$ : o gesto é considerado tanto como acompanhamento quanto como enquadramento da enunciação, capaz de enunciar categorias abstratas

\footnotetext{
${ }^{31}$ A câmera, ao aproximar-se do rosto de uma pessoa que sofre, por exemplo (em PP), pode não querer apenas mostrá-lo maior ou comunicar um detalhe, mas procurar ir além dele, construindo valores de morte, em uma prática que podemos identificar como mítica; o gesto audiovisual pode também ser lúdico, mediando a comunicação e a não comunicação: um travelling pode mimetizar o corpo de um personagem que anda, comunicando ao mesmo tempo as características de um espaço percorrido e a ação de um ser vivo; da mesma maneira a gestualidade da câmera pode apenas ser estética e utilitária, e comunicar uma rua, uma festa, uma cidade perto do mar, uma criança triste, outra câmera etc. Logicamente esses exemplos são apenas parciais, e os gestos atribuídos à câmera dependem, de um lado, das intenções da narrativa; e de outro, são baseados em uma teoria do uso do corpo humano em semióticas espaciais tridimensionais, necessitando de mais ajustes e averiguações.

${ }^{32}$ Segundo Greimas e Courtés (2011) a gestualidade é um componente do sentido difícil de definir, oscilando entre linguagem e não linguagem. Enquanto alguns semioticistas quiseram tratá-la como linguagem, aplicando a forma saussuriana de "sistemas de signos", que seriam reconhecidos com a ajuda de testes de comutação, os inventários
} 
que tomam a forma quer de enunciados modais (asserção, negação, dúvida e certeza, etc), quer de enunciados de quantificação (totalização, divisão) e de qualificação (estados eufóricos e disfóricos), quer sobretudo de enunciados fáticos (acolhida e repulsa, abertura para o mundo e fechamento em si, etc.), que transformam a comunicação em comunhão intersubjetiva (GREIMAS; COURTÉS, 2011, p. 236; verbete: gestualidade).

A ideia de gestualidade-recorte da enunciação, que tenta depurar as configurações de sentido não-verbais do corpo humano "real", inserido na cultura, não poderia se ajustar com mais perfeição ao cinema. Assim, enquanto vimos acima que o espaço topológico era modalizado por um poder ou não poder observar, e um fazer e não fazer saber, modalidades controladas por um enunciador, a ideia de gestualidade vai acrescentar ao observador construções de sentido motivadas pelo mundo natural. A gestualidade fílmica, assim como a corporal, também enuncia categorias que tomam a forma de enunciados modais, quantificadores, qualificadores e fáticos. Da mesma maneira, se a distância do plano é flexível em relação ao que enquadra, controlando pontos de vista entre sujeitos e espaços, a ideia de gestualidade como apoio do enquadramento não fixo revela o texto fílmico como uma rede de graduações gestuais tensivas.

Se existem dúvidas sobre a gestualidade como uma linguagem com unidades mínimas e comutáveis em um sistema, o fato é que, de um lado ela existe dentro da enunciação, seja ela verbal ou não verbal (podemos pensar, além do cinema e da dança, nos gestos percebidos na escultura, na pintura, na fotografia etc., mas também em todas os conjuntos significativos humanos que envolvem o corpo); de outro, sua existência como possível paralinguagem não lhe tira o caráter tensivo e figurativo de existência. Se o plano da expressão é sempre elusivo, sendo difícil determinar com exatidão todas as categorias expressivas e formantes que compõe a expressão de todas as linguagens, esse problema pode ser contornado pela ideia de manifestação e gestualidade segmentada minimamente em unidades plástico-cinemáticas gerais. Assim, do nosso ponto de vista, o filme será um texto, além de simbólico, também gestual e proxêmico, ou seja, decupado a partir de oscilações de distância, ângulo e altura e dos vários tipos de movimento do enquadramento.

$\mathrm{Na}$ introdução e nesse capítulo, procuramos apresentar a teoria semiótica em relação, primeiramente ao conteúdo, que é semântico e tensivo, e depois em relação à manifestação, ou

dos gestos comunicativos que puderam ser constituídos não se revelarem como estruturáveis em sistemas, não remetendo a nenhuma organização semântica (a não ser a de centros de interesse). Neles se encontram misturados gestos de acompanhamento, ícones, e sobretudo sintagmas gestuais estereotipados, dessemantizados e convencionalizados, de modo que uma linguagem gestual autônoma parece longe de estar assegurada (p. 236; verbete: gestualidade). 
seja, como esse conteúdo é expresso. Discutimos, a partir das relações entre o plano de conteúdo e o plano de expressão, e das coerções de cada linguagem, a questão da figurativização, da ilusão referencial e do semissimbolismo. Apesar de todo texto figurativo, como o literário e o fílmico, possuir um observador, sua existência será homologada a diferentes categorias expressivas e coercitivas, que são relacionadas a tipos de linguagens e seus suportes. Tendo considerado alguns tipos de texto literário como o fílmico, ou seja, sincréticos, além de poéticos, introduzimos em nossa reflexão sobre a adaptação algumas diferenças entre a literatura e o cinema no que concerne a construção do espaço e do sujeito cognitivo, observando no segundo, devido ao seu caráter plástico, cinemático e motivado, a questão da proxêmica e da gestualidade, que também existe na literatura, mas como construção conceitual e arbitrária: a enunciação fílmica, diferente da verbal, apoia-se na construção plástica de distâncias e recortes cinemáticos do texto audiovisual, e da definição da duração dos elementos de seus planos de sentido audiovisual, podendo construir a ilusão de movimentos do corpo humano e seus comportamentos somáticos. A partir desse panorama teórico partimos para a análise dos dois textos envolvidos na adaptação intersemiótica. 


\section{O ROMANCE PARANOID PARK}

Paranoid Park (2006) é um romance de Blake Nelson, autor americano de literatura infantil e infanto-juvenil (teen novelist), nascido em Portland, Oregon (1965). O livro foi transformado em um filme homônimo dirigido por Gus Van Sant (2007), e ganhou o prestigiado Prêmio Grinzane Cavour na Itália (2010). Outros dois romances do autor foram adaptados para a TV e o cinema ${ }^{33}$. Paranoid Park, cujo título pode ser traduzido como Parque da Paranóia ou Parque Paranóico, possui uma narrativa que mescla "suspense psicológico" e "confissão", em uma história que pode ser vista como um momento de autoconhecimento e amadurecimento. Escrito na primeira pessoa do singular, o romance possui forma epistolar, sendo o relato de um jovem de dezesseis anos a uma colega de escola, Macy, sobre um trágico evento no qual ele se envolve, e que é mantido em segredo por alguns meses, de setembro a dezembro, até que finalmente é relatado pelo protagonista em um conjunto de cartas.

O romance é dividido em sete capítulos, que correspondem a sete cartas escritas no começo do mês de janeiro, na casa do tio, na praia, e sempre iniciadas com o mês, o dia e o período do dia em que são escritas. De um lado, os escritos não revelam o nome do remetente, ou destinador (utilizaremos o nome do personagem no filme: Alex); da mesma maneira, o destinatário só é conhecido posteriormente, no texto da última missiva: a saudação dear (querido ou querida, em inglês), escrita no início de todas as correspondências, não é seguida do nome do endereçado, que será descoberto apenas no corpo da última carta. Em seus relatos, o ator (protagonista) Alex conta o seu envolvimento em um crime ocorrido dentro de pátio de trens, espaço vizinho da pista de skate apelidada de Paranoid Park, local que o atrai pela má fama, construído ilegalmente pelos jovens carentes da comunidade norte-americana de Portland, em Oregon.

O protagonista explica que ao ir a Paranoid Park pela segunda vez, sozinho, à noite, conhece um jovem de rua, Scratch, que o convida a cruzar a cidade em cima de um trem. Ao invadirem o pátio de manobras, ao lado da pista de skate, os jovens são perseguidos por um vigia, que começa a agredi-los. Em um gesto de autodefesa e proteção do outro jovem, Alex atinge o segurança com seu skate, várias vezes, causando acidentalmente a sua morte: ao tentar se defender do ataque do jovem, o segurança perde o equilíbrio e cai nos trilhos, sendo arrastado pelo comboio, atropelado e morto, e tendo o seu corpo cortado ao meio pelas rodas do vagão. Assustados com o acidente, a dupla foge do local e não mais se encontra. Alex, em pânico, joga

\footnotetext{
${ }^{33} \mathrm{Em} \quad$ wikipedia: https://en.wikipedia.org/wiki/Blake_Nelson\#cite_note-1 e blog do autor: http://blakenelsonteennovelist.blogspot.com.br/p/media.html . Acesso em 10/ 06/ 2019.
} 
o seu skate no rio, ao lado do pátio de manobras, e vai para a casa de Jared, um amigo que lhe emprestara as chaves, e com quem tinha combinado a segunda visita à pista de skate naquela noite, mas desistira. Lá ele passa o resto da noite.

No dia seguinte o narrador volta para a casa dos pais, que estão se separando (o pai não mora mais com eles), e tenta retomar a sua rotina de estudante, guardando o segredo do evento por vários meses. Amedrontado com a possibilidade de ser descoberto e preso, Alex tenta fingir normalidade e continua a ter uma vida social, suportando os humores da nova namorada, que ele percebe não amar, indo a festas e a encontros na casa dos amigos, e acompanhando a investigação da morte pelos meios de comunicação. Algumas semanas depois do incidente, a polícia encontra o skate de Alex, e decide falar com os garotos skatistas das escolas da região sobre a noite da morte do segurança. O jovem dá seu depoimento ao detetive responsável pelo caso, mas não revela a verdade.

Dividido entre o dilema de confessar e ser preso, ou continuar sua vida normalmente, o protagonista não consegue se abrir com ninguém e afastar a angústia que o domina. Ele mente à polícia, aos pais e amigos, e torna-se paranóico e arredio, tendo constantes pesadelos e pensando em se entregar ou confessar o crime a alguém, mas nunca o faz. Durante todo o semestre o adolescente sente medo, inquieta-se, torna-se um mal aluno, e é invadido por ondas de pânico sempre que ouve sobre a morte do vigia ou vê a polícia na rua. Macy, uma de suas colegas de escola, e vizinha, que já se apaixonara por ele no passado, percebe a mudança no comportamento do colega e o aconselha a escrever o que o aflige.

Durante as férias de janeiro, e depois de perceber que o crime é arquivado pela polícia, que não resolve o caso, o adolescente, mais calmo, narra rapidamente os motivos de seu comportamento e preocupações, contando sobre a morte do vigia e as consequências da tragédia em sua vida. O choque do evento, ainda presente em suas lembranças, e a angústia causada pelo peso do terrível segredo, que jamais deverá ser revelado, fazem o jovem abordar vários temas em suas cartas, tais como a família, os amigos, o amor, a vida, Deus, a escola, o mundo dos adultos e dos adolescentes. Em sua última carta, Alex se diz menos angustiado e revela o destinatário de suas confissões, que é Macy, a quem agradece o carinho e o suporte, e confessa o seu amor.

O romance sugere que as cartas nunca são enviadas, pois o protagonista, depois de terminá-las, dá a entender que vai queimá-las.

\subsection{Resumo do romance (as cartas)}




\section{Capítulo 1 (3 de janeiro)}

Figura 16 - O início do capítulo 1

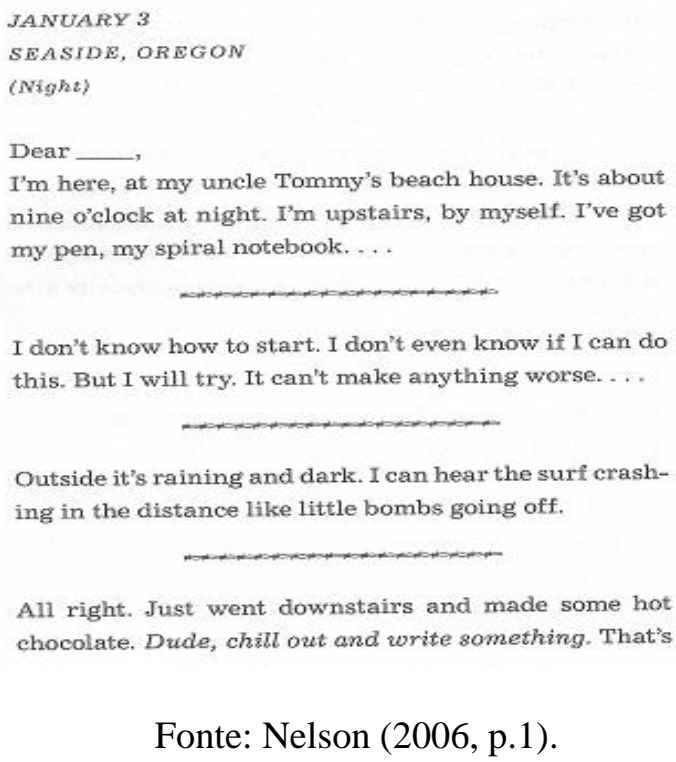

Fonte: Nelson (2006, p.1).

Querid (o /a)

Estou aqui na casa de praia do meu tio Tommy. É tipo nove horas da noite. Estou sozinho no andar de cima. Estou com a minha caneta, meu caderno espiral...Não sei como começar, nem sei se posso. Mas eu vou tentar. Não vai piorar...Lá fora está chovendo e escuro. Dá para ouvir as ondas quebrando ao longe como pequenas bombas explodindo. Tudo bem. Acabei de descer e fazer um pouco de chocolate quente. Cara, relaxa e escreve alguma coisa. Esse sou eu falando comigo mesmo. Eu só tenho que começar do começo, vai com calma, vai devagar... Paranoid Park. Foi lá que tudo começou. ${ }^{34}$

A primeira página da primeira carta é importante, pois revela a insegurança e a angústia do remetente, que não acredita poder levar seu projeto adiante. Inicialmente, o discurso do jovem é truncado e denota um presente intenso e repleto de incertezas. Para se motivar a escrever, Alex fala consigo. Após o início incerto, o primeiro tópico de suas cartas é Paranoid Park, local que ele associa ao começo de suas atribulações e motivo de suas cartas. Ao explicar sobre a pista de skate, o jovem revela sua admiração pelo lugar, descrevendo-o com tons utópicos, como um mundo subterrâneo, marginal, perigoso e livre:

Paranoid Park. Foi lá que tudo começou. Paranoid Park é uma pista de skate no centro de Portland. Está embaixo da Eastside Bridge, nos velhos armazéns. É uma "pista de rua" subterrânea, o que significa que não há regras, ninguém

34 "Dear I'm here at my uncle's Tommy beach house. It's about nine o'clock at night. I'm upstairs, by myself. I've got my pen, my spiral notebook...I don't know how to start, I don't even know if I can do this. But I will try. It can't make anything worse...Outside it's raining and dark. I can hear the surf crashing in the distance like little bombs going off. All right. Just went downstairs and made some hot chocolate. Dude, chill out and write something. That's me talking to myself. I just have to start at the beginning, take it easy, take it slow....Paranoid Park. That's where it started" (NELSON, 2006, p. 1). 
é dono e você não precisa pagar para andar de skate. Eles dizem que alguns caras da velha guarda do skate a construíram anos atrás e, de alguma forma, ela sobreviveu todo esse tempo. Muitos dos melhores skatistas vão lá, da Califórnia, da Costa Leste, de todas as partes. É também uma espécie de ponto de encontro de meninos de rua. Tem umas histórias, como a de um skinhead que foi esfaqueado lá uma vez. É por isso que eles chamam de Paranoid Park. Ela tem aquela vibe perigosa e imprecisa ${ }^{35}$.

A pista de skate é relacionada tanto a Jennifer, menina com quem teve uma rápida relação nas férias e por quem ele não se sente especialmente atraído, e aos seus pais, cuja relação tensa o impele a ficar fora de casa, aprendendo skate com Jared, um dos melhores skatistas de sua escola. Alex explica que a primeira vez que foi a Paranoid Park com Jared, foi na última semana de férias de verão:

Esta foi a última semana de férias de verão. Foi também a semana em que Jennifer Hasselbach me ligou pela primeira vez. Ela era essa garota com quem eu tinha ficado no começo do verão. Ela tinha sido monitora de um acampamento em julho e agosto, então a gente não se viu. Mas agora ela tinha voltado e queria sair. Ela me ligou três vezes naquela semana. Eu não estava muito a fim. Quero dizer, ela era fofa e tudo mais. Mas quando eu tentei contar a ela sobre Paranoid Park ela não entendeu nada. Ela pensou tipo, "Por que alguém ia preferir um lugar sujo se tinha a Skate City?" Lá era o lugar onde todos os Preps locais patinavam. Era um lugar sem graça, atrás do shopping. Se ela não podia ver a diferença, para que ficar com ela? Outra coisa, e isso é importante: durante todo o verão meus pais estavam brigando e falando sobre separação, então era tudo muito estressante. Meu irmãozinho Henry vomitava o tempo todo. Minha mãe quase saiu de casa, mas resolveu ficar, e então meu pai começou a ficar no meu tio Tommy. Foi uma época ruim; o verão inteiro foi uma espécie de desastre. Eu acho que isso foi outro motivo. Eu saía mais com Jared. Ele era tão "louco" que quando se estava com ele se esquecia de todo o resto. Esse também era o atrativo de um lugar como o Paranoid Park você tem a sensação de que mesmo que a sua família seja ruim, a desses caras é pior. Os caras eram verdadeiros órfãos. Alguns deles provavelmente viveram toda a vida nas ruas. Não dava para culpar eles (3 de janeiro - Anexo A).

As considerações do adolescente revelam que ele procura uma maneira de se sentir melhor, depositando parte de sua felicidade no amigo mais velho, Jared, que é sexualmente mais experiente, e no skate, esporte que ainda está aprendendo. Paranoid Park torna-se, então, um lugar especial e cativante, e com o qual Alex se identifica imediatamente, por sentir que ele e os usuários da pista têm algo em comum, relaciondo ao abandono. Ao ressentir o fato de

\footnotetext{
35 "Paranoid Park. That's where it started. Paranoid Park is a skatepark in downtown Portland. It's under the Eastside Bridge, down by the old warehouses. It's an underground, "street park", which means there are no rules, nobody owns it, and you don't have to pay to skate. They say some old-school guys built it years ago, and somehow it's survived all this time. A lot of the best skaters come there, from California and the East Coast and all over. It's also kind of a street-kid hangout. There's all these stories, like how a skinhead got stabbed there once. That's why they call it Paranoid Park, it has that dangerous, sketchy vibe to it" (NELSON, 2006, p. 3).
} 
Jennifer não entender a importância da pista comunitária e marginal, sancionada negativamente por ela e por sua classe social, e evitar o espaço usado pelos jovens de classe média, atrás do shopping, o protagonista de dezesseis anos busca definir valores, revelando sua frustração com o status quo, e buscando uma comunidade alternativa que o acolha. Em sua carta, o protagonista revela excitação e nervosismo ao visitar a pista, para a qual ele não se sente preparado. Paranoid Park é descrita como um lugar de desafios, para a qual ninguém está pronto, sendo um tipo de teste:

Bom, durante a última semana de verão, um dia estávamos no centro da cidade e Jared disse que deveríamos dar uma olhada em Paranoid Park. Eu não falei nada no começo. Eu tinha ouvido falar do lugar, é claro, mas nunca havia pensado em ir até lá. Eu achava que era muito pra mim. Mas quando eu disse que achava que não estava pronto, Jared riu e disse algo como: "Ninguém está pronto para Paranoid Park". Então nós fomos. Eu estava nervoso, lógico, mas também estava meio que empolgado. Praticar skate na Paranoid. Era uma conquista. Era algo que você poderia contar às pessoas. ${ }^{36}$

Alex explica que ele e o amigo decidem voltar à pista no sábado seguinte, à noite. $\mathrm{O}$ protagonista mente à mãe, dizendo que irá dormir na casa de Jared (vazia, uma vez que os pais estão viajando), pois irão a uma exposição de esportes, e pega o carro dela emprestado. Ao chegar à casa do amigo, no sábado, este lhe explica que uma menina por quem estava interessado tinha-o convidado para visitá-la fora da cidade. Jared decide viajar naquela noite para encontrá-la, atrapalhando os planos de ir a Paranoid Park. Contrariado, Alex leva Jared até a estação de ônibus, sentindo-se traído e desejando um amigo melhor. Jared lhe empresta as chaves de casa.

Ao invés de dirigir pela cidade ou convidar Jennifer para passar a noite com ele na casa vazia do amigo, Alex decide ir à Paranoid Park sozinho. Lá, um grupo de jovens senta-se ao lado dele e ele conhece Scratch, um Streeter, ou morador de rua, que pede o seu skate emprestado por alguns minutos. Apreensivo, o adolescente cede ao pedido do desconhecido, que cumpre sua promessa, volta com o objeto, e eles começam a conversar. Alex o descreve como "assustador ou esquisito (creepy), sujo (dirty), e "um tipo" (a kind of a character) (NELSON, 2006, p.11-12). Scratch trata o adolescente como um "expert" sobre skate (p. 14), e diz o quanto ele ama a filosofia daquele esporte, que tem uma natureza rebelde, explicando

\footnotetext{
36 "Anyway, during the last week of summer, we were downtown one day and Jared said we should check out Paranoid Park. I didn't say anything at first. I had heard of it, of course, but had never thought of going there. I had assumed it was out of my league. But when I said I didn't think I was ready, Jared laughed and said something like: 'Nobody's ever ready for Paranoid Park'. So we went. I was nervous, naturally, but I was also kinda psyched. Skating Paranoid. That was an accomplishment. That was something you could tell people about." (NELSON, 2006, p.3).
} 
que "era como ser um samurai, mas com "pranchas ao invés de espadas"” 37 . O protagonista relata que "pensou em ir embora", mas "era excitante estar lá, conversando com alguém como Scratch" 38 . Como é tarde da noite, o jovem marginal convida Alex a invadir o pátio de trens para que eles possam ir rapidamente ao outro lado da cidade, em cima de um trem, comprar cerveja e cigarros em um lugar que ele conhece. Ao aceitar o convite do outro, Alex dá a entender que seus valores estão sendo postos à prova, pois já não sabe explicar se foi convencido ou desejou fazer aquilo: "Eles me convenceram a fazer isso. Ou eu concordei. Eu não me lembro exatamente" 39 . A aventura é vista como uma maneira de punir Jared: "Jared ficaria com ciúmes. Bem feito!"40.

Os dois jovens passam por debaixo da cerca do pátio de trens e trepam em um trem que está vindo vagarosamente. Alguns minutos depois, um segurança aparece, alcança o comboio, e corre ao lado dos jovens, tentando atingi-los com o seu cacetete. Alex pula do trem, e vê o segurança ir ao encalço de Scratch, arrancá-lo do trem e derrubá-lo no chão. Alex, tentando proteger o companheiro, surpreende o segurança por trás, batendo nele várias vezes com o seu skate. Tentando se defender, o guarda perde o equilíbrio e cai ao lado do trem onde os jovens estavam. Ao tentar se levantar, suas roupas ficam presas em uma parte metálica de um dos vagões, o que faz com ele seja arrastado para baixo do comboio e seja atropelado, tendo o corpo cortado ao meio pelas pesadas rodas do vagão. Ao ver o corpo do segurança, Alex entra em choque e fica paralisado.

$\mathrm{Eu}$ fiquei onde estava. Eu não pude acreditar nos meus olhos. O trem continuou a passar enquanto eu estava tremendo de adrenalina e choque. Eu não podia acreditar no que estava vendo: um homem cortado ao meio [...]. Eu simplesmente não conseguia acreditar. Não era possível. ${ }^{41}$

Scratch foge. O adolescente explica que entra em estupor, perde a noção de tempo e de espaço, e seus sentidos intensificam-se. Ele se descreve em transe:

E o fedor daquilo. Quando o cheiro de suas entranhas chegou a mim eu engasguei. Eu quase vomitei. Comecei a recuar, andando para trás, mas incapaz de tirar os olhos. Eu tropecei em algo e caí. Isso quebrou o transe. Eu olhei em volta. Onde eu estava? O que acabara de acontecer? De repente, o ar

\footnotetext{
37 "Scratch talked the most. He asked me questions about skating stuff, treating me like I was an expert, and always saying how much he loved the philosophy of skateboarding and the rebel nature of it. It was a loner sport, he said. It was like being a samurai but with "board instead of swords" (NELSON, 2006, p. 14).

38 "It was fun talking to them. I kept meaning to leave, but I had nowhere to go, and it was kind of a thrill being there, talking to someone like Scratch" (Ibid., p. 14).

39 "They talked me into it. Or I agreed. I don't remember exactly" (Ibid., p. 16).

40 "Jared would be so jealous. It served him right!" (Ibid., p. 16).

${ }^{41}$ I stood where I was. I couldn't believe my eyes. The train continued to move while I stood trembling with adrenaline and shock. I couldn't believe what I was seeing: a man cut in half [...]. I simply could not believe it. It was not possible (NELSON, 2006, p. 23).
} 
ao meu redor parecia crepitar com energia ruim. Uma corrente de medo bloqueava os circuitos do meu cérebro. Eu senti como se estivesse fora do meu corpo, que meu corpo não era mais meu. Eu senti cada molécula na terra se voltar contra mim. Meus pulmões não funcionavam. Eu não conseguia respirar. Eu abaixei minha cabeça e tentei retomar minha respiração ${ }^{42}$.

Angustiado, os pensamentos do jovem tentam compreender o que está acontecendo. Ele se faz perguntas, seus pensamentos estão confusos e ele passa por emoções intensas. Ao fugir, ele passa pelo carro de patrulha do vigia, pensa em usar o rádio para chamar socorro, mas desiste, percebendo que está confuso:

Não, eu não deveria tocar nas coisas. Eu deveria ter cuidado com isso. No caso de... no caso de eu precisar... para que? Eu me afastei do carro. Eu tinha que pensar sobre isso. E se eu fosse acusado de alguma coisa? Foi um acidente, mas e se os policiais não vissem assim? Ou se não foi um acidente? Eu bati nele com o meu skate. Isso foi contra a lei? Talvez fosse autodefesa. Eu não sabia. Eu tinha que pensar. Eu tive que processar exatamente o que aconteceu na minha cabeça. A gente estava no trem... O guarda de segurança viu a gente... . Não adiantava. Meu cérebro não funcionava. Eu não conseguia ter um único pensamento claro. Senti outra onda de pânico. Meu corpo inteiro tremeu violentamente. Senti alguma coisa fazendo cócegas no queixo. Toquei minha bochecha. Lágrimas escorriam pelo meu rosto ${ }^{43}$.

\section{Capítulo 2 (4 de janeiro)}

\footnotetext{
${ }^{42}$ And the stink of it. When the smell of his insides reached me, I gagged. I almost threw up. I began to retreat, walking backward, but not quite able to pull my eyes. I tripped over something and fell. That broke the spell. I looked around. Where was I? What had just happened? Suddenly the air all around me seemed to crackle with bad energy. A low current of fear seemed to jam the circuits of my brain. I felt like I was out of my body, that my body was no longer my own. I felt every molecule on earth had turned against me. My lungs wouldn't work. I couldn't breathe. I lowered my head and tried to steady my breathing (Ibid., p. 24).

${ }^{43}$ No, I shouldn't touch things. I should be careful about that. Just in case...just in case I needed...to what? I stepped back from the car. I had to think about this. What if I got accused of something? It was an accident, but what if the cops didn't see it that way? Or what if it wasn't an accident. I did hit him with my skateboard. Was that against the law? Maybe it was self-defense. I didn't know. I had to think. I had to process in my brain just exactly what had happened. We were on the train...The security guard saw us... It was no use. My brain wouldn't work. I could not maintain a single clear thought. Another wave of panic swept through me. My whole body shook violently. I felt something ticking my jaw. I touched my cheek. Tears where pouring down my face (Ibid., p. 25).
} 
Figura 17 - O início do capítulo 2

\begin{abstract}
JANUARYA
SEASIDE, ORECON

(SAornisg)

Dear

So yeah, that's where I found myself. The hardest thing was not to run. I kept starting to run and then stopping myself. I was also hyperventilating. I tried to remember how you stopped that. You were supposed to breathe in a bag or something.

I ended up running toward the river. I jogged halfway across the parking lot before I realized I still had my skateboard. I jumped on it and instantly fell. I scraped my arm pretty bad, but I didn't stop to look. I jumped up and kept going.

At the end of the parking lot, I found an access road that ran parallel to the river. I could see the River Walk, the long bike path that goes by the river, I had skated it many times. But there might be people there, so I stayed away.
\end{abstract}

Fonte: Nelson (2006, p. 26).

Em sua segunda carta, o jovem continua descrevendo suas emoções e sensações em relação ao evento. Ele foge do local e não sabe se anda, corre ou pára, percebendo-se ofegante e aterrorizado: "Eu corria e parava. Eu também estava hiperventilando" (NELSON, 2006, p. 26). Lembra-se que está com seu skate, tenta andar, mas cai e machuca-se. Mesmo assim ele continua a fugir, evitando os acessos públicos. Como é sábado a noite, há pessoas na rua e ele se preocupa, evitando-as e pensando que pode estar sendo observado. Na pressa é quase atropelado e esbarra em pessoas, mas tenta parecer calmo e normal. Inspecionando o próprio corpo, Alex percebe que suas roupas estão sujas, com manchas de sangue, terra e graxa. Enquanto se dirige ao estacionamento onde deixou o carro da mãe, seu andar oscila como o seu pensamento. Ele explica que é tomado por momentos de pânico, pensando que sua cabeça irá explodir (p. 29) ${ }^{44}$. Preocupado, o protagonista procura racionalizar o crime: "Mas foi um acidente. Foi. Não foi minha culpa. Ou foi? Eu o matei? Fui eu quem realmente o matou? " ${ }^{45}$; fala sozinho: "Porque você fez isso? Eu rosnei para mim mesmo cerrando os dentes" ${ }^{46}$; pensa nas consequências do crime, imaginando explicar à polícia o ataque ao segurança como um ato

\footnotetext{
44 "I kept starting to run and then stopping myself. I was also hyperventilating"."I was running now". "Waves of panic kept hitting me". "I thought my head was going to explode" (Nelson, 2006, p.26-27-29).

${ }^{45}$ But it was an accident. It was. It wasn't my fault. Or was it? Had I killed him? Was it me who actually killed him?" (Ibid., p.30).

46 "Why did you do that? I snarled at myself through gritted teeth" (Ibid., p.32).
} 
de legítima defesa: "Não, delegado, é como eu te falei, nós apenas trepamos no trem por um segundo, só para ver como é, e então esse cara da segurança me atacou, totalmente do nada. Ele estava tentando matar a gente. Eu juro..." 47 (itálicos no original). Ao cruzar a ponte que dá acesso ao estacionamento onde o seu carro está, ele percebe que o seu skate tem manchas de sangue e o arremessa no rio.

Apesar de pensar em ligar para a polícia, o protagonista não consegue fazê-lo: "Eu tinha que contar a alguém. Eu devia ligar 911. Se eu não fizesse isso, estaria em um problema ainda pior, é o que eles sempre diziam: diga a verdade ou as coisas só vão piorar. Mas isso era realmente verdade? E se não fosse culpa sua?"48. Seu pânico é tão grande que ele tem alucinações e imagina um pôster na rua com o seu rosto desenhado: "Eu podia ver o pôster, um esboço policial do meu rosto"49. Alex chega ao carro e sai rapidamente do estacionamento. Dirigindo-se para a casa do amigo. O jovem pensa que vai enlouquecer.

Na estrada, comecei a ficar realmente louco. Meu cérebro, meus pensamentos giravam descontroladamente em todas as direções. Pela primeira vez na minha vida entendi como o estresse extremo podia levar o cérebro a lugares impossíveis. Isso poderia distorcer seu pensamento, te colocar em direções perigosas que podiam fazer total sentido na hora ${ }^{50}$.

Ao chegar à casa de Jared o adolescente relata que tira a roupa suja e vai para o chuveiro, onde chora incontrolavelmente. ${ }^{51}$ Mais tarde, na próxima carta, vai dizer que ao chorar sente que fala com Deus, apesar de não saber se acredita nele. Depois do banho, exausto, ele adormece e tem um pesadelo. $\mathrm{O}$ adolescente relata que tenta ligar para o pai, mas confuso, desiste e vai dormir. Na manhã seguinte, domingo, Alex veste algumas roupas de Jared, jogando as suas fora, e para evitar suspeitas, volta para a sua casa mais tarde, e sem o skate.

Em casa, a mãe pergunta por que ele chegara tão cedo. O protagonista mente, dizendo que não tinha ido à exposição na noite anterior, pois o amigo ficara doente. A mãe, preocupada com Alex por causa da tensa relação conjugal, comenta que o tio ligara dizendo que recebera uma ligação dele, na madrugada. Ela pergunta ao filho se tinha tentado falar com o pai. Alex

\footnotetext{
47 "No, officer, it's like I told you, we just hopped on for a second, just to see what is like, and then this security guy attacked me, totally out of nowhere. He was trying to kill us, I swear he was..." (NELSON, 2006, p.30).

48 'I had to tell someone. I should call 911. If I didn't, I would be in worse trouble, that's what they always told you: Tell the truth or things will only get worse. But was that really true? What if it wasn't even your fault?" (Ibid., p. 33).

49 "I could see the poster, a police sketch of my face" (Ibid., p.34).

50 "On the freeway, I seriously began to lose it. My brain, my thoughts - they spun wildly in every direction. For the first time in my life, I understood how extreme stress could drive your brain to impossible places. It could warp your thinking, pointing you in dangerous directions, which seemed to make perfect sense at the time" (Ibid., p.35). 51 "I tried to relax, or at least stop shaking. But it was hopeless. I couldn't stop. My lower lip trembled uncontrollably. Then I started to cry. It happened suddenly and once it started I couldn't stop" (Ibid., p.38).
} 
mente, explicando que provavelmente tinha ligado por engano, enquanto dormia. A mãe pergunta sobre o skate e ele mente novamente, dizendo que o tinha deixado na casa de Jared. Alex sabe que as suas explicações são um pouco suspeitas, mas percebe que a mãe de nada desconfia.

Incapaz de ficar em casa, Alex diz à mãe que pretende ir ao shopping para visitar uma loja de skates. Lá, ele compra um jornal, entra em uma lanchonete, e tenta encontrar algo sobre a morte do segurança. Na lanchonete ele encontra Macy, uma colega da escola, sua vizinha, que desconfiada, acha estranho vê-lo tão cedo em um lugar como aqueles, lendo jornal. Alex desconversa e explica que precisava fazer um favor para a mãe no shopping. Volta para a casa e liga para Jared, que tinha tentado se comunicar com ele naquela manhã. O jovem conversa com o amigo e inventa uma história sobre o que tinha feito a noite em que o deixou na estação de ônibus. Jared comenta que algumas roupas suas tinham desaparecido e Alex lhe explica que tinha pegado emprestado alguns itens porque tinha se molhado muito na chuva.

\section{Capítulo 3 (5 de janeiro)}

Figura 18 - O início do capítulo 3

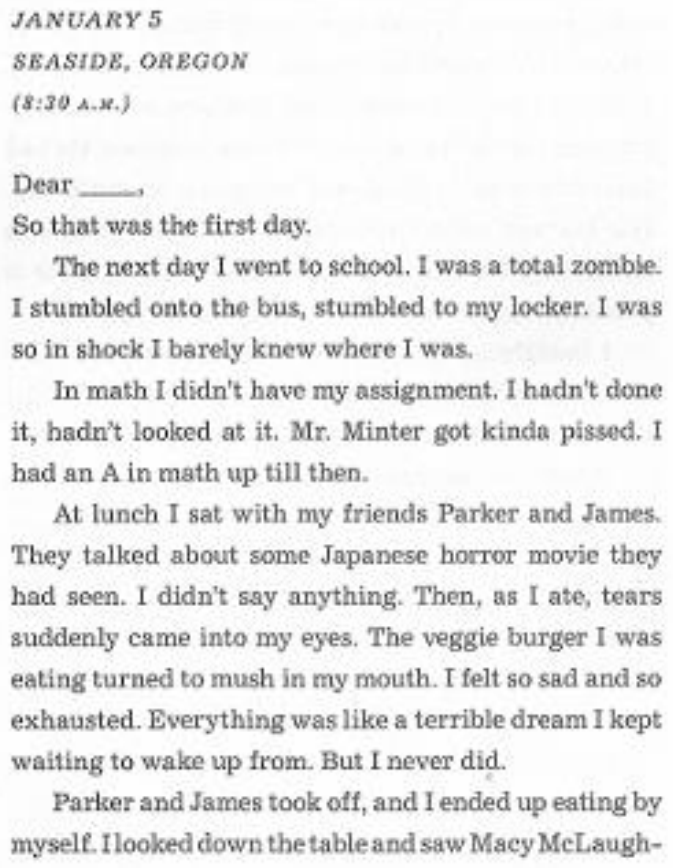

Fonte: Nelson (2006, p. 56). 
O terceiro capítulo é iniciado com a sentença "Então, aquele foi o meu primeiro dia", deixando claro que grande parte do relato anterior ocorre basicamente em 24 horas (da noite em que ele vai à pista de skate sozinho, sábado, e mata o segurança acidentalmente, até o final de domingo). Alex explica que no dia seguinte, segunda-feira, ao ir à escola, sente-se como um zumbi, tropeçando ao entrar no ônibus, tão chocado que mal sabia onde estava ${ }^{53}$. Distraído, explica que não consegue fazer a prova de matemática e no almoço, com os colegas, fica calado e chora, comparando tudo a um sonho do qual não consegue acordar. Ele mente à Jennifer sobre o final de semana, dizendo que nada tinha feito, e explica aos amigos que deixou o seu skate em casa. Depois da aula, Alex vai à casa da namorada, que está vazia, e ambos ficam mais íntimos. O jovem, no entanto, sente-se mal, explicando a Jennifer que está com tonturas. Os adolescentes tentam fazer sexo, sem sucesso. Alex reclama de cansaço e decide ir embora, desculpando-se por talvez estar doente ou com febre.

No caminho de casa o protagonista considera a possibilidade de ir a uma igreja para confessar o crime a um padre, mas não toma a iniciativa. Naquela noite come algo, pois nada ingerira desde a noite do acidente, sonha acordado imaginando se entregar à polícia e, no quarto, é chamado pela mãe, que diz que o seu pai está em casa e quer falar com ele. Alex vai ao encontro do pai, na garagem, que está recolhendo alguns pertences. Eles conversam. O pai, envergonhado pela separação, desculpa-se por ter colocado Alex e o irmão naquela situação tensa e imprevisível, depois pergunta sobre os colegas do filho e oferece ajuda. $\mathrm{O}$ adolescente, calado, novamente pensa em contar sobre o acidente, mas nada diz. Durante a conversa, porém, pensativo e fechado em si mesmo, Alex confessa o crime mentalmente:

Eu matei alguém, pai. As palavras pulavam na minha cabeça. Eu não disse nada, lógico [...]. Eu peguei ele com meu skate, pai. Eu rachei a cabeça dele [...]. Eu matei alguém, pai. Ele me atacou, mas eu fiquei na minha, esperei o momento certo e derrubei ele. Se tivesse que fazer isso você seria capaz, pai ? $?^{54}$

Nessa carta, Alex relata fatos triviais sobre a família, a escola e os amigos. Apesar de confessar que se sente melhor, sabe que está sendo um mal aluno, pois esquece a data das provas. Ao ver um carro de polícia na rua, fica imóvel. Ao pensar em sua situação e na dos pais, separados, chora, culpando-se por fazer o mundo pior. Alex conta que vai à igreja, anda pelas

\footnotetext{
52 "So, that was my first day. The next day I went to school. I was a total zombie. I stumbled onto the bus, stumbled to my locker. I was so in shock I barely knew where I was" (NELSON, 2006, p.56).

53 "I was so in shock I barely knew where I was" (Ibid., p. 56).

54 “I killed someone, Dad. The words bounced through my head. I didn't say them of course [...]. I nailed him with, my board, Dad. I cracked him in the head [...]. I killed someone, Dad. He attacked me, but I kept my head and waited for my moment and I took him out. Could you do that, Dad? If you had to?" (Ibid., p.68-69).
} 
ruas, pensa na guerra do Iraque e do Vietnã e em toda a violência do mundo, presente até nos video games. Diz que continua a pensar no incidente e, às vezes, vê o corpo do segurança nos trilhos.

Em um dos finais de semana, em uma festa, Alex e Jennifer fazem sexo novamente. O adolescente continua a se sentir "estranho", desumano, como se não estivesse lá, desejando algo como a morte. Junto com a namorada, que está feliz com a perda da virgindade (ela se tranca no banheiro e telefona para uma amiga para contar o feito), o jovem conclui que a vida é uma grande encenação, comentando: "As pessoas faziam o que achavam que deveriam fazer. Aprender a beijar aos quatorze anos. Aprender a dirigir aos quinze anos. Aprender a fazer sexo aos dezesseis anos. A vida era fácil. Basta seguir o cronograma, não cometer grandes erros, e tudo ficará bem" ${ }^{\prime 55}$. Na semana seguinte, após o final de semana romântico, Alex e Jennifer discutem na escola por causa de proteção sexual. Ela lhe pergunta se ele tinha comprado mais camisinhas e ele nega, o que a deixa irritada. A namorada confessa que muitas vezes acha o jovem estranho, agindo como se estivesse infeliz em vê-la ou quisesse evitá-la. Ele inventa uma desculpa e a acalma.

Alex pensa se um dia falaria sobre a noite fatídica em Paranoid Park e conclui que não, comparando suas memórias do incidente ao compartimento de um submarino, que precisa ser fechado por causa de um vazamento. Ele manifesta a certeza de que guardará aquele segredo, em nome da família e do futuro, mesmo que aquilo fosse um sacrifício e significasse noites de insônia. Ele terá que ser um homem:

O que mais eu poderia fazer? Arriscar tentando dizer a alguém? Apostar toda a minha vida na decisão da polícia, dos advogados e dos juízes se um skatista tem o direito de se defender? Eu sentia muito, me sentia mal pelo segurança e sua família. Mas agora não tinha conserto. Estava feito. Todos nós tínhamos que seguir em frente com nossas vidas. E se isso pesasse em mim, se isso significasse algumas noites sem dormir, bem, isso era um sacrifício que eu faria para as outras pessoas envolvidas. Para meus pais, para meu irmão, para as pessoas que me ensinaram e me ajudaram e investiram no meu futuro. Para eles, eu suportaria o fardo. Para eles eu seria um homem ${ }^{56}$.

\footnotetext{
55 "People did what they thought they were supposed to do. Learn to kiss at fourteen. Learn to drive at fifteen. Learn to have sex at sixteen. Life was easy. Just follow the schedule, don't make any big mistakes, and everything will be fine" (NELSON, 2006, p. 81).

${ }^{56}$ What else could I do? Risk trying to tell someone? Gamble My whole life on if the police and the lawyers and the judges decided a skater has a right to defend himself? I was sorry, I felt bad for the security guard and his family. But there was no fixing it now. It was done and over with. We all had to move on with our lives. And if it weighed on me, if it meant some sleepless nights, well, that was a sacrifice I would make for the other people involved. For my parents, for my brother, for the people who had taught me and helped me and invested in my future. For them, I would bear the burden. For them I would be a man (Ibid., p. 85).
} 


\section{Capítulo 4 (6 de janeiro)}

Figura 19 - O início do capítulo 4

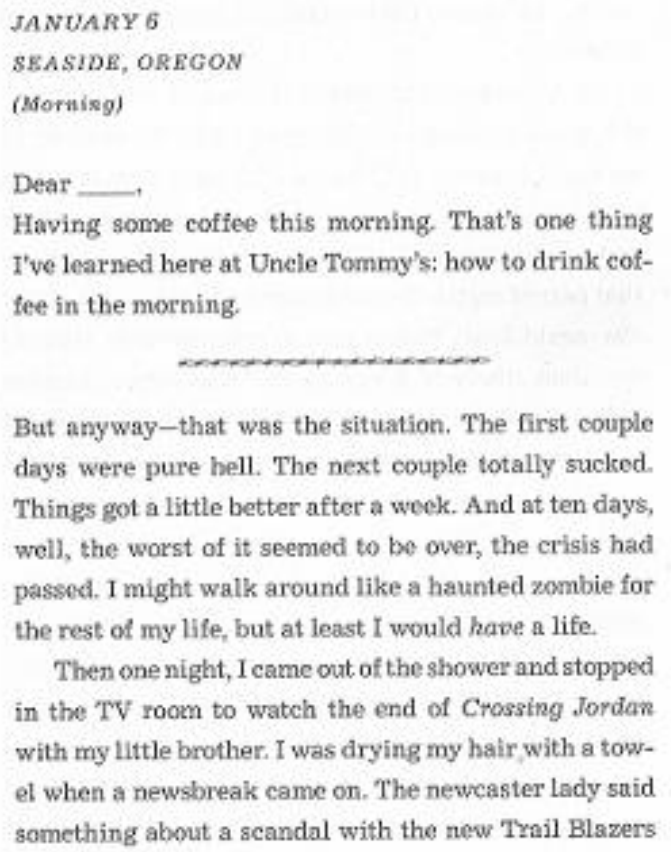

Fonte: Nelson (2006, p. 86).

Algumas semanas depois do incidente, Alex explica que está mais calmo, mas confessa que ainda sente o peso emocional do evento ocorrido na pista de trens. Alex compara esse período de vida com os dias passados, confessando que seria para sempre um zumbi:

Bem, essa era a situação. Os primeiros dois dias foram puro inferno. Os seguintes foram deprimentes. As coisas melhoraram um pouco depois de uma semana. E depois de dez dias, bem, o pior parecia ter acabado, a crise tinha passado. Eu poderia andar por aí como um zumbi assombrado pelo resto da minha vida, mas pelo menos eu teria uma vida ${ }^{57}$.

Apesar do tom mais otimista, dois eventos desestabilizam novamente o jovem: a morte do vigia é noticidada no jornal; e um inspetor da polícia visita a escola. Assim, em casa, Alex assiste à TV local na Internet e defronta-se com a reportagem da morte do segurança no pátio de trens, tratada como um possível homicídio. Frente à notícia, o ator conta que revê a noite do crime e seus detalhes, e teme o futuro mais uma vez: pensa sobre as roupas jogadas fora, vestígios do incidente no carro da mãe, possíveis testemunhas, o skate atirado no rio, a volta de

57 "But anyway, that was the situation. The first couple of days were pure hell. The next couple totally sucked. Things got a little better after a week. And at ten days, well, the worst of it seemed to be over, the crisis had passed. I might walk around like a haunted zombie for the rest of my life, but at least, I would have a life" (NELSON, 2006, p. 86). 
Scratch e uma possível delação etc. Por um momento ele memoriza o telefone do site de notícias e pensa em ligar para "fazer a coisa certa" 58 . O pânico cresce novamente. Alex começa a imaginar um depoimento para a polícia, para a qual liga, mas rapidamente desiste. Naquela noite, o jovem não dorme bem e relata: "Eu deitei na cama com minha cabeça girando cada vez mais rápido. Todas as possibilidades, todo tipo de coisa que eu podia fazer, tudo terminava em desastre. Eu podia sentir o peso daquilo me destruindo". O jovem, então, confessa: "Eu era uma má pessoa" ${ }^{59}$.

No café da manhã o adolescente chora novamente, evitando os olhares da mãe e do irmão caçula, e escondendo-se no porão da casa. Ao ir para a escola, ele dá carona a Macy, que percebe algo estranho em sua expressão. Alex evita falar sobre o assunto e desconversa, explicando que está de mau humor. Mais tarde, os jovens conversam novamente e Alex deixa escapar que algo muito sério tinha acontecido com ele. Percebendo que falara demais, diz que está exagerando e desconversa, comentando que a vida, às vezes, é difícil.

Dois dias depois, alguns estudantes são chamados à diretoria: todos são skatistas. Alex também é convocado. Os adolescentes são levados a uma sala de aula, onde encontram um detetive de polícia chamado Matthew Brady, que se apresenta e diz estar investigando o assassinato ocorrido no pátio de trens. Ele explica que a polícia encontrou, na margem do rio, perto de onde o crime acontecera, um skate sujo de sangue, concluindo que o assassinato poderia estar relacionado aos usuários de Paranoid Park. O investigador deixa claro que ninguém é suspeito, pergunta o nome dos adolescentes e todos falam bastante.

Ao perguntar se os alunos conhecem a pista, Jared menciona que ele e Alex tinham ido ao local uma ou duas semanas antes do crime, e planejado voltar no final de semana em que o guarda fora assassinado. Jared explica que tivera que viajar naquela noite. O detetive olha para Alex e pergunta o que ele tinha feito, e o adolescente responde que apenas saira para dirigir. $\mathrm{O}$ investigador dá a cada um dos jovens o seu cartão.

Alguns dias depois, o detetive volta à escola e colhe os depoimentos individuais de todos os alunos que tinham ido ao parque na semana do crime. Alex também é entrevistado. O detetive lhe pergunta sobre a família, a namorada, a separação dos pais, o que tinha feito na noite da morte do segurança, e comenta que seus pais também tinham se separado quando era adolescente. Alex mantém a frieza e conta ao detetive a história que já tinha ensaiado,

\footnotetext{
58 [...] "do the right thing" (NELSON, 2006, p. 90).

59 "I lay in bed, my brain spiraling downward, faster and faster, every possibility I could think of, every course of action, it would all end in disaster. I could feel the weight of it destroying me. [...] I was a bad person" (Ibid., p. 92-93).
} 
explicando que não tinha ido à pista, apenas dirigido, levado Jared à estação de ônibus e ido a uma lanchonete. $\mathrm{O}$ detetive pergunta o que o jovem faria se ele, ou um garoto como ele, tivesse cometido o crime, ou testemunhasse alguém o cometendo. Alex olha para baixo e evita o olhar do policial, dizendo que chamaria a polícia ou, se tivesse cometido o crime, correria.

\section{Capitulo 5 (7 de janeiro)}

Figura 20 - Início do capítulo 5

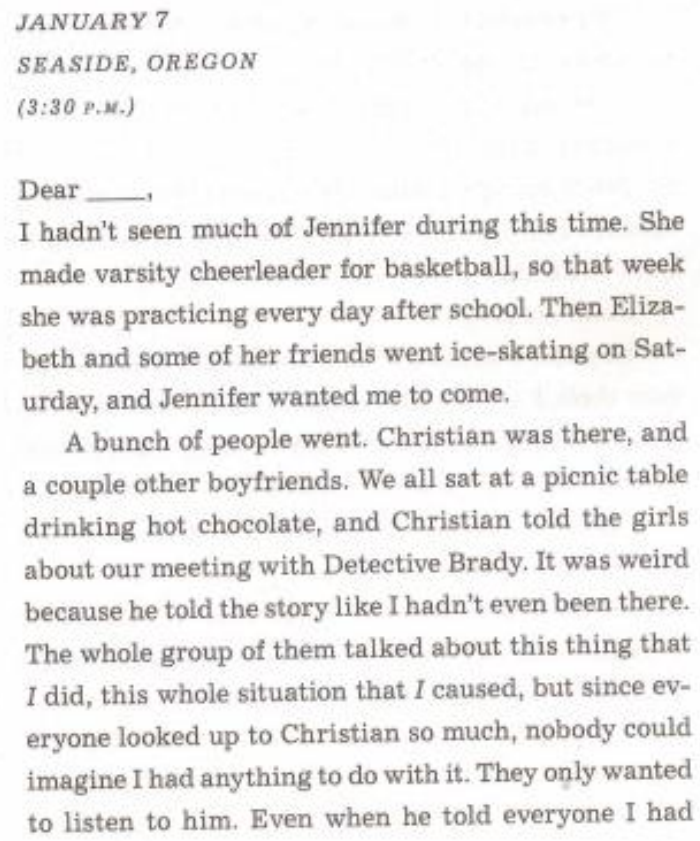

Fonte: Nelson (2006, p. 128).

Alex explica que vai patinar no gelo com os amigos e a namorada. Após tentarem fazer sexo, novamente sem sucesso, o casal discute mais uma vez, e Jennifer reclama que o namorado continua estranho e ausente, e que precisa arranjar um carro ao invés de andar de skate. Alex, em sua carta, confessa que não se importa, e diz que vai embora de skate, no escuro e na chuva, dizendo que "é feliz só" 60 . Nessa mesma noite, o protagonista diz que sonha com o detetive Brady: ele é um parente da família e ambos conversam sobre o divórcio dos pais e como ele se tornou um policial. O jovem relata que na noite seguinte ao sonho pensa em fugir de casa, roubar um carro e ir ao México, ou viver solitariamente nas montanhas do Canadá, caçando, pescando e vivendo da terra, talvez encontrar uma mulher, mas duvida que possa fazê-lo. Alex conclui: "Essa era a coisa sobre segredos. Eles te deixavam louco. Verdade. Eles isolavam você.

60 "I skateboarded home from her house, in the rain, in the dark. I was glad to do it. I was glad to be on my own" (NELSON, 2006, p. 131). 
Eles separavam você de sua tribo. Eles acabavam destruindo você. A menos que você fosse forte. A menos que você fosse muito, muito forte" ${ }^{\prime 61}$.

Nessa carta Alex relata que decide romper o namoro com Jennifer, que depois o acusa de usá-la apenas para sexo. A notícia é espalhada rapidamente e, no dia seguinte, toda a escola fica sabendo da separação. Os colegas do ator comentam a separação.

Ao voltar para casa, o jovem encontra o inspetor Brady no ponto de ônibus. O detetive lhe pede para acompanhá-lo em uma volta pelo centro da cidade para reconhecer alguns skatistas. Alex conta ao policial que se separou da namorada. O protagonista confessa que gosta do detetive. Sobre estar no carro com Brady, ele escreve:

Eu também senti como... bem...eu meio que gostei de Brady por algum motivo. Quero dizer, eu estava com medo dele, naturalmente. Mas estar perto dele parecia mais seguro do que não estar, sem saber o que ele estava fazendo ou pensando. E outra coisa: ele parecia diferente das outras pessoas. Ele era um policial. Ele viu coisas. Ele lidou com as realidades brutais da vida. Não como a maioria das pessoas. A maioria das pessoas nunca lidou com nada ${ }^{62}$.

Alex relata que é outono, portanto, outubro, e confessa que sua vida está normal. O processo legal do divórcio dos pais começou, sua mãe está tomando pílulas para dormir e sendo amparada pela avó ou pela tia. O jovem pensa no detetive Brady, desejando falar com ele e imaginando os seus conselhos, e descreve-se como anestesiado (numb, p. 145), explicando que suas notas continuam baixas, mas não sendo incomodado pelos adultos por causa do divórcio. Ele diz que já não tem sente mais medo, e parou de se preocupar se será preso, pois lera na Internet que se a polícia não resolve um caso de assassinato nas duas primeiras semanas, as chances de sucesso diminuem drasticamente. Apesar de tudo, o jovem se descreve como catatônico e sem vontade, e propenso a ter câncer:

Eu tentava fazer lição de casa. Cerca de uma vez por semana, eu estudava por algumas horas e realmente lembrava o que estudava. Mas na maioria das noites eu estava ausente. Sentava na frente da TV, catatônico. Não me sentia feliz nem me sentia triste; eu só me sentia doente. Sentia que ficaria doente. Eu tinha certeza que acabaria tendo câncer. ${ }^{63}$

\footnotetext{
61 "That was the thing about secrets, they drove you insane. They really did. They isolated you. They separated you from your tribe. They destroyed you even actually. Unless you were strong. Unless you were very, very strong" (NELSON, 2006, p. 136).

62"I also felt like... well... I sorta liked Brady for some reason. I mean, I was terrified of him, naturally. But being near him seemed safer than not being around him, and not knowing what he was doing, or thinking. And another thing: He seemed different from other people. He was a cop. He'd seen stuff. He'd dealt with the brutal realities of life. Not like most people. Most people never dealt with anything."(Ibid., p. 141).

63"I I tried to do homework. About once a week or so, I would study for a couple hours and actually remember what I studied. But most nights I would zone out. I'd sit in front of the TV and go catatonic. I didn't feel happy, I didn't feel sad; I just felt sick. I felt like I would get sick, I was pretty sure I'd eventually get cancer (NELSON, 2006, p. 146).
} 
No final de outubro, Alex relata que encontra Macy em um café e os dois conversam bastante: falam sobre o divórcio dos pais, o rompimento do namoro, e as dificuldades da vida. Os dois voltam para casa de ônibus. Sentado ao lado da jovem, Alex explica que se sente bem e percebe a beleza da amiga. Macy mais uma vez tenta saber o que aconteceu, pois o achava diferente, relacionando o fato à recente separação dos pais. O jovem fica em silêncio e ela não insiste.

\section{Capítulo 6 (8 de janeiro).}

Figura 21 - Início do capítulo 6 (a primeira carta do dia)

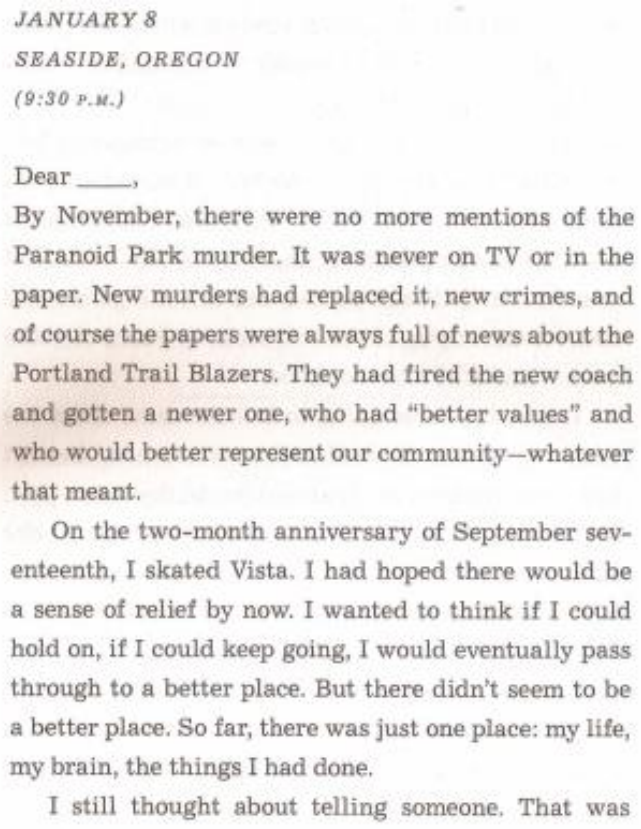

I still thought about telling someone. That was

Fonte: Nelson (2006, p.157).

Alex comenta que é final é novembro, e que apesar de o crime não ser mais mencionado na mídia, ele ainda se sente mal: "Agora achava que iria me sentir aliviado. Imaginava se poderia aguentar. Se sim, as coisas melhorariam. Mas não parecia existir um lugar melhor. Até agora existia apenas minha vida, minha mente, as coisas que eu havia feito" 64 . O jovem relata que ainda considera contar o que aconteceu à polícia, mas depois de tanto tempo tudo parece um sonho, sendo difícil voltar atrás na mentira. No entanto, o jovem reconhece que jamais esqueceria o ocorrido:

64 "I had hoped there would be a sense of relief by now. I wanted to think if I could hold on, if I could keep going, I would eventually pass through to a better place. But there didn't seem to be a better place. So far, there was just one place: my life, my brain, the things I had done" (Ibid., p.157). 
De uma coisa eu tinha certeza: eu jamais esqueceria. Talvez fosse verdade que o tempo curava todas as feridas, mas não podia apagar as cicatrizes. Daqui a vinte anos, eu não teria boas memórias do colegial, das meninas, festas e jogos de futebol. Minha memória mais viva seria a daquele guarda nos trilhos. Seria sempre assim. Eu jamais sentiria o mesmo a respeito das pessoas da minha vida. Eu ainda teria amigos, mas não como uma pessoa normal. Essa parte era realmente a pior: jamais me sentir a vontade perto de outras pessoas. Jamais poder realmente relaxar e simplesmente rir e ser honesto. Eu não sabia o que fazer sobre isso. Eu não sabia se isso mudaria ${ }^{65}$.

Algumas semanas depois do dia de Ação de Graças (a última semana de novembro), Alex vai, pela terceira vez, a Paranoid Park, onde lembra de tudo e é perseguido por alguns jovens de rua, amigos de Scratch, que sabiam que os dois tinham saído juntos na noite do crime. Quem salva o jovem é o detetive Brady, que estava de ronda no local. Após ser salvo, o jovem entende que ele é a pessoa certa para falar sobre o incidente no pátio de trens e pensa em confessar o crime, mas novamente não tem coragem, pois encontra um cartão postal dentro do carro do investigador que, pelos nomes dos remetentes e destinatários, sugere que nem ele e nem os pais sejam divorciados, contrariando o que tinha sido dito no dia do depoimento. $\mathrm{O}$ jovem fica confuso e desconfia das verdadeiras intenções do investigador. Apesar de terem se passado três meses do ocorrido, Alex escreve que ainda sente suas "ansiedades costumeiras" (usual anxieties, p. 174), esperando o telefone tocar ou Brady aparecer na escola, algemá-lo e levá-lo.

Alex lembra que um dia está praticando skate na frente de casa e encontra Macy. A adolescente diz que tinha pensado no que o jovem dissera sobre não a angustia de não poder contar um terrível segredo a ninguém, e lhe sugere, para tirar o peso dos ombros, que ele escreva uma carta à pessoa a quem ele tenha causado o problema, como um pedido de desculpa, ou a alguém em quem ele realmente confia, alguém com quem ele se sinta bem, como um professor, os pais, ou um amigo, como ela. Depois, ele pode fazer o que quiser com a carta.

Alex diz que pensará no assunto.

\section{Capítulo 7 (8 de janeiro)}

\footnotetext{
65 "One thing was for sure: I was never going to forget. Maybe it was true that time healed all wounds, but it couldn't erase the scars. Twenty years from now, I would not look back on my high-school days with fond memories of girls and parties and football games. My clearest memory would be that security guard on those tracks. And it always would be. I was also never going to feel the same about the people in my life. I would still have "friends," but not like a normal person. That really was the worst part: not ever feeling quite right around other people. Not ever being able to truly relax and just laugh and be honest. I didn't know what to do about that. I didn't know if that would change" (NELSON, 2006, p. 158).
} 
Figura 22 - Início do último capítulo (a segunda carta do dia)

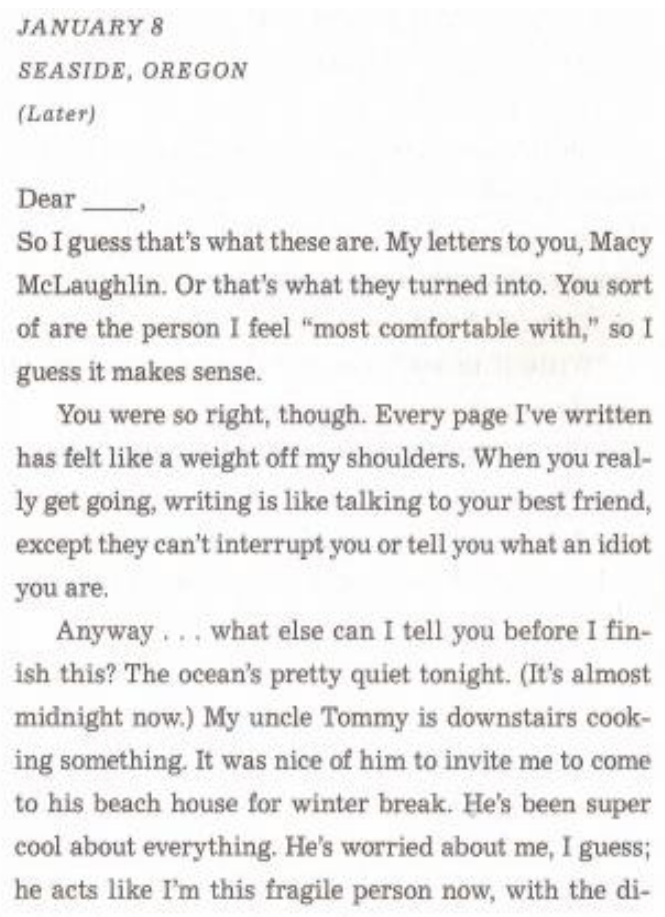

Fonte: Nelson (2006, p. 178).

Querido (a)

Então eu acho que é isso que elas são. As minhas cartas para você, Macy McLaughlin. Ou é nisso que elas viraram. Você é tipo a pessoa com quem eu me sinto à vontade, então acho que tem tudo a ver. Mas você estava tão certa. Cada página que eu escrevi pareceu um peso tirado dos ombros. Quando você começa, escrever é como conversar com seu melhor amigo, exceto que ele não pode te interromper ou te dizer que você é um idiota. Bom, o que mais eu posso te dizer antes de terminar? O mar está bem calmo esta noite. (É quase meia-noite) Meu tio Tommy está lá embaixo cozinhando alguma coisa. Foi legal da parte dele me convidar para passar as férias de inverno na casa da praia. Ele tem sido super legal em tudo. Eu acho que ele está preocupado comigo; agora, com o divórcio acontecendo, ele age como se eu fosse uma pessoa frágil. Ele nunca fica bisbilhotando, ou pergunta o que eu fico fazendo aqui, a noite toda, escrevendo como um louco, ou coisas desse tipo. Bem, antes de terminar, a coisa principal que eu queria te dizer é: obrigado. Eu não tenho certeza do que, exatamente. Por você estar comigo, eu acho. Por andar de ônibus comigo no Vista aquela noite. E por não sair da minha cabeça. Eu tipo estou pensando em você, agora. Principalmente porque eu te escrevi essas cartas enormes. Mas em outras horas, também, como quando eu ando na praia, ou à noite, antes de dormir. Eu sempre me perguntei o que ia substituir as imagens horríveis na minha cabeça. Eu nunca pensei que seria a aluna irritante da sexta série que morava na rua. Sobre o que eu vou fazer..., quem sabe? Ainda tem dias que eu espero que Brady apareça na minha porta, com algemas. Outras vezes eu quero entrar em uma delegacia e confessar tudo. Eu gostaria de confiar mais nas pessoas. Eu gostaria de ter mais fé nas coisas. Mas por que brincar com o destino? Nem sempre os adultos fazem a coisa certa. Eles estão mais ferrados do que os adolescentes. Pelo menos a gente sabe que faz merda. Essa é a coisa legal de ter saído com você nos últimos dois meses. Você meio 
que me salvou. O motivo é que eu confio em você, de verdade. É o que importa: saber que existe uma pessoa ao seu lado, uma pessoa que te protege. Isso é o suficiente para não te deixar louco. Ah, sim, e já que isso é o fim, acho que posso dizer uma coisa: eu tipo gosto de você. Eu sei, isso não é ridículo? Tão típico. Na hora que você pára de gostar de mim, eu começo a gostar de você. Deus brinca com a gente desse jeito. De verdade. Tudo faz parte de uma grande piada cósmica. Ok, Macy McLaughlin. Está tarde, agora, e eu vou parar. Obrigado por me fazer companhia. Obrigado por muitas coisas. Agora eu vou procurar alguns fósforos... (carta traduzida na integra: Anexo 1).

\subsection{A construção discursiva do acontecimento e do sobrevir: memória e transformação}

$\mathrm{O}$ escritor Blake Nelson, explicando sua preferência pela literatura infanto-juvenil e a temática da adolescência, comenta:

Eu realmente gosto dessa fase da vida, e que há todo um gênero disso. É por isso que me tornei um escritor sobre adolescentes. Se você é um escritor adulto, eles deixam você escrever uma história sobre maioridade em sua carreira. Se você é um escritor infanto-juvenil, você pode construir toda uma carreira baseada em histórias desse tipo ${ }^{66}$ (tradução do autor).

O discurso do autor nos interessa, pois não apenas mostra as motivações criativas do autor, mas revela também uma consciência relacionada à mudança e à transformação do herói, à maioridade, associada aos ritos de passagem. Joseph Campbell entende que o caminho padrão da aventura mitológica do herói é uma magnificação da fórmula representada nesses tipos de rito, construídos na ordem separação-iniciação-retorno, que podem ser vistos como uma unidade nuclear do monomito, explicada mais detalhadamente como "uma separação do mundo, uma penetração em alguma fonte de poder, e um retorno que intensifica a vida" (1949 apud RUTHVEN, 2010, p. 95): para ser aceito como elemento importante da comunidade, o iniciado precisa passar um período longe do grupo, vivendo fora das regras da vida civilizada, em um estado natural, passando por um período de marginalização e segregação, até renascer em outra vida (CANTARELLA, 1986, p. 79). Essa base mítica, ou consciência mitológica do rito de passagem, no entanto, para a semiótica será depurada em uma estrutura básica semionarrativa que, como vimos, é figurativizada de várias maneiras no nível discursivo do texto, em sua superfície mais concreta e superficial, adquirindo vida própria.

\footnotetext{
66 "I really like that stage of life. And I love that there's a whole genre of it. That's why I moved over to become a YA writer. If you're an adult writer they let you write one coming of age story in your career. If you're a YA writer, you can make a whole career out of writing coming of age stories" (NELSON, 2006). Blake Nelson teen novelist. General Print Interview. Disponível em http://blakenelsonteennovelist.blogspot.com.br. Acesso em 02 / 06 / 2019.
} 
Como configuração mitopoética contemporânea, Paranoid Park (doravante $P P$ ) é sobre um jovem que está deixando a pré-adolescência (tem 16 anos) e passa por um momento de busca independente de valores, uma vez que o lar já não mais o atrai e os pais, em fase de separação, estão cada vez mais distantes. Enquanto aventura-se longe de casa, envolve-se na prática do skate e conhece adolescentes diferentes, o ator sofre um evento traumático que o desestabiliza completamente e o separa parcialmente de sua comunidade, relacionado à morte acidental de um homem, e cujas consequências serão sofridas em segredo. Depois de alguns meses do incidente, confuso, amedrontado e solitário, Alex resolve isolar-se e escrever rapidamente suas aflições, revendo valores e repensando-se como sujeito; finalmente, na última carta, revelando-se apaixonado e mais confiante, está mais forte para retornar à rotina e à "comunidade", enquanto descobre-se outro, um adolescente mais experiente e seguro de si, e que consegue imaginar-se no futuro, como adulto. Nesse sentido, a temática da escrita inserese em uma proposta temática do enfrentamento de problemas e do amadurecimento.

Em chave mitológica, pode-se dizer que o vigia morto acaba sendo a primeira batalha de Alex, relacionado ao aventurar-se longe de casa em um lugar estranho e na qual ele faz um gesto nobre, ou belo gesto, ao salvar um desconhecido, representante da nova comunidade com a qual o jovem se identifica, das garras da lei ${ }^{67}$. Para escrever suas lembranças, o ator se isola, abandonando o contato social para fazer um balanço de si mesmo, em uma jornada interior na qual confronta o passado, e ao fim da qual é sancionado. No enredo mítico desse romance de transformação, o herói participa de um evento que envolve sacrifício humano e derramamento de sangue, e pode ser visto como o começo de uma iniciação: ao escrever, Alex se encontra e retorna à sociedade.

Nesse rito de passagem contemporâneo, porém, os desafios de Alex, e também o seu tímido heroísmo, são particulares e restritos, e interessam apenas a ele, que na verdade fala consigo próprio nas cartas que queima. De outro lado, ao saber que suas mãos estão sujas de sangue, tem consciência do mal que cometeu, mas ameniza a culpa em favor de um futuro livre, da tranquilidade familiar, e da confiança nos desígnios de Deus. Solitário, ao indicar na última carta que se sente melhor, demonstrando amor e sugerindo que vai queimar os manuscritos,

\footnotetext{
${ }^{67}$ Segundo Greimas e Fontanille (2014[1993]), o belo gesto é uma invenção por negação: negação de uma moral social fundada sobre a troca, negação de um sistema de valores cuja valência é função dos desejos da coletividade, negação de programas narrativos cujo desenvolvimento em processo é dessemantizado e dessensibilizado; invenção de uma ética individual não reproduzível, de um universo de valores aberto sobre múltiplos possíveis ainda indeterminados, invenção de formas de vida [...] que se instalam, pouco depois da negação fundadora, graças a uma nova afirmação que imporá suas determinações. Desse ponto de vista, o belo gesto é sem dúvida o melhor exemplo de uma articulação da estética com a ética, pela qual o valor de uma conduta torna-se sensível por meio de uma maneira de ser ou de fazer (p.33).
} 
Alex encontra a serenidade, mas mostra a força da lembrança do evento trágico, que estará presente para sempre na memória, como segredo: diferente dos mitos primitivos, a volta do herói ao cotidiano é problemática, e a maioridade é tingida com tons de medo, segredo, individualidade, solidão e egoísmo. A partir daí a ideia de maioridade deve ser relacionada a uma volta problemática para um centro, menos da comunidade, do que de si mesmo, a partir de um balanço da própria existência. Como todo rito de passagem possui um componente de construção de identidade, Alex não pode evitar a reconstrução de si-próprio e a incorporação de novos valores.

$P P$, como romance que aborda o crescimento e a maioridade, é principalmente voltado para os estados de alma do sujeito, que o fazem refletir sobre o indivíduo e o social, o que provoca a reconstrução da subjetividade. De modo geral, ao afastar-se de casa para procurar novos valores em outras esferas sociais, sofrer o acontecimento, e mergulhar na paranóia de ser descoberto e preso, Alex é configurado como sujeito intenso da falta em busca da realização de uma plenitude:

Figura 23 - O campo de presença e a tonicidade perspectiva

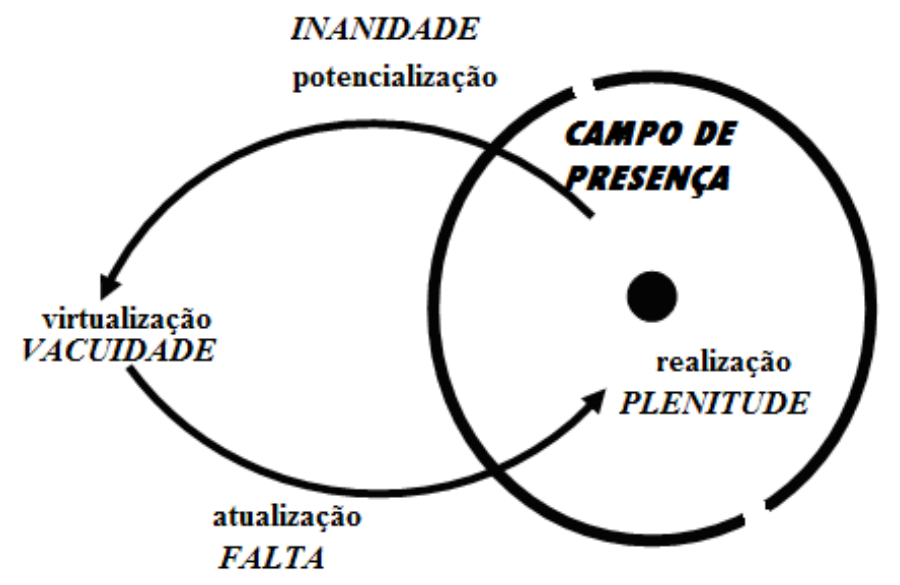

Fonte: Fontanille, Zilberberg (2001), p. 135.

A busca de valores e a maturidade do jovem ator são relacionados tanto à pista de skate clandestina e marginal, local onde os jovens são indivíduos e possuem, cada um, sua própria identidade, como a um evento traumático ligado diretamente a essa pista e a seus usuários. $\mathrm{O}$ acidente no pátio de trens faz Alex mergulhar em um mundo interior e secreto, de medos e ansiedades, e que em chave semiótica se dá a partir de um acontecimento, cuja consequência é a irrupção do sobrevir em seu campo de presença como sensação afetiva desconcertante, parada da rotina cotidiana. A palavra "paranóia", que dá nome à pista de skate e ao romance, explicita 
a ideia do sobrevir, significando turvamento da razão, loucura, sendo também um termo psiquiátrico que engloba as formas crônicas de delírios de relação, ciúmes e perseguição, e a chamada esquizofrenia paranóide, problemas psíquicos que se manifestam na forma de um delírio sistematizado (Houaiss).

Segundo Zilberberg (2011), que propõe uma semiótica a partir da ideia de evento, o acontecimento que Alex sofre é relacionado à surpresa, ao assomo, à exclamação, concebido como vivência de significação, um sobrevir que comove o discurso na qualidade de recurso próximo, de não-resposta imediata. Se esse assomo exclamativo for brutal, e o afeto, intenso, então a não-resposta instantânea será semelhante à interjeição, à transição entre o mutismo daquele a quem o acontecimento deixou sem voz, e a retomada da palavra, a qual, de acordo com seu andamento, resolverá com o tempo, normalizará cedo ou tarde, sob a forma de um estado, de um discurso (p. 21). É justamente por não mais poder suportar o peso do segredo e do silêncio, provocados pelo acontecimento e pelo sobrevir, que causam uma aceleração delirante na vida do jovem, uma saturação tônica vivenciada a contragosto em uma crise fiduciária radical (ZILBERBERG, 2011, p. 277), que ele abandona o seu mutismo e escreve rapidamente, "como um louco", desejando voltar a um estado de normalidade.

Em PP, o acontecimento dá-se também em forma de fratura estésica organizada pela relação de um sujeito a um objeto, figurado como um corpo humano literalmente "cortado ao meio", imagem que atormentará o jovem por toda a vida e é descrita como marca eterna na pele e no corpo: uma cicatriz. A fratura estésica, representada como corpo cortado e mutilado, favorece o surgimento de outra semantização do mundo percebido e do sujeito que percebe, de modo que "se esta vivência sensível opera transformações, é porque o arranjo estético produz quebras de estereótipos e de simulacros preconstituídos" (GREIMAS, 2002, p.11): estamos na dimensão das linguagens e da construção de sentido ativada pela estesia. Em relação à apreensão estésica Landowsky (20020 explica que

mediante uma ruptura súbita que, ao que parece, em nada depende da vontade
do sujeito, modifica-se então a maneira de ser do mundo externo, de tal modo
que um determinado componente sensível do ambiente, em vez de manter-se
distanciado e quase imperceptível como estava ainda no estado anterior, de
repente entra, por assim dizer, nele, absorve-o, domina-o, impõe-lhe sua
presença e, por meio de uma comoção "estésica", revela-lhe justamente esse
sentido outro, a espera do qual ele se havia consumido (p. 132).

Vimos que após a constatação da morte do vigia e da imagem de seu corpo cortado ao meio, o ator fica paralisado, não acreditando no que vê, fato que demonstra a modalização subjetiva do crer da assunção desestabilizada. O acontecimento insere o sujeito em uma espécie 
de estupor, causa dúvidas sobre a objetividade do tempo e espaço, e cria a sensação de transe. Angustiado, Alex tenta compreender o sobrevir que o assola; seu pânico é tão intenso, que ao ir para a casa do amigo, depois do incidente, sofre alucinações, imaginando que está enlouquecendo. Escondido na casa de Jared, o adolescente reza e chora descontroladamente até adormecer, tendo pesadelos. No dia seguinte ao incidente, Alex descreve-se como um "zumbi", incapaz de controlar o próprio corpo, e confessa que essa sensação perdura fortemente pelos dez primeiros dias após o choque: o jovem tem a impressão de que tal sensação será eterna.

Em sua penúltima carta, a do dia 8 de janeiro, e após quase quatro meses após o evento, o protagonista descreve-se como "catatônico". A palavra "zumbi”, além de seu significado mais popular, que é "morto-vivo" possui, também, outros sentidos relacionados à morte: "alma que vagueia a horas mortas, e fantasma de animal morto". Da mesma maneira o termo "catatônico", utilizado em psicopatologia, alude à "forma de esquizofrenia que apresenta uma alternância entre períodos de passividade e de negativismo e períodos de súbita excitação" (Houaiss). Alex explica que não se sente feliz, nem triste, apenas doente: são os efeitos do sobrevir.

$\mathrm{O}$ incidente com o segurança do pátio de trens, evento que transtorna o ator a ponto de fazê-lo sentir-se totalmente inerte, sendo decisivo na configuração de seus estados patêmicos, pode ser associado a um objeto inesperado que penetra em seu campo de presença tensivo, transtornando-o, e incidindo sobre suas atitudes, comportamentos e afetos. Paralisado pelo choque de ter provocado acidentalmente a morte de um homem, o jovem é modalizado por um poder não ser, que corresponde à contingência, relacionada a um fato imprevisível ou fortuito que escapa ao controle, uma eventualidade (Houaiss). Ao poder não ser Alex também não pode fazer e torna-se impotente (inclusive no âmbito afetivo): tais modalizações passionais, que em chave psicológica apontam para a interferência na libido, uma energia vital ou psíquica (Houaiss), mostram que o protagonista do romance é mergulhado em intensidades afetivas incontroláveis. Ao ver o corpo do homem morto, inicia-se a parada da continuação de sua rotina, e o jovem é mergulhado na continuação dessa parada.

Conduzido passivamente pela própria rotina amortecida pelo choque do acontecimento, Alex é mergulhado em um "mundo epifânico" ${ }^{6}$, que "valoriza o intervalo, ou seja, uma porção de tempo e espaço em cujo interior só transitam continuidades" (TATIT, 2010, p. 67). Após a noite do incidente terrível, ele se sente em um sonho do qual não consegue acordar (p. 56). Segundo Tatit, a efemeridade dos sinais epifânicos deve-se à simultaneidade, no imaginário do sujeito, de dois percursos narrativos: ao do cotidiano, que tende à superação dos limites,

\footnotetext{
${ }^{68}$ A epifania está relacionada ao acontecimento, que pode ser positivo ou negativo.
} 
impostos por forças antagonistas e, portanto, à evolução ininterrupta; e ao do epifânico, que representa um intervalo, uma duração sem limites internos, que por ser intenso e ter alta densidade de presença retém o progresso do espaço englobante, tende a ser comprimido e, por fim, suprimido pelo mundo cotidiano (p. 70).

Preso entre um mundo cotidiano adolescente e sua dinâmica fragmentada e eufórica do dia-a-dia, e um mundo epifânico e sua dinâmica contínua e disfórica, o ator vive ambas, a duração do sobrevir gerado pelo acontecimento e a urgência de sua finalização, e a fratura estésica e a tentativa de escapatória. Na existência epifânica do ator, podem-se observar valores remissivos contínuos que evitam sua conjunção com o mundo adolescente desejado e valores de liberdade, família, felicidade e, principalmente, continuidade, ou seja, a continuação da continuação: assim, enquanto leva uma rotina secreta e apavorante, Alex tem constantes pesadelos, sofre com as notícias da morte do vigia na mídia, não consegue se relacionar com as pessoas, torna-se um aluno disperso e fraco, e pensa sempre em confessar o crime ou em fugir de casa.

Do ponto de vista da fratura, subentende-se que houve uma mudança no quadro narrativo de evolução do sujeito, de modo que a partir de algum estímulo sensorial esse actante percebe-se repentinamente interagindo com outras forças actanciais, exercidos por atores que não participam de seus programas narrativos de rotina. Assim, em vez da busca habitual do objeto, o sujeito se sente tomado pela presença ofuscante de um evento que o retira temporariamente de sua trajetória de vida, roubando-lhe parte de sua condição ativa. $\mathrm{Na}$ tentativa de sanar a fratura, ou seja, na escapatória, existe o anseio de ressemantização do contato com os acontecimentos estéticos, em um exame de modo no qual verifica-se até que ponto pode-se construir a "espera do inesperado" (TATIT, 2010, p. 50-51).

Escrevendo, Alex ressemantiza o acontecimento e o sobrevir e inicia um movimento que visa à escapatória do mundo epifânico disfórico ao qual está aprisionado: assim, tanto as cartas como o ato de escrever, e falar, representam a tentativa de reencontrar os valores de vida, perdidos depois da morte do vigia. Segundo Tatit, a fratura e escapatória são dimensões indissociáveis do acontecimento, pois "de um lado, ele nega os programas narrativos habituais do cotidiano e, então, define-se como 'fratura'; e de outro, pressupõe os mesmos programas e define-se assim como "escapatória'” (p. 52). Podemos inferir que ao continuar uma rotina mecânica depois do incidente traumático que altera a sua vida, Alex procura manter-se no exercício, em um devir que é ainda passivo e atônico devido ao sobrevir, equilibrando-se sobre a linha movente que separa as ações referentes ao pervir, de um lado - e que devem por 
equidade ser contadas ao seu favor - e, de outro, acontecimentos que, como se costuma dizer, 'o pegaram de surpresa' (ZILBERBERG, 2011, p. 284).

Através da escrita das cartas projetam-se dois momentos na vida do adolescente: o passado trágico após a morte do vigia, percebido como mal-estar, doença e pesadelo; e o presente do restabelecimento, associado à escrita, a partir do qual se elabora o início de uma volta ao familiar e ao rotineiro que, no entanto, jamais serão os mesmos. Podemos ilustrar esse movimento, que é o da morte à vida, tensivamente, do somente mais, relacionado à saturação causada pelo acontecimento, a um menos mais, relacionado a uma atenuação desse acontecimento a partir da escrita. Tatit explica que o indivíduo surpreendido, como Alex, se põe imediatamente a reconstituir a duração omitida na esperança de reassumir o controle do seu tempo interior, de sua própria identidade. "Arrumar-se" para avaliar um acontecimento corresponde a desacelerar o que se apresentou de modo excessivamente veloz e a transformar o sobrevir em devir (TATIT, 2010, p. 82).

Assim ao lembrar e escrever seus sentimentos, o jovem procura transformar o acontecimento e suas consequiências em fato, e inicia a desaceleração e atonização do sobrevir. Suas cartas podem ser tomadas como um discurso onde a intensidade é diminuída e transformada em extensidade, o mais sensível em mais inteligível. Como ao escrever o adolescente vai da parada da continuação, provocada pelo acontecimento, à continuação da continuação, à volta ao cotidiano, o acontecimento pode ser comparado a forças remissivas do antidestinatário, e a escrita das cartas a forças emissivas do destinatário. É no momento em que o jovem escreve, que se produzirá o efeito estético, provocado menos pela surpresa, mas por sua desaceleração, ou seja, "o restabelecimento de uma duração mínima, ao longo da qual flexibilizam-se as funções do sujeito e objeto, e vislumbra-se a possibilidade de plenitude juntiva” (TATIT, 1998, p. 198).

Como vimos, não só todas as cartas são escritas rapidamente, aceleradamente, mas duas são escritas no mesmo dia, fato que mostra como o objeto-acontecimento continua presente na memória afetiva do ator. Zilberberg explica que os traços negativos de tal objeto, assimétricos, intransitivos e sobretudo inconexos, são tendencialmente exclamativos e atualizam a resolução, ou seja, a inversão dos traços negativos que, uma vez realizado, exige a equanimidade, elemento tendência da frase declarativa (ZILBERBERG, 2011, p. 281). Segundo a ideia tensiva de junção entre homem e mundo, o discurso sobre a memória do acontecimento atualiza o discurso do sujeito, pois 
a memorização supõe, de um lado, o retorno dos dados realizados à condição de norma, ou sistema em nosso universo cognitivo. De outro, supõe uma reabsorção da experiência sensível num quadro em que o tempo do sujeito, suspenso pelo choque do acontecimento, começa a se recompor até poder se reatualizar em discurso, não mais com a agudeza sensorial de sua apreensão direta inicial, mas com a inteligibilidade necessária para se tornar um fato social (TATIT, 2010, p.155).

Em $P P$, a escrita é manipulada por um destinador que colocar o sujeito em conjunção com o seu objeto-valor "paz interior", para fazê-lo continuar o programa narrativo interrompido, e iniciar novos programas conjuntivos. Antes do acontecimento, Alex é um sujeito distendido, que evita ficar em casa, cansado de testemunhar a briga dos pais, a dissolução da família e o sofrimento do irmão menor; ao ir a Paranoid Park e sofrer o acontecimento, ele se torna um sujeito desconectado, alheio, abatido, um "zumbi catatônico"; escrevendo as cartas, transforma-se em sujeito mobilizado, sujeito do fazer e agir ${ }^{69}$. Assim:

Figura 24 - Modos de existência do sujeito Alex no romance

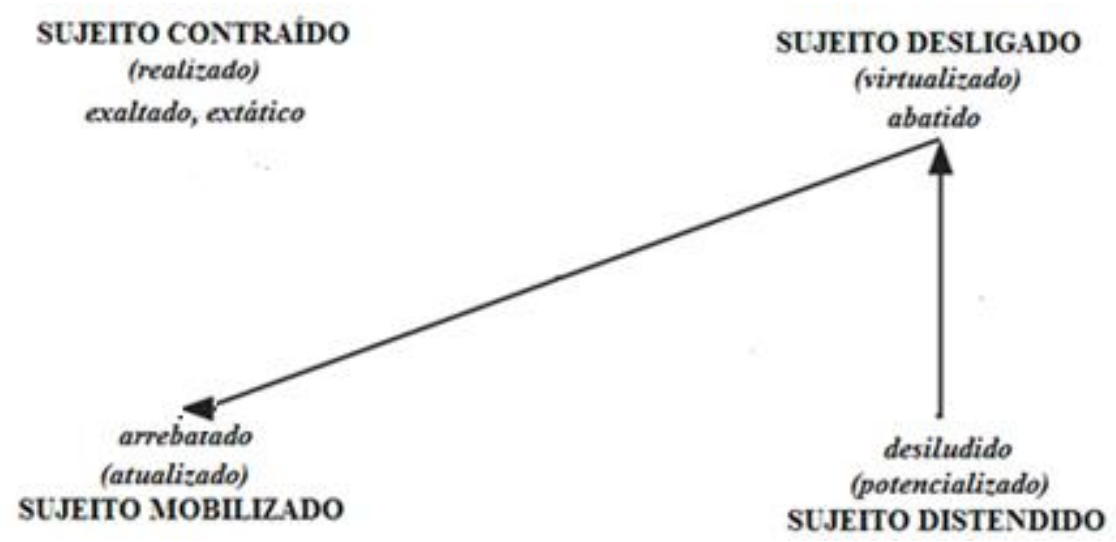

Fonte: adaptação de Fontanille; Zilberberg (2001, p. 143-144).

Em chave passional tensiva, ao agradecer a amizade de Macy e lhe confessar o seu amor na última carta, o ator apresenta um percurso passional que vai da pura emoção do sobrevir ao sentimento. A primeira, que pode ser vista como "explosão, golpe ou acento (FONTANILLE; ZILBERBERG, 2001, p. 283), e a segunda, que pode ser traduzida como apego e aptidão, revela o recrudescimento do pervir e a volta à normalidade do cotidiano. Tal percurso mostra que Alex, ao final de sua escrita, agora quer e pode controlar seus atos e paixões, começando a estabilizar-se emocionalmente. Assim:

\footnotetext{
${ }^{69}$ Fontanille e Zilberberg (2001) explicam que um sujeito mobilizado será arrebatado pela emoção, vindo a tornarse, quando dotado das competências e dos programas de uso requeridos, fantasmático; um sujeito concentrado, cujo corpo carrega consigo todo o ser, poderá ser considerado exaltado, extático e em alguns conceitos, embevecido ou entusiasta; o sujeito distendido estaria desiludido; o desligado, abatido (p. 143-144).
} 
Figura 25 - As cartas e as emoções do protagonista

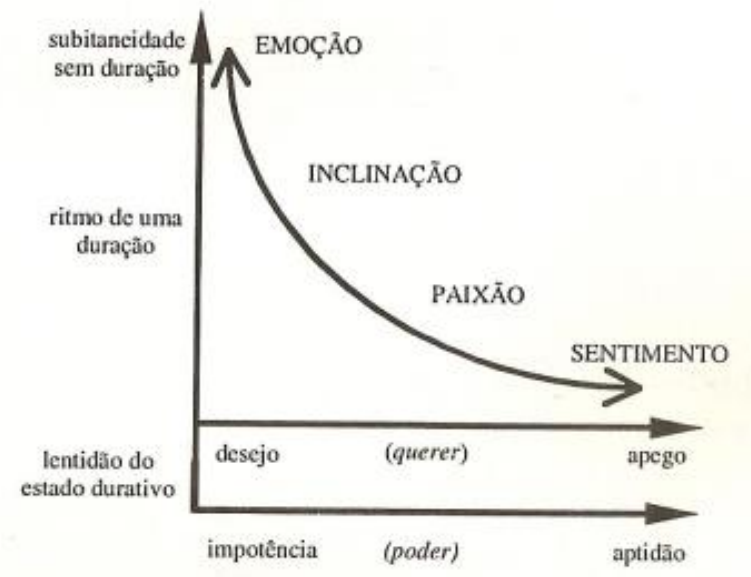

Fonte: Fontanille; Zilberberg (2001, p. 284).

Apesar de "voltar ao normal", Alex explica que jamais esquecerá as imagens do homem morto, de modo que estará para sempre conectado ao objeto estésico. Dessa forma, o retorno à cotidianidade parece ser apenas parcial, marcando uma diferença entre o Alex do passado e do presente. Trata-se do efeito do acontecimento, figurado como cicatriz e preso indefinidamente em sua memória, de modo que:

\begin{abstract}
A perda de densidade de presença do acontecimento como objeto é condição para que a experiência de plenitude se mantenha no universo subjetivo do sujeito. De acordo com o nosso ritmo de vida introjetado, jamais uma situação de êxtase emocional pode alongar-se indefinidamente. Entretanto, se atenuamos sua presença, convertendo-a em motivos associados a figuras da lembrança, nostalgia ou da saudade, essa situação de encontro pleno pode adquirir um caráter permanente e, se for o caso, recobrar de quando em quando, e por alguns instantes, sua alta densidade de presença (TATIT, 2011, p. 97).
\end{abstract}

É importante notar que ao escrever, é a primeira vez que o protagonista abre-se com alguém e fala sobre o homicídio que comete: assim, é a primeira vez que ele precisa lembrar, organizar fatos, e reviver o passado disfórico recente: à potencialização tônica "pertencem os conteúdos que se realizaram com alta intensidade de presença e que, em seguida, se integraram no universo subjetivo como crenças essenciais, assumidas, e que, provavelmente, serão incentivos para novas atualizações" (TATIT, 2010, p. 156). O evento traumático é tão devastador que ao iniciar o seu relato, o discurso do enunciador-ator adota forte caráter concessivo, de modo que o narrador / ator confessa sua incerteza na capacidade de relatar o ocorrido, continuando a ser modalizado por forças contrárias acionadas pelo sobrevir potencializado: um querer-fazer, mas um não poder fazer: "Não sei como começar, nem sei se 
posso. Mas eu vou tentar" (NELSON, 2006, p. 1). Apesar da forte presença afetiva do trauma no campo tensivo do jovem, que gera angústia e medo, as cartas apontam para o início de um desprendimento sensível desse objeto. Assim:

Figura 26 - A densidade da presença do acontecimento-objeto no campo de presença do protagonista

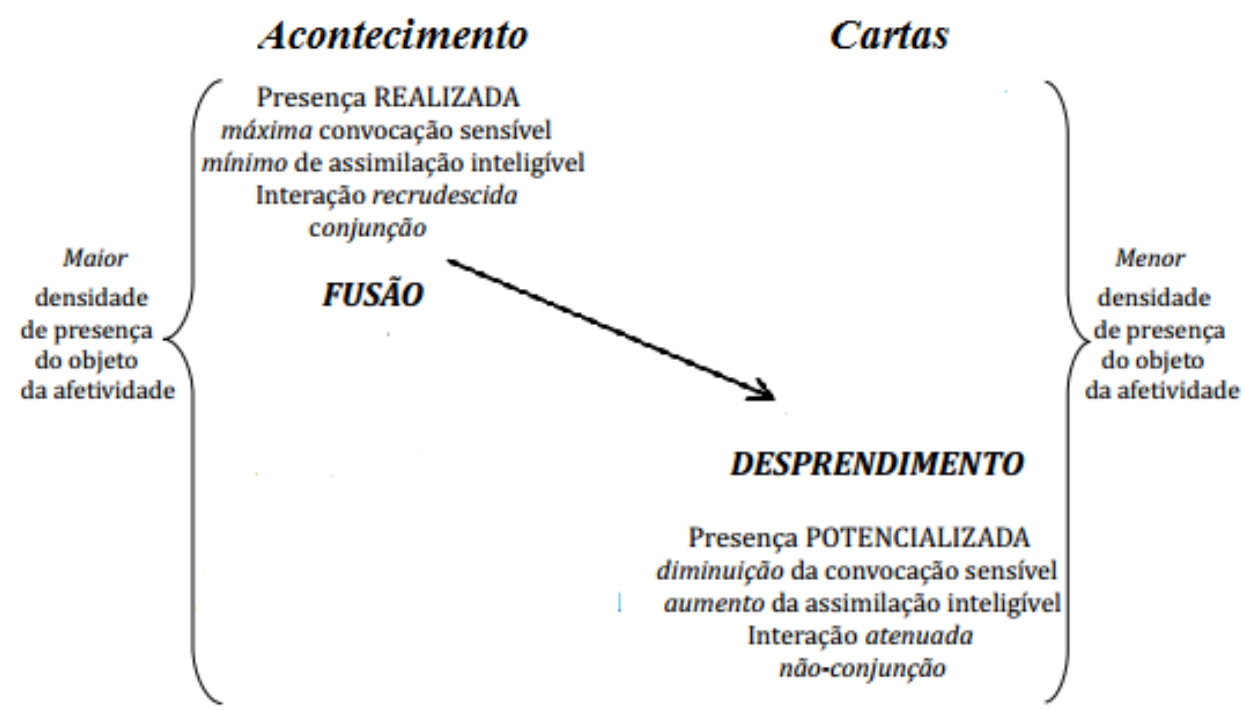

Fonte: adaptação de Lima (2014, p. 57).

Em sua penúltima mensagem, o ator explica que apesar de o "assassinato de Paranoid Park" ${ }^{\prime 70}$ não ser mais mencionado na mídia, ele ainda se sente mal, pensando que não conseguirá superar o que lhe aconteceu: "Agora achava que eu me sentiria aliviado. Imaginava se suportaria. Se sim, as coisas melhorariam. Mas não parecia existir um lugar melhor. Até agora existia apenas minha vida, minha mente, as coisas que eu havia feito"71. Percebendo que sua vida voltará ao normal, mas jamais se sentirá o mesmo em relação as pessoas, continuando a ter amigos, mas não como uma pessoa normal, e não se sentindo bem ao redor de outras pessoas $^{72}$, o ator revela, de um lado, uma existência pautada pela atenuação dos valores de absoluto, instaurados pelo acontecimento, e de outro, valores de universo mais concentrados provocados pela potencialiazação do sobrevir na memória. Dessa forma, mesmo voltando à normalidade e ao cotidiano, sua vida será marcada por uma intensidade tênue e concentrada:

Figura 27 - Os valores semióticos do protagonista

\footnotetext{
70 “the Paranoid Park murder" (NELSON, 2006, p.157).

71 "I had hoped there would be a sense of relief by now. I wanted to think if I could hold on, if I could keep going, I would eventually pass through to a better place. But there didn't seem to be a better place. So far, there was just one place: my life, my brain, the things I had done" (Ibid., p.157).

72 "I was also never going to feel the same about the people in my life. I would "still" have friends, but not like a normal person. That really was the worst part: not ever feeling quite right around other people” (Ibid., p. 158).
} 


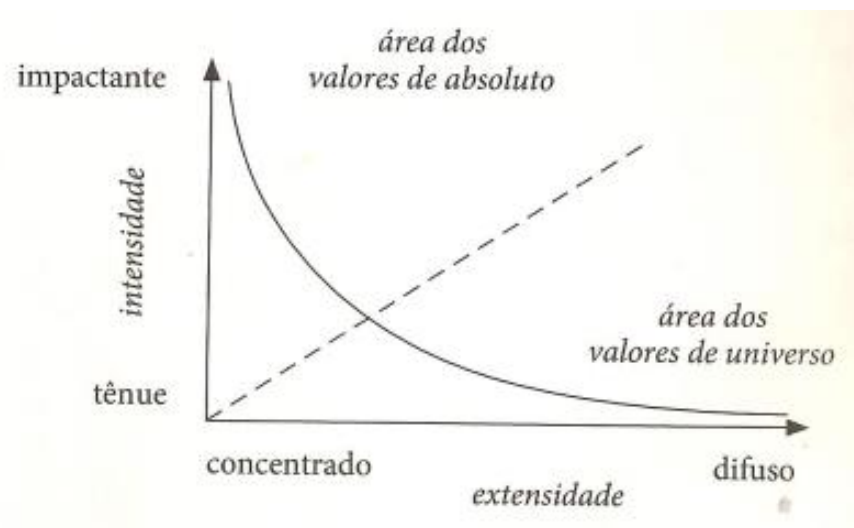

Fonte: Zilberberg (2011, p. 90).

Isso posto, procuramos mostrar nesse subcapítulo como as noções de acontecimento, fratura estésica e sobrevir são importantes para a constituição e composição da obra, sendo temas centrais na elaboração de seu sentido. Zilberberg (2011) explica que a reflexão sobre o acontecimento é muito mais antiga do que a linguística e a semiótica, aparecendo em Descartes como "admiração", em seu tratado "As Paixões da Alma" (p. 164), e acredita ser provável que "a tipologia dos discursos seja superponível à tipologia dos acontecimentos" (p. 172). Ademais o semioticista indica que tal noção está igualmente presente, de forma mais velada, nas operações concessivas e metafóricas da linguagem, sendo a base das discussões sobre a retórica assim como das considerações sobre a falta, a surpresa, o sublime, o sofrer etc., de maneira que a ideia de acontecimento como modalização tensiva repercute em toda a geração de sentido.

Assim, a partir do esquema de Zilberberg, que une modos semióticos e sintaxes discursivas tensivas, adotaremos o ponto de vista de que o romance, como trata da memória de um trauma potencializado no campo de presença do jovem, sendo relatado pela primeira vez, apresenta um discurso modalizado pela eficiência do sobrevir, pela existência relacionada ao foco, e pela junção do sujeito com o mundo ao acontecimento; a partir daí os estilos sintáticos adotados serão os da intensidade da ascendência, da extensidade da triagem e da sintaxe juntiva da concessão. Tais modos e sintaxes devem ser tomadas como estratégias gerais de discurso e simulações de estados tensivos relacionados também a paixões: um regime geral de sentido.

Dessa forma, tratamos de um primeiro projeto enunciativo que vai administrar essas modalidades e estruturas, que serão mais e menos tônicas durante o romance, mas funcionarão como um guia semio-tensivo para a semiose do discurso, incluindo o seu andamento, em um texto que pretende mimetizar o estado interior invadido pelo sobrevir e marcado eternamente pelo acontecimento. Com esses modos e sintaxes em mente, continuaremos a explorar o romance, observando-o dentro do percurso de sentido para definir como suas estruturas 
discursivas e semionarrativas são articuladas para dar conta do conteúdo proposto pelo enunciador, além de algumas características de seu plano de expressão, categorias expressivas que homologuem as categorias semânticas de seu conteúdo, modalizado pela intensidade. Uma vez que o percurso de sentido do romance é articulado pela linguagem verbal, gráfica e visual, observaremos como os modos tensivos configuram sincreticamente o texto: com nossas análises, buscaremos elementos do plano do conteúdo e da expressão que possam ser comparados ao projeto enunciativo do texto adaptado ad quem.

\subsection{O percurso do sentido de Paranoid Park}

\subsubsection{O narrador / ator}

A enunciação produz o discurso e instaura o sujeito da enunciação. O lugar da enunciação, instaurado pelo ato, é semioticamente vazio e semanticamente cheio, um depósito de sentido (GREIMAS; COURTÉS, 2011 [1979], p. 167; verbete: enunciação). O primeiro nível da enunciação tem como actantes o enunciador e o enunciatário: o primeiro é o destinador implícito da enunciação; o segundo é o seu destinatário implícito, que como filtro e instância pressuposta no ato de enunciar é também sujeito produtor do discurso: assim o sujeito da enunciação recobre as duas posições actanciais, a do enunciador e a do enunciatário. O segundo nível da hierarquia enunciativa é a do destinador e do destinatário instalados no enunciado, que correspondem aos actantes da enunciação enunciada, chamados de narrador e narratário, sujeitos diretamente delegados do enunciador e do enunciatário. O terceiro nível da hierarquia enunciativa instala-se quando o narrador dá voz a um actante do enunciado, operando uma debreagem de $2^{\circ}$ grau. Surgem actantes da enunciação instalados por uma debreagem interna, que instaura um diálogo. Como este é um simulacro da estrutura da comunicação criado no interior do discurso, pressupõe os dois actantes da comunicação, o destinador e o destinatário que, nesse nível, denominam-se interlocutor e interlocutário (FIORIN, 2001, p. 6, 66, 67). Essas relações podem ser ilustradas da seguinte maneira: 
Figura 28 - A hierarquia enunciativa

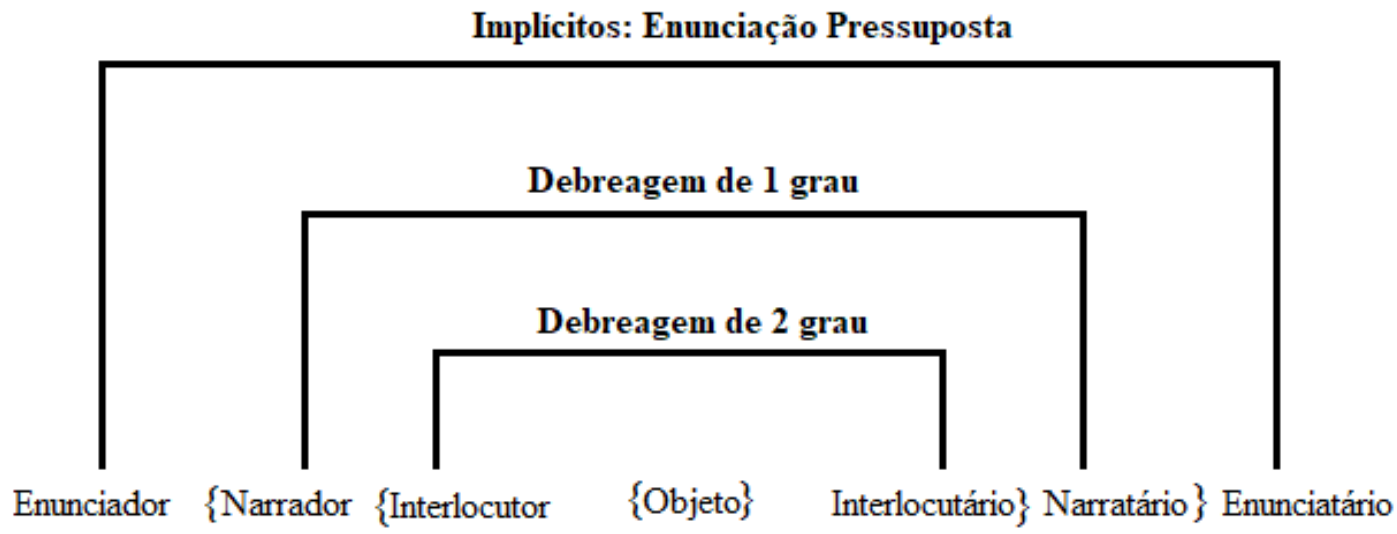

Fonte: Barros (2002, p.75).

O enunciador de Paranoid Park, a partir dos modos semióticos do acontecimento, do sobrevir e do foco / apreensão opera uma debreagem enunciativa e opta pelo uso de um narrador / ator que relata, em primeira pessoa e a partir do presente, suas experiências passadas, ainda recentes e tônicas na memória. Assim, instalam-se no enunciado do romance os actantes da enunciação ( $e u$ : Alex /tu: Macy, revelada apenas na última carta), o espaço da enunciação (aqui: casa do tio) e o tempo da enunciação (agora: mostrado pelas datas das cartas). Enquanto conta fatos e eventos pessoais que ocorreram em um tempo não-concomitante e anterior ao agora da enunciação, o narrador / ator Alex executa debreagens enunciativas relativas ao lá e ao então. Partindo desse tipo de debreagem, que instala os simulacros ego-hic-nunc enunciativos, o romance cria efeitos de subjetividade que serão ligados a figurações afetivas e perceptivas desse ator, ou seja, ao seu campo de presença.

Ao referir-se sobre si mesmo no passado, o narrador / ator realiza uma debreagem enunciativa interna, de modo que temos dois eu para designar a mesma pessoa, ser do mundo discursivo, que são, entretanto, duas instâncias enunciativas distintas. Dessa forma Alex é ao mesmo tempo narrador / ator e ator / interlocutor, que dialoga com outros atores no presente e no passado. Macy, ao ser o destinatário das cartas de Alex, torna-se um narratário / interlocutor ${ }^{73}$. Assim:

\footnotetext{
${ }^{73}$ Cf. FIORIN, 2002, p.74
} 
Figura 29 - Alex como dois tipos de sujeito da enunciação no romance

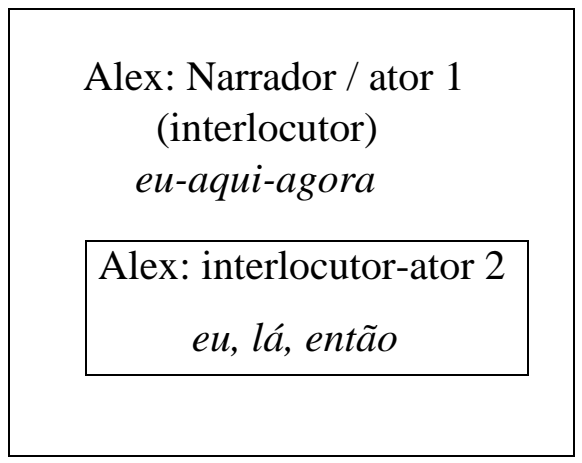

Fonte: elaboração do autor.

Além da debreagem em primeira pessoa, a instância da enunciação do romance também cria efeitos de intensidade do campo do narrador / ator, operando embreagens temporais e espaciais que resultam no retorno à enunciação, produzido pela neutralização das categorias de espaço e tempo, assim como pela denegação da instância do enunciado (FIORIN, 2011, p. 48). Assim, em muitas passagens da narrativa sobre o passado, ao invés do narrador utilizar o lá ou o então, ou equivalentes, o advérbio de tempo now (agora) é acionado no lugar de then (então), e o pronome demonstrativo this (isso ou isto) substitui that (aquele ou aquela) ${ }^{74}$. Tais embreagens, que projetam um sistema enunciativo dentro de um enuncivo (o do narrado), são importantes, pois criam tensões na narrativa que emergem da mescla de sistemas enunciativos e enuncivos, figurando uma mistura de tempos e espaços, e mostrando um passado intenso e tônico estreitamente ligado ao presente: as embreagens simbolizam os efeitos do acontecimento e do sobrevir no campo de presença do sujeito.

O narrador, em textos figurativos, é auxiliado por um observador que marca a transformação do sujeito narrativo em processo graças às categorias aspectuais (BARROS, 2002, p. 86; 87). Em PP, uma vez que o narrador, debreado em primeira pessoa, é também ator e conta fatos, sensações e percepções pessoais, existe um sincretismo entre narrador e observador / sujeito cognitivo, de maneira que tudo que é percebido pelos cinco sentidos do

\footnotetext{
${ }^{74}$ Uma pesquisa no Antconc revelou 50 ocorrências da palavra "agora" (now) relativas a embreagens. Alguns exemplos: It was totally dark now (Estava totalmente escuro agora [então]); But it was too late now (Era muito tarde agora [então]); I was running now (Eu estava correndo agora [então]). Da mesma forma, 87 ocorrências do pronome this referem-se a embreagens: I tried to ignore this and act natural and keep moving (Eu tentei ignorar isso [aquilo], agir naturalmente e continuar andando); I had to think about this. What if I got accused of something? (Eu tinha que pensar sobre isso [aquilo]. E se eu fosse acusado de alguma coisa?); Brady thought about this for a long time (Brad pensou sobre isso [aquilo] por um longo tempo). Esses exemplos foram retirados do narrador relatando o passado: dêiticos utilizados em diálogos no passado, mas em discurso direto, não foram computados, assim como os da narração no presente da enunciação, quando Alex explicita que está na casa do tio.
} 
jovem, e também aspectos temporais, espaciais e interações com outros personagens, que são muitas e geralmente em forma de discurso direto e diálogos, contribuem para a construção da profundidade de seu campo de presença inteligível e sensível. Auxiliado por um actante observador / informante (cognitivo e pragmático) o narrador, ao lembrar e escrever suas cartas, torna-se sujeito da percepção e objeto percebido, tanto em sua enunciação como no enunciado, em uma estratégia enunciativa que contribui para os modos semióticos do acontecimento utilizados no romance.

Relacionado ao fazer interpretativo de um mundo diegético, o observador possui forte participação na dimensão pragmática dos enunciados narrados, que corresponde às descrições, nas narrativas, “dos comportamentos somáticos significantes, organizados em programas e recebidos pelo enunciatário como acontecimentos, independentemente de sua eventual utilização no nível do saber (GREIMAS; COURTÉS, 2011 [1979], p. 379; verbete: pragmático). A partir da aproximação entre o actante observador e a figura do focalizador (termo usado pela narratologia), e consequentemente entre a observação e a focalização, podese sugerir que tanto aquela como esta, além de condicionar a quantidade de informação veiculada, tal como eventos, personagens e espaços, também cuida de sua qualidade, traduzindo certa posição afetiva, ideológica, moral e ética em relação a essa informação ${ }^{75}$.

É dessa forma que o narrador observador / informante ganha estabilidade como sujeito corporificado e pertencente a uma comunidade. A cena na qual Alex vê o corpo do vigia morto nos trilhos, por exemplo, possui forte caráter visual e olfativo: "Eu não podia acreditar no que estava vendo: um homem cortado ao meio [...]. E o fedor daquilo. Quando senti o cheiro de suas entranhas, engasguei”: assim, a enunciação da fratura estésica relaciona a significação a um dos cinco sentidos, estabelecendo a experiência estética na dimensão visual, mas estendendo-a a uma dimensão “odorante”. De maneira geral, apesar da menção ao odor do corpo mutilado, o sentido mais usado pelo narrador / observador cognitivo é a visão ${ }^{76}$. A partir da análise dos verbos do sentido watch e listen (assistir e escutar, verbos ativos), e see e hear

\footnotetext{
75 “Correspondendo à concretização, no plano do enunciado narrativo, de diversas possibilidades de ativação da perspectiva narrativa, a focalização pode ser definida como a representação da informação diegética que se encontra ao alcance de um determinado campo de consciência [...] de uma personagem da história [...]; consequentemente, além de condicionar a quantidade de informação veiculada (eventos, personagens, espaços etc.), ela atinge a sua qualidade por traduzir uma certa posição afetiva, ideológica, moral e ética em relação a essa informação" (REIS; LOPES, 1988, p.246-247).

${ }^{76}$ Em uma pesquisa dos verbos relacionados aos sentidos, realizada pelo Antconc, detectou-se o uso maior dos verbos see e watch (ver e assistir), seguidos dos verbos feel, hear, listen e touch (sentir, ouvir, escutar e tocar), de modo que obteve-se as seguintes quantidades: Para see, saw, seeing, seen (116 ocorrências); look, looked, looking (114 ocorrencias); fell, felt feeling (87 ocorrências); watch, watched, watching (61 ocorrencias) hear, heard, hearing (27 ocorrências); listen, listened, listening (12 ocorrências); smell, smelled, smelling (5 ocorrencias); touch, touched, touching (4 ocorrências); taste, tasted, tasting (1 ocorrência).
} 
(ver e ouvir, verbos passivos), percebe-se que os segundos são mais utilizados que os primeiros, de modo que o ator parece ser mais invadido por sons e imagens do que em controle dessas ações. A escolha desses verbos pelo enunciador conota um sujeito sensível mais passivo do que ativo, e realça a intensidade de um mundo natural expressivo difícil de ser controlado pelo sujeito. Assim, sons, imagens e odores, durante a parada da continuação do cotidiano causada pelo acontecimento e sua continuação como sobrevir tornam-se forças pouco controláveis, simbolizando atitudes involuntárias relacionadas à fragilidade de um ator passivo e invadido.

\subsubsection{A temporalização}

A temporalização, que produz o efeito de sentido da temporalidade e transforma uma organização narrativa em história, pode ser dividida em programação temporal, que converte o eixo das pressuposições (lógica dos encadeamentos dos programas narrativos) em eixo de consecuções (ordem temporal e pseudocasual dos acontecimentos), localização temporal e aspectualização. No entanto, não se deve confundir a programação temporal com a programação textual, pois o enunciador pode reorganizar a ordem temporal da narrativa. Em $P P$ pode-se estabelecer, de modo geral, e a título de exemplo, a seguinte programação temporal lógica dos programas narrativos de uso no romance: a ida à pista de skate $\rightarrow$ a morte do vigia e o sobrevir $\rightarrow$ o mergulho no "insuportável" do mundo epifânico angustiante $\rightarrow$ a sugestão da escrita das cartas $\rightarrow$ a escrita das cartas. A programação textual do romance, porém, inverte a ordem dos programas e o romance é iniciado com a escrita das cartas, que contam a ida à pista de skate $\rightarrow$ a morte do vigia e o sobrevir $\rightarrow$ o mergulho no "insuportável" do mundo epifânico angustiante $\rightarrow$ a sugestão da escrita das cartas. A partir dessa programação temporal, que inicia essa narrativa circular, que vai do presente ao passado e volta, o romance enfatiza a imagem da transformação, completude e da "recuperação afetiva", o final de um ciclo e a entrada em um novo. Como vimos, o discurso do narrador apresenta-se como uma resolução parcial do trauma.

A localização temporal, que se vale dos mesmos procedimentos de breagem, organiza a narrativa em relação ao narrador e ao ator. Enquanto o tempo do Alex que conta, como vimos, é o do presente, tempo em que ocorre a escrita das cartas, o tempo do Alex narrado se dá no passado, que é lembrado, de forma que a narração é relacionada à concomitância, à enunciação enunciativa do aqui e agora, e o narrado à não-concomitância e anterioridade relacionada ao lá e ao então, à enunciação enunciada. Nos dois casos a programação textual é igual à programação temporal, ou seja, cronológica e linear. Assim na concomitância da enunciação enunciada é possível estabelecer os dias do mês, da semana e horários precisos em que o 
narrador-protagonista lembra, e que se dão do dia 3 ao dia 8 de janeiro (de provavelmente 2007: de quarta a segunda-feira de acordo com o calendário daquele ano). Os respectivos períodos ou horas do dia de cada carta também são registrados, e o narrador-protagonista começa e termina de escrever à noite (carta 1 , à noite; carta 2 , de manhã; carta 3 , às 8:30 da manhã; carta 4, de manhã; carta 6, às 3:30 da tarde, carta 7, às 21:30; e carta 8, no mesmo dia, quase à meia-noite); na não-concomitância e anterioridade as lembranças do protagonista são também narradas em ordem cronológica: do começo de setembro ao final de novembro, sendo que o dia da morte do vigia ocorre no final de semana do mês de setembro, entre os dias 16 e 17 de supostamente 2006 (ano em que o livro foi escrito) ${ }^{77}$. Dessa forma, as cartas escritas em 2007 acompanham o calendário do enunciador.

A partir desses dois momentos temporais a aspectualização ${ }^{78}$, que transforma as funções narrativas de tipo lógico em processo, graças ao observador colocado no discurso enunciado, fornece um ponto de vista sobre a ação. $\mathrm{O}$ arranjo sintagmático dos semas aspectuais, capaz de explicar um processo, toma a forma de incoativo (pontual) $\rightarrow$ durativo (descontínuo ou contínuo) $\rightarrow$ terminativo (pontual). As categorias aspectuais, organizadas em sistemas, caracterizam os aspectos discursivos:

Figura 30 - As categorias aspectuais do discurso

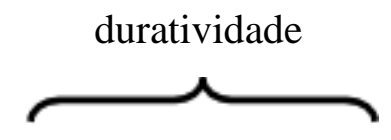

descontinuidade $v s$. continuidade (aspecto iterativo) (aspecto durativo)

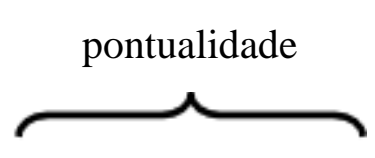

incoatividade $v s$. terminatividade (aspecto incoativo) (aspecto terminativo)

Fonte: Barros (2001, p. 91).

Em relação ao romance, a categoria aspectual utilizada pelo narrador é regida pela duratividade, pois Alex, ao lembrar, vai e volta ao presente da enunciação e, portanto, à casa do tio, na praia, de modo que sua participação na diegese oscila entre o aspecto iterativo e durativo. Ao final do romance, o aspecto durativo da enunciação é marcado por uma ação que ocorrerá no futuro, logo após a escrita da última carta: “agora, vou procurar fósforos” (NELSON, 2006,

\footnotetext{
${ }^{77}$ Uma pesquisa no calendário desse ano confirma que os dias se referem, respectivamente, a sábado e a domingo, seguindo a lógica cronológica da diegese.

${ }^{78}$ Barros (2002) explica que a aspectualização mantém relativa independência da enunciação, pois esta desembreia dois sujeitos: o sujeito do fazer, que $f a z$; e o sujeito cognitivo que observa, que $l \hat{e}$, no fazer do sujeito, os semas de duratividade, pontualidade e outros (p. 91).
} 
p. 180), sugerindo, através da intenção de um fazer futuro, a continuidade dentro desse momento de referência temporal.

Do ponto de vista do enunciado, do que é narrado, o aspecto é marcado pelo ponto de vista pontual, tendo começo e fim. O início da narrativa é marcado a partir da frase "Paranoid Park, foi lá que tudo começou”, e o fím é estabelecido na última carta, que encerra o relato, pois o narrador chega à conclusão de que tudo foi contado e explica: "Bom, acho que elas são isso: minhas cartas para você, Macy McLaughlin”. Ao mesmo tempo, vimos que a categoria aspectual de duratividade também é importante no enunciado, pois trechos de tempos e espaços considerados importantes para o sujeito da enunciação são "editados". De modo geral, propomos o seguinte quadro aspectual temporal para o romance:

Figura 31 - A temporalização em Paranoid Park

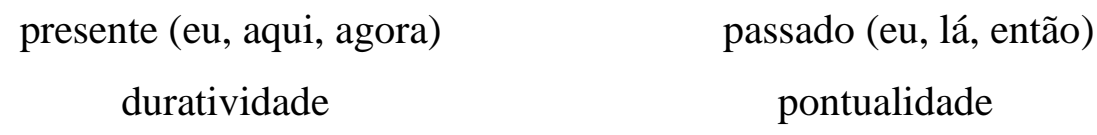

(o agora do narrar: o contínuo)

(o então do narrado: o descontínuo)

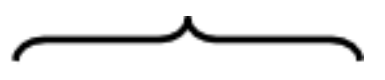

descontinuidade vs. continuidade

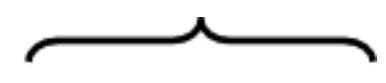

incoatividade vs. terminatividade

(aspecto iterativo) (aspecto durativo) (aspecto incoativo) (aspecto terminativo)

Fonte: autor.

Uma característica interessante do texto é que, por se tratar de uma lembrança, não podemos descartar o aspecto temporal relacionado à memória, de modo que a narrativa sobre $\mathrm{o}$ passado também assume o caráter frouxo de fluxo de consciência ${ }^{79}$, sendo que o tempo pode ser visto como a construção subjetiva do narrador-ator, oscilando de acordo com o seu espaço tensivo, que controla a existência dos elementos lembrados em seu campo de presença. Sem entrarmos em discussões psicológicas ou filosóficas sobre o caráter do tempo subjetivo, basta ressaltarmos que em relação à memória do passado há, também, continuidades e descontinuidades que revelam as triagens operadas pelo protagonista, marcadas por pausas e elipses, relacionadas à velocidade do texto. Assim:

\footnotetext{
${ }^{79}$ Não se trata, logicamente, de compará-lo ao caráter mais experimental de Virginia Wolf, por exemplo, pois não parece ser essa a intenção do autor. Basta dizer que o texto é possível graças a esse tipo de experimentalismo narrativo e possui esses traços.
} 
Figura 32 - A temporalização em Paranoid Park

$$
\text { passado (eu, lá, então) }
$$

duratividade (a memória em pedaços)

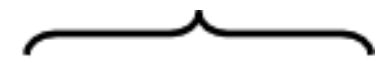

descontinuidade vs. continuidade

(aspecto iterativo) (aspecto durativo)

Fonte: autor.

A questão da descontinuidade da memória e da velocidade do discurso leva-nos ainda a um último comentário sobre a enunciação e o eixo da extensidade, que controla o tempo e o espaço, e o tempo da narração e do narrado. Escritas em apenas seis dias, as cartas de Alex condensam aproximadamente quatro meses de experiências disfóricas e modalizadas pelo sobrevir. Ao descrever o evento no qual se dá o acontecimento e seus efeitos imediatos, ou seja, o momento da morte do vigia, a fuga da cena do crime, a ida à casa do amigo e o resto da noite, o narrador alonga o breve, uma vez que o evento ocorre em poucas tempo (da noite de sábado à madrugada de domingo), em uma descrição que ocupa mais de uma carta. Assim, o enunciador retarda o andamento do discurso. Podemos, a partir daí, observar como a programação temporal textual do enunciador é tensiva, manipulando o elã da enunciação, relacionada à rapidez e ao impulso, mas tornando a parte do acontecimento mais extensa (e que possui as características de uma cena descrita minuciosamente) e desacelerada. Relatando com minúcias o evento traumático, Alex mostra não apenas a importância e a intensidade da fratura estésica em sua vida, mas a refaz pela primeira vez.

\subsubsection{A espacialização}

Segundo Greimas e Courtés (2011) a espacialização comporta os procedimentos de localização espacial, interpretáveis como operações de embreagem e debreagem efetuados pelo enunciador, e inclui os procedimentos de programação espacial graças aos quais se realiza uma disposição linear dos espaços parciais, conforme a programação temporal dos programas narrativos (verbete: espacialização; p. 176-177). Uma análise rápida dos primeiros três capítulos do romance revela os seguintes espaços e suas disposições lineares na narrativa: 


\begin{tabular}{|c|c|c|}
\hline DIA 3 & DIA 4 & DIA 5 \\
\hline 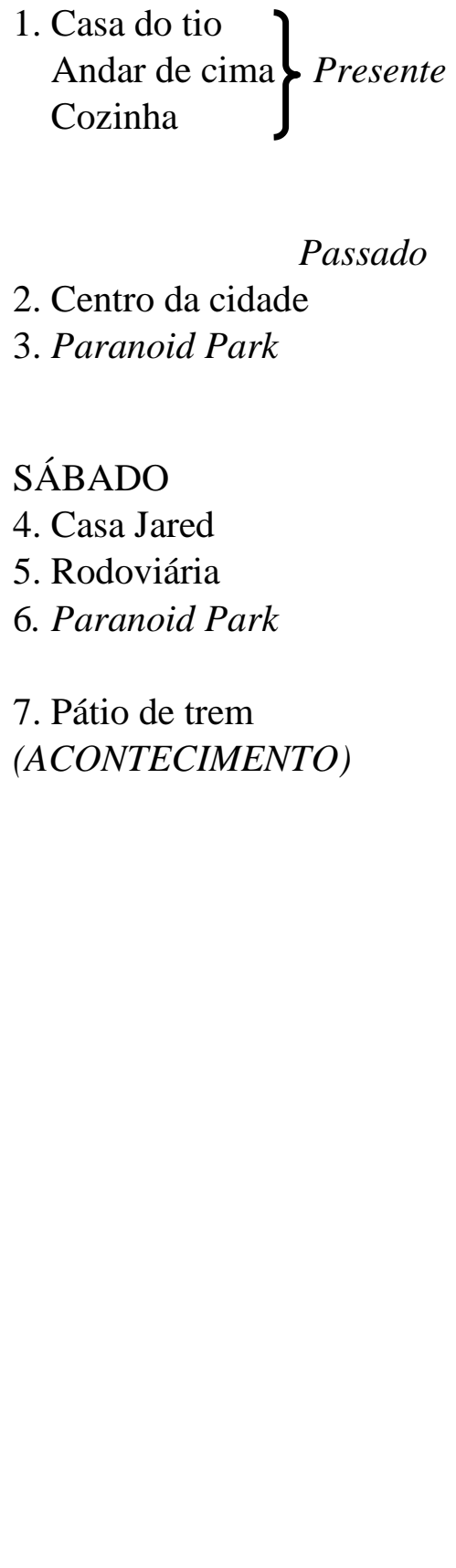 & 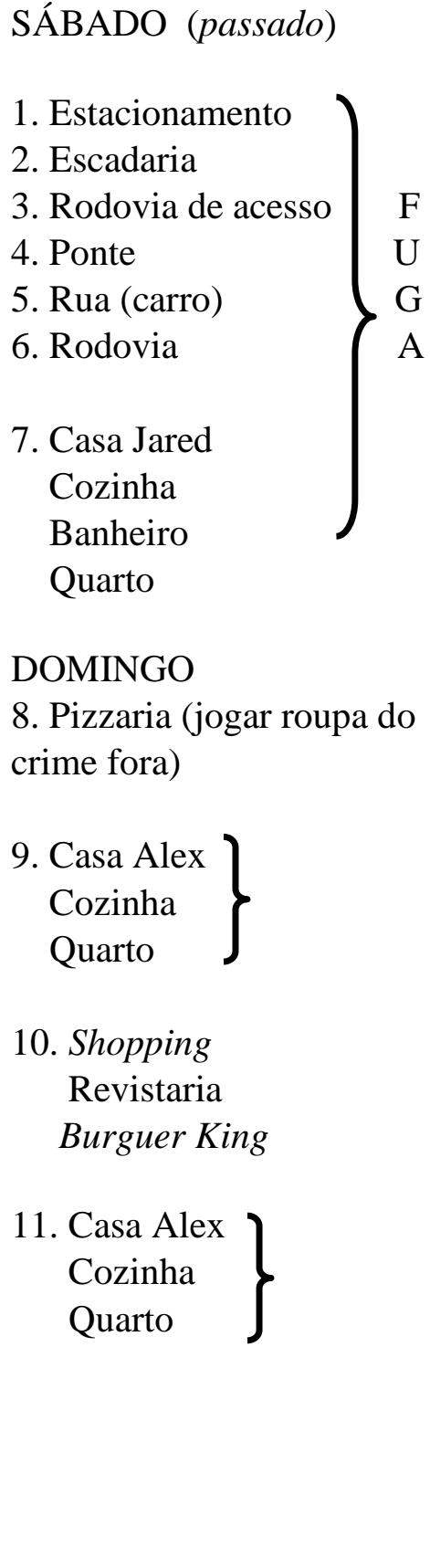 & $\left.\begin{array}{l}\text { SEGUNDA-FEIRA (passado) } \\
\left.\begin{array}{l}\text { 1. Escola } \\
\text { Lanchonete } \\
\text { Corredor } \\
\text { Estacionamento }\end{array}\right\} \\
\left.\begin{array}{l}\text { 2. Casa Jennifer } \\
\text { Quarto (sexo) }\end{array}\right\} \\
\text { 3. Casa Alex } \\
\text { Garagem (conversa com pai) } \\
\text { 4. Escola } \\
\text { Estacionamento }\end{array}\right\}$ \\
\hline
\end{tabular}

Fonte: autor.

A tabela acima indica os espaços onde a ação acontece e a ordem em que foram dispostos ao longo da narrativa, servindo também para figurar o cotidiano do narrador / ator assim como sua classe social. Podemos, por exemplo, observar uma visita a igreja, no tempo "passado" do dia 5, local frequentado apenas uma vez por Alex. De modo geral, pode-se depreender dos espaços do romance que, com exceção da igreja, da pista de skate e da casa do 
tio, o narrador-protagonista, um jovem estudante sob o cuidado dos pais, frequenta repetidamente os mesmos locais. Dessa forma, não parece haver grande interesse em tal mapeamento no momento, salvo o fato de que alguns desses locais serão retomados na adaptação do romance. Em nosso ver o ponto mais interessante da análise espacial do romance será a construção desse objeto do ponto de vista do sujeito cognitivo e seus estados patêmicos, pois a pista de skate, o pátio de trens e a casa do tio são ressaltados no romance, como locais onde as manipulações, aquisição de competências, performances e sanções ocorrem: a partir da casa na praia, que podemos descrever como espaço que oscila entre o familiar e o não-familiar, são lembrados os espaços familiares e estranhos ao protagonista. Como um jovem aprendiz do skate, Alex também é caracterizado como um ator que se movimenta no espaço de maneira particular.

Enquanto o presente da enunciação acontece na casa do tio, na praia, o passado do enunciado se dá sempre na cidade, em uma divisão que cria uma importante caracterização espacial, relacionada à localização do enunciador-ator que lembra: PRAIA- AQUI = espaço da narração-enunciação; CIDADE- LÁ = espaço do narrado-enunciado. Percebe-se, também, que esses locais possuem características bem particulares, relacionadas aos elementos natureza vs. cidade, e terra vs. água. Assim, de um lado, os espaços praia e cidade podem ser relacionados aos termos primitivos e universais natureza / cultura, articulados no nível semionarrativo do percurso pelo quadrado semiótico; de outro, os elementos terra / água, em nosso caso, apontam para a pertinência do uso simbólico dos quatro elementos naturais. Alex refere-se duas vezes ao elemento água em suas cartas: na primeira página da primeira carta e na última. Em ambas o mar é utilizado como predicador dos sentimentos do narrador/ ator: no início de suas cartas ele está agitado; no fim, calmo. Lembramos que em chave psicanalítica o mar serve como metáfora do inconsciente. Além disso tudo indica que, ao acabar de escrever as cartas, o elemento fogo vai selar esse período de vida traumático do jovem, o que pode indicar renascimento, mas tal ideia fica apenas potencializada no romance.

As dicotomias vida / morte e natureza / cultura, relacionadas à cidade e ao litoral indicam que a pista de skate e a casa do tio são os espaços mais importantes para o protagonista. A primeira é o local da marginalidade, da loucura, apelidado pela comunidade de Paranoid Park e, nas palavras do protagonista, um local com "uma vibe perigosa e imprecisa" (sketchy, adjetivo utilizado duas vezes na descrição do lugar), mas também da individualidade, pois seus usuários são diferentes uns dos outros. A pista é um espaço intenso por excelência, incerto e complexo, sendo o local para onde o jovem é atraído com promessas de irmandade e felicidade, portador de traços eufóricos, e a partir do qual ele sofre o acontecimento (podemos compará-lo 
ao seu oposto, à pista do shopping Skate City, um lugar atônico e evitado). A pista é descrita mitopoeticamente pelo jovem, que a considera o "centro do universo do skate" (NELSON, 2006, p. 5), lugar localizado nas profundezas, sem regras, gratuito, sem proprietário, antigo (“que sobreviveu a todos esses anos"), e frequentado por pessoas que vêm de todas as partes (p. 3). O caráter de profundidade, ou inferioridade, e centralidade, transforma a pista em um espaço englobado pela cidade e diferenciado, distante dos espaços suburbanos da classe média com quais o jovem está acostumado. Por outro lado, ao ser descrito como espaço "impreciso", sendo fisicamente conectado ao pátio de trens, onde se dá o acontecimento disfórico, torna-se um local igualmente surpreendente e ameaçador, podendo ser considerado um ator complexo na narrativa, parte destinador e parte antidestinador ${ }^{80}$, e para o qual ninguém está pronto. Do ponto de vista aspectual, a pista de skate e seus usuários são marcados pela incoatividade, pois o romance indica que é a primeira vez que o jovem a frequenta, retornando a ela apenas duas vezes.

Se a pista de skate é marcada pela complexidade, oscilando entre vida e morte, o espaço casa na praia, local próximo à água, sugere a reflexão, a purificação e a atividade de um actante destinador, transformando-se em espaço utópico. Enquanto em Paranoid Park dão-se fazeres de ordem pragmática, relacionados à natureza somática e gestual, na casa do tio dão-se fazeres de ordem cognitiva, relacionados à comunicação e à construção de objetos (GREIMAS; COURTÉS, 2011, p. 203). É nesse espaço que Alex não apenas controla o sobrevir e seu caráter disfórico de contraprograma e continuação da parada, mas também age e sanciona-se, de modo que esse espaço pode também ser identificado com o da prova decisiva, relacionada à performance, entendida como aquisição e/ou produção de valores, e a prova glorificante, na qual se dá o reconhecimento ${ }^{81}$. Em nosso caso, tal reconhecimento ocorre no âmbito individual, subjetivo e secreto, e não social.

Assim, se de um lado a pista de skate possui as características da intensidade, tonicidade e aceleração, o espaço casa na praia é o espaço da atonicidade, da extensão e da desaceleração. Como espaços de aquisição de competência (querer-fazer) e performance (decisões e

\footnotetext{
${ }^{80}$ Greimas e Courtés (2011 [1979]) comentam que a categoria destinador/destinatário, que somente é explorada para a determinação de um tipo de actante, poderia assim servir para designar os espaços e os tempos de origem e de destinação, sendo o fazer identificado, no nível figurativo, com o devir dos seres e das coisas. Ainda é apenas uma possibilidade de análise: raras são as pesquisas realizadas nessa perspectiva (p. 295).

81 "No sentido mais geral, o reconhecimento é uma operação cognitiva pela qual um sujeito estabelece uma relação de identidade entre dois elementos, dos quais um está presente e o outro ausente (alhures ou passado), operação que implica procedimentos de identificação capazes de permitir discernir as identidades e as alteridades. (É o que acontece, por exemplo, quando a identificação se efetua pela memória)" [...]. O pivô narrativo, de ordem cognitiva, chamado reconhecimento, não é a passagem da ignorância ao saber, mas de um certo saber (errôneo) a um outro saber (verdadeiro)" (GREIMAS; COURTÉS, 2011, p. 409).
} 
execuções) eles podem ser vistos como tópicos, aqueles em que as coisas importantes acontecem, os espaços das transformações narrativas. No interior do espaço tópico distinguemse os espaços paratópicos, entendidos como espaços de aquisição de competência e de sanção, do espaço utópico da performance principal do sujeito (BARROS, 2001, p. 92). No caso de Alex, que lembra e fala pela primeira vez sobre o acontecimento na casa da praia, os espaços paratópicos da memória e do enunciado mesclam-se ao espaço utópico onde ocorre a enunciação.

\subsubsection{A actorialização (destinadores, sujeitos e paixões)}

No nível discursivo, a actorialização corresponde ao estabelecimento dos atores no discurso, que são constituídos de pelo menos um papel actancial e um papel temático (em nosso caso: pai, mãe, amigo, namorada, vigia, detetive etc.) e dotados de um modus operandi e um modus essendi (um modo de fazer e um modo de ser). $\mathrm{O}$ ator, obtido pelo procedimento de embreagem e debreagem, que remete diretamente à instância de enunciação, possui um conteúdo semântico próprio que consiste na presença do sema de individualização que o faz parecer como uma figura autônoma do universo semiótico, podendo ser individual ou coletivo (GREIMAS; COURTÉS, 2011 [1979], p. 45; verbete: ator). Para os primeiros podemos citar Alex, Macy, Scratch; para os segundos, os usuários de Paranoid Park, por exemplo, ou a própria pista, como indicamos acima.

No romance o narrador / ator é cercado de outros atores, tanto no presente como no passado, com os quais tem uma relação afetiva, e que podem ser mais e menos temidos ou amados. Podemos definir a relação de Alex com os outros sujeitos como empática, antipática e neutra. Isso não significa que elas não se transformem (vimos que Alex se enfurece com Jared quando descobre que ele não irá à pista de skate na noite do acidente, mas parece perdoá-lo). De modo geral, os atores-sujeitos com quem Alex simpatiza, a partir de sua nova fase "longe de casa e aprender skate", na qual se dá a busca de novos valores, são Macy, Jared, Scratch e os usuários de Paranoid Park, e o detetive.

Macy, como vimos, é a pessoa que percebe o sofrimento do protagonista, fala com ele e o ajuda em seu momento de vida mais difícil, conquistando o seu amor. Ao longo do romance ela é tratada em terceira pessoa até a penúltima carta, quando finalmente é tratada por $t u$, ganhando mais corpo, espaço e tornando-se mais tônica no campo de presença do protagonista: no início da narrativa é apenas alguém presente perto do narrador; depois, alguém com quem ele fala, e finamente alguém que ele toca, no ônibus. Siderado e perdido por causa do sobrevir, 
e incapaz de diminuir o seu transtorno interno, é ela que manipula o jovem a escrever as cartas e lhe transmite a competência do querer. Como sujeito destinador, Macy sugere ao jovem aflito que ele escreva seus problemas e os envie a alguém, ou os queime; Jared, uma amizade recente "que gostava de ensinar e mostrar coisas" 82 , ajuda o protagonista a aprender skate e a relaxar dos problemas domésticos, leva-o a Paranoid Park e lhe fornece um "esconderijo" depois do incidente com o vigia. Alex desaponta-se com o amigo, mas tal sentimento não interfere na amizade dos dois; Scratch, um dos usuários de Paranoid Park, também manipula Alex, seduzindo-o e tratando-o como um "expert" no esporte (p. 14). Na noite do acidente, em Paranoid Park, o protagonista explica que pensa em ir embora, mas é excitante estar lá, conversando com aquele jovem de rua, que vê os adeptos do esporte como samurais. Ao aceitar o convite de Scratch para cruzar a cidade em cima de um trem, o jovem é ambíguo em relação às suas motivações, não sabendo explicar se foi convencido ou se desejou fazer aquilo, parecendo ser modalizado por um não querer não fazer: "Eles me convenceram a fazer isso, ou eu concordei. Eu não me lembro exatamente" ${ }^{83}$; o protagonista é também empático em relação aos usuários da pista de skate clandestina, sendo solidário e imaginando que eles também sofrem com problemas familiares. Ao mesmo tempo, enxerga aqueles jovens como sujeitos com identidade e portadores de valores individuais. Ao ir à pista pela primeira vez e observar um dos skatistas, Alex comenta em sua carta:

Na nossa frente vimos um cara mais velho e magricela na vala da pista. Ele usava calças marrons, cortadas na panturrilha, com meias esparradas pretas e Vans detonados. Tinha duas tatuagens enormes nos braços e uma grande cicatriz no estômago. Seu skate era uma coisa velha e esquisita, totalmente ferrado, mas ele arrasava. O cara era fera. Os outros eram iguais. Eles não só sabiam andar, mas tinham um 'jeito' próprio. Eu já tinha visto caras do skate da pesada aqui e ali no centro da cidade, mas nunca tinha visto todos eles num lugar só. Esse era o lugar deles, pensei ${ }^{84}$.

Entre os atores considerados oponentes do sujeito, estão Jennifer, a namorada recente, o vigia do pátio de trens, morto acidentalmente pelo protagonista, e o detetive Brady. A nova namorada do jovem, que o narrador / ator confessa não amar já no início de seu relato, não gosta de Paranoid Park, quer que ele compre um carro e comporte-se como adulto; o vigia do pátio

\footnotetext{
82 "He liked being a teacher and showing me stuff" (NELSON, 2006, p. 3).

83 “They talked me into it. Or I agreed. I don't remember exactly" (Ibid., p. 16).

84 "We watched a scrawny older guy in the bowl across from us nail a lip-grind. He wore brown slacks, cut off at the calf, with black socks and black ragged Vans. He head two huge tattoos on his arms and a big scar across his stomach. His deck was some weird old thing, totally beat to hell, but he killed. He was great. The other guys there were the same. Not only could everyone skate, they all had their "own" look. I had seen hard-core skater guys here and there downtown. But I had never seen them all in one place. This was their place, I realized. The center of the true skate universe. Or at least that's what it felt like to me" (Ibid., p. 5).
} 
de trens, morto acidentalmente e relacionado diretamente ao acontecimento, também é visto com ambiguidade pelo ator: de um lado ele sente a morte do homem, refletindo, em um de seus rápidos comentários, sobre seus amigos e família; de outro, porém, considera seu próprio futuro e família, sabendo que precisa crescer e continuar, seguir o seu percurso de vida. Mesmo durante o acontecimento, ao ver o homem ser morto pelo trem, Alex evita incriminar-se, alegando autodefesa ${ }^{85}$. Apesar de se mostrar pesaroso em relação à morte do segurança, o protagonista não se sente culpado e explica que meses depois do ocorrido, mais tranquilo e resignado, fala com Deus: "Deus, você me colocou nessa posição [...]. Você não pode me culpar por tentar sobreviver" 86 (itálicos no original). Finalmente, a relação que o jovem tem com o detetive é igualmente ambígua, mas resolvida enquanto percepção de alguém que deva ser evitado. De um lado, pode-se dizer que Brady, o policial, acaba exercendo, momentaneamente, o papel de pai, de alguém com o qual o jovem se identifica, admirando a força e a experiência (assim como Jared); de outro, perde a confiança do garoto. Enquanto Jennifer quer um namorado com valores "adultos", ambos o vigia e o detetive representam a lei, a punição e a falta de liberdade e individualidade, simbolizada pela pista de skate.

A partir da semiótica narrativa, podem-se depreender sujeitos auxiliares do poder fazer, que ajudam o protagonista a entrar em conjunção com objetos que considera eufóricos, tais como o esporte, a comunidade skatista "séria", a formação de uma identidade própria, um local de irmandade etc., e aqueles que o impedem de tal conjunção, os oponentes, que referem-se ao não poder fazer. Os primeiros seriam Jared, Scratch, Paranoid Park e sua comunidade, e Macy, que também podem ser descritos como destinatadores do destinátario Alex. Do outro lado do espectro, como sujeitos que impedem a conjunção do protagonista com os objetos-valor que busca, fazendo o papel de antissujeitos e controlados por um antidestinador, estão Jennifer, o vigia do pátio de trens, e o detetive.

A aspectualidade, que pode ser utilizada também para a inserção dos atores da narrativa, revela um fato interessante relacionado à ideia do novo e do atual: Paranoid Park, Scratch, o vigia e o detetive (e de certa maneira podemos incluir Jennifer e Jared, sujeitos que ele encontra naquele verão), são observados a partir de uma "primeira vez", ou próximos de uma primeira vez, e possuem aspecto incoativo. Em alguns casos, tal pontualidade é marcada como existência física dos atores na própria narrativa, tal como Scratch e o vigia, que Alex encontra apenas uma

\footnotetext{
85 "I stepped back from the car. I had to think about this. What if I got accused of something? It was an accident, but what if the cops didn't see it that way? Or what if it wasn't an accident. I did hit him with my skateboard. Was that against the law? Maybe it was self-defense. I didn't know. I had to think." (NELSON, 2006, p. 25).

86 “God, you put me in this place [...]. You can't blame me for trying to survive (Ibid., p. 173).
} 
vez, e que desaparecem do romance. Além disso, o jovem rompe com Jennifer, encontra o detetive em quatro ocasiões (supomos que o jovem não o verá mais), e visita a pista de skate apenas três vezes ao longo da narrativa, todas narradas pontualmente. $\mathrm{O}$ fato indica que muito do que é descrito pelo enunciador-ator corresponde a novidades relacionadas à busca de novos valores e à maioridade. De maneira geral, o acontecimento, a temporalidade, a espacialidade $\mathrm{e}$ a actorialização, tratados como objetos no campo de presença do sujeito Alex, que realiza a memória, revelam pontos de vistas $(\mathrm{PdV})$ relacionados à intensidade do próximo, do aqui e do agora. Assim:

Figura 34 - Presença dos objetos, tempos e espaços na memória do ator Alex

\begin{tabular}{|l|l|}
\hline EGO PdV do sujeito & Presença realizada \\
\multicolumn{1}{|c|}{ PdV da relação com o objeto } & espantado \\
\hline AQUI & novo \\
& próximo \\
AGORA & atual \\
\hline
\end{tabular}

Fonte: adaptação de Fontanille; Zilberberg (2001, p. 128).

Diferentemente dos atores citados acima, a família de Alex, em franca dissolução, não possui a força nem do actante destinador ou do antidestinador, não configurando sujeitos ou antissujeitos importantes no momento em que o jovem escreve: as mentiras contadas aos pais, os silêncios, a ausência de casa, e o quarto usado como esconderijo comprovam a atonicidade do núcleo familiar no campo de presença de Alex, e consequentemente na narrativa. No fim da carta, o protagonista é simpático em relação ao tio, achando-o "super legal" (super cool), mas sente que é visto pelo adulto como uma pessoa frágil e que inspira cuidado por causa do divórcio dos pais ${ }^{87}$. Isso não significa, porém, que a família não seja importante, tanto que ela é crucial na decisão do protagonista de continuar mentindo e esconder o segredo. No entanto, sua presença é fraca na vida do adolescente, e ela é colocada marginalmente no romance.

Alex é o personagem mais complexo da narrativa, pois além de ser o narrador-ator, como vimos, muitas vezes é sincretizado, no nível narrativo, ao sujeito do fazer, do estado, e ao destinatário manipulador e sancionador. Na primeira carta, notamos o fato de que o jovem

\footnotetext{
87 "He's been super cool, about everything. He's worried about me, I guess; he acts like I am this fragile person now, with the divorce on" (NELSON, 2006, p. 179).
} 
tenta se convencer a escrever, projetando-se como $t u$ em sua enunciação, e falando consigo mesmo: "vai com calma, vai devagar" (NELSON, 2006, p. 2): nesse sentido, pode-se perceber uma fratura entre os dois Alex, e como o jovem do passado, ainda amedrontado e vivendo dentro do mundo epifânico disfórico, influencia o jovem do presente, que procura voltar ao cotidiano e obter paz através da escrita. $\mathrm{O}$ adolescente também decide retornar à pista de skate sem o amigo Jared, protege Scratch do ataque do vigia, e guarda o segredo sobre a morte que causa. Nas cartas, Alex compila uma sanção cognitiva de si mesmo, na qual não há nenhum tipo de interferência exterior. Em suas cartas, o adolescente julga-se e se absolve, entendendo que os adultos são tão complicados quanto os jovens. Assim, se de um lado Alex se diz mais protegido e tranquilo, sabendo que existe alguém como Macy no mundo, que se importa com ele, de outro, ele sabe que continuará só, tornando-se "anormal", assumindo a personalidade de skatista solitário e sujeito de uma falta potencializada.

$\mathrm{O}$ ator, ao envolver-se no assassinato de um homem, além de sofrer uma fratura estésica e a intensidade do sobrevir, mergulhando em um mundo epifânico, adquire no romance uma existência modal e assume papéis patêmicos. Alex agride o homem por impulso e assim, como não sabe se quis ou foi convencido por Scratch a ir ao pátio de trens, fica confuso em relação à sua culpa no crime, julgando-se inocente: tal atitude demonstra um não querer não fazer e um não poder não fazer, acusando desejos ainda latentes nesse sujeito que se transforma. Pode-se dizer que entre o acontecimento e a escrita das cartas, Alex oscila basicamente entre a vontade passiva (não dever não fazer; não querer não fazer) e a abulia ativa (não dever não fazer; querer não fazer $)^{88}$.

Observamos como a utilização do conceito de paranóia é importante para a construção do romance, e como, a partir da morte do vigia, o protagonista não apenas passa a guardar um segredo terrível, que nunca comunica, como também preocupa-se com as consequências do que ele acredita ter sido um acidente. Vimos que o jovem fica confuso, pensando várias vezes em confessar o crime, chora, tem pesadelos, procura constantemente o evento nos jornais e na mídia, pensa em fugir de casa, assusta-se com a presença da polícia em sua escola e nas ruas, e mesmo sabendo que a investigação foi arquivada, tem medo de um dia ser descoberto. Ao fugir do local do crime, observamos como Alex preocupa-se com o futuro, imagina cartazes com o seu nome e fotografia, e diálogos com a polícia, temendo ser descoberto, preso, e pressentindo que sua vida será destruída. Assim além de sentir-se um “zumbi” e "catatônico" meses após o acontecimento, o protagonista sente medo, aflição e insegurança, que são importantes paixões

${ }^{88}$ Cf. Greimas, 2014, p. $97-98$. 
na construção do romance, relacionadas a estados passionais tensos-disfóricos, utilizados após a fratura estésica, que desencadeia a parada da continuação do cotidiano, e será aliviada a partir da escrita das cartas.

Segundo Barros (2002) o medo é uma paixão simples, ou paixão de objeto, resultante de um arranjo modal da relação sujeito-objeto, e relacionada ao não-querer-ser (p. 62). Segundo Rallo Ditche, Fontanille e Lombardo (2005), em termos de tempo e espaço, essa paixão adquire, como inquietude ou ansiedade, uma presença recursiva, uma permanência e insistência que oscila rapidamente em fases disfóricas e neutras e pulsa temporalmente de maneira mais ou menos desordenada: as oscilações e os ritmos do medo podem, portanto, ser entendidos como o vaivém entre a atenção (horizonte do avanço do $e u$ ) e a preocupação particular que apreende os objetos dessa atenção como portadores de uma possível morte, entendida como posição inabitável da existência (p. 220) ${ }^{89}$. Em $P P$ o medo de Alex não é recorrente, específico ou genérico, mas ocasional, provocado por um evento que o invade como o "odor" do corpo do vigia morto no pátio de trens. Não sendo forte o suficiente para paralisar o protagonista, que continua a viver um cotidiano paralelo e estranho, torna-se uma presença fraca e difusa que Fontanille define como aura e força centrípeta (p. 219-220). Como paixão fraca de não-quererser, o medo relaciona-se também à resolução da escrita das cartas e não impede o ator de buscar uma resolução para o seu martírio, o "peso nos ombros".

Da mesma forma pode-se dizer que mesmo aflito e inseguro Alex, ao pensar e aceitar a sugestão da amiga de escrever o que o incomoda, inicia outro percurso patêmico que vai da disjunção com os valores de vida, figurados pela existência epifânica e o medo, e desemboca em um sentimento de maior conjunção com esses valores, pois mostra-se mais relaxado e confessa a amiga que cada página que escreveu foi um peso tirado dos ombros ${ }^{90}$. Assim, se no início da escrita ele se mostra inseguro, não sabendo se poderá narrar o que lhe ocorreu, ao final de sua jornada cognitiva ele demonstra mais confiança e sente-se acolhido e menos só. De maneira geral, e de maneira esquemática, o percurso patêmico do romance, do momento da morte do segurança até o final da escrita das cartas, pode ser ilustrado da seguinte maneira: aflição e insegurança, esperança e segurança, e satisfação e confiança. De outro lado, como o jovem pensa em queimar as cartas que escreve, a sensação de satisfação e confiança é apenas parcial, mas não interrompe o seu querer-ser:

Figura 35 - O percurso passional do ator no romance

\footnotetext{
${ }^{89}$ RALLO DITCHE, E.; FONTANILLE, J.; LOMBARDO P. Dictionnaire des passionas littéraires. Paris: Belin, 2005

90 “Every page I've written has felt like a weight off my shoulders" (NELSON, 2006, p. 178).
} 


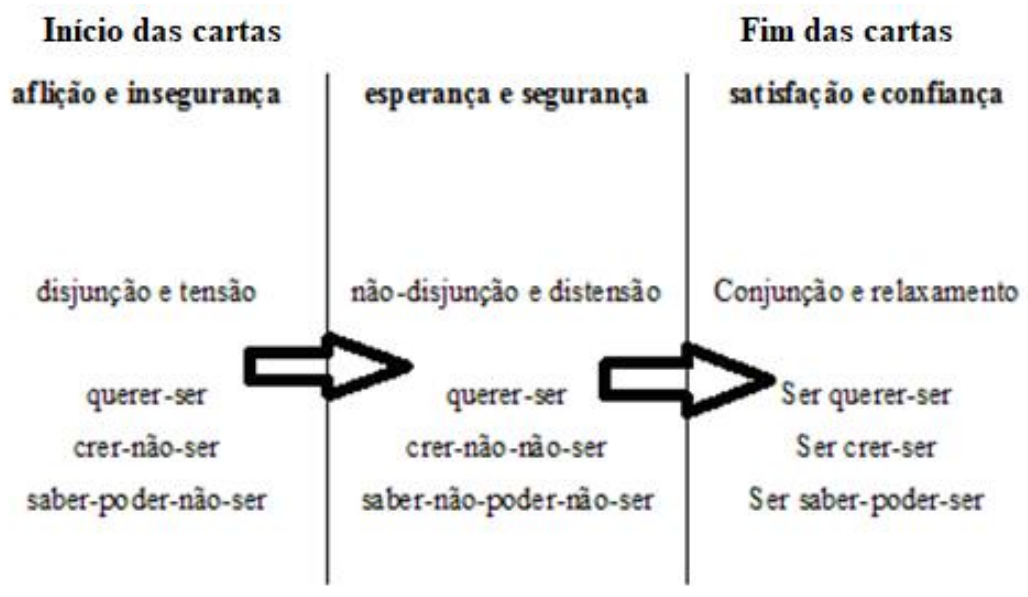

Fonte: adaptado de Barros (2002, p.64).

\subsubsection{Tematização, figurativização e manifestações do sensível}

Os valores de morte, relacionados ao medo e à angústia do sobrevir, as modalizações de não poder ser e fazer, e a disjunção do objeto-valor cotidiano causada pela parada da continuação do acontecimento apontam para temas importantes relacionados à vida adolescente "normal e esperada", à afetividade, às relações interpessoais, entre outros, e ligam-se também à ideia de paranóia e maioridade. Tais discursos temáticos, que realizam um ou mais percursos, classificam e organizam a realidade significante do jovem e, juntamente com a figurativização, que constitui um novo investimento semântico que instala figuras do conteúdo, tais como "adolescente de 16 anos", "zumbi”, "jovem afetivamente distante", "aluno distraído" ou "pessoa com catatonia", constroem a ideia do "mundo real vivido" proposto pela ficção. Assim, em relação à tematização e à figurativização, das quais já tratamos parcialmente ao falarmos da temporalização, espacialização e actorialização da narrativa, instauram-se efeitos de realidade que são mediados pela enunciação, ao operar no discurso uma relação intersemiótica entre mundo natural e língua natural.

Os valores assumidos por um sujeito existente, passional e competente disseminam-se sob a forma de temas, em percursos temáticos, e recebem investimento figurativo. $\mathrm{O}$ tratamento dos temas garante a manutenção semântica, na passagem do nível narrativo ao discursivo, cabendo à figurativização o acréscimo de sentido previsto na conversão de um nível ao outro. Enquanto a tematização é a formulação abstrata dos valores, na instância discursiva, e sua disseminação em percursos, a figurativização constitui um novo investimento semântico pela instalação de figuras do conteúdo que se acrescentam, recobrindo-o, ao nível abstrato dos temas. No discurso o enunciador utiliza as figuras para fazer-crer, manipulando o enunciatário para 
reconhecer imagens do mundo e, a partir daí, estabelecer um contrato veridictório. O enunciatário, por sua vez, crê-verdadeiro (ou falso, mentiroso ou secreto), graças ao reconhecimento do mundo natural (BARROS, 2002, p. 115-118).

Barros explica que a configuração discursiva é definida como uma espécie de "lexema do discurso", que subsume vários percursos figurativos e temáticos, além dos narrativos, e conta com algumas figuras invariantes. Assim, se PP é uma história sobre a maioridade, ela existe enquanto configuração que possuirá um núcleo figurativo com uma figura comum sobre o tema (no nosso caso o protagonista de 16 anos), mas variações figurativas, percursos temáticos e narrativos diferentes: observamos como o romance utiliza destinadores e antidestinadores, sujeitos e antisujeitos e objetos de valor próprios, ou seja, relativos a certo momento histórico, social e geográfico (Estados Unidos, século 21, capitalismo, democracia, sociedade permissiva em relação ao sexo entre adolescentes, divórcio etc), e que podem ser depreendidos no contexto do romance.

Em $P P$, como vimos ao falarmos sobre a figurativização no capítulo anterior, espaços, tempos e atores são tratados por cronônimos, topônimos e antropônimos. O enunciador do romance não apenas nomeia os atores do enunciado, criando antropônimos, mas também utiliza topônimos associados a lugares "reais", de modo que Paranoid Park é uma pista de skate que existe em Portland, cidade onde a ação se passa ${ }^{91}$, e Alex e os outros atores vivem e agem em uma cidade e um país nomeados como lugares geográficos conhecidos pelo homem, e dentro de uma macrossemiótica do mundo natural: assim, todos os espaços nomeados pelo narrador / ator podem ser encontrados e visitados; em termos de cronônimos já observamos, ao discutirmos a temporalização, que dias e meses citados no passado e no presente coincidem com o calendário do ano em que o romance foi escrito, e meses e estações do ano também são citados: o acontecimento acontece no fim do verão e o jovem escreve no inverno. O que nos interessa nesse tipo de construção é seu efeito de alta intensidade, manobra que permite que não apenas a história ganhe concretude e espessura física (os lugares onde a ação se passa podem ser observados em fotografias, por exemplo), mas que realce a existência dos atores, que adquirem maior densidade icônica.

Como os temas disseminam-se pelo texto em percursos e figuras os recobrem, a reiteração discursiva dos primeiros e a redundância das segundas, quando ocupam a dimensão total do discurso, denominam-se isotopias, que são recorrências e podem ser classificadas em

\footnotetext{
${ }^{91} \mathrm{O}$ local da filmagem, no entanto, foi outra locação na mesma cidade, uma pista de skate sob uma ponte.
} 
temáticas e figurativas e vistas tensivamente como mais ou menos graduais. A partir da entrevista do autor, citada no início do subcapítulo anterior, pode-se entender a ideia de maioridade em PP como uma isotopia temática abrangente e dominante relacionada ao querer, crer e poder ser e fazer, que rege outras isotopias temáticas e figurativas menores, encaixadas no tema principal. Assim, dentro de outras temáticas associadas ao tema central, podemos observar diversos subtemas e suas figuras, desenvolvidos a partir do tema principal: entre as isotopias temáticas, mas nem sempre figurativizadas no romance, destacamos as religiosas ou espirituais, familiares, interpessoais, psicológicas ou afetivas, sociais, e relacionadas aos meios de comunicação. Assim, o romance trata de:

a. Temas religiosos e espirituais: a reza no chuveiro; a visita à igreja; a idéia de confissão; as discussões sobre a existência de Deus.

b. Temas familiares: o divórcio dos pais; a preocupação com a saúde do irmão menor; a conversa com o pai na garagem; relações com outros familiares, como o tio.

c. Temas interpessoais: as relações com os amigos da escola e fora dela (festas, patinação no gelo); relações com outros adultos (detetive Brady); shopping; Paranoid Park.

d. Temas psicológicos e afetivos: o medo, a paranóia de ser descoberto e a angústia; algumas manifestações somáticas, tais como choro e hiperventilação; a impressão de "catatonia" e disforia (zumbi); a relação com o sexo oposto (sexo e Jennifer); a afeição a figuras paternas (detetive); os pesadelos.

e. Temas sociais: seu papel como estudante (mau aluno), cidadão (menção à guerra do Iraque, às crianças com fome na África, preocupação em entregar-se a polícia e em ser uma boa pessoa), e filho.

f. Temas dos meios de comunicação (que Alex sempre consulta durante o romance): jornais, telefones, sistema global de rede de computadores, televisão, além das cartas que escreve.

Vimos acima que Fiorin discrimina dois tipos básicos de discurso: os com função utilitária, que procuram informar, convencer, explicar, documentar etc., e os com função estética, relacionados a dinâmicas artísticas e criativas. Nos primeiros há uma aproximação do pólo da mímese e do plano do contéudo; nos segundos do pólo da poiése e do plano da expressão, a partir de uma consciência da relação arbitrária e deformante que o trabalho artístico estabelece com a realidade (FIORIN, 1998, p. 109). No texto com função utilitária, o plano da 
expressão é pouco relevante, pois vai-se direto ao seu conteúdo informativo ou comunicativo; no texto poético ocorre o contrário, e a expressão ganha relevância, pois o escritor procura não apenas dizer o mundo sensível, mas recriá-lo nas palavras, de tal sorte que o modo como se diz é tão importante quanto o que se diz" (FIORIN, 2008, p. 58). No entanto, como todos os textos são biplanares, possuindo conteúdo e expressão, e tanto um poema pode adquirir forte caráter informativo, como um texto jornalístico ou publicitário, poético, pode-se dizer que mímese e poiése são questões pertinentes a efeitos de sentido de um enunciador, existindo dentro de questões tensivas relacionadas a gradações semânticas e sintáticas, de modo que não devem ser vistas como descontinuidades, mas como pontos de chegada de um continuum. A partir daí, pode-se concluir que muitos textos literários ficcionais existem como construções artísticas que se aproximam mais do pólo mimético, como aqueles que se preocupam mais com a intriga e a ação (romances policiais, por exemplo, e muitos best-sellers e novelas cor-de-rosa, que sempre suscitam a discussão entre boa e má literatura).

Tais questões interessam à nossa discussão no que tange à manifestação do conteúdo temático e figurativo do romance em questão, pois enquanto $P P$ é um tex to literário e, portanto, apresenta-se como um produto artístico, poético e estético, ele é também figurado como um conjunto de cartas, ou seja, um conjunto de textos com forte apelo utilitário, e que procura comunicar um fato ocorrido. Tais cartas, no entanto, escritas como uma confissão e um desabafo de um jovem angustiado e tomado pelo sobrevir, revelam um texto complexo, informativo, intenso e particular, mimético e poético, alicerçado por operações figurativas que esbarram em questões discursivas relacionadas aos modos de eficiência apoiados no sobrevir, de existência, no foco, e de junção, no acontecimento, e suas sintaxes correspondentes da ascendência, triagem e concessão.

A figurativização em $P P$, ao construir a ilusão referencial do mundo, preocupa-se não apenas em constituir o "real", onde o protagonista habita, mas principalmente o seu mundo subjetivo e fraturado estésicamente. Assim, a partir de sua biplanaridade, o plano expressivo do romance é também acionado, e o enunciador tenta dar conta de um sensível relacionado não apenas ao agora da enunciação, mas ao então do enunciado, ou seja, da memória tomada pela intensidade do passado ainda presente no campo de presença do narrador / ator, balanceando, assim, operações miméticas e poéticas.

Se de um lado o texto informativo privilegia a informação, o texto poético, em sua relação biplanar mais intensa, aciona procedimentos discursivos e textuais que, segundo Barros (1998), geram uma ambivalência relacionada à continuidade e à fratura do cotidiano, em uma dinâmica que mostra a graduação entre mímese e poiésis, pois o texto estético também informa, 
mas a partir de relações "inesperadas" "92 . Barros entende que a ambivalência poética é acionada na sintaxe discursiva (jogos enunciativos de projeção de pessoa, de tempo e de espaço, que produzem o efeito de perspectivas múltiplas; debreagens e embreagens; e recursos diversos relacionados à dialogia, que produzem efeitos discursivos mono e polifônicos); na semântica discursiva (rupturas de isotopia e organização pluriisotópica, estabelecimento de relações entre isotopias, e figurativização da relação sensorial entre sujeitos e objetos); e na manifestação textual, na qual o sensorial faz sua grande aparição, uma vez que as figuras do discurso são figuras do conteúdo, resultantes da conversão de traços da forma da expressão do mundo natural em traços da forma do conteúdo das línguas naturais. No nível do texto, em que o plano da expressão e do conteúdo são articulados, o sensível é construído a partir da manipulação mais intensa do plano de expressão, uma vez que o poético pode ser caracterizado pela singularidade da relação que se estabelece entre esses dois planos (p. 126).

Barros elege cinco pontos que devem ser ressaltados na caracterização da estesia, ou do sensível, e que podem ser observados na composição figurativa poética de $P P$ : ruptura e mudança de isotopia, tanto semântica (passa-se do quotidiano ordinário ao extraordinário, da realidade à sobrerrealidade, do assematinzado, ou automatizado, ao semantizado e ressemantizado) quanto veridictória (passa-se do parecer ao ser, da aparência à essência, ou seja, à realidade escondida, com duração dominante e onipresente ${ }^{93}$ ); manifestação discursiva da fratura, principalmente espacial e temporal, aspectualizada pela descontinuidade; transformação de estado de disjunção em estado de conjunção, ou fusão total com o objeto (no nosso caso a junção tensa entre o protagonista e o acontecimento na memória); a manifestação passional da estesia; e a mudança de dimensão de análise (a imperfeição quotidiana é pragmática ou cognitiva, enquanto a perfeição é sensível, sensorial: “em outras palavras, a estesia é entendida como uma relação sensorial que se estabelece entre Sujeito e Objeto e que ocorre no nível discursivo como figura de conteúdo" (BARROS, 1998, p. 122). Em PP, por exemplo, vimos que o objeto estético "corpo cortado ao meio" é realizado como penetração visual e olfativa no corpo do sujeito Alex, assim como o acontecimento causa pânico, medo e catatonia, tomando a forma de cicatriz indelével. Assim, o objeto-valor estésico torna-se mais poderoso que o sujeito e manifesta-se como invasão e impregnação: tanto o objeto quanto aquilo que ele representa espoliam o protagonista, que se torna passivo e absorvido, e precisa diminuir,

\footnotetext{
92 BARROS, Diana Luz de. De la perfection: duas reflexões. 1998. p. 119-133.

${ }^{93} \mathrm{O}$ fato de que Alex jamais esquecerá a imagem do corpo do vigia cortado ao meio flexibiliza as funções ativa e passiva entre sujeito e objeto, regulando a passagem da realidade presente à realidade escondida, o que tem por corolário a supressão das demarcações aspectuais em favor de uma duração dominante e onipresente (TATIT, 1998, p. 202).
} 
a partir das cartas, os efeitos disfóricos do "estupor" e da fratura estésica presentes em seu campo de presença.

A partir dessas considerações do mimético, o poético e o estésico, cumpre tecer alguns comentários sobre os procedimentos discursivos de PP que, dentro do gênero infanto-juvenil, articula uma práxis enunciativa que mescla o gênero epistolar, o romance psicológico, o romance de suspense e um pouco do romance policial. Tal estratégia prática permite uma construção narrativa que enquanto simula a "intensidade subjetiva" e procura narrar de maneira "informativa", atoniza o "peso do literário" e abre caminho para a informalidade e a flexibilidade do uso da linguagem verbal e de outras linguagens, admitindo um texto sincrético. Ao mesmo tempo, unidades discursivas que compõe o discurso, tais como descrições, diálogos, resumos, digressões etc., além de estratégias retóricas e semissimbólicas de sentido, são utilizadas para figurar uma narrativa marcada pela intensidade não apenas afetiva e sensível, mas de andamento.

Chatman (1978) entende que nos romances epistolares o narrador em primeira pessoa relata de maneira diferente dos narradores clássicos, e que utilizam a terceira pessoa (a enunciação enunciada), pois escolhe temas e tópicos relacionados a si mesmo ou pertinentes ao seu núcleo social mais próximo, escreve sobre eventos importantes de seu ponto de vista, pressupõe um destinatário (ou narratário, que geralmente é explicitado) e desconhece totalmente o futuro, do qual pode apenas fazer previsões. Assim a "narrativa epistolar é uma encenação, um texto narrativo não-mediado, embora uma mediação secundária é sempre possível e geralmente ocorre" (CHATMAN, 1978, p. 171, tradução nossa) ${ }^{94}$. A partir desse teórico, argumenta-se que ao compor um texto que privilegia a narração como "encenação" de alguém que escreve cartas a partir de um aqui e um agora, o enunciador é capaz de imprimir no romance um tom subjetivo e ritmo acelerado: vimos que o narrador, não é apenas debreado em primeira pessoa, mas opera voltas ao presente da enunciação e embreagens constantes, de modo que a escrita das cartas adquire o valor de cenas com aspecto durativo ${ }^{95}$.

Ian Watt, ao discutir o nascimento do romance inglês, chama atenção para uma importante quebra na tradição literária, relacionada justamente ao que foi visto acima sobre alguns os elementos figurativos de Paranoid Park: o uso diferenciado de antropônimos, cronônimos e topônimos. Segundo Watt, alguns autores (que não coincidentemente foram os

\footnotetext{
94 "Thus, epistolary narrative is an enactment, an unmediated narrative text - although secondary mediation is always possible and indeed generally occurs".

${ }^{95}$ Segundo o Dicionário de Teoria da Narrativa, a cena pode ser compreendida no domínio da velocidade imprimida no relato, e constitui a tentativa mais aproximada de imitação, no discurso, da duração da história (LOPES; REIS, 1988, p. 233).
} 
primeiros “jornalistas") tentavam convencer os seus leitores de que suas históricas não eram fictícias, ocorrendo em espaços "reais", e tratando menos de personagens do que de pessoas de carne e osso. Tais narrativas buscavam ir além das práticas medievais de composição textual, construindo uma nova forma de "realismo", alicerçado na construção da biografia, ou seja, na composição da subjetividade e da identidade pessoal, que permanecia ou se transformava dentro do fluxo da experiência do cotidiano: o romance epistolar insere-se nesse novo paradigma de composição literária.

Com a privatização do espaço trazida pela modernidade, o gênero epistolar vai além de seu uso oficial e político e invade a vida privada, ganhando tons pessoais e particulares, construindo um espaço íntimo e sendo utilizado pelos indivíduos para falar de suas experiências pessoais e, consequentemente, configurar a subjetividade através de um discurso livre, quase direto. Samuel Richardson ${ }^{96}$ importa o gênero desses novos contextos e práticas e o adapta ao romance, sendo um dos primeiros autores da literatura inglesa que melhor articula essas novas tendências, pois

foi muito cuidadoso em localizar todos os eventos de sua narrativa em um esquema de tempo sem precedentes: o sobrescrito de cada carta nos dá o dia da semana, e muitas vezes a hora do dia; e isso, por sua vez, atua como estrutura objetiva para os detalhes temporais ainda maiores das cartas. O uso de Richardson da forma epistolar também induzia no leitor um senso contínuo de participação efetiva na ação, inigualável em sua completude e intensidade. Ele sabia [...] que eram as 'situações críticas, que podiam ser chamadas de descrições instantâneas e reflexões' que melhor envolviam a atenção; em muitas cenas, o ritmo da narrativa era retardado pela descrição minuciosa de algo muito próximo da experiência real. Nessas cenas Richardson conseguiu para o romance o que a técnica do "close-up", de D.W. Griffith fez para o filme: adicionou uma nova dimensão à representação da realidade ${ }^{97}$ (WATT, 2000 , p. 24, 25).

\footnotetext{
${ }^{96}$ Samuel Richardson (1689 - 1761) foi um escritor e editor inglês do século XVIII. É mais conhecido por seus três romances epistolares: Pamela: Or, Virtue Rewarded (Pamela: ou, a virtude recompensada - 1740), Clarissa: Or the History of a Young Lady (Clarissa: ou a história de uma jovem - 1748) e The History of Sir Charles Grandison (A História de Sir Charles Grandison - 1753). Em https://pt.wikipedia.org/wiki/Samuel_Richardson. Acesso em 10/06/2019.

97 "He was very careful to locate all his events of his narrative in an unprecedently detailed time scheme: the superscription of each letter gives us the day of the week, and often the time of the day; and this in turn acts as an objective framework for the even greater temporal detail of the letter themselves. Richard's use of the letter form also induced in the reader a continual sense of actual participation in the action which was until unparalleled in its completeness and intensity. He knew, as he wrote in the 'Preface' to Clarissa, that it was 'Critical situations...with what may be called instantaneous descriptions and reflections' that engaged the attention best; and in many scenes the pace of the narrative was slowed down by minute description to something very near that of actual experience. in these scenes Richardson achieved for the novel what D.W. Griffith's technique of the 'close-up' did for the film: added a new dimension to the representation of reality”. (Tradução nossa).
} 
O escritor de Pamela e Clarissa imaginava que a caneta lhe oferecia a possibilidade de satisfazer duas necessidades psicológicas profundas, que eram o abandono do convívio social e a descarga da tensão emocional, comparando a ferramenta da escrita, a pena, a um para-raio, e o local da escrita, o papel, a um ambiente de descarga emocional da eletricidade. Nesse processo, a relação com o objeto da escrita possibilitava ao escritor entrar em conjunção com todo o seu ser, enquanto surgia um novo tipo de relação social. A correspondência, segundo Richardson, era o selo e cimento da amizade, sendo mais pura e ardente, e mais fluida que a comunicação oral, uma vez que permitia a deliberação em suas fases de construção, da preparação do texto ao ato de escrevê-lo (WATT, 2000, p. 191-192) ${ }^{98}$.

Apesar da possibilidade de deliberação, ou por causa dele, o formato desse gênero, quando usado como expressão pessoal de sentimentos, encoraja a falta de critério para a seletividade das cenas por parte do autor, impelindo o leitor a ter um envolvimento mais participativo nos eventos e sentimentos descritos, pois este necessita registrar itens significativos de personalidade e comportamento em meio a uma riqueza de detalhes em conjunto (p. 193). Segundo Watt, o problema principal em retratar a vida íntima é da ordem da temporalidade, uma vez que "a experiência diária do indivíduo é composta de fluxos contínuos de pensamentos, sentimentos e sensações" (p. 191), detalhes de micro-acontecimentos dispostos no tempo, que existem em bem menor quantidade nos discursos biográficos e autobiográficos, em um tempo acionado menos pelo relógio, ou calendário, do que pela memória. Esses conteúdos temporais mnemônicos constituem a personalidade do indivíduo e ditam a sua relação com os outros: a carta privada é o mais fiel registro da consciência no dia a dia, do fazer da loquacidade que revela todo o ser, com descrições e reflexões instantâneas (p. 192). O discurso de Alex, alicerçado pela forma carta, pode deixar as coisas em condições de "estarem sendo feitas", tonificando o aspecto durativo do enunciado; tem coerência textual frouxa; narra eventos menos previsíveis; e estabelece uma relação de maior proximidade entre o enunciador e o enunciatário).

Se levarmos em conta que esse gênero opera pequenas narrativas de caráter mundano de maneira mais informal e pessoal, podemos compará-lo às primeiras crônicas jornalísticas: na verdade os dois meios de comunicação são parentes e opostos à grande história, que Zilberberg denomina cronografia. Assim como o jornal "registra dia-a-dia os fatos menores que a pequenez do intervalo adotado lhe proporciona", as cartas são textos nos quais eventos triviais e sem importância têm seu lugar. Por ser analítica “a 'historieta', própria ao jornal

\footnotetext{
${ }^{98}$ WATT, I. The Rise of the Novel. London: Pimlico, 2000.
} 
manifesta uma densidade elevada, resvalando por vezes na insignificância" (ZILBERBERG, 2011, p. 193): o mesmo pode ser dito das missivas de caráter pessoal e privado. Assim, ao utilizar a carta como um tipologema figurativo de suporte do romance, o sujeito da enunciação de Paranoid Park recupera o seu valor íntimo de uso, comentado acima. O narrador / ator Alex, que descreve suas lembranças para desacelerar o sobrevir pode, nas páginas que escreve, comunicar-se abertamente e construir-se como sujeito da lembrança e do sofrer, do presente e do passado, demonstrando suas emoções livremente, de maneira simples e informal, ao mesmo tempo em que se resguarda.

$P P$, além da escolha da forma epistolar, e por causa do modo acontecimento, também adota um estilo concessivo que "faz do discurso o vetor do inédito e da novidade" (ZILBERBERG, 2011, p. 216). Desde o início das cartas, vimos que o protagonista mostra-se pouco confiante na habilidade de relatar o evento traumático e suas consequências, de modo que a narrativa existe dentro de uma tensão concessiva que aumenta o seu grau de surpresa e instabilidade, revelada tanto no conteúdo como nas formas gráficas e tipológicas do texto literário: apesar de querer se divertir, o personagem mata um homem; apesar de seu skate ser encontrado perto da cena do crime, ele não é descoberto e nem preso; apesar de se sentir um “zumbi catatônico", ele continua a viver; apesar de querer confessar e fugir de casa, ele não o faz; apesar de o fato ter acontecido no passado, ele estará para sempre presente na memória daquele que o lembra etc. $\mathrm{O}$ discurso concessivo vem mesclado a uma série de tropos que organizam a narrativa e ajudam a construção do sobrevir: no nível enunciativo da sintaxe discursiva podemos destacar, além das frases curtas, orações coordenadas sem conectivos e frases nominais, o uso da hipotipose, da elipse, da metalepse, da hipérbole, da reticência e da interrogação com valor de surpresa e exclamação.

A hipotipose coloca-se ao serviço do realce das ideias (mise-en-valeur), é uma descrição que apresenta uma saliência perceptiva, tingida pela subjetividade, e procura a construção da mímese, descrevendo coisas passadas ou irreais feitas sempre no presente: presente do presente e presente do passado, acionado pelo pretérito imperfeito (FIORIN, 2016, p. 155). Como ferramenta descritiva da cena, de seus valores e de saliências perceptivas aspectuais, pode-se associá-la ao observador. No caso de $P P$, escrito na língua inglesa, algumas questões sobre a hipotipose devem ser discutidas: de maneira geral o romance, no nível enunciativo, correspondente ao nível do narrador que relata sobre o passado, e a maioria dos verbos é utilizada no pretério simples, fato que impediria os efeitos miméticos do agora no passado. No entanto, não apenas o tempo verbal past continuous, que dá o efeito de duratividade no passado (estava fazendo) é frequentemente utilizado no romance, assim como verbos que podem ser 
entendidos como palavras com valor aspectual durativo, ou pretérito imperfeito, e que na língua inglesa não são marcados por morfemas diferenciados, como no português, tais como: wore (vesti ou vestia: 7 vezes), wanted (quis ou queria: 50 vezes), looked, ou seemed seguidos de adjetivo (pareceu ou parecia alguma coisa: 8 vezes cada), needed (precisei ou precisava: 17 vezes), kept seguido de verbo no particípio presente (continuei ou continuava fazendo algo: 27 vezes).

Além disso, no nível enuncivo de segundo grau do discurso, ou seja, na narração sobre o passado, há o uso substancial do discurso direto entre aspas, introduzidos pelo verbo introdutório said (disse ou falou), de maneira que mesmo referindo-se ao passado, o romance é fartamente dialogado, criando uma série de cenas com aspectos durativos, e que criam a ideia de aceleração do discurso, por serem rápidas e estabelecerem o aqui e o agora do passado. Finalmente, não podemos esquecer que o narrador vai e volta ao presente e utiliza embreagens. Assim, parece-nos que o argumento da utilização da figura da hipotipose pelo enunciador do romance, procurando causar efeitos de intensidade, é justificado.

Além do uso dos tempos verbais pretéritos com valor durativo, e dos diálogos em discurso direto entre aspas, observa-se a utilização bem particular e diferenciada da elipse. Como figura de diminuição, ela é um processo de construção que "omite elementos linguísticos de qualquer dimensão: uma palavra, um sintagma, uma oração, uma ação narrativa, os acontecimentos de um período de tempo (FIORIN, 2016. p. 165). O Dicionário da Teoria Narrativa (DTS) compara essa figura à pausa, signo que possui um movimento anisocrônico, ou seja, relacionado à alteração da duração da história no plano discursivo (REIS; LEMOS, 1988, p. 233).

No romance, além das elipses mais comuns, as verbais, detectamos elipses plásticas, inúmeras interrupções de caráter visual que subdividem as páginas das cartas, de modo que cada capítulo é feito em "pedaços menores" que quebram o texto em partes menores a partir de um sinal gráfico que representa um pedaço de arame farpado: ( De um lado, esse tipo de elipse intensifica ainda mais o texto, acelerando-o, pois representa saltos na narrativa; de outro, conotam a dinâmica do pensamento do narrador / ator, suas triagens, relacionadas ao reconhecimento. Descontinuada, a narrativa esfacela-se em construções anafóricas e catafóricas imprevisíveis e dinâmicas. A manifestação visual do arame farpado também pode ser vista como uma metáfora, conotando separação e dor; e como metonímia, sendo extensiva ao espaço urbano onde os atores estão inseridos, e a pista de skate.

O discurso do romance também possui em sua sintaxe metaplasmos, que são variedades linguísticas que indicam identidades sociais, regionais ou temporais e igualmente intensificam 
o sentido, pois dá concretude aos atores (FIORIN, 2016, p. 188-189). Nas cartas de Alex, escritas de maneira informal, há uma série de gírias comuns aos adolescentes, tais como Streeter, Prep, kinda, bro, chrissakes, wow, psyched, dunno, rad etc, e também o uso de contrações entre palavras, indicando forte oralidade. Tais contrações podem ser tomadas como tipos de síncopes (a queda de um som no meio da palavra), haplologias (síncope de uma sílaba no meio da palavra) e apócopes (queda de um som no final da palavra), ou seja, figuras de redução ou encurtamento que igualmente aceleram e intensificam o discurso, emprestando-lhe o caráter real do ato da enunciação, sejam elas do nível enuciativo ou enuncivo.

Os metágrafos, que são "mudanças gráficas, pois muitas vezes são as letras e não os sons que significam" (p. 196), são amplamente utilizados na forma do tipo itálico, que vimos acima na primeira página da primeira carta, utilizado para dar conta do pensamento do jovem (o sujeito destinatário) antes de começar a escrever, e pertencendo tanto ao nível da enunciação ("Cara, relaxa e escreve alguma coisa"), como do enunciado, quando o protagonista quer confessar o crime ao pai, mas nada fala, apenas imagina o seu discurso: "Eu matei alguém, pai. Ele me atacou, mas eu fiquei frio e esperei a hora certa para matar ele. Você faria isso se tivesse que fazer, pai ? $^{99}$. Os itálicos também indicam paixões, como a raiva e a frustração, como no enunciado "Era tão injusto" $" 100$; fontes e qualidades sonoras, como o noticiário da TV: "Qualquer pessoa com informações sobre o incidente é instruída a ligar para a linha de polícia de Portland em 555-778-7778” 101; a fala de outros personagens (que não escapa ao narrador / ator); e o volume da voz: "Deus, me ajude, eu murmurei" ${ }^{102}$. Enquanto discurso que quer ser afetivo, o texto possui uma diagramação e uma paralinguagem visual que simboliza o ato cognitivo de lembrar e sofrer, e qualidades orais que sensibilizam a imagem acústica das palavras, buscando construir também um corpo enunciativo somático; ambas motivam dois tipos de manifestação que acentuam diferentes estratégias de produção de sentido.

Se entendermos os metágrafos como construções plásticas de sentido alicerçadas na escolha de tipos diferentes de fontes, e os relacionarmos aos espaços entre as cartas e às imagens de arame farpado, percebe-se um forte investimento visual no romance, que aumenta a intensidade do sentido da visão e a sinestesia entre o plástico, o afetivo e o sonoro: assim, podese dizer que o discurso de $P P$ é sincrético, uma vez que o texto apresenta manifestações de

\footnotetext{
99 "I killed someone, Dad. He attacked me, but I kept my head and waited for my moment and I took him out. Could you do that, Dad? If you had to?" (NELSON, 2006, p.69. Itálicos no original);

100 "It was so not fair" (Ibid., p. 38. Itálicos no original)

101 "Anyone with information regarding the incident are instructed to call the Portland's Police hotline at 555778-7778” (Ibid., p. 88. Itálicos no original).

102 "Oh God, please help me, I whispered" (Ibid., p. 42. Itálicos no original).
} 
caráter fortemente visual e relacionado a expressões de ordem tipográfica. Exemplos são o pôster que o jovem imagina depois que cometeu o crime e está fugindo do local, e o cartão que o inspetor de polícia lhe entrega após o interrogatório na escola. Ambos encontram-se isolados no meio da página do texto literário, e grafados com outro tipo de fonte:

Figura 36 - O pôster da polícia (imaginado pelo jovem); e o cartão do detetive entregue ao jovem

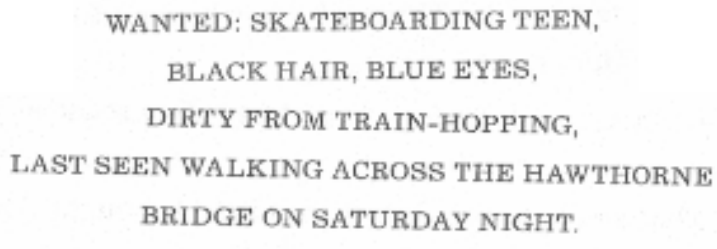

Fonte: Nelson (2006, p. 34).

\section{Detective Matthew Brady \\ Portland Police Departuent \\ HoMicide Division}

Fonte: Nelson (2006, p. 117).

Da mesma forma, dentro do projeto gráfico do livro, os tipos utilizados no título do romance, tanto em sua capa como em sua contracapa (letras góticas), revelam a preocupação com a construção do sentido em termos visuais. Na imagem da direita, percebe-se que os tipos, retos e não-serifados, são ainda marcados por efeitos de quebra, a borda das letras é irregular a a palavra PARK está fora do alinhamento horizontal:

Figura 37 - Tipos na capa e na contracapa do romance
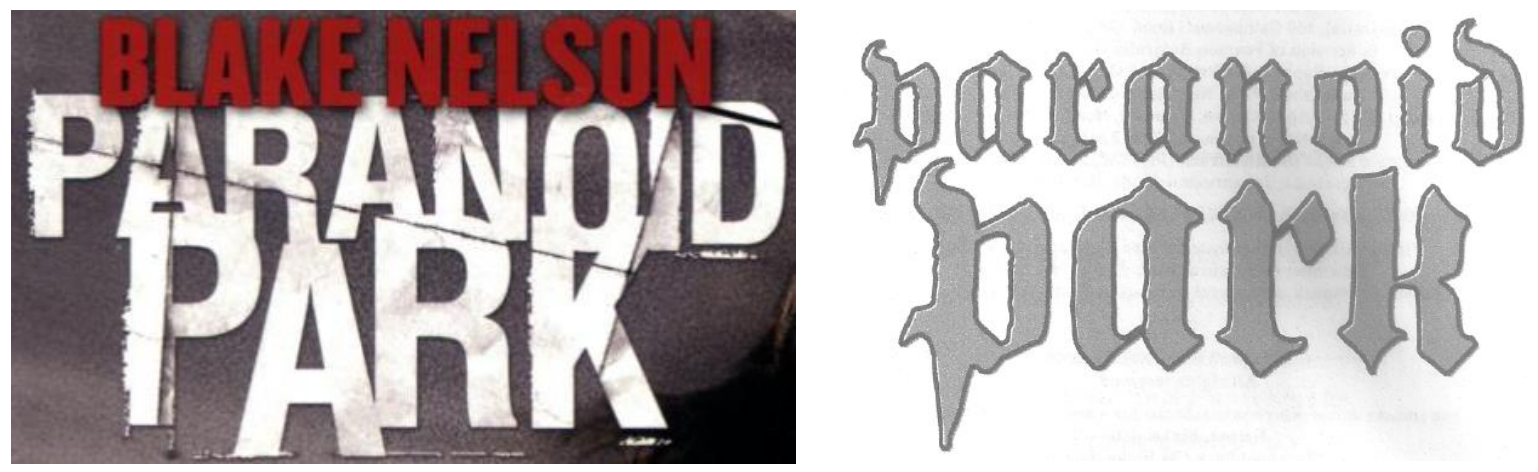

Fonte: Nelson (2006: capa e contracapa).

Outros procedimentos retóricos muito utilizados são relacionados à pontuação, principalmente à reticência e à interrogação ${ }^{103}$. A reticência aponta para a ação de guardar algo

\footnotetext{
${ }^{103}$ O estudo da disposição dos sinais de pontuação no discurso de Guimarães Rosa mostra que eles são capazes de recriar a oralidade. Além disso, Martins acredita que o sinal de pontuação não tem um valor fixo, representando bem mais do que somente pausas e entonações, pois além de delimitar sequências gráficas, oferecem ao escritor flexibilidade, sendo multifuncionais, podendo ser utilizado para indicar vários tipos de grandezas intensivas que entram no campo de presença do sujeito (MARTINS, 2006, 10).
} 
dentro de si, interromper-se ao falar, fazer silêncio, calar, e ocasiona uma diminuição da extensão do enunciado, com um consequente aumento de sua intensidade, sendo uma difusão semântica que transforma o espaço ocupado pelos três pontos em discurso interrompido ${ }^{104}$. A interrogação retórica é uma figura de troca com valor de afirmação, ou seja, é uma "troca pela afirmação" (FIORIN, 2016, p. 184), que não deve ser confundida com a interrogação processada na simples dinâmica dialógica. É principalmente na cena do acontecimento no pátio de trens, na qual não existe diálogo entre personagens e o ator fala consigo mesmo, que essa figura ganha destaque, revelando confusão e pânico. Assim, para revelar o medo e a desorientação no espaço e no tempo, causada pelo choque da morte do segurança, o narrador / ator faz várias perguntas, tais como "Onde eu estava? O que acabara de acontecer? Eu deveria gritar por socorro? E se Scratch me ouvisse? (NELSON, 2006, p. 24); E se eu fosse acusado de alguma coisa? Foi um acidente, mas e se os policiais não vissem assim? Ou se não foi um acidente? Isso era contra a lei? (p. 25). Enquanto volta para o estacionamento e vê pessoas na rua: E se eu fosse acusado, fosse para a prisão e nunca mais visse mulheres como aquelas? E se eu perdesse os meus vinte anos? E se eu fosse preso por dez anos? Ou vinte? Ou trinta?! (p. 30) etc. Do momento em que o ator vê o corpo do vigia até o momento em que ele volta para a casa dos pais, no dia seguinte (que correspondem a 21 páginas do romance), há 56 usos desse sinal gráfico. Tal investimento expressivo igualmente "acelera o andamento discursivo e intensifica o sentido" (FIORIN, 2016, p. 184).

A construção hiperbólica, ligada ao excesso da expressão e à intensidade, e podendo variar de uma locução ao texto inteiro, é utilizada tanto na linguagem verbal quanto na visual, possuindo dimensões variadas (p. 75-76) ocorrendo de várias maneiras ao longo do romance. Já demonstramos, por exemplo, sua utilização em adjetivos como "zumbi" e "catatônico". No início do romance, as ondas do mar são descritas como "bombas explodindo" (bombs going off: NELSON, 2006, p. 1); ao fugir da cena do crime, o protagonista comenta: "Se os policiais me

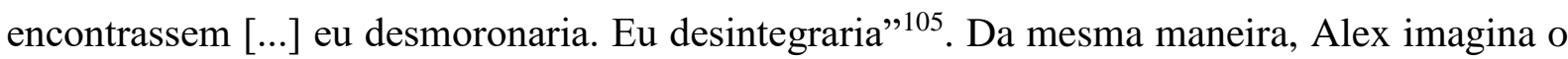
efeito da notícia de seu envolvimento na morte do vigia nos pais e em sua vida, "Isso os destruiria. Isso os separaria. Isso destruiria tudo" ${ }^{106}[\ldots]$. "Eu tinha estragado toda a minha vida [...]. Com um passo em falso, eu destruí toda a chance que eu tinha para uma existência

\footnotetext{
${ }^{104}$ Através do Antconc foram contabilizados 138 usos de reticência, sendo que 22 são utilizados na cena do acontecimento; e 66 usos do ponto de exclamação, sendo que 5 são utilizados na cena do acontecimento.

${ }^{105}$ If the cops found me [...] I would crumble. I would disintegrate (NELSON, 2006, p. 30)

${ }^{106}$ It would destroy them. It would separate them. It would destroy everything (Ibid., p.30).
} 
normal" "107. De um modo geral, podemos observar a hipérbole como o estilo expressivo do enunciador-ator Alex, que tomado pelo sobrevir, intensifica o sentido semântico das palavras para descrever o seu estado de alma. O mais interessante, porém, é que além de permear o texto, como enunciado, essa figura pode ser atribuída igualmente à enunciação: o uso dos espaços da página, itálicos, pontuação etc.

A metalepse é também importante figura utilizada pelo enunciador, pois cria dimensões espaciais e temporais diferentes no romance, relacionadas à narração e ao narrado, à enunciação e ao enunciado. Segundo Fiorin ela é "a mudança de um actante do nível enunciativo para outro, é uma permutação da instância narrativa para outra", passando a ser um tropo gramatical (FIORIN, 2016, p. 104). Do ponto de vista do enunciado, o narrador em primeira pessoa, ao se transportar para o mundo da lembrança, opera a metalepse, que "consiste precisamente em introduzir em uma situação, por meio do discurso, o conhecimento de outra situação" (p. 104). A estratégia também ocasiona uma difusão semântica e aceleração: "um valor semântico transfere-se de um elemento ao outro, numa dispersão sêmica, que cria uma intensidade no sentido, acelerando-o" (p. 103). Sendo um tipo de metonímia, a metalepse relaciona os dois sujeitos Alex, o que permite a caracterização de um Alex da focalização, do agir e do devir (o que lembra e tenta controlar o sobrevir) e de um Alex focalizado e do sofrer, controlado pelo sobrevir e o objeto estésico.

Além das figuras de retórica observadas no romance, todas relacionadas ao discurso do narrador / ator, destacamos também o uso de um paratexto em forma de epígrafe, que pode ser considerado um arranjo metonímico em relação ao texto base. O texto localizado fora da narrativa, um trecho retirado de Crime e Castigo, de Dostoievsky, além do título do livro, como vimos acima, procura dirigir o enunciatário para uma chave interpretativa de $P P$ por pressuposição interdiscursiva da narrativa, operando igualmente como marca de intensidade, pois cria suspense em relação ao que será lido, ou seja, uma espera intensa de confirmação de sentido:

\footnotetext{
${ }^{107}$ I had blown my whole life. With one wrong move, I had destroyed any chance I had for a normal existence (NELSON, 2006, p. 31).
} 
Figura 38 - Epígrafe do romance ${ }^{108}$

\section{"Young man," he went on, raising his \\ head again, "in your face I seem to \\ read some trouble of mind." \\ -Crime and Punishment, \\ Fyodor Dostoevsky}

Fonte: NELSON, 2006.

Finalmente, ressaltamos também, no plano da sintaxe discursiva do romance, o uso de unidades discursivas tais como o diálogo (que na verdade compõem cenas), a digressão (ou comentário, segundo o DTN), a descrição e o resumo, que juntos imprimem diferentes efeitos de velocidade e ritmo à narrativa, causando o efeito de transformação e ação de sujeitos dentro do espaço e do tempo. Segundo Greimas e Courtés as unidades discursivas, cujos limites no plano da manifestação, corresponderão ou não aos planos das sequências temáticas (passeio, dança, sonho, etc.) são estabelecidas pela discursivização das estruturas semióticas de caráter narrativo, reconhecíveis e definíveis por modos particulares da enunciação narrativa. Tais unidades, possibilitadas pelos procedimentos de debreagem e embreagem, podem incidir sobre a dimensão pragmática ou cognitiva do discurso, seja sobre o discurso persuasivo ou interpretativo, seja sobre o discurso figurativo (GREIMAS; COURTÉS, 2011 [1979], p. 518519; verbete: unidade).

O diálogo está ligado ao esquema narrativo, tendo como actantes o destinador e o destinatário sincretizados com interlocutores, e designa a unidade discursiva de caráter enunciativo obtida pela projeção, no discurso-enunciado, da estrutura de comunicação. $\mathrm{O}$ diálogo relatado comporta muitas vezes um enquadramento. O elemento enquadrante, cuja função principal é assinalar o ato de falar enquanto ato somático (disse, insistiu, falou, respondeu etc), contém informações relativas ao tópico do diálogo (com voz comovida, com nervosismo etc) (p. 138; verbete: diálogo ). Como já observamos, o romance que analisamos é narrado em primeira pessoa por um narrador / ator que estabelece um ato comunicativo com outro. Apesar de essa comunicação não estabelecer um diálogo propriamente dito, o gênero romance-epistolar apresenta uma situação dialógica virtualizada (podemos imaginar o

\footnotetext{
108 "Jovem", ele continuou, erguendo novamente a cabeça, "em seu semblante, parece que leio preocupação" (NELSON, 2006, epígrafe). Tradução nossa.
} 
destinatário respondendo ao remetente), estabelecendo certos tópicos do diálogo (o interlocutor Alex, por exemplo, no início da narrativa, aparenta certo nervosismo ao começar a escrever). Além disso, o romance é repleto de situações dialogadas compostas em discurso direto, o que o afasta do gênero epistolar propriamente dito, delimitando cenas, que são momentos "de dramatização da narrativa que constitui a tentativa mais aproximada de imitação, no plano do discurso, da duração dos eventos diegéticos". Tais cenas dialogadas estabelecem uma forma mimética de representação e contêm indícios socioletais e idioletais (REIS; LEMOS, 1988, p. 236). Em Paranoid Park, há muitas cenas do protagonista conversando com o pai, a mãe, os amigos, a polícia etc, e que serão recriadas no texto fílmico.

O comentário, que é uma unidade discursiva de caráter interpretativo e temático obtida por meio de debreagem enunciva ou enunciativa (GREIMAS; COURTÉS, 2011 [1979], p. 70; verbete: comentário), é também essencial na construção do romance. Reis e Lemos (1988) o comparam à digressão, que interrompe a dinâmica da narrativa para que o narrador formule asserções ou reflexões que são normalmente de teor genérico e transcendem o concreto dos eventos relatados, de modo que ela corresponde à suspensão momentânea da velocidade narrativa adotada. Por outro lado, a digressão revela algumas afinidades com o discurso abstrato traduzindo afirmações de caráter ideológico: vimos que Alex, ao lembrar e repensar a sua vida a partir do acontecimento, não apenas relata elementos relacionados à morte do segurança e seus medos e inseguranças sobre o futuro, mas faz comentários breves sobre religião, guerra, literatura, amor, e a personalidade de outros atores, como o irmão menor, a namorada etc., desviando-se da narrativa principal que se propõe a escrever. Tais comentários podem ser relacionados às várias isotopias temáticas que destacamos acima.

Segundo Greimas e Courtés a descrição é ainda um objeto a ser definido (p. 129; verbete: descrição), o que revela, pelo menos do ponto de vista da semiótica discursiva, certa cautela em relação ao termo. No DTN tal percepção é confirmada devido à extensão do verbete, que indica seu caráter ambíguo, pois a descrição parece ser o todo narrado, a própria discursivização, que reúne atores, tempos e espaços. Para não nos estendermos, vamos seguir o ponto de vista de que ela representa um fragmento discursivo que porta informações que configuram um cenário e são "facilmente destacáveis do conjunto textual, sendo tendencialmente estáticas e proporcionando momentos de suspensão temporal e pausas na progressão linear dos eventos diegéticos" (REIS; LOPES, 1988, p.23).

A partir daí, podemos dizer que a utilização dessa unidade discursiva pode ser detectada mais fortemente em relação à pista de skate e seus usuários, um local que denominamos eufórico para o protagonista, e principalmente no momento mais importante do romance, a 
morte do vigia e a fuga do local do crime, que observamos ser um longo trecho em relação ao resto da narrativa, sendo descrito detalhadamente, e causando o efeito de congelamento temporário do avanço da história, uma suspensão determinada pela fratura estésica e pelo sobrevir, que precisa ser desacelerado para ser compreendido.

Reis e Lopes (1988) explicam que o resumo é proveniente da crítica e teoria literária anglo-americana, designando toda a forma de resumo da história, de tal modo que o tempo aparece reduzido a um lapso durativo sensivelmente menor do que aquele que a sua ocorrência exigiria. Novamente, trata-se aqui de uma unidade que controla a velocidade narrativa, relacionada com outras modalidades de representação anasocrônica, como a elipse e a pausa, que é oposta à velocidade isocrônica da cena. Se a cena corresponde a uma representação dramatizada, o resumo implica da parte do narrador um comportamento completamente distinto, que acentua a sua distância em relação aos eventos, e opta por uma atitude redutora relacionada à onisciência, que pode abreviar fatos (p. 293). Seria trabalhoso e inútil pontuar e especificar todos os momentos em que o narrador resume partes de vida cotidiana e aspectos de seu passado. Basta dizer, no entanto, que como as cartas de Alex narram um período de quase cinco meses, resumidos em seis dias, Paranoid Park existe como um romance epistolar construído a partir da ideia de resumo, que tensivamente implica a sintaxe da triagem. A partir do gênero romance-epistolar, das unidades discursivas diálogo, comentário, descrição e resumo, dos procedimentos retóricos, e da linguagem sincrética que mescla verbo e imagem gráfica, pode-se observar como os modos semióticos e sintaxes tensivas são construídas.

Finalmente, do ponto de vista semissimbólico, que une categorias do nível da expressão com categorias do nível do conteúdo, e a partir do sincretismo do texto literário, que utiliza semióticas verbais e plásticas, percebe-se que o romance utiliza uma série de recursos verbais e gráfico-tipológicos para tematizar e figurar um texto intenso e estésico que mimetiza a escrita de um jovem invadido pelo sobrevir e tomado pela intensidade do acontecimento. Entre eles, destacamos os itálicos, para paixões ou qualidades sensíveis, e as fontes góticas, como tematização do disfórico. De maneira geral, categorias cromáticas e eidéticas tipográficas são utilizadas para simbolizar categorias discursivas. Os espaços em branco das páginas ou o aproveitamento de seu espaço planar, que são categorias topológicas, funcionam como a representação das triagens da memória e da ansiedade do sujeito, que muitas vezes escreve em "pedaços", ou de objetos visuais planares: cartões, cartazes e bilhetes escritos. Do ponto de vista sincrético, há também a imagem icônica de arame farpado. Todas as estratégias sincréticas e semissimbólicas estarão a serviço da figuração dos estados de alma do sujeito "siderado", mas também do tempo e do espaço da narrativa. 


\subsubsection{O nível fundamental do sentido}

A partir dessas considerações, podemos vislumbrar elementos semânticos básicos para a construção do discurso do romance, relacionados à foria, à tensão e a termos hipotéticouniversais do universo semântico individual: o eixo semântico vida / morte, cuja categoria semântica pode ser denominada "existência", e é relacionado também à agua, ao fogo, e à terra, é considerado uma estrutura elementar temática e uma categoria suscetível de ser homologada a categorias tímicas e fóricas. Assim, em relação ao romance, temos:

Figura 39 - Nível fundamental do romance

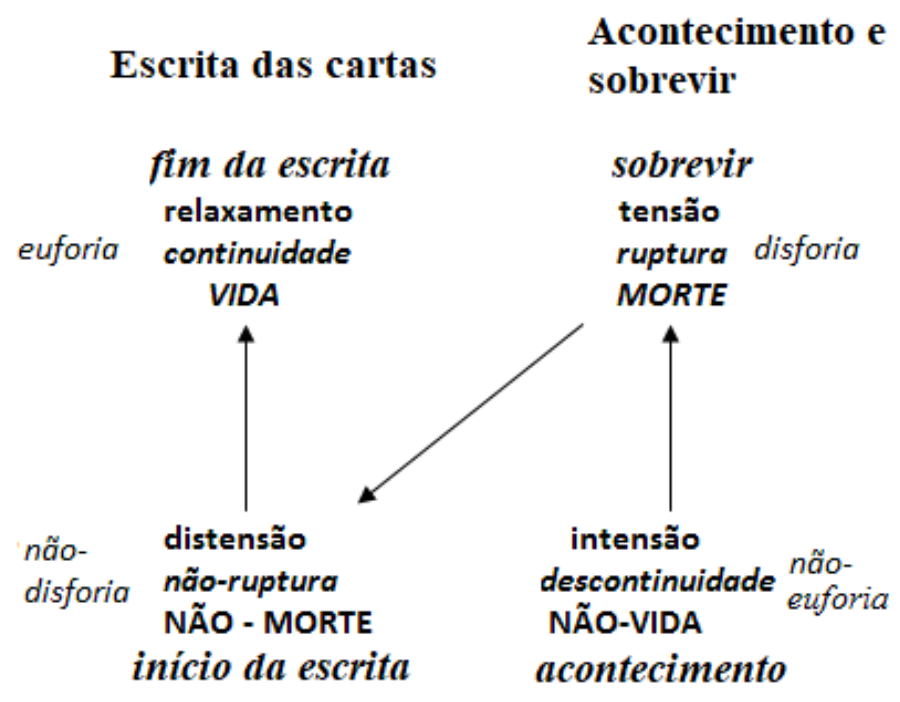

Fonte: autor.

A ruptura, provocada pelo acontecimento em Paranoid Park, será o ponto onde tudo recomeça para o protagonista, a partir de uma experiência disfórica relacionada aos valores de morte: justamente por isso haverá renascimento e transformação dentro de uma continuidade, agora marcada pela diferença: "a cicatriz na alma”. Alex, transformado, continuará em direção à vida adulta e voltará ao percurso relacionado ao mundo cotidiano, iniciando uma nova trajetória que fica apenas sugerida e potencializada no romance. Os elementos semânticos que vimos acima podem ser homologados ao nível tensivo do plano do conteúdo do romance. Assim, temos o ritmo aspectual que faz da vida do protagonista um continuum portador de limites e durações, de paradas e retomadas: o que dura (continuação da continuação) tende a parar (parada da continuação) e o que continua parado (continuação da parada) tende a recobrar o fluxo (parada da parada). A partir daí, de um lado temos o relaxamento, relacionado a um percurso narrativo do cotidiano, e de outro, a retenção, ligada ao percurso narrativo epifânico. 
De certa forma, podemos dizer que o romance, adotando dois locutores, o Alex da memória e do enunciado (no passado), e o Alex da memorização e da enunciação (no presente), emerge semanticamente da seguinte forma:

Figura 40 - Análise do continuum tensivo do romance

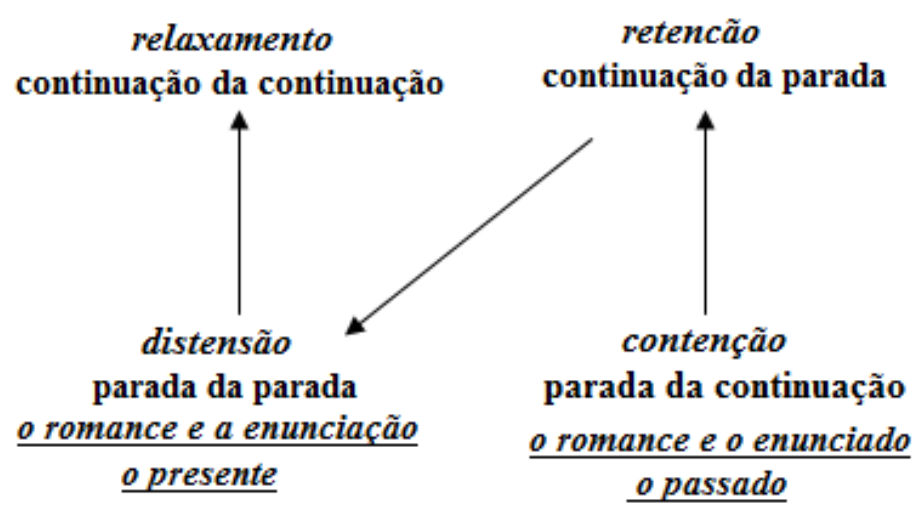

Fonte: gráfico invertido de Tatit (2001, p. 190).

Como o Paranoid Park aborda a maioridade, que identificamos como rito de passagem, o que não significa que o protagonista transforme-se em adulto, mas que consiga voltar ao cotidiano e à comunidade, mais experiente e transformado, há também um forte investimento nos semas fundamentais identidade vs. alteridade, que inicia-se com a decisão de "ficar mais fora de casa", abandonar a pista de skate convencional do shopping, conhecer e admirar jovens de outra classe social e de outro espaço urbano, ir só a um lugar proibido etc. Assim:

Figura 41 - A transformação do protagonista

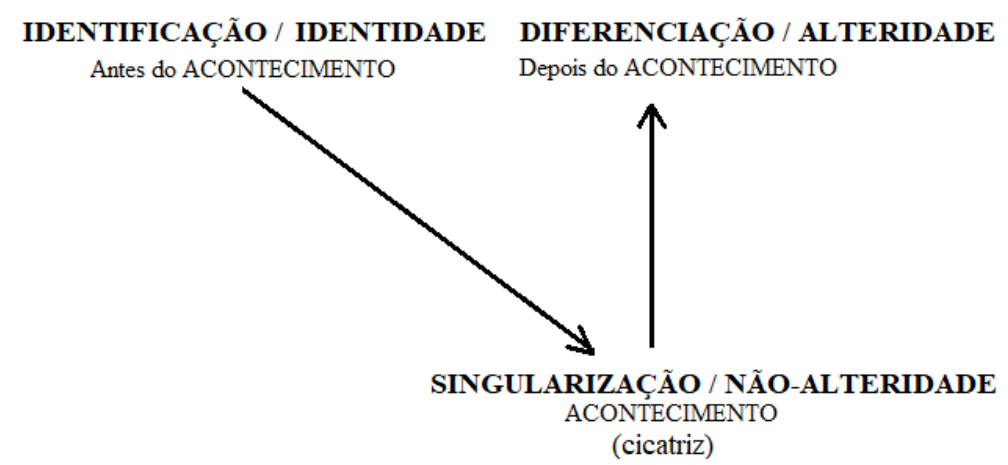

Fonte: autor (adaptado de Pietroforte, 2008 p. 86).

\subsection{Resumo das estratégias de produção do sentido do romance}


Como já comentamos, acreditamos que a adaptação do texto literário pelo cinema, assim como de qualquer outra adaptação textual, pode ser balizada através do percurso gerativo de sentido, que através de suas categorias fornece um simulacro da produção do sentido capaz de oferecer um conjunto coeso de operações mais concretas e superficiais, e mais profundas e abstratas, presentes em todos os conjuntos significantes, sejam eles verbais ou não verbais. $\mathrm{O}$ percurso deve ser considerado como a forma semanticamente mais concreta e sintaticamente mais fina das articulações da significação, que se inscreve como sentido articulado na dicotomia sentido / significação, e é apreensível apenas no momento de sua manipulação, no momento em que o enunciador é levado a operar transposições, traduções de um texto para outro texto, de um nível de linguagem para outro ou de uma linguagem para outra, em um fazer parafrásico, que pode ser considerado como representação da significação enquanto ato produtor que reúne numa única instância o enunciatário intérprete e o enunciador-produtor. A partir da semiótica discursivo narrativa e tensiva foi possível averiguar os modos e sintaxes tensivas, e a figurativização acionada pelo sujeito da enunciação (enunciador e enunciatário) que faz as seguintes operações:

- Modo tensivo semiótico do discurso: sobrevir, foco / apreensão e acontecimento; sintaxe tensiva: ascendência, triagem e concessão.

- Texto informativo / poético sincrético verbo-visual-gráfico (arame farpado, pôster, cartão, itálico etc): gênero carta (romance epistolar).

- Tema principal: maioridade (busca e construção de valores próprios) e subtemas: família, religião, amizade, amor, solidão, paranóia, comunidade, irmandade etc.; e isotopias temáticas e mais ou menos figurativas relacionadas aos temas principais.

- Na discursivação a utilização da debreagem enunciativa: narrador-ator debreado em primeira pessoa que enuncia, a partir do presente (eu, aqui e agora), e opera debreagens enunciativas internas para produzir enunciados sobre o próprio passado (eu, lá, então); utilização de embreagens temporais e espaciais que causam o efeito de retorno à enunciação (agora com valor de então, e aqui com valor de lá).

- Na temporalização, oscilação entre presente e passado: o nível da enunciação apresenta uma aspectualização durativa do presente e incoativa do passado. No nível enuncivo, o passado é durativo. Discurso ordenado cronologicamente e linearmente. 
- Na espacialização, o nível da enunciação apresenta um espaço interior subjetivo; no nível do enunciado o espaço divide-se em cultural, que corresponde à cidade, e o natural: casa na praia. No espaço cultural cidade, que conjunge escola, casa do protagonista etc, a pista de skate e o pátio de trens são espaços paratópicos, relacionados à manipulação, aquisição de competências e performances pragmáticas; a casa do tio é relacionada ao espaço utópico, performances cognitivas e à sanção do ator. O espaço paratópico Paranoid Park é complexo, relativo à vida e à morte; o espaço paratópico pátio de trens é relacionado à morte, ao acontecimento: ambos são associados à parada da continuação do cotidiano. A casa da praia como espaço utópico é relacionado aos valores de vida, aos elementos naturais água e fogo, e à parada da parada dos efeitos do sobrevir, ou seja, a volta ao cotidiano.

- Na actorialização, Alex é o ator principal; os outros atores representam a família, os amigos da escola do protagonista, alguns atores da pista de skate e da polícia. O protagonista é construído como ator jovem, inexperiente e com problemas domésticos que procura evitar aprendendo skate. Depois de sofrer uma experiência traumática, transforma-se em sujeito do estado e do reconhecimento, e passa a viver em um espaço interior sensível e secreto.

- Na sintaxe discursiva verbal: uso de unidades discursivas que privilegiam a intensidade e a aceleração, e procuram dar conta do mundo afetivo e sensível, estabelecendo ritmo na narrativa (o diálogo cena, a digressão, o resumo, a descrição); uso retórico que privilegia a intensidade, a aceleração textual e efeitos estésicos e somáticos (hipotipose, metaplasmos, hipérboles, exclamações, reticências, elipses etc).

- No nível narrativo os atores são Macy, Jared, Scratch (vistos também como destinadores) e os usuários da pista de skate. No nível narrativo os atores antisujeitos são o detetive, vigia e Jennifer (vistos como andidestinadores). Os membros da família são não-sujeitos e não anti-sujeitos e não destinadores ou não antidestinadores. O objeto de valor do sujeito é voltar ao cotidiano e tirar o peso dos ombros. O sujeito Alex, após o acontecimento e o sobrevir, torna-se sujeito da aflição e insegurança da falta, sendo modalizado por um não-ser (querer ser; crer não ser; saber poder não ser). Ao escrever, manipulado pelo destinador Macy, é modalizado por um ser (querer ser; crer ser; saber poder ser) e atinge um estado patêmic, na última carta, de esperança e segurança (espera paciente). Ao manter segredo sobre a morte do vigia, é modalizado pelo ser e não 
parecer. Do ponto de vista da narrativa, Alex é um actante-sujeito sincretizado: ele combina as características do narrador / enunciador, e do narrado / enunciado.

- No nível fundamental o discurso programa valores de morte relacionados ao acontecimento e ao sobrevir, que tensivamente refletem a parada da continuação e a parada da parada do cotidiano; e valores de vida ligados à escrita das cartas, que articulam a parada da parada e a continuação da continuação. 


\section{O FILME}

\subsection{Os primeiros 13 minutos de Paranoid Park}

A abertura do filme, na qual se dá a exibição dos créditos, revela o espaço englobante no qual a narrativa ocorrerá, parte da cidade onde Alex mora ${ }^{109}$. A imagem mostra uma ponte suspensa fotografada contra um céu nublado e carregado, sob a qual provavelmente ficam a pista de skate e o pátio de trens, locais onde o jovem sofre o acontecimento. A velocidade da imagem é levemente acelerada, e sombras de nuvens negras passam mais rápido que o normal, projetadas rapidamente em uma coluna da ponte: registra-se a passagem inexorável do tempo, que a partir dessa figuração torna-se um elemento plástico e palpável.

Em termos sonoros, apesar de o som dos carros, à distância, não serem ouvidos, podese perceber nitidamente o ruído do vento, que parece soprar com força perto da câmera, que trataremos como um dos modos do observador, dividido entre som e imagem ${ }^{110}$. A cena é acompanhada de uma trilha sonora que não é original do filme ${ }^{111}$, a música de Nino Rota, composta para Amarcord (Federico Fellini), que oscila entre dois ritmos diferentes, parte música rápida com características de banda circense, e parte dramática, mudando drástica e subitamente de compasso e tom, conotando tragicidade: esse texto musical ambíguo e complexo aponta para os valores de vida e morte e constrói, discursivamente, certa tragicomicidade irônica.

O céu, a trilha ambígua de Rota e a imagem de uma cidade esmagada na parte inferior do quadro criam uma sensação de peso, sufocamento e fragilidade do mundo secular e cultural da trama, construindo um ambiente audiovisual intenso e disfórico.

\footnotetext{
${ }^{109}$ A imagem que abre o filme é a da ponte Burnside, localizada em Portland, cidade natal do cineasta e do escritor do romance.

${ }^{110}$ Em nossa discussão, e seguindo Fontanille, o observador do nível da enunciação será chamado apenas de observador; o do nível do enunciado de informante, seja ele como narrador ou ator.

111 Boa parte da trilha sonora do filme pode ser ouvida no site you tube: https://www.youtube.com/watch?v=hiJ068QT6os\&list=PLBkXWjf0sMS5FAkC1nkyBTm5V18myXvgd.
} 
Figura 42 - Abertura do filme e créditos. A cidade esmagada pelo céu

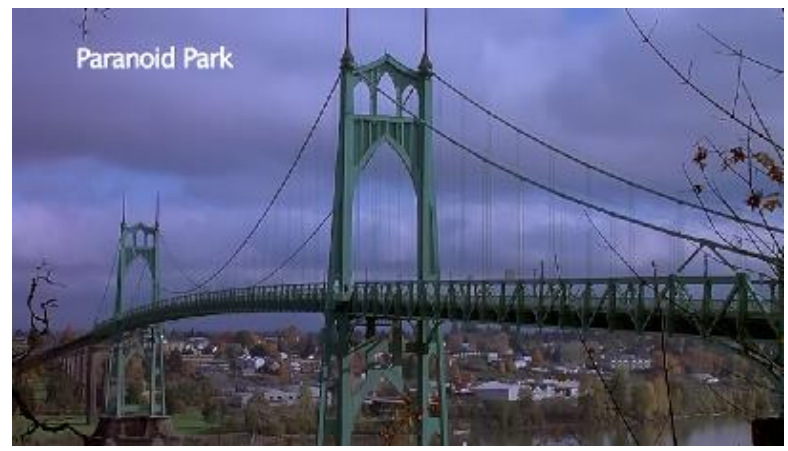

Fonte: Paranoid Park (Gus Van Sant) ${ }^{112}$

Após a imagem relativamente escura da abertura, segue-se um plano detalhe, ou primeiríssimo plano (PPP) com tons claros, e filmado em velocidade normal, da mão do protagonista, que escreve o título do filme (e do romance: Paranoid Park) em uma folha de caderno branca pautada. A imagem, que pode ser associada à focalização do narrador / ator Alex, é narrada por um informante (no cinema: câmera subjetiva)

Figura 43 - O título do filme é reescrito pelo ator Alex

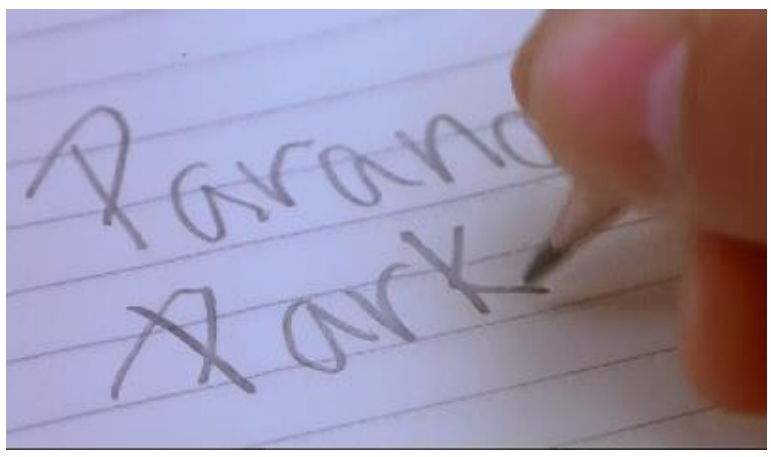

$\mathrm{Na}$ imagem seguinte Alex está dentro da casa de seu tio, na sala, escrevendo em um caderno. $\mathrm{O}$ adulto entra em quadro, vindo de outro aposento, passa por detrás do jovem, silenciosamente, e recolhe um saco de papel e um prato com comida colocados em uma mesa ao lado do protagonista, retornando ao lugar de onde veio, provavelmente a cozinha. Apesar do silêncio, ambos se cumprimentam brevemente, mas não trocam olhares. O gesto do tio revela um sujeito carinhoso e afetivo, que parece não querer incomodar a atividade do sobrinho, sugerindo a personalidade tranquila e delicada que o jovem comenta no final do romance.

\footnotetext{
112 Todas as imagens utilizadas no trabalho são do filme Paranoid Park (Gus Van Sant, 2007).
} 
Figura 44 - Alex escreve na casa do tio
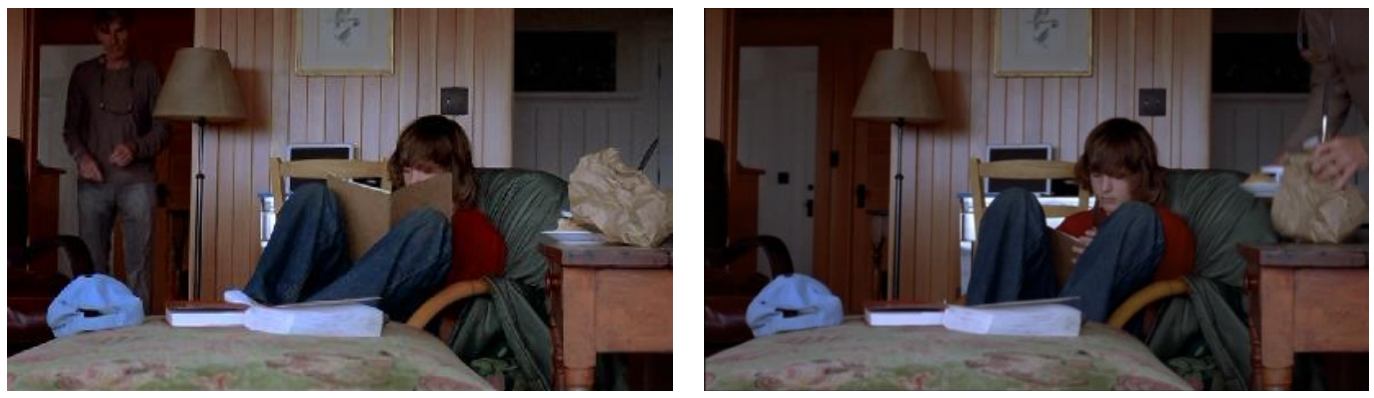

Enquanto o jovem escreve, outra trilha sonora incidental e não diegética, e que não é musical e nem melódica como a do início do filme, composta de sons desconexos e eletrônicos, pode ser ouvida em baixo volume, e depois aumenta e torna-se plenamente audível à medida que a cena avança. Trata-se de uma composição eletroacústica conhecida como paisagem sonora (ou soundscape), que cria uma atmosfera diferente e estranha ao mundo representado ${ }^{113}$.

Na próxima cena, ainda embalada pela mesma composição sonora, agora em volume normal, Alex é mostrado à distância, andando, e cruzando um espaço natural. A composição imagética, como a utilizada na exibição dos créditos, divide o espaço em duas áreas bem distintas: o céu, menos carregado e limpo, e a terra, de vegetação ressecada e sem vida, sugerindo um ambiente frio e seco. A composição do quadro apresenta duas cores dominantes, o azul e o marrom, que definem duas categorias cromáticas opostas: claro vs. escuro. Mostrado à distância, em um plano geral (PG) o personagem torna-se minúsculo dentro do espaço imenso e aberto. Apesar de se tratar da imagem do jovem em movimento, o discurso fílmico é mais pontual, possuindo um aspecto menos durativo, pois mostra o deslocamento do ator, que não é visto "entrando ou saindo" do quadro, apenas cruzando-o brevemente. Assim, descreve-se apenas parte da direção do cruzamento do quadro.

\footnotetext{
${ }^{113} \mathrm{O}$ soundscape é uma "paisagem sonora" feita de diferentes sons que compõem um determinado ambiente, sejam esses sons de origem natural, humana, industrial ou tecnológica. O estudo de paisagens sonoras enquadra-se no âmbito da Ecologia Acústica. Dependendo de sua utilização, podem causar estranheza quando acoplados à imagem (ex: o som de lobos uivando, ou de uma revoada de pássaros em uma paisagem lunar). Esses tipos de composição, sendo menos da ordem da música do que dos "efeitos sonoros", geram certa conscientização do espaço sônico e provocam profundidade na imagem, adicionando-lhe outras camadas de sentido.
} 
Figura 45 - Alex vai à praia

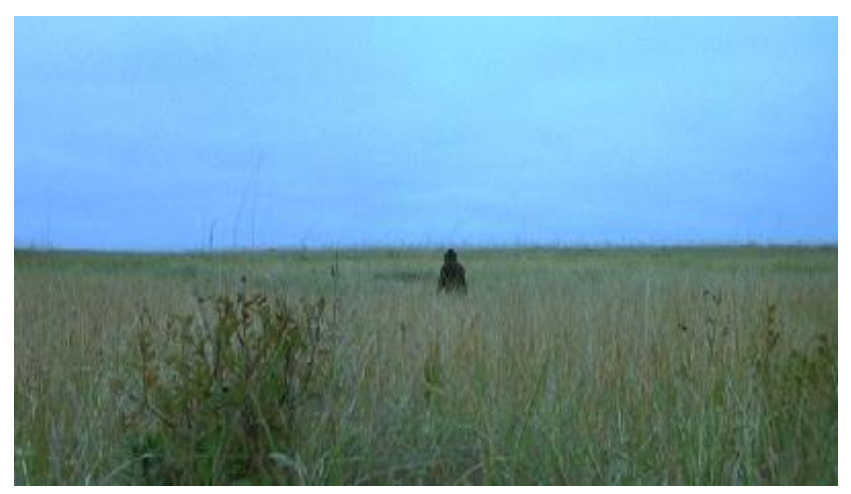

A cena seguinte é uma sequência de imagens de uma pista de skate retratada no período diurno. A pista é observada de maneira fluida, mas nem sempre estáveis, e "tremidas", filmadas em câmera lenta, tornando o ponto de vista enquadrado instável, e causando efeito de estranhamento no espaço, que parece se distorcer, assim como o som. Outra trilha sonora de caráter experimental, e composta de sons que constroem falas e ruídos (vozes em francês, nem sempre inteligíveis, mescladas a sons metálicos, de vidro quebrando etc), é adicionada à imagem, não possuindo nenhuma relação diegética com a imagem observada, e cujo ambiente sonoro é inaudível. A sequência é longa (quase dois minutos), feita de poucos planos que oscilam em seus eixos verticais e horizontais, e sendo "editada" ou "cortada" pelo próprio enquadramento fluído e oscilante da câmera, que mostra a pista de skate em várias direções, como se uma cabeça humana observasse o espaço esférico e profundo, cruzando-o. Em termos expressivos plásticos, as categorias topológicas, cromáticas e eidéticas oscilam e se transformam por causa do movimento constante acionado por categorias cinemáticas relacionadas à aceleração da projeção, que desacelera a enunciação, e pelo discurso figurativo proxêmico que executa gestos de um olhar inconstante que vasculha o espaço (associados a outros usuários da pista, o observador pode ser associado ao interlocutor audiovisual informante).

Adicionada à instabilidade das categorias plásticas, tanto a textura da imagem é alterada, de modo que fica mais "grossa" e granulada, ou texturizada, esmaecendo cores e contrates. Além disso, há também alterações de foco, o que causa mais ou menos nitidez no que é observado. A luz do sol e as sombras não são evitadas, criando situações de contrastes luminosos acentuados. A trilha sonora eletroacústica e incidental, as imagens granuladas e saturadas, o enquadramento fluido e os efeitos de luz criados pelo movimento livre da câmera (aéreo) sugerem um espaço abstrato, onírico, ilimitado e contínuo, e possuidor de forte carga afetiva. Aliadas ao aspecto temporal durativo, as imagens granuladas constroem um discurso 
audiovisual intenso e tátil. Observa-se, nesse tipo de discurso, que deforma o espaço, tornandoo mais complexo visual e sonoramente, uma intenção enunciativa que o torna mais incerto, ou seja, mais acessível do que exibido, em uma estratégia que figura a memória.

Como nenhum ator da diegese pode ser visto, no entanto, sugerimos que a pista em questão possui uma relação ambígua com a narrativa, podendo pertencer tanto às lembranças do jovem que escreve, quanto ser um comentário independente do enunciador fílmico. A ambiguidade do caráter discursivo da cena, que existe entre enunciação e enunciado, e ficção e documentário, indicam forte presença do enunciador, que veremos com mais cuidado no capítulo 4.

Figura 46 - a primeira visita a Paranoid Park: manhã
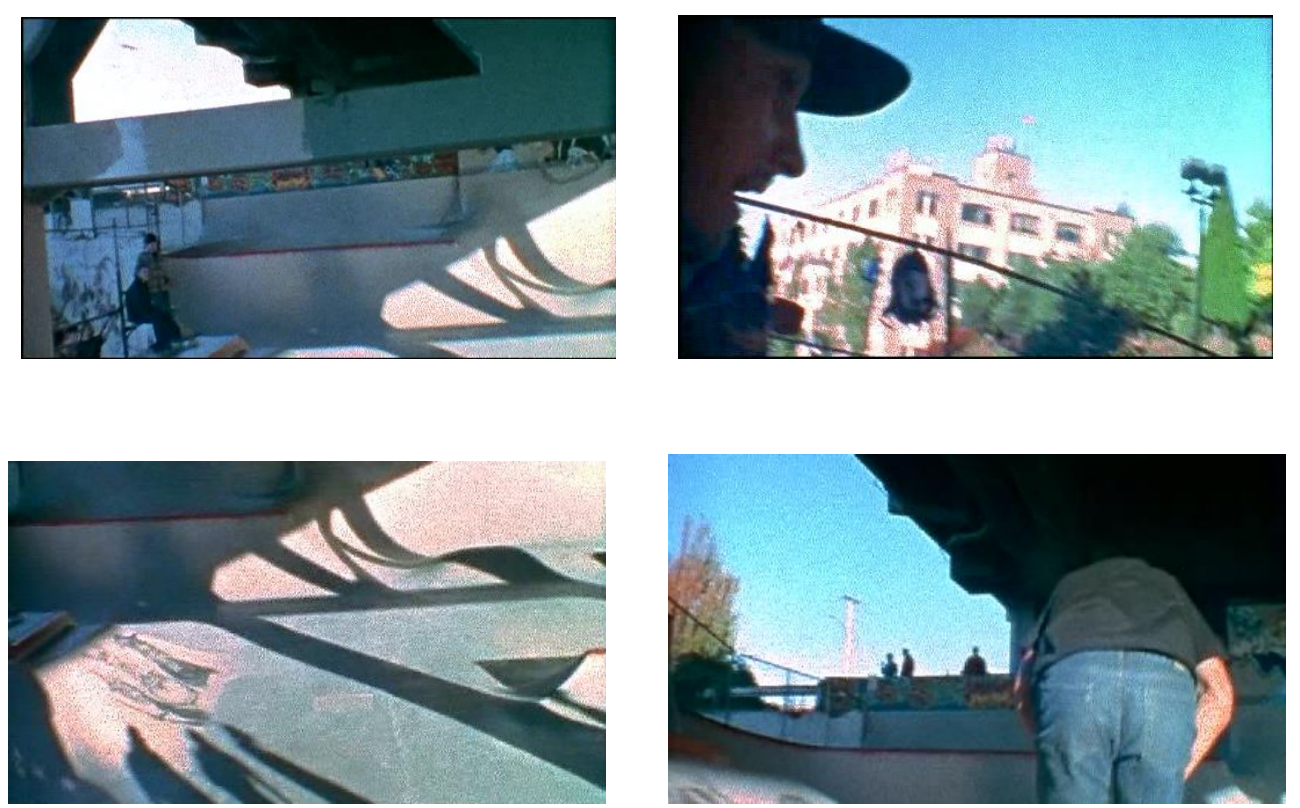

Eixo do enquadramento desnivelado
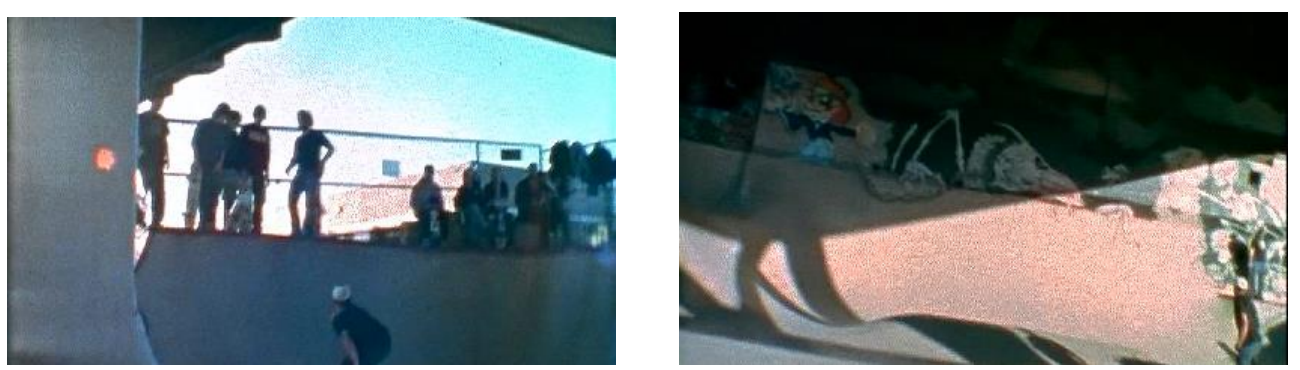

A luz do sol invade a lente 

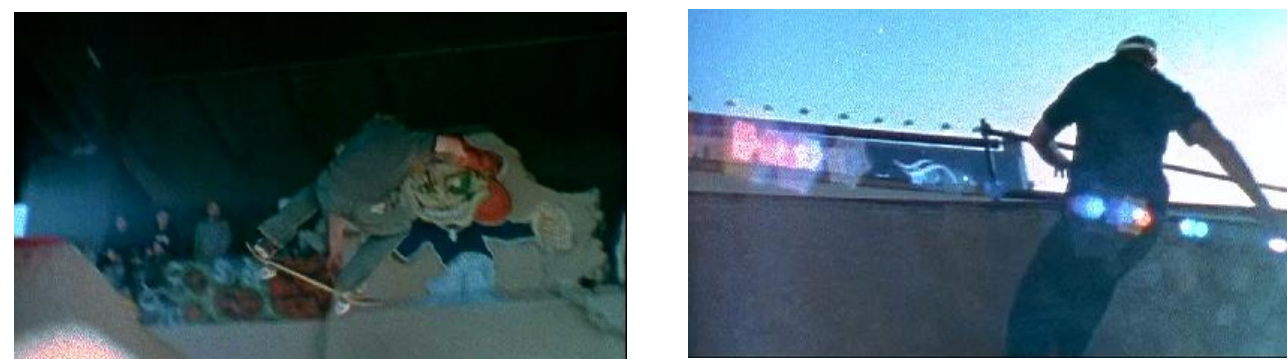

A cena seguinte mostra o protagonista, de costas, indo em direção à praia por uma trilha em um matagal, acompanhado de um cão, que nem sempre é visível. A trilha sonora eletroacústica é a mesma, não sendo diegética, encobrindo totalmente os sons do espaço natural percorridos. A imagem é igualmente granulada, fora de foco e instável como as da pista de skate. Como essa cena, referente ao presente, é enunciada da mesma maneira que a sequência da pista de skate, no passado, a construção desse tipo de expressão parece ir além da representação apenas temporal.

Nesse plano, o garoto é seguido por um observador que aspectualiza o espaço alternando levemente sua distância do ator, distanciando-se e se aproximando dele. Em certo momento da sequência a câmera adota a posição subjetiva de Alex, que parece observar o espaço ao redor, tornando-se um informante. É importante ressaltar que no romance não existe nenhum cão; e no filme, ele existe apenas nessa cena. O tipo de enunciação imagética e a presença pontual de um cão mais uma vez parecem adições no discurso fílmico que vão além de questões de "mudança" da narrativa.

Figura 47 - Alex vai à praia (imagem granulada e fora de foco; aproximação do ator)
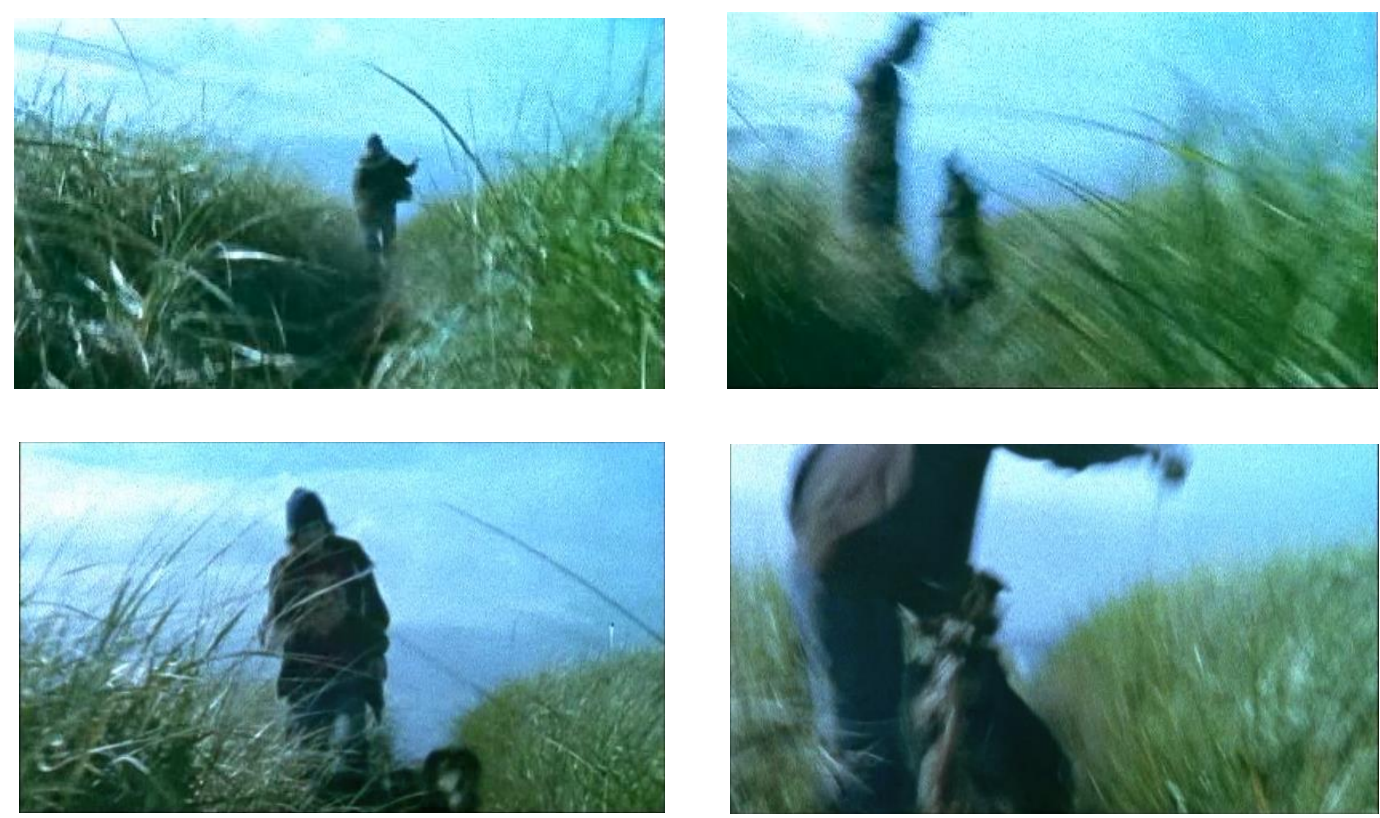
Enquanto caminha, Alex parece observar a paisagem à sua volta

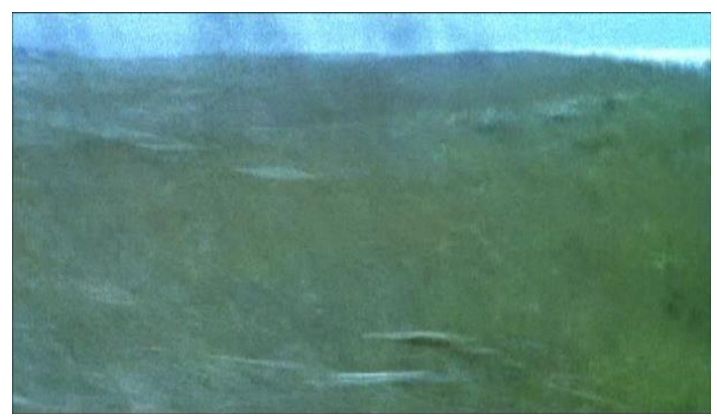

A imagem seguinte é similar a anterior, e o protagonista parece estar no mesmo espaço, mas em outro tempo, pois o cão não pode ser visto (a caracterização do figurino, no entanto, é a mesma). Nesse caso, porém, não há texturização da imagem, e ela é definida "normalmente", de modo que existe um ganho no efeito de iconização. Percebe-se que o jovem está indo em direção ao mar, que pode ser visto ao fundo, sendo seguido pelo observador. A trilha sonora eletroacústica é alterada, mas mantém a qualidade onírica e estranha do espaço representado.

Figura 48 - Alex vai à praia (imagem nítida)
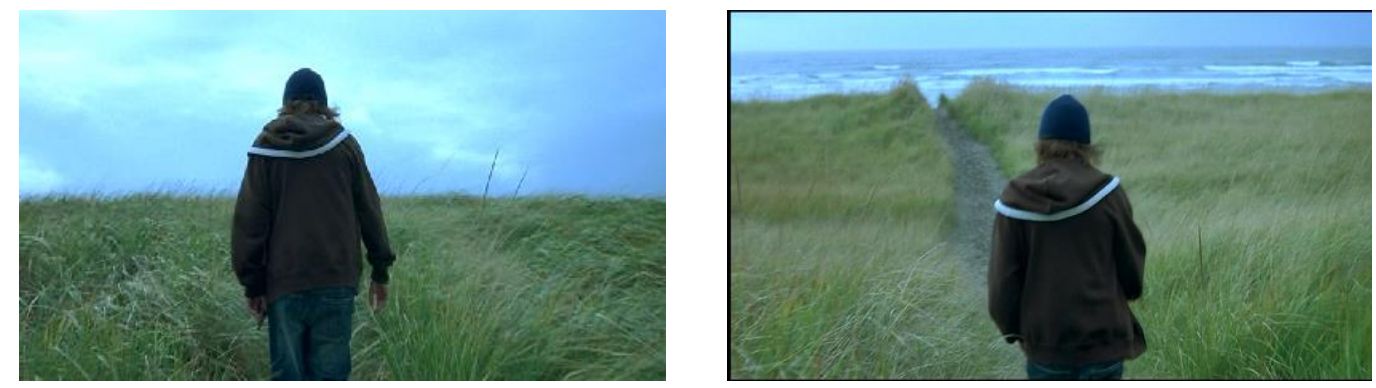

Ao compor uma imagem semelhante a anterior, mas com categorias expressivas plásticas e cinemáticas diferentes, o discurso opera uma duplicação do ator, condizente com a ideia de transformação: uma vez que as duas cenas exibidas em sequência correspondem ao presente, ou seja, à casa do tio na praia, as categorias expressivas diferenciadas sugerem, no mínimo, uma ambiguidade entre eu e outro; ao mesmo tempo, inserem-se na questão discutida acima, a da presença de um enunciador fílmico que procura ir além da simples adaptação da diegese literária. Como no caso da pista de skate, que não associamos necessariamente à narrativa, pode-se perguntar se o Alex "granulado e acompanhado de um cão" é o ator da diegese, ou se sua presença indicaria um acréscimo de sentido, sendo desencadeadora de uma nova isotopia. Por outro lado, o fato de Alex ser figurado com as mesmas características expressivas de Paranoid Park, opera uma relação entre a pista, os seus usuários e o jovem. 
Na proxima sequência Alex aproxima-se de um banco da praia, senta-se, abre o mesmo caderno visto no início do filme, na casa do tio, e começa a escrever. Ouve-se a sua voz narrando o que escreve. Trata-se do uso de uma voz-over ${ }^{114}$ :

Figura 49 - A praia é um dos lugares onde Alex escreve suas cartas

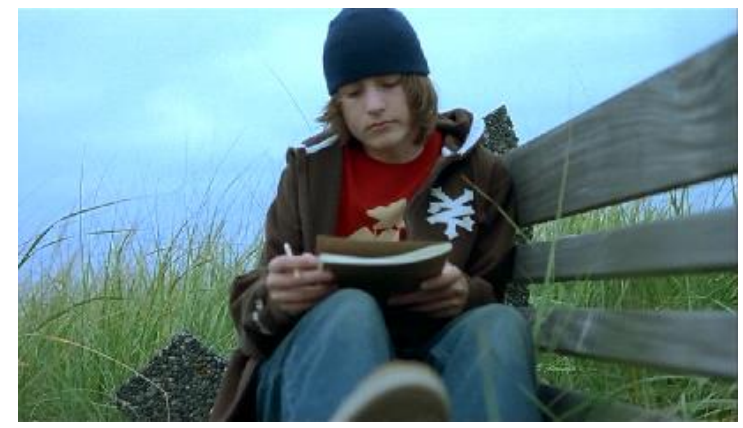

$\mathrm{Na}$ última semana de verão, em um lindo dia, a gente estava na cidade. Eu estava com Jared, que é mais velho do que eu. Ele disse que devíamos dar uma olhada em Paranoid Park. Eu tinha ouvido falar nele, é claro, mas nunca tinha pensado em ir lá. Eu achava que era demais para mim. Mas quando eu disse "Eu não acho que eu estou pronto", Jared riu e respondeu algo tipo "Ninguém está pronto para Paranoid Park". Nós fomos à pista juntos, no dia seguinte.

A partir da narração do ator, confirma-se a ideia de que o jovem está escrevendo e narrando sua própria história, que de alguma maneira está relacionada ao título Paranoid Park, mostrado no início do filme. Essa cena também marca uma estabilidade na figurativização do discurso filmico, que até então parecia caótico e desconexo, devido à mescla de tempos e espaços diferentes, e começa a ser ordenado. O enunciador, após alguns momentos de composição intensa do discurso, até agora fragmentado e sem continuidades entre tempos e espaços, e com fortes características remissivas, produz uma primeira desaceleração no andamento do discurso, a partir da instalação de uma enunciação enunciativa (eu, aqui, agora) e de uma enunciação enunciada ( $e u$, lá, então), que propõe espaços e tempos mais extensos e têm caráter emissivo, pois dá ordem e propõe um início a um discurso que até agora parece confuso.

A narração do ator em voz-over, igualmente debreada em primeira pessoa (debreagem de segundo grau), é alterada em comparação à narração do livro: o adjetivo fine é acrescentado, o que parece caracterizar um sujeito mais feliz e relaxado (em contraste com sua caracterização

\footnotetext{
${ }^{114} \mathrm{~A}$ voz-over, que não deve ser confundida com a voz-off, ou a voz fora do campo, é um artifício utilizado para mostrar que alguém (um narrador, protagonista ou não) está relatando algo (pessoal ou impessoal) que pode ou não estar conectado à imagem exibida: assim, ela pode ser mais ou menos incidental.
} 
no resto da narrativa); Jared é apresentado como um adolescente mais velho que o protagonista (como no romance); dois verbos no passado são substituídos pelos mesmos verbos no tempo presente (didn't e was); a informação que os jovens foram à pista de skate no dia seguinte é acrescentada; e uma sentença em discurso indireto é enunciada em discurso direto ("Eu não acho que estou pronto"). Assim, o enunciador fílmico condensa as informações dispersas no romance, mantendo as características atoriais e temporais do texto fonte, mas não as espaciais, pois o romance indica que as cartas do jovem foram todas escritas dentro da casa do tio. A partir dessas mudanças, de um lado o espaço natural exterior, inexistente no romance, é acrescentado ao filme; de outro, e em nível verbal, o tempo presente é mais tonificado, e constrói-se a ideia de diálogo, ou seja, de cena, que será repetida de maneira figurativa na sequência fílmica seguinte. No romance, o texto e original e suas mudanças no filme são as seguintes:

During the last week of summer, we were downtown one fine day. One day I was with Jared, who is older than me. He said we should check out Paranoid Park (Ididn't say anything at first).I had heard of it, of course, but had never thought of going there. I had assumed it was out of my league. But when I said "I (didn't) don't think I (was) am ready", Jared laughed and said something like (that): "Nobody's ever ready for Paranoid Park.". We went to the Park together, the next day ${ }^{115}$.

Do ponto de vista sonoro da construção do narrador / ator, a voz-over estabelece o sujeito interior da cognição, duplicado, transformado, e projetado como voz-pensamento. A divisão sonora entre o narrador do presente e o interlocutor do passado, a partir da justaposição de vozes, recria as relações do romance entre continuidades e descontinuidades do sujeito do presente e do passado. O uso sonoro de um texto verbal que registra a fala de um sujeito que diz $e u$, serve ainda como estratégia de aumento de sua densidade corporal e, consequentemente, da caracterização do personagem principal. Segundo Doane (1983) o som da voz no cinema possibilita a representação de um corpo mais cheio (e organicamente unificado), confirmando "o status da fala como um direito de propriedade individual" (p. 458). Demonstrando o que a imagem muitas vezes não pode, a voz-over no cinema é capaz de exceder o visível e revelar uma vida interior, virando o corpo do avesso e manifestando menos uma extensão do que um alinhamento (p. 466). Esse tipo de voz intensifica a figuração do ator, dando-lhe mais concretude e existência icônica (antropomorfa e psicológica), inclusive como sujeito que elabora o próprio discurso. Se de um lado a voz-over do ator existe como símbolo do pensamento e da interioridade, e fornece espessura ao corpo do sujeito; de outro, a identidade

\footnotetext{
115 Os trechos sublinhados existem apenas no filme. Os trechos entre parênteses, e cortados, pertencem ao texto original e não foram utilizados.
} 
entre as diferentes vozes, a do presente e a do passado, unificadas no mesmo sujeito, constroem a ideia de relação entre dois espaços e tempos.

Assim que o narrador / ator começa a narrar sua história, no banco da praia, os fatos narrados são reconstruídos figurativamente como lembrança visual, e os jovens são mostrados conversando, no passado. O discurso direto narrado anteriormente por Alex, em sua enunciação no presente, será sobreposto ao discurso enunciado, de modo que, a partir do som, presente e passado são mesclados. $\mathrm{Na}$ fala de Jared, o adjetivo really é acrescentado, enfatizando o poder e a força da pista de skate, já caracterizada no romance como actante dominante capaz de um poder-fazer virtualizado. Como no romance, a pista não perde o seu caráter de destinador complexo:

Alex: "I don't think I'm ready for Paranoid Park".

Jared: "Nobody's really ready for Paranoid Park."116

Figura 50 - Alex e Jared falam sobre Paranoid Park no passado

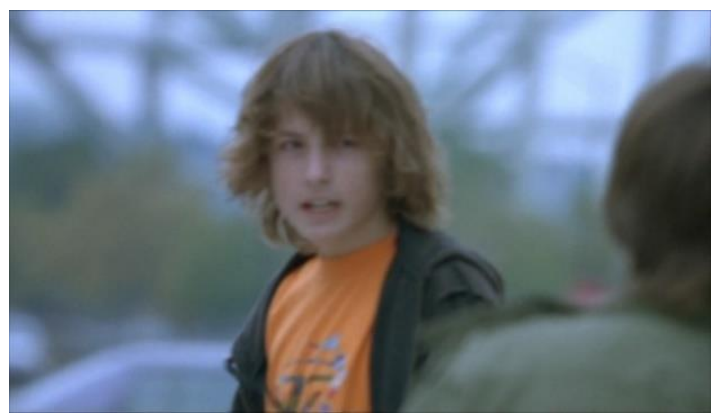

Alex e Jared vão à Paranoid Park pela primeira vez. Após dois planos que mostram, primeiro, o protagonista de costas, e depois um primeiro plano (PP) de seu rosto observando um grupo de jovens, o observador mais uma vez torna-se informante, adotando a posição subjetiva do ator no enunciado. $\mathrm{O}$ foco da câmera explora a composição da distância, e cria imagens mais ou menos definidas. Alex observa um grupo de jovens, que lhe devolvem o olhar:

${ }^{116}$ Ninguém está "realmente" pronto para Paranoid Park. 
Figura 51 - Alex pela primeira vez em Paranoid Park
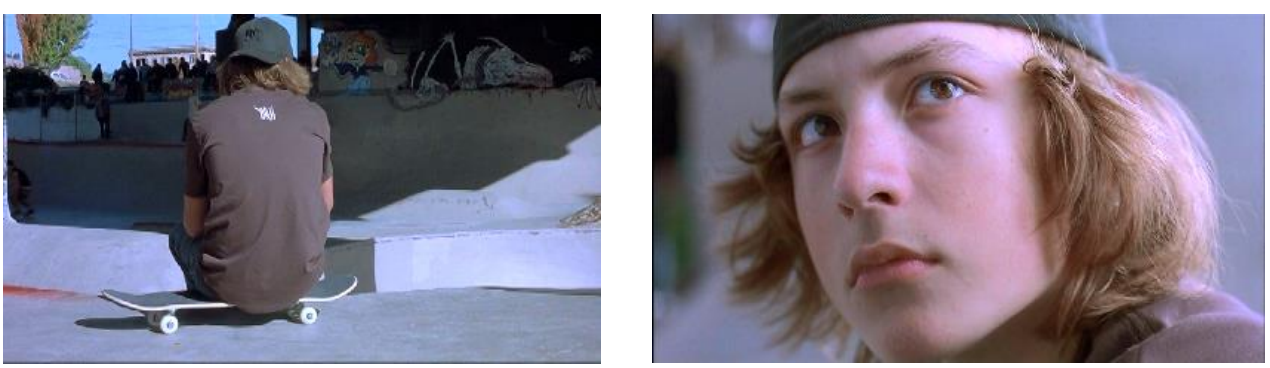

Figura 52 - Alex observa alguns usuários de Paranoid Park (em câmera lenta, um skatista invade o quadro e sai)
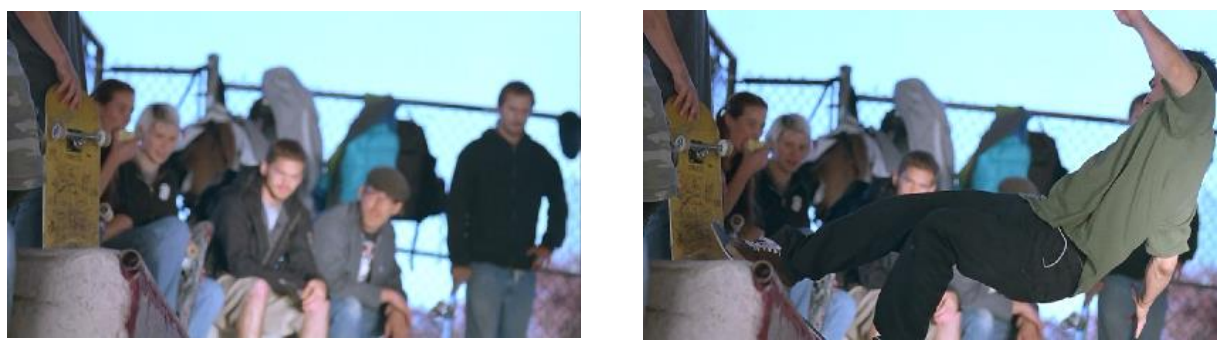

Mais cenas da pista de skate são mostradas a partir do mesmo estilo das anteriores, sendo granuladas e com cores menos vivas, enquadramento instável e fluido, câmera lenta e utilização de música eletroacústica. A trilha sonora utilizada é a mesma das primeiras imagens da pista, e a velocidade do discurso visual é igualmente desacelerada; a impressão de sonho e estranhamento persiste:

Figura 53 - Paranoid Park e Alex andando de costas
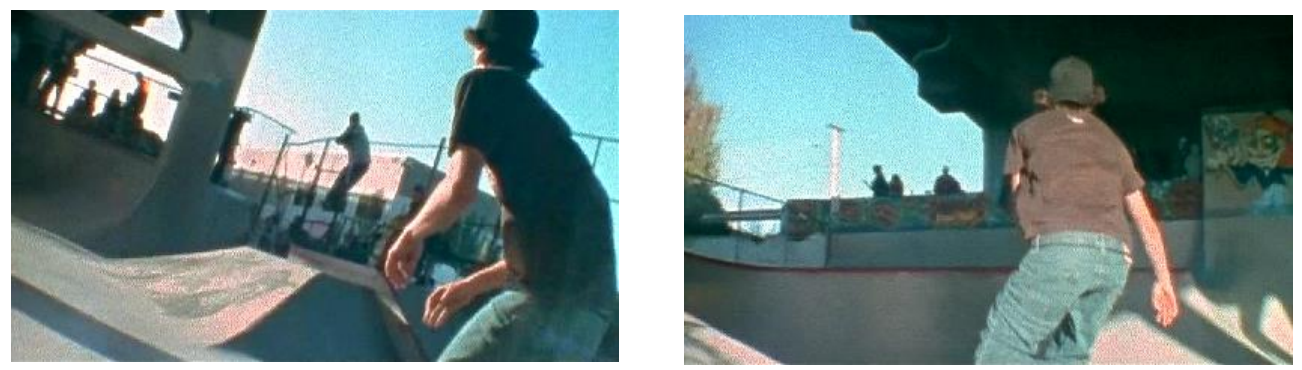

Depois que ambos os amigos experimentam a pista de skate ${ }^{117}$, sentam-se lado a lado: os efeitos de velocidade e de granulação são abandonados, a imagem torna-se nítida novamente,

\footnotetext{
117 Não fica claro se Alex anda na pista de skate, pois sua imagem nunca é mostrada frontalmente. No entanto é possível que o jovem seguido de costas represente o protagonista, que admite no romance que anda na pista quando a visita pela primeira vez. A caracterização do skatista parece ser a mesma de Alex, sentado, na próxima imagem (boné e camisa escura com um desenho nas costas). De qualquer maneira, a dúvida se o jovem mostrado é um personagem ou apenas um jovem qualquer filmado, e que "não pertence à narrativa" ainda persiste.
} 
o filme volta à velocidade normal e o som diegético da pista de skate substitui gradualmente a trilha sonora incidental (sons de skate e gritos). Jared comenta: "Cara, que lugar maneiro. A gente devia voltar no sábado" ${ }^{118}$ (fala original do filme).

Figura 54 - O enunciado fílmico "volta ao normal".

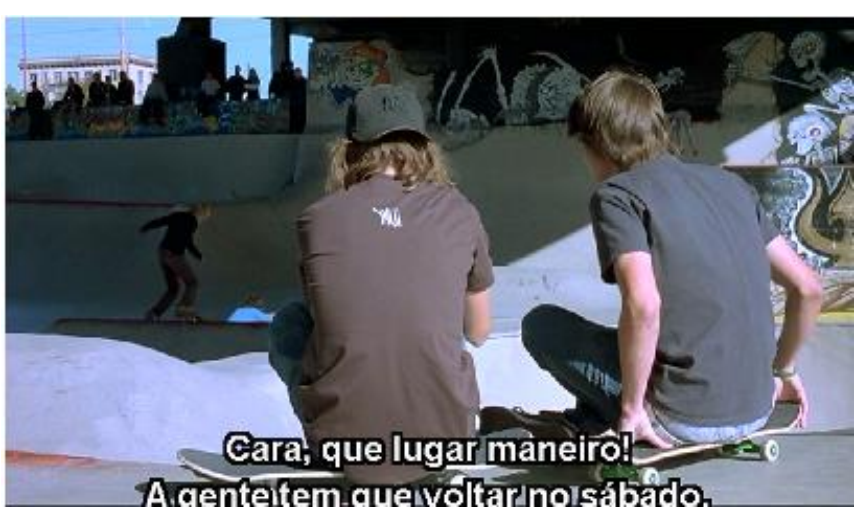

Na cena seguinte, Alex está escrevendo na praia, e continua a relatar a sua história em voz-over (a cena parece ser a continuação da anterior). Sendo subexposta e superexposta à luz, as categorias cromáticas da imagem alteram-se rapidamente, de modo que ela fica primeiramente mais clara, e logo em seguida mais escura que o normal, em uma representação que parece simbolizar operações cognitivas da memória, ou do reconhecimento. Nesse plano, que é ligeiramente desnivelado e mostra o ator de cima para baixo (plongé), pode-se ver o mar atrás do narrador. O jovem escreve que: "Cerca de um mês depois, na metade da aula de matemática, ouvimos um chamado com o meu nome. Só o meu, de mais ninguém" ${ }^{119}$ (essa fala e cena são alteradas, e tiradas de outro contexto no romance).

Figura 55 - Alex escreve na praia. Há alterações cromáticas na imagem, que fica primeiramente mais clara, e depois mais escura
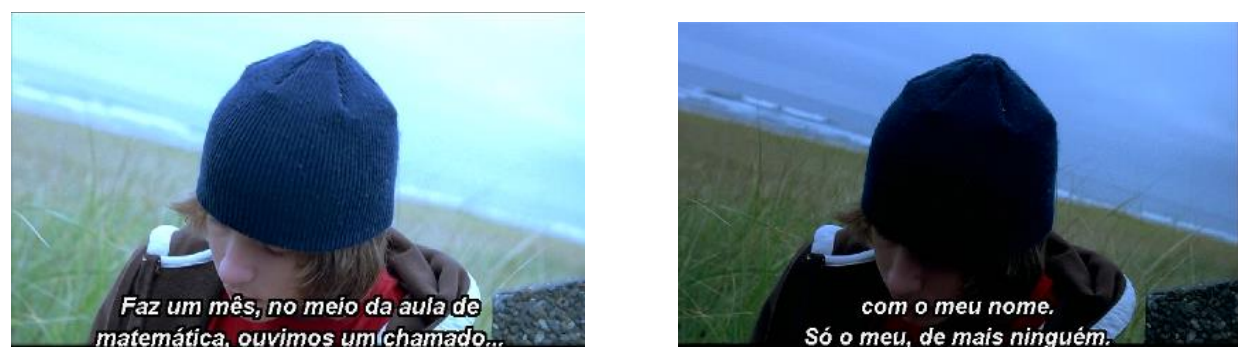

\footnotetext{
118 "Dude, this place is tight. We should hit it up on Saturday".

119 "About a month later, halfway through math class, there was an announcement. My name. My name, and no others".
} 
A cena seguinte é o espaço de uma sala de aula. A mão de um professor sobre a luz do retroprojetor constrói, mais um vez, uma forte oposição entre sombra e luz, definindo as categorias cromáticas claro vs. escuro.

Figura 56 - A imagem do planeta Terra em um retroprojetor

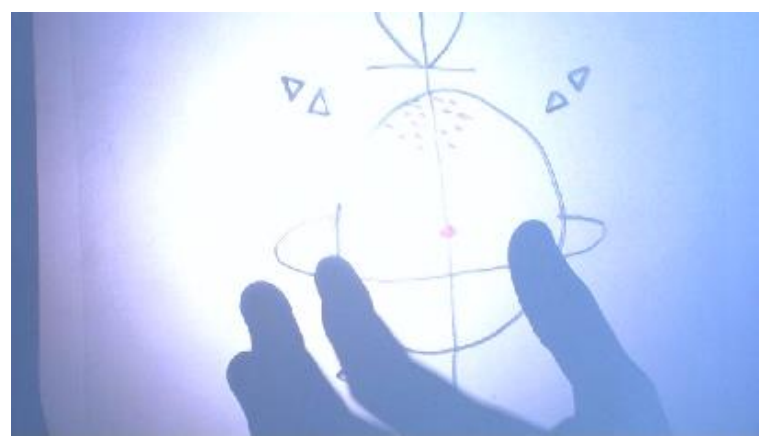

O observador desloca-se para a esquerda (por meio de uma panorâmica ${ }^{120}$ ) e mostra Alex acompanhado a explicação do professor. Jennifer, a namorada, está ao seu lado direito. A cabeça de Alex encontra-se na parte inferior da imagem e ele, entre os colegas de classe e o professor, que está de pé e mais próximo da câmera, parece menor e diminuído.

Figura 57 - Alex na escola, em sala de aula

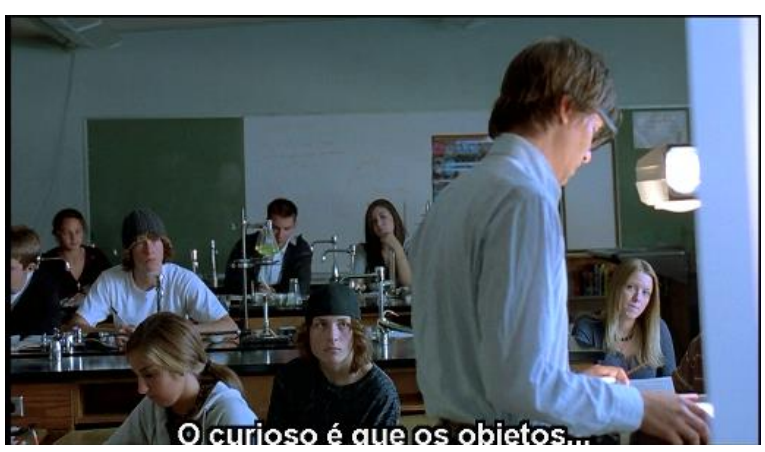

O jovem levanta-se, sai da sala e dirige-se ao local onde é requisitado. Trata-se de um plano longo acompanhado de uma trilha sonora de estilo pop e não diegética.

\footnotetext{
${ }^{120}$ A PAN (panorâmica) é um tipo de movimento em que o corpo da câmera está fixo, e apenas a câmera se move para capturar a imagem.
} 
Figura 58 - Alex andando pelo corredor da escola depois de ser chamado

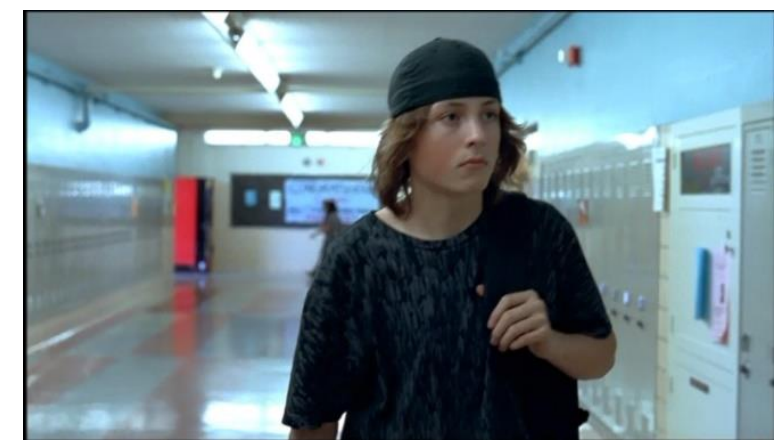

Em outra sala o detetive Lu aguarda o jovem para interrogá-lo:

Figura 59 - Alex chega na sala e é interrogado pela polícia

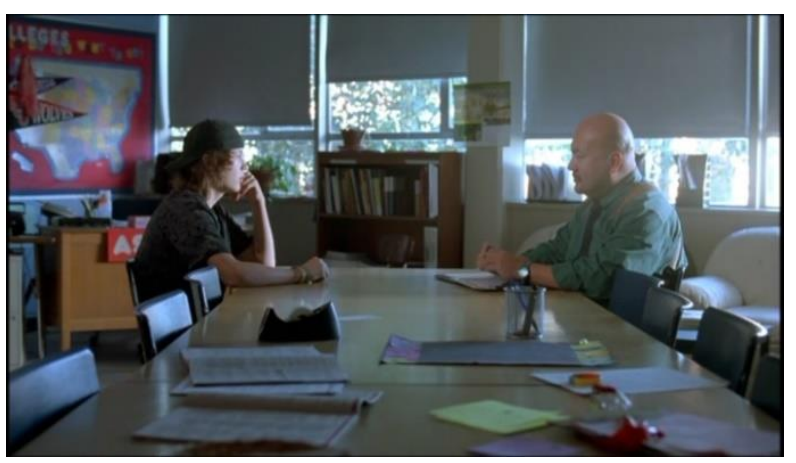

A sequência do interrogatório possui o plano mais longo do filme (3'29”), tratando-se de um plano-sequência ${ }^{121}$ cujo observador primeiramente é mais enuncivo (informador), representando o olhar do jovem narrador / ator que chega à sala e a perscruta até encontrar o detetive, sentado e o olhando fixamente; e depois mais enunciativo (em primeiro grau), de modo que o observador cruza o espaço e aproxima-se lentamente dos dois personagens que conversam, sentados e frente a frente. A sequência, a partir desse longo plano, possui ainda três planos menores. Esse é o primeiro momento do filme em que dois atores dialogam longamente, de modo que uma série de informações sobre a narrativa, ainda desconexa, é apresentada. É também a primeira vez que a morte do vigia, que denominamos acontecimento, é comentada.

A cena entre os personagens existe no romance, como ja observamos, mas é colocada fora da ordem original proposta, como todas as cenas anteriores relatadas até agora. O diálogo contém trechos idênticos aos do romance, mas há três importantes exceções: uma discussão sobre o que o adolescente comeu na noite do crime (em itálico) é adicionada; e um trecho no

${ }^{121}$ Em nossa discussão diferenciamos o plano longo do plano sequência, o que nem sempre é feito. Para nós, o primeiro é mais descritivo e remissivo, mostra movimentos e espaços; o segundo, mais dramático e emissivo, mostra o sujeito relacionando-se com outros sujeitos e dialogando. Tal diferenciação, no entanto, é frágil. 
qual o detetive pergunta a Alex o que ele faria se fosse um dos jovens, ou se tivesse amigos envolvidos no crime, além de perguntas sobre sua relação com a namorada Jennifer (Anexo B: em inglês) são retirados. No filme, o diálogo entre o adolescente e o detetive é o seguinte:

Detetive: Olá Alex. Vem sentar aqui. Desculpe tirar você da aula.

Alex: Tudo bem.

Detetive: Bem, eu conversei com o seu amigo Jared. Ele disse que vocês quase foram à pista de skate, na noite do dia 17. É verdade?

Alex: É.

Detetive: Saiu de carro naquela noite?

Alex: Como é?

Detetive: Saiu de carro naquela noite?

Alex: Sim.

Detetive: Passou de carro por lá, naquela noite? Perto da pista?

Alex: Não.

Detetive: Onde você foi?

Alex: Naquela noite eu passeei de carro pelo centro, fui comer alguma coisa. Estacionei perto do rio e fui dar uma volta a pé.

Detetive: Andou de skate?

Alex: Sim. Bom, não. Eu estava com o skate, mas não sou muito bom. Eu fico praticando sozinho.

Detetive: Você sabe os horários em que fez isso, aproximadamente?

Alex: Passei no Jared entre 7 e 8 horas e fui deixar ele na rodoviária. Logo depois fui dar uma volta. Eu me confundi com uma coisa. Eu não voltei para a minha casa, voltei para a casa do Jared porque a gente tinha combinado passar a noite na casa dele.

Detetive: Certo. E os pais dele?

Alex: A mãe dele estava em Las Vegas e o pai não mora mais com eles.

Detetive: Não tinha nenhum irmão dele lá? Quer dizer, a casa estava vazia?

Alex: Sim.

Detetive: Seus pais sabiam que não tinha ninguém na casa dele?

Alex: Eles não ligam para isso.

Detetive: Bom, tudo bem. Conheço bem esse truque. Você diz aos seus pais que vai dormir na casa do Jared, mas eles não sabem que os pais dele não vão estar lá. Assim vocês podem fazer o que quiserem.

Alex: É isso aí. Se bem que a minha mãe nem liga.

Detetive: Tudo bem. Eu costumava fazer isso. Esse truque é velho. Sem problema. Qual é a situação dos seus pais?

Alex: Como assim?

Detetive: Os seus pais ainda estão juntos?

Alex: Eles estão separados faz um tempo e vão se divorciar agora.

Detetive: Sei. Meus pais se divorciaram. Na época eu tinha a sua idade. Sei que não é fácil. Você tem irmãos ou irmãs?

Alex: Tenho um irmão mais novo. Ele tem 13 anos.

Detetive: E irmã?

Alex: Não.

Detetive: E namorada?

Alex: Sim. Jennifer.

Detetive: Onde ela estava aquela noite?

Alex: Minha namorada? Ela estava com umas amigas.

Detetive: Ligou para ela aquela noite? Você tem celular?

Alex: Não, eu não liguei. Eu não tenho celular. 
Detetive: Bem. Só estou anotando aqui. É o seguinte...vou dizer em que situação me encontro. Tenho um segurança que foi encontrado morto na linha do trem. Pensamos que ele tivesse tropeçado ou levado um tombo, mas a autópsia disse que ele foi atingido por um objeto. E também temos uma testemunha que disse ter visto alguém atirar alguma coisa no rio de cima da ponte. Saiu de carro aquela noite? Nós estamos com esse objeto que é um skate. O curioso é que existem traços de DNA no skate mostrando que ele estava no local do crime. Por onde andou?

Plano 25 (original do filme)

Alex: Dei uma volta pelo centro e parei no Subway para comer.

Detetive: Existem mais de 2000 Subways. Em qual você foi?

Alex: Perto do rio.

Detetive: Aquele perto do World Trade Center?

Alex: Sim.

Detetive: $O$ que comeu?

Alex: Peru, presunto, baguete com parmesão, orégano, tomate, alface, picles, azeitona, mostarda, azeite e vinagre.

Detetive: Pediu maionese?

Alex: Não.

Detetive: Tem que comer maionese com isso.

Alex: Maionese é nojento.

Detetive: Que pão era?

Alex: Com parmesão e orégano.

Detetive: Tem o recibo com você?

Alex: Não, não guardo recibos do Subway.

Detetive: Quanto custou então?

Alex: Mais de 6 dólares. O Subway é caro.

Detetive: Meio sanduiche ou inteiro?

Alex: Meio.

Detetive: Meio sanduíche por 6 dólares. Deve ter pedido o combo, certo?

Alex: Não, só pedi uma bebida. Dr. Pepper grande.

Detetive: Com quem você comeu?

Alex: Sozinho. Fui de carro sozinho até lá.

Plano 26

(OUVE-SE O GRITO DE UM HOMEM)

Detetive: OK. Não posso demorar. Vou deixar meu cartão com você.

Plano 27

Detetive: Se tiver mais alguma coisa para me dizer, quero que ligue para mim OK? Pode fazer isso?

Plano 28

Alex: Posso voltar para a classe?

Detetive: Sim, pode. Muito obrigado.

\section{Diálogo cortado do filme}

Detetive: $\mathrm{O}$ que estou tentando imaginar é o seguinte: o que esses garotos fazem? Onde vão? Que tipo de jovens são?

Alex: É uma boa questão.

Detetive: O que você faria se fosse um deles?

Alex: Eu...eu não sei. Chamar a polícia?

Detetive: E se fossem amigos seus? Voce chamaria a polícia?

Alex: Eu acho que sim, se alguém fosse morto. Ou se fosse um acidente ou qualquer coisa. 
Detetive: E se estivesse sozinho e alguma coisa desse tipo acontecesse?

Alex: Então eu com certeza chamaria a polícia. Porque não? Só se você quisesse matar o cara. Quer dizer, eu não tenho nada contra seguranças.

Detetive: Certo. Mas o que você faria se não chamasse a polícia? Se você estivesse assustado e não soubesse o que fazer?

Alex: Não tenho certeza.

Detetive: Você provavelmente correria. E voltaria à pista de skate e contaria aos amigos. Ou, se você fosse esperto, não voltaria. Iria pelo rio, esperando que ninguém o visse.

Alex: É, acho que sim.

Detetive: E esses garotos. Eles provavelmente estão de passagem. Ou são fugitivos. Se eu fosse eles, acho que pularia no primeiro trem para fora da cidade. Sairia do estado. Do país, talvez...

Alex: Eu ouvi falar que uma vez alguém foi esfaqueado lá.

Detetive: Você conhece algum menino de rua? Quer dizer, pessoalmente?

Alex: Não, quer dizer, eu já vi eles. As pessoas chamam eles de "Rueiros".

Alguns andam de skate. Mas a maioria só pede esmola, coisa assim.

Detetive: Se eu te mostrasse algumas fotos, você reconheceria gente que viu na área?

Alex: Eu duvido. Não é que eu conheça eles.

Uma importante característica da cena é relacionada ao som, pois durante a conversa entre os atores um grito angustiante, que parece ser de um homem, é ouvido entre os planos 25 e 26.

Figura 60 - Durante o depoimento do jovem, ouve-se o grito de um homem que começa em um PP de Alex e termina em um PP do detetive.
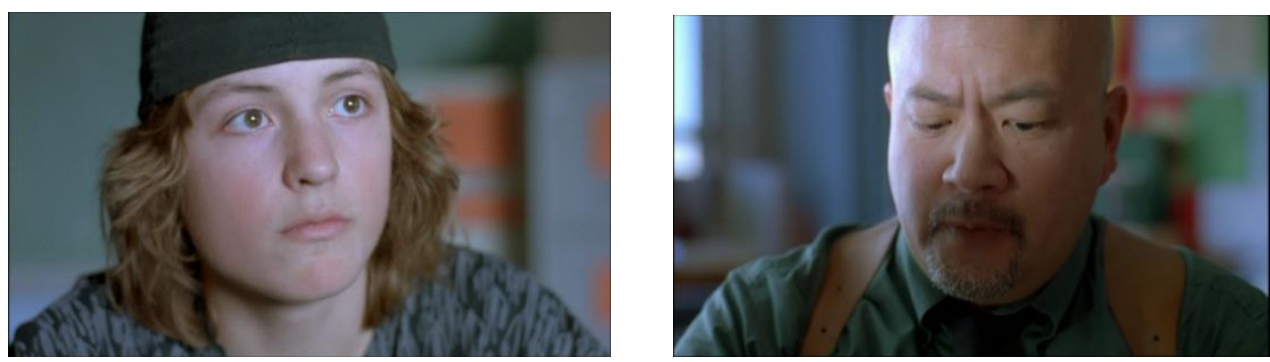

Esse som, colocado sobre a transição da imagem do rosto de Alex e do detetive, ambos em PP, não é diegético, e ressoa pela cena criando um breve estranhamento. Narrativamente, o grito é ambíguo, pois não se sabe se está conectado ao jovem ou ao detetive, que imagina a situação. Relacionado a Alex, pode ser a lembrança do jovem do grito do vigia ao cair nos trilhos do trem, ou simbolizar o seu próprio medo. O fato é que como a cena ocorre antes do evento trágico, e fora de ordem, sendo a primeira do filme a organizar causas e consequências, tendo característica emissiva, a relação entre o jovem, o grito, o crime sendo explicado e o detetive é ainda tênue. Através do grito, o envolvimento do protagonista com o crime é sugerido, mas apenas sutilmente. Ao mesmo tempo, a 
retirada do diálogo das perguntas e respostas relacionadas ao que o jovem teria feito, se tivesse participado, ou fosse amigo de um dos criminosos, o enunciador fílmico evita dar informações que serão mostradas mais tarde, uma vez que o detetive imagina o crime quase como ele realmente aconteceu.

O deslocamento dessa unidade discursiva para o primeiro diálogo da narrativa, que no romance ocorre bem depois, não é aleatória, tendo um papel fundamental para a o projeto enunciativo da adaptação, pois serve como resumo de fatos e personagens, explicando boa parte das sequências narrativas. Assim, pode-se libertar o texto de sua cronologia, e torná-lo mais expressivo do que cognitivo, sem a perda de um encadeamento lógico mínimo da sequência dos eventos, explicado nessa sequência, a maior e com mais diálogos do filme. Além de resumir o passado da história, construindo um tipo de flashback verbal e sendo anafórico, o diálogo também revela algumas características da vida afetiva e social do jovem, além da personalidade do detetive, que parece ser compreensivo e amável.

No final da cena existe uma interessante operação de adaptação relacionada ao sincretismo do romance, ou seja, tanto à linguagem verbal quanto à linguagem gráfica. No romance, quando o detetive encerra a entrevista ele dá a Alex o seu cartão e o narrador / ator faz um comentário sobre suas mãos: "Eu notei suas mãos enquanto ele o entregava (o cartão) para mim. Elas eram grandes e grossas, carnudas. Ele usava um daqueles anéis grandes, como os de um vendedor de carros, nos filmes" ${ }^{22}$. A imagem é considerada importante pelo narrador / ator, e transposta para o filme, sendo observada como um detalhe (PPP) das mãos de ambos os atores: a mão do detetive primeiramente bate algumas vezes o cartão na mesa, depois o desliza suavemente pela superfície de madeira. A mão de Alex vai de encontro ao cartão:

Figura 61 - O detetive entrega o seu cartão a Alex
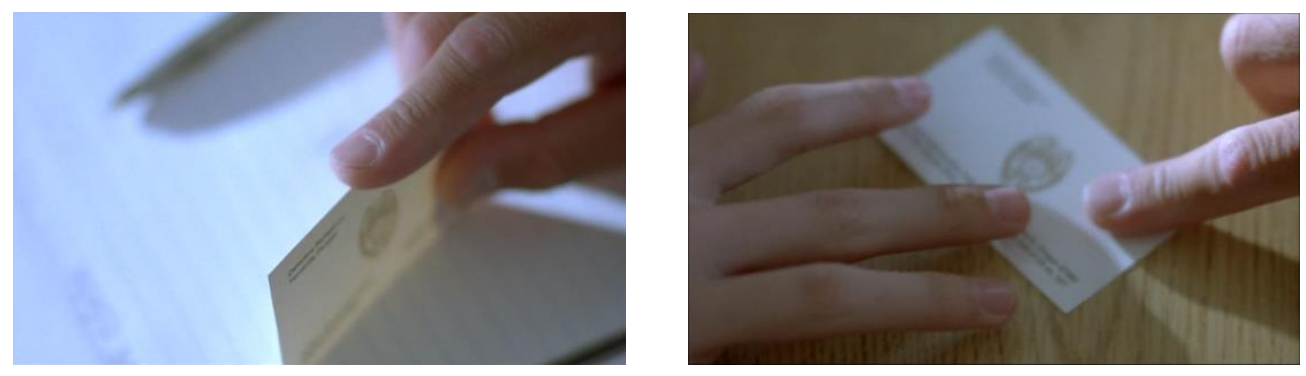

${ }^{122}$ I noticed his hands as he handed it to me. They were big and thick, meaty-looking. He wore one of those big rings, like a car salesmen in movies (NELSON, 2006, p. 127). 
A composição da cena da entrega do cartão, que mostra, em detalhe a mão do jovem e do adulto quase se tocando, adiciona um tom afetivo à imagem, conotando uma relação diferenciada entre os dois, mas que não será desenvolvida no filme como no romance. Apesar disso, ela é um exemplo de figuração temática proposta do romance.

Na cena seguinte Alex encontra-se na casa do tio, no presente, e confessa:

Estou escrevendo isso um pouco fora de ordem. Desculpe, não me saí tão bem em Escrita Criativa. Mas, no fim, escrevo tudo ${ }^{123}$ (fala original do filme).

Figura 62 - Alex escreve suas cartas e explica que suas lembranças estão fora de ordem (13’05”)

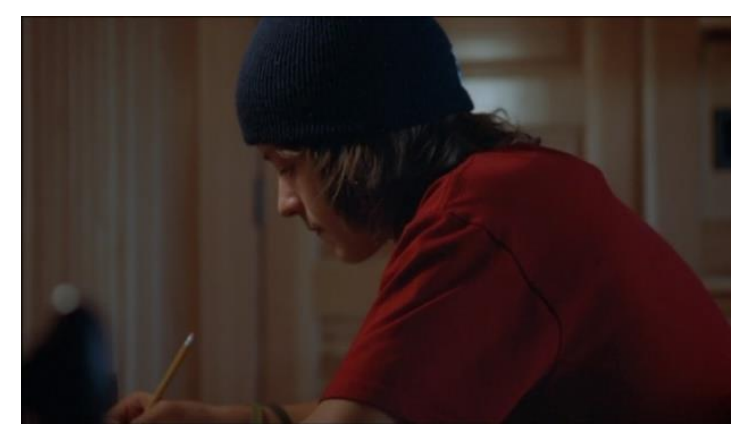

\subsubsection{Comentário sobre os primeiros minutos do filme:}

A partir do que foi examinado acima, podemos destacar uma série de estratégias da narrativa audiovisual para adaptar o conteúdo do texto literário, relacionados à estruturas discursivas e semionarrativas do percurso gerativo. Em relação à figuração do narrador / ator, vimos que a voz-over do protagonista marca um espaço interior e subjetivo, e estabelece a presença de um corpo mais denso do sujeito, quebrando a bidimensionalidade da imagem, assim como o nível enunciativo do discurso e o tempo presente. O sujeito da enunciação observador, que oscila entre os níveis discursivos do enunciador e do narrador, também auxilia a construção de Alex em ator com visão e corpo, uma vez que pode ser desdobrado em imagem subjetiva com movimento e olhar. Se de um lado Alex conta, no romance, a sua história em primeira pessoa, alternando presente e passado, e narrando ações e pensamentos relativos a ambos os tempos e espaços, o enunciador fílmico não utiliza a voz-over para o presente, apenas para o passado, em uma estratégia que altera levemente o sentido do discurso. Assim, no filme, enquanto o passado do protagonista é "observado" e "relatado" verbalmente, o seu presente é

123 "I'm writing this a little out of order. Sorry, I didn't do so well in Creative Writing. But... I'll get it all on paper, eventually". 
apenas "observado", dando a impressão de que ele esteja menos consciente de sua condição atual. Tal estratégia, unida ao fato de que há o uso pontual da câmera subjetiva no passado, revela uma intenção de "separar" o observador do narrador, fazendo com que o discurso oscile entre um observador e um informante. O observador, transformado em informante, também faz as vezes de outros possíveis atores, que podem ser caracterizados como os usuários da pista de skate. Como informante, o observador denota as direções do olhar e do corpo em movimento.

Sendo utilizado no nível enunciativo, como observador, e no enuncivo, como informante (Alex ou usuários da pista de skate) o observador muitas vezes aspectualiza o espaço profundo como cruzamento, quando mostra Alex cruzando o campo fílmico, ou como distância, quando se aproxima dos elementos contidos nesse campo, quando segue o protagonista andando por uma trilha, na praia, quando aproxima-se do jovem e do detetive, enquanto eles conversam, sentados em uma mesa, ou quando penetra na pista de skate. Assim, a partir de gestos flúidos e "aéreos", o observador aspectualiza os espaços como contínuos, esféricos e profundos, a partir de enquadramentos que podem ser dinâmicos, multidirecionais e sem cortes.

Observamos a construção de alguns atores do romance, tais como Alex, o seu tio Tommy, Jared e o detetive que investiga o assassinato do vigia no pátio de trens; alguns espaços, tais como a cidade, a casa na praia e ao seu entorno, principalmente o mar, a pista de skate Paranoid Park, e alguns ambientes escolares e tempos: o presente, que corresponde ao tempo da enunciação em segundo grau, e o passado, o tempo do enunciado. Além do narrador / ator, a personalidade de dois atores foi parcialmente caracterizada: a do tio, representado como um homem carinhoso que não interfere na escrita do jovem Alex; e a do detetive, que entendendo as aventuras cometidas pelo jovem e expressando empatia por sua situação familiar, mostra ser um adulto compreensivo e aberto. Percebeu-se também, como estratégia de adaptação do romance, o aproveitamento de unidades discursivas na composição do discurso fílmico: a mão do detetive, que entrega o cartão ao narrador / ator é transposta para o filme, mimetizando a focalização do narrador e a descrição dessa imagem no texto literário. A partir desse detalhe, a mesma ligação afetiva entre o jovem e o adulto é sugerida, mas não desenvolvida.

Notamos também uma série de operações sonoras e imagéticas que fornecem uma paleta expressiva observada na construção do texto. Em termos da manifestação visual, vimos que o cinema articula imagens em movimento, trabalhando com categorias não apenas plásticas, mas também cinemáticas, relativas à velocidade, à direção, à altura e à distância não apenas dos atores da diegese, mas do sujeito da enunciação e do enunciado (observador e informante). 
Observaram-se dois tipos básicos de construção imagética relativa à plasticidade visual e sonora, e à cinematicidade do discurso: eixos horizontais, verticais e profundos tendendo a fixos (ou estáticos) vs. eixos horizontais, verticais e profundos fluidos e dinâmicos; ângulos de 90 graus vs ângulos inclinados; cores vivas e vibrantes vs. cores esmaecidas e "lavadas"; cores claras vs. cores escuras; superfícies lisas da imagem (não-texturizadas) vs. superfícies granuladas (texturas), que produzem formas mais figurativas (menos nítidas) vs. formas mais icônicas (mais nítidas); mudança de velocidade da imagem: acelerado, normal e lento; contraponto entre imagem e som; e sons sobrepostos.

Dentro dessas dicotomias de ordem plástica e cinemática, percebeu-se que todas as imagens relacionadas ao mundo do skate foram manifestadas como dinâmicas, granuladas, desaceleradas e com cores esmaecidas, enquanto as demais foram manifestadas como mais estáticas, velocidade normal, cores fortes e vibrantes, e superfícies lisas: uma exceção apontada é a do jovem andando na praia, pois essas dicotomias expressivas também foram observadas nas duas sequências em que Alex anda por uma trilha em direção ao mar: a primeira, na qual o protagonista brinca com um cão, que segue o estilo narrativo visual da pista de skate; e a segunda, em que o protagonista anda só pela mesma trilha, composta no mesmo estilo das demais imagens. A escolha de mostrar o presente na praia com imagens granuladas mostra que elas não são usadas apenas para representar o passado, propondo outras relações de sentido, de ordem semissimbólica ou intertextual. Sugeriu-se que a sequência de Alex com um cão, que não existe no romance é expressa com a mesmas características da pista de skate, e as imagens da pista poderiam estar relacionadas a uma diferenciação entre ficção e não-ficção, de modo que a adaptação construiria uma nova isotopia.

Em relação ao som do filme, observamos que as trilhas sonoras também possuem funções figurativas. A de Nino Rota, parte circense e parte dramática, utilizada juntamente com a imagem da ponte sob a qual a pista de skate e o pátio de trens está localizada, separando-a de um céu escuro, empresta à narrativa um tom tragicômico, ao mesmo tempo eufórico e disfórico, relacionados aos valores de vida e morte. Da mesma maneira, todas as composições eletroacústicas, utilizadas nas cenas da pista de skate e nas do protagonista escrevendo e caminhando na praia, constroem espaços profundos e estranhos que podem ser associados ao pensamento e à memória, ou seja, ao espaço interior do ator. A utilização desse tipo de música revelou um som que manifesta vozes e ruídos nem sempre inteligíveis, mas principalmente marcado pelas categorias de continuidade e ausência de ritmos ou tons musicais.

No nível sonoro da manifestação da fala e da verbalização da narração, houve mudanças nas estruturas linguísticas da enunciação do narrador / ator, de modo que tempos verbais e tipos 
de discurso foram também alterados para dar lugar ao presente e ao discurso direto, em uma estratégia que aproxima a enunciação de segundo grau do enunciado, e o narrador / ator locutor do presente com interlocutor do passado. Outro importante uso do som é sua manifestação em grito de um homem, na cena em que o jovem e o detetive conversam, criando certo suspense em relação à trama, pois conecta livremente o jovem ao detetive, e ao crime sendo discutido. Além da unidade discursiva "descrição", que vimos na cena "entrega do cartão", a unidade discursiva "diálogo" é bem aproveitada no filme, sendo atualizada pelo enunciador fílmico.

Em uma fala que não existe no texto fonte, o protagonista admite que está narrando sua história fora de ordem. Assim, o filme diferencia-se substancialmente do romance. Enquanto neste, tanto o presente como o passado possuem ordem cronológica e linear (as cartas são escritas do dia 3 ao dia 8 de janeiro, e a lembrança é explicada de setembro a dezembro do ano anterior), naquele a estratégia é abandonada, de modo que as cartas e os dias em que são escritas no presente da enunciação, os meses do ano anterior não são descritas. Assim, destaca-se a “desordem" espaçotemporal dos enunciados fílmicos, organizados minimamente e pontualmente através da voz-over de Alex e do diálogo travado entre ele e o detetive, o mais longo do filme, e com a função estratégica de resumir e ordenar a história até então composta em pedaços. Dessa forma, tanto a voz que narra como o diálogo serão utilizados para diminuir o andamento intenso do discurso audiovisual e desacelerá-lo, gerando momentos de maior extensidade entre espaço e tempo, e criando uma lógica narrativa momentânea. A partir daí, sugerimos que a voz-over é utilizada como ferramenta de missividade do discurso, possuindo características mais emissivas, pois tende a organizar os enunciados e projetar a narrativa para frente, enquanto as imagens fragmentadas e sem voz-over são mais remissivas, necessitando de mais tempo para serem compreendidas.

A partir do discurso fílmico fragmentado, verificamos que enquanto no romance a cena da morte do vigia, o acontecimento, ocorre logo no início da narrativa, depois de alguns fatos resumidos por Alex, no filme, ele é primeiramente apenas mencionado na cena da conversa entre o jovem e o detetive: a morte do vigia, diferentemente de seu lugar no romance, será apresentada apenas no meio do filme, aproximadamente 40 minutos após o seu início. Uma vez que ele é o pivô narrativo de toda a trama, e está relacionado diretamente ao tema central maioridade e à ideia de paranóia, iremos explorá-lo em seguida. 


\subsection{Adaptando o acontecimento e o sobrevir: estudo do espaço topológico verbal e audiovisual e figurações do espaço.}

Como o acontecimento transforma completamente a vida do narrador protagonista, instalando o sobrevir em seu campo de presença, analisaremos de que maneira o enunciador fílmico constrói esse momento crucial, buscando comparar o conteúdo do texto literário com o do texto audiovisual em termos topológicos e figurativos. Em nossa análise, editaremos o romance para observar como ambos os discursos, o verbovisual e audiovisual, convergem semanticamente, de modo que várias passagens literárias serão excluídas para dar espaço às similaridades figurativas entre os enunciados do livro e do filme.

A cena do acontecimento será delimitada a partir do momento em que os dois jovens invadem o pátio de manobra de trens, sobem em um vagão e são perseguidos pelo segurança, até o momento em que Alex acorda no dia seguinte na casa de Jared, depois do acidente trágico, e volta para sua casa, no domingo. A análise será dividida em duas partes: antes e depois da chegada na casa de Jared. O que nos interessará nesse estudo será observar como imagens e sons são enunciados tanto no texto verbal como no texto audiovisual, prestando atenção na transposição da descrição literária em audiovisual. A partir daí, faremos algumas considerações sobre o observador, algumas diferenças entre as cenas, e observaremos como podemos utilizar uma semiótica proxêmica e gestual para a análise da adaptação.

O acontecimento é narrado já no primeiro capítulo do livro, na carta do dia 3 de janeiro:

Nós saímos de Paranoid Park por um buraco na cerca de arame. Eu segui o Scratch, deslizando de bunda pela colina de terra. Eu via a parte de trás de sua cabeça atarracada, esperando não fazer nada estúpido [...]. No fundo da colina, nós nos limpamos. Foi quando ouvi o apito do trem tocar (...). ${ }^{124}$

Os dois adolescentes invadem o pátio de trens e andam em direção a um trem que se aproxima, o das 22:30. Em ambas a imagens o observador é estático, ou inerte, e os atores cruzam o espaço:

\footnotetext{
${ }^{124}$ We left Paranoid through the hole in the chain-link fence. I followed Scratch, sliding on my ass down the dirt hill. I watched the back of his stubby head and hoped I wasn't going to do anything stupid [...]. At the bottom of the hill, we dusted ourselves off. That's when I heard the train horn blare [...] (NELSON, 2006, p. 16).
} 
Figura 63 - Alex e Scratch invadem o pátio de trens

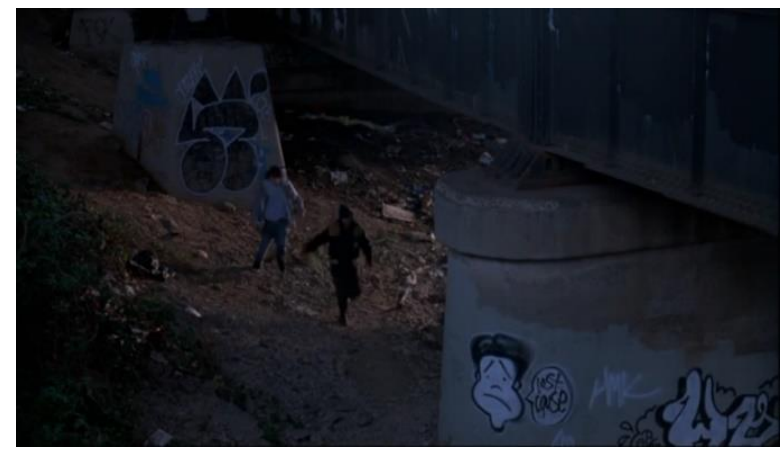

"É isso aí!", gritou Scratch, e ele começou a correr, excitado. Eu corri com ele, todo o meu corpo formigando de antecipação. Eu não conseguia acreditar que estava fazendo isso. Eu ia subir num trem! Jared ficaria com ciúmes. Bem feito! Corremos pelos edifícios antigos até chegarmos aos trilhos. O trem estava realmente lá, estava realmente chegando. O único farol dianteiro brilhava diretamente em nós ${ }^{125}$.

Figura 64 - Os jovens correm em direção ao trem e ouve-se um apito.

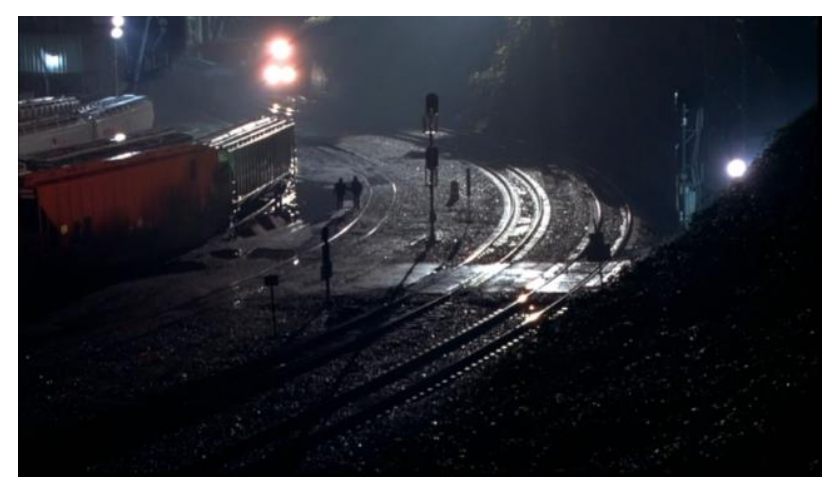

Nós dois nos abaixamos atrás de uma doca de carregamento. Agachamos ali, observando, ofegantes. A locomotiva chegou até nós. Eu não podia acreditar como ela era grande e poderosa. Depois que passou, Scratch se inclinou para frente e examinou os diferentes vagões, vendo-os passar ${ }^{126}$.

125 "That's it!" shouted Scratch, and he broke into an excited run. I ran with him, my whole body tingling with anticipation. I couldn't believe I was doing this. I was going to hop a train! Jared would be jealous. It served him right! We ran through the old buildings, until we came to the train tracks. The train was really there, it was really coming. The single front headlight shone directly at us (NELSON, 2006, p.16).

${ }^{126}$ We both ducked behind a loading dock. We crouched there, watching, breathing hard. The locomotive came even with us. I couldn't believe how big and powerful it looked. After it passed, Scratch leaned forward. He studied the different cars, watching them pass (Ibid., p. 17). 
Figura 65 - Alex e Scratch preparam-se para trepar em um vagão
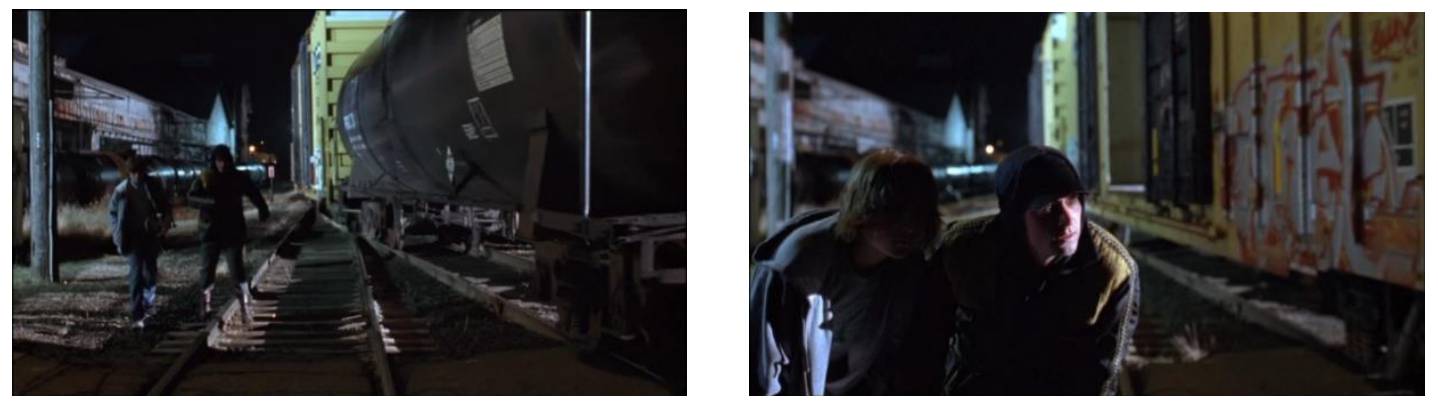

Então ele escolheu um e começou a correr ao lado dele. "Vamos, corra!", ele gritou por causa do barulho. Agarrei meu skate e corri atrás dele, na escuridão. Um trem parece devagar até você tentar correr ao lado dele. Nós dois tivemos que correr para acompanhá-lo ${ }^{127}$.

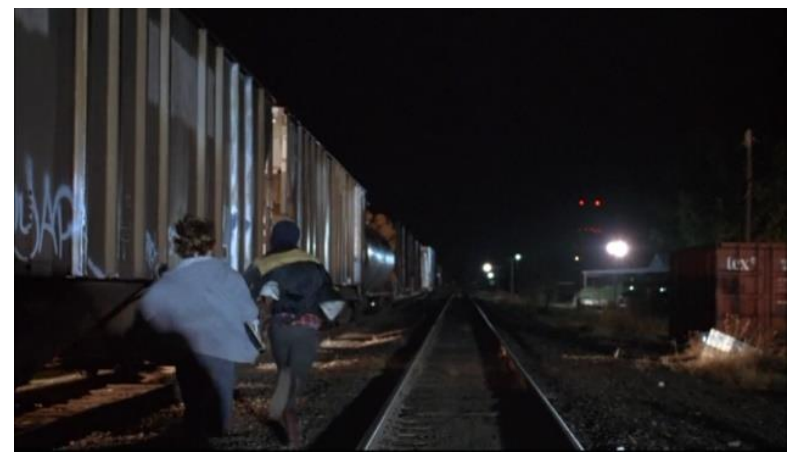

Scratch correu atrás de uma escada de metal ao lado de um carro de grãos. Ele pulou para pegá-lo e se levantou até ficar no degrau mais baixo. Ele gesticulou para eu fazer o mesmo ${ }^{128}$.

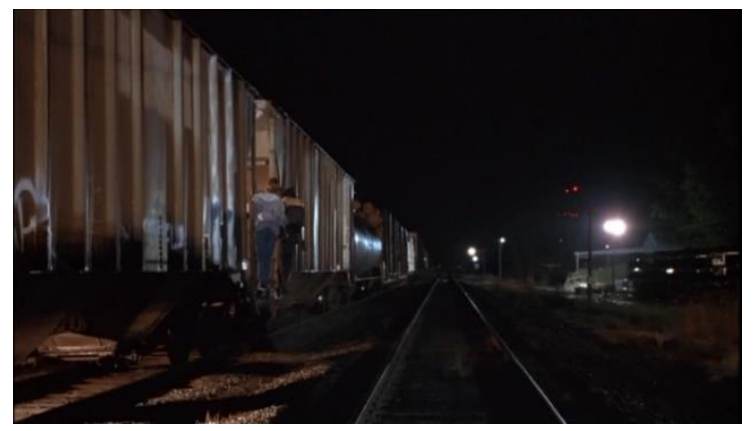

127 Then he picked one and started to jog alongside it. "Come on, run!" he shouted over the noise. I clutched my board and dashed after him in the darkness. The train didn't seem to be going very fast- until you tried to run alongside it. We both had to sprint to keep up (Ibid., p.17).

${ }^{128}$ Scratch ran after a metal ladder on the side of a grain car. He jumped for it, caught it, and pulled himself up until he stood on the lowest rung. He pointed for me to do the same (Ibid., p.17). 
Agora estávamos no trem, e andando. Scratch gritou coisas por causa do barulho. Ele disse que o trem ia mais uns dois quilômetros para um pátio. Nós pularíamos lá e caminharíamos até o Safeway ${ }^{129}$.

Figura 66 - Alex e Scratch no trem
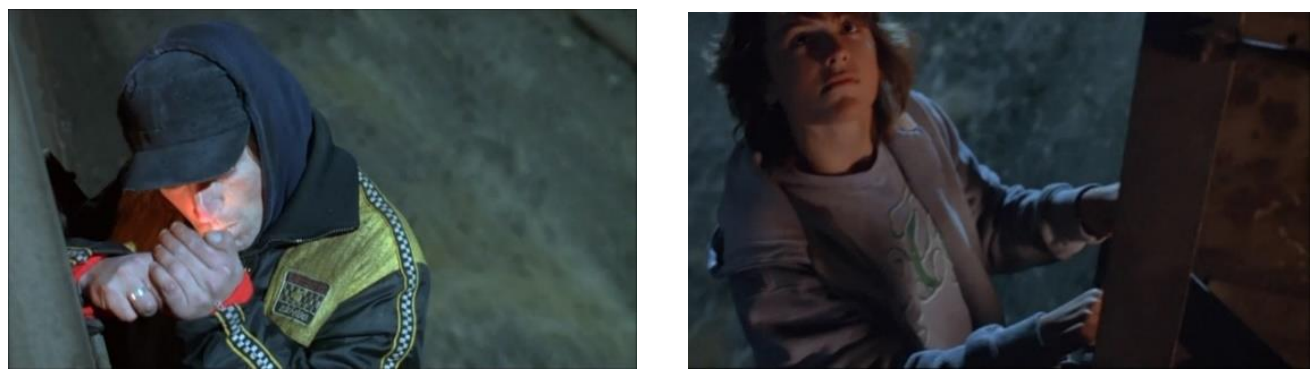

No filme, Scratch faz recomendações a Alex, que não existem no romance:

Figura 67 - Scratch fala com Alex (fala no filme)

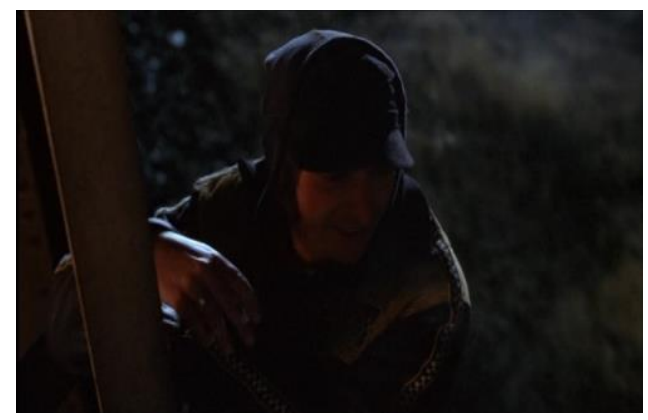

Legal, né?

Se quiser pegar outro trem, pegue no mesmo

lugar. Lá é mais seguro.

Se sua mão escorregar e você for para o lado, você bate na lateral e volta.

Agora, se você cair aqui, vai parar nos trilhos.

Então Scratch começou a acenar freneticamente para mim. Eu não entendia o que ele estava dizendo. Ao mesmo tempo, ele subiu mais a escada e tentou se espremer atrás dela. Ele parecia estar tentando se esconder. Eu não entendia. ${ }^{130}$

Scratch vê o segurança aproximando-se e pede a Alex para se esconder. No filme, Scratch fala a Alex: "vai, vai, se esconde". Alex desloca-se para a parte superior do vagão por meio de uma escada.

\footnotetext{
${ }^{129}$ Now we were on the train. We were riding it. Scratch yelled stuff to me over the noise. He said the train went another quarter mile or so to a train yard. We'd jump off there and walk to Safeway (NELSON, 2006, p.18).

${ }^{130}$ Then Scratch began waving frantically at me. I couldn't tell what he was saying. At the same time, he wriggled farther up his ladder and tried to squeeze himself behind it. He looked like he was trying to hide. I didn't understand (Ibid., p.17).
} 
Figura 68 - Os garotos vêem o vigia
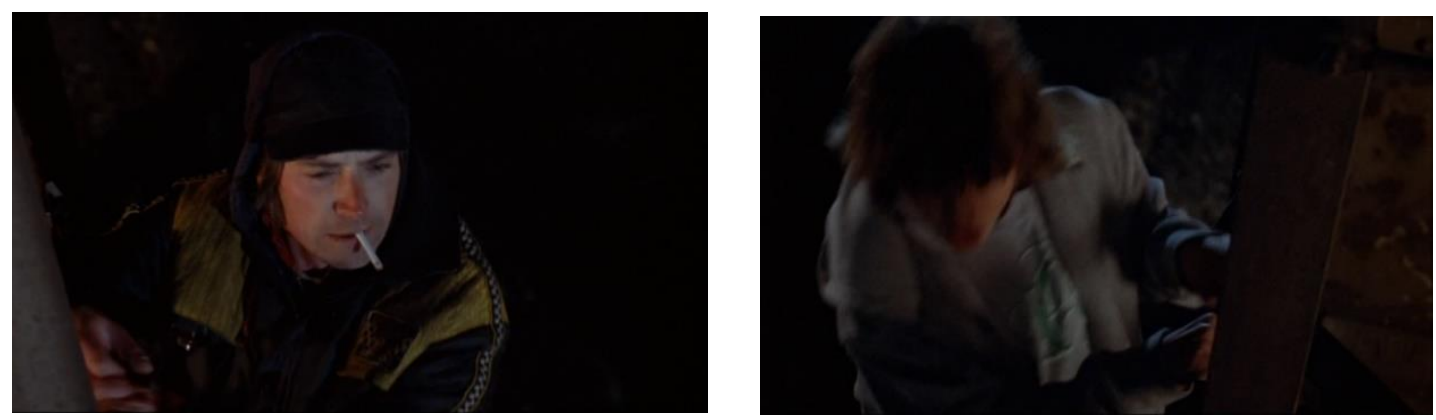

Então eu vi um carro. O carro de segurança particular estava estacionado de frente, no cascalho, à frente. Seus faróis brilhando sobre os vagões de carga enquanto eles passavam. Ao lado, estava um homem de uniforme de segurança. Ele tinha luvas pretas e um cassetete preto nas mãos. $\mathrm{O}$ guarda de segurança nos viu imediatamente. Foi minha culpa. Não me escondi, apenas fiquei pendurado lá. Eu não tinha experiência. ${ }^{131}$

Figura 69 - O segurança vê os invasores
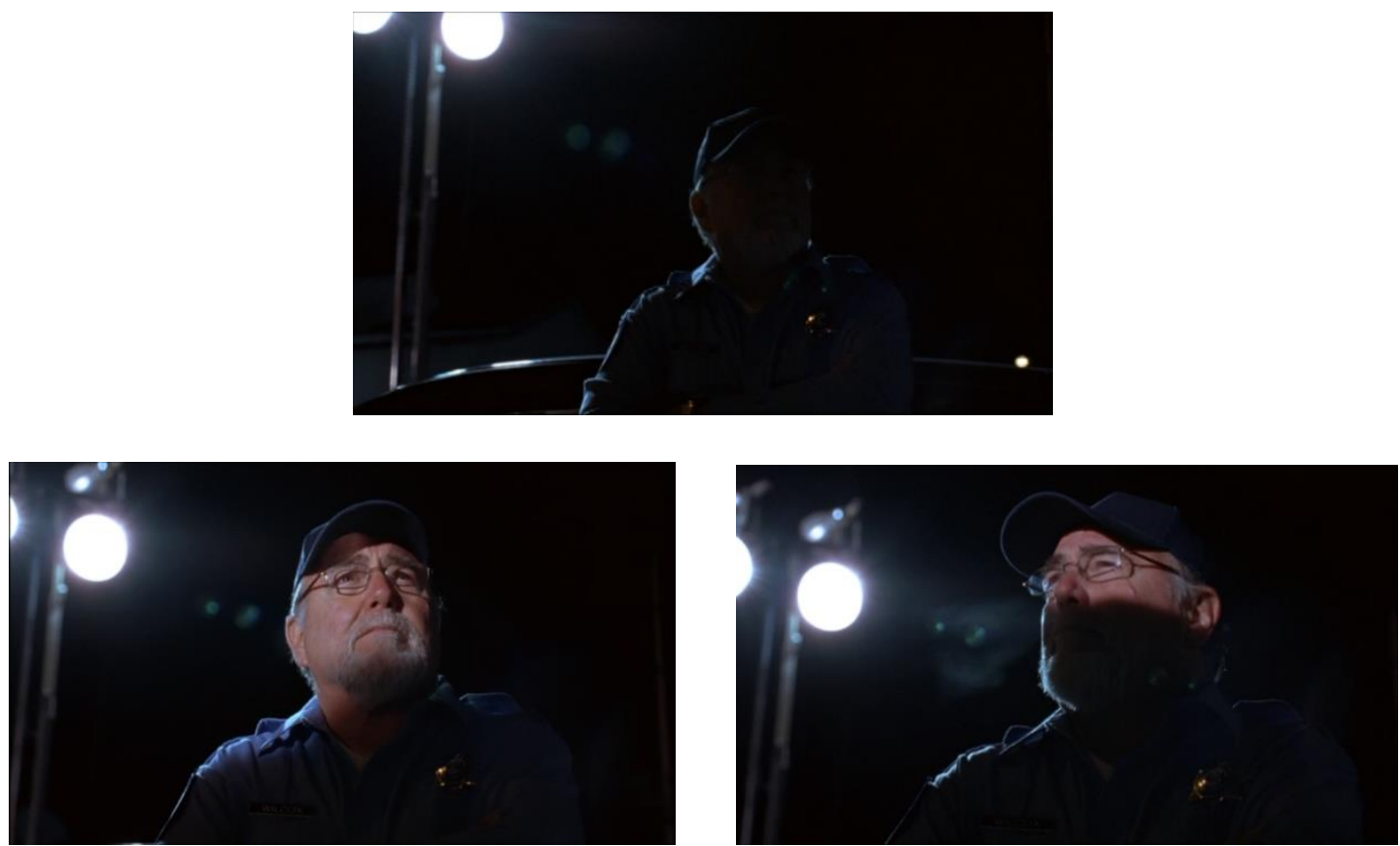

131 Then I saw the car. There was a private security car parked on the gravel up ahead. It faced the train, its headlights shinning onto the freight cars as they passed. Standing beside it was a man in a security uniform. He had black gloves on and a black nightstick in his hands. The security guard spotted us immediately. This was my fault. I didn't hide, I just hung there. I didn't know any better (NELSON, 2006, p. 19). 


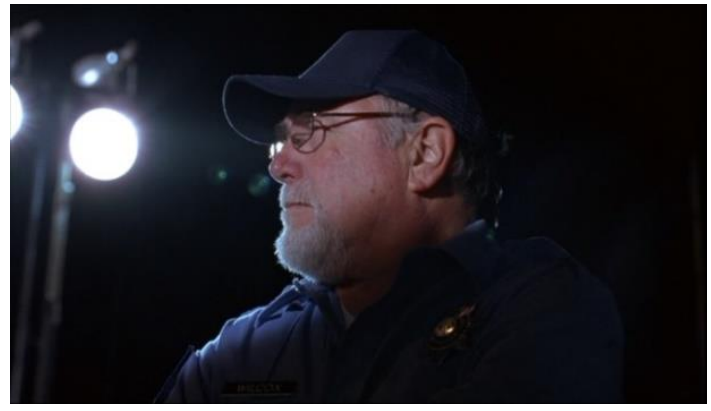

[...] Ele correu em nossa direção. Ele era grande, não exatamente gordo, mas meio que gingava com seu uniforme de segurança [...]. O guarda de segurança veio em mim primeiro. Eu estava no alto, então ele só podia alcançar meus joelhos. Mas ele desferiu um golpe com seu cassetete e eu juro, se tivesse acertado, teria quebrado todos os ossos da minha perna [...]. O segurança teve que correr ao lado dele (do trem) para nos acompanhar [...]. ${ }^{132}$

\section{(O acontecimento: enunciado em câmera lenta)}

O segurança aproxima-se correndo na mesma direção do trem e atinge os invasores com o seu cacetete.

Figura $70-\mathrm{O}$ vigia do pátio de trens ataca os jovens e é derrubado por Alex
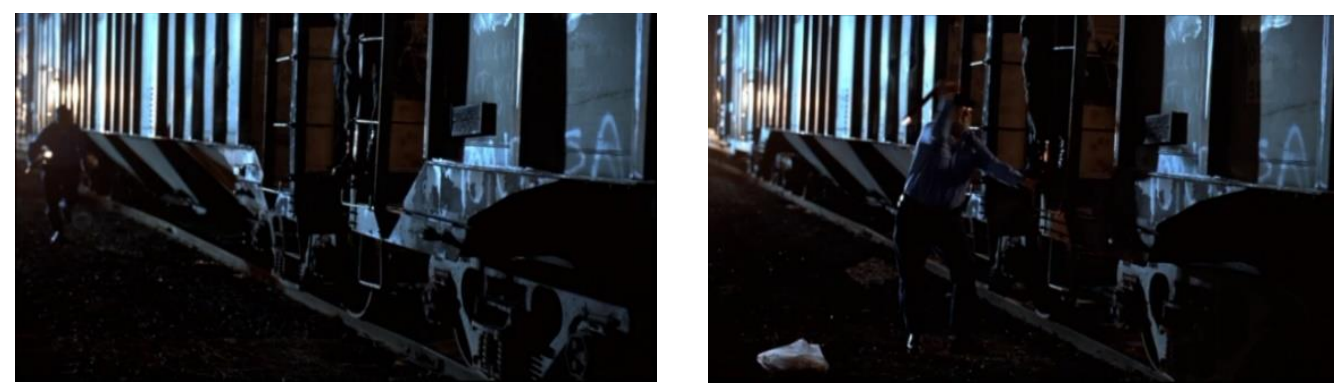

Alex, em cima do vagão, bate no segurança com seu skate. O segurança é atingido, perde o equilíbrio, afasta-se do trem onde Alex está e anda para trás, em direção à outra linha.
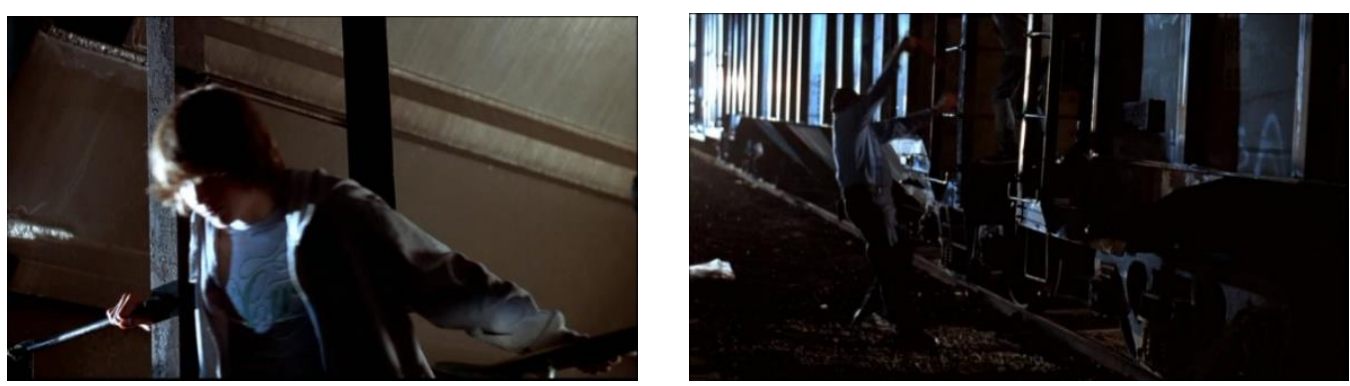

${ }^{132}[\ldots]$ He ran towards us. He was big, not fat exactly, but he kind of waddled in his security guard uniform [...]. The security guard went for me first. I was high up, so he could only reach my knees. But he took a vicious swing with his nightstick and I swear, if he had connected, he would have broken every bone in my leg [....]. The security guy had to jog beside it to keep up with us [...] (NELSON, 2006, p. 19). 
Ele não gritou. Não havia som algum, exceto pelo alto gemido metálico do trem. Fiquei onde estava. Eu não pude acreditar nos meus olhos. O trem continuou a se mover enquanto eu estava tremendo de adrenalina e choque. ${ }^{133}$

O segurança cai no trilho oposto, por onde onde outro trem aproxima-se. Alex vê o segurança ser atropelado.

Figura 71 - O vigia cai nos trilhos de um trem que se aproxima
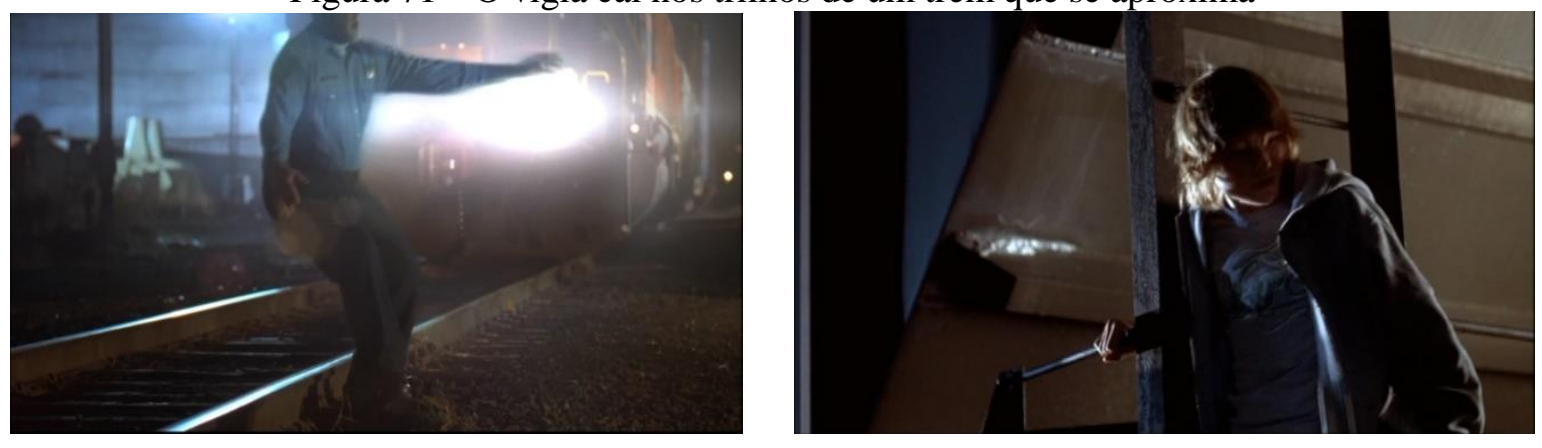

Detalhe das rodas do trem que atropela o segurança. $O$ trem vem, em ângulo perpendicular, na direção do observador, estático.

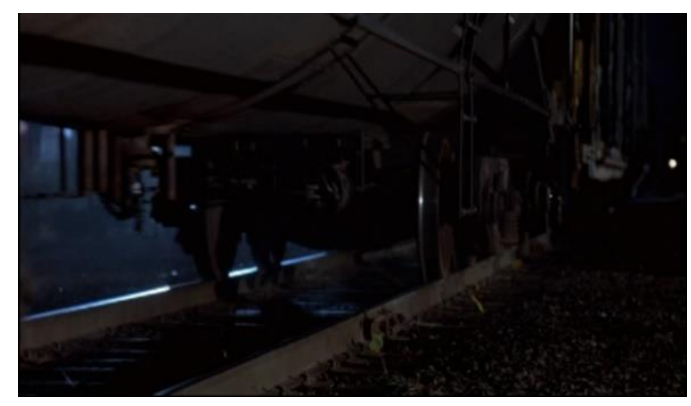

Eu não podia acreditar no que estava vendo: um homem cortado ao meio. Um homem deitado no cascalho em duas partes. Eu simplesmente não conseguia acreditar. Não era possível. Scratch se mandou. Ele correu pela estrada de cascalho, pulou a vala e subiu na margem de terra. Eu nunca vi alguém correr tão rápido na vida [...]. Eu não corri. Fiquei de pé. Vi meu skate a alguns metros de distância e o peguei. Olhei para o ponto escuro no chão onde o segurança estava. Dei alguns passos para frente. Senti que deveria fazer alguma coisa, como se eu devesse tentar ajudar. Uma terrível sensação de medo inundou meu peito.

O último carro do trem passou. Não havia vagão no final, apenas um último vagão. Segui o último carro até onde o corpo estava. Eu não pude

\footnotetext{
${ }^{133} \mathrm{He}$ didn't scream. There was no sound at all, except for the loud metallic groaning of the train. I stood where I was. I couldn't believe my eyes. The train continued to move while I stood trembling with adrenaline and shock (NELSON, 2006, p. 23).
} 
acreditar nos meus olhos. Bem na minha frente havia um corpo humano cortado ao meio. Um corpo humano que estava vivo apenas trinta segundos antes $^{134}$.

\section{(Velocidade normal da imagem)}

Os jovens, vendo o acidente, pulam do trem em que estavam e correm. O trem que atropela o segurança passa de perfil em primeiro plano, cruzando a imagem.

Figura 72 - Trem passa de perfil

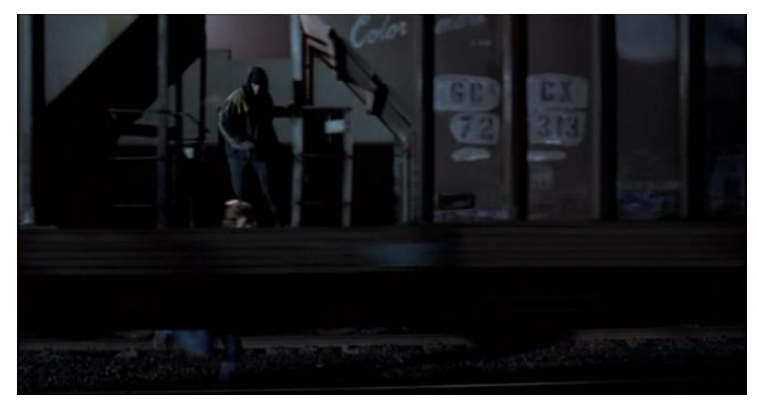

Ambos aproximam-se do local onde o segurança foi atropelado. Alex vai ao encontro do corpo e Scrach o segue. Ao ver o vigia nos trilhos, ele foge do local e abandona Alex.

Figura 73 - Garotos aproximam-se e observam o corpo do vigia atropelado
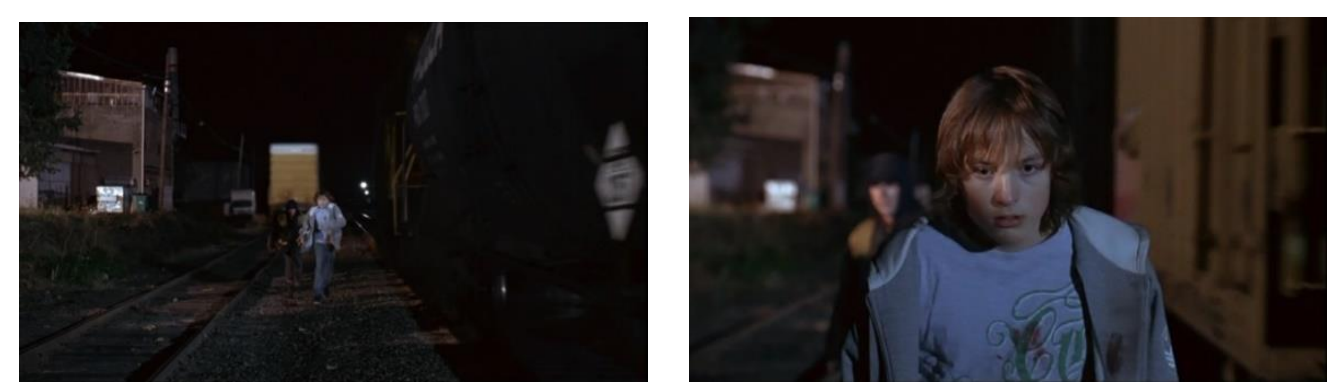

(Enunciados originais do filme)

\footnotetext{
${ }^{134}$ I couldn't believe what I was seeing: a man cut in half. A man, lying in the gravel, in two parts. I simply could not believe it. It was not possible. Scratch bolted. He sprinted down the gravel track bed, jumped the ditch, and scrambled over the dirt bank. I never saw anyone move so fast in my life [...]. I did not run. I stood. I saw my skateboard a few feet away and picked it up. I stared at the dark spot on the ground where the security guard lay. I took a few steps forward. I felt like I should do something, like I should try to help. A terrible sense of dread flooded into my chest. The last car of the train passed by. There was no caboose at the end, just one final boxcar. I followed that last car forward to where the body was. I couldn't believe my eyes. Right in front of me was a human body cut in half. A human body that had been alive just thirty seconds before (NELSON, 2006, p. 23).
} 
O trem que atropela o segurança passa em primeiro plano e revela ao fundo o corpo decepado do segurança que, ainda vivo, rasteja na direção do protagonista.

Figura 74 - O trem passa e revela o vigia e o protagonista juntos
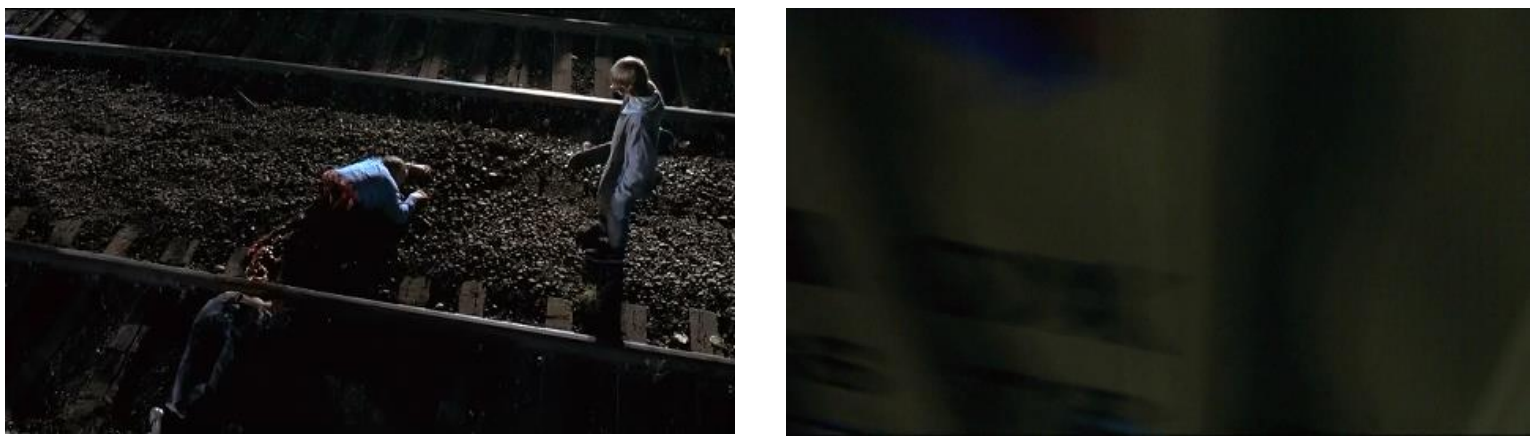

O segurança, arrastando-se no chão, aproxima-se levemente do narrador / ator e olha em sua direção. O protagonista, escrevendo sobre o acontecimento, na praia, olha para baixo na direção do corpo do segurança. Alex é mostrado primeiramente na praia, onde escreve suas memórias, no tempo presente.

Figura 75 - A cena do acidente é interligada por três faces
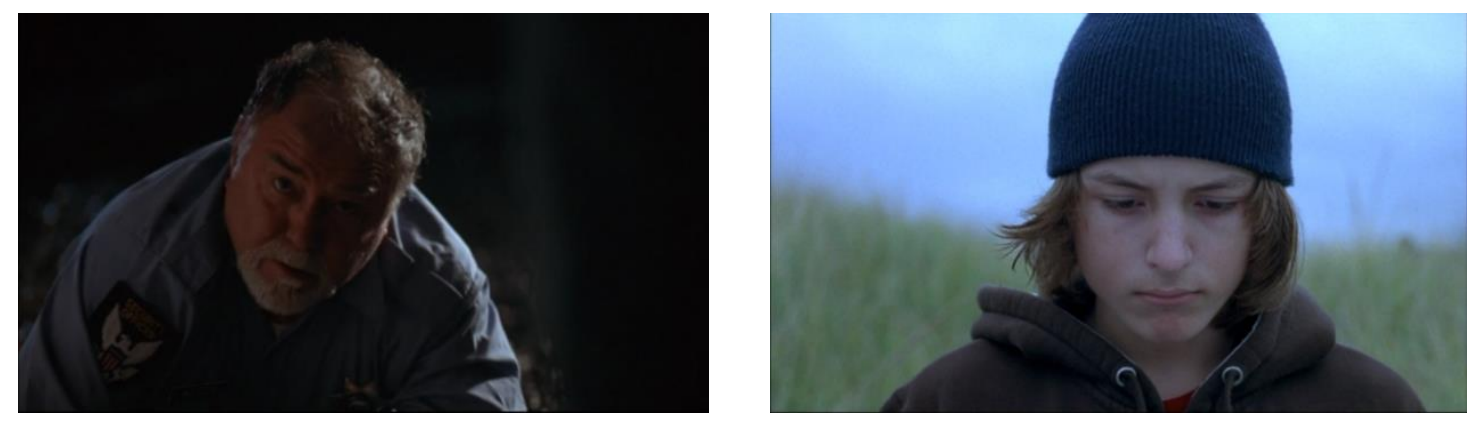

Depois é mostrado na entrevista com o investigador, na escola, sobre a morte do segurança, ocorrida quase um mês atrás. A expressão facial do jovem conota a memória e o trágico segredo, que é escondido do investigador. Finalmente, o discurso filmico volta ao presente da enunciação da memória, e o segurança é mais uma vez observado: seus olhos estão voltados para cima, na direção de Alex. 

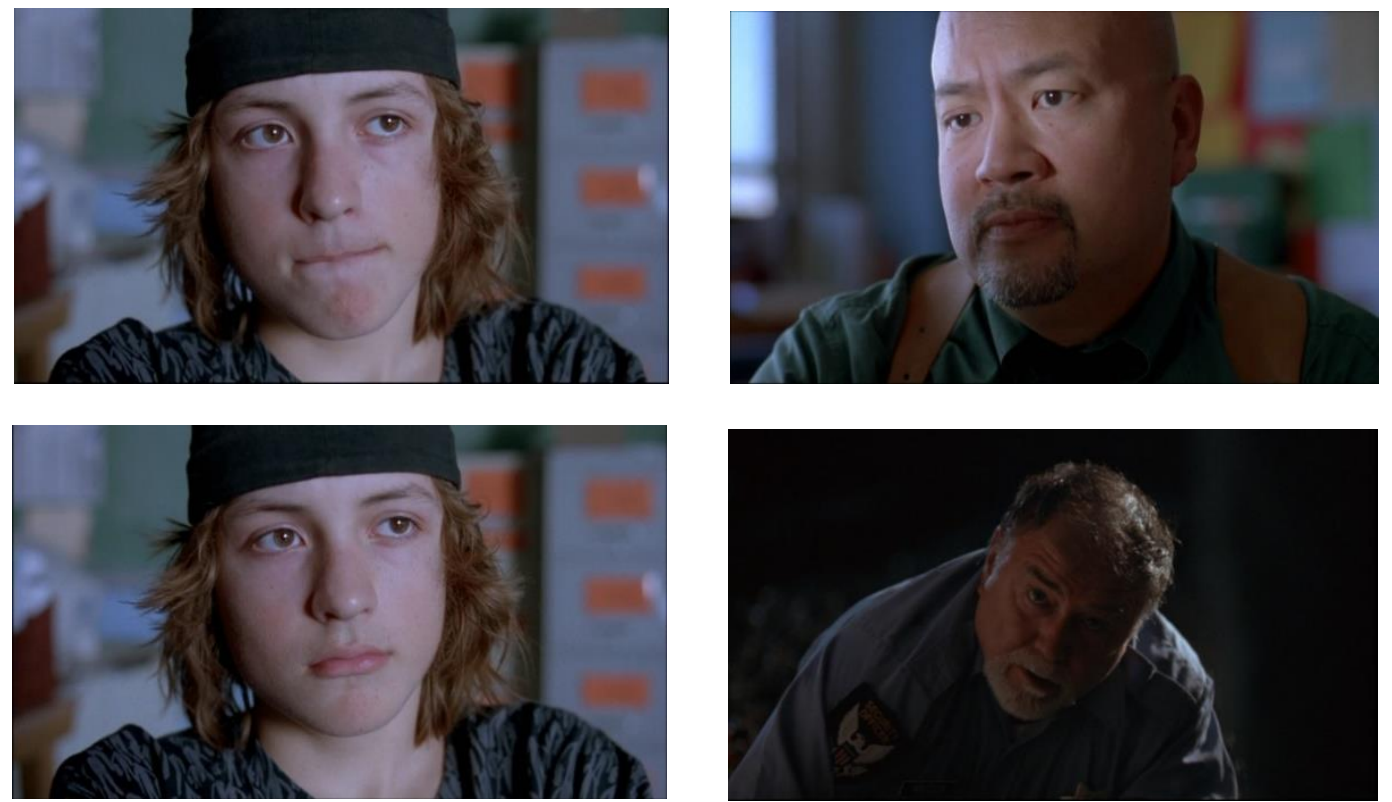

(de volta ao romance)

\section{O início do sobrevir}

Romance: Eu tropecei em algo e caí. Isso quebrou o feitiço. Olhei em volta. Onde eu estava? O que tinha acontecido? De repente, o ar ao meu redor parecia crepitar com energia ruim. Uma baixa corrente de medo pareceu obstruir os circuitos do meu cérebro. Eu senti como se estivesse fora do meu corpo, que meu corpo não era mais meu. Eu senti que todas as moléculas da Terra se voltavam contra mim. Meus pulmões não funcionavam. Não conseguia respirar. Abaixei a cabeça e tentei recuperar o fôlego. Eu tinha que chamar a polícia. Essa foi a primeira coisa. Tinha que ligar para alguém. Devia gritar socorro? Mas eu não conseguia respirar $[\ldots]^{135}$.

O observador volta para Alex, que está em choque. A passagem literária é sobrecarragada de descrições sobretudo somáticas e fisicas, revelando o corpo como espaço interno. No filme, olhando fixamente para baixo, o ator anda para trás, desiquilibrado, como se fosse desmaiar. Sua gestualidade conota a perda de controle do corpo.

Figura 76 - Alex, olha fixamente para o vigia no chão, em choque

\footnotetext{
${ }^{135}$ I tripped over something and fell. That broke the spell. I looked around. Where was I? What had just happened? Suddenly the air all around me seemed to crackle with bad energy. A low current of fear seemed to jam the circuits of my brain. I felt like I was out of my body, that my body was no longer my own. I felt every molecule on earth had turned against me. My lungs wouldn't work. I couldn't breathe. I lowered my head and tried to steady my breathing. I had to call the police. That was the first thing. I had to call someone. Should I yell for help? But I couldn't get any air [...] (NELSON, 2006, p.24).
} 


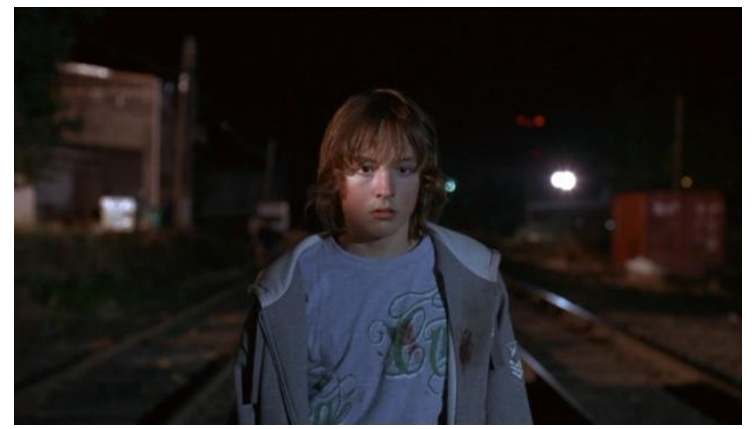

Eu comecei a andar. Fui ao carro do guarda de segurança. Ainda estava parado ao lado dos trilhos. A porta do lado do motorista estava aberta e a luz do lado de dentro acesa. [...] Deve ter um rádio dentro, eu pensei. Eu chamaria a polícia. Eu explicaria a eles o que aconteceu. Houve um terrível acidente. Eles precisavam vir imediatamente. Me inclinei para dentro do carro para encontrar o rádio, mas depois me dei conta de que não devia tocar em nada.

Não, eu não deveria tocar nas coisas. Deveria ter cuidado com isso. Apenas no caso... apenas no caso de eu precisar ... de quê?

Me afastei do carro. Tinha que pensar nisso. E se eu fosse acusado de alguma coisa? Foi um acidente, mas e se os policiais não o vissem assim? $\mathrm{Ou}$ se não foi um acidente. Eu bati nele com meu skate. Era contra a lei? Talvez tenha sido autodefesa. Eu não sabia. Eu tinha que pensar. Tinha que processar no meu cérebro exatamente o que tinha acontecido. Nós estávamos no trem... O guarda de segurança nos viu...

Não adiantou. Meu cérebro não funcionava. Não conseguia manter um único pensamento claro. Uma onda de pânico me varreu. Meu corpo inteiro tremeu violentamente. Eu senti algo escorrendo no queixo. Toquei minha bochecha. Eram lágrimas que escorriam pelo meu rosto.

Me afastei do carro. Tinha que ir a algum lugar onde pudesse me acalmar por um minuto e parar de surtar. Andei em uma direção, depois outra. Meu cérebro estava um caos e meu corpo em pânico total. Havia um grande estacionamento em frente aos trilhos. Fui na direção dele. Primeiro eu andei, depois fui mais rápido, então comecei a correr... ${ }^{136}$

No romance, o corpo continua sendo um conjunto de figuras que constroem o sobrevir.

Alex, no fílme, age como na descrição do romance: passa pelo carro do segurança, com a porta

\footnotetext{
${ }^{136}$ I started walking. I came to the security guard's car. It was still idling by the side of the tracks. The driver's side door was open, and the inside light was on. [...] There must be a radio inside, I though. I would call the police. I would explain to them what happened. There had been a terrible accident. They needed to come right away. I leaned inside the car to find the radio, but then I found I didn't want to touch anything. No, I shouldn't touch things. I should be careful about that. Just in case...just in case I needed...to what? I steeped back from the car. I had to think about this. What if I got accused of something? It was an accident, but what if the cops didn't see it that way? Or what if it wasn't an accident. I did hit him with my skateboard. Was that against the law? Maybe it was self-defense. I didn't know. I had to think. I had to process in my brain just exactly what had happened. We were on the train... The security guard saw us...It was no use. My brain wouldn't work. I could not maintain a single clear thought. Another was of panic swept through me. My whole body shook violently. I felt something ticking my jaw. I touched my cheek. Tears where pouring down my face. I backed away from the car. I had to go someplace where I could calm down for a minute and stop freaking out. I walked in one direction, then another. My brain was in chaos, and my body was in total panic. There was a big parking lot across from the tracks. I went toward it. I walked at first, then walked faster, then I started to run... (NELSON, 2006, p. 25).
} 
aberta, e pensa em se comunicar com a polícia. O jovem entra no carro, mas desiste, e continua correndo para longe. Nesse trecho, a descrição continua a enfatizar as paixões e sensações que o ator sofre: ele não consegue pensar, o corpo treme, ele chora e sente-se em pânico, e começa a correr.

Figura 77 - Alex pensa em pedir ajuda no rádio do carro do segurança, mas foge
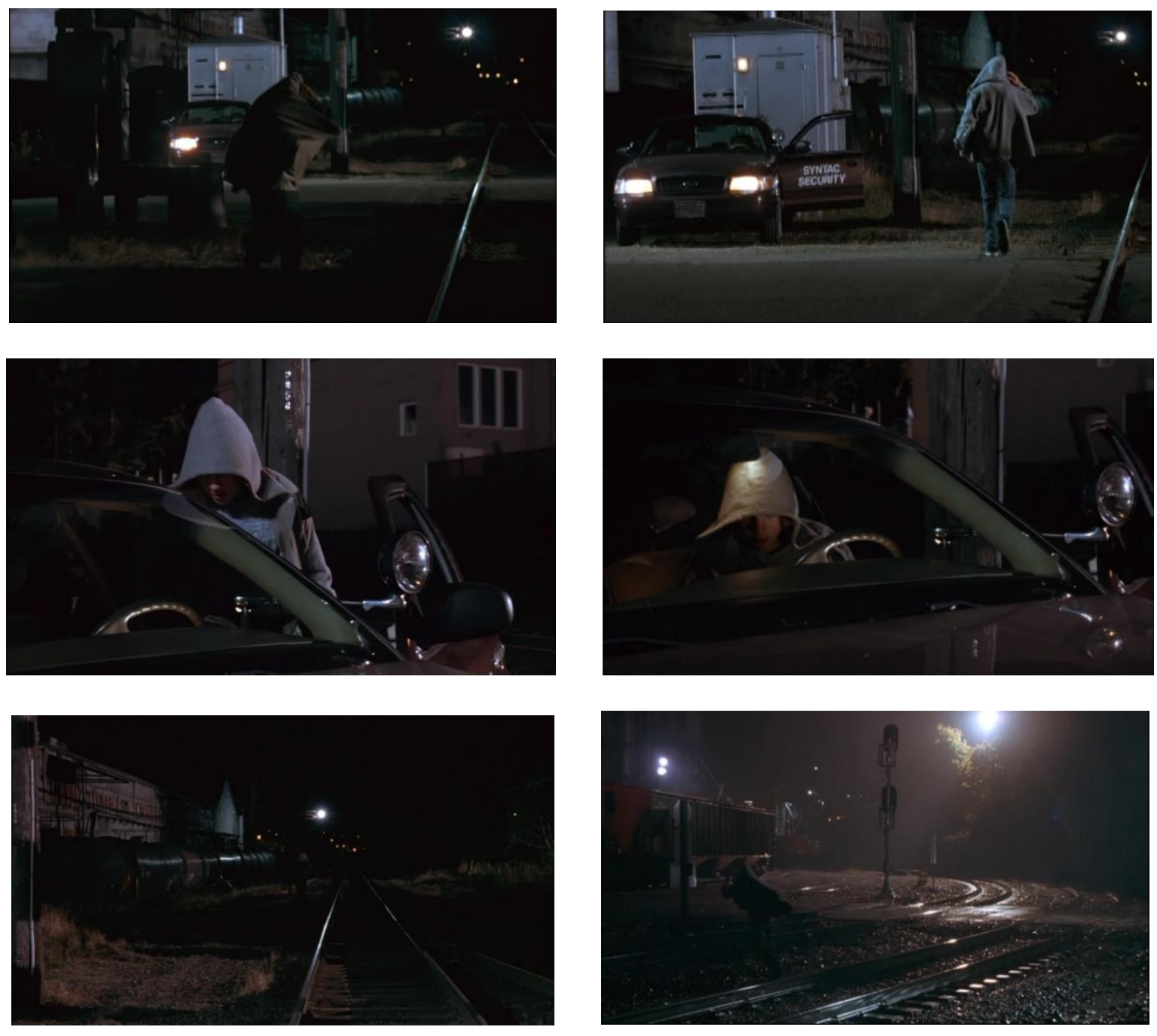

Chove e relampângos iluminam o céu. A cor e a nitidez da imagem são alteradas e suas categorias plásticas oscilam. O conteúdo figurativo chuva e relâmpagos, e a manipulação das categorias plásticas, de um lado conotam o estado emocional do jovem, e de outro constroem uma figura proposta pelo romance: o narrador / ator, quando vê o corpo do segurança nos trilhos, nos conta que o ar estava cheio de eletricidade. Apesar disso, enquanto no romance não chove, no acontecimento do texto filmico há uma chuva constante. A figuração espacial e temporal do acontecimento, no filme, composta de noite escura, chuva e ar estático remetem à 
práxis de outras enunciações filmicas, outras práticas de ajuste de sentido, utilizadas pelo cinema para conotar disforia. ${ }^{137}$

Figura 78 - Chuva e relâmpagos que não existem no texto original, mas figuram a ideia de eletricidade no ar
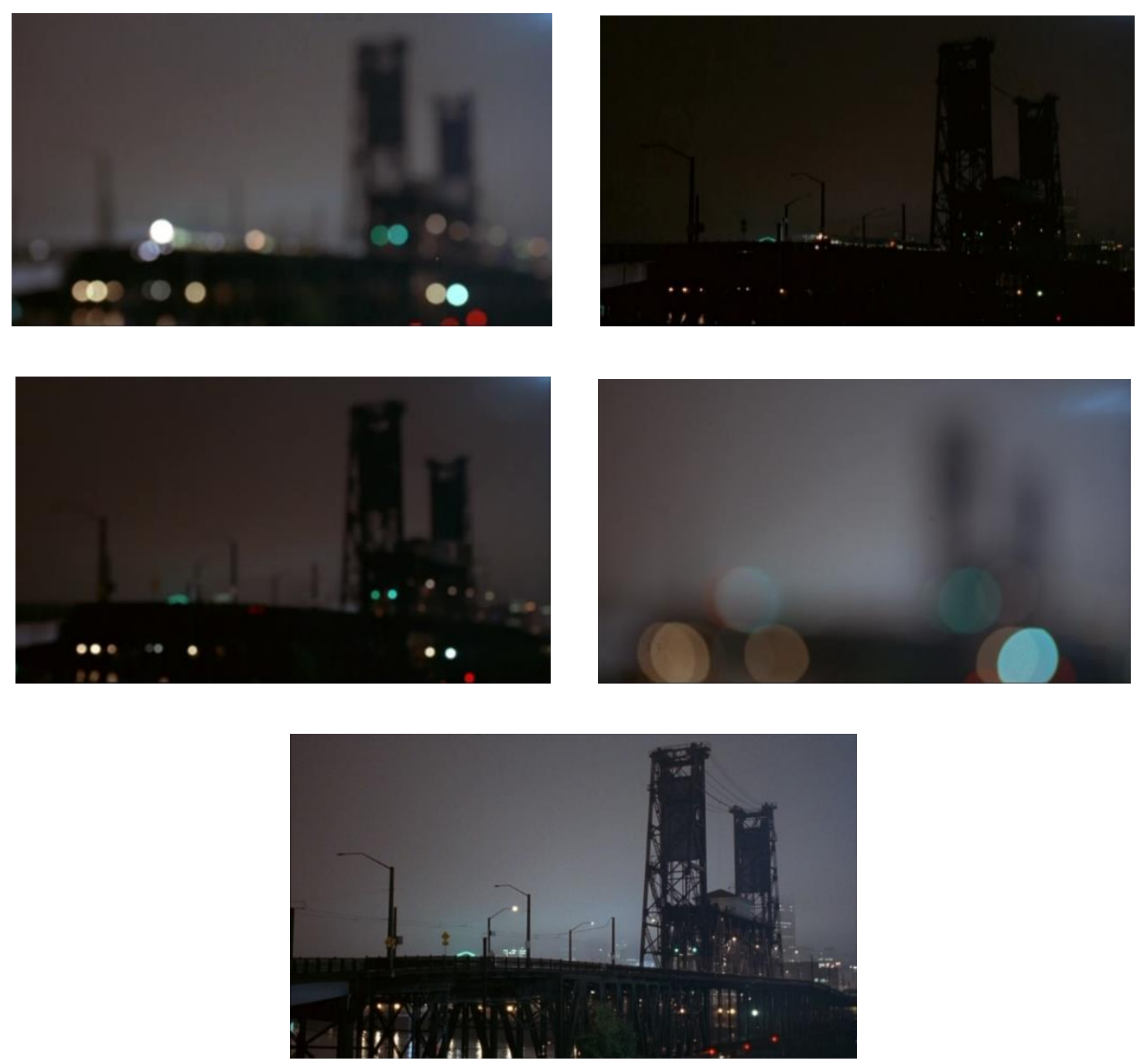

Carta 4: [...] Uma hora tive que atravessar o rio para chegar ao meu carro [...]. Caminhei. Ondas de pânico me atingiam. Queria, mais do que tudo, correr. Mas não conseguia. Tinha que manter a calma. Tinha que agir normalmente [...]. "Não, policial, é como eu te disse, nós apenas pulamos por um segundo, só para ver como era, e então esse cara de segurança nos atacou totalmente do nada. Ele estava tentando nos matar, eu juro que ele estava ..." [...]. "Não, oficial, eu te disse, eu não conhecia o outro cara. Eu tinha conhecido eles cinco minutos atrás. Por que você precisa mesmo de uma descrição dele? Ele não fez nada. O guarda é quem fez alguma coisa. Ele nos atacou. Vá

${ }^{137}$ Tais tipos expressivos são utilizadas em todos os gêneros filmicos. Podemos pensar em crimes, noites chuvosas e relampagos em narrativas de terror, drama, e em comédias. 
encontrar aquele cassetete, você verá por si mesmo. Tinha chumbo naquilo. Ou alguma coisa. Eu juro que sim..." [...]. "Eu sou apenas uma porra de criança, pelo amor de Deus! Eu tava assustado! O que você faria? O que deveria ter feito? Ele tinha um cacetete de ferro. Ele estava tentando matar a gente! É difícil de entender?" (itálico original). ${ }^{138}$

Enquanto Alex, tomado pelo medo e pelo pânico, dirige-se ao seu carro, ele fala sozinho e pensa. Na verdade é a primeira fez que há na sequência uma pequena mistura de voz diegética e vozover, de modo que até esse momento, toda a ação é encoberta por ruídos diegéticos e música (exceto o momento em que Scratch conversa com Alex, em cima do trem). Além da superposição da voz diegética e da voz-over, há uma pequena falta de sincronização entre som e imagem, de modo que os pensamentos confusos, construídos a partir de sobreposição sonora e manipulação sincrônica audiovisual figuram o estado emocional de medo causado pelo sobrevir. Alex percebe que suas roupas estão sujas. O observador movimenta-se e acompanha o personagem.

Figura 79 - Alex foge perdido em pensamentos (falas no filme sobrepostas)

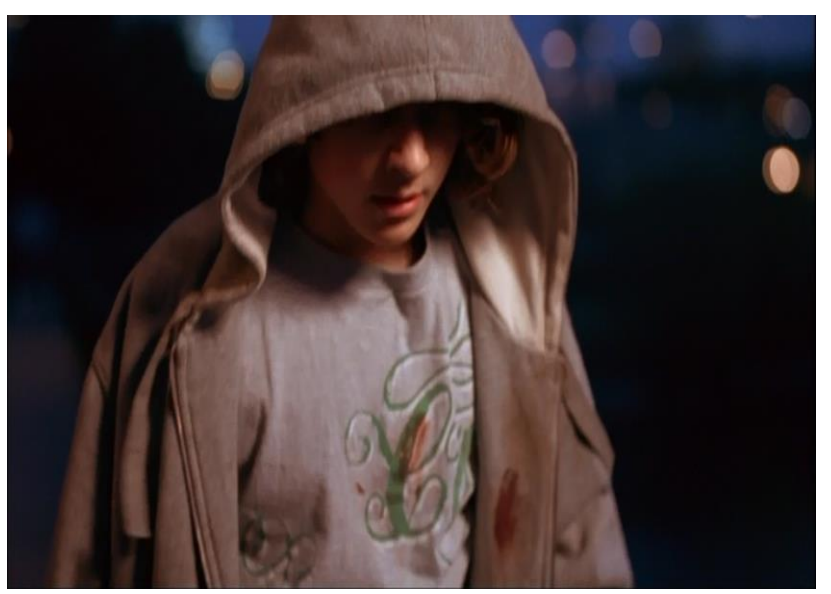

Ele tentou matar a gente.

Ele tinha um ferro na mão.

Por que não entendem? Chame a polícia.

Tudo bem Alex, você não vai para

cadeia.

Ligue para casa. Estou ferrado.

Chame alguém. Foi legitima defesa.

Diga a verdade ou vai ser pior.

Mas foi verdade mesmo?

É normal tentar se defender.

E se a culpa não foi sua?

Preciso contar para alguém.

Chame um advogado.

Como meu irmão vai ficar?

Fica calmo Alex. O que meu pai faria?

Eu olhei para as minhas mãos de novo, rapidamente, secretamente. Elas estavam sujas, esfoladas; um dos meus dedos sangrava. Olhei a minha camisa encardida. Tinha sangue nela, algumas manchas abaixo do cinto. De quem era aquilo? [...] Então eu notei o meu skate. Estava sujo, também. Examinei o bico dele. Estava levemente rachado [...]. Aí eu vi sangue, ou algo parecido. Havia uma minúscula mancha preta, bem no lugar que a ponta atingira o

\footnotetext{
138 [...] I had to cross the river at some point, to get to my car [...]. I walked. Waves of panic hitting me. I wanted to run. I wanted to run more than anything. But I couldn't. I had to stay cool. I had to act normal [...]. "No, Officer, it's like I told you, we just hopped on for a second, just to see what it was like, and then this security guy attacked us totally out of nowhere. He was trying to kill us, I swear he was...". [...] "No, Officer, I told you, I didn't know the other kid. I just met him five minutes before. Why do you even need a description of him? He didn't do anything. The guard is the one who did something. He attacked us. Go find that nightstick, you'll see for yourself. It had lead in it. Or something. I swear it did...". [...] 'I'm just a frickin' kid for chrissakes! I was scared! What would you do? How am I supposed to know what his problem was? He had a lead bat. He was trying to kill us! Why can't you understand that?" (NELSON, 2006, p. 28, 29, 30, 31).
} 
segurança. Joguei ele da ponte. Eu joguei meu skate de cima da ponte. Não foi minha decisão. Aconteceu. Joguei meu skate da ponte como se fosse uma batata quente queimando minhas mãos. Eu não vi ele bater na água. Não olhei. Enfiei minhas mãos sujas nos bolsos e fingi que nunca havia andado de skate. ${ }^{139}$

No filme, Alex também verifica que suas roupas estão sujas e as joga, junto com o skate, no rio. Enquanto no romance as ações de Alex são descritas até ele chegar ao carro, e também seus pensamentos ao dirigir à casa de Jared, o texto filmico opera uma elipse e mostra o jovem já na casa do amigo, em sua cozinha.

Figura 80 - Alex joga as roupas e o skate no rio
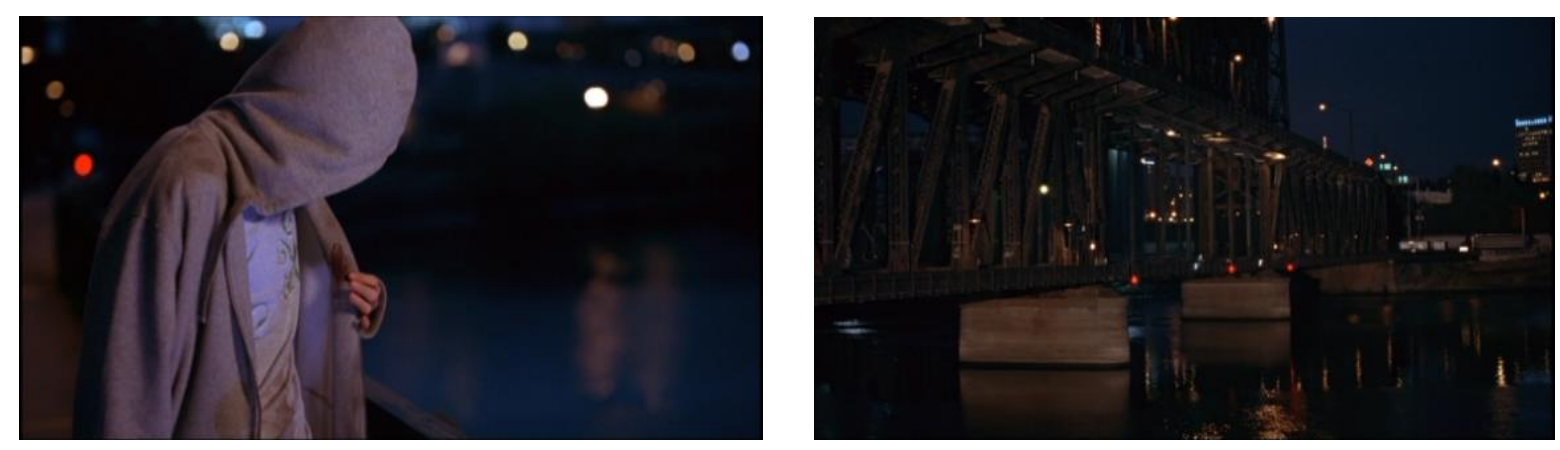

\subsubsection{Parte 2 do acontecimento: Na casa de Jared}

[...] A primeira coisa que fiz foi me limpar [...] Arranquei meus sapatos. Tirei minhas meias brancas, que tinham anéis escuros de sujeira ao redor do tornozelo. Enfiei as meias dentro dos sapatos. Entrei com os pés descalços na cozinha de Jared e encontrei um saco de lixo de plástico embaixo da pia. Coloquei meus sapatos e meias na bolsa. Então, de pé na cozinha dos Fitch, tirei minha camiseta e coloquei-a cuidadosamente na sacola plástica. ${ }^{140}$

Figura 81 - Na cozinha da casa do amigo, Alex põe as suas roupas sujas em um saco plástico

\footnotetext{
${ }^{139}$ I looked at my hands, quickly, secretly. They were dirty, scraped; one of my fingers was bleeding. I looked at my blackened shirt. There was blood on it, a couple spots down my belt, whose was that? [...] Then I looked at my skateboard. It was dirty, too. I looked at the front of it. It was slightly cracked at the very front [...]. Then I saw blood. Or something. There was a tiny black spot right where the point had hit the security-guard. I threw it off the bridge. I threw my skateboard over the side of the bridge. I didn't decide to do it; it just happened. I threw my skateboard off the bridge like it was a hot potato, burning my hands. I didn't see it hit the water. I didn't look. I jammed my dirty hands in my pockets and pretended like I had never had a skateboard (NELSON, 2006, p. 32). ${ }^{140}[\ldots]$ The first thing to do was clean up [...]. I yanked my shoes off. I took off my white socks, which had dark rings of dirt around the ankle. I stuffed the socks inside my shoes. I tiptoed barefoot into Jared's kitchen and found a plastic garbage bag under the sink. I put my shoes and socks in the bag. Then, standing in the Fitches' kitchen, I peeled off my T-shirt and put it carefully in the plastic bag (Ibid., p. 36, 37).
} 


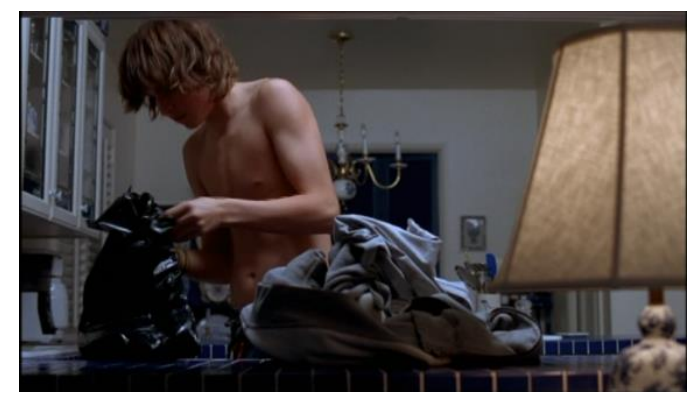

Então notei a janela sobre a pia. Dava para a rua. Os vizinhos do outro lado da rua podiam me ver. Me abaixei e fui para o corredor, onde não podia ser visto, e terminei de me despir. Não tinha exatamente um plano, então coloquei todas as minhas roupas no saco de lixo ${ }^{141}$.

Figura 82 - Alex percebe que pode ser observado do lado de fora, agacha-se, e atravessa a sala engatinhando
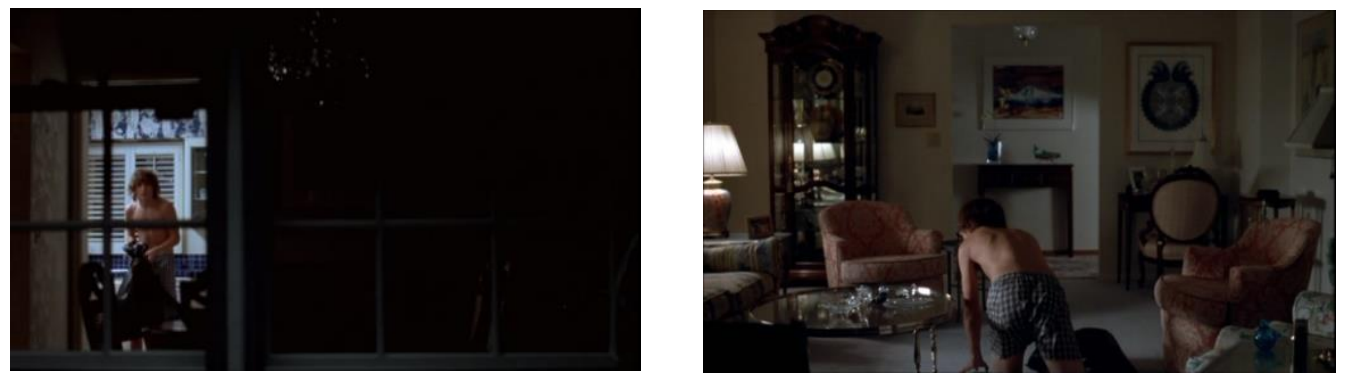

Eu fui para o banheiro e liguei a água do chuveiro [...]. Fechei os olhos e deixei a água quente bater nas costas e no pescoço. Tentei relaxar, ou pelo menos parar de tremer. Mas não adiantou. Não podia parar. Meus lábios tremiam incontrolavelmente.

Então, de repente, comecei a chorar. Eu não conseguia parar. Eu chorava e soluçava. Chorei e solucei e gemi até que não pude mais ficar de pé. Tive que sentar no fundo da banheira enquanto a água quente caia na frente da minha cabeça. Depois que chorei por um longo tempo, comecei a falar. Eu não sei com quem falava. Deus talvez. Eu ficava dizendo que sentia muito. Eu não queria fazer isso. Perguntei por que isso aconteceu. O que fiz para merecer aquilo? Não era uma pessoa violenta. Nunca entrei em brigas. Não era justo. Não era justo... ${ }^{142}$

${ }^{141}$ Then I noticed the window over the sink. It faced the street. The neighbors across the street could see me. I ducked down and slunk into the hall, where I couldn't be seen, and finished undressing. I didn't have a plan exactly, so I put all my clothes in the garbage bag (NELSON, 2006, p.37).

${ }^{142}$ I stood in the shower and turned on the water [...]. I closed my eyes and let the hot water beat on the back and neck. I tried to relax, or at least stop shaking. But it was hopeless. I couldn't stop. My lower lip trembled uncontrollably. Then I started to cry. It happened suddenly, and once it started I couldn't stop. The tears and sobs came pouring out of me. I cried and sobbed and moaned until I couldn't stand up anymore. I had to sit on the bottom of the tub while the hot water poured over the front of my head. After I'd cried for a long time, I started to talk. I don't know who I was talking to. God maybe. I kept saying I was sorry. I didn't mean to do it. I asked why this had happened. What had I done to deserve this? I wasn't a violent person. I never got into fights. It wasn't fair. It was so not fair...(Ibid., p.38). 
No filme Alex entra no chuveiro, olha para cima e fecha a cortina de plástico. A sequência é longa e o enunciador audiovisual manipula a imagem de modo que, como foi visto acima no caso da tempestade, alteram-se rapidamente categorias plásticas eidéticas, relacionadas a formas e à nitidez. A trilha sonora é composta de uma música eletroacústica que emite um som vibratório cujo volume aumenta à medida que dura. A música é mixada com sons que podem ser parcialmente reconhecidos, lembrando passos em folhas secas e trinados de pássaros, como se alguém caminhasse em uma floresta. As imagens e o som intensificam a ideia do sobrevir e constroem as sensações de pânico do jovem, que parecem crescer.

Figura 83 - Alex no chuveiro, chora e se desespera, em uma imagem que vai da figura ao ícone, e do ícone à figura

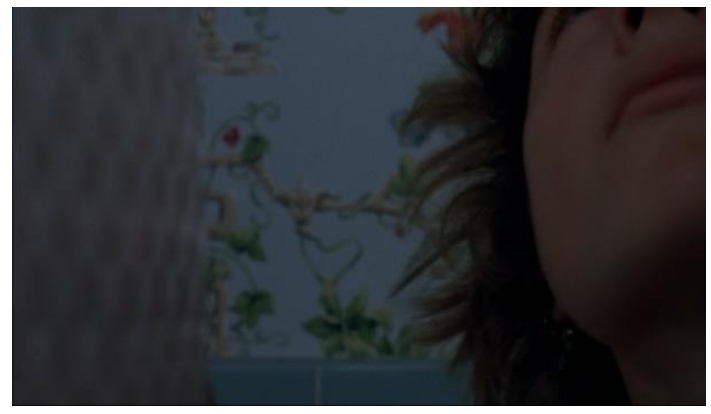

Ícone (imagem mais concreta)
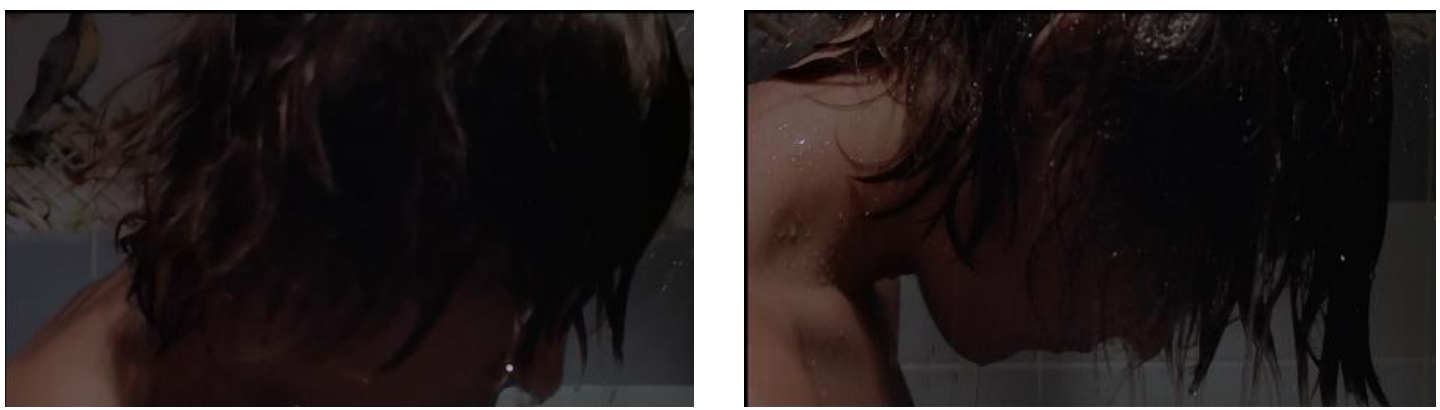

Figura (imagem mais abstrata)
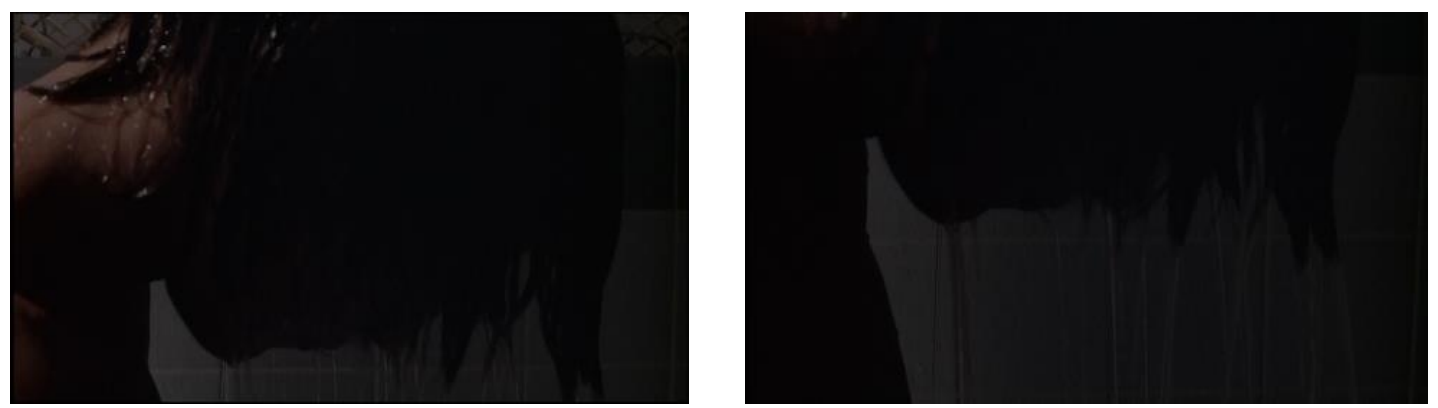
Ícone
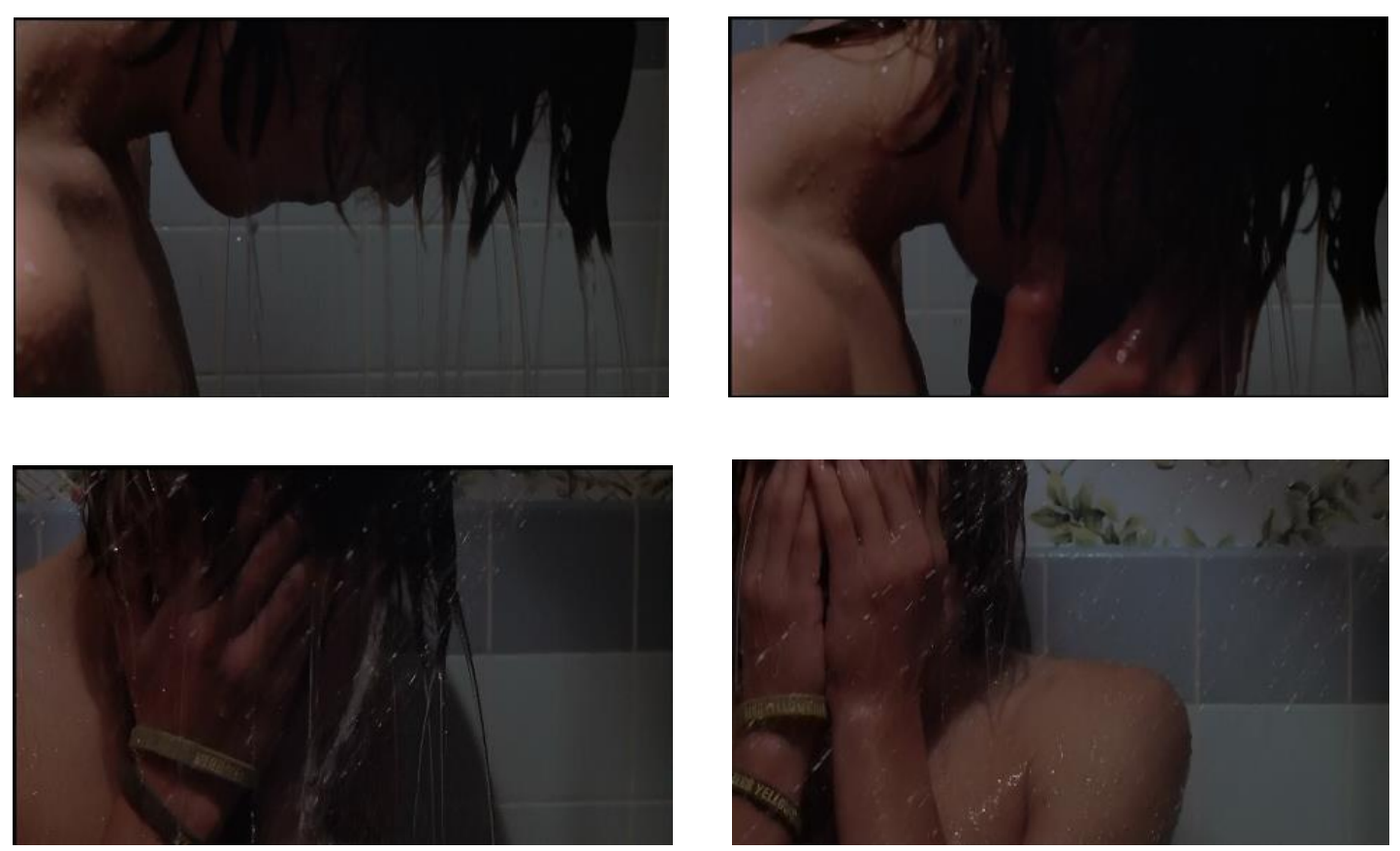

Durante a cena do banho, sons de pássaros são ouvidos, enquanto percebem-se desenhos de pássaros no azulejo do banheiro, ao lado esquerdo da cabeça do jovem. Alex abaixa-se.

Figura 84 - Pássaros cantam no chuveiro
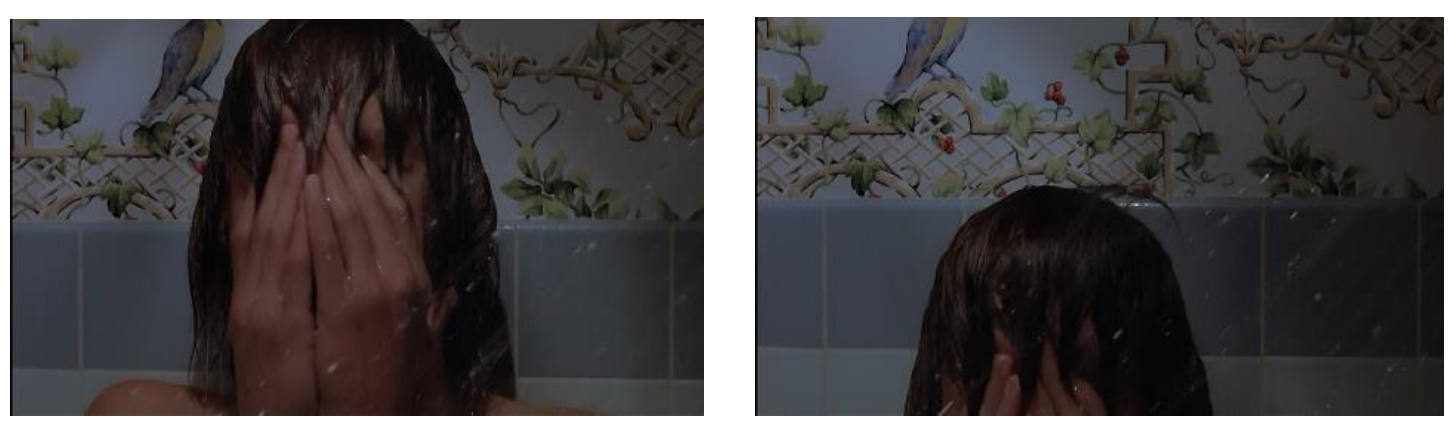

Há um corte e o pânico do jovem continua. Ele se abaixa no chuveiro, e as características plásticas da imagem oscilam, perdendo a cor e a nitidez, até a imagem quase desaparecer, ficando escura, figurando os estados patêmicos do jovem. 
Ícone
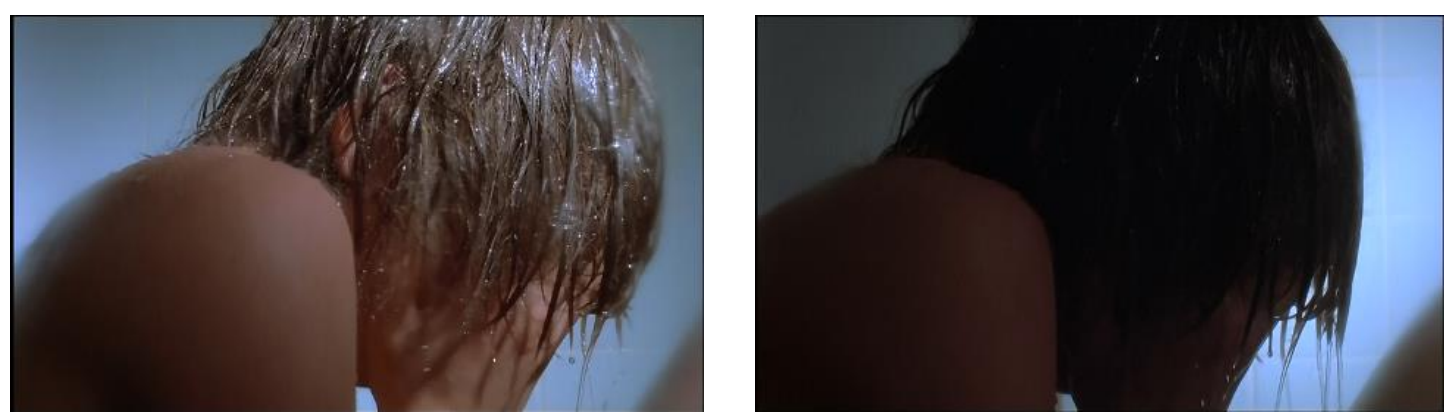

Figura

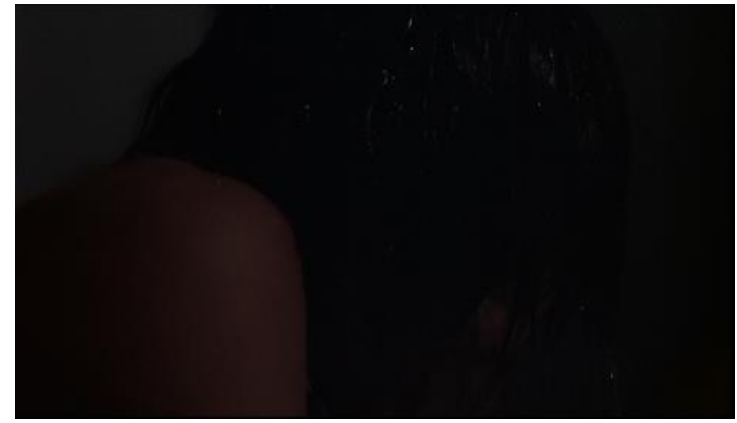

No quarto de Jared me senti melhor [...] Fui ao armário dele e abri a gaveta de cima. Precisava de roupas limpas. Mexi nas coisas dele. Encontrei alguns boxer shorts [...]. Encontrei alguns shortes largos e vesti. Encontrei um grande moletom Rampage e umas meias grossas e as coloquei. ${ }^{143}$

Depois do banho Alex veste as roupas de Jared e deita-se na cama do amigo. Percebese que ele é reenquadrado no filme. O quadro é cortado duas vezes, em um PA (plano americano) que torna-se estreito por causa dos batentes da porta, centralizando sua imagem ainda mais e enfatizando a sua solidão:

\footnotetext{
${ }^{143}$ Jared's room I felt better [...] I went to Jared's bureau and opened the top drawer. I needed clean clothes. I pawed through Jared's stuff. I found some boxer shorts [...]. I went back to the bureau and found some baggy shorts and put them on. I found a big Rampage hoodie and some thick white socks and put those on (NELSON, 2006, p. 38, 39).
} 
Figura 85 - Alex troca de roupa em duplo enquadramento

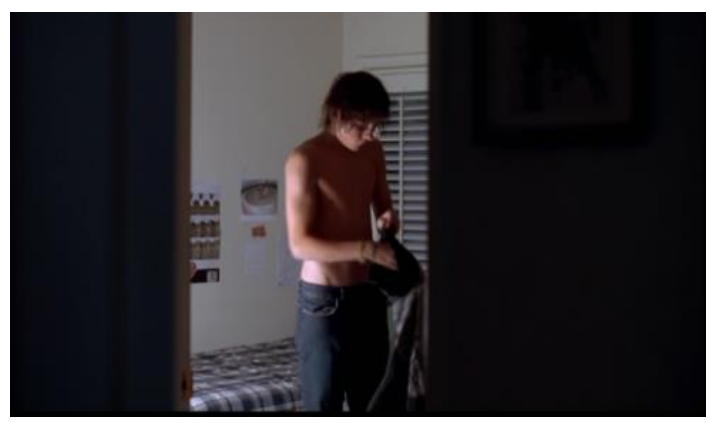

Dormi na cama de Jared, de roupa. Sonhei que estava em uma delegacia de polícia, sentado em uma cadeira, em um corredor. Mas não era exatamente uma delegacia de polícia; era mais como um hospital. ${ }^{144}$

No filme Alex não sonha, mas parece pensativo. Sua face primeiramente é mostrada fora de foco, depois fica nítida, oscilando entre inacessibilidade e exibição, e da figuração à iconicidade. Depois de uma fusão, cujo tempo da exibição do rosto do jovem é maior, e sua imagem é mesclada à imagem seguinte, a uma sequência de cenas de skate que parecem descrever o conteúdo de seus pensamentos. As imagens possuem, como as outras associadas ao skate, textura granulada, e são acompanhadas por música eletroacústica.

Figura 86 - Alex imagina
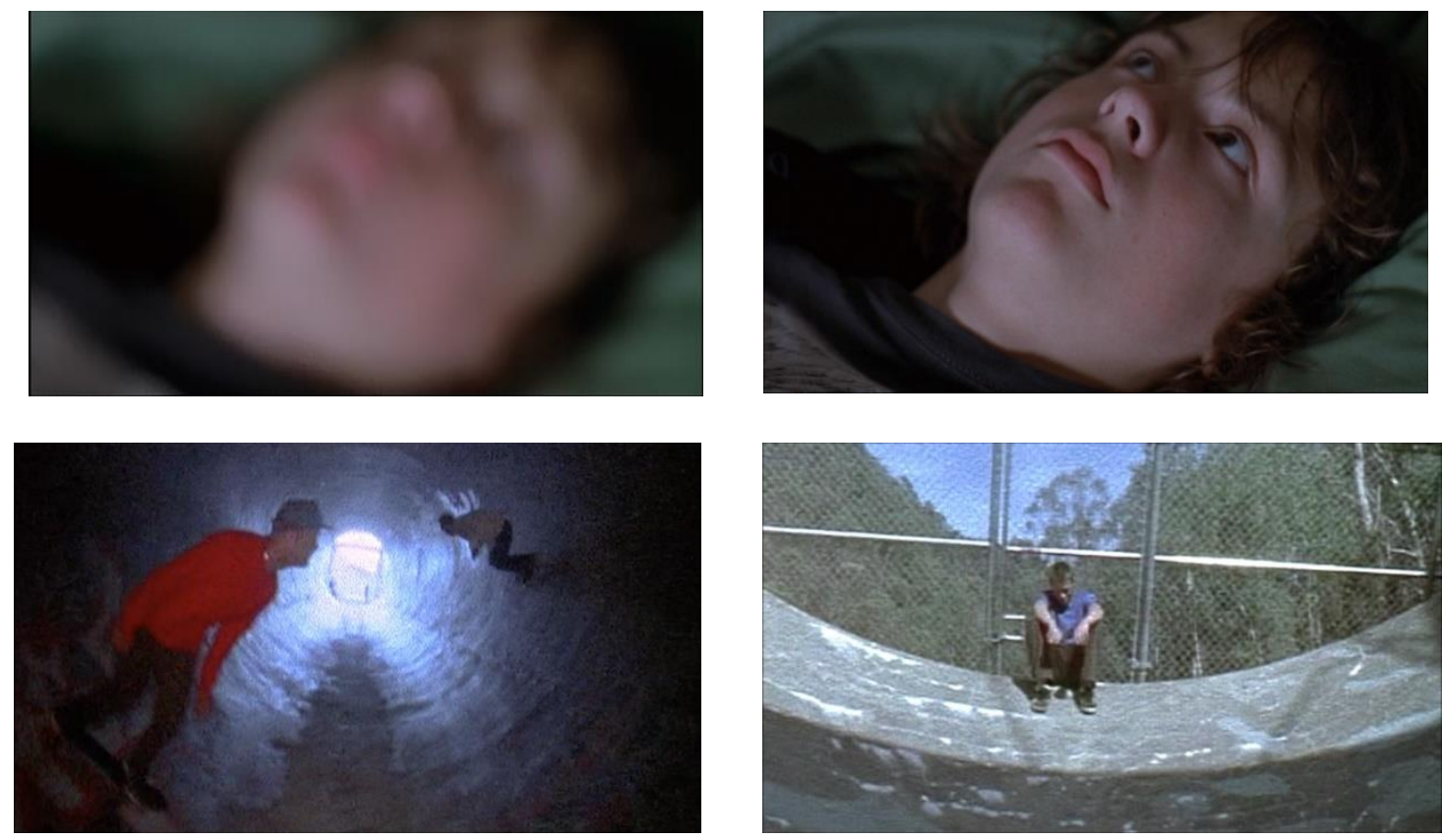

${ }^{144}$ I fell asleep on Jared's bed with my clothes on. I dreamed I was in a police station, sitting on a chair, in a hallway. But it wasn't exactly a police station; it was more like a hospital (Ibid., p.40). 

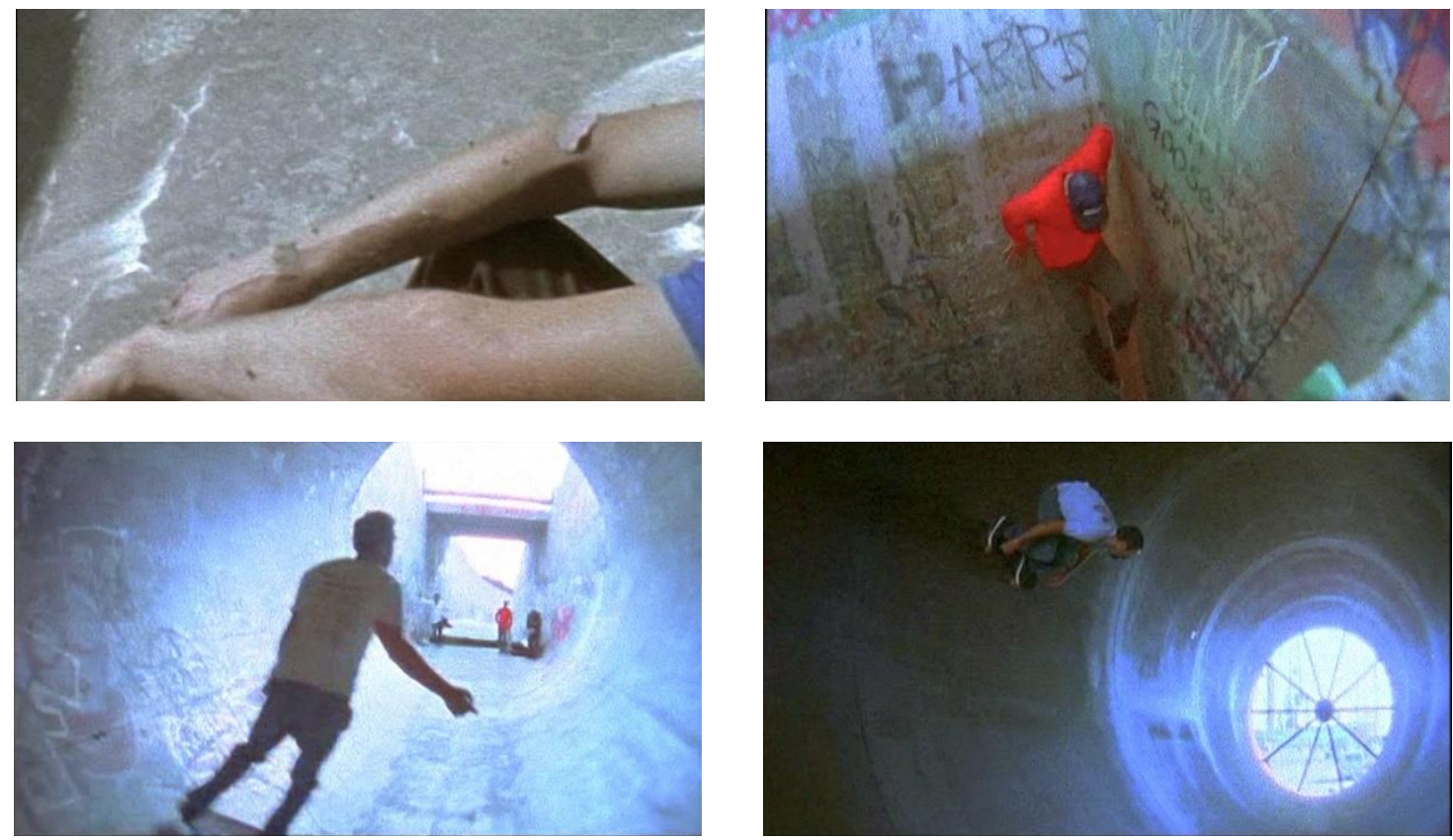

Figura 87 - $\mathrm{O}$ ator sai de seu torpor e abre os olhos

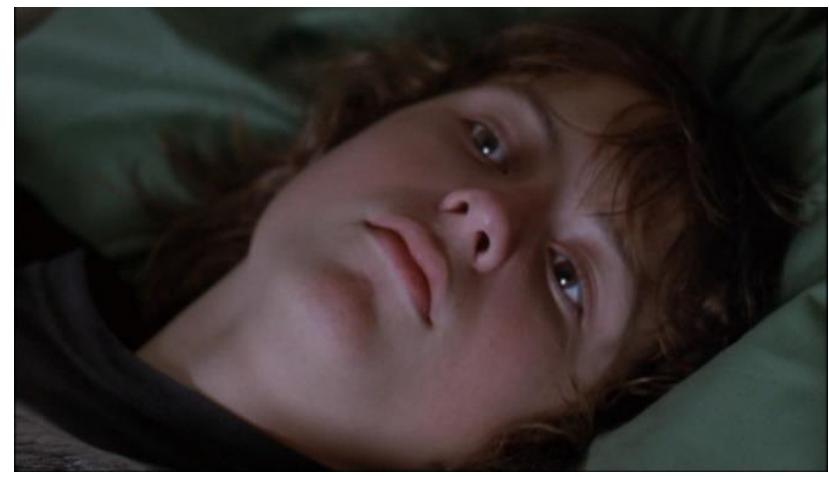

Acordei num pulo [...] Não devia perder tempo. Precisava falar com alguém. Precisava agir e tirar esse peso de mim. Meu pai. Essa era a pessoa com quem conversar. Eu sabia onde ele estava - no meu tio Tommy. Liguei a luz e encontrei o telefone portátil de Jared. Já podia sentir o alívio de contar a ele...Disquei o número do meu tio. Mas não consegui me lembrar dos últimos quatro números. Tentei novamente. Ainda não conseguia lembrar. Disquei 411. A voz automática me deu o número dele. Ela ofereceu para me conectar por cinquenta centavos, mas como era o telefone de Jared, então eu desliguei e liguei por mim mesmo. Esperei. Meu coração começou a bater. O telefone chamou. Meu coração batia no peito. Tocou uma, duas vezes, e desliguei. Que idiotice. O que estava fazendo? Tinha que ligar para o meu pai. Comecei a discar novamente, e parei de novo. Não. Não envolva sua família. Eles não fizeram isso. Eles são inocentes. Eu deveria ligar para a polícia. Mas quem eu estava enganando? Não havia como ligar para a polícia. Comecei a chorar de novo [....$^{145}$

${ }^{145}$ I woke up with a start [...] I shouldn't waste time. I needed to talk to someone. I needed to take action and get this weight off me. My dad. That was the person to talk to. I knew where he was - at my uncle Tommy's. I turned on the light and found Jared's portable phone. I could already feel the relief of telling him...I dialed my uncle's number. But I couldn't remember the last four numbers. I tried again. But I still couldn't remember. I dialed 411. 
(Fala no filme em voz-over): Eu estava ferrado. O que ia fazer? Eu não podia perder tempo. Precisava falar com alguém. Tinha que fazer alguma coisa e tirar esse peso de cima de mim. Meu pai era a pessoa certa para conversar. Eu sabia onde ele estava: na casa da praia, com meu tio Tommy. Eu já podia sentir um alívio de contar para ele.

Figura 88 - Alex tenta ligar para o pai, mas desiste e chora
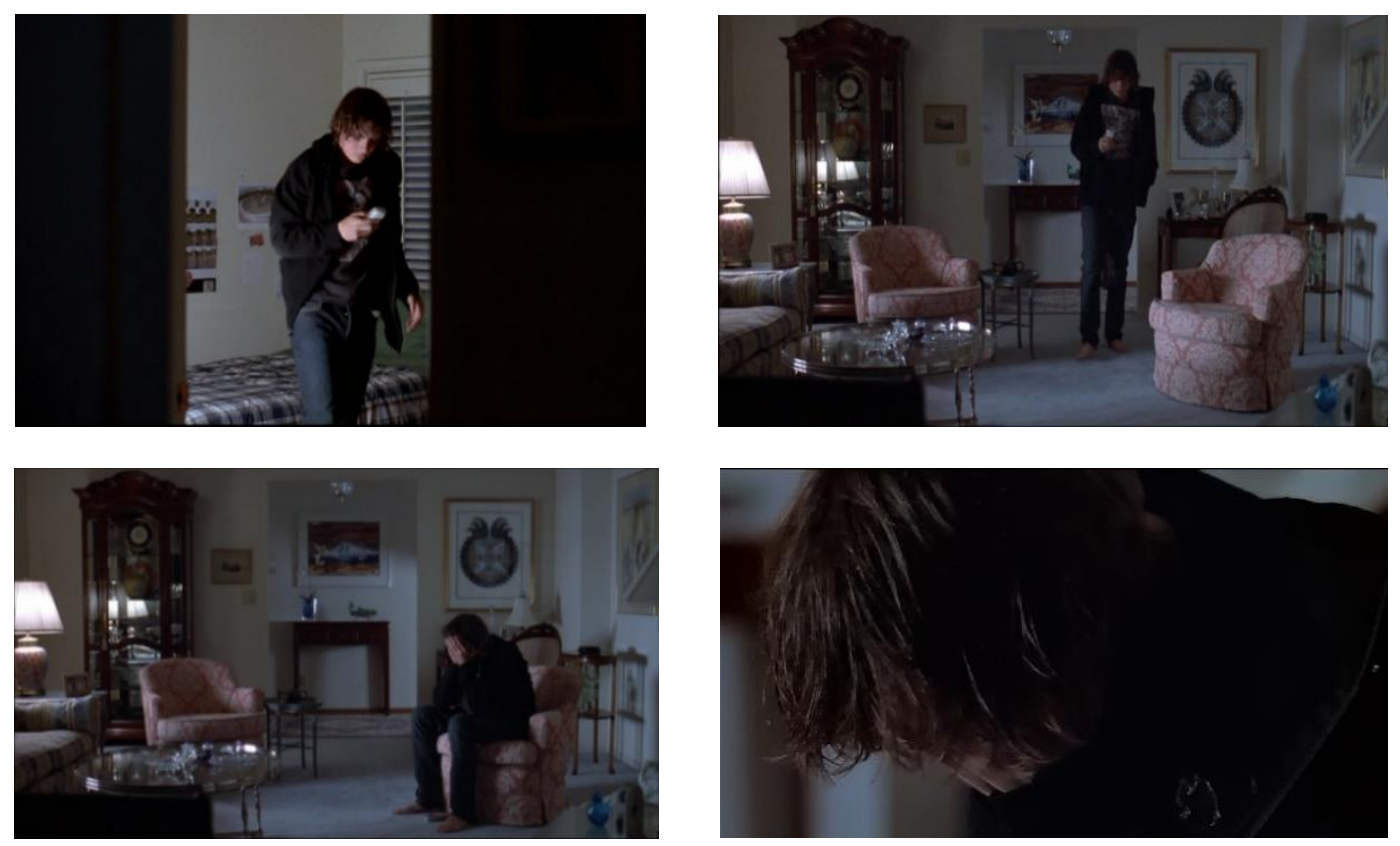

Dormi mal, cochilando e acordando. Às sete da manhã, acordei de uma vez e me preparei para ir embora ${ }^{146}$

Figura 89 - Exausto, Alex dorme, e no dia seguinte vai para a casa
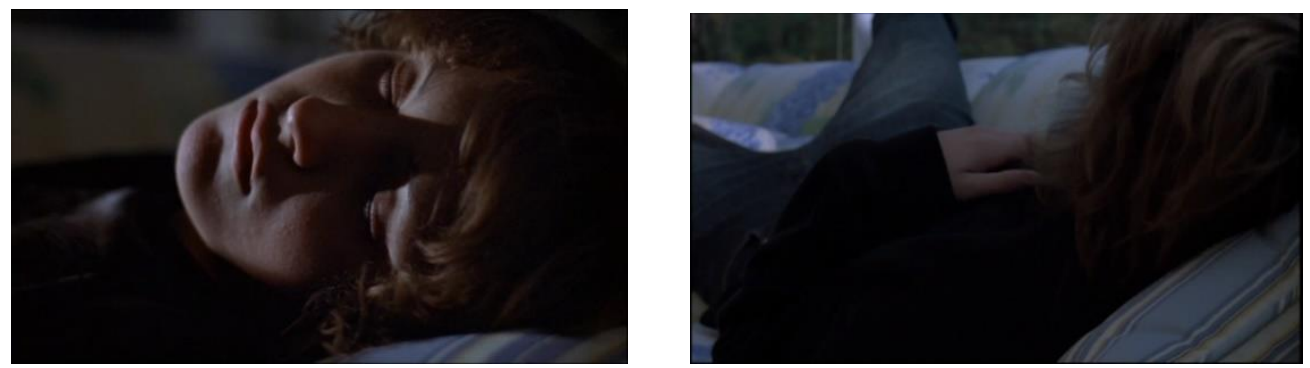

The automated voice gave me my uncle's number. It offered to connect me for fifty cents but it as Jared's phone, so I hung up and dialed it myself. I waited. My heart began to pound. It connected. My heart thudded in my chest. It rang once...twice...I hung up. But that was stupid. What was I doing? I had to call my dad. I started to dial it again, and again I stopped. No. Don't involve your family. They didn't do it. They're innocent. I should call the police myself. But who was I kidding? There was no way I was calling the police myself. I started to cry again [...] (NELSON, 2006, p. 41, 42).

${ }^{146}$ I slept fitfully, dozing in and out. At seven A.M., I woke up completely and got ready to leave Jared's (NELSON, 2006, p. 42). 


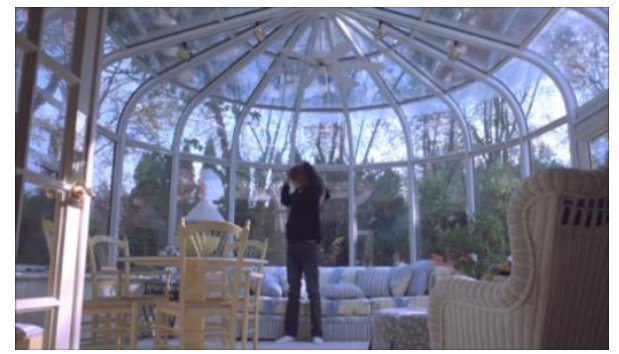

Então, às oito e meia, fui para casa. Coloquei o saco de lixo com as minhas roupas no carro da minha mãe e voltei para o meu bairro [...]. ${ }^{147}$

Figura 90 - Alex coloca o saco de lixo com suas roupas sujas no carro e dirige para a casa
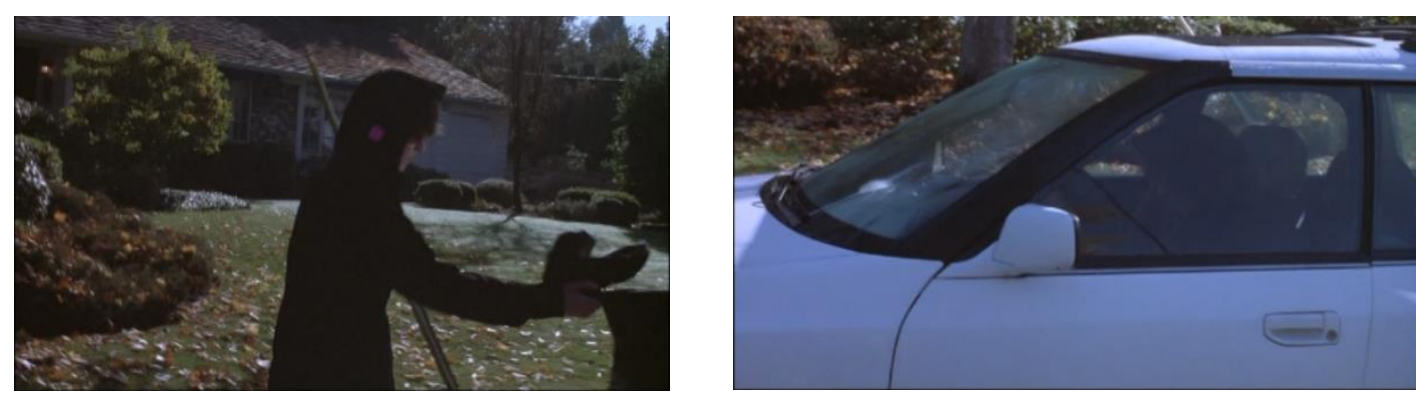

(Fim da sequência acontecimento)

\subsubsection{Análise da sequência}

Em termos discursivos de construção do espaço, podem-se observar certas similaridades figurativas do movimento, que podem ser julgadas proxêmicas, entre os dois textos. No romance, por exemplo, frases como Eu segui Scratch; ele escolheu um (vagão) e começou a correr ao lado dele; o guarda de segurança nos viu imediatamente; o segurança teve que correr ao lado dele (do trem) para nos acompanhar; me inclinei para dentro do carro para encontrar o rádio; me afastei do carro, etc. denotam todas as de figuras de movimentos simples e complexos, construindo direções, cruzamentos, ocupações e difusões. No filme, as mesmas informações espaciais são reconstruídas pelo observador:

- Cruzamento (parcial)

\footnotetext{
${ }^{147}$ Finally, at eight thirty, I headed home. I stashed the garbage bag of my clothes in my mom's car and drove back to my own neighborhood [...] (Ibid., p. 42).
} 
Movimento direcional; relação de englobamento: saída de Paranoid Park e entrada no espaço pátio de trem.

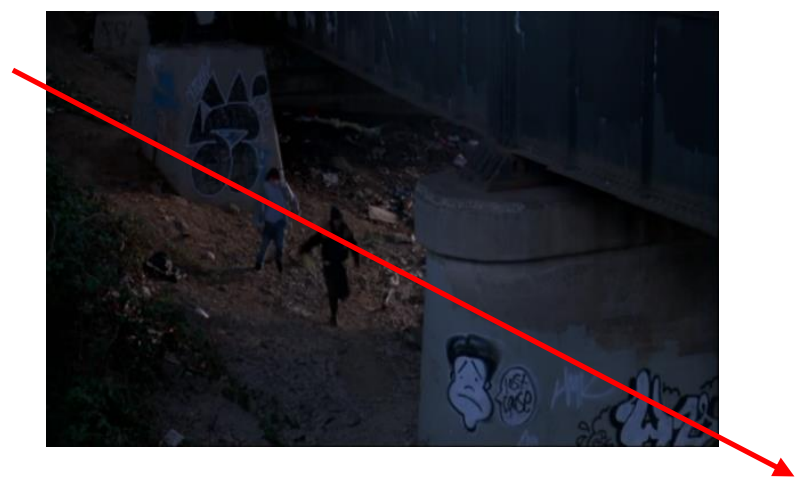

- Entrando e saindo do carro do policial
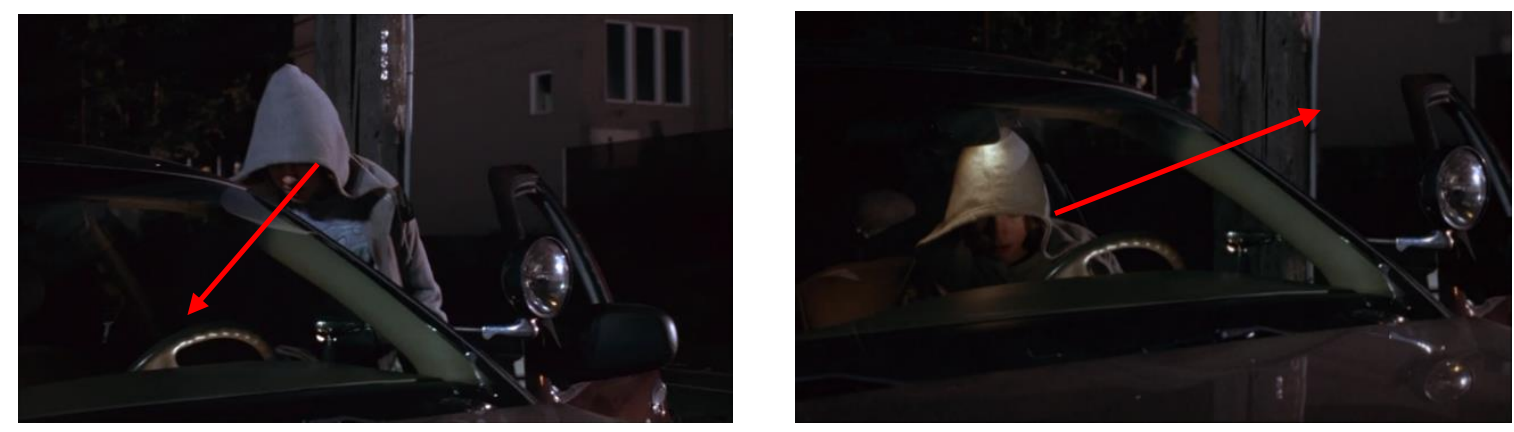

- Cruzamento do espaço através da direção do olhar

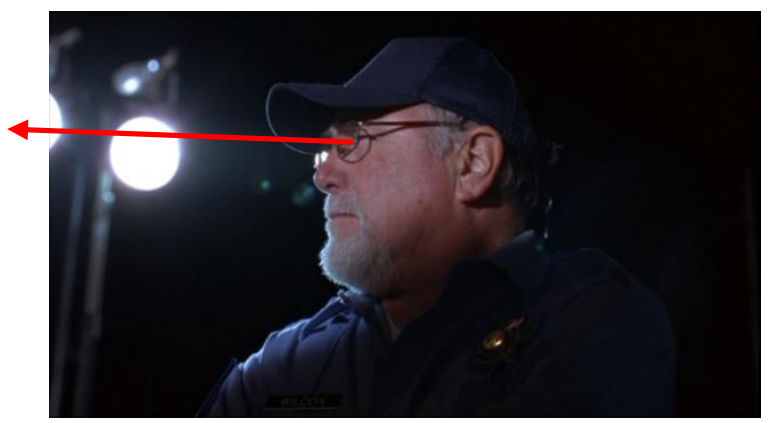

- Distância:

Aproximação dos atores no espaço profundo (movimento direcional; relação direcional): aproximar-se do trem para escolher um vagão; andar ao lado do trem, que possui movimento e direção. 

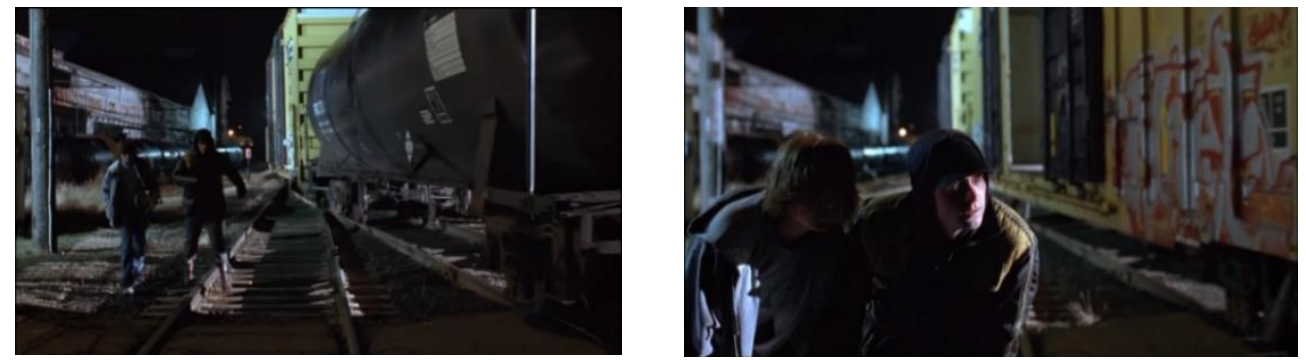

- Aproximação do corpo do segurança:
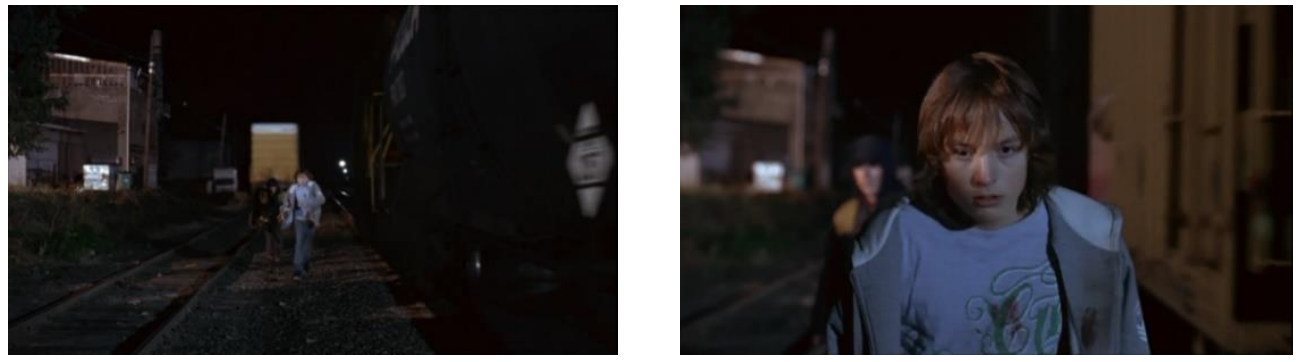

Não só os atores aproximam-se da focalização do observador, mas o contrário também ocorre, e o observador vai em direção aos atores (travelling em profundidade), visando igualmente a aproximação do rosto:

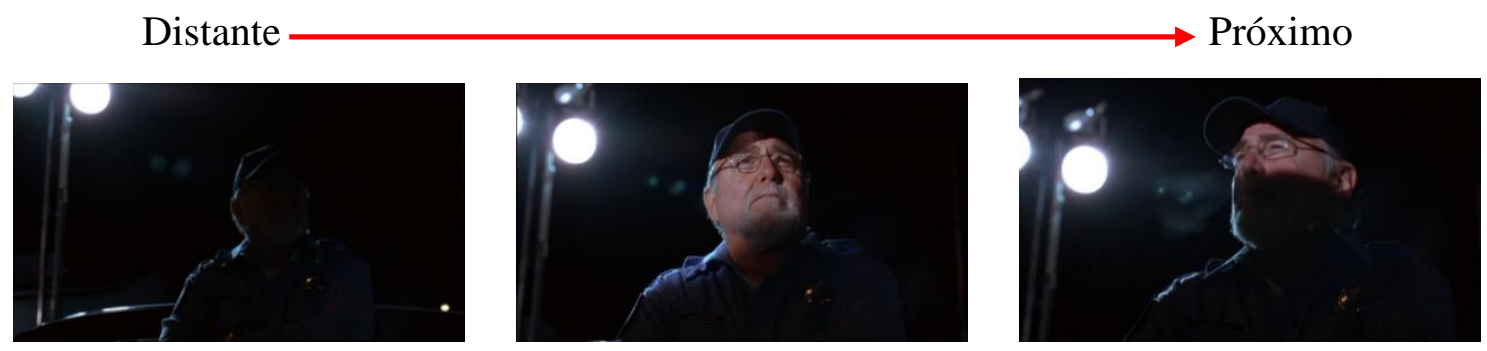

\section{- Difusão ou dispersão:}

Movimento de englobamento e relação direcional: o segurança, que acompanhava o movimento e a direção do trem, correndo ao seu lado (e englobado a ele), tropeça e sai da "direção vetorial do trem", adquirindo o seu próprio movimento e direção: o guarda, ao ser atingido por Alex tropeça e vai para trás (leitura do filme, não do romance, no qual o acidente é diferente). 


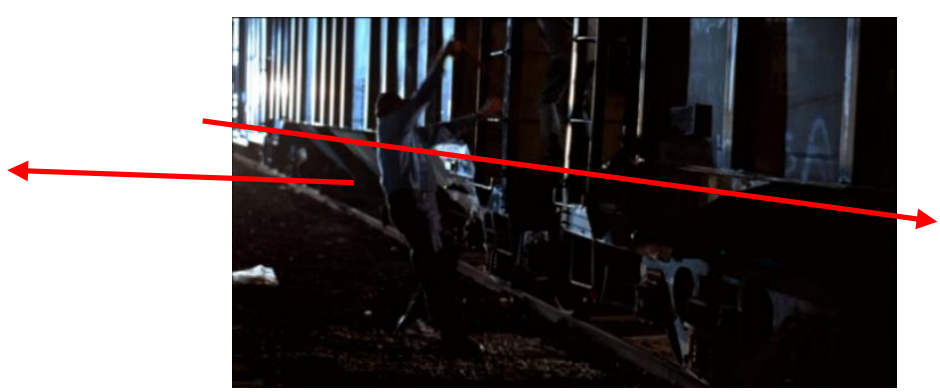

Uma figura do movimento no espaço não observada no acontecimento foi a ocupação, caracterizada como movimento e relação de englobamento, sendo relativa à extensidade e à concentração de figuras no campo visual da imagem, formando núcleos e pontos. Um dos motivos da ausência dessa construção poderia ser explicada pelo pequeno número de atores envolvidos na sequência, que não só é reduzido, mas diminui de três para um durante a sequência, dificultando esse tipo de figuração. Partindo dessas considerações, no entanto, observa-se que o espaço topológico verbal é aproveitado pelo enunciador fílmico.

A partir daí, e diferentemente da literatura, enquanto a figuração dos movimentos simples e complexos parecem, de certa forma, reproduzir os do romance, é preciso lembrar que o enunciador fílmico projeta um observador que irá se posicionar no espaço cognitivo profundo da imagem, construindo tipos diferentes de focalização, expressa por categorias plásticas e cinemáticas. Assim, como vimos, não apenas um ator pode aproximar-se do observador, mas o observador pode aproximar-se do ator.

Tais relações entre o movimento e a direção do observador, e o movimento e direção dos corpos dos atores geram infinitas possibilidades de construção do espaço cognitivo, inclusive as que podem ser denominadas contrapontuais ou desarmônicas: um ator, por exemplo, pode aproximar-se de um limite, enquanto o observador cinemático pode afastar-se dele, indo em direção contrária à do ator, criando um contraponto entre categorias cinemáticas da enunciação e do enunciado; da mesma maneira, a aproximação pode se dar de perfil ou a partir de uma profundidade, como acontece em Paranoid Park, o que significa que os atores não apenas aproximam-se do observador, mas o fazem de um modo que seus corpos sejam recortados de maneira diferente pelo quadro, (vindos de um PCj. e posicionando-se em um PP, por exemplo). Ao aproximarem-se a partir de um eixo da profundidade, os atores também se tornam plasticamente maiores na tela, e suas expressões gestuais mais legíveis.

Assim, como mostra Fontanille, entre o fazer saber do observador-enunciador, e o poder saber do observador-enunciatário (observatário), existe um jogo icônico que mostra e oculta, e forma ou deforma a imagem, de modo que o primeiro manipula as crenças e saberes 
audiovisuais do segundo. Do ponto de vista das modalizações e intersubjetividades entre observador e informante, as imagens e sons do acontecimento, classificadas em exibição, inacessibilidade, obstrução e acessibilidade, apesar de serem utilizadas durante toda a sequência, são mais recorrentes em certos momentos narrativos, formando isotopias icônicodiscursivas que devem ser discutidas:

a. A Inacessibilidade, segundo Fontanille (2009), caracteriza a imagem que se recusa ao observador, como a que se encontra nos limites naturais do campo de visão, ou são totalmente cobertas:
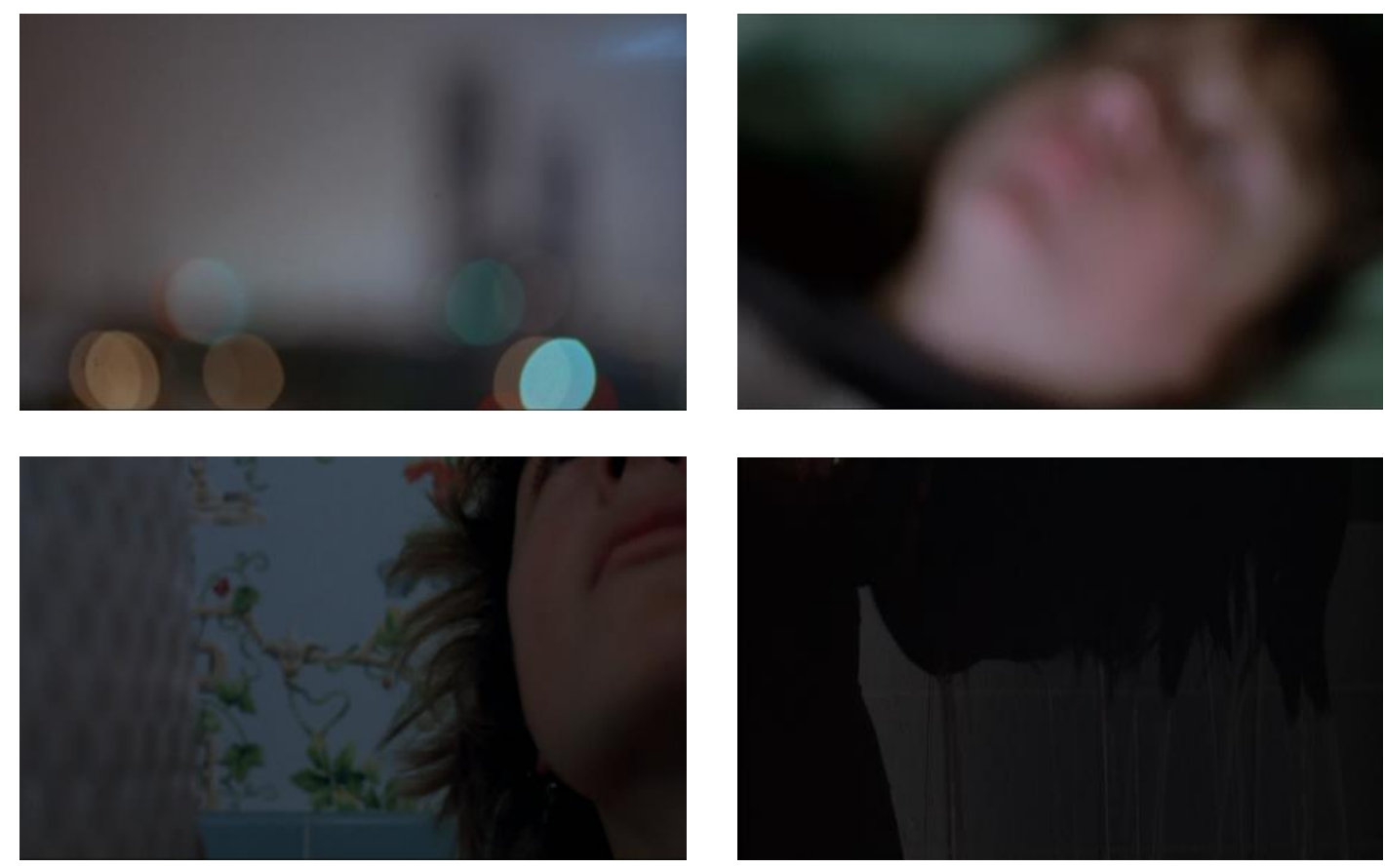

b. A obstrução caracteriza tudo o que é escondido, dificilmente aprendido ou pouco reconhecível, como a negação da exposição (não o seu contrário), tais como objetos parcialmente encobertos, personagens distantes ou vistos de costas. Em nossa opinião, são mais pertinentes nos seguintes planos ${ }^{148}$ :

\footnotetext{
${ }^{148}$ Sugerimos, também, como exemplos de obstrução, o uso gradual ou pontual das categorias plásticas da imagem, topológicas, cromáticas e eidéticas (relacionadas também ao brilho contraste e nitidez da imagem, seu recorte na tela, ou efeito ótico) com o intuíto de distorcer, negar ou fragmentar a imagem. Logicamente, há problemas na tipologia que não queremos resolver aqui.
} 

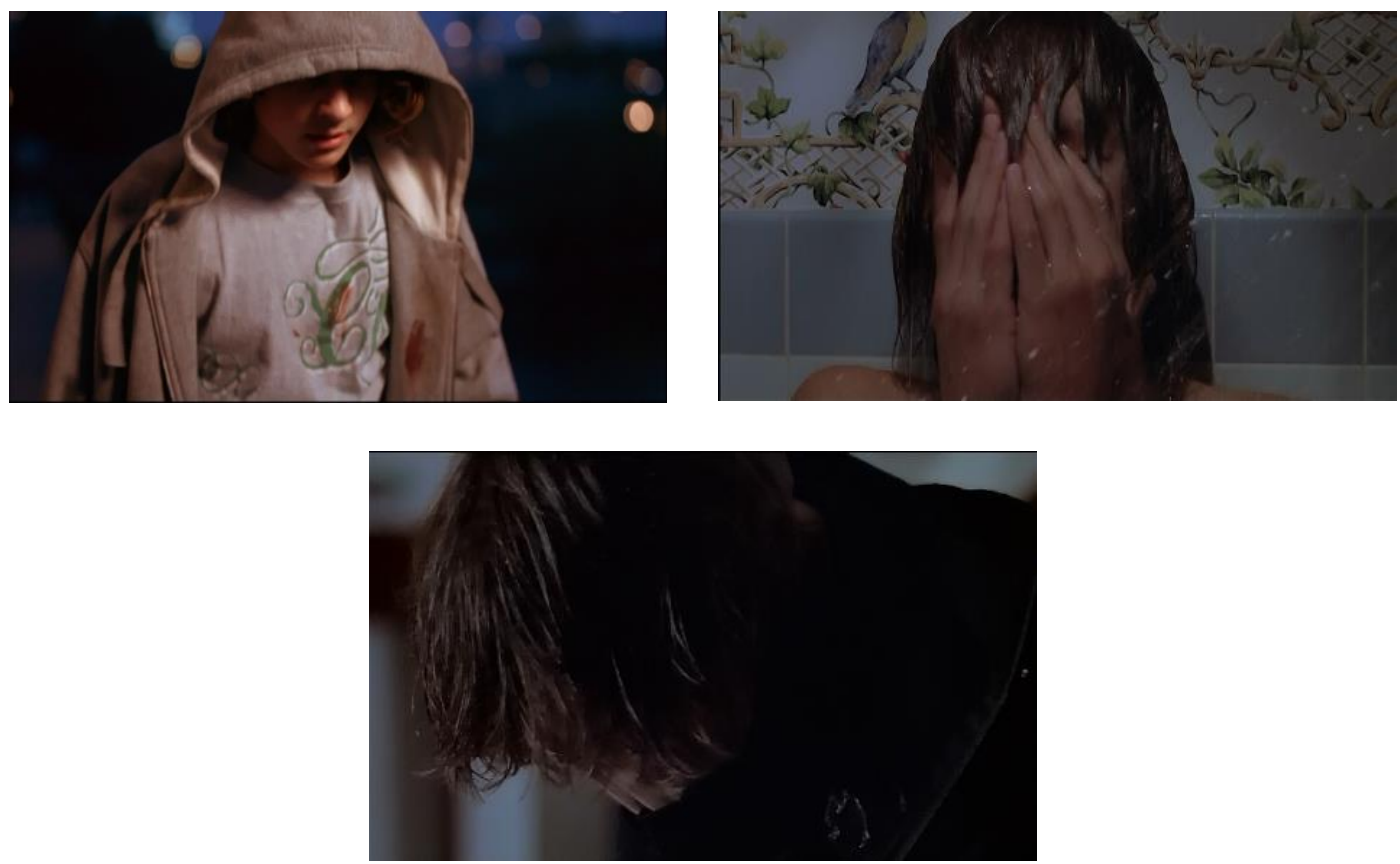

c. A Acessibilidade: tratada por Fontanille (1989) como o que se deixa perceber, entrever, falhas no obstáculo que recuam os limites do campo visual, Alex é observado entre janelas e batentes na casa de Jared. No filme, a utilização dessa modalidade é simbólica e enfatiza, a partir da redução do espaço e da distância, a solidão do personagem, seu enclausuramento e sufocamento, que se coadunam com a modalidade de obstrução:
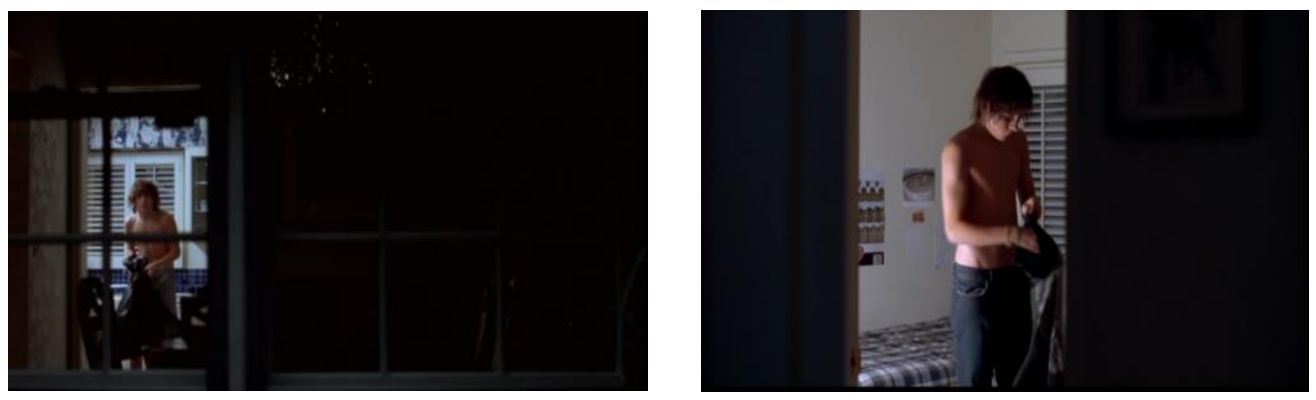

d. A Exposição: Caracterizada como o contrário da inacessibilidade (e não sua negação, como a acessibilidade), a exposição é tudo o que se mostra ao observador, como, por exemplo, um personagem visto em PP. Desse ponto de vista, e dado que o cinema é uma linguagem visual que mostra, ou exibe, no caso da exposição é preciso ainda tentar discutir o que é mostrado, e poderia não ser, ou ser evitado, e não é; ou se ela parece surpreendente ou inesperada dentro de um contexto ou gênero. Assim, ela deve ser tratada mais como discurso retórico cognitivo, do que como capacidade inerente e pragmática da linguagem, uma vez que todo o texto, seja ele verbal ou não verbal, exibe ou mostra, através de operações figurativas. Assim, de um lado, a sequência do 
acontecimento em Paranoid Park tudo mostra, e o enunciatário é capaz de ler e entender o texto filmico; de outro lado, nem sempre o que é mostrado é esperado ou relacionado ao contexto diegético, realizando metáforas, por exemplo.

Na sequência estudada do filme, a exibição do corpo do segurança cortado ao meio, marca de uma fratura estésica que jamais será esquecida pelo ator Alex, sendo um dos elementos que compõe o seu sobrevir, é a mais pertinente dessa modalidade (o mesmo pode ser dito do texto literário $)^{149}$. Vimos que como imagem-acontecimento, o corpo do segurança é também contraposição ao mundo adulto (lei, ordem e violência), representadas também pelo detetive, e fazem parte da busca de Alex de novos valores:

Figura 91 - Figura de uma exposição inesperada

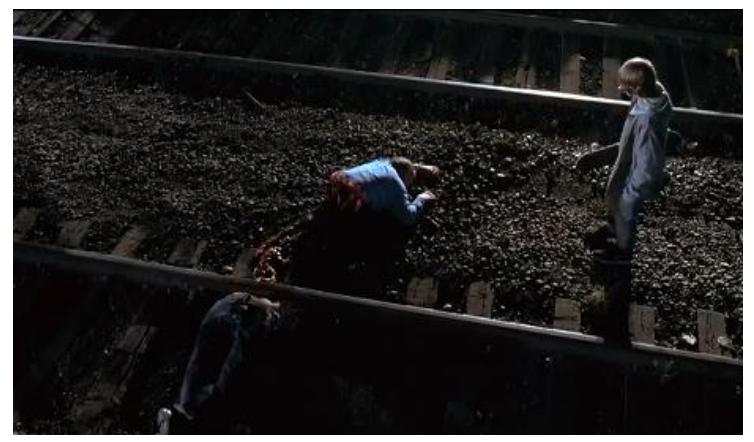

Ao mesmo tempo, observa-se que, se desde o início da sequência o observador utiliza com maior frequência a modalidade da exibição, é apenas após a imagem-acontecimento que as modalidades de inacessibilidade e obstrução passam a ser mais operadas, sendo, portanto, relativas ao sobrevir (entendemos que essas modalidades também existem antes da morte do segurança, quando os atores são mostrados à distância, invadindo o pátio de manobras, ou de costas, quando são mostrados correndo atrás do trem, mas são pouco pertinentes para a análise do discurso fílmico, baseado no acontecimento e no choque estésico).

Assim, se enquanto a modalidade de exibição é utilizada dentro de uma unidade de sentido descritiva do espaço, percebe-se que as modalidades de inacessibilidade e obstrução são intensificadas semanticamente depois da morte do vigia, sendo utilizadas em conjunto para figurar os estados passionais do ator, ou seu espaço interior. Em comparação com as categorias figurativas da aspectualização, distância, ocupação, cruzamento e difusão, que ocorrem por todo texto de maneira mais descritiva e superficial, pode-se argumentar que as primeiras são

\footnotetext{
${ }^{149}$ A imagem nos faz lembrar a noção de punctum, de Barthes, mas aqui utilizada para o texto fílmico.
} 
utilizadas para compor o espaço externo do ator, enquanto as modalidades do espaço observado como inacessibilidade e obstrução incidem mais sobre a construção de seu mundo interno.

\section{- O espaço sonoro do acontecimento e do sobrevir}

Do ponto de vista audiovisual responsável pela construção do espaço acústico, observaremos brevemente como as três unidades textuais sonoras fílmicas, ruídos, diálogos e música, adaptam o espaço sonoro do romance em relação ao acontecimento, mas voltaremos à questão em outro momento. Em termos de som, mais uma vez percebe-se a leitura atenta da figuração do espaço cognitivo em relação a ruídos e diálogos. No caso dos ruídos, que no filme são diegéticos e constroem os espaços sonoros dos ambientes onde os atores agem, o pátio de trens e a casa de Jared, chamamos a atenção para o apito do trem que se aproxima, que também existe no romance; no caso dos diálogos do filme, a maioria é literária, mesmo aquelas que são apenas sugeridas em descrições: no primeiro caso, observamos a narração do protagonista do romance, (re)enunciada pelo narrador em voz-over; e os pensamentos preocupados de Alex em pânico, ao cruzar a ponte após a fuga da cena do crime. Do ponto vista da sugestão da fala, o romance indica que Scratch "grita coisas no barulho do trem", não especificando o que é dito: o filme, no entanto, cria essas falas. Temos, nesse caso, isotopias temáticas verbais da ação reconstruídas em isotopias figurativas sonoras motivadas.

Em termos musicais propriamente ditos, toda a sequência utiliza duas composições: uma é eletroacústica, sendo uma mixagem de tons eletrônicos e ruídos ambientais que destoam das imagens, executada no começo da sequência, quando os jovens invadem o pátio de trens, e mais no seu final, quando Alex, deitado na cama de Jared, pensa em jovens andando de skate; o outro gênero é o clássico, e assim que os jovens trepam no trem em movimento, o quarto movimento da Nona Sinfonia de Beethoven, que possui um potente coro, insinua-se timidamente no discurso visual, tornando-se mais alto e perceptível à medida que a cena avança, até que seu momento mais intenso, acompanhado pelo explosão da orquestra e do coro, culmina na alternação das imagens do corpo do vigia decepado ao meio, de seu rosto olhando para Alex, do rosto do jovem no presente e no passado, e da face do detetive.

Como vimos na questão do espaço cognitivo, os sons, que também possuem movimento e direção, são passiveis de serem modalizados e figurados como a imagem: assim, ele pode tanto ocupar, cruzar, ser difuso ou possuir uma direção, como também ser exibido, inacessível, obstruído ou acessível. A gradação do volume do som em movimento (duração no espaço), em um processo de aumentos e diminuições de intensidade sonora, criam um percurso modal 
sintático que pode se estender da inacessibilidade à exposição de um som, que ao encobrir o outro paulatinamente, constrói operações afirmativas e negativas de sua existência e continuidade no discurso. Assim ruídos podem encobrir falas, falas podem encobrir músicas e ruídos etc. A trilha sonora musical, tanto eletroacústica como clássica, do ponto de vista tensivo cria gradações mais /menos na continuidade da presença motivada das categorias expressivas sonoras figuradas nos conteúdos fala, música e ruído, gerenciando o sentido de um espaço mais ou menos rotineiro ou estranho, ou interior e exterior. A música eletroacústica, por exemplo, que ocorre logo no início da sequência e é diminuída, voltará com força total, mas de outra maneira, na cena do chuveiro: no primeiro caso, os sons diegéticos não são totalmente encobertos, sendo apenas obstruídos; no segundo caso, o ruído da água que cai do chuveiro torna-se totalmente inacessível, e o estranho espaço sonoro toma conta da cena, simbolizando o espaço interior de Alex.

Da mesma forma, a música clássica vai insinuar-se no filme a partir do momento em que ambos os garotos sobem no trem, perdurando até o momento em que Alex corre da cena do crime. Enquanto a Nona Sinfonia de Beethoven inicia-se como obstrução, sendo fracamente ouvida, pois é coberta pelo som do trem, o seu volume cresce e ela é totalmente exibida no momento em que o jovem, o detetive e o segurança moribundo trocam olhares, que cruzam espaços e tempos. Além disso, o acontecimento e o choque estésico ocorrem quando, na sinfonia, mesclam-se música e um potente coro de vozes, marcando o ponto mais intenso e dramático da obra, e cheio de sonoridades. Nesse momento, todos os outros sons são tornados inacessíveis. A Nona Sinfonia, dessa forma, ajudará a descrever o trágico do acontecimento.

- A tensão do discurso do acontecimento: espacialização e temporalização dos planos

Apesar de ocorrer no pátio de trens, o espaço diegético, o acontecimento e o sobrevir no discurso fílmico, por serem manifestações plástico-cinemáticas, serão enunciados dentro de um espaço e um tempo enunciativos. De forma geral, em relação ao cinema, podemos dizer que a espacialização da enunciação fílmica se dá pelos planos e a temporalização fica a cargo da montagem, que encaixa imagens em movimento dentro de um tempo, e determina a modalidade de existência dos enunciados imagéticos, que são realizados, potencializados, virtualizados e atualizados.

Se levarmos em conta que o PPP e o PP são planos intensos, pois tratam de detalhes de elementos que ocupam o espaço, inclusive o corpo e a face humana, e o PP transforma o mundo em rostidade, sendo capaz de revelar as sutilizas da gestualidade facial expressiva podemos 
propor que o PPP e o PP são planos apostos ao PG (plano geral). Ao mesmo tempo, os planos enfatizariam mais o sujeito dentro do espaço, ou mais o espaço ocupado pelo sujeito. Ademais, propondo que um plano menor temporalmente, possui também menos espaço e, portanto, é igualmente mais intenso (um plano de curta duração, por poder ser menos percebido, torna-se também uma imagem que pode obstruir, por sua velocidade, a cadeia do sentido). Assim, partindo do princípio que ambos, os planos próximos (PPP e PP) e os menores (1 segundo ou menos, sendo que cada segundo equivale a 24 fotogramas) são unidades discursivas intensas, propomos a seguinte tabela de espacialização, temporalização e aspectualização da sequência do acontecimento:

Figura 92 - Tipos de planos e suas durações na sequência do acontecimento

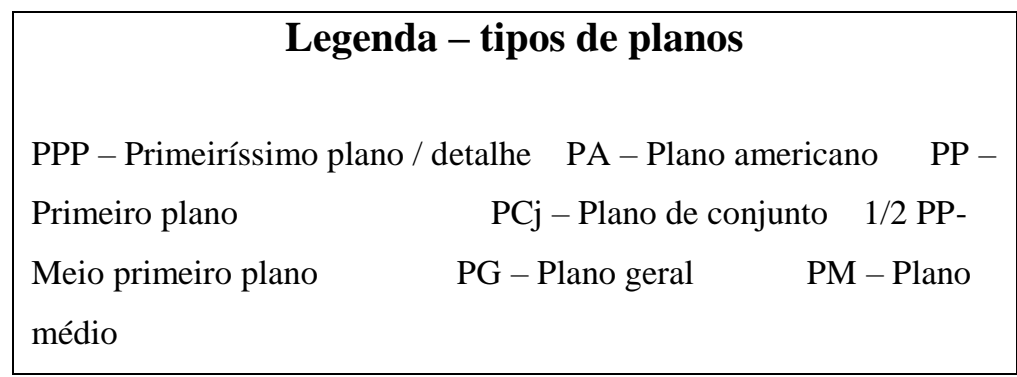

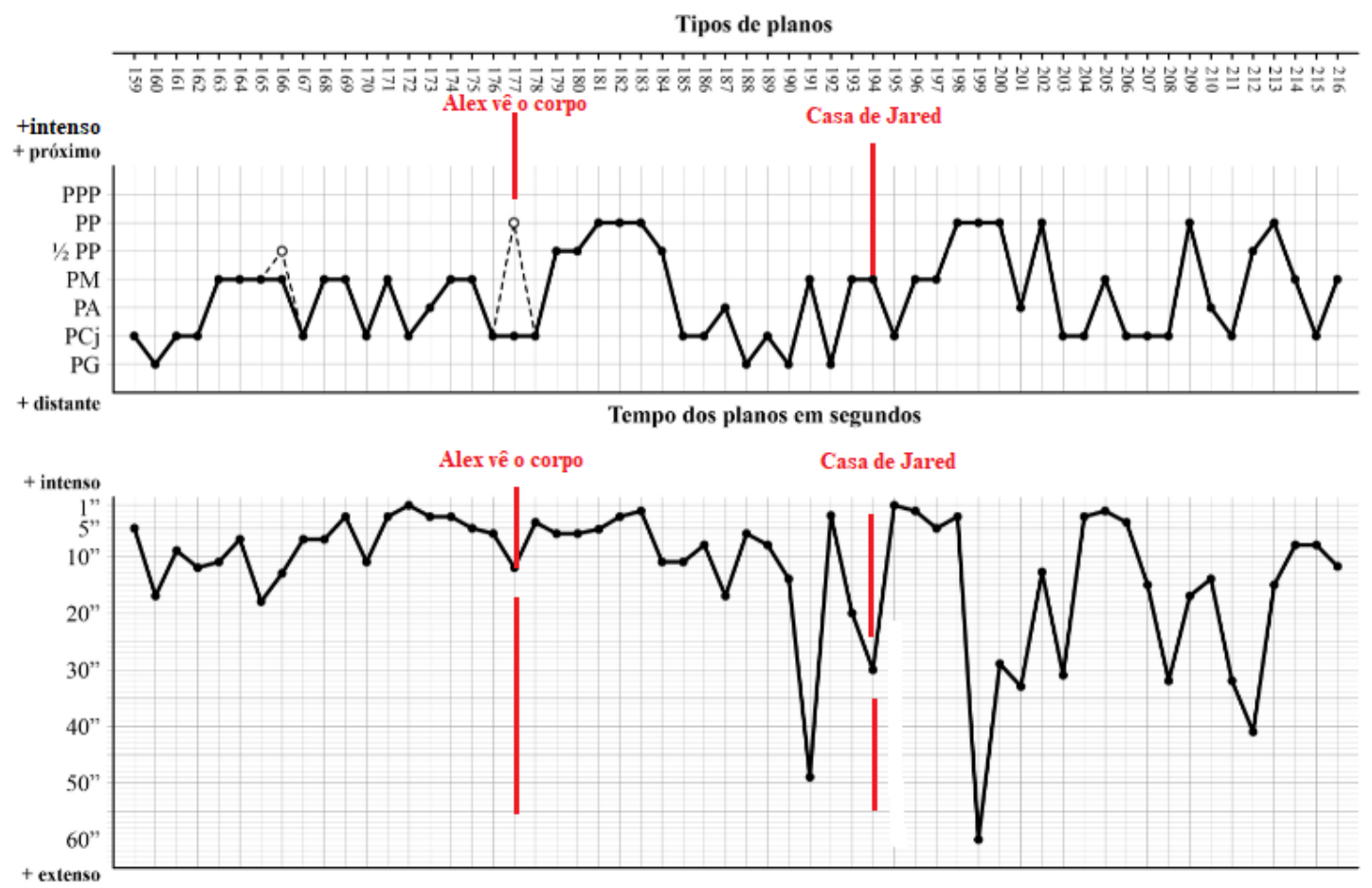

A sequência do acontecimento é composta de 58 planos, que duram aproximadamente 7 minutos e 31 segundos, e cuja média de duração é de 12 segundos, o que revela planos relativamente longos. Do ponto de vista da espacialização, ou seja, do tipo de enquadramento, 
há interessantes observações a serem feitas. Antes do plano 177, que é quando o jovem se aproxima para ver o corpo do vigia, nota-se que a sequência é formada de planos que oscilam, em grande medida, entre o PM e o PCj, o que significa que o espaço da ação é mais enfatizado do que o rosto dos sujeitos. A partir do plano 177, porém, que identificamos como acontecimento e o início do sobrevir, os PP tornam-se mais frequentes, focalizando o rosto dos atores, Alex, o vigia e o detetive, para registrar a gestualidade facial de cada um: Alex aparece olhando para baixo, na praia, para o rosto do detetive, na escola, e o rosto do detetive olha para Alex, na sequência que já observamos no início do filme. Depois desses planos aproximados, Alex foge da cena do crime, e o observador passa a registrar mais o espaço novamente em PA e PG (o jovem vai ao carro do vigia e entra nele, sai correndo pelo pátio de trens, na chuva, o céu relampeja e ele cruza a ponte, falando sozinho). Notamos como o espaço é importante para descrever a turbulência afetiva do ator.

$\mathrm{Na}$ casa de Jared, o enunciador utiliza o uso de planos mais intensos e enunciativos, momento em que o medo já está instalado, de modo que o estado de sobrevir recrudesce e acompanhará o personagem até o momento em que ele resolve escrever as cartas. Os planos espaciais mais extensos e enuncivos são menos acionados: não há, nesse momento, a utilização de PG, talvez pelo fato de o personagem estar em um espaço interior. Entre os PM e os PCj, que existem em menor quantidade, lembramos ainda, como vimos acima, que a imagem do ator é, nesse momento, mais modalizada pela obstrução e pela inacessibilidade, de modo que mesmo que o corpo inteiro de Alex seja mostrado, ele é de certa forma oculto ou reduzido na composição plástica.

Em termos de duração temporal de cada plano, percebe-se também uma diferença cronológica geral entre os dois momentos do acontecimento: do plano 159 ao plano 190, $\log 0$ que Alex foge da cena do crime e podem-se ver imagens oscilantes de um céu relampejante, os tempos dos planos são relativamente mais curtos, oscilando aproximadamente entre 1 e 17 segundos. Assim, toda a primeira parte da sequência, até o momento em que Alex corre, é marcada pela intensidade espaçotemporal. Após a saída do espaço traumático, a partir da travessia da ponte, a intensidade diminui e dá lugar a extensidades espaçotemporais: de um lado, planos mais longos (sendo que o maior é quando o jovem atravessa a ponte e fala consigo mesmo); de outro, mais diferentes entre si. Assim, se em um primeiro momento existe uma gradação de quadros mais fluida e menos brusca, mas que mantêm uma regularidade, ou extensidade, na casa de Jared tal graduação de distâncias se faz por saltos, e planos curtos são mesclados a planos longos, próximos a distantes, em uma construção que denota a intensidade e conota a figuração visual do sobrevir. 
Finalmente, se adotarmos uma perspectiva mais geral da sequência como um todo, atentando para o uso mais específico dos planos e sua duração como isotopias, podemos perceber que os PP e 1/2PP são, de forma geral, utilizados nos momentos mais intensos e traumáticos da sequência: no momento do acidente, quando imagens do jovem no passado e no presente, intercaladas com o rosto do segurança e do detetive simbolizam relações afetivas e paixões; na cena do chuveiro, quando o seu rosto, coberto com as mãos, parece "derreter" na água; e quando ele se deita na cama e lembra-se do mundo do skate. Somadas, as imagens que se aproximam mais do garoto, denotam com mais ênfase o mundo interior e surpreso do ator, o aqui e o agora do trauma.

Em termos de duração, os que mais chamam atenção são os planos longos, e há dois momentos em que eles são utilizados: na cena da ponte, quando o ator fala consigo mesmo; e o momento do chuveiro, quando ele chora. No filme, ambos os planos possuem um tratamento sonoro diferenciado que, ou produzem reverberações da voz (ecos), e mais uma vez denotam um espaço interno e vasto, ou são compostos de música eletroacústica, que constrói um espaço sonoro contrapontual ao espaço diegético, destruindo os efeitos de verossimilhança: a partir das desarmonias entre som não-diegético e espaço diegético, a imagem de um espaço interior traumatizado é construído.

Do ponto de vista da manifestação plástico-cinemática do sentido dessa sequência, percebe-se que ela opera uma série de categorias relacionadas à velocidade do enunciado da imagem (a sequência da perseguição do vigia e sua morte é em câmera lenta), movimento do observador (que se aproxima ou se afasta dos atores), efeitos óticos, tais como foco e super / subexposição da luz (nas imagens do céu que relampeja e quando ele toma banho e chora), e granulação da imagem (quando Alex pensa nos skatistas).

De uma totalidade de 58 planos, 19, ou mais de um terço, são planos com movimento, que perfazem 4 minutos e nove segundos de uma sequência de 7 minutos e meio. Assim, mais da metade da sequência possui quadros com tremores ou correções da câmera, que tentam centralizar o seu objeto, ou movimentos mais amplos, como travellings e panorâmicas. Apesar da grande incidência desse tipo de plano, porém, mais da metade deles, 10, são lentos, perfazendo 2 minutos e 41 segundos, e determinando que um terço da sequência possua o andamento lento. Assim, se de um lado mais da metade da sequência possui algum tipo de movimento espacial, tornando-a mais oscilante, ela é lenta tanto por causa do baixo número de planos que a compõe, como também dos planos com velocidades anormais e desaceleradas. $\mathrm{O}$ gráfico abaixo mostra como a sequência é expressiva, para construir o efeito de surpresa, medo e intensidade. Pode-se observar que do plano 199 ao 208, uma série de categorias plásticas e 
cinéticas são utilizadas conjuntamente, e excessivamente, correspondendo aos planos do chuveiro e dos skatistas. Assim:

Figura 93 - Manifestações de categorias expressivas

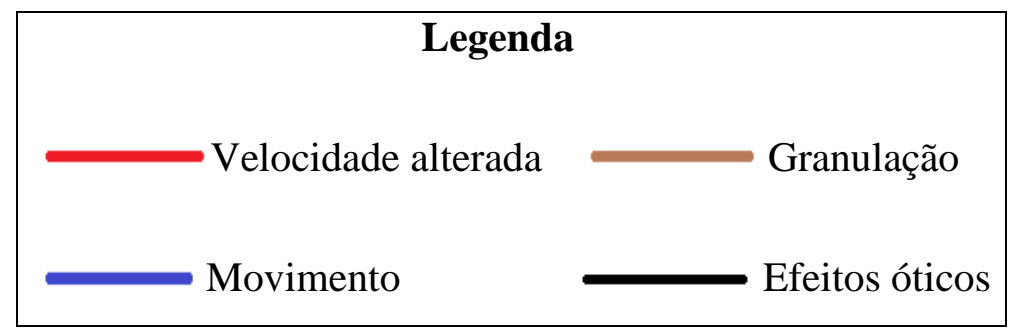

Planos

ーN

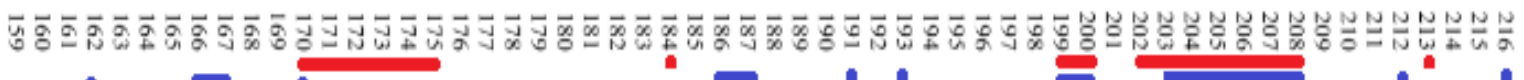

- 1.

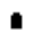

De forma geral a sequência acontecimento é elaborada de planos que oscilam entre fixos e dinâmicos, construída por figuras da obstrução, da inacessibilidade e da acessibilidades, e expressa por um conjunto de categorias plásticas, sonoras e cinemáticas que tendem à intensidade por seu excesso e sobreposição, que cria efeitos não apenas contrapontuais, mas que aceleram e tonificam mais o discurso, por possuírem ritmos plásticos intensos, ou seja, muitos contrastes internos que ocorrem em várias camadas do texto: a câmera lenta, a textura oscilante, a assincronia, sons sobrepostos etc. Tais efeitos, utilizados muitas vezes de forma recrudescida, necessitam de mais tempo de absorção, e vão figurar o sobrevir e a fratura estésica provocada pelo acontecimento.

\section{- Fragmentos do acontecimento, suspense e diferenças entre romance e filme}

Há algumas diferenças entre a sequência do acontecimento no romance e no filme que foram observadas e devem ser mais comentadas, pois demonstram novos investimentos de sentido do enunciador do texto adaptado. Dentro dos 58 planos utilizados, como vimos, nem todos pertencem ao encadeamento de eventos que ocasionam a morte do segurança, relativos à fuga de Alex e os seus momentos de angústia na casa de Jared. Alguns desses eventos foram alterados ou não aparecem no texto fonte: em primeiro lugar, a morte do segurança é alterada no filme, uma vez que no livro, Alex, ao ser atingido pelo vigia, pula do trem em movimento, 
mas vendo que o homem continua a perseguir e bater em Scratch, decide protegê-lo, correndo para salvá-lo; da mesma maneira, no romance, não há dois trens e o vigia não é morto ao cair em outra linha. Em segundo lugar, no romance, o corpo do segurança, cortado ao meio depois do acidente, jaz imóvel no chão, e não se arrasta em direção a Alex e nem o encara: no filme, ao fazer que o vigia cortado ao meio olhe fixamente para o jovem, a imagem do segurança ganha contornos metafóricos.

Quando Alex vê o corpo do homem que acaba de sofrer o acidente, o enunciador fílmico volta ao momento em que Alex está escrevendo na praia, no presente, e no momento em que o jovem está dando o seu depoimento ao detetive que investiga o caso, em um passado depois do acidente, ou seja, entre o acidente e a escrita das cartas. Como se trata das lembranças do passado, pode-se dizer que as inserções de dois períodos temporais antes da escrita das cartas podem ser consideradas flashbacks de flashbacks, que constroem não apenas a ideia de passado a partir do presente da enunciação, mas de discurso confuso e fora de ordem, articulado a partir de um sobrevir intenso. De outro lado, discutimos como a ligação visual entre o jovem, o vigia vivo e o policial tornam-se simbólicas, relacionadas ao segredo e ao enfrentamento do mundo adulto.

Finalmente, outra cena que destoa do romance é a dos jovens andando de skate, que parecem ser imaginadas por Alex quando ele se deita, exausto e confuso, no quarto de Jared. Enquanto no romance o jovem tem pesadelos, no filme sua lembrança, como vimos em outras imagens do mesmo tipo, é relacionado ao mundo do skate e seus indivíduos, fazendo parte dos valores eufóricos que Alex busca. De maneira geral, no entanto, os investimentos de sentido do enunciador fílmico não alteram os investimentos temáticos principais do romance, mantendo o acidente traumático do jovem e seus estados patêmicos.

Como já observamos anteriormente, é interessante observar que a sequência do acontecimento descrita acima, que ocorre aos 42 minutos do filme, é a mais completa, ou seja, mostra o que realmente aconteceu do momento em que os atores invadem o pátio de trens até o momento em que Alex volta para casa, no dia seguinte, realizando assim causas e consequências lógicas para a narrativa, já sugeridas no diálogo entre o jovem e o detetive: essa grande sequência, que equivale ao início do romance, às cartas 3 e 4, será tratada bem depois no discurso fílmico, a partir de uma lembrança fragmentada. Uma vez que não aparece logo no início da narrativa fílmica, ao contrário do romance, e é fruto de um discurso não linear do jovem, o acontecimento torna-se também fragmentado, até que ele seja totalmente explicado. Diferentemente do discurso literário, o filme, enquanto não mostra a sequência completa, opera sugestões do evento terrível, atrasando sua realização e o potencializando na narrativa, em uma 
estratégia de suspense e estranhamento que se alonga até que a sequência seja completamente exibida.

Assim, vimos que a primeira menção do acontecimento não é visual, mas sonora, e ocorre aos 12'32" do filme, quando Alex está dando o seu depoimento e ouve-se um grito de pânico que parece ser de um homem (na sequência acontecimento, diferentemente da sequência depoimento, o grito não existe nem como som, pois a cena é encoberta pela música clássica, e nem gestualmente, pois a câmera não mostra o rosto do vigia).

A segunda menção do acontecimento ocorre aos 24'57”. Alex já está na casa de Jared, na cozinha, guardando as suas roupas em um saco de lixo, sendo focalizado de fora da casa, pela janela. Tal cena, no entanto, que será repetida posteriormente, é um pouco maior, e revela o jovem abaixado sobre o saco de lixo (esse movimento não será repetido mais tarde). Depois da cena da janela, o enunciador mostra Alex engatinhando na sala, tomando banho brevemente (na repetição ela é mais longa, como discutimos) e tentando ligar para o pai. Depois, em PP, a cabeça de Alex cai sobre o travesseiro em câmera lenta. Todas essas cenas serão repetidas, como vimos agora, de maneira mais ou menos similar:

Figura 94 - Cenas fragmentadas do acontecimento, que serão repetidas posteriormente na íntegra
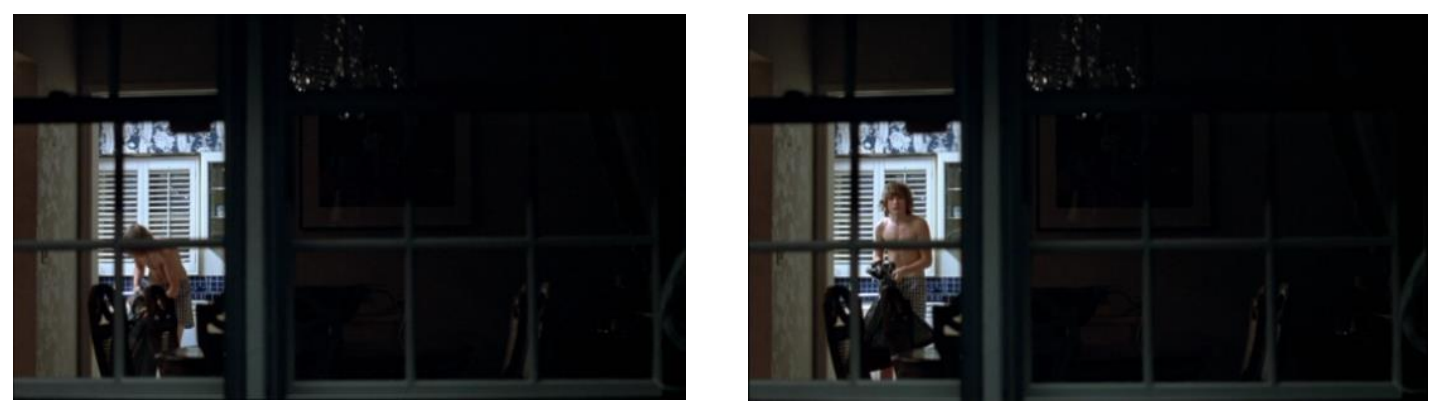

Apenas alguns segundos da imagem do banho
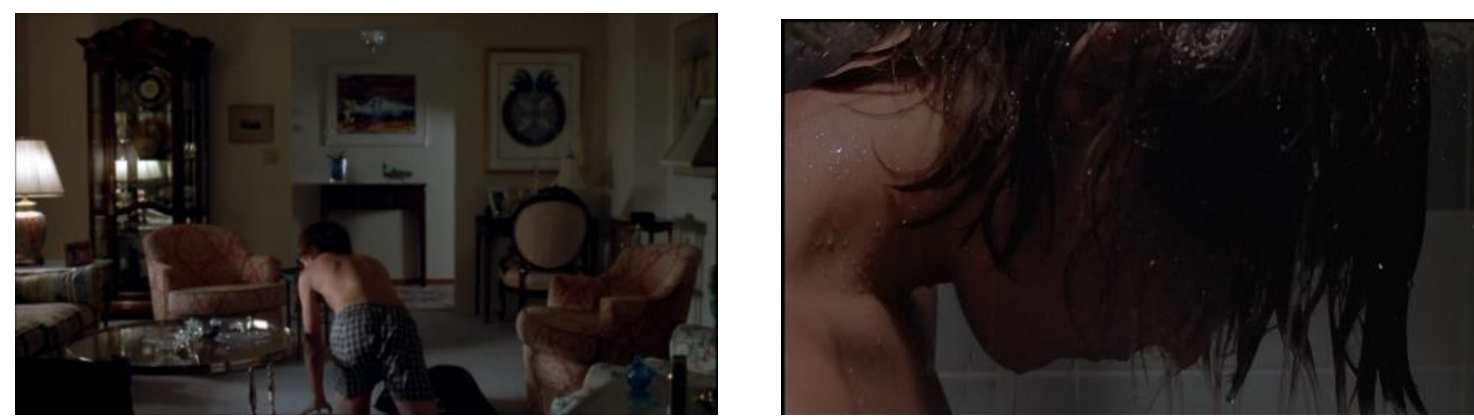
Alex tenta ligar para o pai, desiste e chora
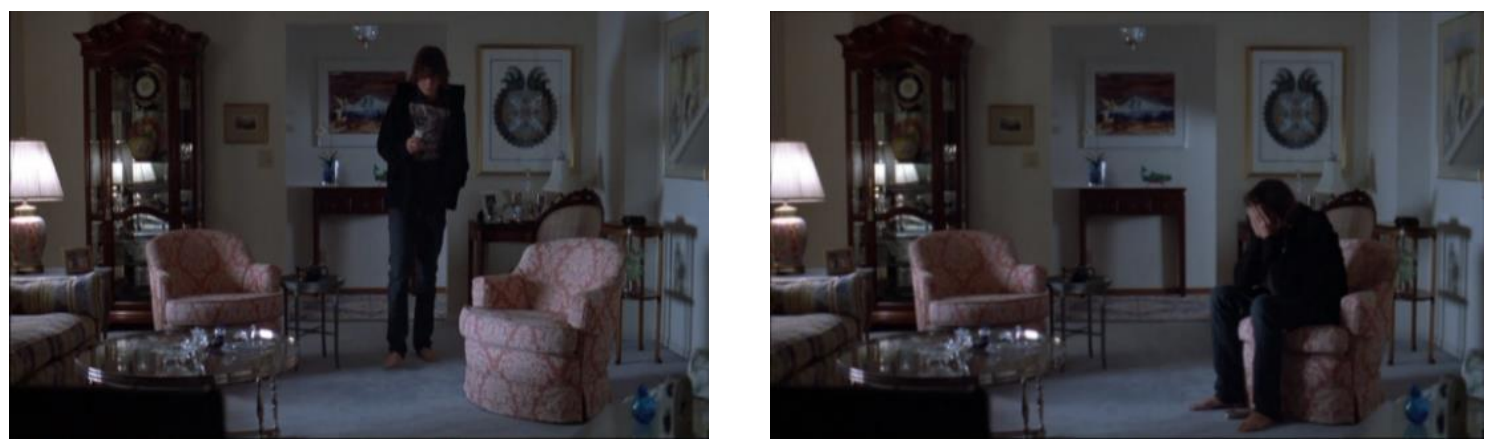

Indo dormir

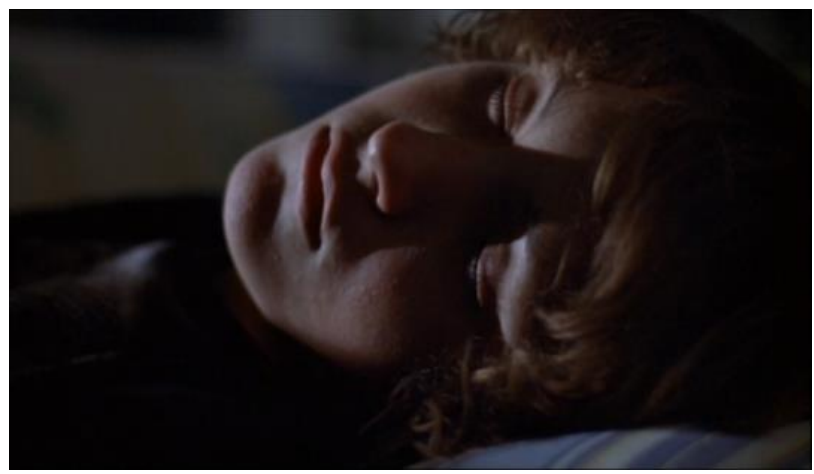

A terceira menção do acontecimento se dá aos 34' 01" do filme, quando Alex assiste a um telejornal. Um repórter explica o caso:

Figura 95 - O acontecimento na TV
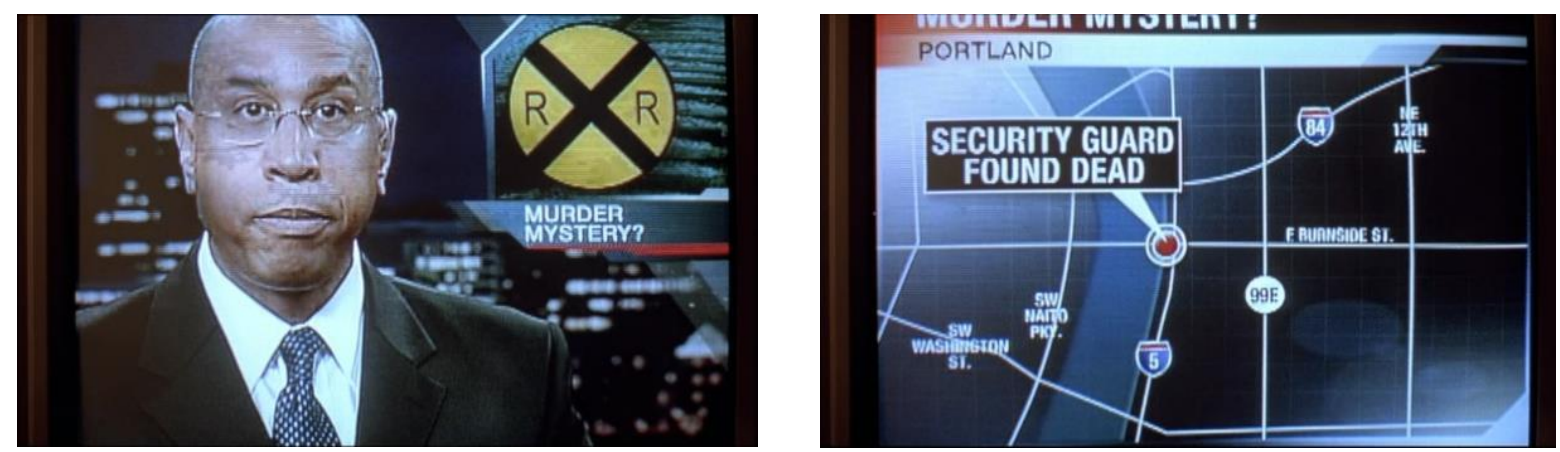

A quarta menção do evento ocorre aos 35'12", quando Alex está na biblioteca da escola e lê sobre o acidente no jornal: 
Figura 96 - O acontecimento em um jornal da biblioteca da escola "Polícia solicita ajuda em tragédia de trem"

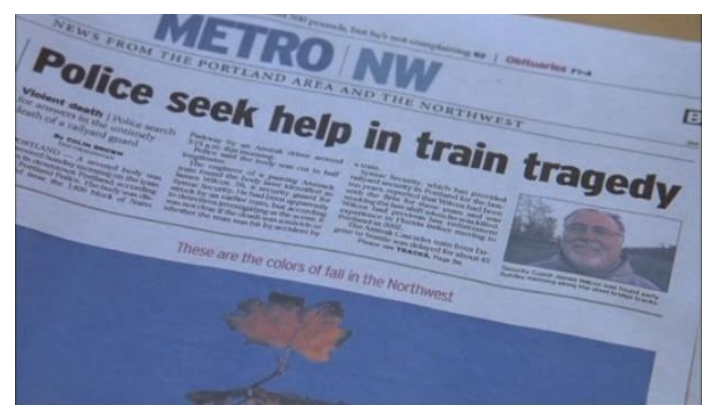

Finalmente, a quinta e última menção antes da revelação de todo o acidente acontece aos 41'50", por meio de uma fotografia que o detetive entrega na escola, enquanto fala com os alunos que praticam skate, perguntando-lhes sobre a noite da morte do segurança: é a partir dessa cena que toda a sequência do acontecimento, decupada acima, ocorre. Alex, no filme, comenta: "Eu tinha tentado apagar aquela parte da minha memória, mas a foto me fez lembrar de tudo. Era a minha chance de dar um tempo para raciocinar, pensar no que fazer" (a cena não existe no romance).

Figura 97 - Foto do acidente no pátio de trens distribuída pelo detetive Lu aos alunos

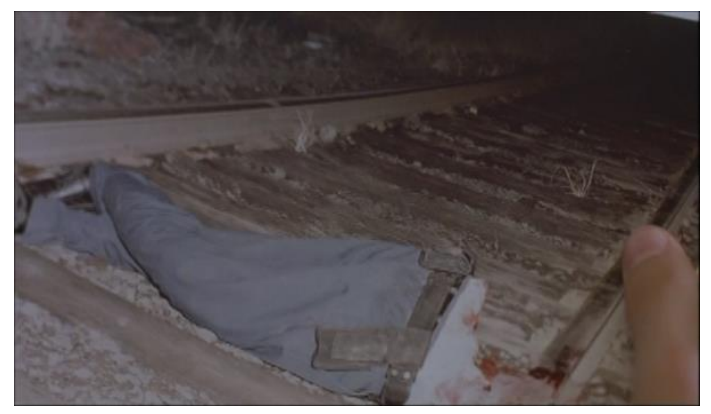

A partir daí, podemos estabelecer que livro e romance, por tratarem da posição do acontecimento de maneiras diferentes, produzem uma curva tensiva igualmente particular em cada discurso: o romance, por revelar rapidamente o sofrimento de Alex e a causa de seus medos e angústias, começa tonicamente, e torna-se menos intenso à medida que o tempo passa e a polícia desiste da investigação; o filme, em contrapartida, por atrasar a cena do acontecimento e mostrar um jovem angustiado e calado, em um discurso audiovisual repleto de sugestões de um evento importante que já ocorreu, oscila entre a normalidade e anormalidade, e objetividade e subjetividade, denotando espaços interiores sensíveis e comportamentos estranhos que não são rapidamente explicados, e construindo uma curva tensiva vagarosa e crescente, a partir de cada fragmento que é adicionado à história, em forma de um quebra-cabeças, cujo sentido será 
mais quanto mais os fragmentos forem conectados. Assim, por causa do discurso do acontecimento e seus efeitos, podemos sugerir um gráfico inverso para o romance e converso para o filme:

Figura 98 - Esquemas tensivos do romance e do filme

O romance

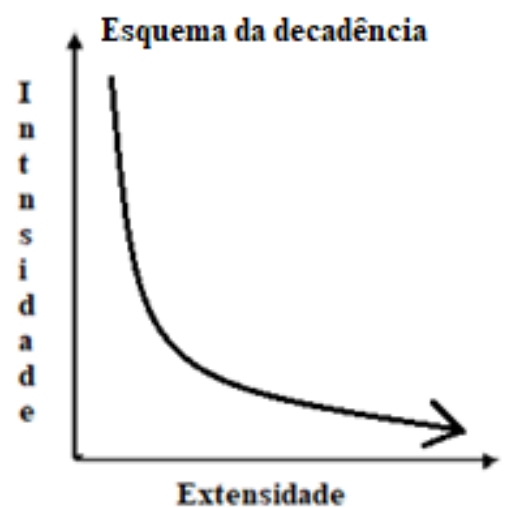

O filme

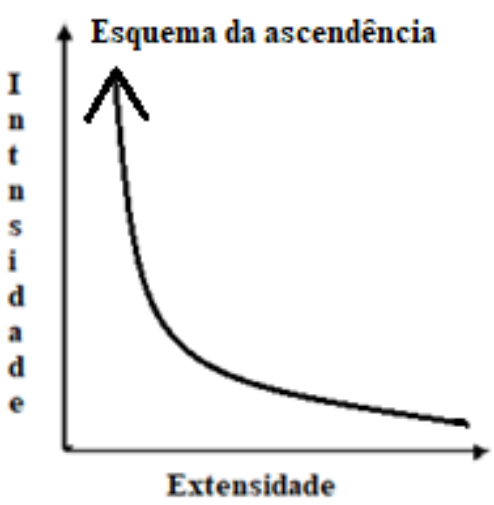

Fonte: Fontanille (2008, p. 111).

No primeiro caso, a intensidade combinada com o desdobramento da extensão produz um relaxamento cognitivo. Segundo Fontanille (2008), neste cenário parte-se de um realce da intensidade, de um choque emocional para o relaxamento produzido pelo desenvolvimento, uma explicação, ou ainda uma reformulação em extensão; no segundo, que é baseado em um princípio de gradação geral, que parte de um mínimo de intensidade e de uma fraca extensão que desemboca em uma tensão máxima, igualmente desdobrada na extensão. Nesse caso, o aumento da informação e o desdobramento cognitivo provocam um aumento na intensidade, e o sensível e o inteligível crescem conjuntamente (p. 115).

A ascendência é o contrário da primeira, conduzindo a uma tensão final que faz, explosivamente e de modo afetivo, a soma de tudo que antecede. Fontanille (2008) lembra nas estruturas narrativas, esse tipo de esquema administra, por exemplo, o crecimento progressivo do medo nas narrativas de terror e suspense (p. 114), mas existem em todas as narrativas, e dentro também, no cinema, do que consideramos uma semiótica proxêmica ${ }^{150}$. Enquanto no romance o acontecimento é a mola propulsora não apenas de todos os medos do jovem, mas também de suas divagações sobre a vida, Deus, a família, o amor etc., no filme ele ocupa o

\footnotetext{
${ }^{150}$ Fontanille (2008) comenta: “A edição cinematográfica, que se crê ser controlada plea instancia enunciativa do filme, também usa muito esse recurso. Quando a edição vale-se de um estreitamento (progressivo ou repentino) do campo até chegar a um rosto enquadrado em close-up ou apreendido por uma 'inserção', ela passa do desenrolar descritivo e narrativo a um efeito puramente emocional" (p. 114).
} 
mesmo lugar central e importante, mas é bem menos relacionado às isotopias temáticas tratadas literariamente, que são apagadas para darem lugar ao silêncio do jovem, o segredo e o vislumbre de uma vida interior intensa. Colocado no meio do filme, o acontecimento figura como evento que liga o início e o fim do sofrimento do jovem. A partir da sequência que mostra a morte acidental, a fuga de Alex e a instauração do sobrevir, o filme segue o esquema tensivo do livro e entra em seu esquema descendente. Assim:

Figura 99 - A ascendência e a decadência da tensão no filme

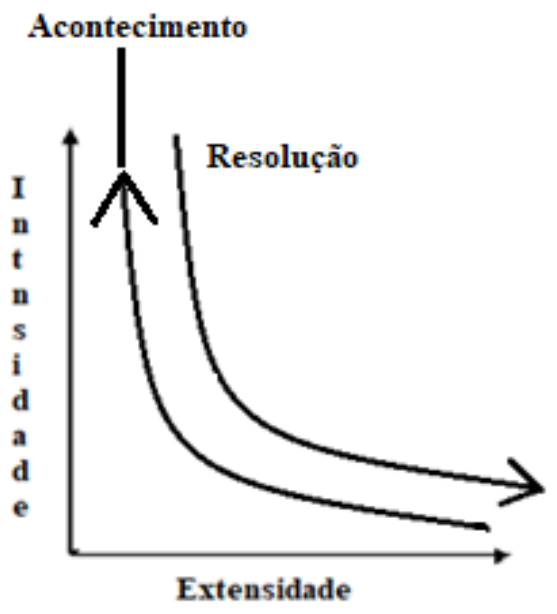

Fonte: autor

A perspectiva tensiva adotada pelo discurso enfatiza o estranhamento da narrativa, pois consequências são mostradas antes de causas, gerando uma atmosfera de segredo e suspense, em uma estrutura menos sintagmática do que paradigmática que intensifica a figuração de um espaço mental confuso e com problemas de reconhecimento. A partir do deslocamento do acontecimento, romance e filme geram suspenses diferentes: no primeiro, pergunta-se o que acontecerá ao protagonista, se será desmascarado ou preso; no segundo, pergunta-se o que aconteceu ao protagonista, e o suspense é construído através do retardamento da explicação de todas as suas consequências: a escrita das cartas na praia, o encontro com a polícia na escola, o semblante sempre fechado etc. A estratégia discursiva de reposicionar o tempo do acontecimento na narrativa não apenas altera o andamento tensivo do discurso fílmico, criando suspense, mas o divide em dois momentos.

O reposicionamento do acontecimento em um ponto equidistante entre fim e começo da narrativa possui ainda outra característica tensiva além da geração do suspense, pois a partir desse momento, e uma vez que o evento trágico que desestabiliza o jovem é finalmente mostrado, em um tipo de clímax, o discurso fílmico passa a ser menos intenso, preparando-se 
para o início de sua conclusão. É depois da sequência acontecimento, por exemplo, que Macy torna-se mais presente, tendo aparecido apenas uma vez anteriormente. É nesse momento, também, que Alex rompe seu relacionamento amoroso com Jennifer. A sequência trágica colocada no meio do filme, momento mais intenso da narrativa, fornece a tensão para a sua atonização, que será marcada pela conjunção de Alex com Macy, e simboliza um tipo de recomeço da narrativa, adquirindo uma figuração menos intensa.

\subsection{A actorialização: adaptando Alex}

Vimos acima que o enunciador fílmico cria, a partir da voz-over, o Alex da enunciação, o narrador / ator, e o Alex do enunciado, o narrado ator / interlocutor, construindo uma densidade física e interior, uma presença ao mesmo tempo imagética e ressonante, que também serve para "costurar" o enunciado fílmico, fragmentado e fora de ordem. O observador, oscilando entre enunciação e enunciado, também contribui para a densidade corporal do protagonista, emprestando-lhe um corpo em movimento. Além desse corpo sonoro e proxêmico, ele também é uma imagem visual enunciada, sendo descrito pela imagem: no romance, a única informação visual sobre o ator é que ele é branco e tem olhos azuis, característica que não foi considerada importante para a adaptação.

Vimos, na sequência acontecimento, como o discurso audiovisual trabalha com modalidades visuais da face do ator, figurando a inacessibilidade, a obstrução, e a acessibilidade. No discurso fílmico, e em termos de exibição, outro recurso visual utilizado para a construção do sujeito, além de sua voz, é o enquadramento, que muitas vezes aproxima o rosto do ator, e utiliza a face para acusar paixões de medo e a existência em segredo. Assim, a interioridade do ator é sugerida visualmente pelo uso maciço de $\operatorname{PP}(\mathrm{s})$, que fazem que a imagem de seu rosto ocupe toda a extensão da tela, transformando-a em objeto-face.

Figura 100 - O rosto do ator como expressão da interioridade
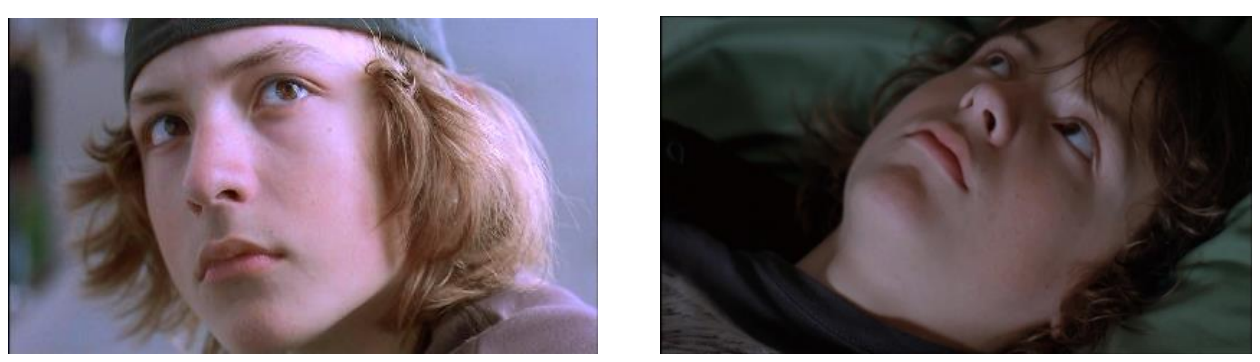

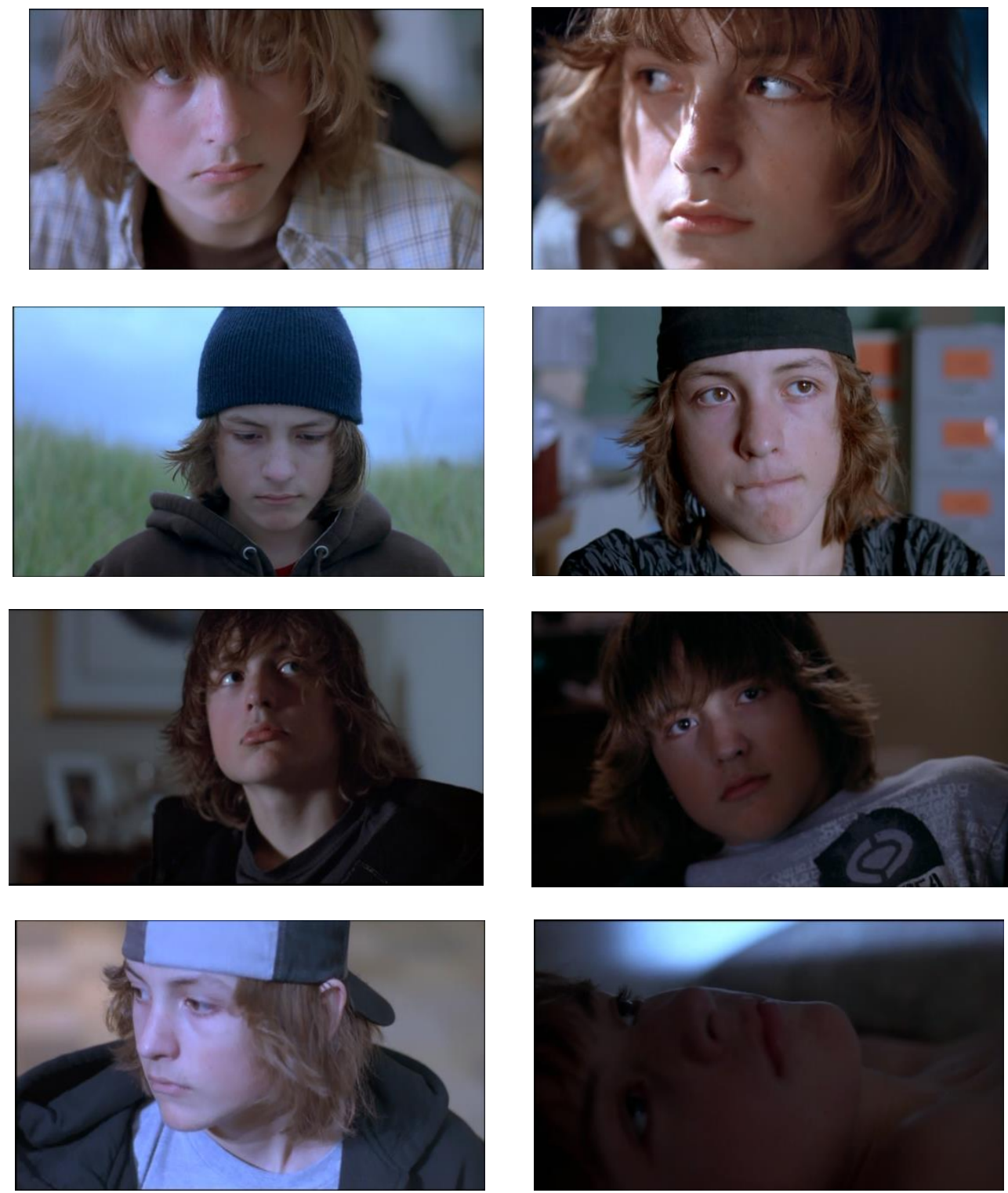

Os PP, tomados como responsáveis por expressar a alma do sujeito através do rosto, logicamente suscitam ainda outra questão: o da gestualidade facial. Assim, nota-se em Alex um rosto muitas vezes "inexpressivo", palavra utilizada em sua acepção mais popular, e que gera um contraponto entre o estado interior do ator, tomado pelo sobrevir, e sua figura facial exterior. Antes de adentrarmos em qualquer discussão da competência interpretativa, vale lembrar que existe um ator que precisa permanecer em segredo, de modo que sua gestualidade facial é utilizada para esconder, obstruir, tornar inacessível, e não revelar. De outro lado, a expressão do jovem conforma-se com a leitura semiótica do romance na qual ele estaria "em outro lugar", um mundo epifânico, figurado como rosto que não pertence ao mundo cotidiano.

A tensão contrapontual causada entre rosto inexpressivo exterior e drama expressivo interior é interessante, pois suscita algumas questões: em primeiro lugar, do ponto de vista do 
sentido passional e tensivo da face, constrói-se uma atonização ${ }^{151}$, em oposição à linguagem facial de gestualidade intensa e dramática, que pode ser aferida pelo excesso de movimento. Como o rosto de Alex esconde estados fóricos e passionais mais intensos, eles são remetidos à instância da enunciação, que como vimos na sequência acontecimento, a partir do plano da expressão plástico, sonoro e cinemático, e do plano do conteúdo espaço, som, movimento, dá conta do espaço afetivo interior. Finalmente, apesar de ser atônico, ou menos ativo, a expressão facial do ator não é menos gradual e tensa, e deve ser contraposta a seus outros tipos de gestualidade: enquanto escreve, por exemplo, o seu rosto é marcado por uma leve concentração, ou rigidez facial. No final do filme, o ator sorri.

Além do medo e do segredo, constroem-se outras emoções a partir da observação enunciativa do espaço, tais como a frustração e a raiva que Alex sente quando Jared lhe comunica que vai abandoná-lo na noite de sábado, e não irá à pista de skate:

Figura 101 - Alex sentindo-se abandonado e traído
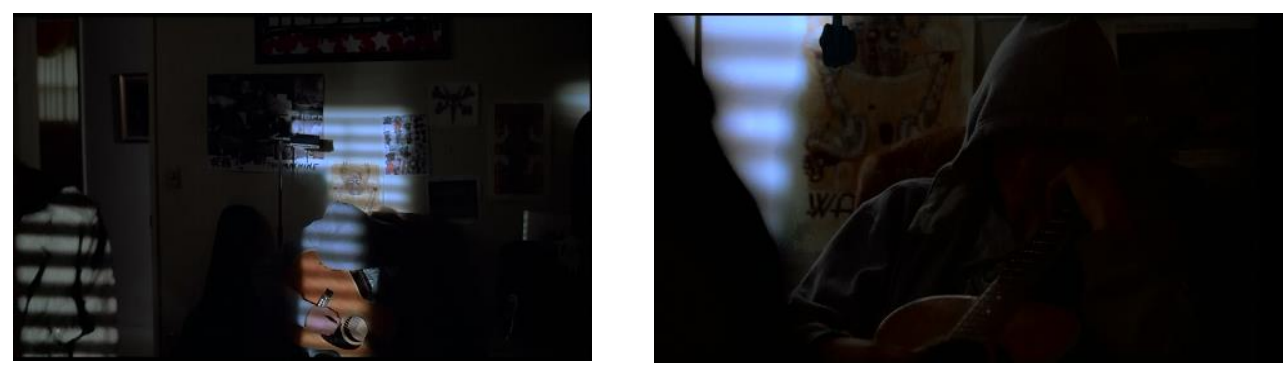

A disposição passional do jovem em relação à namorada, suas dúvidas amorosas e falta de amor são também figuradas a partir de uma proxêmica espacial. A composição da sequência em que os jovens fazem amor pela primeira vez conota dúvida, tristeza e sobrecarga afetiva, relativa ao percurso temático do amor e às modalidades passionais do medo. Tais emoções são figuradas pela cor azulada do ambiente, PPs e construções figurativas de obstrução.

Figura $102-$ O sobrevir e as dúvidas amorosas
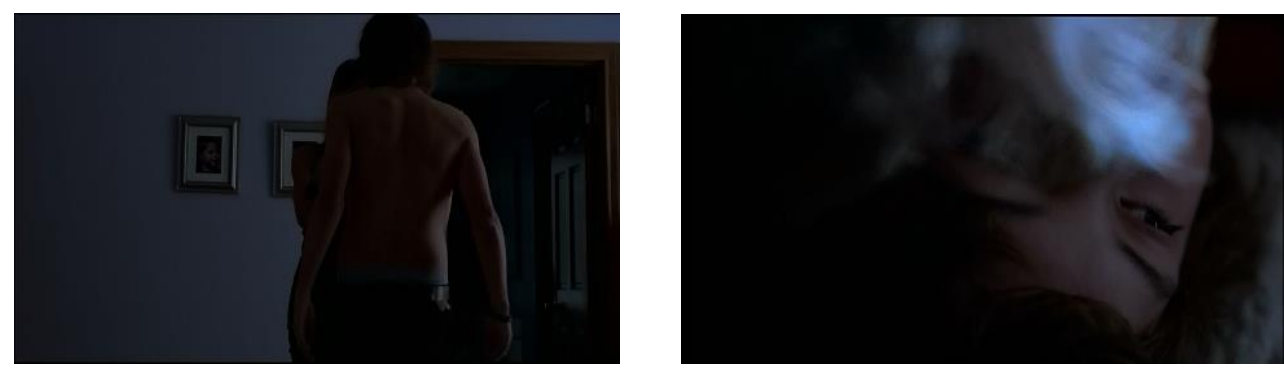

${ }^{151}$ Assim, a questão da atuação do ator, para semiótica, torna-se pouco relevante. 

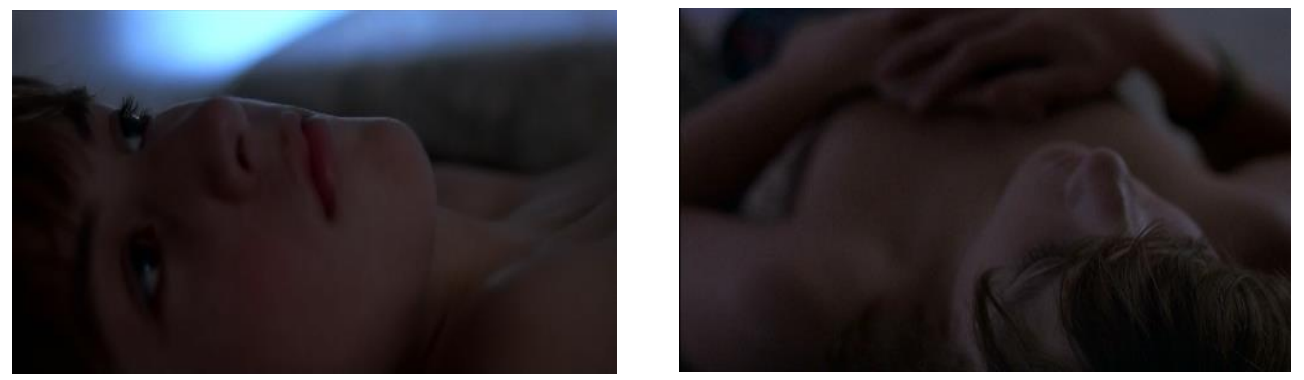

De outro lado, o enunciador audiovisual também mostra a afetividade do jovem por Macy, a paixão do amor, que se torna mais presente a partir da sequência acontecimento, sendo carregada de tensão sexual. As três vezes que Macy aparece na narrativa, depois do acontecimento, possuem o caráter erótico e sensual sugerido no romance: a primeira vez que o jovem a encontra, no domingo depois do acidente, a imagem da menina é desacelerada, e acompanhada por uma trilha suave de Nino Rota. Em uma segunda vez, os sorvetes que os jovens tomam juntos são mostrados em detalhe, em uma poética conotação de doçura e sensualidade. Dentro do ônibus, enquanto Alex encosta o seu braço na perna da amiga, ela torce um pedaço de pano, em uma imagem carregada de desejo sexual:

Figura 103 - O desejo por Macy
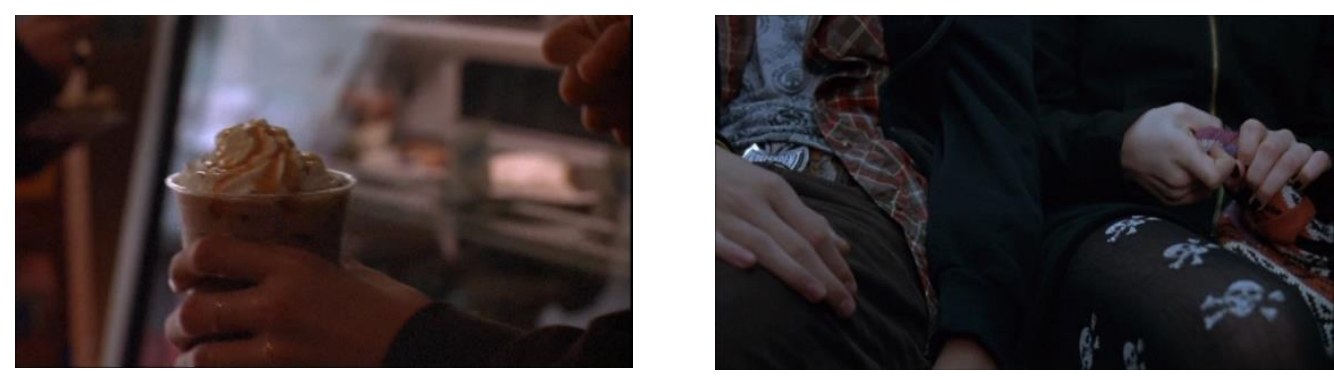

Além do enquadramento da face do ator, das figurações do espaço e das imagens mais simbólicas e figurativas de seu desejo, a imagem de seu corpo inteiro em relação ao espaço que ocupa também constrói estados passionais causados pelo sobrevir. Vimos, por exemplo, tanto nos minutos iniciais da narrativa, como no acontecimento, os vários tipos de tratamento da imagem do narrador /ator, em relação ao enquadramento: Alex apresenta-se muitas vezes diminuído dentro da composição, sua imagem é super / subexposta à luz, claros e escuros, a partir de ângulos desnivelados, em uma instabilidade formal que simboliza a instabilidade interior do próprio ator.

Seu espaço, a partir de uma semioproxemia, é muitas vezes figurado a partir de ângulos pouco convencionais, ou de maneira que sua imagem fique cortada. Se de um lado os espaços do romance foram mantidos, de outro eles foram figurados plasticamente como 
construções passionais que simbolizam a solidão e a inadequação do ator à sua realidade após a instalação do sobrevir:

Figura 104 - Alex e sua relação com o espaço

(distanciamento)

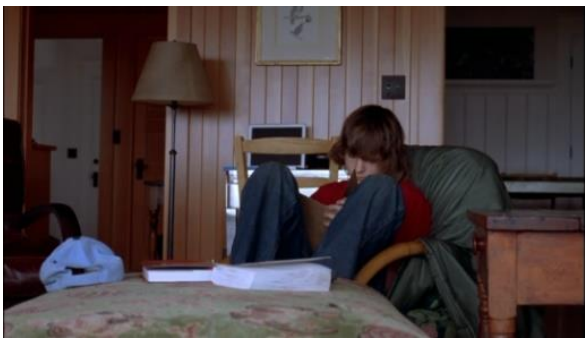

(distanciamento)

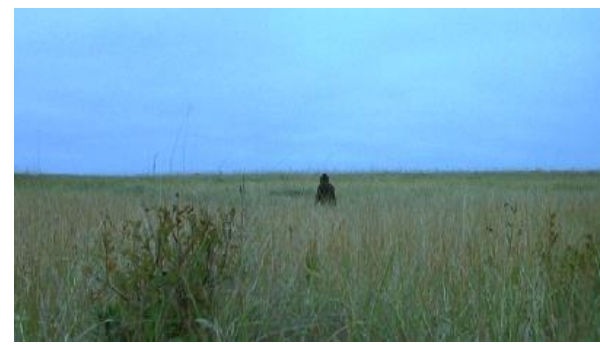

( ângulos acentuados)
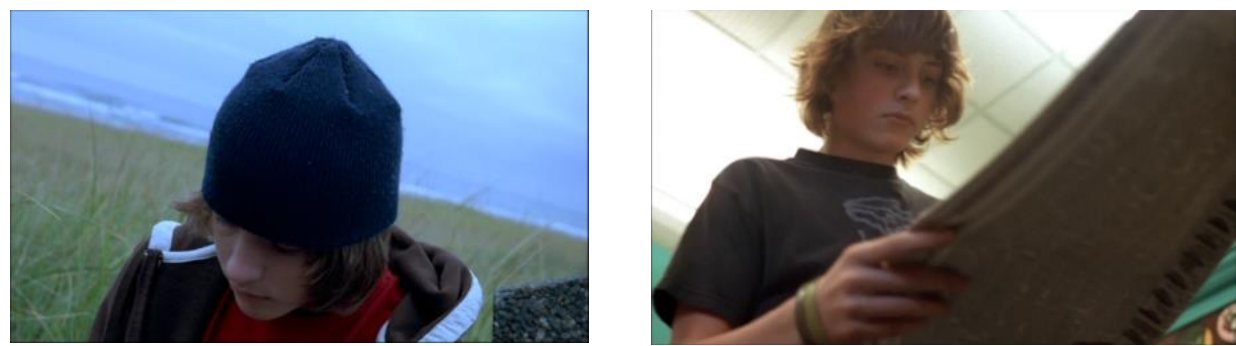

(espaço exterior figura o espaço interior)

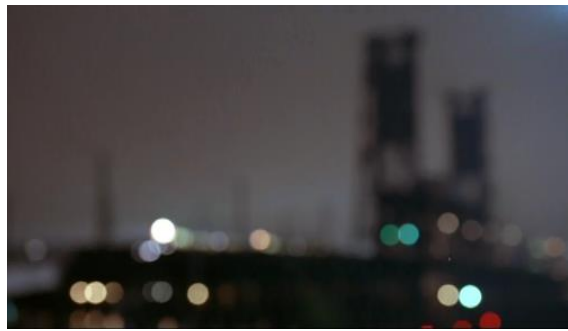

(descentramento e inferioridade)

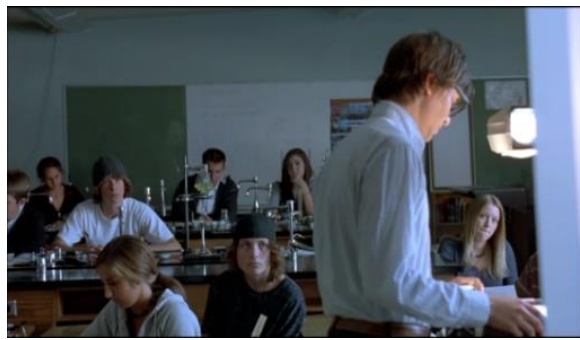

(distanciamento e descentramento)

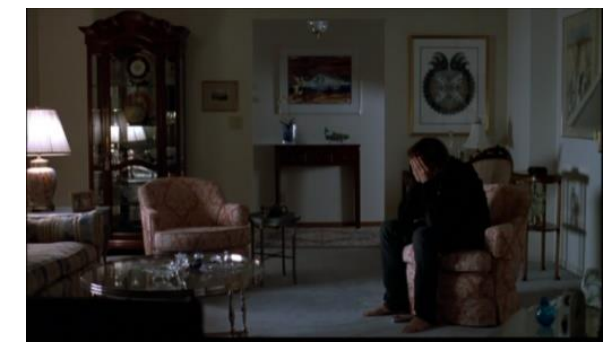

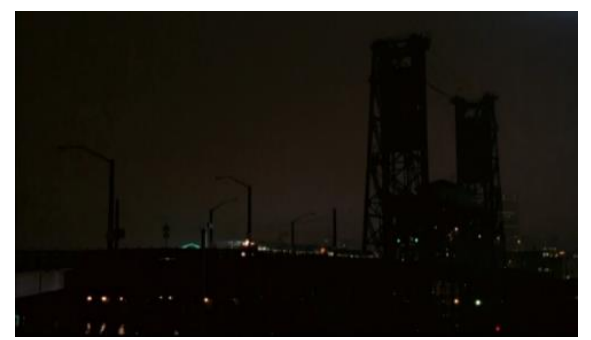



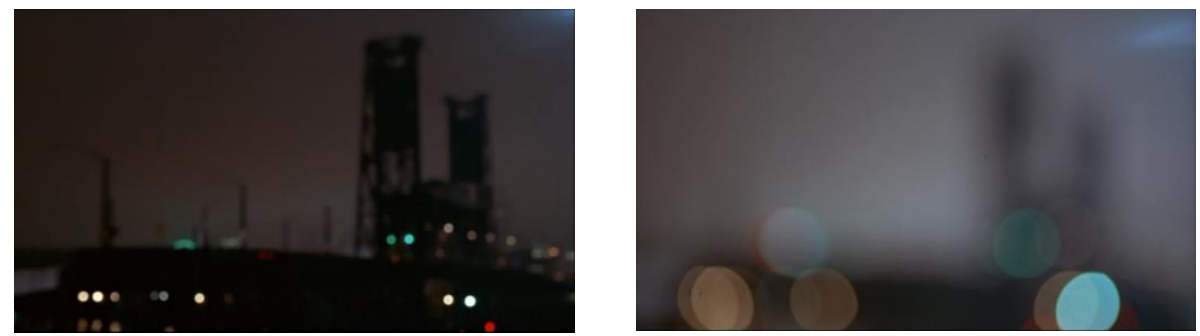

(descentralização, duplo enquadramento e distância)
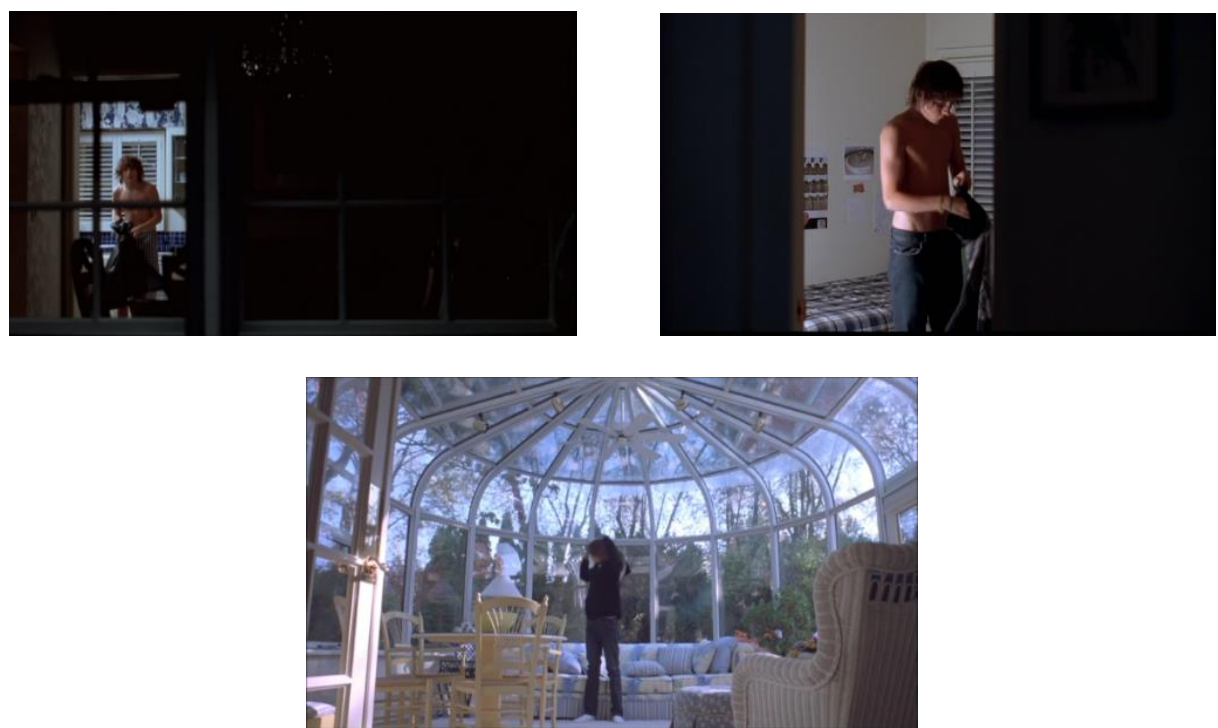

(imagem distorcida)

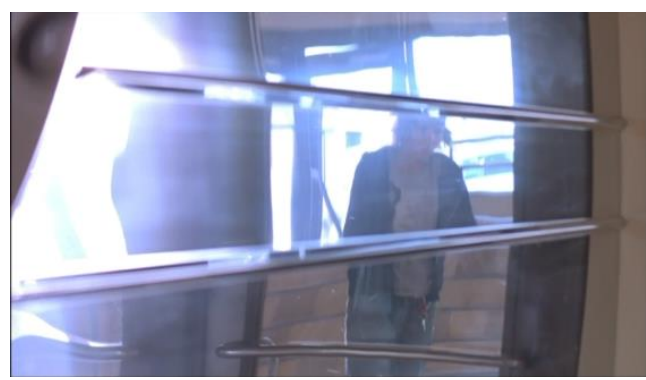

(descentramento e ângulo acentuado)

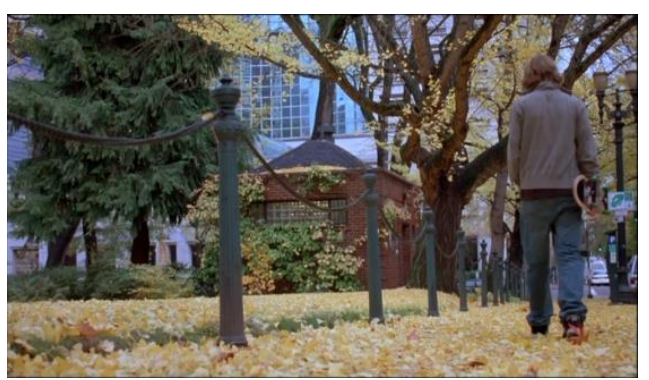

(descentramento e imagem parcial do ator)

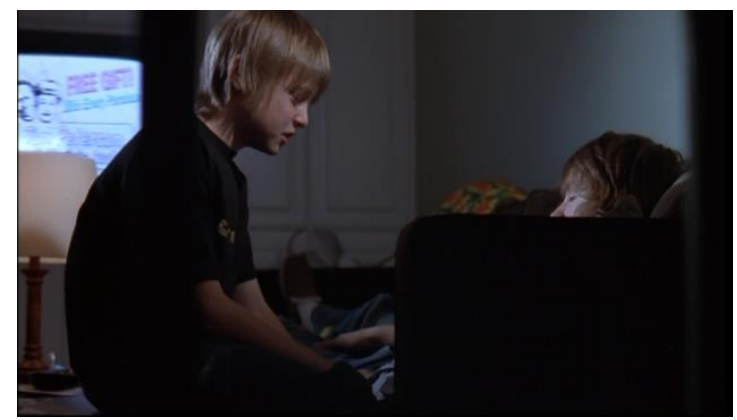


(descentramento e distância)
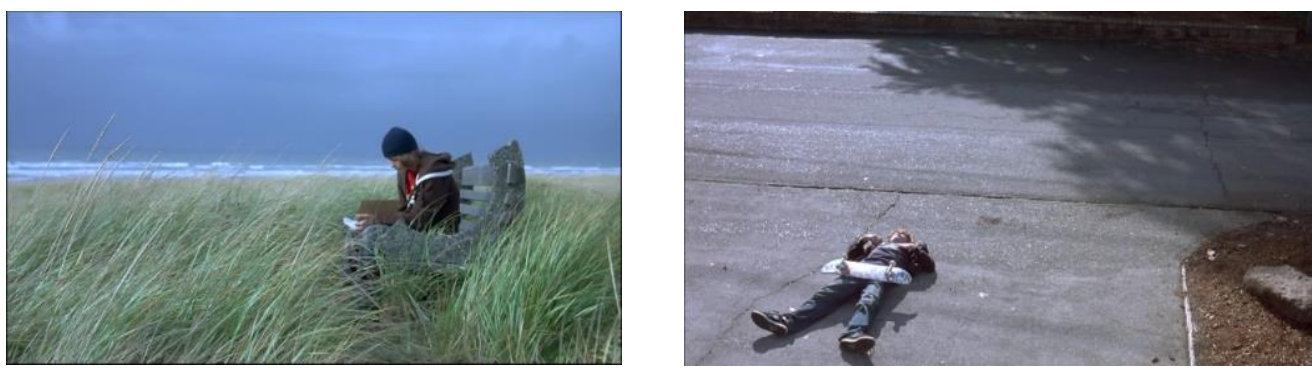

(escrevendo na casa do tio: duplo enquadramento, descentramento e distância)

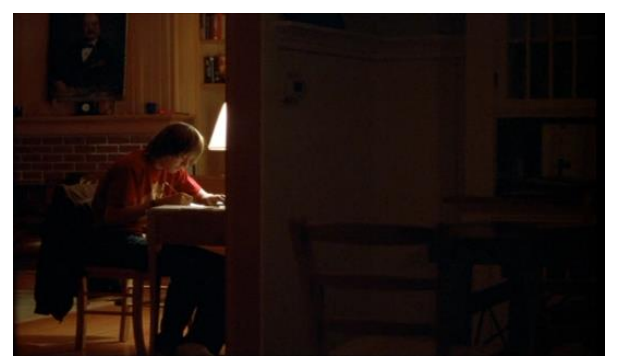

\subsection{Os outros atores}

Vimos, no romance, que todas as pessoas com quem Alex se relaciona, amigos, família, polícia etc, são projeções, no nível superficial narrativo, de destinadores e antidestinadores, e sujeitos e antissujeitos, que existem também no eixo dos subcontrários: não-antidestinadores e não-antissujeitos. Tais actantes vão ajudá-lo ou atrapalhá-lo na busca da conjunção com o seu objeto-valor, relacionado à procura de outros valores, ou ficarão relativamente à margem desse processo, átonos e descentralizados. Como trata-se de um romance sobre um adolescente que tem um irmão de 13 anos, pais em processo de separação, e deve manter o segredo de um crime, seria de se esperar que o jovem se isolasse.

Destacamos, durante a análise semiótica do romance, os destinadores e sujeitos Jared, Scratch e Macy, além do sujeito coletivo Paranoid Park; e os antidestinadores e antisujeitos detetive, segurança do pátio de trens e a namorada. Observamos também que o detetive aparece como um sujeito complexo, uma vez que Alex (cujo pai está ausente de casa devido o divórcio), primeiramente sente-se atraído por ele, vendo-o como amigo e figura paterna (o jovem quase conta a verdade ao policial), e depois, desinteressado, pois desconfia de suas verdadeiras intenções. A relação entre o policial e o jovem não é aprofundada no filme, mas observamos, na análise dos primeiros minutos do filme, como a imagem da mão que entrega o cartão possui 
tons passionais. A partir daí podemos investigar como o discurso audiovisual constrói certas relações afetivas entre Alex e outros atores.

No filme, a relação do jovem com seus sujeitos e antissujeitos é expressa menos pelo diálogo, ou a voz-over, do que pela composição plástica. Entre os sujeitos, por exemplo, percebe-se um tratamento estético geral que os centraliza na composição e os torna totalmente visíveis, ou exibidos. Assim, temos:

a. Macy, colega da escola e vizinha que desconfia do silêncio de Alex, sugerindo que ele escreva o que o incomoda. Alex confessa sua paixão por ela na última carta que escreve.

Figura 105 - Macy
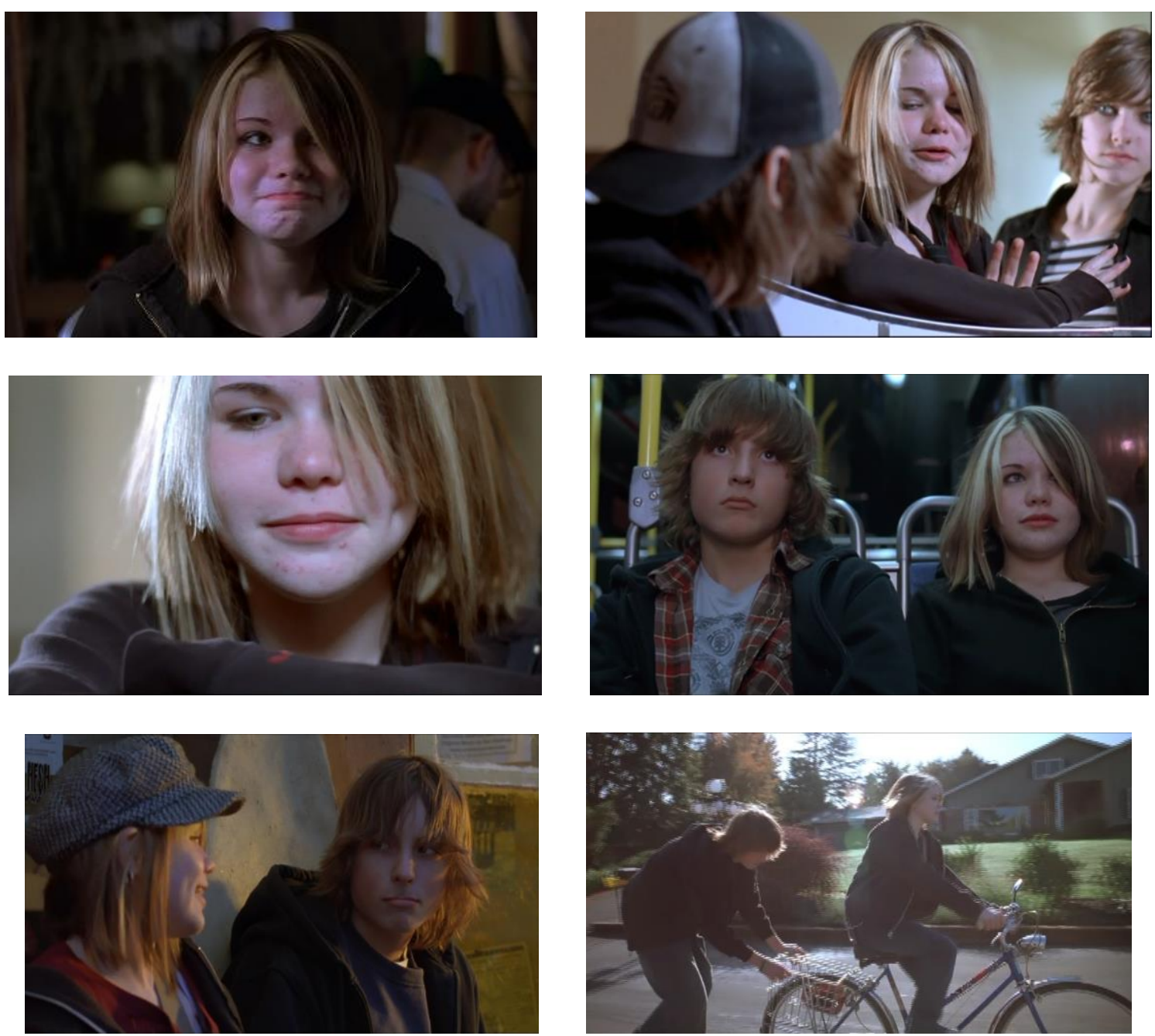


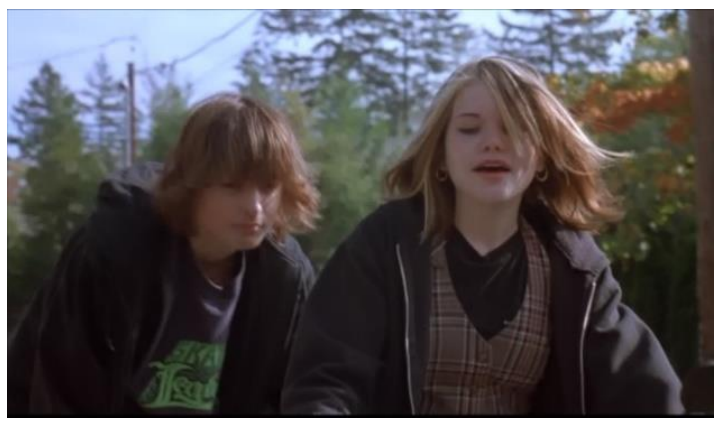

Uma característica interessante sobre o ator Macy é a sua caracterização física. O corte de cabelo faz com que o seu rosto esteja sempre parcialmente coberto, o que lhe empresta certo ar de mistério, a partir da operação figurativa que oscila entre exibição e inacessibilidade.

b. Jared é o amigo recente de Alex, mais velho e experiente, e ensina Alex a andar de skate. Mais experiente, sua figuração é mais "sóbria" e "limpa", em comparação com a figuração do próprio Alex, que parece mais desleixada. Jared traja-se melhor e seu rosto traduz certa maturidade.

Figura 106 - Jared
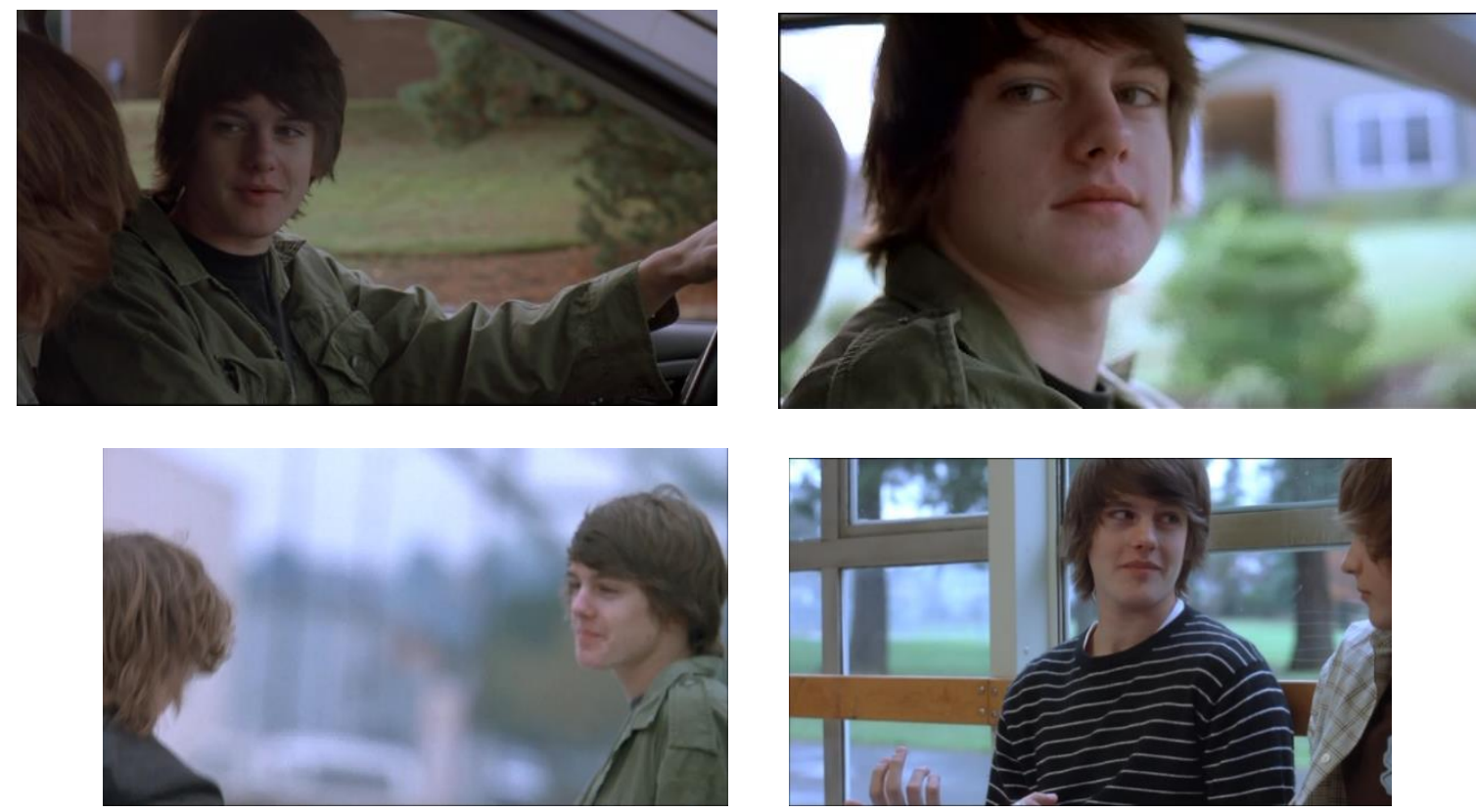


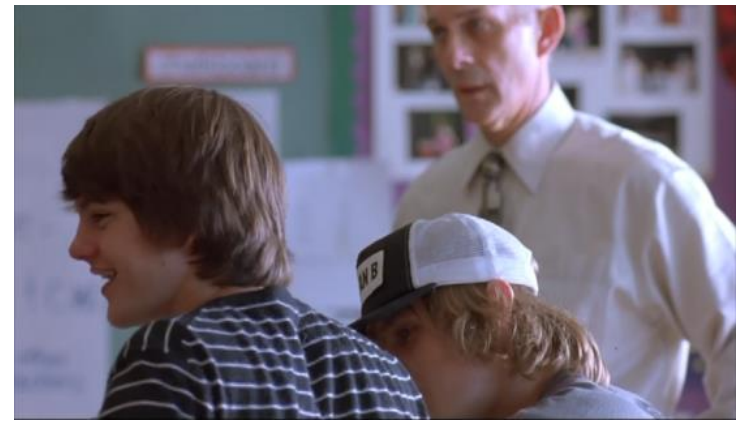

c. Scratch, um "Rueiro" usuário da pista de skate. Convence Alex a surfar um trem para cruzar a cidade. Tanto Scratch quanto Alex, e diferentemente de Jared, com cabelo mais curto, possuem uma figuração que poderíamos ligar à androginia. A maneira de como o garoto fita Alex, na pista de skate, insinua certa intimidade exagerada que parece destoar do fato de que ambos se conhecem há apenas alguns minutos, e Alex sabe que a pista é perigosa, sendo cauteloso. Discutiremos a questão mais abaixo.

Figura $107-$ Scratch

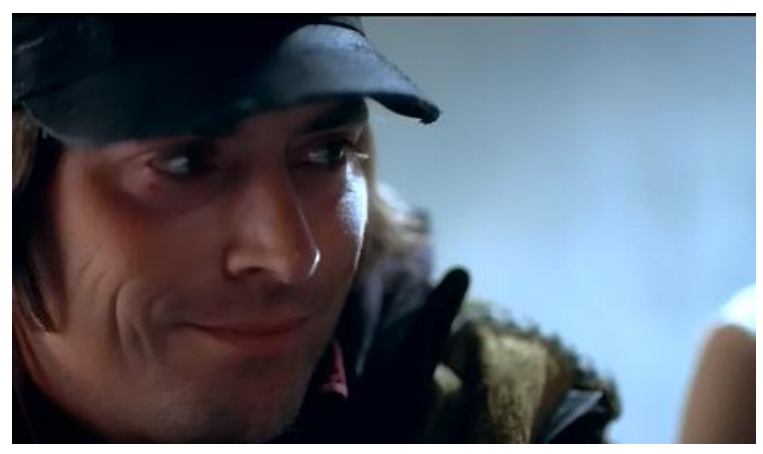

d. O ator coletivo skatistas: Já observamos que Paranoid Park apresenta novos valores a Alex, sendo descrita visualmente como local da cinestesia, do movimento e da instabilidade, metáfora não apenas da juventude, mas da própria transformação, e também como espaço tátil da lembrança, evocando o contato com a pele, por aparecer muitas vezes texturizada. O enunciador fílmico segue o romance e tenta figurar os usuários da pista como grupo misturado, mas cujos indivíduos possuem personalidade e comportamento próprios, e "vindos de todos os lugares". A descrição de Alex desse grupo é transposta para o filme:

Uma coisa interessante de um lugar como Paranoid eram os caras que andavam de skate lá [...]. Surfistas de trem, punks de guitarra, skatistas, 
bêbados, jovens abandonados. Não importava o quão ruim era a sua vida familiar, a desses caras era bem pior.

Após esse texto em voz-over, os usuários de Paranoid Park são observados em câmera lenta e a partir de um observador fixo:

Figura 108 - A comunidade Paranoid Park
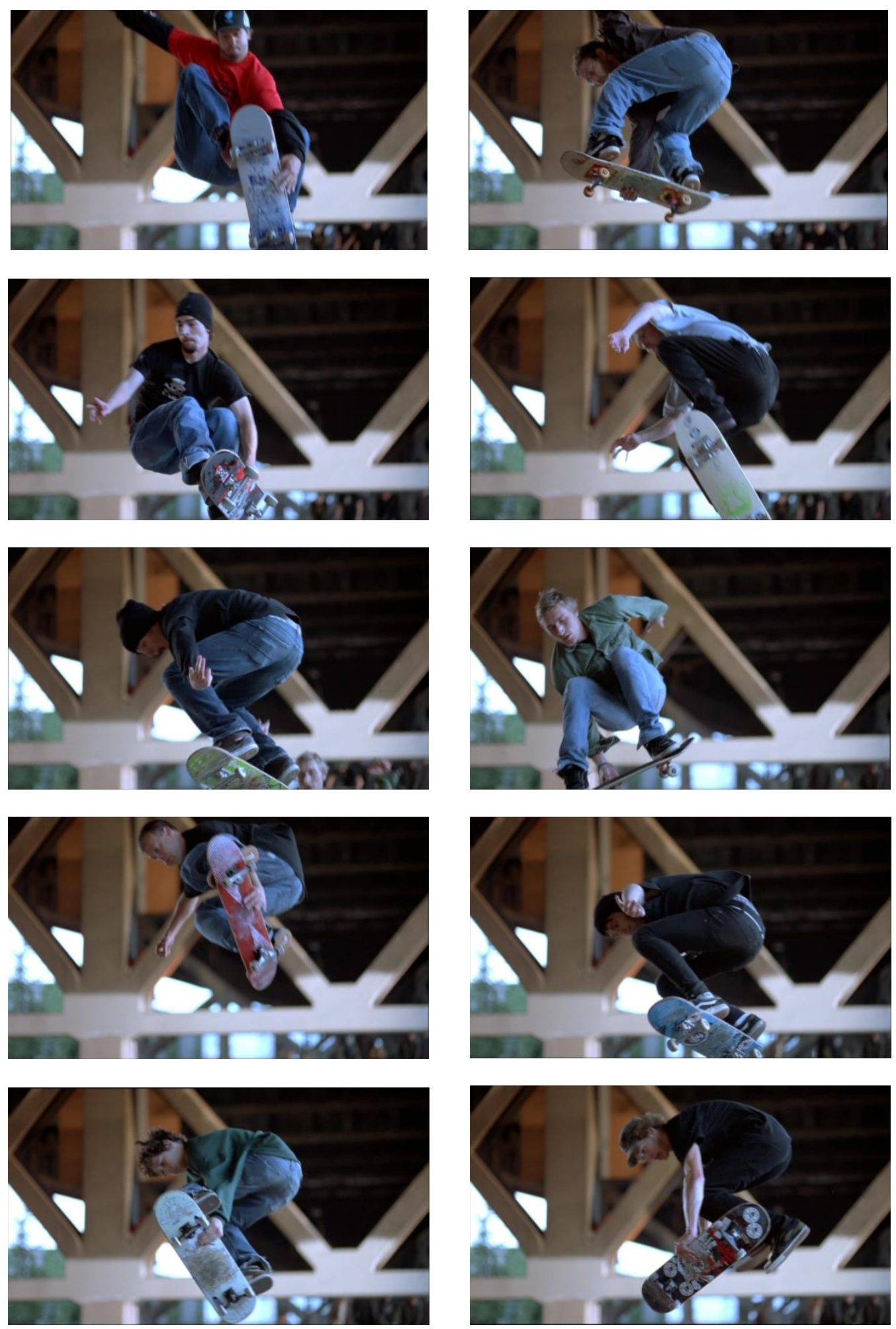
e. Como antissujeito, Jennifer, a recente namorada que Alex rejeita, é sempre figurada de maneira menos nítida ou visível em várias partes da narrativa: diferentemente de Macy, a inacessibilidade é construída no nível da enunciação, e não do enunciado, em uma figuração que se aproxima dos sentimentos do narrador / ator Alex expostos no romance. O rosto da adolescente é mostrado desnivelado, ou seja, olhando para baixo, e não para frente (a cena de amor entre os jovens), e também é recortado pela imagem de Alex. Quanto sua imagem está nítida, exibida e centralizada, Jennifer apresenta uma gestualidade facial contida, que conota as paixões de coléra, sentida muitas vezes em relação ao namorado. Na escola, após o acontecimento, quando Alex passa pela namorada, absorto em seus problemas recentes, a imagem de Jennifer está fora de foco:

Figura 109 - Jennifer
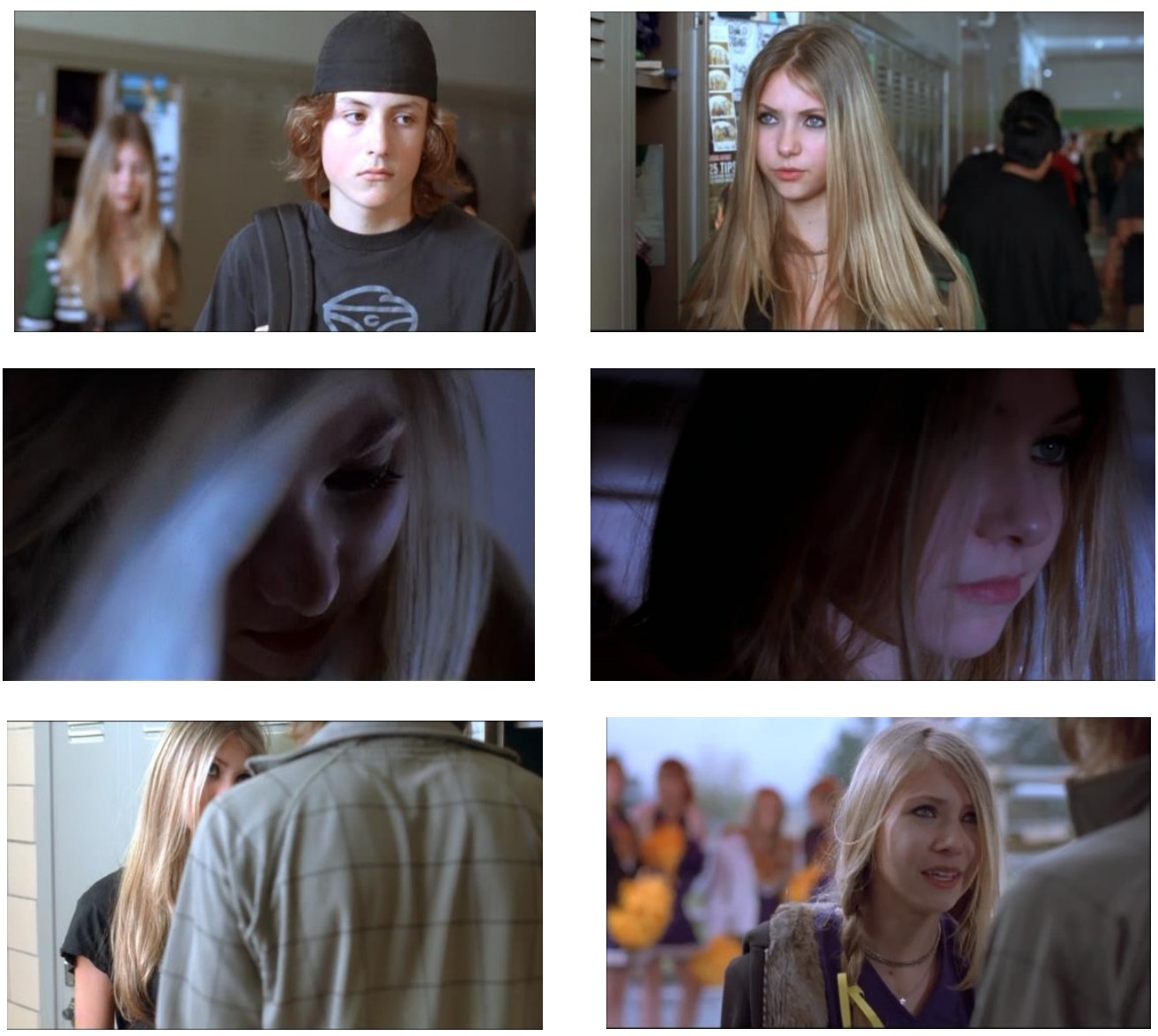

f. O segurança do pátio de trens, morto acidentalmente por Alex, é figurado como homem de meia idade e corpulento, como no romance. No filme, sua imagem é 
relacionada à escuridão da noite. $\mathrm{O}$ vigia primeiramente aparece imponente e ameaçador, observado de baixo para cima (contra-plongée). Depois do acidente, o eixo de observação inverte-se. Mostra-se, de cima para baixo (plongée), o corpo do ator decepado ao meio e arrastando-se no chão em direção ao jovem. No discurso fílmico, o enunciador constrói, a partir do olhar, uma importante relação entre os dois atores, intensificando uma relação afetiva que reverberará, como vimos, no presente do narrador. Enquanto no romance, a imagem do corpo de um homem cortado ao meio será uma lembrança indelével, no filme ela se transforma na própria imagem-acontecimento, carregada de significados e ambiguidades. Segundo Zilberberg (2011) a metáfora é uma tensão discursiva entre implicação e concessão (p. 185). Vimos que o corpo decepado do vigia pode ser entendido como metáfora de um mundo adulto contra o qual o jovem reage. No filme, tal imagem metafórica ganha mais contornos, sendo carregada de intensidade concessiva e tornando-se a própria imagem-exclamação. $\mathrm{O}$ torso humano que se movimenta transforma o vigia em morto-vivo, homem desfigurado e sem pernas que, no entanto, move-se e vê. Ao olhar para o garoto, torna-se o objeto perturbador que olha de volta e jamais será esquecido.

Figura 110 - O vigia do pátio de trens

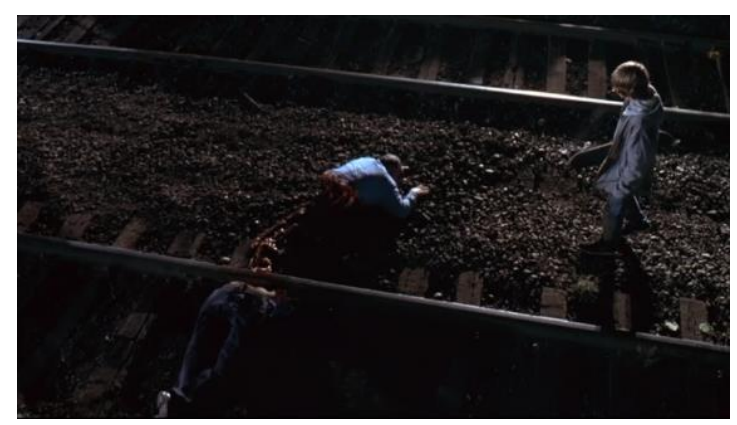

g. Em relação à família mais próxima de Alex, que denominamos não-sujeitos, percebe-se que a imagem dos adultos, tio, mãe e pai, nem sempre é nítida, centralizada ou total. A cabeça ou o corpo do tio são cortados pelo enquadramento, assim como a cabeça da mãe, que também aparece distante e de costas. O rosto do pai, enquanto conversa com o filho na garagem, não é nítido em boa parte da cena. Tais figurações visuais, relacionadas igualmente a estratégias de obstrução, conotam o distanciamento do jovem em relação a família. 
Figura $111-\mathrm{O}$ tio Tommy
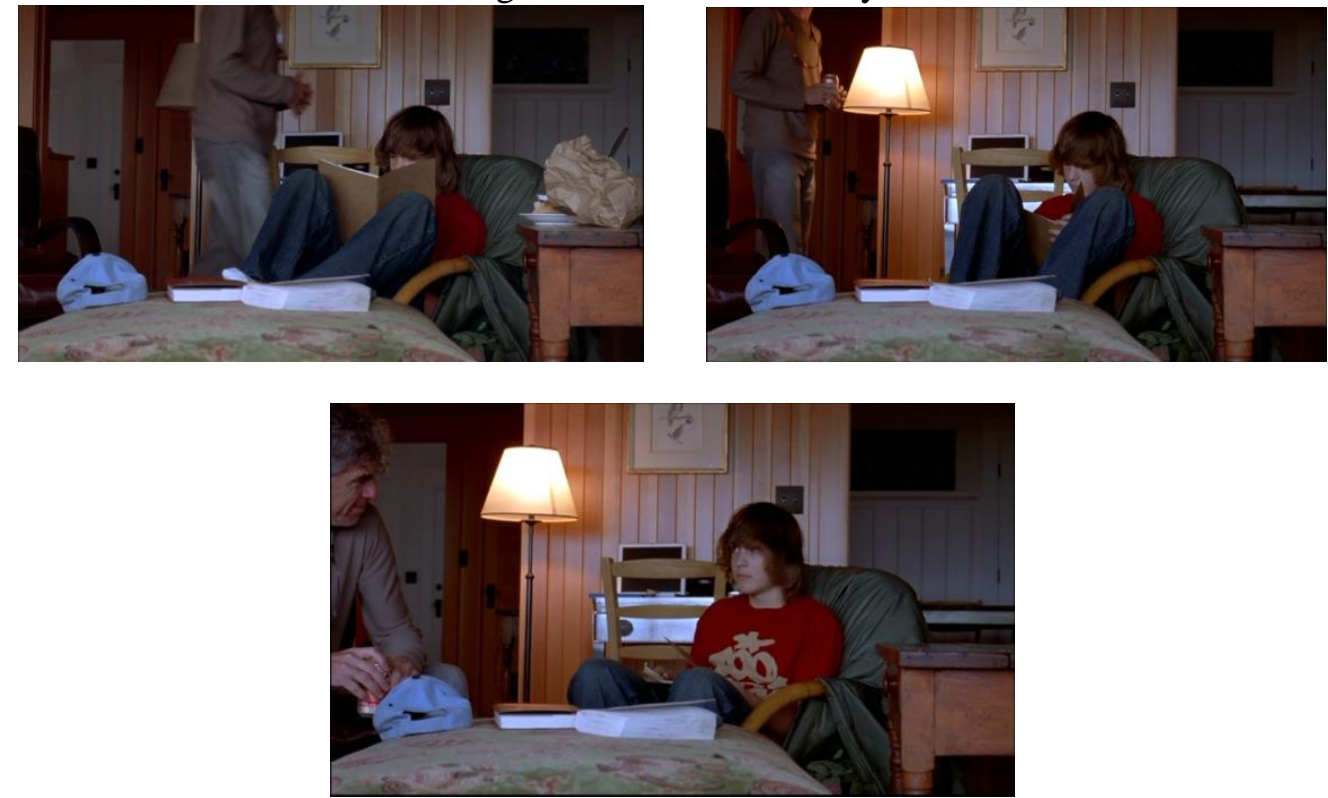

Figura 112 - A mãe
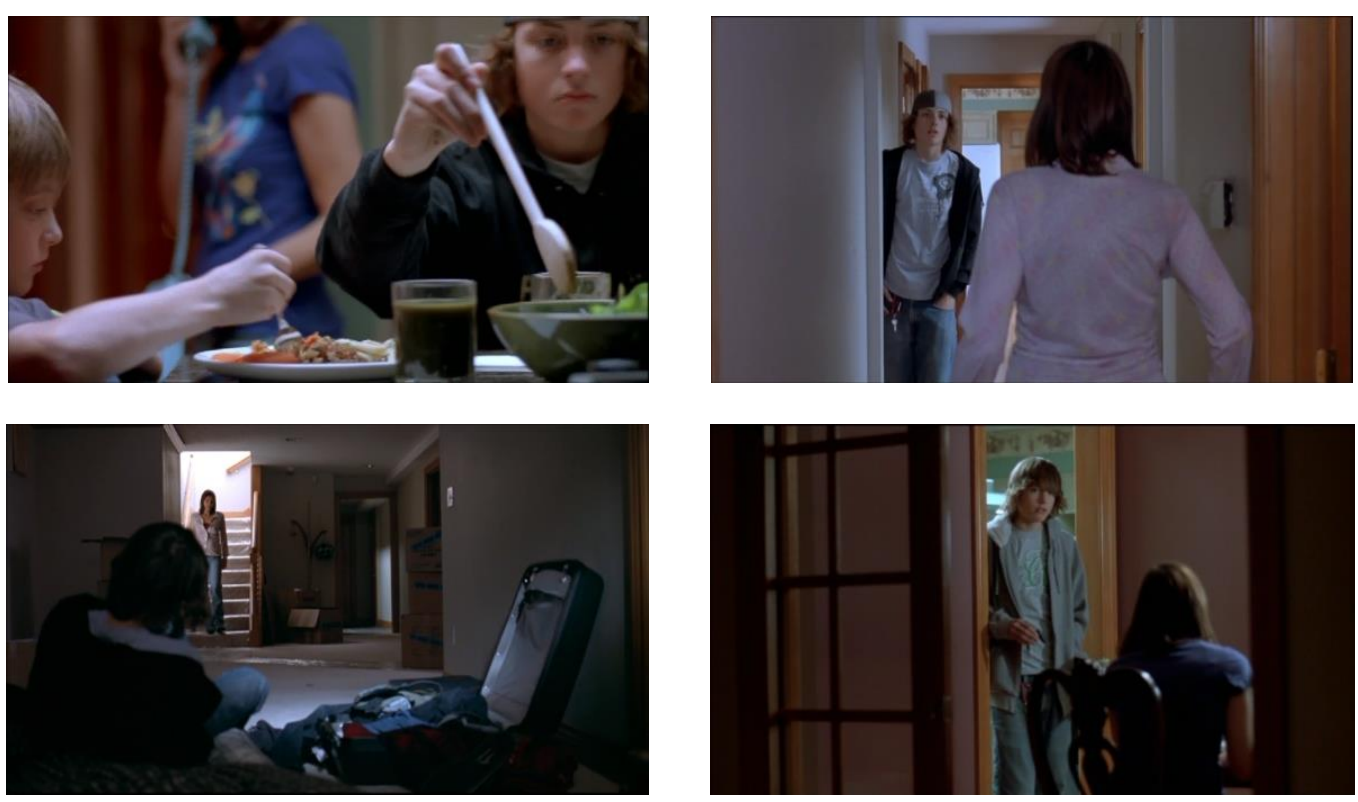

Figura 113 - O pai
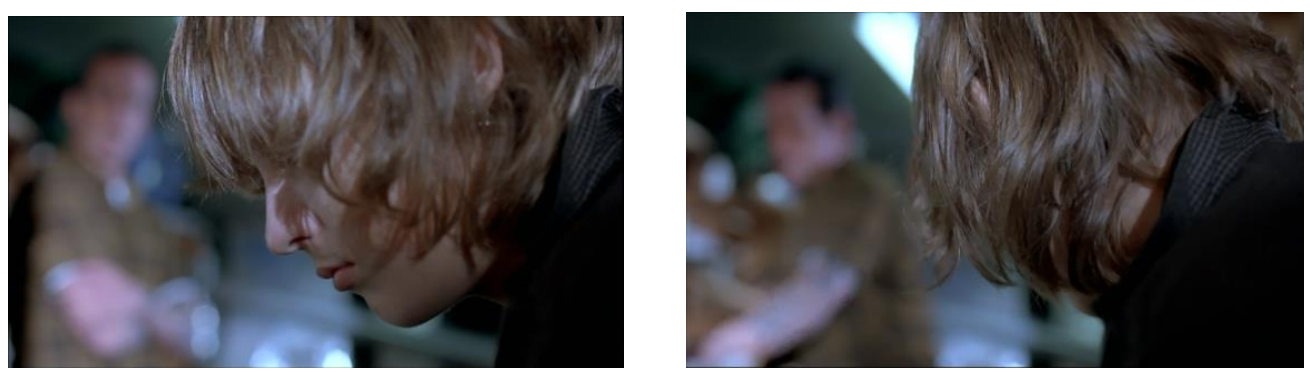


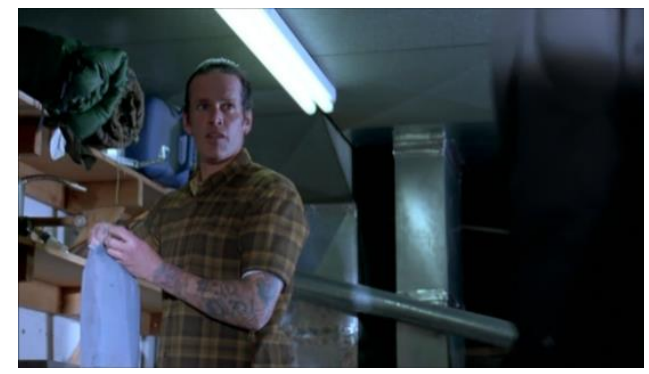

h. Lu, o detetive, enquanto no romance é mais recorrente, aparecendo algumas vezes na vida do jovem, no filme é mostrado apenas em duas sequências: quando visita a escola pela primeira vez, para fazer um primeiro contato com os alunos que praticam skate; e quando colhe o depoimento de Alex, em um momento mais particular, dentro de uma sala de aula (já tratamos dessa sequência ao analisarmos os primeiros minutos do filme). Já comentamos a desconfiança de Alex em relação a esse ator, que possui valores complexos de sujeito e antissujeito. Apesar dessa oscilação de valores, a imagem do detetive é nítida e centralizada, em um tipo de figuração bem diferente da dos outros antissujeitos e não-sujeitos vistos acima. No entanto, percebemos que o mesmo acontece com o pai de Alex, que na longa sequência da conversa na garagem, fica nítido por apenas alguns segundos. Tal isotopia figurativa poderia sugerir uma figuração visual simbólica do triângulo afetivo Alex, pai ausente e detetive, visto como figura paterna: essa relação é apoiada pela imagem da mão do detetive que entrega o seu cartão ao jovem, e constroi uma relação de contiguidade e proximidade entre Alex e o policial. Uma das particularidades da figuração desse ator é sua origem asiática e a mudança de seu nome, que no romance é Mathew Brady. Mais abaixo especularemos sobre a mudança:

Figura 114 - O inspetor de polícia Richard Lu. Diferença étnica não existente no romance
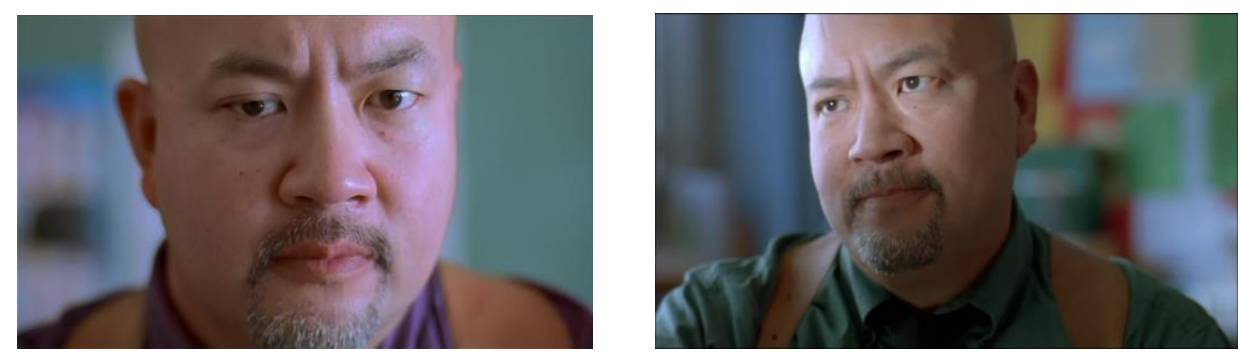


\subsection{Tempo e espaço}

Alex é principalmente o sujeito da memória, sendo que o seu programa narrativo de base é justamente o de lembrar e escrever sobre um evento traumático. Nesse sentido, o romance afirma-se como um ato de reconhecimento por parte do herói. No filme, como já observamos, tal lembrança é desordenada e, como espaços e tempos são filtrados parcialmente pela mente do narrador / ator, o discurso fílmico torna-se a figuração audiovisual de um espaço e tempo interiores, subjetivos e diegéticos, orientados por modos e sintaxes tensivas. A partir da elaboração de uma subjetividade que possui memória e relata a própria vida, espaço e tempo tornam-se, em um primeiro momento, projeções afetivas e passionais do ator, e a narrativa visual estabelece uma série de estratégias expressivas para figurar um espaço projetado por um sujeito cognitivo e sensível.

Em termos fílmicos, podemos dizer que a narrativa do lembrar a partir do presente aciona o flashback, que segundo Turim (1985), é uma imagem ou segmento entendido como representando ocorrências temporais anteriores às imagens (ou segmentos) que o precederam (p. 1), em uma estratégia narrativa que pode ser, a partir de Genette, comparada a analepse na literatura. Há, no entanto, importantes diferenças de sugestão de volta ao passado em relação às coerções de cada suporte: no filme, que possui um espaço bidimensional visual e sonoro, por exemplo, o flashback lida com a construção da figura icônica a partir da plasticidade da imagem e do som: a narrativa fílmica pode sugerir a volta ao passado sonoramente, e não apenas visualmente. Em sua forma clássica, ele é introduzido quando uma imagem (ou som) é seguida por outra, que indica o passado da anterior, e é entendida ou como história-sendo-contada em outro tempo ou como memória subjetiva (TURIM, 1985, p. 1). Turim entende que os conceitos de memória e flashback estão interligados, e o seu funcionamento pode ser explicado por teorias narrativas estruturais e formais, teorias da imagem, da semiótica, da psicanálise, das percepções e da ideologia, e filosofias da memória e da consciência (TURIM, 1985, p. 20) ${ }^{152}$. Da mesma maneira, como pode tratar de uma volta subjetiva no tempo, o flashback insere-se também no discurso sobre o pensamento, a ilusão, a imaginação e o sonho. Como estratégia discursiva enunciativa de temporalização cria um discurso remissivo, de paradas na continuidade do presente da ação, retardando desfechos. Assim, do ponto de vista fórico, o flashback controla o ritmo da narrativa, o seu andamento ${ }^{153}$.

\footnotetext{
152 "The formulations of a theory of flashback needs to borrow from narrative theories of formalism and structuralism, from image theory and semiotics, from psychoanalysis and psycho ercpetual theory, from ideology theory and philosophies of memory and consciousness, all of which explain aspects of flaskback functioning".

${ }^{153}$ Do ponto de vista da retórica, o flashback (e o flashforward) relaciona-se a uma figura de transposição. Segundo Fiorin (2016), a histerologia ou hýsteron próteron (o posterior e o anterior), indica uma construção em que o
} 
A ideia de voltar atrás, desacelerar ou retardar um desfecho não significa, porém, que importantes eventos para a compreensão da trama não possam ser revelados a partir do passado, ou no passado, de modo que muitas vezes a volta ao presente não é articulada. Como estratégia de remissão, o flashback pode ocorrer em qualquer parte da narrativa fílmica. Permitindo a compreensão do presente em relação ao passado, ele pode ser utilizado na busca da solução de enigmas, ou imediatamente antes de revelações importantes para a trama. Por apresentarem repentinamente o passado, oferecem novos significados conectados com qualquer pessoa, lugar, ou objeto, "ganhando uma rica dimensão para a codificação da psicologia do personagem, pois uma vez que sua evidência é o passado, eles imediatamente implicam uma dimensão psicanalítica da personalidade" (TURIM, 1989, p. 12).

Unido à cronologia não linear do filme, o flashback de $P P$ torna-se mais fragmentado, de um lado quebrando o discurso do passado em pedaços; e de outro, procurando mimetizar o fluxo de consciência de uma mente confusa no presente. O flashback subjetivo de Paranoid Park participa igualmente da figurativização da temática do sujeito dividido, pois um personagem é substituído espacialmente e temporalmente por outra versão de si mesmo. Segundo Turim (1989), insistir que no flashback o personagem é o mesmo em cada momento é ignorar a dinâmica do relatar o passado (p. 181). No caso de Paranoid Park, o flashback proposto pelo filme não apenas individualiza cada "Alex" no tempo e no espaço, duplicandoo, como também alude à existência de um mesmo sujeito diferente e transformado ${ }^{154}$.

Como no romance, percebemos que no filme a alternância entre os tempos é bem marcada, e a mudança temporal é expressa não só pelo uso da linguagem verbal, a voz-over, mas também pela figuração de espaços diferentes para o presente, representado pela praia e a casa do tio, e o passado, representado por todos os outros espaços. Além disso percebeu-se a utilização do flashback sonoro (a voz de Scratch na pista de skate, passado, em cima da imagem de Alex escrevendo na praia, no presente). Assim, as dinâmicas entre presente e passado são claras e explícitas. Seguindo o romance, o filme inicia-se no presente da enunciação do narrador / ator, com imagens do jovem escrevendo ou andando na praia. No discurso, tais tempos e

posterior vem antes e pode indicar qualquer alteração na ordem cronológica dos acontecimentos de uma narrativa (p.178). Como figura de transposição, entende-se que o flashback abarca tanto a discursivização quanto a textualização.

${ }^{154}$ Falar de si mesmo no passado constrói relações diferenciadas entre sujeito, tempo e espaço. Assim, dizer "Eu não sou mais a pessoa que eu era", mostra o uso do mesmo pronome para referências diferentes, indicando duas subjetividades separadas no tempo e no espaço, em uma formação discursiva que permite a duplicação espaçotemporal do sujeito. 
espaços serão alternados com tempos e espaços do passado relacionados à pista de skate, à escola, à residência dos atores, aos shoppings etc. Assim:

Figura 115 - Alternando entre presente e passado

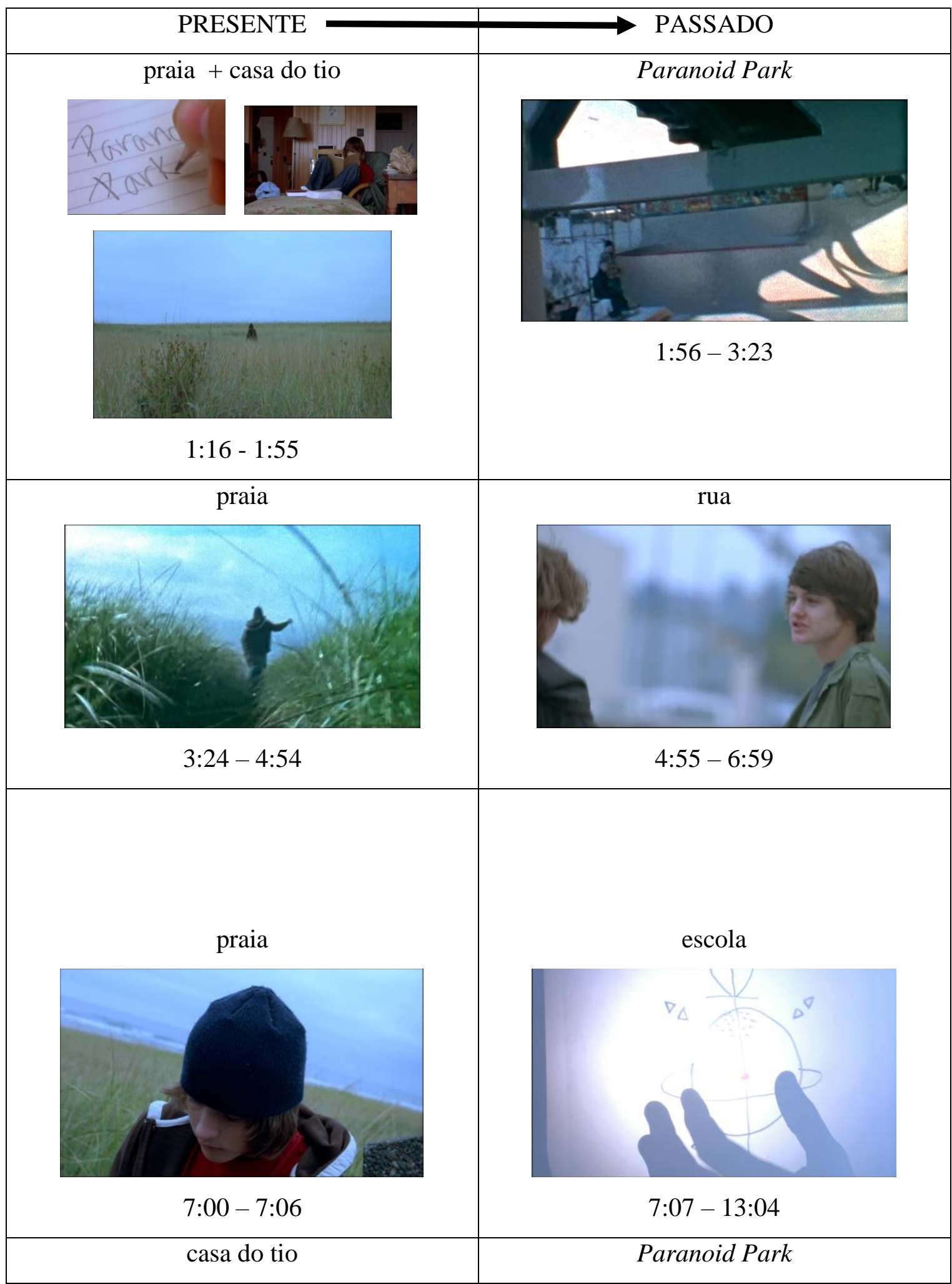




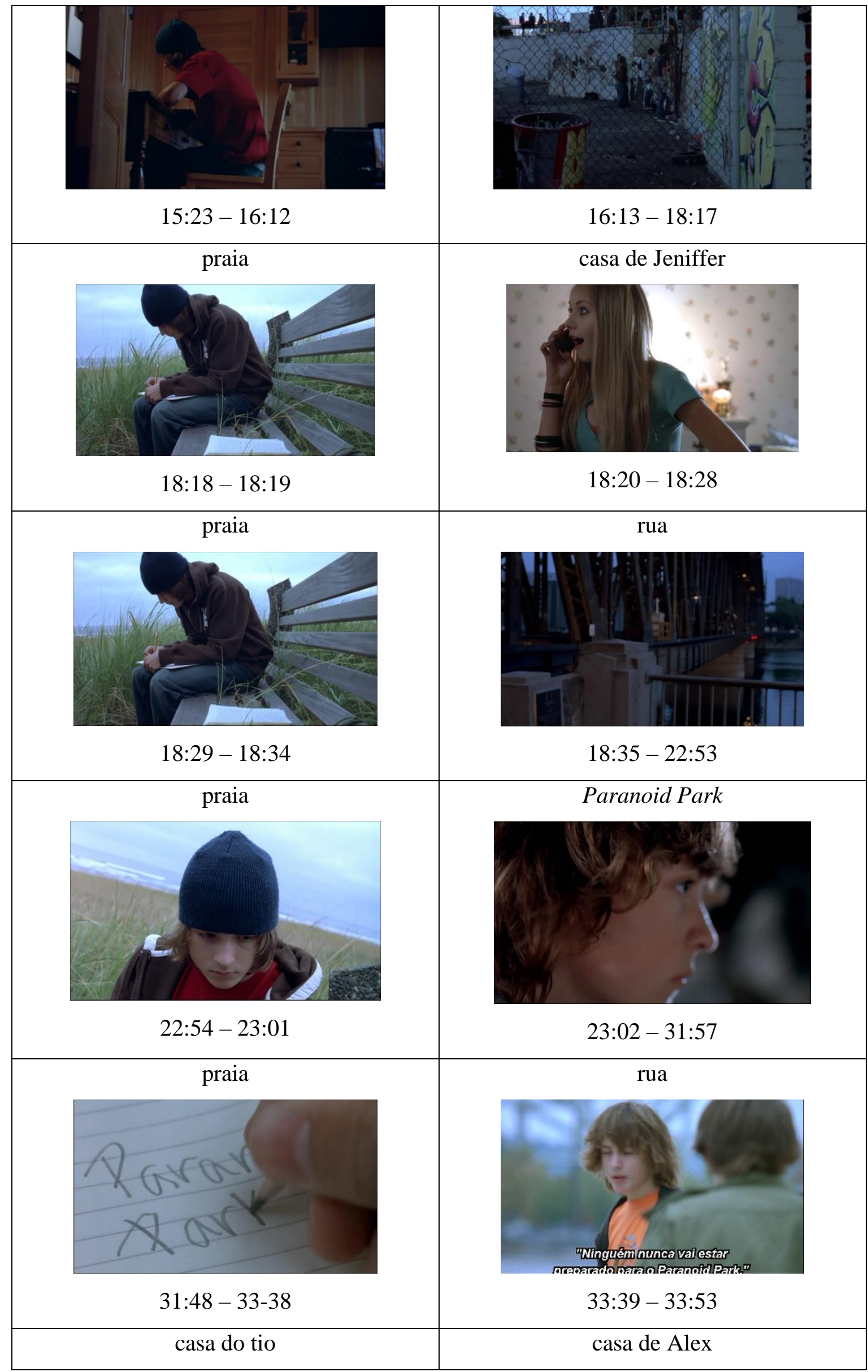




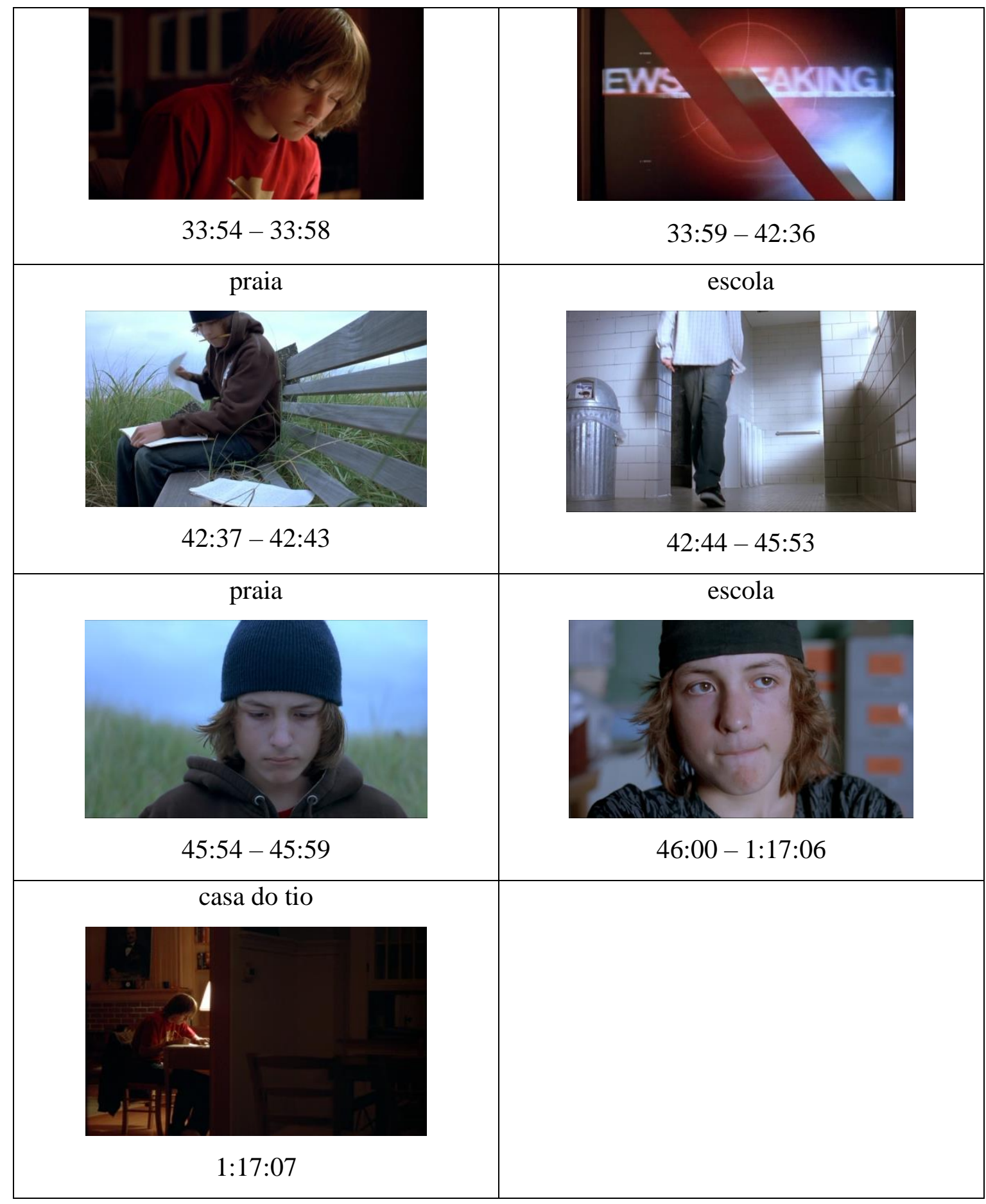

A partir da análise acima e dos fotogramas apresentados, observa-se que a maior parte da narrativa, assim como no texto literário, concentra-se no passado, de modo que o presente é apenas pontual, dando-se muitas vezes apenas de relance e sendo, em alguns casos, extremamente curto (um segundo de exibição). Tal configuração é a mesma do romance. No entanto, enquanto no romance a volta ao presente ocorre apenas três vezes, no discurso fílmico ela é muito mais utilizada, juntamente com a ida a um passado construído como não-linear ou cronológico. A comparação entre as imagens do presente e do passado também revelam que, 
diferentemente do romance, o mar, a areia e a praia são importantes elementos para figurar o espaço presente de Alex, de maneira que o garoto, enquanto escreve, encontra-se mais intensamente ligado a espaços externos e naturais, e ocupando menos o espaço da casa do tio, como no romance.

Outra importante diferença do texto adaptado é que Alex, apesar de estar escrevendo, não menciona nenhuma data, mês ou mesmo quando os eventos descritos se deram. Evitando criar referências temporais precisas e compondo uma temporalidade não-linear, a ideia de que entre o acontecimento e a escrita das cartas passou-se aproximadamente um semestre é suspensa, estratégia que intensifica o presente gnômico ou atemporal e ajuda a figurar os processos da memória em um aqui / agora sempre contínuo e durativo: enunciador e enunciatário lembram juntos. Poderíamos exibir a demonstração da construção espaçotemporal da narrativa fílmica da seguinte maneira:

Figura 116 - O passado fora de ordem e a incerteza das datas da narração e do narrado

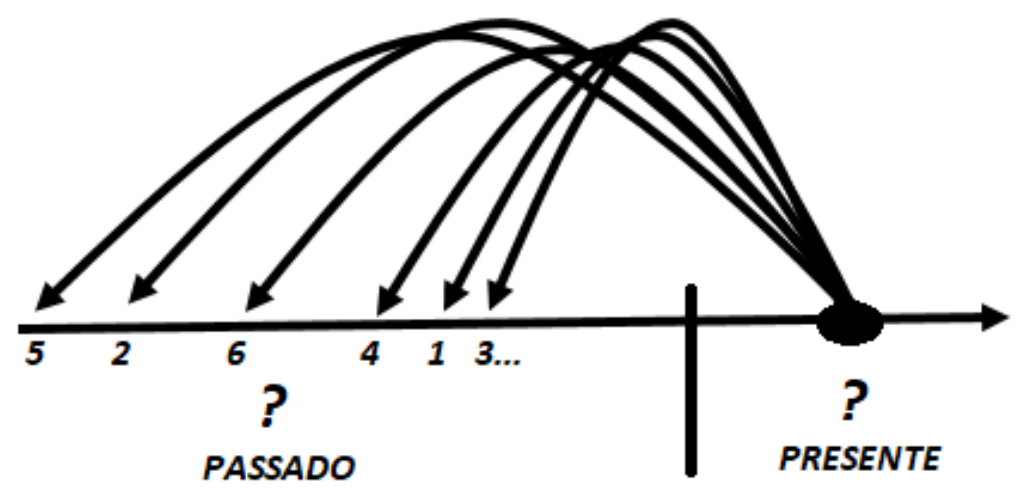

Fonte: autor

Uma interessante construção fílmica da interação entre presente e passado é formulada pela direção do olhar do ator, no presente, antes ou após um plano que mostra o passado. Enquanto o jovem relata a segunda vez que vai a Paranoid Park, sentado em um banco na praia, seu rosto dirige-se para um som, contido na imagem posterior. Assim, quando Alex lembra que é chamado por Scratch, que quer o seu skate emprestado, o rosto do ator, no presente, parece reagir ao som do chamado do outro, no passado:

Figura 117 - Entre o presente e o passado (flashback sonoro)

\begin{tabular}{|c|c|}
\hline Imagem: Presente & Som: Passado \\
\hline
\end{tabular}




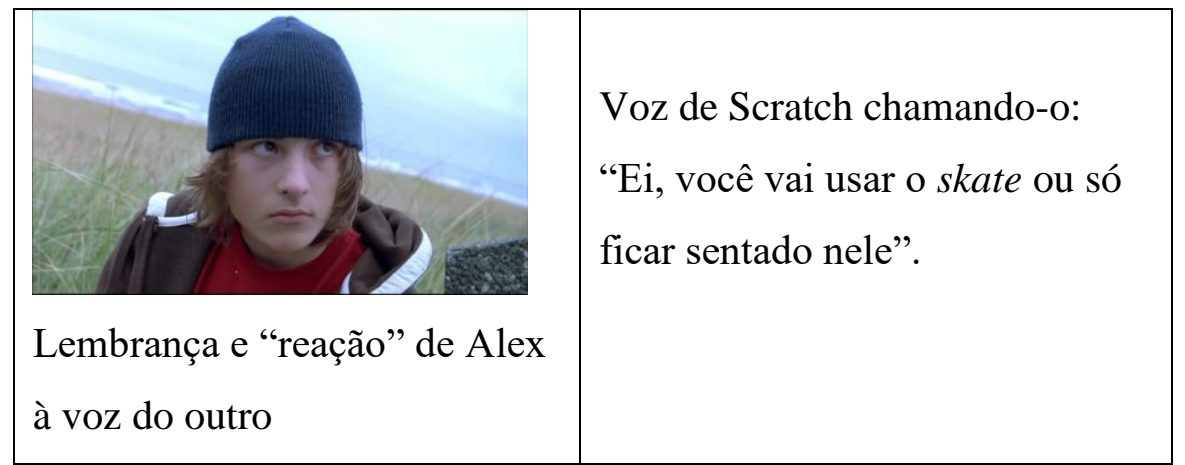

Da mesma maneira, observamos que no acontecimento, o olhar do vigia atropelado pelo trem, no passado, parece se cruzar com o olhar de Alex, no presente:

Figura 118 - Entre o passado e o presente

O olhar de baixo para cima

(Passado)
O olhar de cima para baixo (Presente)

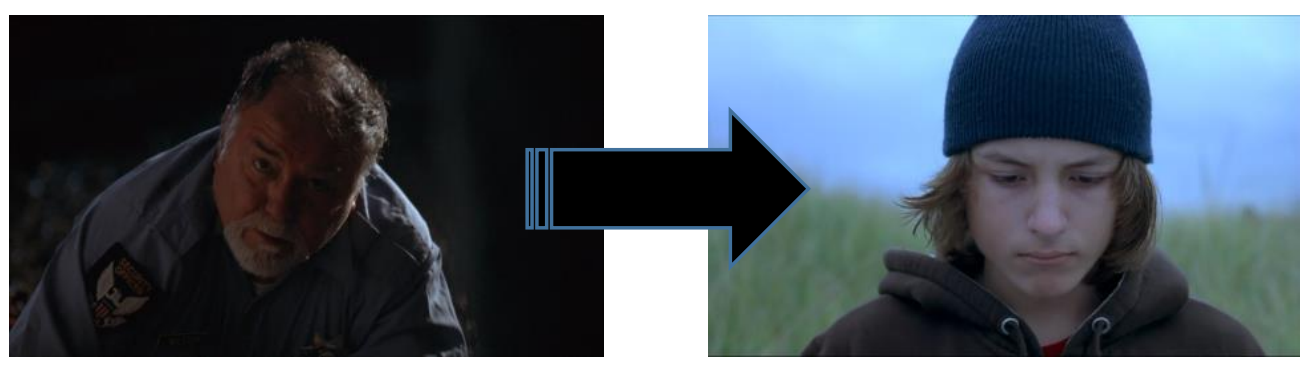

Os espaços importantes para Alex, que chamamos de paratópicos e utópicos, os primeiros relacionados à pista de skate e ao pátio de trens; e o segundo, à casa na praia, também são construidos a partir de configurações topológicas e cromáticas inspiradas no espaço topológico criado no texto literário, pois o filme segue a descrição espacial desses lugares. No romance, como observamos, tanto a pista de skate como o pátio de trens são relacionados ao elemento terra e subterrâneos. No filme, tais caracteristicas são indicadas tanto pela figuração e observação do espaço a partir de um PCj, que revela um local embaixo de uma ponte (a da abertura do filme), assim como pelo movimento e direção vetorial do corpo do ator Alex, que para se aproximar da pista vai da parte superior para a parte inferior do quadro planar, ou seja, “desce". Quando Alex chega à pista, pode-se ver um espaço englobado, quase fechado, que possui um teto formado pela ponte sustentada por vigas. Ao mesmo tempo, quando o protagonista dirige-se à pista de skate, precisa descer uma pequena encosta. Da mesma maneira, mostramos que ao invadirem o pátio de trens, os jovens não apenas descem da pista por um terreno irregular, mas o observador os mostra de cima para baixo: 
Figura 119 - Paranoid Park como lugar fechado e subterrâneo, onde Alex desce
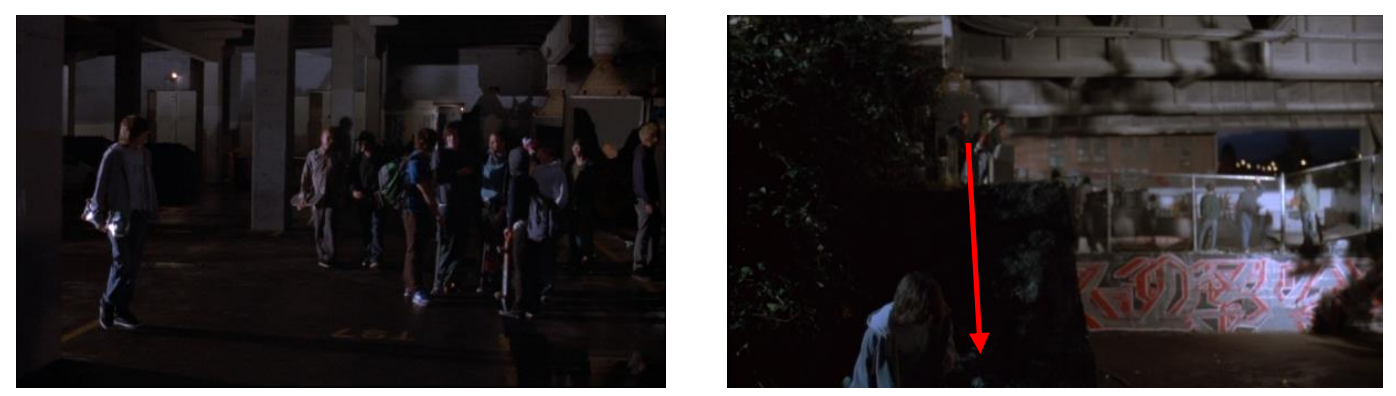

No tocante ao espaço casa do tio, não apenas seus interiores são mostrados, mas também, e principalmente, como vimos ao tratarmos da oscilação entre presente e passado no filme, o seu exterior. Uma observação das categorias cromáticas das imagens desses dois "lados" da casa da praia mostra, ainda, um tratamento diferenciado da cor: o interior é mais quente, sendo figurado por cores avermelhadas; o exterior, mais frio, figurado por cores mais azuladas, em uma oscilação que reflete tanto a estação do ano, o inverno, como os estados patêmicos do jovem enquanto escreve. Segundo Kandisnky (2001) as cores quentes aproximam-se do observador-enunciário, enquanto as cores frias dele se afastam ${ }^{155}$. Nesse sentido, a casa na praia não é apenas o lugar utópico da performance e transformação do ator, mas é figurado como o espaço mais diferenciado da narrativa, instaurando um aqui e um lá heterotópico marcado cromaticamente.

Figura 120 - O interior da casa do tio figurado por cores quentes
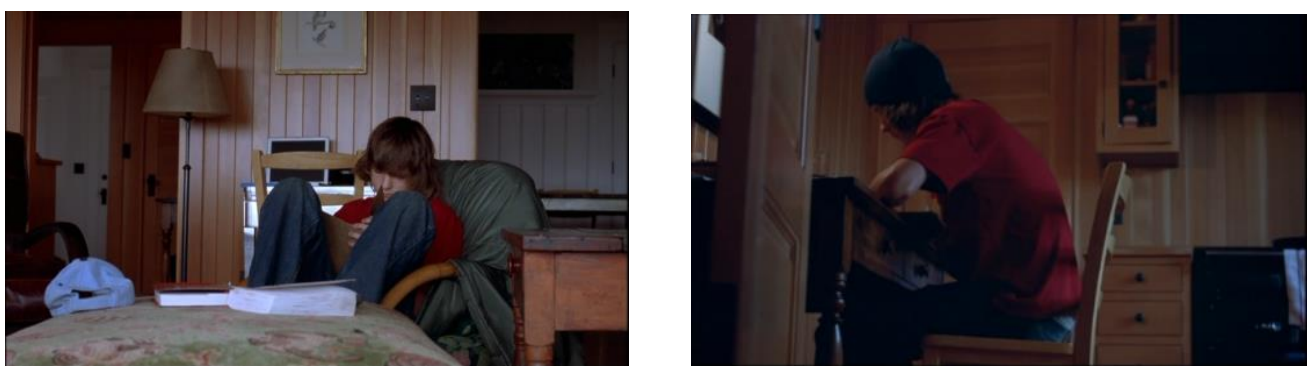

155 “O contraste entre o quente e o frio - tendência ao amarelo ou ao azul - proporciona a dimensão espacial, determinada pela endencia do amarelo a se aproximar do espectador do azul a se afastar" (KANDINSKY, 2001, p. xiv) 

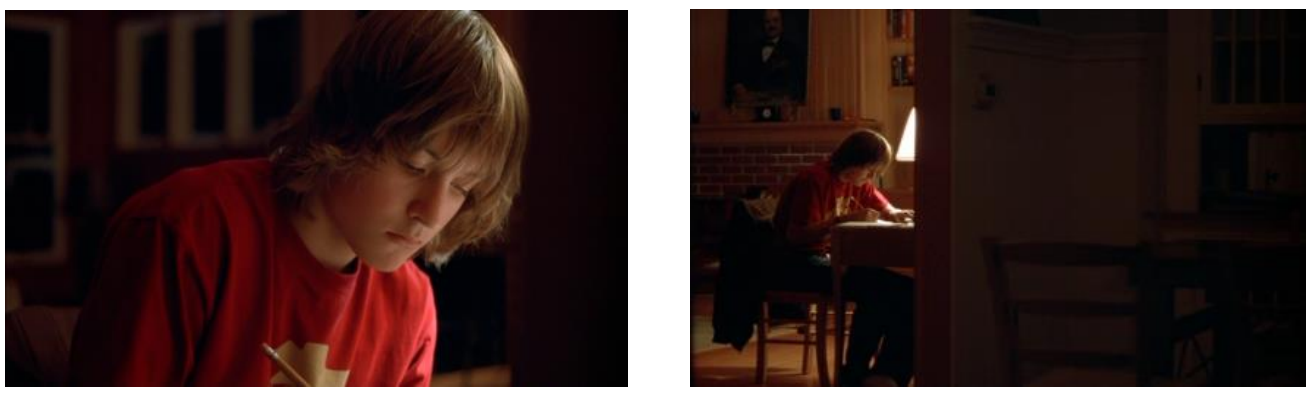

Figura 121 - O exterior da casa do tio figurado por cores frias (inverno)
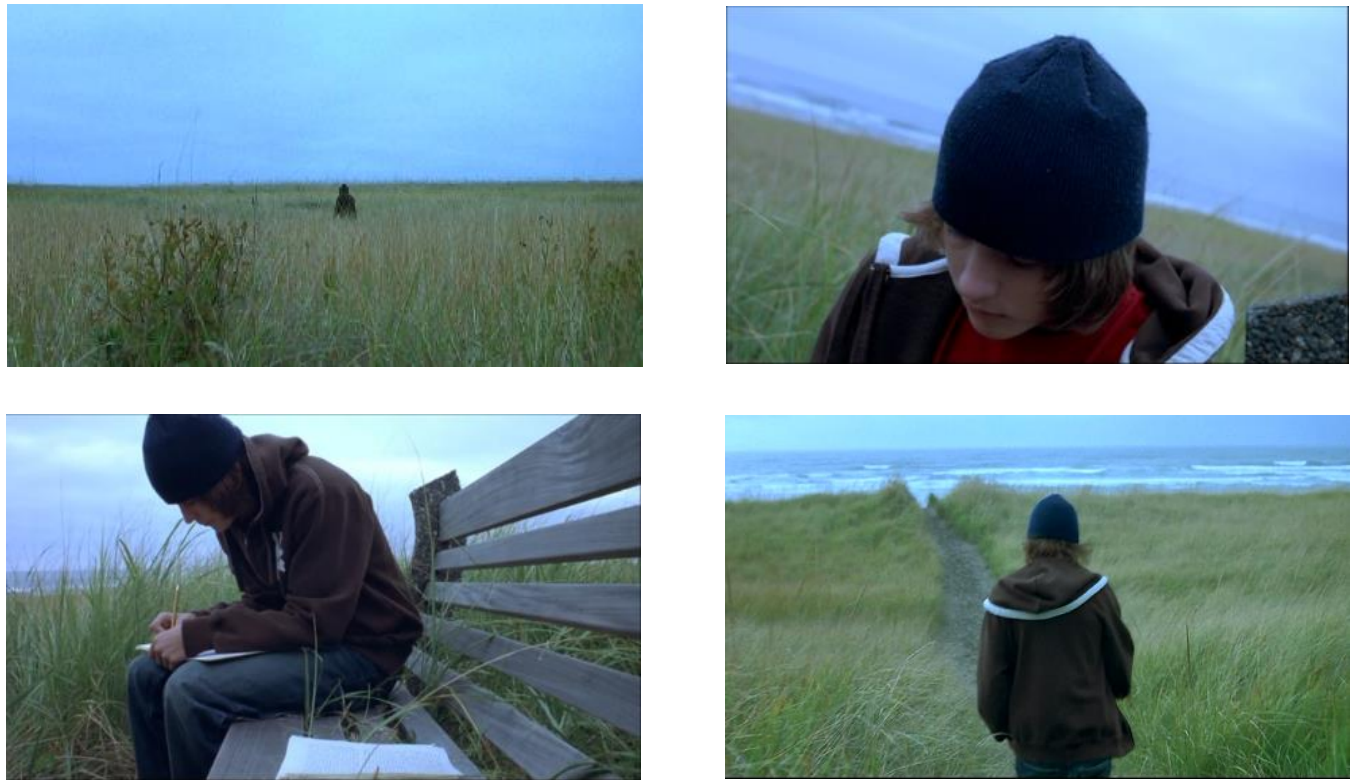

Outra observação que pode ser feita a respeito da posição do ator no espaço, é que enquanto no romance Alex dorme em um quarto localizado no andar superior da casa ${ }^{156}$, no filme ele ocupa o espaço inferior. Quando a mãe pergunta ao jovem sobre a noite de sábado e a ligação para o pai, no domingo, ela desce as escadas e chega a um aposento com caixas de papelão, onde Alex está deitado em uma cama improvisada, ao lado de uma mala aberta com roupas: diferentemente do romance, esboça-se no espaço um caráter de desorganização, recente mudança, e igualmente subterrâneo.

\footnotetext{
${ }^{156}$ No domingo de manhã, quando Alex chega em casa vindo da casa de Jared, ele tem medo de encontrar a mãe, e conta: "Minha mãe e meu irmão estavam acordados. Eu podia ouvir a TV ligada na sala. Eu rezei para que minha mãe não estivesse na cozinha. Ela não estava. Atravessei a cozinha e subi as escadas pulando os degraus [...]. Corri pelo corredor para o meu quarto e fechei a porta (NELSON, 2006, p. 43). "My mom and my brother were both up. I could hear the TV on in the living room. I prayed to God my mom wasn't in the kitchen. She wasn't. I walked through the kitchen and skipped up the stairs [...]. I hurried down the hall to my room and shut the door.
} 
Figura 122 - Alex em casa: desorganização, mudança e outro espaço subterrâneo

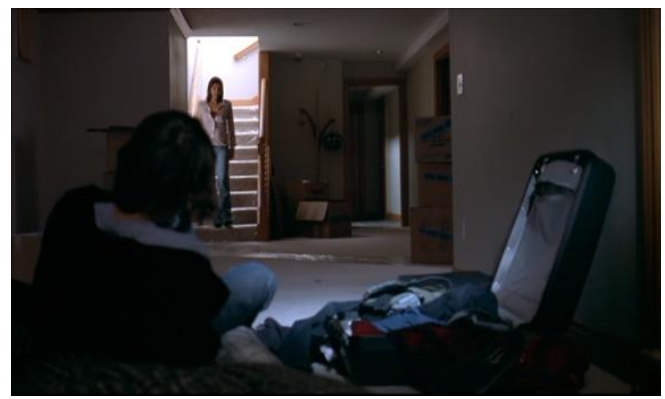

De modo geral, pode-se dizer que a figuração dos espaços ocupados por Alex na cidade é relacionada à desorganização e à transformação, locais profundos que situam-se além da superfície, sendo da ordem do esconderijo e do segredo; em contrapartida, na praia, os espaços são relacionadas à superfície, e a cores quentes e frias, que se de um lado simbolizam os estados afetivos do ator, de outro relacionam-se ao calor e à luz solar, que remetem aos valores de vida.

\subsection{A semiose proxêmica e gestual do observador}

Durante a análise das obras localizamos alguns efeitos de sentido relacionados à construção tensiva, ou seja, maneiras de como o enunciador manipula, durante a discursivização, o andamento do discurso, tornando-o mais ou menos acelerado e tônico. Observamos no texto literário duas características tensivas importantes: a primeira é que as cartas do protagonista são escritas rapidamente, em 6 dias, resumindo aproximadamente 4 meses de eventos disfóricos, e a narrativa de Alex torna-se um grande resumo acelerado desse período, uma triagem de fatos reconhecidos. De outro lado, ao nos concentrarmos sobre o que denominamos a sequência acontecimento e a instalação do sobrevir no campo de presença do narrador / ator, percebemos que, de um lado, ela ocorre logo no início do romance, depois de uma breve apresentação dos fatos que levaram àquele momento; e de outro, que tal sequência causa uma desaceleração no discurso de Alex, dentro do andamento acelerado do romance, sendo uma longa descrição narrativa que relata com minúcias a invasão do pátio de trens, a morte do vigia, a fuga do jovem, a tentativa de ligar para o pai etc., fornecendo detalhes de ações, sensações, emoções e pensamentos do protagonista.

Enquanto acreditamos que o romance é acelerado, detectamos na velocidade do filme o uso tônico de elementos de desaceleração e remissividade: as câmeras lentas, os planos sequência, o flashback, o discurso não-linear, juntamente com a composição plástica carregada 
de texturas e oscilações, e uso de paisagens sonoras, que tornam o filme lento e desacelerado, composto por uma série de camadas de sentido, e difícil de ser processado inteiramente. A desaceleração, no entanto, não significa menos intensidade, pois ela própria pode ser intensa, e nem significa que o filme não tenha momentos acelerados. Assim, sugerimos que romance e filme colocam-se em pólos tensivos apostos e sobrecontrários, e este adapta a aceleração intensa daquele em termos de desaceleração intensa, construindo momentos de inércia. No filme, a desaceleração no andamento apoia o conteúdo denso da narrativa, dando suporte à figuração do mundo subjetivo e epifânico, contínuo e disfórico.

Em relação ao discurso fílmico, percebemos que a sequência da morte do vigia não ocorre no início da história como no romance, mas dentro da ideia de uma memória fragmentada, sendo sugerida aos poucos, a partir de um grito estranho que eclode em uma cena que não o explica, noticiários na TV, recortes de jornal, imagens fragmentadas e fora de sequência do protagonista na casa do amigo depois do crime, até ser totalmente descrito no meio da narrativa. Concluímos que se no romance existe uma intensidade inicial do discurso do jovem, que se arrefece enquanto o romance progride, no filme essa intensidade vai crescendo lentamente, gerando expectativa e suspense sobre o que realmente teria acontecido.

Percebemos também que a sequência acontecimento é enunciada a partir de uma figuração que adota gestos e andamentos relacionados ao antes e ao depois da morte do vigia: a primeira é mais extensa, caracterizada por planos médios e planos de conjunto com aceleração constante, resultando em um andamento mais regular, mostrando mais a ação dos atores e o espaço; na segunda, que corresponde ao acontecimento e ao sobrevir, a aceleração é mais variada, possuindo grandes momentos de desaceleração. No nível do conteúdo, as variações de velocidade se transformarão em intensidades, mescladas ao observador, seus enquadramentos e movimentos, e todo o resto da mise-en-scène.

A partir daí, e conhecendo-se mais a fundo a narrativa, utilizaremos a mesma metodologia empregada na decupagem dos planos da sequência acontecimento em toda a obra, com o intuito de observar a construção proxêmica e gestual do conteúdo audiovisual, que relacionamos à enunciação do observador, uma coreografia visual de aproximações e distâncias, inércias e movimentos, velocidades e andamentos menos dos enunciados do que da enunciação: enquanto a narração possui um tempo e um espaço diegético, a enunciação constrói uma prosódia visual através de distâncias e durações. Nesse trecho de análise, não nos debruçaremos sobre as qualidades da imagem e sobre a construção sonora de sentido, apenas observaremos as dinâmicas proxêmicas como "sílabas tensivas", "gradações de distância" e 
suas durações. $\mathrm{Na}$ análise os tempos da tabela foram alterados, indo de zero a 200" (3’30"). Assim, verificamos as seguintes características entre plano, distância e duração ${ }^{157}$ :

Figura - A prosódia visual de Paranoid Park

Figura 123 - Tabela 1 (planos: 1 - 58; tempo fílmico: 0 - 16’57’)

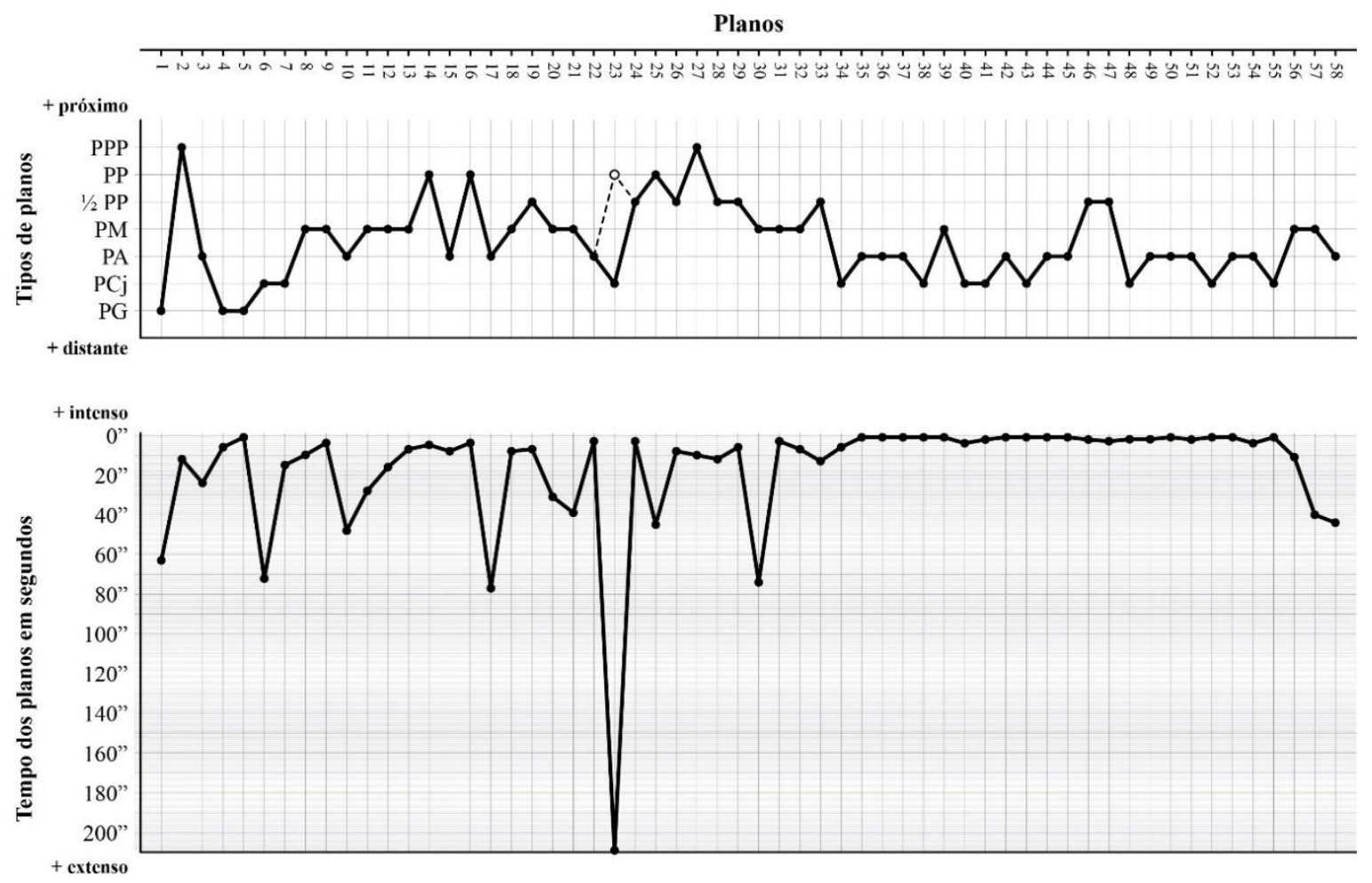

\footnotetext{
${ }^{157}$ Todas as distâncias e medidas temporais podem ser considerados como aproximadas, pois, de um lado, a certeza da classificação de cada plano, como dissemos, não pode ser determinada matematicamente, e leva em conta o entendimento da relação entre sujeito e espaço (ou entorno) que não é objetiva; da mesma maneira, uma vez que a análise foi feita a partir de um computador caseiro e um filme em DVD, a duração de cada plano, medida a partir dos cortes, também pode oscilar. Assim, quando estipulamos o tempo mínimo em segundos, a aferição provavelmente não é exata. No entanto, acreditamos que mesmo aproximados, os cálculos de distancia e duração auxiliam a "ver" como o discurso visual comporta-se em relação ao conteúdo proposto: do ponto de vista tensivo, pequenas incorreções não prejudicarão a análise.
} 
Figura 124 - Tabela 2 (planos: 59 - 116; tempo fílmico: 16'57” - 32'08”)

Planos

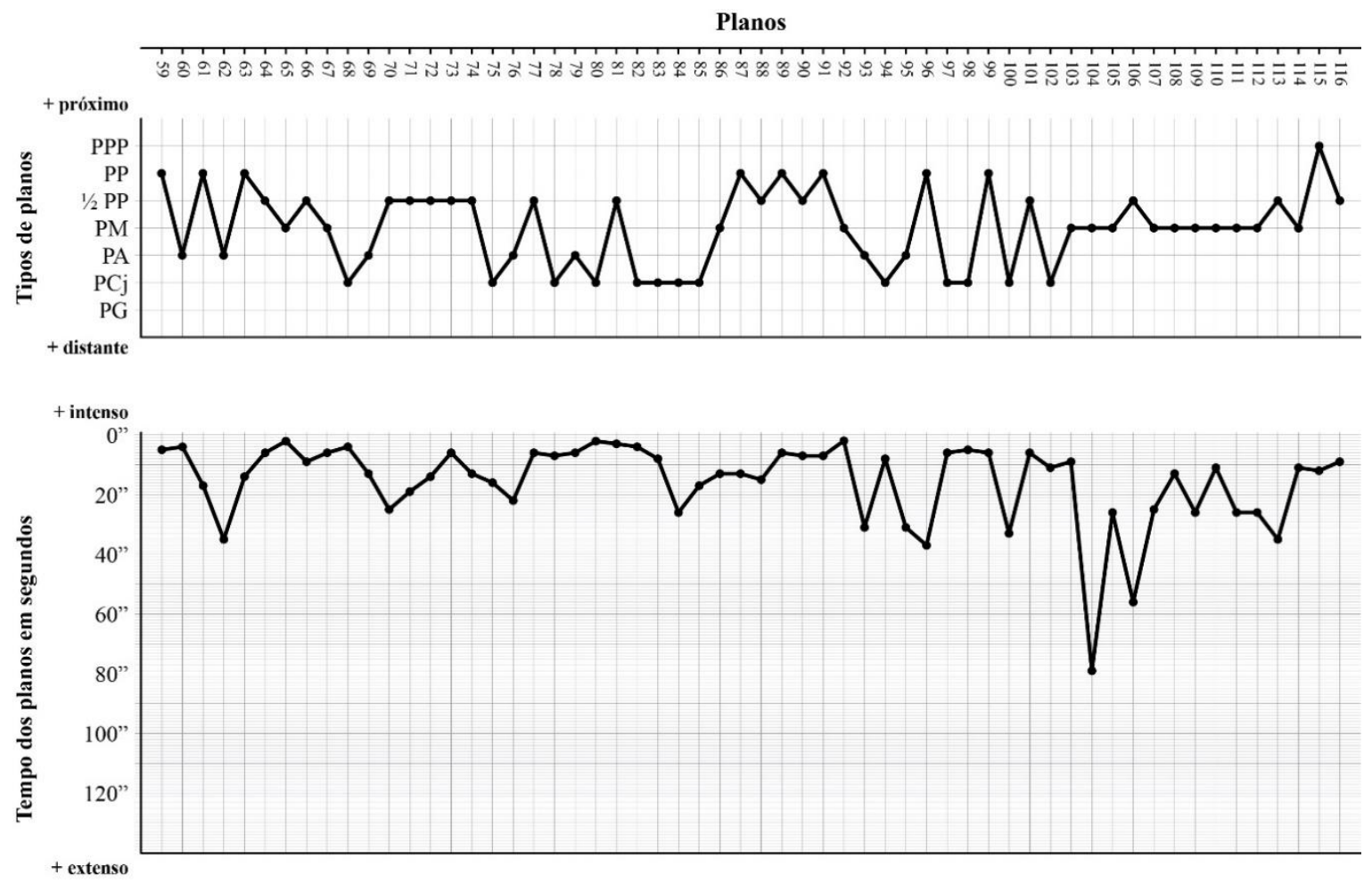

Figura 125 - Tabela 3 (planos: 117 - 174; tempo fílmico: 32’08” - 45’20”)

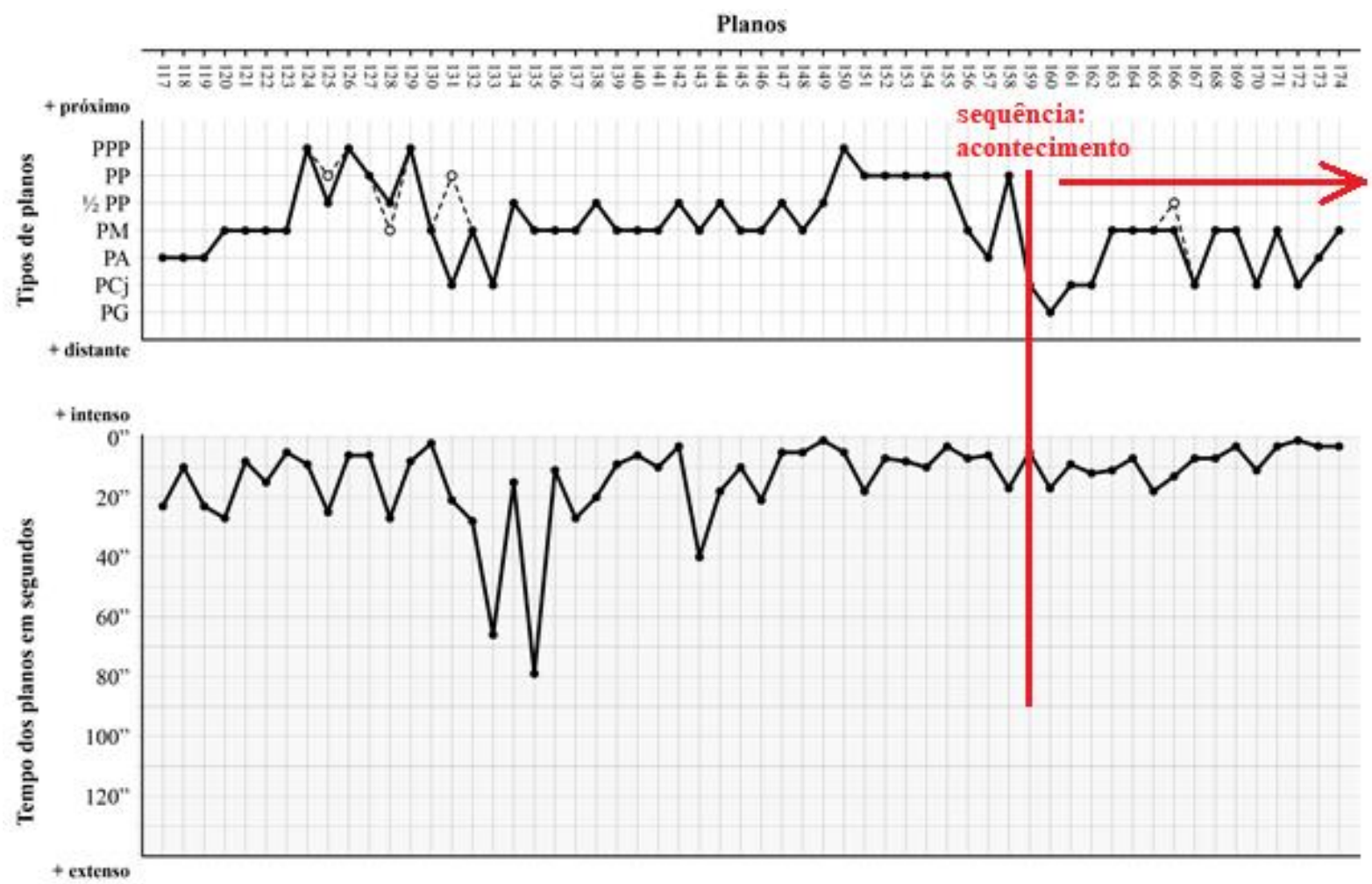


Figura 126 - Tabela 4 (planos: 175 - 232; tempo fílmico: 45'20” - 1h2’29”)

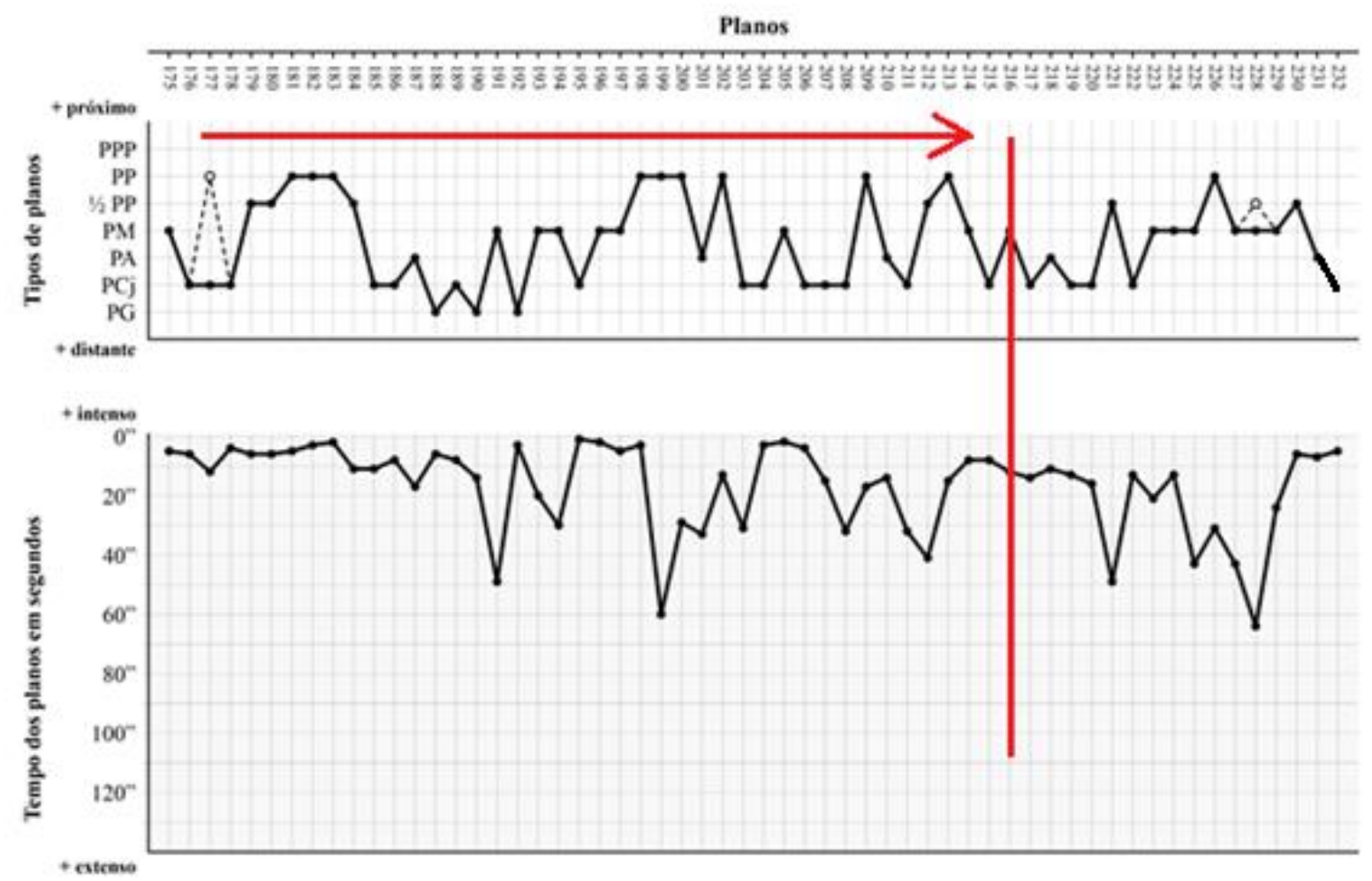

Figura 127 - Tabela 5 (planos: 233 - 281; 1h2'29" - 1h21'16")

Planos

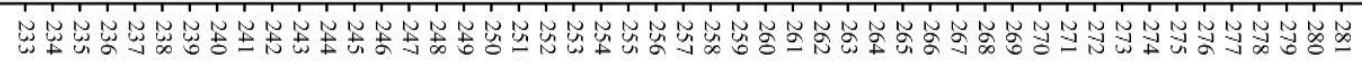

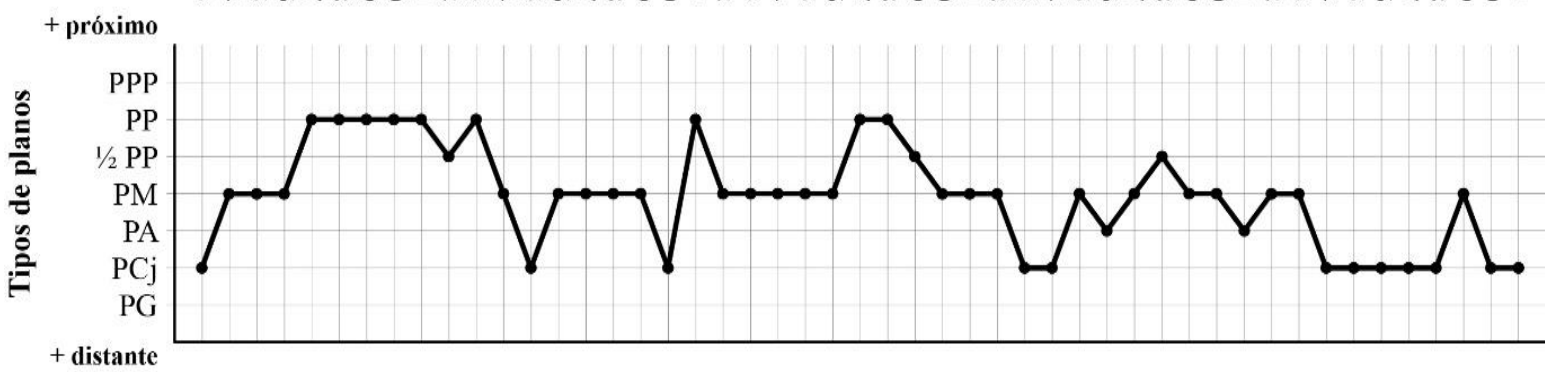




\section{Tabela 1 (planos: 1 - 58; tempo fílmico: 0 - 16'57’)}

Na tabela 1, verifica-se até o plano 27 (final da entrevista com o detetive: detalhe da entrega do cartão do policial), uma oscilação maior entre distâncias, que correspondem a imagens da ponte sobre a cidade do protagonista, ele escrevendo na casa do tio, andando e escrevendo na praia, da pista de skate em dois momentos diferentes, e da entrevista com o detetive. Assim, do ponto de vista proxêmico, os primeiros 13 minutos do filme, privilegiando ora sujeitos ora espaços, e oscilando entre muito próximo e muito distante, produzem valores de intensidade na narrativa, que será acompanhada pelas mudanças da duração de cada plano, que também oscilam entre 1'e 3'29"' (o maior plano do filme, relativo ao diálogo entre o jovem e o detetive $)^{158}$. Do plano 27 ao plano 58, percebemos que a oscilação entre distâncias diminui, de modo que a tensão é reduzida, ou atonizada. $\mathrm{O}$ tempo dos planos também fica mais constante, em torno de 1' cada, correspondendo a imagens granuladas e aleatórias de skatistas andando nas ruas de Portland (com a canção The white lady loves you more, comentamos que a sequência adquire um tom de vídeo clip). Nesse caso a aceleração do filme é constante.

\section{Tabela 2 (planos: 59 - 116; tempo fílmico: 16'57' - 32'08”)}

Nesse intervalo de tempo a narrativa fragmentada mostra as seguintes ações em sequêcia: Alex vai a primeira vez a Paranoid Park com Jared e observa seus usuários; Jennifer é introduzida na narrativa, em uma cena em que fala ao telefone; Alex escreve na praia; cruza a ponte de skate, à noite, indo sozinho pela segunda vez à pista de skate; está em casa e diz à mãe que dormirá na casa de Jared e pede o carro emprestado; dirige pela cidade, à noite, e pára para comprar comida; está na casa de Jared, que lhe conta que os dois não irão à pista aquela noite; leva o amigo à rodoviária; chega em Paranoid Park e observa o local; está em casa, jantando (e fala sobre os conflitos familiares); escreve na praia; na pista de skate, à noite, encontra e conversa com Scratch; está na casa de Jared, depois do acidente com o vigia (rasteja pela sala, toma banho, deita na cama, etc.); conversa com Macy em um café; está na escola, andando distraído pelo corredor, logo após o acontecimento, e não ouve Jennifer chamando-o; Alex e Jennifer estão em uma loja provando roupas; Alex entra no carro de Jared, que lhe dá uma carona, e eles discutem sobre o novo skate do protagonista; Alex e Jared estão em uma loja de CDs e discos; e Alex escreve na praia.

\footnotetext{
${ }^{158}$ Para maiores informações sobre as imagens e a trilha sonora rever o capítulo da tese "Os primeiros 13 minutos do filme".
} 
Percebe-se, por causa da fragmentação da narrativa, um discurso visual intenso, que oscila entre planos distantes e próximos, mas notam-se certos pontos de estabilidade nessas mudanças: dos planos 70 a 74 (Alex dentro do carro: dirigindo, pedindo comida e ouvindo música: 1/2PP); dos planos 82 a 85 (Alex cruza a ponte de skate e chega à pista: $\mathrm{PCj}$ ); dos planos 87 a 91 (imagens de Alex observando a pista, comendo em casa e escrevendo na praia: PP e 1/2PP); e dos planos 102 a 114 (Alex conversa com Macy em um café, e com Jennifer, na escola: 1/2PP e PM). Os trechos cujas distâncias oscilam são: dos planos 59 a 69 (Alex na praia, Jennifer ao telefone, a pista de skate, ponte sendo cruzada e Alex comendo em casa); dos planos 75 a 82 (rodoviária, casa de Jared antes do acontecimento e estacionando o carro da mãe na rua para ir à pista); dos planos 92 a 101 (conversando e observando Scratch andar de skate, rosto de Scratch, e ações na casa de Jared depois do acontecimento). As distâncias mais constantes são construídas por PP e 1/ 2 PP (dentro do carro, da casa, observando a pista, conversando) e PM e PCj (pista de skate, ponte, rodoviária, escola).

Em termos de duração dos planos, podemos dividir esse trecho do filme em duas grandes sequências gerais: uma que se estende dos planos 59 e 91, e outra que se estende dos planos 92 a 116. Como a primeira tem planos cuja média é de 2" a 20" vamos nos ocupar dos planos mais longos, que são os planos 62 (os usuários da pista de skate: câmera lenta), 70 (Alex dirigindo e ouvindo música: hip hop), 76 (Alex e Jared conversam no quarto antes do acontecimento) e 84 (Alex chegando à pista, anda pelo espaço onde a pista é mostrada). Esses planos mais longos correspondem à descrição dos usuários e do espaço Paranoid Park, ambos mostrados de maneiras mais estáveis, ou seja, movimentos fixos ou suaves do observador e dentro do eixo horizontal; e de Alex dentro do carro, onde ouve música e parece relaxado: a velocidade da imagem não é alterada e o andamento é estável. Outro plano longo é o que mostra o jovem, na penumbra do quarto de Jared, ouvindo do amigo que ele viajará naquela noite.

O segundo trecho destacado, que vai dos planos 92 a 116, sendo mais variado em termos de velocidade, corresponde, de modo geral, ao encontro com o protagonista e Scratch, cenas fragmentadas do jovem na casa de Jared, depois do acontecimento, momentos em que ele conversa com Macy e encontra Jennifer na escola; e a cena em que discute com Jared no carro, por causa do skate novo. Nesse trecho, destacamos como planos mais longos, acima de 20", os planos 96 (Scratch e Alex entreolham-se), 100 (na casa de Jared, Alex tenta telefonar para o pai, mas desiste, senta e chora), 104 (diálogo entre Alex e Macy), 106 (Alex caminha pelo corredor da escola e não ouve Jennifer chamá-lo: câmera lenta) e 113 (Jared dirige o carro depois de discutir com Alex: câmera lenta e canção punk rock): os planos 96 e 106 e 113 chamam a atenção por seu tema e duração, parecendo serem pouco descritivos e almejando a 
construção do afeto entre o protagonista e Scratch (atração), Jennifer (distanciamento) e Jared (raiva). Dessa maneira, apesar dos planos menores e discurso mais acelerado, o contraste entre eles mostra que os afetos são mais longamente mostrados do que as ações.

\section{Tabela 3 (planos: 117 - 174; tempo fílmico: 32’08” - 45’20”)}

Nesse trecho do filme, observaremos a proxêmica do observador do plano 117 ao plano 158, pois a partir dele inicia-se a sequência que denominamos acontecimento, e que já foi analisada acima. Nota-se, nessa parte do discurso, uma homogeneidade na articulação das distâncias que oscilam, em sua maior parte, entre 1/2PP e PM, pois tratam de cenas dialogadas e feitas dentro da escola. No início desse trecho, planos 117 a 123, Alex é mostrado escrevendo na praia, levantando-se e andando em uma trilha, depois entra na casa do tio, onde bebe água e volta a escrever em uma escrivaninha (PA). Os PPP e PP referem-se ao jovem assistindo, na TV, o noticiário sobre o corpo do guarda encontrado, e uma longa sequência em que o detetive vai à escola de Alex para falar do crime cometido e mostrar fotos do vigia, de modo que o observador registra o rosto e as reações dos interlocutores nesse espaço fechado. É depois que Alex vê as fotos distribuídas pelo detetive que ele vai ao banheiro, vomita, e a sequência inteira do acontecimento é revelada, de modo que sua participação direta no crime é finalmente confirmada. Nesse trecho há alguns PPP, detalhes referentes ao jovem assistindo o noticiário de TV (tela de tv), e um artigo do crime com a foto do segurança em um jornal na biblioteca da escola. Nota-se que o observador aproxima-se do jovem enquanto ele assiste ao noticiário da $\mathrm{TV}$, tanto para mostrar sua reação como a consciência de estar mais ameaçado, e faz o mesmo em relação à página do jornal e à foto do vigia; na cena da biblioteca. É o próprio Alex que se afasta do observador enquanto caminha com o jornal e senta-se em uma mesa para ler a notícia. Os planos 131 e 133, dois PCj, são utilizados para mostrarem um aluno sendo escoltado pela polícia por causa de drogas, e para o grupo de alunos skatistas que é chamado para conversar com o detetive, e do qual Alex faz parte.

Em relação ao tempo, pode-se perceber que muitos planos desse trecho são longos, possuindo mais de 20", o que revela um observador acionado para descrever mais, dentro de ações aspectualizadas como durativas. De modo geral o observador é dinâmico, e movimentase pelo espaço, acompanhando ou revelando os sujeitos em seus espaços. Os dois planos mais longos possuem mais de 1 minuto, e referem-se ao plano 133 e 135 . O primeiro mostra os alunos chamados pela escola, que aos poucos vão saindo de suas salas de aula e enchendo o corredor da escola, enquanto andam em direção ao observador; e o segundo refere-se ao 
detetive, que interage com os alunos, explicando o crime e fazendo perguntas: o plano 133 destaca-se pela diminuição da extensidade do espaço horizontal do quadro, que gradualmente vai sendo preenchido por um aumento gradual da quantidade de alunos, que formam um bando.

\section{Tabela 4 (planos: 175 - 232; tempo fílmico: 45'20" - 1h2'29")}

Novamente, trataremos do plano 217 ao plano 232, pois a proxêmica do observador e a duração dos planos já foi discutida no capítulo reservado ao acontecimento. A partir do plano 217, Alex joga as roupas sujas em um lixo perto de casa, chega em casa e vai para um aposento na parte inferior da casa, onde dorme. Enquanto troca de roupa a mãe desce as escadas e lhe pergunta se teria ligado para o pai naquela madrugada de domingo, enquanto estava em Jared. Alex inventa uma desculpa, sobe para o térreo e diz à mãe que irá ao shopping, mentindo que está sem o seu skate porque o esqueceu na casa de Jared. Em uma lanchonete, enquanto folheia os jornais, ele encontra Macy e uma amiga, que o convidam a ir ao cinema, mas ele recusa (o observador aproxima-se dos jovens). Depois Alex é mostrado andando pelo shopping, e depois na rua, entrando em uma loja de skate. Dentro da loja ele conversa com um vendedor e examina alguns modelos.

Nesse trecho os PCj são utilizados para mostrar onde o jovem dorme, enfatizando um espaço desorganizado, o shopping, a rua e a loja de skate. Os PM e PP conduzem os diálogos entre ele e a mãe, e depois entre as amigas, ressaltando sua expressão facial, que esconde um segredo, e enquadram também o rosto das garotas, especialmente o de Macy.que parece desconfiada de Alex, ao encontrá-lo domingo de manhã, em uma lanchonete, e lendo um jornal.

Os planos desse trecho são relativamente extensos. Os planos 221 (49”), 223 (21”), 225 (43”) e 227 (43”) duram mais do que 20" e referem-se a diálogos com a mãe e com as amigas. O plano 226 (31”), em PP, apenas mostra em câmera lenta, através de um observador em movimento, o rosto das duas amigas lado a lado enquanto conversam com Alex. O plano 228, com mais de 1 minuto, segue o jovem andando pelo shopping. Dessa vez, os planos mais longos, além de serem utilizados para os diálogos, servem também para descrever pessoas e espaços e ações: o plano 226 destaca-se por ter sua velocidade alterada, e a diminuição do andamento estar relacionada a Alex e a paixão do amor, em uma exploração visual e lenta do sexo oposto.

Tabela 5 (planos: 233 - 281; 1h2'29" - 1h21'16") 
Nesse trecho percebem-se várias áreas de estabilidade de distância entre o observador e os elementos observados na diegese, que correspondem a cenas íntimas, diálogos ou imagens de skatistas. O primeiro, é uma distância para descrever a intimidade sexual dos jovens, pontuando a primeira relação sexual de Jennifer. Assim, dos planos 237 a 241, apesar de os jovens fazerem sexo, eles são mostrados em PP e 1/2PP, de modo que de um lado, suas faces, principalmente a de Alex, que parece alheio à situação, são enfatizadas; e de outro, o enunciador preserva o corpo do casal, evitando uma cena mais explícita, e mantendo certo decoro, que também existe no romance, pois Alex pouco comenta sobre o evento, e nada descreve sobre a relação: os PP dos rostos são relativos aos momentos antes e depois do sexo. Outros momentos em que a distância se repete são: entre os planos 246 a 249 (diálogo com Jennifer na escola, no dia após a relação sexual), 252 a 256 (que correspondem tanto ao rompimento do namoro com Jennifer como à reação dos amigos sobre o fato: ambas as cenas são dialogadas). No final desse trecho, dos planos 271 até o final, apesar de se tratarem de distâncias diferentes, a temática das imagens é a mesma: imagens aleatórias de skatistas nas ruas de Portland fazendo manobras, similares as que vimos anteriormente, mas nas quais Alex está inserido.

Há também planos em sequência irregular, que oscilam de extensos e distantes a mais intensos e próximos: no início desse trecho os planos 233 a 237 correspondem a sequências diferentes, mas possuem a mesma lógica, mostrando primeiro o espaço e depois focalizando mais os atores. Alguns deles, como o 243, 244 e 245 mostram momentos diferentes, e registram o ator Alex em distâncias diferentes: primeiro em PP, conversando dentro de uma jacuzzi, depois em PM, sentado e sozinho fora da jacuzzi, e finalmente em um PCj, andando de skate na rua. Da mesma maneira, os planos 258, 259, 260, 261, 262 e 263 são relativos a momentos diferentes da vida do ator: Macy e Alex pedindo e tomando café; ambos em um ônibus; Alex conversando com o irmão menor, na sala de casa; Alex e Macy em outro lugar, conversando. O conjunto de distâncias que oscilam nos planos de 263 a 270 também abordam tempos e espaços diferentes: de 263 a 265, Alex e Macy brincam na rua, e esta sugere àquele que escreva o que o aflige; de 266 a 268, Alex escreve a última carta e a queima na praia: nesse conjunto de planos, como em outros, a aproximação do observador, que mostra a solidão do ator e invade a sua intimidade, é nítida: 
Figura 128 - Alex termina a última carta e queima tudo o que escreveu: cortes do mais distante, ao mais próximo
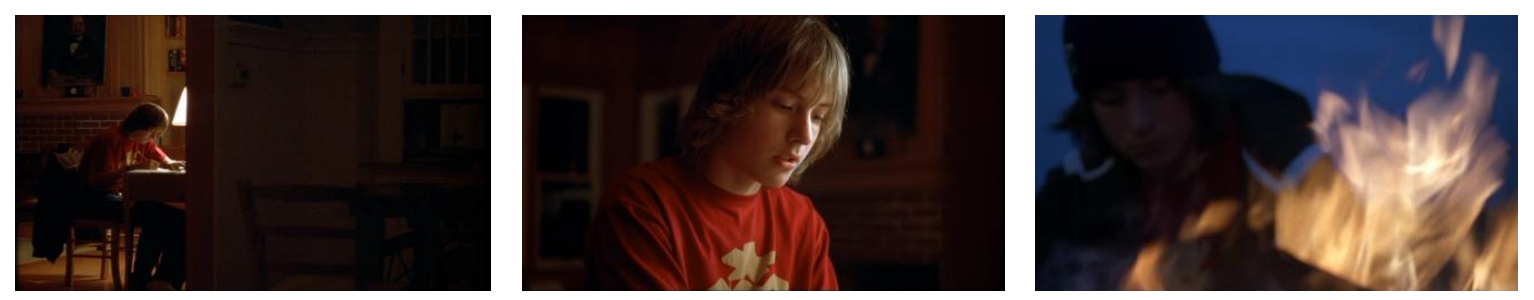

Novamente, nesse trecho, percebem-se "picos" extensos de planos longos, que superam a marca dos 20 " e são referentes, em sua maioria, a cenas dialogadas ou falas, mas há exceções referentes a simples "descrições" do observador da ação, na qual ninguém fala, ou ela é encoberta por uma trilha sonora. Assim, no plano 234, Alex e amigos estão patinando no gelo e conversando; nos planos 235 e 236, o observador em movimento acompanha Alex e Jennifer por uma casa, onde farão sexo; no plano 241, Alex, na cama, ouve Jennifer, no banheiro, ligar para a amiga e falar de sua primeira experiência sexual; no plano 248, Alex e Jennifer discutem na escola; no plano 25, Alex e pai conversam na garagem; nos planos 252 e 253 Alex rompe com Jennifer e vai embora; no plano 261, Alex e o irmão menor conversam na sala; no plano 262, Alex e Macy conversam; no planos 263264 e 265, Alex e Macy brincam na rua e conversam: sugestão da escrita das cartas; no plano 267, Alex está escrevendo a última carta; e no plano 268, Alex está queimando as cartas na praia.

\section{Análise do gráfico:}

De forma geral, é difícil estabelecer um padrão exato no uso de diferentes distâncias e tempos, que são alternados constantemente para servir aos vários momentos e inflexões da narrativa e, portanto, preferimos vê-los como uma paralinguagem de apoio, gestos estéticos: nota-se, porém, que as imagens com velocidade alterada relacionam-se mais ao acontecimento e a estados passionais: o mundo do skate; a morte do vigia; o banho no chuveiro; andar perdido em pensamento; briga com Jared; Macy e a amiga; e patinando com amigos. Como discurso concessivo, a dinâmica proxêmica do filme é intensa, mas dentro de um andamento desacelerado. Assim, propomos que:

a. No eixo da intensidade, relativo ao andamento, o filme oscila entre minimização e atenuação, preferindo a narrativa fora de ordem e retardando o acontecimento. Ao 
mesmo tempo, no romance, o discurso literário é mais acelerado, repleto de elipses, e projeta-se para o futuro. Assim:

\begin{tabular}{|l|l|l|l|l|}
\cline { 2 - 5 } \multicolumn{1}{c|}{} & \multicolumn{2}{c|}{ FILME } & \multicolumn{2}{c|}{ ROMANCE } \\
foremas & minimização & atenuação & restabelecimento & recrudescimento \\
\hline direção & $\begin{array}{l}\text { ir lentamente } \\
\text { =arrastar-se }\end{array}$ & desaceleração & aceleração & precipitação \\
\hline posição & anacronismo & atraso & adiantamento & prematuridade \\
\hline elãa & inércia & lentidão & rapidez & vivacidade \\
\hline
\end{tabular}

b. No eixo da intensidade, relativo à tonicidade, em ambos os discursos há uma oscilação entre restabelecimento / recrudescimento:

\begin{tabular}{|l|l|l|}
\cline { 2 - 3 } \multicolumn{1}{c|}{} & \multicolumn{2}{c|}{ FILME E ROMANCE } \\
foremas & restabelecimento & recrudescimento \\
\hline direção & tonificação & avultação \\
\hline posição & superior & excessivo \\
\hline elãa & movimento & golpe \\
\hline
\end{tabular}

Uma vez que a proxêmica e a duração dos gestos fixos e dinâmicos do observador foram descritas superficialmente, podemos agora fazer algumas observações sobre o tempo e a distância do observador: sem contarmos os créditos finais do filme (paratexto), e considerando sua duração em 1 h 21' (desprezaremos 19”), obtemos aproximadamente 72' de narrativa. Esse tempo, dividido pelos 281 planos do filme, indicam uma duração média para cada plano de quase 4 minutos (3.9), o que revela um filme com andamento lento ${ }^{159}$. Já tínhamos comentado na análise das durações dos planos que muitos deles eram extensos, e percebemos muitos planos maiores do que 20", sendo que o maior é de aproximadamente 3'29”. O número de planos e sua duração revelam que apesar da maioria dos planos oscilarem entre 1 e 5 segundos (74 planos que correspondem a aproximadaemente $26.3 \%$ do discurso fílmico), os planos de 6 a 30

\footnotetext{
${ }^{159}$ Bordwell (2013a) explica que atualmente os filmes mainstream são cortados muito mais rapidamente do que no período entre 1930 e 1960, época em que um filme era composto de 300 a 500 planos (p. 384). Paranoid Park é menos cortado do que esses filmes.
} 
segundos perfazem quase $60 \%$ do texto, sendo que a segunda maior duração utilizada é a de 6 a 10 segundos. Assim:

Figura 129 - Planos classificados pela duração em segundos

\begin{tabular}{|c|c|c|}
\hline $\begin{array}{l}\text { PLANOS } \\
\text { (em segundos) }\end{array}$ & QUANTIDADE & PORCENTAGEM \\
\hline $1 "-5 "$ & 74 & $26.3 \%$ \\
\hline $6 "-10 "$ & 67 & $23.8 \%$ \\
\hline $11 "-15 "$ & 44 & $15.6 \%$ \\
\hline $16 "-20 "$ & 22 & $7.8 \%$ \\
\hline $21 "-30 "$ & 31 & $11.3 \%$ \\
\hline $31 "-40 "$ & 16 & $5.6 \%$ \\
\hline $41 "-50 "$ & 9 & $3.2 \%$ \\
\hline $51^{\prime \prime}-1 '$ & 4 & $1.4 \%$ \\
\hline $\begin{array}{l}1 ' 01 " \\
1 ' 10 "\end{array}$ & 7 & $2.4 \%$ \\
\hline 1'11"'-1'50"' & 5 & $1.7 \%$ \\
\hline $\begin{array}{l}\text { 1'51" } \\
21^{\prime} 50^{\prime \prime}\end{array}$ & 1 & $0.3 \%$ \\
\hline 2'50"- 4’' & 1 & $0.3 \%$ \\
\hline
\end{tabular}

Em relação à distância dos planos, temos a seguinte configuração geral ${ }^{160}$ :

Figura 130 - A quantidade de 7 tipos de plano em tabela e gráfico

\begin{tabular}{|l|l|}
\hline TIPOS DE PLANOS & QUANTIDADE \\
\hline PPP & 6 \\
\hline PP & 38 \\
\hline $1 / 2$ PP & 45 \\
\hline PM & 90 \\
\hline PA & 36 \\
\hline PGj & 60 \\
\hline PG & 7 \\
\hline
\end{tabular}

${ }^{160}$ Alguns planos, por causa do movimento da câmera foram divididos em dois. O plano sequência entre o detetive e o jovem, por se tratar de um plano de mais de 3', no qual o observador se aproxima lentamentes dos atores, provocando várias distâncias, não foi computado. 
Assim:

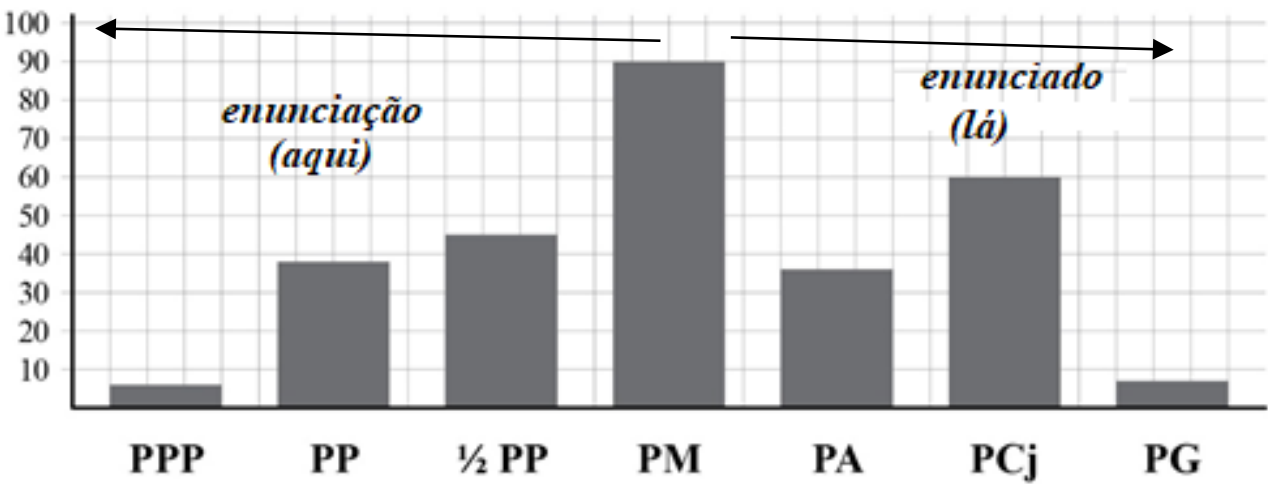

Fiorin (2002) faz uma interessante aproximação entre a debreagem enunciativa, que diz eu, e o close ou PP, que como já explicamos, aproxima e rostifica o enunciado fílmico (p. 296), sendo da ordem da intensidade. A ideia é de que quanto mais próximo da câmera é o rosto do ator, mais se opera uma debreagem eu / aqui / agora. No filme, a utilização de planos mais aproximados revela um texto que privilegia e tonifica a debreagem enunciativa. A partir daí diríamos que o PM, o plano mais utilizado, torna-se um termo complexo que articula sujeitos, espaços e tempos ambíguos. Tal estratégia de distância coaduna-se com a construção da subjetividade de um ator profundo e sensível, e apoia a utilização da voz-over em primeira pessoa. O movimento constante de aproximação, de um lado, permite que Alex seja enunciado visualmente em primeira pessoa, como no romance, a partir de uma construção proxêmica mais intensa, relativa à diminuição da extensidade do espaço ao redor de seu rosto; de outro, amplia a ideia de espaço interior e privacidade.

\subsection{A trilha sonora}

Durante a segmentação que fizemos dos primeiros minutos do filme e da sequência do acontecimento, já consideramos alguns aspectos de seu texto sonoro, observando o uso de composições de Nino Rota, de paisagens sonoras eletroacústicas, de falas de personagens em outra dimensão temporal (os flashbacks auditivos) e da voz-over do narrador, que invade o presente e o passado. Assim, percebemos que a trilha sonora do filme não é apenas muito rica, mas utiliza os vários sons para fortalecer os efeitos de construção da realidade diegética proposta, alicerçados na ideia de um sujeito traumatizado que lembra e revive o passado. Apesar de figurar um espaço interior e oscilar entre passado e presente, a narrativa audiovisual trabalha com muitas sonoridades, de modo que não há espaço para o silêncio absoluto no filme. A ideia 
de que a trilha sonora de um filme é composta de três partes básicas: música, ruídos e fala, ou diálogo (BORDWELL, 2013a, p. 416), que relacionamos a formas do conteúdo textual audiovisual, é um bom ponto de partida para tratarmos do aspecto sonoro-narrativo de Paranoid Park.

A trilha sonora de Paranoid Park aponta para um estilo já tratado em três filmes imediatamente anteriores a ele, e cujos temas igualmente envolviam a morte e a adolescência. (Elefante, Gerry e Últimos dias: conjunto conhecido como a "trilogia da morte", à qual Paranoid Park é as vezes adicionado, formando uma tetralogia). Nesses filmes, GVS oferece um modelo intrigante, que recontextualiza o som no discurso fílmico, pois mistura gêneros, superpõe camadas sonoras e desconstrói expectativas culturais. As paisagens sonoras, por exemplo, que são composições que podem mesclar ruídos, vozes e músicas, sendo não diegéticas, adicionadas aos ruídos, vozes e músicas da diegese, confunde e mescla enunciação e enunciado, realçando o mundo sonoro além do mundo visual, e propondo, de um lado um espaço acústico diferenciado do visual, o que causa um discurso audiovisual concessivo, baseado principalmente em efeitos de surpresa e estranhamento.

Em Paranoid Park observa-se uma interessante escolha de músicas e canções, e combinações sonoras que pretendem expressar as ideias e emoções do jovem que lembra e conta a sua história: como a narrativa trata da memória, todos os sons diegéticos externos, ou seja, que possuem uma fonte física no mundo da ficção (sons de skates, portas, vozes etc), podem ser entendidos como sons subjetivos e internos, ou seja, relacionados ao personagem, que os lembra a partir do presente. Uma vez que a trilha sonora e a trilha imagética combinadas criam um mundo audiovisualmente "estranho", tempo e espaço são também (des)figurados: dessa maneira, a trilha sonora também figura o acontecimento e os efeitos do sobrevir do ator, em processo de reconhecimento e busca de valores. Dentro da proposta temática de maioridade, ou rito de passagem, o filme, a partir do som, busca menos o "realismo" do mundo do que a descrição de uma subjetividade sensível e em transformação.

\section{Os ruídos}

De modo geral, os ruídos do filme criam efeitos icônicos, construindo "realismo" e sendo utilizados em consonância com a imagem, de maneira que pretendem gerar certo naturalismo à história, não causando contrapontos ou surpresas na narrativa, e sendo menos importantes para a construção da subjetividade do ator e de seu espaço tensivo, do que os diálogos e as músicas. No entanto, tais ruídos "naturais" são muitas vezes encobertos, ou 
plasmados a outros conteúdos sonoros (canções, música instrumental, eletrônica, eletroacústica e clássica), ou deslocados da imagem, de maneira que certas ambiguidades e metáforas são geradas. Dois ruídos responsáveis por elaborarem tais efeitos, e que devem ser destacados são: um grito angustiante ouvido na cena em que o jovem é entrevistado pelo detetive, na escola; e o trinar de pássaros ouvido na cena em que Alex, desesperado, toma banho na casa do amigo, após ter ocasionado acidentalmente a morte do segurança. Ambos, já comentados, são relacionados ao acontecimento e ao sobrevir sentido pelo sujeito.

O grito ilustra bem o uso da trilha sonora, pois é uma operação dissonante entre imagem e som, provocando vários efeitos de sentido: tensão e intensidade; antecipação e suspense; sugere a participação do adolescente; e também pode possuir contornos metafóricos, parecendo simbolizar o estado de alma de Alex, com medo e em pânico de "alguma coisa" que só ele sabe, ou sente, e que ainda não foi explicada na narrativa fílmica. O grito oscila entre o mundo diegético e não-diegético, parecendo fazer parte da narrativa e da lembrança do jovem, mas ainda deslocado de qualquer lógica contextual. Outra interessante característica desse som em relação ao conteúdo visual no qual é utilizado, é que ele relaciona o jovem adolescente ao policial adulto, iniciando em um plano aproximado do rosto de Alex, e continuando, em um mesmo tipo de plano, no rosto do investigador.

Figura 131 - Um grito de horror é ouvido no meio da conversa entre o jovem e o investigador do crime. $\mathrm{O}$ corte entre eles se dá durante o grito, que ressoa nas duas imagens.

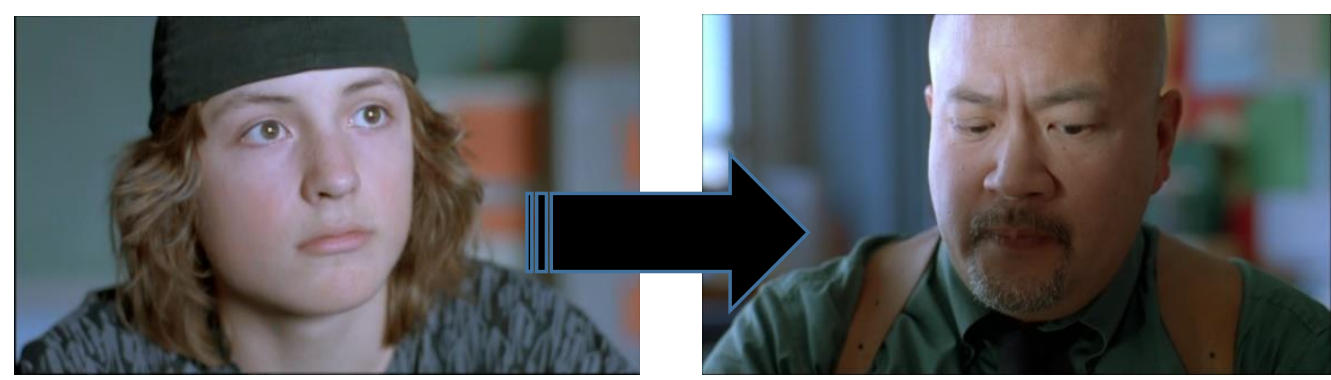

Observamos, ao analisarmos a sequência acontecimento, que nela o grito não é ouvido, pois é encoberta pela Nona Sinfonia de Beethoven: assim, nenhuma voz ou som humano podem ser detectados na cena em que o vigia cai nos trilhos, e nenhum som pode ser realmente relacionado à vítima, de modo que a ligação entre grito e vigia torna-se apenas uma pressuposição. Finalmente, o grito parece não ser realista em relação à cena do qual supostamente faz parte: de um lado, tem a qualidade de som reutilizado, como se pertencesse a outro filme ou mídia; de outro, não parece ser realista em relação a ação, sendo alto e contínuo demais, como o grito de alguém que cai em um abismo. Dessa maneira, mesmo em 
retrospectiva, e depois de todas as causas e consequências da narrativa serem explicadas, a origem e causa do som ainda não pode ser abordada com segurança, de modo que ele se torna uma figura complexa de não ser e não parecer, oscilando entre enunciação e enunciado, e não encontrando uma solução lógica dentro da narrativa.

Da mesma forma, quando Alex foge da cena do crime e dirige-se à casa do amigo, onde toma um banho de chuveiro para tentar relaxar do medo e do pânico que o invadem, outro efeito sonoro desestabiliza a construção do "real" da cena. Ao encostar na parede do banheiro, cobrir o rosto com as mãos e chorar, um trinado de pássaro, som que é usado como elemento da composição eletroacústica da paisagem sonora Dedan, Dehors, de Parmegiani (1970) ${ }^{161}$, que não está na trilha sonora original do filme, pode ser ouvido. Juntamente com o som dos pássaros, um pulsar eletrônico, que é a base da composição, torna-se mais intenso e mais agudo, em uma longa sequência (aproximadamente 2'27').

Os ladrilhos que recobrem as paredes do chuveiro do ator têm motivos de pássaros e a trilha sonora cria dois ambientes diferentes no discurso fílmico, e concessivamente integrados. Novamente, o som de pássaro e a imagem impressa no ladrilho do banheiro adquirem características simbólicas e metafóricas. Em relação ao romance, por exemplo, pode conotar religiosidade ou espiritualidade, pois o protagonista explica que tenta falar com Deus embaixo do chuveiro. Essa cena, que não existe no filme, é substituída pela composição musical:

Depois de ter chorado por muito tempo, eu comecei a falar. Eu não sei exatamente com quem. Deus, talvez. Eu fiquei repetindo que estava arrependido. Não foi minha intenção. Eu perguntei porque aquilo tinha acontecido. O que tinha feito para merecer aquilo? Eu não era uma pessoa violenta. Eu nunca entrei em brigas. Não era justo. Era tão injusto... ${ }^{162}$.

\footnotetext{
${ }^{161}$ https://www.youtube.com/watch?v=sYGzDorXowQ. Tal composição não faz parte do CD da trilha do filme. 162 After I'd cried for a long time, I started to talk. I don't know who I was talking to. God maybe. I kept saying I was sorry. I didn't mean to do it. I asked why this had happened. What had I done to desserve this? I wasn't a violent person. I never got in fights. It wasn't fair. It was so not fair... (NELSON, 2006, p. 38).
} 
Figura 132 - Alex chora no chuveiro ao som de pássaros. Nos azulejos do banheiro há pássaros pintados

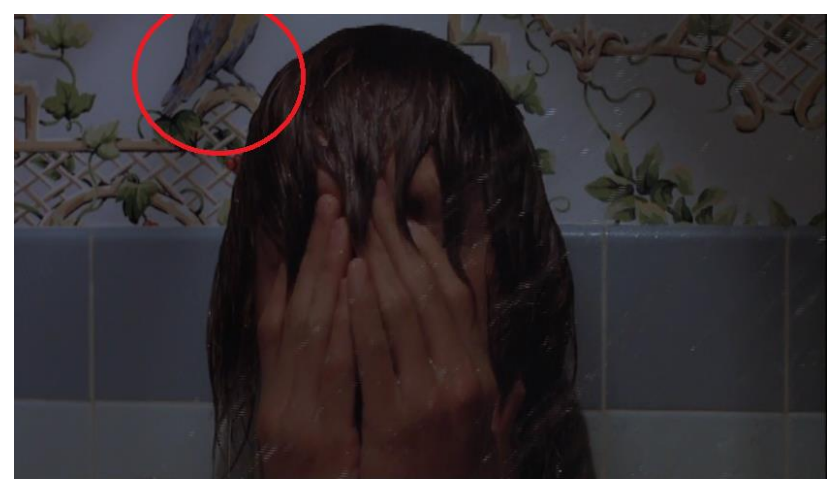

\section{Músicas e canções}

A trilha musical de Paranoid Park possui uma compilação eclética de gêneros e ritmos e, como os ruídos, vai entrar em consonância ou dissonância com a trilha imagética, ser mais ou menos incidental, e pertencer mais ou menos à diegese. Apoiando a narrativa de um sujeito amedrontado, confuso e em busca de valores, ela auxilia a figuração do espaço, do tempo e do ator, funcionando como caracterizadora de pensamentos e estados de alma de Alex, comentado suas paixões. Assim, em relação ao romance, a música e as canções também substituirão muitas passagens verbais dialogadas, procurando figurar os temas trabalhados no discurso literário. A trilha sonora musical do filme ${ }^{163}$ pode ser subdividida, de maneira geral, nos seguintes gêneros:

1. Trilha musical de outros filmes (instrumental): La Grandisca e Il Principe (de Nino Rota para o filme Amarcord); Il Giardino Delle Fate / La Porticina Segreta / L'Arcobaleno per Giulietta (de Nino Rota para o filme Julieta dos espíritos).

2. Blues (instrumental): Tunnelmouth Blues (Henry Davies).

3. Indie rock / folk (canção): Angeles; The White lady loves you more (Elliott Smith).

4. Rock experimental / progressivo / techno (canção): Strongest man in the world (Menomena).

5. Country music (canção): I can help (Billy Swan); Outlaw (Cast King).

6. Hip-Hop (canção): I heard that (Cool Nutz).

${ }^{163}$ Existe uma discrepância entre o CD do filme e as composições mencionadas nos créditos finais da obra. Várias das composições que constam nos créditos não existem no $\mathrm{CD}$, ou não foram observadas no filme. Para a nossa análise, utilizaremos as composições executadas no filme. 
7. Música instrumental eletrônica / eletroacústica: Song One, Song Two e Song Three (Ethan Rose); La chambre blanche (Robert Normandeau); Walk through resonant landscape 2 (Frances White) e Dedan, Dehors (Bernard Parmegiani).

8. Música clássica: Sinfonia 9 em ré menor op. 125 (Beethoven).

9. Punk rock (canção): We will revolt (The Revolts)

Para organizarmos esses inúmeros gêneros e estilos, vamos reduzi-los a dois tipos de composições musicais: as verbais e não-verbais, ou seja, canções e músicas instrumentais; e as diegéticas, e não-diegéticas, ou ambas. Comecemos pelas canções, fazendo uma breve análise de seu estilos e discursos verbais, e observando como elas complementam a obra adaptada, sendo utilizadas como ferramentas narrativas e, em alguns casos, sendo repetidas e acumulando outras funções.

\section{As composições não-diegéticas com textos verbais:}

Angeles e The White Lady loves you more (indie rock / folk)

Essas duas canções serão tratadas conjuntamente por serem composições do mesmo artista, Elliott Smith, cantor e compositor americano que viveu em Portland, e que emerge em 1990 como uma das mais autênticas vozes de sua geração (SCARUFFI, 1999). Ambas são extremamente melodiosas e melancólicas, e cantadas de maneira tímida e sussurrada, como era o estilo do autor. Scaruffi (1999) explica que os personagens de Smith são desajustados consumidos por uma paixão que pode ser literal, álcool ou drogas, ou metafóricas ${ }^{164}$, e cujas vidas parecem estar em estados degenerativos (CALVERT, 2010) ${ }^{165}$. Em Angeles, canção que pode ser interpretada como a representação de uma barganha faustiana aceita por músicos cooptados por grandes gravadoras, que trocam o seu talento por dinheiro (GUNSELI, 2015) ${ }^{166}$, o que nos interessa é justamente, além do tom melancólico, a isotopia temática de um mundo disfórico e dominado pelo mal, e no qual o homem luta pela sobrevivência e dinheiro, em uma vida sem promessas de redenção.

\footnotetext{
164https://www.scaruffi.com/vol5/smith.html (Elliott Smith)

${ }^{165}$ http://thequietus.com/articles/05286-elliott-smith-an-introduction-to-review (Elliott Smith: an introducion to...).

${ }^{166}$ https://crackmagazine.net/article/lists/celebratingelliottsmith/ Celebrating Elliott Smith: his five most significant tracks).
} 


\section{Angeles}

Someone's always coming around here, trailing some new kill

Says: "I've seen your picture on a hundred dollar bill"

And what's a game of chance to you, to him is one of real skill

So glad to meet you, Angeles

Picking up the ticket shows, there's money to be made Go on and lose the gamble, that's the history of the trade And you add up all the cards left to play to zero

And sign up with evil, Angeles

Don't start me trying now

'Cos I'm all over it, Angeles

I can make you satisfied in everything you do

All your secret wishes could right now be coming true

And be forever with my poison arms around you

No one's gonna fool around with us

No one's gonna fool around with us

So glad to meet you, Angeles
Alguém está sempre aparecendo por aqui, rastreando uma nova presa

Diz: "Vi seu rosto em uma nota de cem dólares"

E o que é um jogo de azar para você, para ele é uma rara habilidade

Tão feliz de te encontrar, Angeles

Pagando os ingressos do show,

Há dinheiro para ser feito

Vá em frente e perca a aposta, esta é a história do negócio

E você soma todas as cartas restantes para jogar a zero

E faz um pacto com o diabo, Angeles

Não comece a me julgar agora

Pois superei isso, Angeles

Eu posso te deixar satisfeito em tudo o que você faz

Todos os seus desejos secretos poderiam tornar-se reais agora mesmo

E estar sempre te abraçando como os meus braços envenenados

Ninguém vai nos fazer de bobos

Ninguém vai nos fazer de bobos

Tão feliz de te encontrar, Angeles

A canção é utilizada no final do filme, quando Alex escreve a última carta e a queima na praia, acabando com o peso do segredo que o atormenta e marcando o iníco da volta à uma vida normal. De um lado, a canção delimita não apenas o final do sobrevir, mas também o amadurecimento do personagem. Ao viver com a memória da morte de um homem, pela qual não se sente responsável, e mentir para todos para não se prejudicar e nem perder os prazeres da liberdade, Alex, de certa maneira, justifica e minimiza o seu ato, e aprende o lado maligno e violento da sobrevivência. Ao mesmo tempo, no romance, ele confessa o medo de perder sua vida de adolescente classe-média, e sabe a importância da liberdade para o futuro. Assim, junto com suas mentiras, Alex protege o seu status quo, que é um forte destinador e faz o jovem manter segredo. 
Figura 133 - A canção Angeles é executada quando Alex termina as cartas e as queima na praia
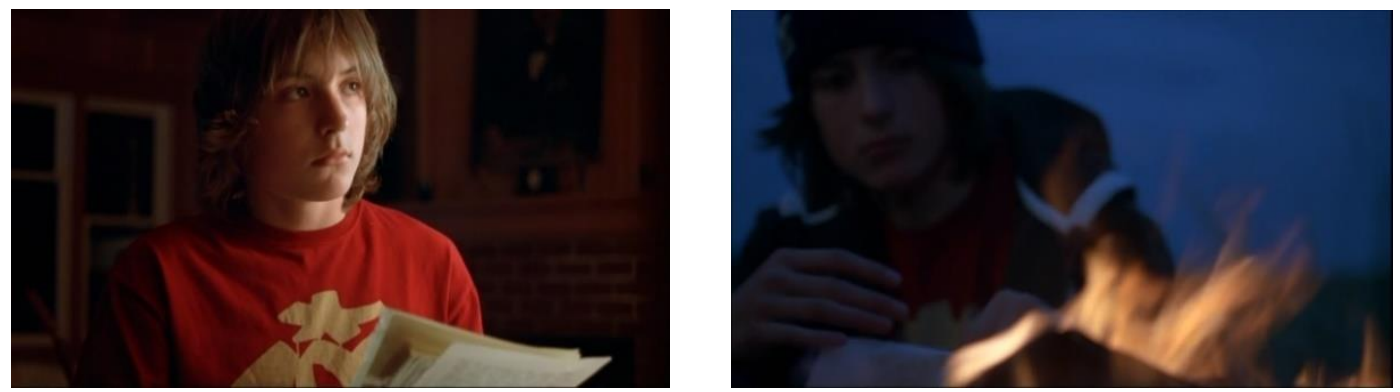

The White Lady loves you more

Keep your things in a place meant to hide

But I know they're there somewhere

And I know that's where you'll go tonight

I'll be thrown over just like before

The White Lady loves you more

Need a metal man just to pick up your feet

It's a long time since you cared enough for me to even be discrete

I know what this metal is for

The White Lady loves you more

I'm looking at a hand full of broken plans

And I'm tired of playing it down

You just want her to do anything for you

There ain't nothing she won't allow

You wake up in the middle of the night

From a dream you won't remember

flashing on like a cop's light

You say "she's waiting" and I know what for

The White Lady loves you more
Deixe as suas coisas em um esconderijo preferido

Mas sei que estão lá, em algum lugar

E eu sei que é para lá que você irá à noite

Ficarei jogado como antes

A Dama Branca te ama mais

Precisa de um homem de ferro só para te erguer

Há tempos você não se importa comigo,

e nem mesmo finge

Eu sei para o que é esse metal

A Dama Branca te ama mais

Estou olhando para uma mão cheia de planos errados

E cansado de ignorar

Você só quer que ela faça qualquer coisa por você

Não há nada que ela não permita

Você acorda no meio da noite

De um sonho do qual não mais se lembra brilhando como a sirene da polícia

Você diz "ela está me esperando" e eu sei para que

A Dama Branca te ama mais 
Nessa canção, que pode ser descrita como uma balada romântica, há a figura central da Dama Branca, que apesar de ser relacionada à cocaína, à heroína ou outras drogas, é euforizada e personalizada, possuindo traços espirituais, maternos e eróticos, e simbolizando a morte, o amor, a maternidade e a sexualidade ${ }^{167}$. The White Lady inicia-se após a entrevista com o detetive. O filme volta ao presente da narração e mostra Alex, na casa do tio, que explica que está contando a sua história fora de ordem. Enquanto a canção toca, podemos ver o ator escrevendo, absorto, na casa do tio, depois saindo da sala de aula onde houve a conversa, e andando pelo corredor da escola (flashback), imagens de garotos andando de skate na rua (as imagens são granuladas como as utilizadas em figurações da pista de skate Paranoid Park), e Alex com o tio na sala (volta ao presente).

A canção é tocada inteiramente, e o filme parece trabalhar, intertextualmente, a linguagem do vídeo-clip. A letra da canção menciona um local secreto, um esconderijo e, portanto, um local de proteção e encontro com a Dama Branca. Relacionada a imagens de jovens na rua, a Dama Branca aparece como figura materna e protetora de uma juventude prdida em uma sociedade autoritária (algumas cenas mostram a polícia interpelando os adolescentes: um jovem negro mostra o que parece ser uma multa, para a câmera); ao mesmo tempo, sendo uma canção calma e sussurrada, soa como uma cantiga de ninar, tornando-se metáfora da liberdade, da inocência e da própria cultura do skate. Assim, as isotopias temáticas de proteção materna, juventude, inocência e vida marginal em comunidade são figuradas pela ideia de uma Dama Branca e semissimbolizadas pela expressão musical.

Figura 134 - Imagens mostradas durante a canção The white lady loves you more
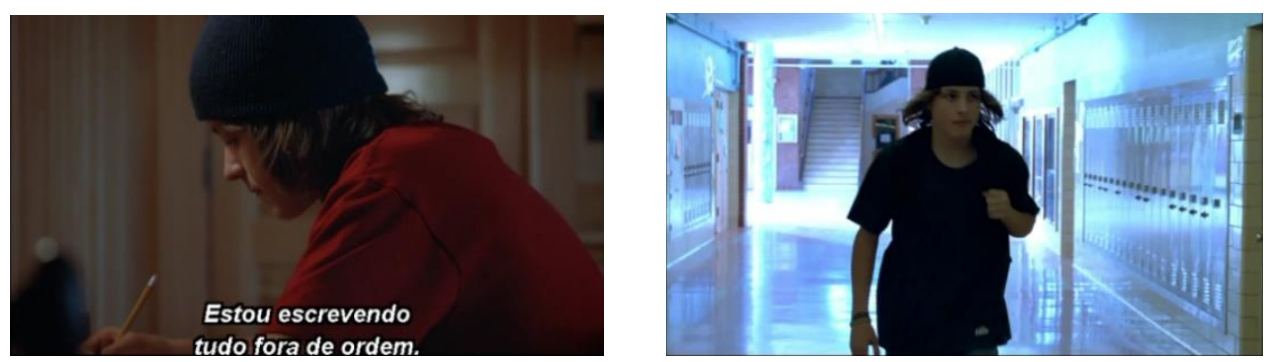

${ }^{167}$ Camus (2013) explica que "com uma melodia triste e melancólica e um título que mais uma vez faz referência ao vício e a uma figura sagrada, a música é solene e tem uma letra angustiada": "With a sad and melancholic melody and a title which makes once again reference to a drug addiction and a holy figure at the same time, the song has a solemn delivery and anguished lyrics. Em http://rocknyc.live/elliott-smiths-roman-candle-elliott-smitheitheror-xo-and-figure-8.html. Elliott Smith Reviews Reposted (Alyson Camus, 2013). Acesso em 01 / 08 / 2019. 

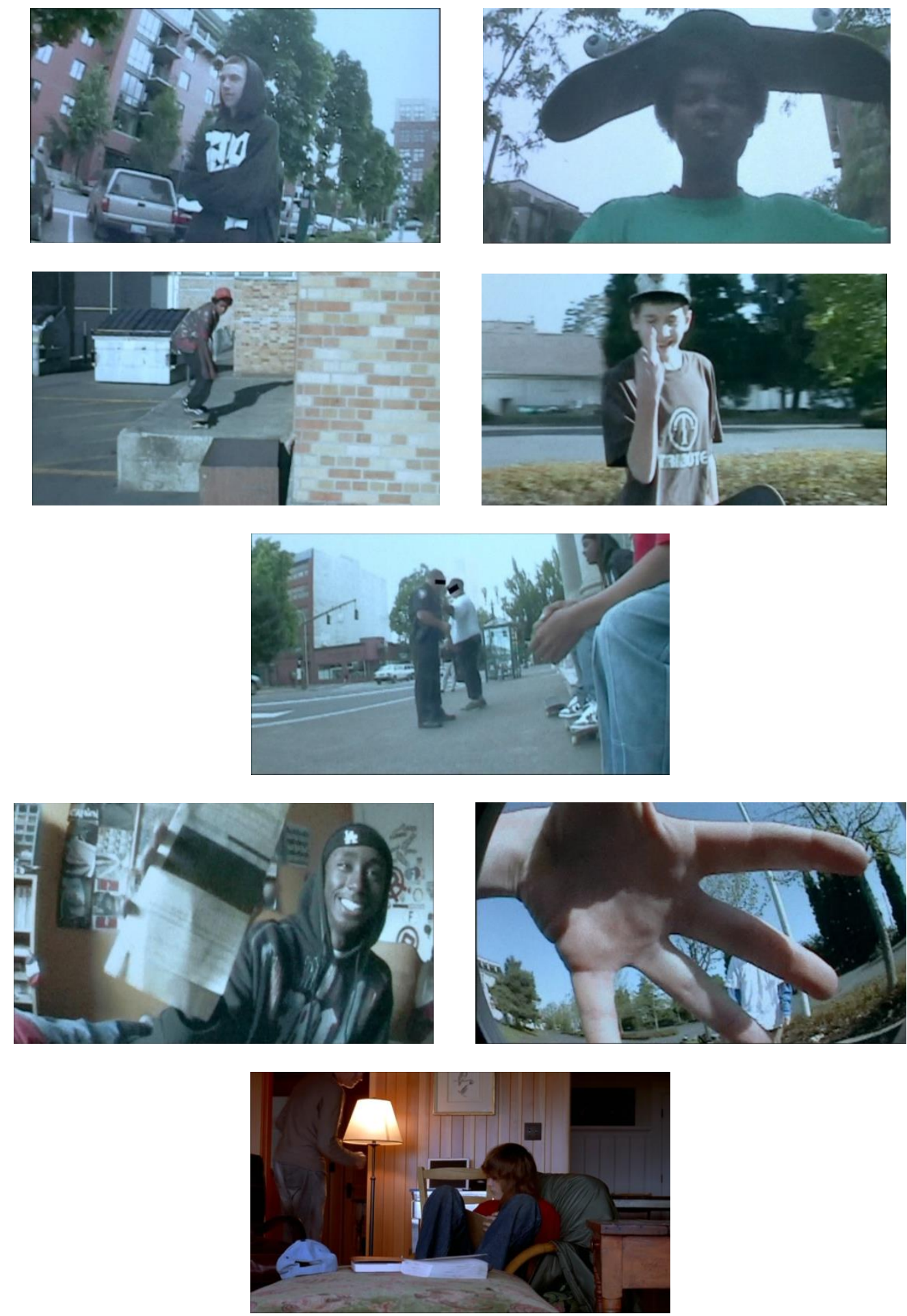

I can help (country music, rock e blues)

If you've got a problem,

I don't care what it is...

If you need a hand,

I can assure you this

I can help! I've got two strong arms,

I can help!
Se você tem um problema,

Eu não me importo qual seja...

Se você precisa de uma mão,

$\mathrm{Eu}$ te prometo uma coisa

Eu posso ajudar! Eu tenho dois braços fortes, eu posso ajudar! 
It would sure do me good to do you good, Let me help!

It's a fact that people get lonely,

Ain't nothing new

But a woman like you baby,

Should never have the blues

Let me help! Take a tip from me,

Let me help!

It would sure do me good to do you good,

Let me help!

When I go to sleep at night you're always

A part of my dream

Holding me tight and telling me

Everything I wanna hear

Don't forget me baby, all you gotta do is

call

You know how I feel about you

If I can do anything at all

Let me help! If your child needs a daddy, I can help!

It would sure do me good to do you good,

Let me help!
Com certeza me faria bem te fazer bem

Deixe-me ajudar!

É um fato que as pessoas ficam sozinhas,

Não é uma novidade

Mas uma mulher como você, baby,

Nunca deveria estar triste

Deixe-me ajudar! Ouça minha sugestão,

Deixe-me ajudar!

Com certeza me faria bem te fazer bem,

Deixe-me ajudar!

Quando vou para cama, à noite, você é sempre parte do meu sonho

Me segurando forte e me dizendo

Tudo o que eu quero ouvir

Não me esqueça, baby, você só precisa

ligar

Você sabe o que eu sinto por você

Se eu puder fazer qualquer coisa

Deixe-me ajudar! Se o seu filho precisa de um papai, eu posso ajudar!

Com certeza me faria bem te fazer bem

Deixe-me ajudar!

I can help (sucesso em 1974 e gravada por Elvis Presley) é uma canção bem-humorada e alegre, que mistura o ritmo da música country com o rock mais antigo, tipo anos 40 e 50 (rockabilly), e o Blues (Buskin, 2007) ${ }^{168}$. Nessa canção, um homem revela seu interesse afetivo por uma mulher bonita, oferecendo-lhe ajuda e até propondo-lhe matrimônio. Enunciada em primeira pessoa, trata-se de uma canção rápida, com um texto verbal informal e estilo pouco romântico, o que ajuda a definir as intenções de um galanteador, que não parecem ser muito sinceras ou profundas. Em relação a $P P$, a canção é utilizada em apenas um momento do filme, ocorrendo na cena em que Alex é chamado para conversar com o detetive em particular, acompanhando o jovem da sala de aula à sala onde o detetive o espera, em um longo plano que o mostra andando lentamente pelos corredores da escola. Comentando uma cena tão banal, o refrão I can help ganha tons irônicos, indicando um problema. Como essa canção alegre e bemhumorada ocorre antes do diálogo entre o jovem e o detetive, e a canção após o diálogo, The White lady loves you more, tem tons disfóricos, podemos então associá-las a uma mudança de humor do jovem, antes e depois do encontro com o representante da lei em seu encalço.

Figura 135 - Imagens da canção I can help (Alex é chamado para encontrar o detetive)

${ }^{168}$ https://www.soundonsound.com/people/billy-swan-i-can-help. Billy Swan 'I Can Help' (Richard Buskin) 

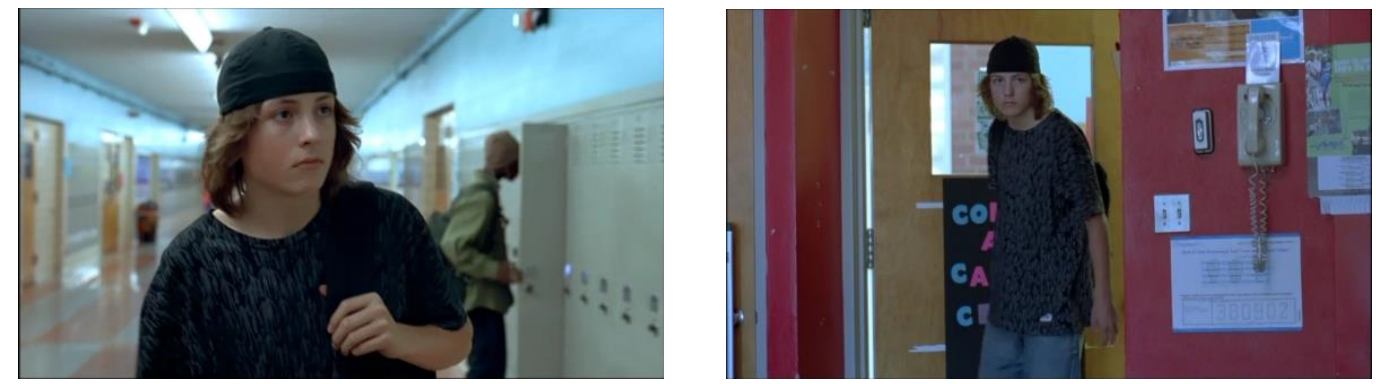

Outlaw (country music)

Oh, the black-haired stranger rode into town,

His guns were tied down.

He rode a tall, black stallion

Fourteen hands high, with a shaggy

mane

The week he died.

He rode up to the ol' dust saloon

"Where's lightnin' Sam?" "He's in the back room"

You better run, Sam, you better run

He's got 21 notches on his gun.

"there's a time to run, a time to stand,

I can't beat him, I'll die like a man, die

like a man, die like a man."

Oh, the sun was high

And the wells were dry

And the hungry birds looked down from the sky.

And the rattlesnake was comin' out of that red hot desert ground

Was a holiday in hell, that main Texas town.

The outlaw calls from the street,

And the fastest gun alive,

Sam I've got you be

Then I heard a shotgun rolling,

The lightning sound comes through the saloon doors

He said "I had to get my silver shells,

That thing wasn't a man

That was a devil right out of hell."

He reached up and he took his badge off his chest

He said "son, you're the sheriff now,

You're awful young,
Oh, o estranho de cabelos negros cavalgou cidade adentro

Suas pistolas penduradas.

Ele montava um garanhão alto, negro

e com uma crina desgrenhada

A semana em que ele morreu.

Ele cavalgou até o velho salão empoeirado

"Onde está o relâmpago Sam?" "Ele está no quarto dos fundos"

É melhor você correr, Sam, é melhor correr

Ele tem vinte e um entalhes em sua pistola

"há um tempo para correr e para lutar,

Eu não posso vencê-lo, vou morrer como um homem, morrer como um homem, morrer como um homem ".

Oh, o sol estava alto

E os poços secos

$\mathrm{E}$ as aves famintas olhavam para baixo, do céu.

E a cascavel saia daquele chão quente e vermelho do deserto

Era um feriado no inferno, aquela cidade principal do Texas.

O bandido chama da rua,

E a pistola mais rápida viva

Sam, você é.

Então ouvi um tiro de espingarda ecoando,

O som de trovão através das portas do salão

Ele disse "Eu tive que pegar minhas balas de prata,

Aquela coisa não era um homem.

Era um demônio saído direto do inferno".

Ele ergueu o braço e tirou seu distintivo do peito

Ele disse "filho, você é o xerife agora, 
I hope you stand the test

Cause I'm gonna hit the trail, I can't keep demons and devils locked in no jail"

So old Sam he headed out across the desert.

He didn't have no water for his canteen, Leading that sack of bones he called a horse.

Two and a half years later during the rainy season

We had water in the well, I thought I'd try to cross the desert,

Maybe I'd find me a gal.

I was about three days and a half out in that barren waste

When I saw something laying by a mesquite bush.

I looked and it was Sam's old shotgun.

Nearby lay his old saddle, what the varmints had't eaten

Well I says "I'll be darned, Sam did't

kill that devil,

He tricked him into trying to cross that desert with no water for his canteen

Leading that sack of bones he called a horse."

And it seemed that I could hear a voice "he died like a man, he died like a man, he died like a man..."
Você é terrivelmente jovem,

Espero que você aguente o teste

Porque eu vou cair na estrada

Eu não posso manter demônios e diabos presos em nenhuma cadeia."

Então o velho Sam foi embora em direção ao deserto.

Ele não tinha água no cantil,

Levando aquele saco de ossos que ele chamava cavalo.

Dois anos e meio depois, durante a estação chuvosa

Nós tivemos água no poço. Eu pensei em tentar atravessar o deserto,

Talvez eu encontrasse uma garota.

Eu estava cerca de três dias e meio naquela vastidão estéril

Quando vi algo deitado em um arbusto de Mesquite.

Eu olhei e era a antiga espingarda de Sam.

Perto estava sua velha sela, o que os bichos não tinham comido

Bem, eu digo "Que Deus me castigue, mas Sam não matou aquele diabo,

Ele o convenceu a tentar atravessar o deserto sem água no cantil

Levando aquele saco de ossos que chamava cavalo."

E parecia que eu podia ouvir uma voz

"ele morreu como um homem, ele morreu como um homem, ele morreu como um homem..."

Outlaw é uma canção cantada lentamente, quase falada, por uma voz masculina acompanhada apenas por um violão, e conta a história de "Relâmpago Sam", o xerife de uma cidade texana que a princípio engana o Diabo, sacrifica-se e morre como um homem. A música é tocada inteiramente no final do filme, depois que Alex queima as cartas, e continua na exibição dos créditos finais. A voz grave, cansada e velha do intérprete e compositor, cujas narrativas lidavam com temas western, tais como a pobreza, relacionamentos rompidos e assassinos, possuindo uma qualidade crua e comovente ${ }^{169}$, é utilizada como comentário da situação do personagem do romance, simbolizando sua maturidade, crescimento e sacrifício pessoal. A partir dessa canção, podemos entender que Alex, depois de lembrar e reviver o acontecimento e atonizar o sobrevir, encerra uma fase de sua vida, tornando-se mais "velho" e

169 https://en.wikipedia.org/wiki/Cast_King (A tradução é nossa) 
experiente, e marcado por uma eterna "cicatriz". A canção comenta: "Filho, você é o xerife agora. Você é terrivelmente jovem. Espero que aguente o teste" (um dos traços marcantes da canção é que o narrador que conta a história de Sam é justamente o jovem que substitui o xerife e o encontra morto no deserto, e agora está igualmente velho). Ao mesmo tempo, a afirmação do narrador do texto de que o xerife na verdade não matou o diabo, mas foi convencido a suicidar-se no deserto, acusa um heroísmo inútil, e a impossibilidade de extermínio do mal, que é o que Alex sente.

Dialogando com a sequência anterior dos skatistas de rua, as cenas finais do filme são acompanhadas por essa canção western. A música sóbria e lenta de King igualmente oferece uma visão mais crítica da adolescência, criando um contraponto entre a voz de um homem velho e vivido, e as imagens de jovens que andam de skate na rua, infundindo na sequência, a partir de um discurso concessivo, um tom mais poético e metafórico. A dissonância entre voz envelhecida sobre imagens de adolescentes felizes e inconsequentes que brincam fora de casa, não apenas suscita categorias semânticas opostas, tais como felicidade vs. tristeza, juventude vs. velhice, relacionados a vida e à morte, mas a ideia de crescimento e transformação. Um dos jovens mostrados no final do filme é Alex, que olha em direção à câmera.

Figura 136 - No final do filme, a canção Outlaw e cenas de jovens andando de skate na rua
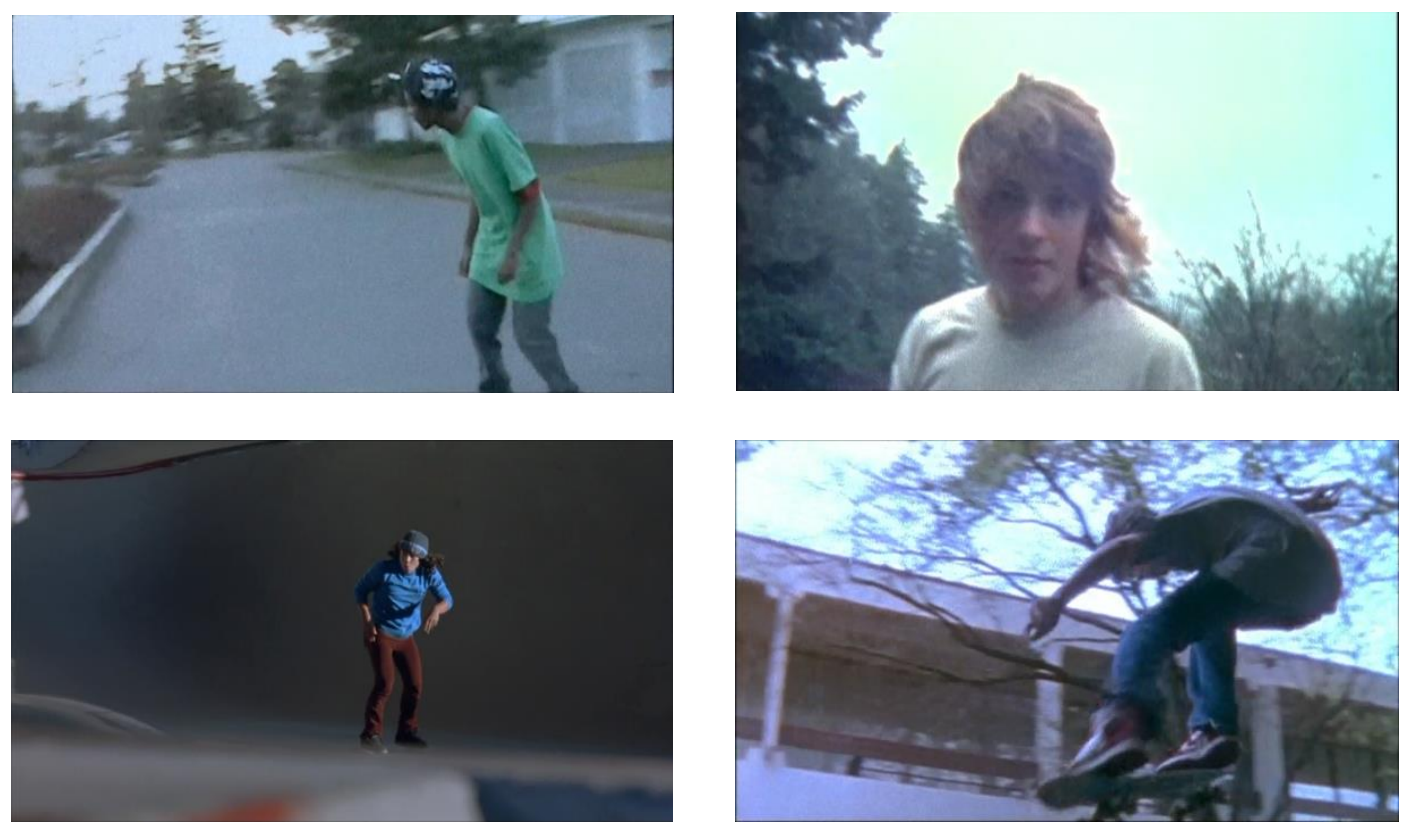

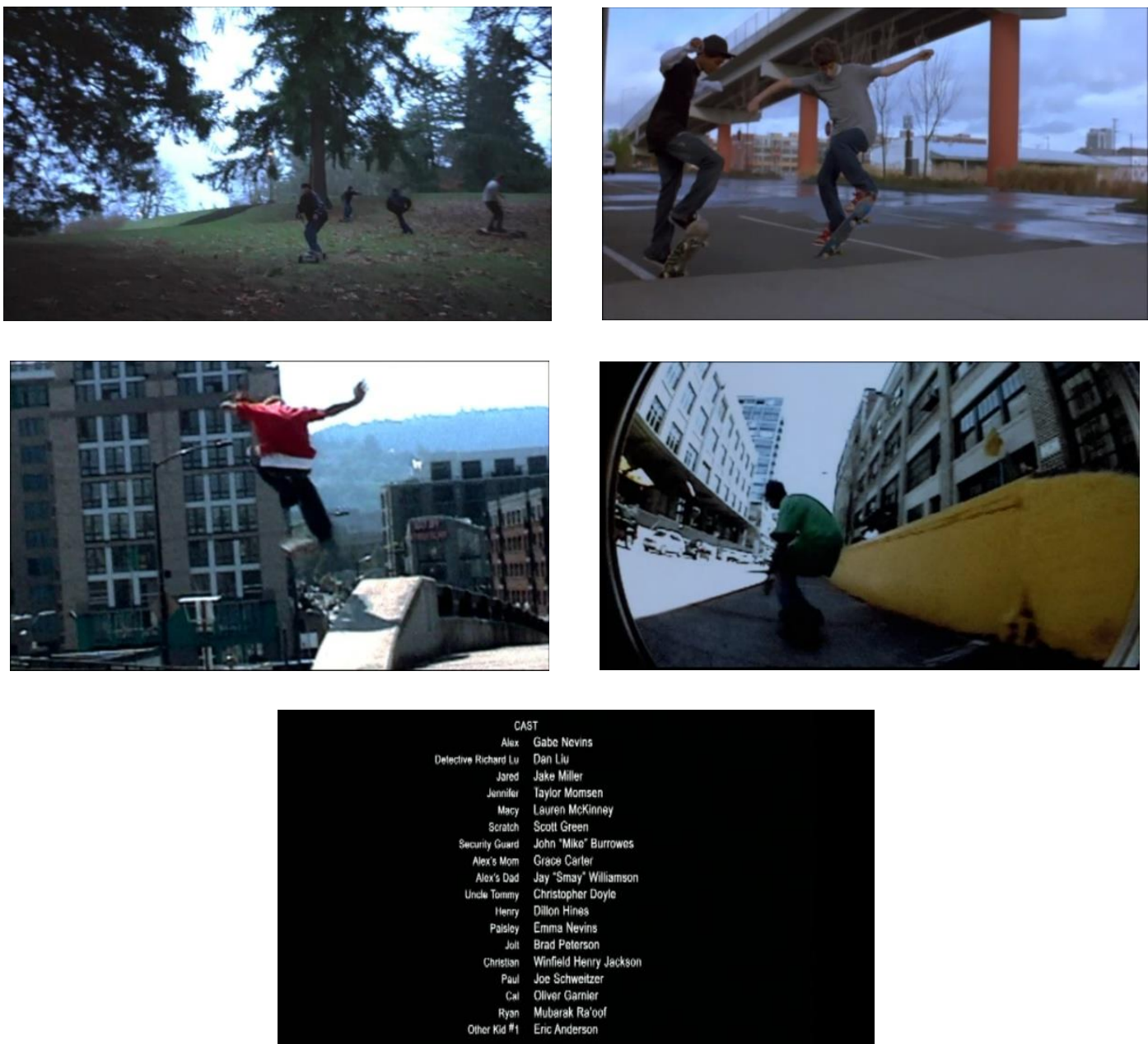

We will revolt (punk rock)

Infelizmente, não conseguimos obter a letra dessa canção, cujo ritmo é bem acelerado, e é enunciada de maneira mais "gritada" do que cantada. Com seu estilo pesado e violento, a canção é utilizada quando Jared dá uma carona a Alex e observa o novo skate do amigo, fazendo um comentário homofóbico. Essa cena existe no romance, mas com uma importante diferença: a palavra wuss, no romance, é substituída pela palavra $f a g^{170}$. Assim, no filme:

\footnotetext{
${ }^{170} \mathrm{Na}$ gíria inglesa wuss não tem necessariamente uma conotação homossexual, significando fraco, estupido,
} covarde ou "bunda mole". Por outro lado, uma das conotações da palavra fag é homossexual. 
Figura 137 - Jared percebe que Alex tem um novo skate e reclama

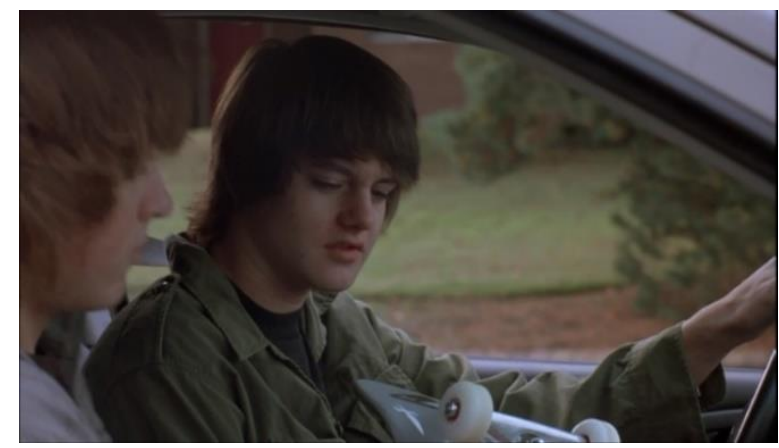

Jared: Cara, esse não é o seu skate.

Alex: É sim, eu acabei de comprar.

Jared: Porque você comprou um skate novo?

Alex: Porque eu queria tentar algo diferente.

Jared: Porque você não me contou?

Alex: Porque eu te contaria? É só um skate novo.

Jared: Cara, porque eu tenho que andar de skate com você, e não vou andar perto de um cara com skate de veado.

Alex: Uau...não é nem um skate de veado. Dirige aí, vai.

Jared: Sei...Ok ${ }^{171}$.

Figura 138 - O punk rock toca sobre o rosto de Jared, depois de uma discussão envolvendo homofobia

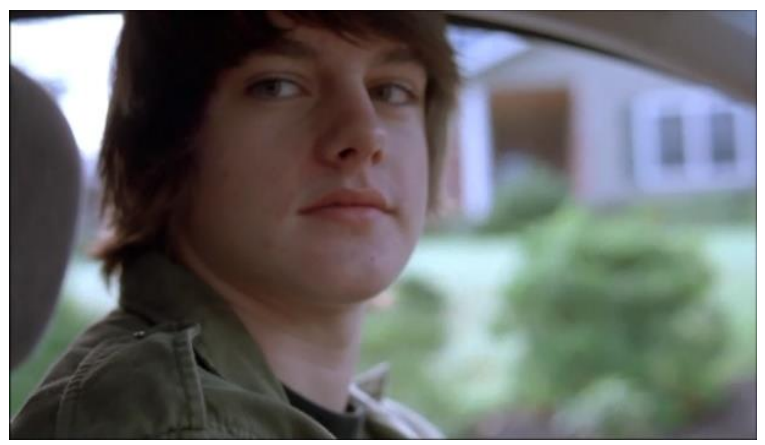

\section{Composições não-diegéticas e sem texto verbal:}

1. A Nona Sinfonia de Beethoven (música clássica)

Apesar de não ser uma canção, a última sinfonia escrita por Beethoven possui um coral de vozes masculinas e femininas, que canta uma poesia escrita por Schiller, denominada Ode à

\footnotetext{
171 Jared: Dude, that's not your board. Alex: Yeah it is, I just got it.

Jared: What'd you get a new board for?

Alex: Because I wanted to try something different.

Jared: Why didn't you tell me about this?

Alex: Why would I tell you? It's just a new board.

Jared: Dude, because I gotta skate with you and I can't have some fag (wuss: no romance) board riding next to me. Alex: Wow, it's not even a fag board. Just drive.

Jared: Yeah, ok (Paranoid Park: Gus Van Sant).
} 
alegria, e é alterada levemente pelo compositor alemão. De maneira geral, a sinfonia é extremamente complexa tanto em sua expressão como conteúdo, e relaciona-se, de maneira intertextual, a outros gêneros. Segundo Buch (2001), nessa obra monumental de Beethoven, a expansão da forma sinfônica encontra-se aliada a uma verdadeira retórica dos gêneros musicais que evoca o universo militar e o religioso, dos quais emerge o hino, sagrado ou profano, "pelo qual os homens celebram o fato de estar juntos" (p. 9). A partir de ideal tão grandioso e abstrato, relacionado à irmandade e à celebração da comunidade, Beethoven cria um texto musical sincrético e intertextual que acolhe o canto, a poesia, o hino, a música folclórica, a marcha, a fanfarra, a música turca, o oratório etc, e que se torna "a mais convincente das imagens sonoras sobre a utopia" (BUCH, 2001, p.12).

Cook (1993), que questiona se a sinfonia é um retrato, uma biografia, ou mesmo uma autobiografia, comenta que a ideia temática no primeiro movimento claramente soa como uma marcha fúnebre, não se podendo dizer ao certo, porém, porque ela está lá ou para quem é, e nem como se relaciona com o resto da composição, de modo que o texto se constrói a partir da ambiguidade de sentido. Segundo Cook, essa sinfonia proclama as ideias de irmandade universal e alegria (compatíveis com os valores da época), mas ao mesmo tempo joga um véu de dúvida sobre elas, enviando mensagens incompatíveis, e resistindo a uma interpretação definitiva (p. 104).

A parte da sinfonia utilizada no filme é um trecho cantado do quarto movimento, e auxilia a figuração da sequência do acontecimento, quando Alex acidentalmente mata o segurança do pátio de trens. A poesia é a seguinte:

Ihr stürtzt nieder, Millionen? Ahnest du den Schöpfer, Welt? Such ihn übern Sternenzelt! Über Sternen muss er wohnen.
Vós vos prosternais, milhões de seres?

Mundo, pressentes o criador?

Procura-o acima da abóbada estrelada!

Acima das estrelas, lá deve ser sua morada.

Não é difícil imaginar como, a partir de uma música tão grandiosa, a Nona Sinfonia redimensiona o tempo, o espaço e tonifica a disforia da morte, emprestando à cena do acontecimento não apenas calor, mas um tom mítico e trágico, e sustentando a figuração do choque, do sobrevir, conotando o espetacular e o surpreendente. Através dessa música romântica, o acontecimento ganha mais dimensão e profundidade, tornando-se palpável e concreto, e infundindo nas imagens a ideia de medo e terror, as paixões que Alex experimenta no romance ao ver o corpo do vigia cortado ao meio. No filme, a cena em que o segurança moribundo e o jovem entreolham-se é acompanhada pela parte mais intensa da sinfonia cantada. 
A música de Beethoven empresta à cena a própria grandiosidade do trágico mítico, cuja função é a de prover à violação do tabu, "a grandeza humana e a marca da condenação, para compensar um culpa" (TARASTI, 1972, p. 21). Em nosso caso, como não se trata de culpa, a música define, de um lado, a própria estesia do herói, a estesia da violação do tabu do assassinato, ligado ao acontecimento; de outro, busca o efeito de catarse, através de um trecho musical marcado pela duratividade da própria intensidade. A sinfonia também enfatiza e tonifica a imagem-acontecimento do vigia cortado ao meio que se arrasta em direção ao protagonista; dentro da sequência, relacionada a memória, ela também liga as imagens de Alex olhando para o vigia, as imagens dele próprio, na praia, e as do rosto do detetive.

Figura 139 - A Nona Sinfonia liga breves momentos do passado (a morte do vigia e a conversa com o detetive), e do presente, na praia (sequência de imagens do filme)
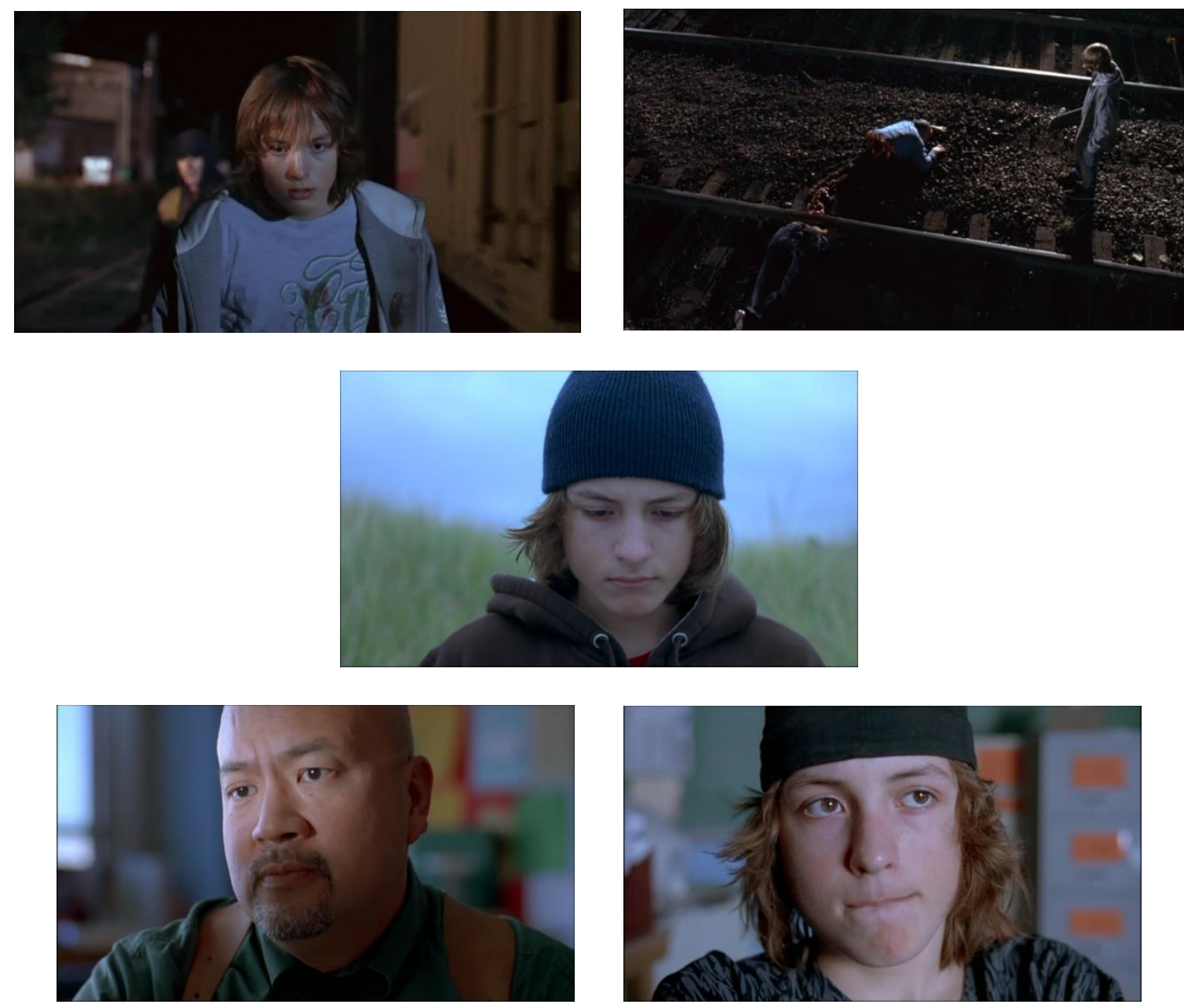

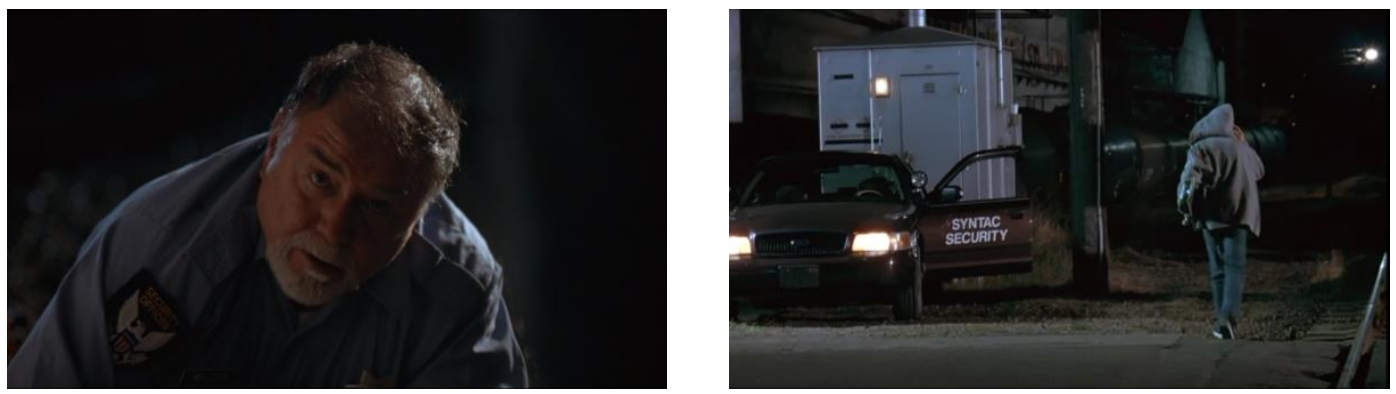

2. La Grandisca e Il Principe; Il Giardino Delle Fate; La Porticina Segreta; L'Arcobaleno per Giulietta (trilhas sonoras de Nino Rota para os filmes de Fellini)

Em nossa segmentação inicial, citamos o uso da trilha sonora de Amarcord nas imagens aceleradas que acompanhavam os créditos iniciais do filme, e mostravam a ponte sobre Paranoid Park, a cidade onde o ator mora, e o céu, símbolo do destino e do incomensurável. Observamos que a música escolhida para a imagem dos créditos possui características dramático-cômicas, combinando gêneros bem dissimilares, e com uma estrutura estilística de caráter contrapontual e ambíguo. Funcionando como elemento predicativo da narrativa que está por vir, a trilha sonora de Amarcord articula, através de operações interdiscursivas e semânticas, conteúdos que permitem pensar em concessividade, sonho, memória, alegria e tristeza, ou seja, elementos pertencentes tanto aos modos semióticos da narrativa como aos estados de alma do personagem.

Falsetto (2015) comenta que o uso das trilhas de Nino Rota compostas para dois filmes de Fellini, "não é comum para um filme contemporâneo sobre skatistas" e, assim, parece quebrar paradigmas. No entanto, a conexão com o universo de sonho de Julieta ou a obra de Fellini sobre a memória, Amarcord, não é totalmente inapropriada" (p. 105). Natalia Ginzburg fala de Amarcord como sendo "um coro de memórias cantado alto em uma síntese de reminiscências, sonhos e experiências" (1994 apud DYER, 2010, p. 173. Tradução é nossa) ${ }^{172}$. Segundo Dyer (2010), na parceria Fellini-Rota, imagem e música geralmente resgata o passado tanto como história do que como experiência, ou seja, memória (p.163).

Além dos motivos oníricos e nostálgicos das composições de Nino Rota, suas características também jogam luz sobre a sua utilização em Paranoid Park, que além de oscilarem entre o cômico e o trágico, possuem um tom de leveza, superficialidade e humor,

172 "Natalia Ginzburg spoke of the film as 'a choral memory sung out loud in a synthesis of reminiscences, fantasies, dreams and actual experiences"” (a citação não tem fonte). 
bem ao estilo do músico italiano. Segundo Dyer (2010), a melodia é a base principal na música desse compositor, sendo sempre longa e clara, e evitando ser arrastada ou ter sobressaltos. As frases melodiosas de Rota dividem-se em dois tipos básicos: lenta e levemente romântica, e animada e agitada, podendo ser facilmente cantadas, de modo que sugerem um lirismo popular e simples (p. 27).

Dyer acredita que as harmonias agradáveis e os ritmos encantadores criados pelo compositor italiano emprestam à sua música uma qualidade de "candura" ou "inocência"173, termos que englobam também a ideia de simplicidade, franqueza, transparência e não afetação, dando a impressão de espontaneidade e de comunicação direta (p. 27). Operando a partir do já codificado e popular, mas também controlando a intensidade da afetividade, as composições do músico italiano, que incorpora estereótipos e clichês de maneira consciente, é difícil de ser caracterizada: "é triste, mas nunca trágica, sombria ou desesperadora, romântica mas não ardente, sentimental mas não lacrimosa, alegremente energética mas nunca, ou nunca por muito tempo, excessivamente frenética ou maníaca" (DYER, 2010, p. 27. Tradução nossa) ${ }^{174}$. A partir daí o estilo musical do compositor italiano é caracterizado por uma certa energia bemhumorada, beirando a sátira, de modo que não se ignora completamente o lado emocional dos filmes, mas evita-se o excessivamente sentimental, chegando-se ao assunto obliquamente e com um leve tom de absurdo (p. 27)

Em Paranoid Park, as trilhas do compositor italiano que, como Falsetto explica, parecem não fazer parte do filme e nem do mundo teenager norte-americano do século 21 , soando como destacadas da narrativa ou fora de lugar, revelam outra característica dessas composições, que menos compõe para a imagem, do que cria estruturas melódicas que podem ser "recicladas" ou escutadas em outros contextos, independentemente da forma e conteúdo narrativo fílmico. Segundo Dyer (2010), que comenta certa ironia imparcial por parte do compositor, as trilhas musicais para o cinema de Rota existem dentro e fora do filme, pois simpatizam com o que está na tela, mas não se apegam aos personagens e eventos, convidando ao envolvimento ou à identificação. As partituras estão em sintonia com o filme, mas não reagem a todos os movimentos, mudanças de emoção ou desenvolvimento minucioso do enredo, colocando-se dentro e fora do mundo diegético ao mesmo tempo. Tal efeito é conseguido

\footnotetext{
173 A palavra em italiano é candore.

174 "It is said but never really tragic, bleak or despairing, romantic but not ardent, sentimental but not tearjerking, cheerfully energetic but never, or never long, excessively busy or manic".
} 
através das qualidades inerentes de imediatismo e reticência, ironia e retidão das composições, do uso de motivos que não se prendem rigorosamente a personagens, situações ou ideias, da utilização de formas musicais que referem-se a outras, e jogando com a diferença entre a música que emana do mundo ficcional e a que vem de fora dele, em uma trilha que, de forma geral, não segue o filme servilmente e nem o guia (p. 40. Tradução nossa) ${ }^{175}$.

Assim, as composições de Rota utilizadas em Paranoid Park causam a mesma sensação entre trilha musical e trilha imagética já observada em outras películas, destacando-se levemente das imagens, e muitas vezes parecendo artificiais, de um lado mantendo-se à parte da narrativa e, de outro, servindo menos como descrições exatas do mundo interior fragmentado de Alex, do que como comentário de seus desejos e estados afetivos relacionados ao sexo oposto, tratando também da figuração da isotopia do amor e das relações interpessoais com as mulheres. Como parecem não ilustrar exatamente as tensões presentes no conteúdo visual ou nas falas dos personagens, trazendo certa leveza irônica à narrativa, têm também o poder de realçar esses momentos.

As músicas do compositor italiano, "que era inclinado a escrever música que acentua emoções misturadas ou contrárias" (DYER, 2010, p. 113. Tradução nossa) ${ }^{176}$, além de aparecerem nos créditos iniciais do filme, conotando humor e dramaticidade, são também utilizadas nos vários encontros "românticos" do protagonista, assim como em seus momentos menos dramáticos. As melodias mais leves e românticas de Amarcord e Julieta dos espíritos aparecem nas cenas entre Alex e Jennifer na escola, nas quais eles estão sempre discutindo; quando os jovens rompem o namoro; em um encontro entre Alex, Macy e uma amiga no shopping, no qual a trilha de Rota, suave, doce e com tons românticos e sensuais e parece comentar não apenas o interesse do jovem por Macy, mas a libido; e em algumas cenas em que Alex caminha pelo shopping e compra um novo skate, ou simplesmente anda pela rua: momentos triviais da rotina.

\footnotetext{
175 "Rota's film scores symphatise with what is on-screen, but they not cleave to the characters and events in ways that invite involvement or identification; they are in tune with what is on-screen but they do not respond to every movement, shift of emotion or minute plot development; they are close, very close, to the world of the film, but not at one with it, neither a part, but not yet apart. They achieve this partly through his music's inherent qualities of immediacy and reticence, irony ans strighforwardness, and also through a use of musical motifs that do not stick rigorously to characters, situations or ideas, the extensive deployment of forms of musical reference that register the fact of main reference, play on the difference between music emanating from the fictional world of the film and that coming from without it, and overall scoring that neither follows the film slavishly nor leads the way".

176 "Rota is particularly inclined to write music that perceives and brings out mixed or contrary emotions".
} 
Em todos esses momentos as composições de Rota, que já pareciam antiquadas em sua época ${ }^{177}$, tornam-se ainda mais anacrônicas em relação ao mundo que retrata e, por isso, saindo do lugar comum, estabelecem certa autenticidade e leveza à narrativa, possuindo igualmente valor concessivo.

Figura 140 - A música de Rota é utilizada na imagem inicial do filme, nas cenas entre Alex, Jennifer e Macy (românticas e tensas), e quando ele passeia pelo shopping, faz compras e anda pela rua
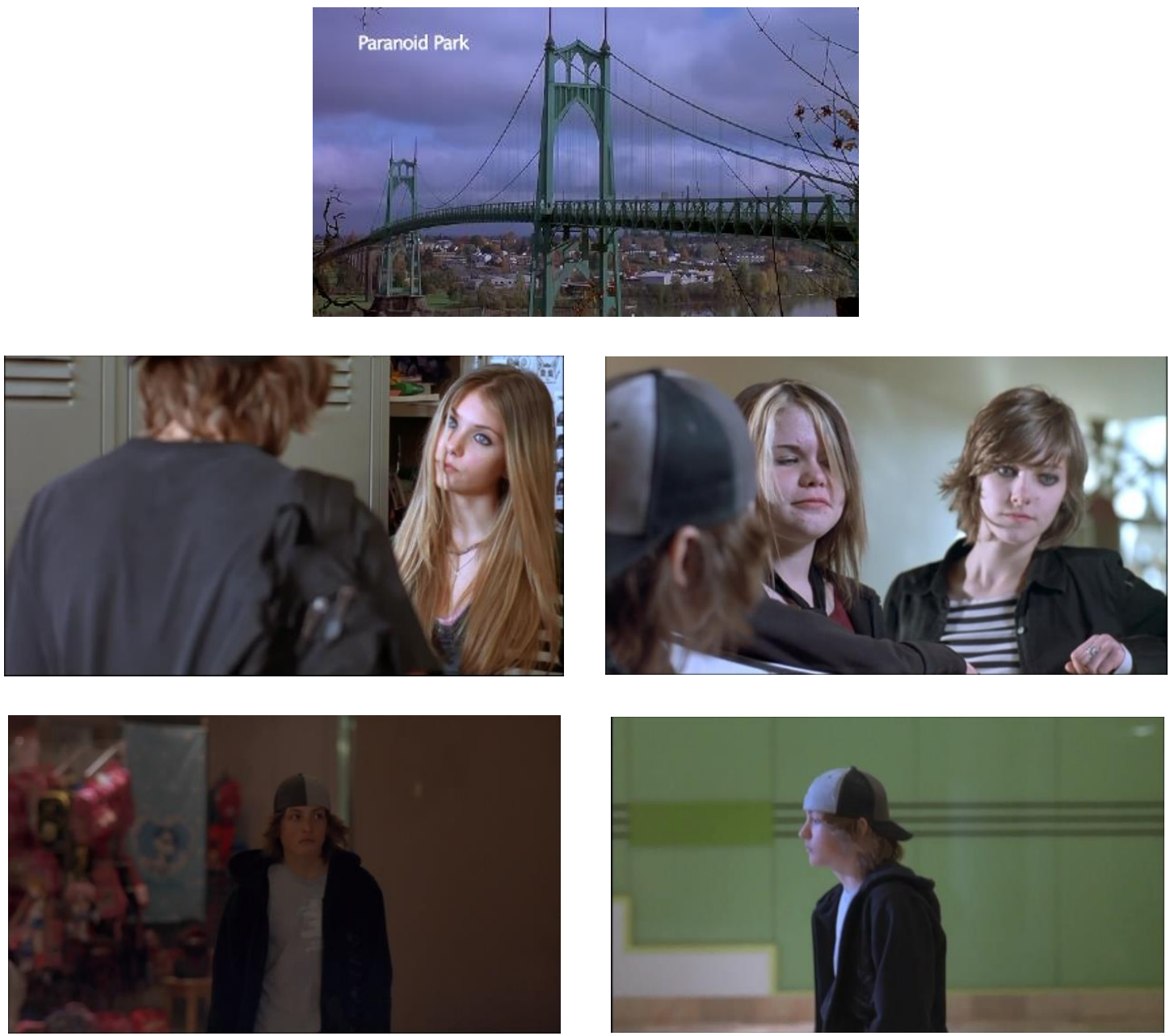

177 Dyer (2010) comenta que Nino Rota "pertenceu à geração musical de 1880 mas nasceu estranhos vinte anos após ela; sua própria geração trilhou o caminho da atonalidade, serialismo e uma seriedade intensa e grave que ele não estava inclinado a seguir" (p. 38). 

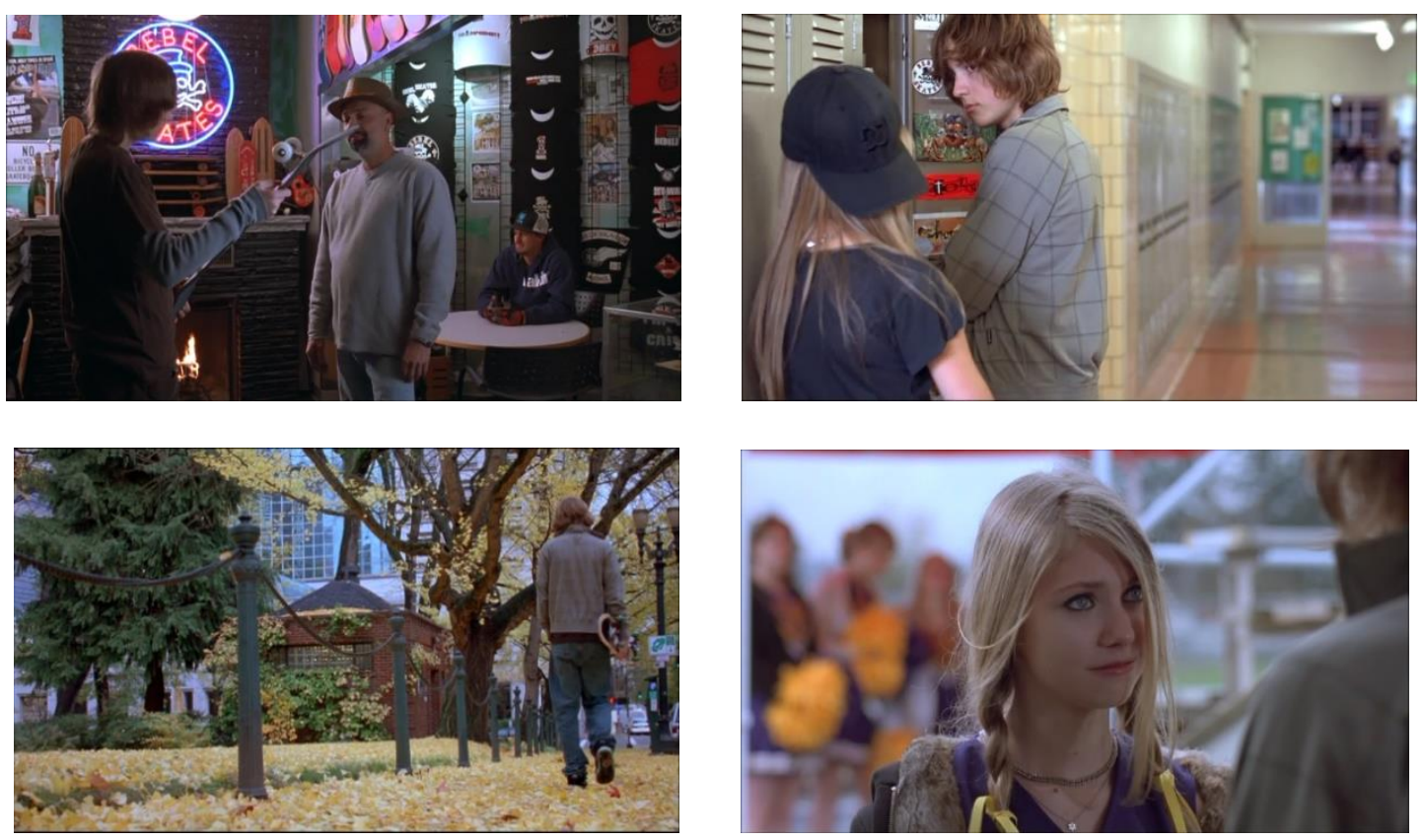

3. Song One; Song Two; Song Three; La chambre blanche; Walk through resonant landscape 2, Dedan, Dehors (composições eletroacústicas).

Como já foi dito na decupagem que fizemos do filme, no começo do capítulo, observouse a utilização de soundscapes, ou paisagens sonoras, que compõem grande parte da trilha sonora de Paranoid Park, apoiando figurativamente muitas sequências, inclusive as que se passam no presente. Uma paisagem sonora é composta pelos diferentes sons que compõem um determinado ambiente, sejam esses sons de origem natural, humana, industrial ou tecnológica, e o seu estudo enquadra-se no âmbito da Ecologia Acústica. No cinema, esses tipos de composição, sendo menos da ordem da música do que dos "efeitos sonoros", geram certa conscientização do espaço sônico e provocam certa profundidade na imagem, adicionando-lhe outras camadas de sentido.

Ao invés de isolarem alguns sons do mundo e ajustá-los à música, fazem justamente o contrário, mesclando conhecimentos musicais aos sons do mundo natural, de modo que "é precisamente o contexto ambiental que é preservado, melhorado e explorado pelo compositor" (JORDAN, 2012, p. 249). Segundo Jordan, o precursor desse tipo de composição é a própria prática de sound design, ou desenho do som, que pode ser comparada ao tratamento da imagem do filme pelo diretor de fotografia e a equipe que comanda. A partir do uso desse tipo de trilha sonora, o som de um texto fílmico é visto menos como construção apenas realista e referencial, do que uso retórico com capacidade simbólica. As composições dessa narrativa sônica, 
conhecidas também como música concreta, constroem um mundo próprio, e não necessariamente musical.

Katharine Norman refere-se a esse tipo de composição como "música do mundo real”, "uma forma que se baseia no equilíbrio entre o naturalismo dos ambientes gravados que compõem os blocos de composição e sua mediação através de tecnologias de gravação e transmissão eletroacústica" (1996 apud JORDAN, 2012, p. 249. Tradução nossa) ${ }^{178}$. Truax entende que o gênero tem como premissa uma dialética entre o real e o imaginário, assim como entre o referencial, ou o concreto, e o abstrato (2001 apud JORDAN, 2012, p. 250) ${ }^{179}$. Tais epítetos e observações apontam para a discussão de uma fenomenologia sonora que envolve um corpo receptor vibrátil, e questões de construção e desconstrução da natureza dos sons. Norman acredita que a estratégia de montagem da paisagem sonora, ou a "música do mundo real" se dá pelo desejo de mimetizar o trabalho da imaginação para que, através de uma escuta imaginativa do que é 'imanente no real', possa-se descobrir o que é imanente no sujeito. Dessa forma, o objetivo desse gênero seria o de redescobrir o mundo a partir da construção de um limite que separa a experiência interna do mundo externo. Ao trabalhar nessa fronteira, tais composições são capazes de reconstruir a subjetividade imersa no espaço e no tempo.

Segundo Jordan (2007), Van Sant cria filmes baseados na desarticulação de relações convencionais entre som e imagem cinematográfica para explorar o ambiente cultural de uma juventude também desarticulada e que sofre todo o tipo de privação (p.1). Do ponto de vista semiótico, a paisagem sonora auxilia a figuração do sujeito, espaço e tempo, a partir da mistura e triagem de traços sonoros, e da construção de sons mais ou menos icônicos, intensos e contínuos do mundo natural. Ao relacionar-se com as imagens, elas podem criar um discurso audiovisual concessivo e, integradas a outros sons diegéticos, suscitar estranhamento.

Em Paranoid Park, a escolha desse gênero musical pelo enunciador acentua a linha experimental do filme, demonstrando uma pesquisa consciente do espaço sonoro, tornando-o mais palpável e carregado de simbolismos. Assim, enquanto o som de um filme geralmente contextualiza os ambientes apresentados na tela, a trilha sonora de Paranoid Park inverte essa relação, "pois o que se ouve muitas vezes se torna uma superfície que frustra a compreensão

\footnotetext{
178 'Katharine Norman evocatively refers to such composition as 'real-world music', a form that relies on a balance between the naturalism of the recorded environments that make up the compositional building blocks, and their mediation through technologies of electroacoustic recording and transmission”. Norman, Katharine. Real-World Music as Composed Listening. In A Poetry of Reality: Composing with Recorded Sound. Ed. Katharine Norman. Contemporary Music Review 15(1-2): 1-27. 1996.

${ }^{179}$ Truax, Barry. Acoustic Communication, 2nd ed. Westport, CT: Alex Publishing. 2001
} 
coerente dos espaços apresentados na imagem" (JORDAN, 2007, p.1. Tradução nossa) ${ }^{180}$. Dessa maneira desfaz-se o espaço e o tempo rítmico, que se transformam em elementos mutantes, disformes, expressivos e, consequentemente, estésicos e sinestésicos. As composições tornam-se tão abstratas, mescladas a outras manifestações sonoras da diegese, que seu reconhecimento nem sempre é possível ${ }^{181}$.

Posto isso, as paisagens sonoras estão a serviço principalmente da figuração da memória afetiva de Alex como fluida e complexa, e também dos efeitos contínuos do sobrevir, que relacionamos ao mergulho no mundo epifânico. Por se tratarem de obras que evadem o ritmo, a melodia, a harmonia e o tom, eliminando a ideia de tempo e andamento, tais composições sugerem profundidade, interioridade e duração temporal subjetiva e instrospectiva, ou seja, certa consciência de individualidade e jornada mental, que é tratada no romance a partir da primeira pessoa, do narrador restrito, e do texto "quebrado" e concessivo. Relacionadas ao mundo interior, e separando interno e externo, as músicas eletroacústicas muitas vezes funcionam como envelope sônico e inconsútil do jovem, pois, de um lado, o aliena dos espaços e tempos concretos (os outros ruídos e sons são apagados ou diminuídos); e de outro, tudo relacionam, servindo como superfície sonora de contato entre o ator e tudo que o rodeia sonoramente. Assim, operando como uma espécie de invólucro, de pele vibratória e porosa, as paisagens sonoras servem tanto como contenção do ator, sugerindo o limite de uma interioridade fechada, solitária e vibrante, assim como sua conexão com espaços e sons que o cercam, operando como triagens do fora e do dentro. Possuindo um caráter não-diegético, e ao mesmo tempo simbolizando a subjetividade diegética, essas sonoridades eletroacústicas produzem no filme uma tensão entre enunciação e enunciado, propondo novos sentidos criados a partir de uma "escuta reflexiva" propiciada pelas impressões que causam.

Em $P P$, já vimos que esse tipo de composição musical é associado, de maneira geral, à pista de skate e os seus usuários, e acrescenta, nesse caso, movimento, leveza e distorção espaçotemporal, além da ideia de desaceleração, ou parada no tempo, que é intensificada pelo uso da câmera lenta. Além disso, esse tipo de música possui a importante função de conectar as lembranças "fora de ordem" e as passagens entre passado e presente. Assim, além de todas as cenas envolvendo Paranoid Park e os seus usuários, as paisagens sonoras são também utilizadas quando Alex escreve e está absorto; quando anda pela praia; quando encontra Scratch,

\footnotetext{
180 "What we hear often becomes a surface which frustrates a coherent understanding of the spaces given to us on the image track".

${ }^{181}$ Song One, Two e Three, por exemplo, por tratarem-se de "movimentos" da mesma composição, nem sempre podem ser discernidos, pois suas gradações sonoras eletroacústicas muitas vezes são mínimas, quase imperceptíveis, causando a ideia de uma continuidade ininterrupta e tensa.
} 
e sente-se atraído por ele; e quando toma banho, depois do acontecimento, na casa de Jared. Na maioria dos casos, essas composições apagam ou descentralizam os sons diegéticos do filme, e substituem os pensamentos do jovem, criando apenas um efeito de estranheza, fluxo de pensamento e tempo subjetivo.

\section{Músicas e canções diegéticas:}

I heard that (hip-hop), The strongest man in the word (rock progressive / experimental/ techno); Tunnelmouth Blues (blues); Outlaw e a Nona Sinfonia (analisadas acima).

Algumas canções e músicas sem texto verbal, além da música clássica, são também utilizadas como elementos diegéticos, ou seja, pertencem ao mundo fictício do filme, sendo supostamente ouvidas pelos atores da narrativa. Tendo menos importância para a nossa análise, auxiliam a construção dos espaços, servindo como parte da figuração do mundo do protagonista. Enquanto as músicas e canções não-diegéticas são tocadas quase que inteiramente no filme (com exceção da Nona Sinfonia), as músicas e canções diegéticas são apenas sugeridas e apresentadas brevemente, tendo pouca relação com a construção do acontecimento, do sobrevir e com o tema "maioridade". As músicas não-diegéticas também se tornam diegéticas, sendo repetidas brevemente e pontualmente, perdendo o seu caráter simbólico, e podendo ser entendidas como textos não-marcados, ou seja, desprovidas de um sentido diretamente relacionado à subjetividade do narrador, apoiando apenas a contextualização do espaço e do tempo. No filme o hip-hop, a Nona sinfonia e a música country também tocam no rádio do carro, sendo ouvidos pelo ator enquanto ele dirige pela cidade após ter deixado Jared na estação de ônibus, momentos antes de ir à pista de skate sozinho pela segunda vez; a música eletrônica techno é tocada em uma loja de discos que Alex e Jared visitam; e o blues em uma loja de roupas de segunda mão (único momento mais descontraído entre Alex e a namorada, em uma cena que não existe no romance):

Figura 141 - Alex ouve hip-hop, música clássica e country no carro (reações ao ritmo)
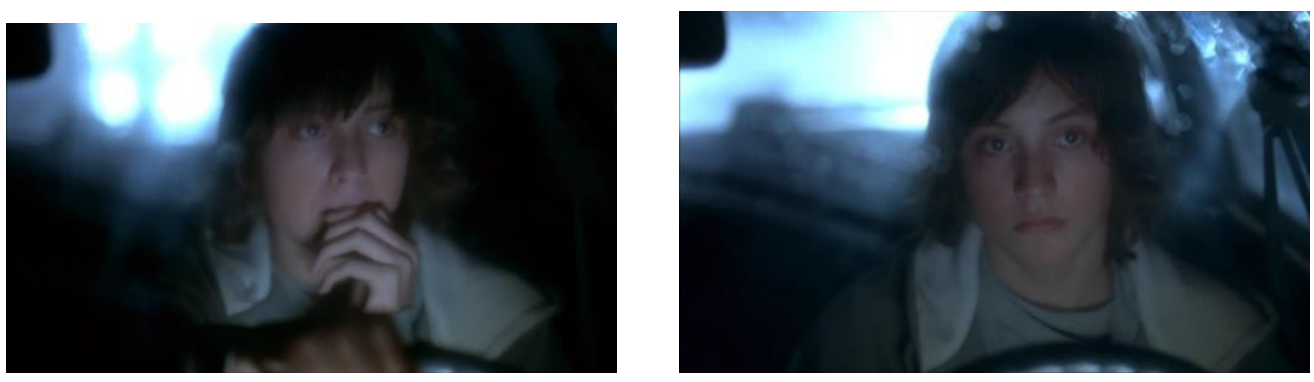


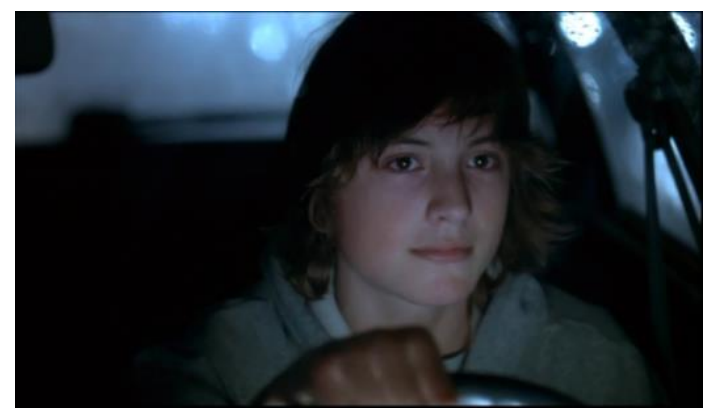

Figura 142 - Na loja de discos e CDs, enquanto Alex e Jared olham as novidades uma música eletrônica pode ser ouvida brevemente

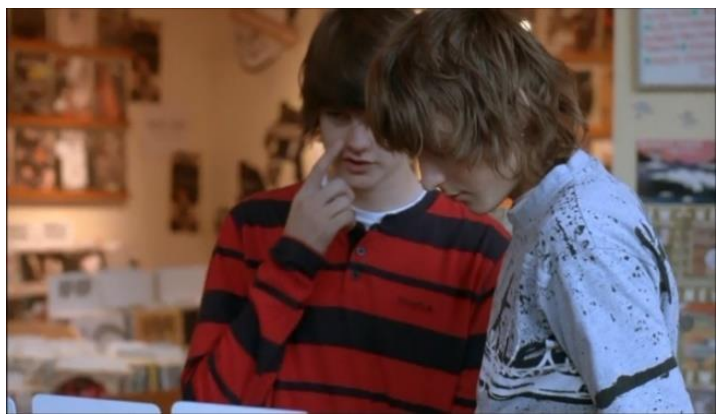

Figura 143 - Na loja de roupas usadas onde Alex e Jennifer divertem-se, a música de fundo é um blues

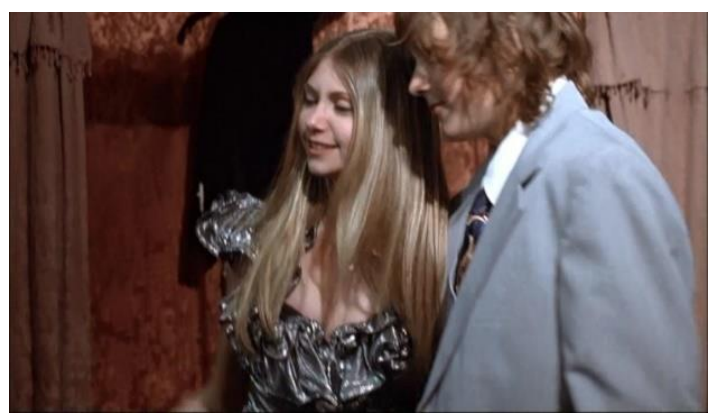

\subsection{Falas e diálogos}

Do ponto de vista verbal, a partir da narração do enunciador no romance, supomos que diálogos e falas são construídos no filme para operar dentro de uma gradação de sentido, atualizando o texto fonte verbal, mantendo parte do seu sentido e construindo novos. No filme, como se trata no mergulho de uma subjetividade fraturada, há articulações de sentido que figuram o estranhamento, relacionado ao acontecimento e ao sobrevir. Há efeitos criados pelo enunciador, relacionados ao que Chion denomina descentralização, definida como tipo de estratégia discursiva na qual a clareza e a inteligibilidade do texto são respeitados, mas dentro de um filme em que "todos os elementos (movimentos e ações dos atores, enquadramento, 
planificação e até argumento) não estão centrados no diálogo, e por isso não ajudam a sua audição, de tal modo que eles estão isolados do resto" (CHION, 2008, p. 142) ${ }^{182}$. A descentralização, de certa forma, está intimamente relacionada à sincronia entre som e imagem, mas também de como cortes e planos capturam as imagens daqueles que falam. De certa maneira, tal estratégia remete à noção de harmonia e desarmonia entre o plano sonoro e o visual, e também constrói um discurso concessivo, pois apesar de os atores falarem, não se consegue identificar com precisão a relação entre som e fonte sonora, que pode estar parcialmente velada, ou obstruída. Da mesma forma, apesar de se ouvir vozes, não é possível identificar com precisão as palavras emitidas com a imagem de sua articulação labial.

Em Paranoid Park, tal uso da voz não é absoluto e nem constante, sendo até mínimo, mas a ideia de Chion joga luz sobre certos aspectos da trilha falada, que se articula com a trilha sonora geral do filme e sua edição, que observamos ser contínua, fluida e muitas vezes realizada em camadas superpostas, de modo que o uso do som nem sempre pretende a sincronia absoluta. Vimos, na sequência acontecimento, que quando Alex corre da cena do crime, o filme procura, mesclando vários enunciados do mesmo ator, mimetizar o turbilhão de pensamentos que invadem o jovem: essas falas, que são superpostas (em uma estratégia de sentido comum no cinema), reverberam e ecoam no espaço sônico da diegese e figuram a confusão de ideias, o pânico do ator, sua ausência do mundo cotidiano, e a entrada no epifanico. Assim:

Figura 144 - Imagens e vozes dessincronizadas

Voz de Jennifer que Alex não ouve (reverberação no espaço)

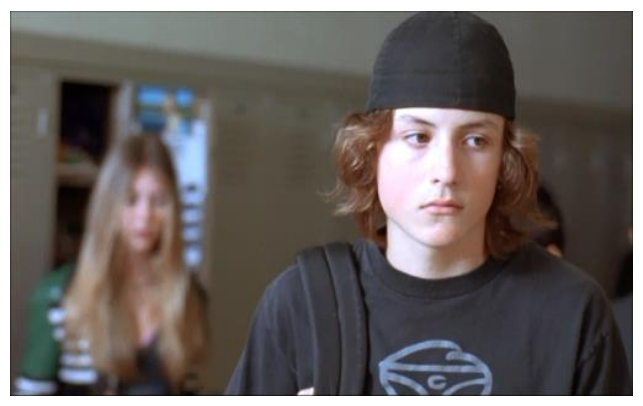

Voz de Alex falando consigo mesmo misturada à voz de seus pensamentos (reverberação no espaço)

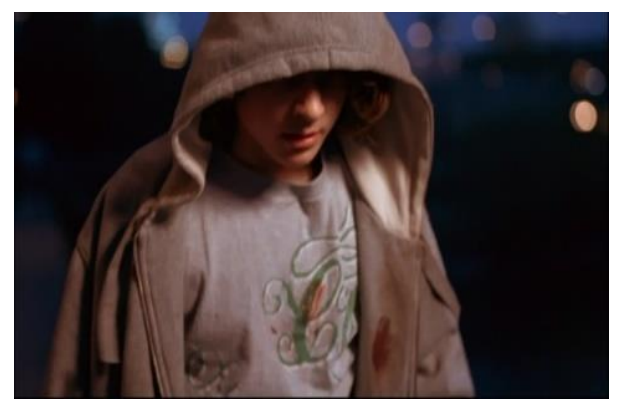

\footnotetext{
${ }^{182}$ Chion cita os filmes de Fellini (que aliás sempre foram dublados pelos atores, pois o diretor gostava, talvez
} para ter mais liberdade criativa, de colocar as falas "em cima" das bocas dos personagens), e Tarkovsky. 
Voz desconectada da imagem de Scratch

\begin{tabular}{|c|c|}
\hline Imagem: Presente & Som: Passado \\
\hline $\begin{array}{c}\text { Lembrança e "reação" de Alex à voz } \\
\text { do outro }\end{array}$ & Voz de Scratch chamando-o: \\
& "Ei, você vai usar o skate ou só ficar sentado \\
& nele". \\
\hline
\end{tabular}

Patinando no gelo:

Voz dessincronizada de Jennifer ao telefone (câmera lenta e vozes dessincronizadas)
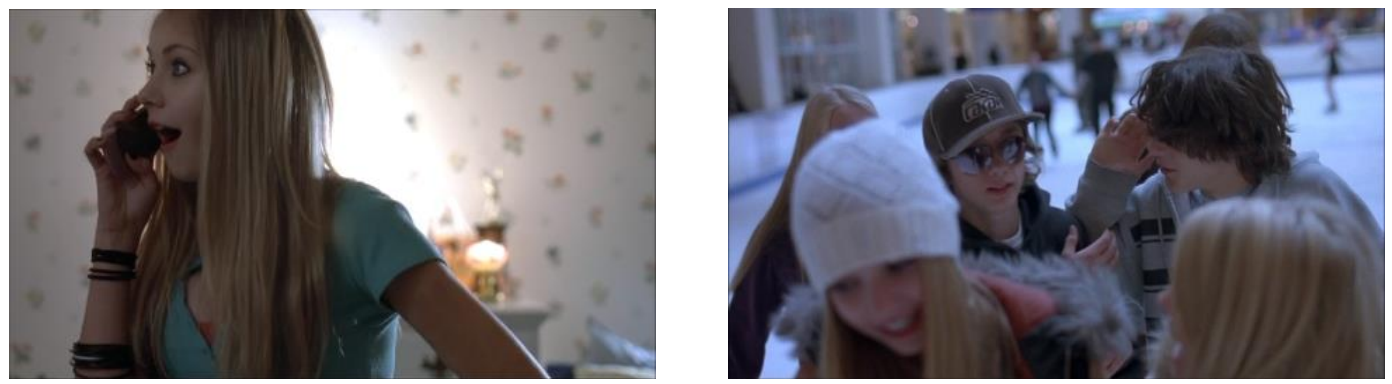

Relacionada ao corpo do ator, a fala fílmica é bem diferente da literária, pois é motivada e construída sonoramente, sendo motivada e articulando iconicidade a partir de categorias expressivas sonoras, formantes acústicos e expressivos que veiculam ideias relacionadas à afetividade e à passionalidade, e consomem espaços e tempo. A voz-over de Alex, no entanto, que mimetiza uma voz interior do pensamento e da consciência, descrevendo fatos passados, é tratada mais como som uniforme e sem amplas variações de altura, volume e intensidade (diferentemente da voz de Jennifer, por exemplo), assim como seus gestos faciais, que parecem contidos e inexpressivos. De maneira geral, a voz de Alex como ator do enunciado possui as mesmas características de sua voz-over de narrador / ator, e define um sujeito resignado e levemente deprimido. De outro lado, observamos, no início do capítulo, que a voz-over utilizada no filme constrói a ideia de duplicidade do jovem e empresta profundidade e espessura à sua figura, tornando-a mais concreta e subjetiva, estabelecendo com segurança a separação temporal entre presente e passado.

É interessante, no entanto, que no final da narrativa a voz que narra é finalmente ligada à imagem de Alex, ou seja, sincroniza-se ao corpo do narrador, que ao terminar as cartas, fala sozinho, “Ok Macy. Está tarde. Eu vou parar”. Esse é o momento em que o ator iniciará a parada da parada e o retorno ao cotidiano, sentindo-se apto a voltar à normalidade de sua vida, 
retornando ao devir, e sendo até capaz de sentir e expressar amor. Em relação ao romance, seria a última carta do livro, que não é expressa no filme. Dessa maneira, o fim do sobrevir, a volta ao cotidiano e aos valores de vida são figuradas audiovisualmente, por uma voz que se une ao corpo e um indivíduo que se torna inteiro e coeso, em um uso metafórico da sincronia entre o som da fala e o rosto do falante.

Figura 145 - Voz-over e corpo do narrador /ator unidos no final da narrativa

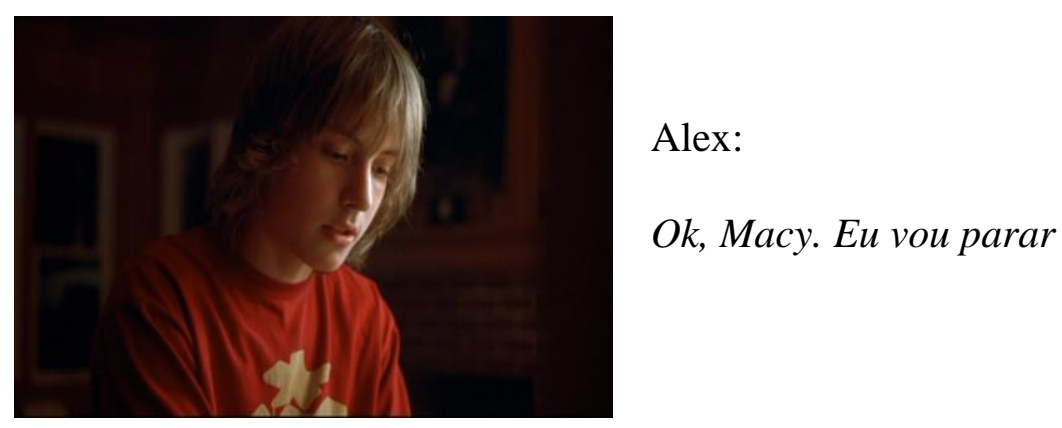

Além disso, a voz-over do protagonista, que dá conta da narração dos fatos a partir do tempo presente, é bem reduzida no filme, pontuando momentos na narrativa, mas importantes para a construção da subjetividade do protagonista que narra. Enquanto todo o romance é construído pela narração em primeira pessoa, no filme há dezenove intervenções da narração, que procuram, além de ordenar a estrutura não-linear do discurso fílmico, ajudando a entender o quebra-cabeças proposto e possuindo um caráter emissivo, esclarecem pontos sobre a aspectos da pista de skate e o encontro com Scratch, fatos sobre Jennifer, as relações familiares, e poucos pensamentos relacionados ao acontecimento: nada é expresso verbalmente sobre o vigia morto, Macy, Jared e o detetive. Nenhum conteúdo da última carta escrita, inclusive o agradecimento pelo carinho da amiga e a declaração de amor a ela, é transportado para a narração do protagonista. O que a voz-over do narrador / ator fala durante o filme, é o seguinte:

Plano 11: Na última semana de verão, a gente estava na cidade, num dia de sol. Um dia, eu estava com Jared, que é mais velho do que eu. Ele disse que a gente devia ir conhecer o Paranoid Park. Eu já tinha ouvido falar, é claro, mas nunca tinha pensado em ir até lá. Eu não me achava tão bom assim. Mas quando eu disse, "não estou preparado", o Jared deu uma risada e disse algo como "ninguém nunca vai estar preparado para o Paranoid Park". A gente foi junto até o parque no dia seguinte.

Plano 19: Faz um mês, no meio da aula de matemática ouvimos um chamado com o meu nome. Só o meu, e de mais ninguém.

Plano 29: Estou escrevendo tudo fora de ordem. Desculpe, não sou muito criativo para escrever. Mas vou acabar colocando tudo no papel. 
Plano 57: Depois que o Jared falou do Paranoid Park aquela primeira vez, a gente acabou indo lá no dia seguinte.

Plano 59: Não foi na noite na qual o detetive de polícia estava falando. Mas foi a primeira vez lá.

Plano 60: Curti o lugar logo de cara.

Plano 61: Uma das coisas legais do parque eram os caras que andavam de skate lá. Eles tinham construído o parque sozinhos, ignorando a lei. Caras que pulavam em trens, punks guitarristas, skatistas bêbados, moleques largados. A sua vida familiar podia ser ruim pra caramba, mas a deles era pior.

Plano 63: O primeiro problema com o plano de Jared foi Jennifer, a minha namorada.

Plano 65: Ela queria que eu saísse com ela naquela noite.

Plano 67: A Jennifer até que era legal. Mas ela era virgem. O que significa que ela ia querer transar em algum momento. $E$ aí as coisas iam ficar sérias.

Plano 69: Eu disse para minha mãe que eu ia dormir na casa do Jared para a gente poder ir no domingo cedo até a Feira de Esportes e pedi o carro emprestado.

Plano 79: Eu não queria que detonassem o carro da minha mãe e fui estacionar do outro lado do rio, que era mais seguro

Plano 87: Paranoid era demais. Eu podia ter passado a noite lá, vendo os skatistas, as meninas e aquilo tudo rolando. A única coisa chata foi ter começado a pensar em outras coisas, tipo meus pais.

Plano 88: Meu pai, teoricamente tinha mudado, mas continuava ligando lá em casa, perturbando, e minha mãe ficava mal. E o coitado do meu irmão, Harry, ele tinha 13 anos, ficava tão nervoso que vomitava o que comia. Ele não segurava a onda mesmo.

Plano 89: Eu também pensei na Jennifer. Ela estava decidida a ficar comigo. Quer dizer, vinha coisa pior por aí. Eu queria gostar mais dela e ter mais coisas em comum com ela.

Plano 96: Ele perguntou se eu estava a fim de uma cerveja. A cerveja eu não sabia, mas eu estava a fim de pegar um trem de carga. Mais tarde eu voltei para a casa do Jared. Tive que trocar de roupa, aquela estava toda suja.

Plano 158: Eu tinha tentado apagar aquela parte da minha memória, mas a foto me fez lembrar de tudo. Era a minha chance de dar um tempo para raciocinar, pensar no que fazer

Plano 191: Eu precisava contar para alguém. Eu precisava pensar com calma. Meu corpo só queria uma coisa, dar o fora dali.

Plano 209: Eu estava ferrado. O que eu ia fazer? Eu não podia perder tempo. Eu precisava falar com alguém. Eu tinha que fazer alguma coisa e tirar esse peso de cima de mim. Meu pai era a pessoa certa para conversar. Eu sabia onde ele estava: na casa da praia com meu tio Tommy. Eu já podia sentir o alívio de contar para ele.

Plano 267: Ok Macy. Está tarde. Eu vou parar. 
Ao discutirmos o uso da hipotipose como figura que "presentifica" a cena, construindo a ideia de mimese do "real" que se desenrola "na frente dos olhos" do enunciatário (descrição dos sentidos, da sensações e sinestesias), comentamos que uma das estratégias do enunciador do romance é o de utilizar muitos diálogos / cenas e o discurso direto. No filme, uma vez que há poucas intervenções do narrador, todas as cenas dialogadas principais do livro são transpostas para o filme. Assim ambos, romance e filme, compartilham as mesmas unidades discursivas. Os diálogos preservados são:

a. Entre Alex e Jennifer na escola: sobre o fim de semana logo após o acontecimento; sobre a compra de preservativo, no dia seguinte à relação sexual do casal em uma festa; no dia em que os jovens rompem o namoro;

b. Entre Alex e o pai, na garagem.

c. Entre Alex e a mãe: quando o protagonista volta da casa de Jared, no domingo de manhã, e mente sobre o que fez faz na noite do crime.

d. Entre Alex e Macy: quando ela encontra Alex no shopping, lendo jornal; quando ambos saem para tomar café, ou se encontram; quando ela o convence a escrever as cartas sobre o que está o incomodando.

e. Entre o detetive e os colegas da escola: sobre a morte do vigia e o provável envolvimento de algum usuário de Paranoid Park.

f. Entre Alex e o detetive: sobre a noite da morte do vigia.

g. Entre Alex e amigos, em uma festta: sobre a aparição do detetive na escola; e o rompimento com Jennifer.

h. Entre Alex e Jared: sobre Paranoid Park, antes do evento traumático; e a troca de skate.

i. Entre Alex e Scratch em Paranoid Park.

Depois de analisarmos algumas características do som em $P P$, pudemos observar que, manifestado como ruído, música e fala, presentes tanto no nível da enunciação como do enunciado, ele permite a construção da subjetividade do narrador / ator Alex, o seu ato de reconhecimento do passado, e a figuração de elementos pertinentes ao acontecimento, ao sobrevir, à memória e ao tema maioridade. De modo geral, e do ponto de vista de uma sintaxe concessiva, vimos como som e imagem são mesclados de maneira contrapontual para construir a sensação de estranhamento de espaços e tempos, e sugerir os estados e paixões eufóricos e disfóricos do ator. Observamos como o ruído de um grito durante o diálogo de Alex e o detetive 
provoca ambiguidade e suspense na narrativa, assim como o trinado de pássaros evoca certa calma que se contrapõe ao pânico do personagem depois da morte do vigia.

O uso de canções e músicas não originais permitiu que sujeitos, espaços, tempos e temas tratados e figurados no romance fossem, a partir de conteúdos semânticos e musicais sonoros, recriados no filme, de modo que sugerissem solidão, amor, maturidade, transformação, surpresa, medo etc., assim como denotassem ambiguidades, fraturas estésicas, espaços e tempos oníricos e trágicos, servindo também como comentário de uma fase da vida humana, relacionada a adolescência e ao crescimento. Ao tratarmos das falas e diálogos percebeu-se que em alguns momentos as vozes dos atores são utilizadas fora de sincronia com suas bocas, em uma estratégia que quebra o realismo fílmico, figura a lembrança confusa e o espaço interior do personagem. Em comparação com o romance, percebeu-se também que a maioria dos diálogos foi utilizada com pequenas alterações e cortes que não descaracterizaram o seu sentido. A participação de um narrador sonoro em voz-over foi diminuída e utilizada para tratar de questões pontuais concernentes a uma mínima "ideia" de organização da narrativa, sendo emissiva.

Outra característica interessante da trilha sonora utilizada é o seu ecletismo, pois contém vários tipos de gêneros, inclusive o clássico romântico, passional e caloroso. Além disso, tanto a escolha de Beethoveen quanto a de Rota indicam a preferência por artistas que trabalham a intertextualidade discursiva, absorvendo em suas composições vários tipos de gêneros musicais. No que concerne alguns artistas e grupos musicais, tais como como Elliot Smith, o grupo Menomena e Cool Nutz, percebe-se que todos pertencem ao cenário musical da cidade de Portland, no estado de Oregon, escolhida pelo diretor do filme como cidade preferida e base principal de seus projetos, inclusive o filme Paranoid Park. Assim, percebe-se por parte do cineasta não só uma preocupação com a diversidade intertextual, mas também a cultura "nativa" e artistas locais, como o escritor do romance, que também mora nessa cidade. A partir dessas considerações, que revelam, junto com os outros elementos da narrativa fílmica, um "autor" preocupado com certos temas e realizador de certas práticas de composição, partimos para algumas questões entre enunciador e enunciatário, o ator da enunciação e a práxis enunciativa. 


\section{ADAPTAÇÃO: SUJEITO DA ENUNCIAÇÃO, ATOR DA ENUNCIAÇÃO E PRÁXIS ENUNCIATIVA}

Barros (2002) demonstra que a partir do esquema canônico da narratividade (organizado pelos percursos do destinador-manipulador, do destinatário-sujeito e do destinador-julgador), e das distinções apontadas entre unidades narrativas e discursivas, é possível considerar o enunciador e o enunciatário como papeis temáticos sob os quais são reconhecidos papeis actanciais e actantes narrativos. Os papeis temáticos enunciador e enunciatário constituem a neutralização de dois diferentes percursos temáticos, da mesma configuração de enunciação: o de produção, cujo tema é o da ação dos homens sobre as coisas, transformando-as ou construindo-as; e o de comunicação, cujo tema é o da ação dos homens sobre outros homens, criador das relações fundadoras da sociedade. Essa duplicidade permite considerar a enunciação como atividade humana por excelência, ao mesmo tempo produção e comunicação. Os papeis de enunciador e enunciatário são reservados ao percurso temático da comunicação (quem comunica, recebe e interpreta a comunicação), empregando-se o papel de sujeito da enunciação, sincretismo de enunciador e de enunciatário, no percurso da produção. Assim:

Figura 146 - O enunciador e o sujeito da enunciação em relação ao percurso gerativo

\begin{tabular}{|l|l|l|l|l|}
\hline \multicolumn{2}{|l|}{ Estrutura Narrativa } & $\begin{array}{l}\text { Destinador- } \\
\text { manipulador }\end{array}$ & $\begin{array}{l}\text { Destinatário- } \\
\text { sujeito }\end{array}$ & $\begin{array}{l}\text { Destinador- } \\
\text { julgador }\end{array}$ \\
\hline $\begin{array}{l}\text { Estrutura } \\
\text { Discursiva }\end{array}$ & $\begin{array}{l}\text { Papel } \\
\text { temático } \\
\text { da } \\
\text { comunicação }\end{array}$ & ENUNCIADOR & ENUNCIATÁRIO & ENUNCIADOR ${ }^{183}$ \\
\cline { 2 - 5 } & $\begin{array}{l}\text { Papel } \\
\text { temático } \\
\text { da produção }\end{array}$ & & $\begin{array}{l}\text { SUJEITO ou } \\
\text { INSTÂNCIA da } \\
\text { ENUNCIAÇÃO }= \\
(\text { enunciador }++ \\
\text { enunciatário) })^{184}\end{array}$ & \\
\hline
\end{tabular}

Fonte: quadro adaptado de Barros (2002, p.136)

\footnotetext{
183 Barros (2002) lembra que no discurso publicitário, o destinador-julgador é investido pelo mesmo ator enunciador ou por seu delegado no discurso, o narrador. Isso acontece nas propagandas em que o sujeito que comprou o produto anunciado é recompensado com uma bela mulher ou muito dinheiro (p. 155)

184 Barros (2002) explica que o sincretismo destaca o ato de o enunciador e o enunciatário compartirem a responsabilidade da construção do sentido do discurso (p. 139)
} 
$\mathrm{Na}$ enunciação manifestada pelo percurso temático da comunicação, o destinatário se coloca como manipulador, responsável pelos valores em jogo e capaz, nem sempre com sucesso, de levar o destinatário-sujeito, seu enunciatário, a crer e a fazer. O enunciatário deve cumprir os papeis de destinatário-sujeito e realizar o fazer-interpretativo em resposta ao fazer persuasivo do enunciador.

$\mathrm{Na}$ enunciação manifestada como o percurso temático da produção, o enunciador e o enunciatário podem ser entendidos como produtores do discurso-objeto, cujo sentido é sua operação. O sujeito da enunciação é o sujeito realizador de programa de construção do objeto, fabricando-o como lugar de investimento de valores. Sua competência e a performance se refazem a partir do discurso, pois o objeto fabricado traz sempre marcas de seu fabricante e fabricação. Enquanto os procedimentos de sintaxe do discurso permitem construir a competência e a existência modal do sujeito da enunciação, as figuras semânticas acrescentam novos elementos à categorização discursiva revelando, quando examinadas como pontos de intersecção entre texto e contexto, os valores que motivam a construção do discurso.

A enunciação mostra-se como estrutura de mediação entre o discurso e o contexto, que também deve ser entendido como texto ou mundo natural discriminado ${ }^{185}$ : o texto depende também dos discuros de um destinador-manipulador, reconhecido como produtor. Dessa maneira, enquanto no percurso da comunicação o destinador-manipulador, sujeito e julgadores referem-se ao enunciador e ao enunciatário, no percurso temático eles referem-se ao produtor, ao sujeito da enunciação e ao receptor-interpretante:

Figura 147 - O produtor, o sujeito da enunciação e o interpretante m relação ao percurso gerativo

\begin{tabular}{|l|l|l|l|}
\hline $\begin{array}{l}\text { Estruturas } \\
\text { narrativas }\end{array}$ & $\begin{array}{l}\text { Destinador- } \\
\text { manipulador }\end{array}$ & $\begin{array}{l}\text { Destinatário- } \\
\text { sujeito }\end{array}$ & $\begin{array}{l}\text { Destinador- } \\
\text { julgador }\end{array}$ \\
\hline $\begin{array}{l}\text { Estruturas Discursivas: } \\
\text { Temas de produção }\end{array}$ & PRODUTOR & $\begin{array}{l}\text { SUJEITO ou } \\
\text { INSTÂNCIA da } \\
\text { ENUNCIAÇÃO }= \\
\text { (enunciador }+ \\
\text { enunciatário) }\end{array}$ & $\begin{array}{l}\text { RECEPTOR- } \\
\text { INTERPRETANTE }\end{array}$ \\
& & & \\
\hline
\end{tabular}

Fonte: quadro adaptado de Barros (2002, p.140)

185 “O contexto não se confunde com o 'mundo das coisas' e deve ser considerado como um texto maior, uma totalidade de significação, no interior do qual cada texto cobra sentido. O sentido do texto depende do sentido texto-contexto em que se integra. Essa concepção de contexto faz supor, em última instância, uma Semiótica da cultura que estabeleça os papeis narrativo-discursivos devidos a cada texto no macrotexto da cultura" (BARROS, 2002, p. 142). 
O produtor é o destinador-manipulador responsável pela competência do sujeito da enunciação e origem de seus valores, devendo ser entendido como destinador sócio-histórico (ou psico-sócio-histórico). Esse sujeito constrói o discurso enquanto delegado do destinadorprodutor, o que lhe dá autonomia apenas na ordem do fazer, sendo os valores determinados de antemão pelo destinador sócio-histórico; o receptor-interpretante, papel temático do destinador-julgador, julga e sanciona o fazer do sujeito da enunciação com base no contrato passado entre destinador-produtor e sujeito: "determinar os destinadores do sujeito da enunciação corresponde a inserir o texto no contexto de uma ou mais formações ideológicas, que lhe atribuem o sentido" (BARROS, 2002, p. 141). A textualização é também papel do sujeito da enunciação e contribui para a reconstrução dessa instância, "uma vez que as marcas mais propriamente individuais da produção textual encontram-se no texto e não no discurso"186 (BARROS, 2002, p. 152). O plano de expressão do texto auxilia e baseia a construção do sentido a partir de organizações secundárias, que correspondem às configurações e percursos figurativos do conteúdo, investindo e concretizando percursos temáticos abstratos. Figuras da expressão se manifestam sob a forma de unidades reiteradas da expressão, em traços ou conjuntos de traços, que assumem relações de caráter semissimbólico, ou poético, combinandose e confundindo-se com as metáforas e metonímias discursivas na tarefa de produzirem uma nova leitura do mundo. A organização secundária da expressão cumpre o papel "de fabricar o mundo, lido e sabido, a partir de novas perspectivas, e de mostrar uma nova verdade das coisas" (p. 154).

A semiótica discursiva entende que textos, ao fabricarem o mundo, construir verdades e tentarem manipular o enunciatário, não podem existir fora de um esquema narrativo de sentido recoberto por ideologias conflitantes formadas por grupos e crenças heterogêneas. Segundo Vogel (1995)

encarregado de preencher, explicitamente ou implicitamente, papeis enunciativos hierarquizados, o sujeito que instala, necessariamente, a construção de um discurso-ocorrência como conjunto significante, é um lugar no qual se confrontam diversos universos de crenças, diversas maneiras de pensar o sentido do sentido. Constitui-se e se apreende em função de antagonismos ideológicos que determinam uma cultura em um momento de sua evolução histórica. Cada sujeito enunciador, ao se encontrar inscrito em um espaço sócio-cultural específico, realiza de forma única a tarefa de se relacionar a ele a partir de numerosos discursos que precisa confrontar (p. 72. Tradução nossa $)^{187}$.

186 BARROS, 2002, p. 246

187 “Chargé de remplir, explicitemente ou implicitement, des rôles énonciatifs hierarquisés, le sujet qu'insalle, nécessairement, la construction d'un discours comme ensemble signifiant, est um lieu où se confrontent plusieurs univers de croire, plusieurs manièrs de penser le sens du sens. Il se constitue et s'appréhende en fonction des 
A partir desse confronto de crenças e saberes, há um desdobramento polêmico da narrativa em narrativa do fazer do sujeito e do antissujeito, que prevê o aparecimento de antidestinadores, cujos valores opõem-se aos dos destinadores. Temos os embates culturais que também são de ordem discursiva. Na análise da enunciação, a duplicação de percursos e de programas permite situar e esclarecer os confrontos sociais em que se assentam os discursos. A crítica favorável ou a boa aceitação do público decorrem das relações conflituosas entre os produtores, sujeitos da enunciação e interpretantes. Como o objeto-discurso do texto adaptado é um objeto-valor cognitivo e estésico, podemos inferir que a adaptação, ao se referir posteriormente e intencionalmente a outra obra, pode tanto reproduzir como construir valores éticos e estéticos que existem dentro de tensões ideológicas ${ }^{188}$. Ao mesmo tempo, o sujeito da enunciação de um texto alvo adaptado, o destinatário sujeito, é também o receptor interpretante de um texto fonte, um destinador-julgador que partilha uma ideologia.

Barros (2002) sustenta que se a ideologia é uma visão de mundo, deve-se levar em conta "o caráter desequilibrado dos diferentes sistemas de representação e as distorções e ilusões produzidas ideologicamente" (p. 150). Tal desequilíbrio revela que os valores não apenas mudam historicamente, diacronicamente, mas ocorrem simultaneamente, sincronicamente, propagados pelos discursos. Segundo Greimas e Courtés (2011 [1979]) o universo de valores se dá a partir de duas formas: a paradigmática e a sintagmática. No primeiro caso, ele é organizado em sistemas e apresentam-se como taxionomias virtuais valorizadas, designadas como axiologias, sendo resultantes da articulação semiótica do universo coletivo, e pertencendo ao nível das estruturas profundas; no segundo caso, seu modo de articulação é sintático e os valores são investidos como potencialidades de processos semióticos, que podem ser consideradas como ideologias (no sentido restrito, semiótico da palavra). Investindo-se no modelo ideológico, os valores são atualizados e assumidos por um sujeito individual ou coletivo, modalizado pelo querer-ser e querer-fazer (p. 252; verbete: ideologia). Pode-se entender, assim, que todo o signo é ideológico.

Ao discorrermos sobre o filme, principalmente os seus primeiros minutos e a sequência do acontecimento, percebemos um projeto enunciativo bem particular, que não apenas altera algumas configurações importantes do romance, como a cronologia linear, mas foge das

antagonismes idéologiques qui déterminent une culture à un noment de son évolution historique. Et pourtant, chaque sujet énonciateur, quando bien même il se trouve inscrit, inévitablement, dans un espace socioculturel spécifique, accomplit de façon singulière la tâche de lier, entre eux, les nombreux discours auxquels il doit faire face".

${ }^{188} \mathrm{O}$ texto é também um local de conflitos de valores entre enunciador e enunciatário, que o sujeito da enunciação procura gerenciar criando um tipo de manipulação ideal e imaginando um enunciatário ideal. 
convenções narrativas mais utilizadas, apoiando-se em uma diversidade de efeitos óticos, mudanças na velocidade da imagem, alterações visuais e sonoras plásticas, trilha sonora eclética, desnivelamento do eixo horizontal do mundo etc., e que a partir do gênero literário proposto, o romance infanto-juvenil, subverte expectativas e propõe um discurso estruturado de maneira a deixar claro o poder da linguagem fílmica, mostrando suas capacidades expressivas e um estilo de enunciação. Além disso, insere em sua narrativa elementos visuais que parecem não-ficcionais, e nos quais a existência do ator não pode ser assegurada. Esse discurso ambíguo, poético e documental, desacelerado e "pesado" expressivamente, constrói a imagem de um sujeito da enunciação bem particular.

Assim, a partir do texto adaptado por um enunciador fílmico, contemporâneo do enunciador literário, exploraremos o ator da enunciação do discurso audiovisual em termos de estilos e temas, algumas importantes diferenças entre romance e filme, e discutiremos questões da práxis enunciativa filmica, a partir da qual o discurso literário é adaptado. Gus Van Sant não apenas dirigiu o filme, mas também o editou e o escreveu juntamente com o escritor Blake Nelson, tendo liberdade para discutir temáticas pessoais e testar estilos diferentes de expressão. Como ator discursivo formado intertextualmente, Gus Van Sant não só é incapaz de evitar outras práticas enunciativas fílmicas, mas as assume com prazer, adotando um estilo discursivo para o texto ${ }^{189}$. Sendo ator da enunciação, o cineasta revela um éthos que existe no texto enquanto vestígios operacionais discursivos: "escolha do assunto, construção dos personagens, nos gêneros escolhidos, no nível de linguagem usada, no ritmo, na figurativização, na escolha dos temas e isotopias etc." (FIORIN, 2008, p. 143).

\subsection{O ator da enunciação e seu projeto enunciativo}

Segundo Falsetto, os filmes de Gus Van Sant (GVS) exploram temas relacionados a famílias destituídas, pessoas marginalizadas, os socialmente desfavorecidos, e a morte. Para Levy (2015), outro importante assunto do cineasta é a adolescência, e desde os primeiros trabalhos, tem firmado a sua posição como o mais dedicado cronista da juventude no cinema americano, explorando-a de várias maneiras e em suas diferentes formações sociais: a juventude da classe trabalhadora, a descontente da classe média, a negra e carente, e também a regional

\footnotetext{
${ }^{189}$ Segundo Bordwell (2013b), o estilo é o uso sistemático e significativo de técnicas da mídia cinema em um filme, classificadas em domínios amplos: "mise-en-scène (encenação, representação e ambientação), enquadramento, foco, controle de valores cromáticos e outros aspectos da cinematografia, da edição e do som. $\mathrm{O}$ estilo, minimamente, e a textura das imagens e dos sons do filme, o resultado das escolhas feitas pelos cineastas em circunstancias históricas especificas" (p. 17)
} 
de Portland, cidade onde o artista viveu e trabalhou em boa parte de sua vida. Segundo Levy (2015), "adolescentes desconectados e jovens alienados têm sido o foco de seus principais filmes" (p. 201).

Abertamente homossexual após os 30 anos de idade, GVS explora também as subculturas marginais, inclusive a homossexual, mas não necessariamente de forma aberta ou como elemento principal de suas narrativas, de modo que a escolha sexual não é um atributo definidor crucial de identidades ou estilos de vida de seus personagens, que são mais profundos e escapam dos "tipos". A partir daí, pode-se entender porque GVS se interessa por um texto como Paranoid Park, que é escrito por um autor local, e relata as agruras da maioridade de um jovem branco e confuso da idade média, e seu doloroso processo de formação identitária, relacionada a uma pista de skate marginal, considerada um espaço ameaçador e proibido por sua comunidade.

Sem dúvida alguma, é na imagem que Alex escreve o título do filme e da obra adaptada, que percebemos a mescla entre o ator da enunciação e ator do enunciado, em uma sequência que poeticamente simboliza a fusão de GVS não apenas com Alex, mas com o universo dos jovens, com quem se solidariza. A partir de Alex, o cineasta procura, além da construção da subjetividade, uma fusão empática na qual o ator da enunciação coloca-se no discurso fílmico:

Figura 148 - O título da obra escrito duas vezes e nos dois níveis do discurso: o da enunciação e o do enunciado
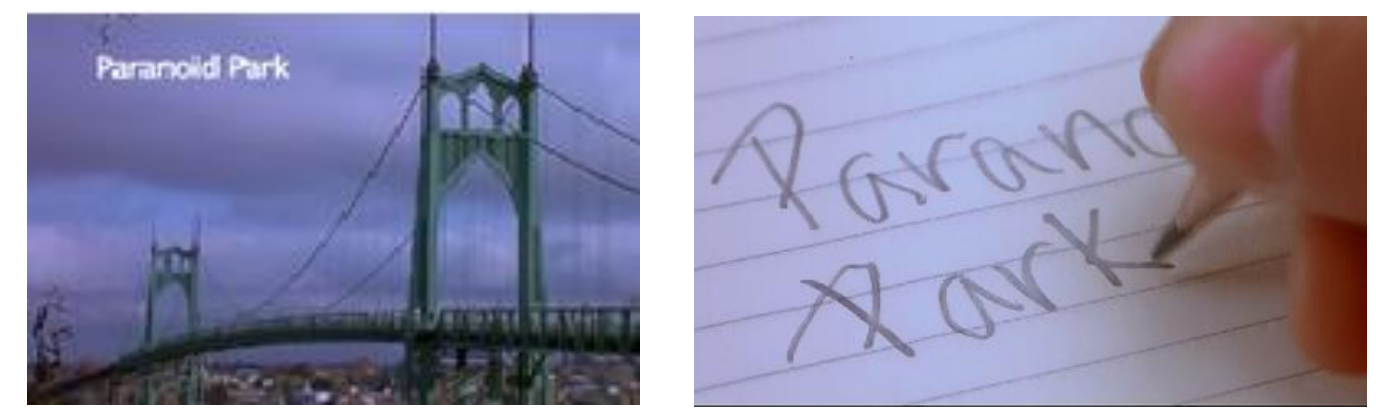

Vicari (2012) compara GVS aos compositores de hip hop e música eletrônica do final dos anos 80, que gostavam de mesclar trechos ou trilhas inteiras de outras canções e músicas em suas próprias composições, operando o sampling, ou seja, uma mistura de diferentes amostras de peças musicais dentro de uma única composição. Logicamente, esse tipo de artista não é característico de apenas um momento histórico, podendo ser observado no final do século 19 e início do século 20, por exemplo, em pintores e compositores que colavam objetos diferentes em suas pinturas, como os surrealistas e dadaístas, ou mesclavam diferentes gêneros musicais em suas sinfonias, como o próprio Beethoven. 
Nesse sentido, tais operações de colagem aproximam-se da noção de bricolagem e de bricoleur, indivíduo visto, por Levi-Strauss ${ }^{190}$, "como um artista que trabalha a partir de um conjunto de utensílios, materiais e resíduos que coleta, reaproveita e conserva ao longo da vida, compondo um tesouro de ideias" (1976 apud CORREA; FRANÇA, 2014 p. 230). Em PP, o ecletismo da trilha sonora, que utiliza composições eletroacústicas e dois compositores igualmente bricoleurs, tais como Beethoveen e Rota, e de imagens captadas por diferentes tipos de películas, $35 \mathrm{~mm}$ e Super 8, revelam o caráter criativo do ator na enunciação, baseado na mescla e sobreposição consciente e voluntária de estilos e gêneros: não sendo propriamente um artista experimental, GVS é inclinado a experimentação, incorporando a colagem desde os seus primeiros filmes. Segundo Floch (1995), a bricolagem é uma forma particular de práxis enunciativa (p.6).

Como o romance é narrado verbalmente e o filme audiovisualmente, a maneira de criação e recepção desses textos altera-se consideravelmente, de modo que a narrativa, em cada um desses tipos de semiose é expressada de maneira diferente, criando desafios de ordem enunciativa e enunciva para o sujeito da enunciação. Apesar de ambas os textos possuírem as mesmas capacidades narrativas e discursivas, a literatura apoia-se em morfemas, palavras, frases, orações parágrafos, capítulos, em uma operação de sentido na qual o mundo "real" é iconizado de maneira mais arbitrária, e da qual o enunciatário precisa conhecer muito bem o código para decifrar o texto. O filme, por sua vez, como linguagem motivada e sincrética, propõe ícones plásticos e sonoros retirados da expressão do mundo "natural", propondo um texto mais facilmente reconhecível pelo enunciatário: assim, apesar de ser enunciado, como o texto literário, compondo unidades discursivas e categorias semânticas e sintáticas, o discurso audiovisual é menos apoiado nas relações arbitrárias entre expressão e conteúdo, em um ganho visual e sonoro que o torna mais "percebido" ou "reconhecido naturalmente" do que "decodificado", aparentando falsa naturalidade e escondendo intrincada complexidade.

Por motivos relacionados à estrutura da linguagem, que o faz mais "facilmente compreendido", coerções expressivas e práticas enunciativas, o cinema torna-se um meio de comunicação de massa, e seus textos são dirigidos a um vasto e variado público, combinando linguagens reconhecidas (música, fala, ruídos, imagens, gestos) que interagem em um complexo sistema de camadas de significação. Possuindo uma complexidade enunciativa diferente da literatura, o discurso fílmico deve, a princípio, ser mais parcimonioso em relação ao número de programas narrativos, diálogos e personagens que elenca para narrar, de modo a

${ }^{190}$ LÉVI-STRAUSS, Claude. O pensamento selvagem. 2 ed. São Paulo, Ed. Nacional, 1976. 
não se tornar denso ou longo demais, ou repleto de detalhes que podem deixá-lo ainda mais "pesado e carregado" de informações. Assim, em relação à obra literária que transpõe, e precisando narrar dentro de um tempo que existe dentro de uma prática social (de 90 a 120 minutos), o filme geralmente reduz as inúmeras relações de sentido da narrativa literária.

Ao mesmo tempo, como o texto fílmico adaptado existe com relativa diferença temporal do texto literário, que pode ser de alguns anos, décadas ou mesmo séculos, há vários ajustes de sentido que podem servir para controlar o "ruído ideológico" entre diferentes gerações, de modo que as ideias e costumes veiculados pelo texto fonte sejam representadas de maneira a não comprometer o projeto enunciativo do texto alvo, que pode querer apagá-los, reforçá-los ou criticá-los. A práxis nos mostra que um texto pode ser mais ou menos atualizado, virtualizado, potencializado e realizado. Em nosso caso, os textos são contemporâneos e o filme não possui nenhuma distância cronológica, espacial e cultural do romance.

Durante nossa análise, comentamos pontualmente algumas diferenças entre romance e filme, que apesar de não alterarem substancialmente o sentido da narrativa fonte, corta, altera e adiciona cenas, construindo-se como discurso autônomo e próprio, e propositor de novas discussões a partir de um ponto de vista sobre o discurso do outro. Observamos, por exemplo, que enquanto o texto literário é linear e acelerado, o texto fílmico prefere contar sua história a partir da não-linearidade e desaceleração de andamento temporal, mas não visual, propondo um conteúdo expressivamente complexo e intenso, em sobreposição e bricolado, instalando forte remissividade. Da mesma maneira, o acontecimento não é apenas deslocado de seu lugar original, ocorrendo no meio do filme, e tendo eventos modificados, mas a morte do vigia ocorre diferentemente. Outras alterações detectadas no filme são os cortes das cenas que mostram o aprofundamento da relação do jovem e do detetive, uma terceira visita a Paranoid Park, pensamentos de fuga, tentativas de ligar para a polícia, uma visita à igreja. A partir dessas escolhas a triagem enunciativa retém, basicamente, cenas da escrita na casa do tio e arredores, de Paranoid Park e o mundo do skate; da relação com Jennifer e alguns colegas, inclusive Macy; de alguns momentos familiares; e do acontecimento, sendo que a entrevista entre o jovem e o detetive, a primeira cena dialogada do filme, serve como sumário organizador da narrativa estruturada como não-linear.

De maneira geral, uma vez que o romance trata das impressões de sujeito, narradas em primeira pessoa, há uma série de pequenos diálogos, reflexões, eventos lembrados brevemente, e comentários sobre a escola, a família, os amigos, desejos etc., que não são utilizadas no filme por serem muitas vezes repetitivos ou se tratarem de digressões que abandonam o núcleo 
principal da trama: apesar das triagens, as isotopias temáticas e figurativas propostas no romance são mantidas.

Além disso, em relação aos diálogos transpostos ao filme, observamos alterações de conteúdo, elementos de sentido subtraídos ou adicionados. No caso da narração em primeira pessoa, por exemplo, utilizada no romance para relatar toda a história, no filme ela é reduzida ao mínimo, sendo substituída por sequências mais ou menos dialogadas, e dentro de um projeto audiovisual no qual a linguagem verbal é, de um lado, menos utilizada e, de outro, parcialmente transferida para as canções, que são tocadas quase inteiramente durante o filme. De modo geral tais alterações, que não são incomuns nas operações intersemióticas entre cinema e literatura, devem ser discutidas em termos de pertinência e importância para a adaptação. Assim, além das diferenças textuais arroladas acima, selecionamos para a análise o que consideramos propostas enunciativas diferenciadas, e que revelam a presença de um enunciador com um projeto enunciativo próprio, ou seja, mais "autoral".

\subsection{Atualizando temas e figuras do romance}

Outra mudança significativa, além da ordem da narrativa, é a figuração do seu fim. De maneira geral, o conteúdo da última carta, a saber, a declaração de amor, as previsões do futuro “disfórico" após o acontecimento, e conjecturas sobre jovens e adultos, não são expressas no filme. Tais triagens amplificam a ideia de solidão, individualidade e o processo de organização da memória afetiva de Alex, que no filme parece um jovem mais isolado e contido. Ao mesmo tempo, enquanto no romance o ator apenas sugere que vai queimar as cartas, no filme ele o faz. Depois, Alex é mostrado em sala de aula, mas de olhos fechados, como se dormisse, transmitindo calma e tranquilidade, em uma imagem que conota a atonização do acontecimento e da intensidade do sobrevir, a continuação da continuação do cotidiano, e a conjunção com os valores de vida, relacionados as modalidades ser querer-ser, do ser-crer-ser e do ser saberpoder. Antes dos créditos finais, no entanto, o filme exibe ainda um último conjunto de imagens de jovens skatistas, texturizadas e não, e em velocidades diferentes, normal e câmera lenta, acompanhadas pela balada country, lenta e triste, cantada por uma voz rouca e envelhecida. Nessa última sequência, Alex é um dos skatistas e olha para a câmera: 
Figura 149 - O final do filme

Alex acaba de escrever as cartas...

... as queima na praia
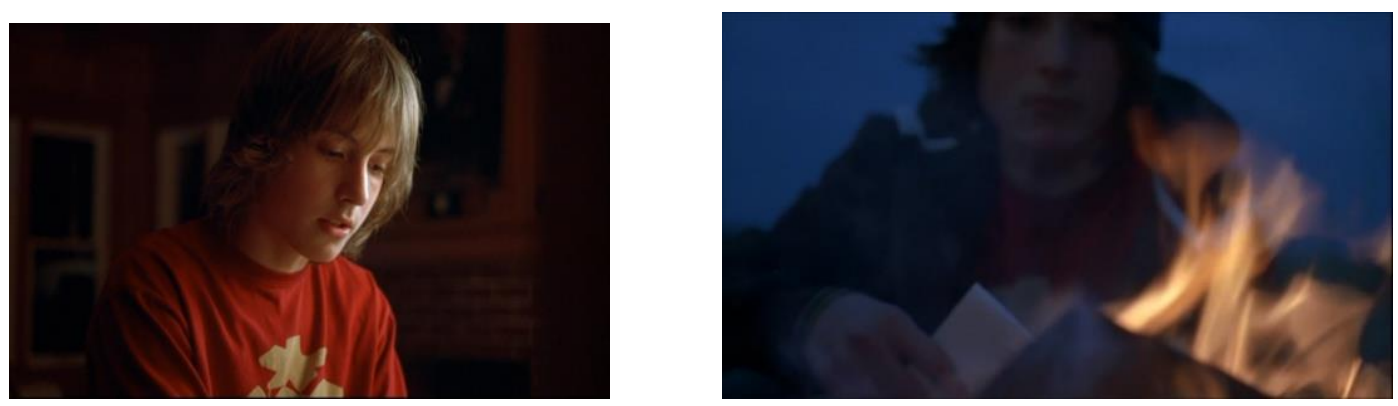

Depois aparece em uma aula, relaxado, de olhos fechados, talvez dormindo.

Um professor o chama mas ele não reage.

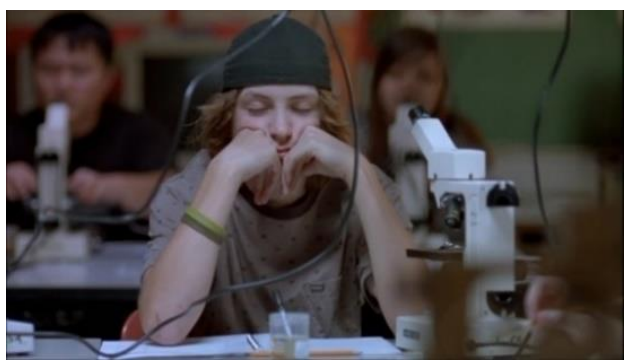

Sequência de skatistas

Alex
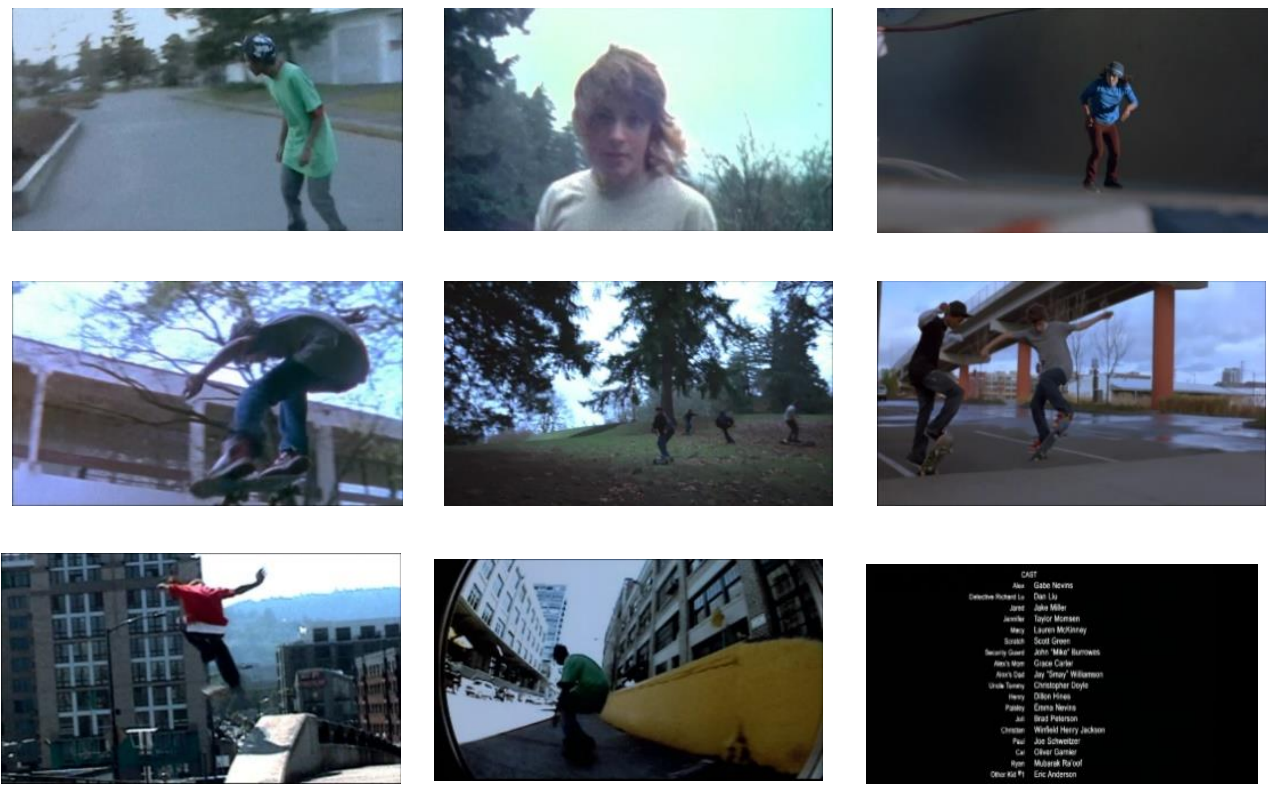

A cena da queima das cartas é uma mudança importante e assume forte carga simbólica dentro da narrativa fílmica, configurando a certeza do ato final do jovem, apenas sugerida no romance, de modo que a intensidade do segredo fica mantida, e o acontecimento 
torna-se mais importante como antidestinador. Assim, enquanto no livro a ideia de que Alex queima as cartas é apenas potencializada, pois o jovem somente comenta que "vai procurar fósforos" (é a última frase de sua última carta, e do romance), no filme ela é realizada dentro de um espaço natural. Como figuração audiovisual de isotopias temáticas e figurativas do enunciado literário, o filme atualiza e tonifica a presença visual dos quatro elementos naturais, explorando-os como figuras mitopoéticas que compõem os espaços paratópicos e utópicos, familiares e estranhos do jovem.

A imagem do fogo, que simboliza purificação e vida, marca o renascimento de Alex como sujeito, o encontro com o valor vida e a volta à rotina de adolescente transformado (lembra-se da figura da Fênix), ou seja, a fim da parada da parada e o início da continuação. Por outro lado, uma vez que ele assume novos valores, adotando uma identidade própria a partir das ações e escolhas feitas longe da família, pode-se entender que Alex nasce para a independência, resultado de suas próprias ações e escolhas, ou seja, é sancionado positivamente e marca sua existência como destinador transcendente, capaz de renascer. $\mathrm{O}$ enunciador do texto fílmico, a partir da sugestão do romance, não perde a chance de mostrar um elemento tão importante e simbólico para a raça humana, e visualmente sugestivo. O enquadramento da queima das cartas, à noite, na qual o fogo aparece em primeiro plano, adota uma relação de obstrução entre atores (fogo e jovem), encobrindo parcialmente o adolescente, e também causa um efeito parcial de fusão entre jovem e fogo.

Figura 150 - O fogo (a cena da queima no romance é apenas sugerida e potencializada; no filme é realizada)

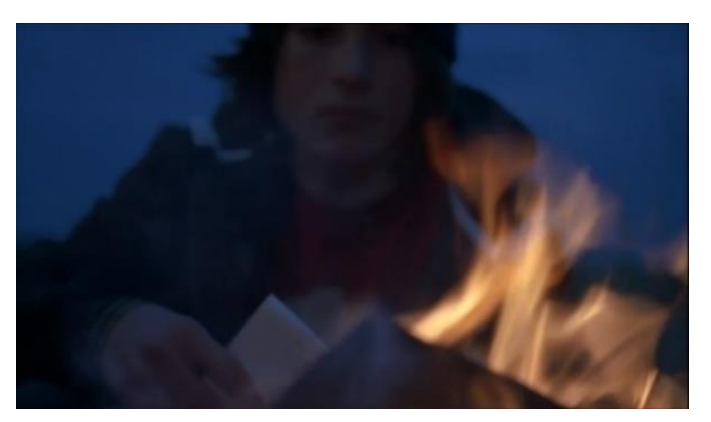

Além desse elemento natural, o filme figura o ar, ligado ao céu e às nuvens; a terra, elemento presente na pista de skate e no pátio de trens, mundos subterrâneos relacionados ao acontecimento e ao sobrevir; e a água, perto da qual o ator lembra e escreve, e com a qual se identifica no começo e no fim do romance (as ondas soando como bombas, no início; e o mar calmo, no fim). 
Em relação ao ar, por exemplo, chamamos a atenção para a figura do céu, que pode estar mais ou menos carregado, ou mais ou menos azulado. Vimos na imagem dos créditos iniciais, que a composição plástica do quadro nitidamente separa natureza e cultura, transformando a cidade em elemento contido e englobado, sufocado e oprimido pela imensidão acinzentada que a abarca. Na primeira cena em que Alex vai à praia escrever, o céu novamente divide o quadro, fazendo contraste com a terra, e reduzindo o tamanho do ator, que parece perdido na imensidão do mundo e de seus pensamentos:

Figura 151 - Os elementos naturais no filme. Céu, terra, água e fogo
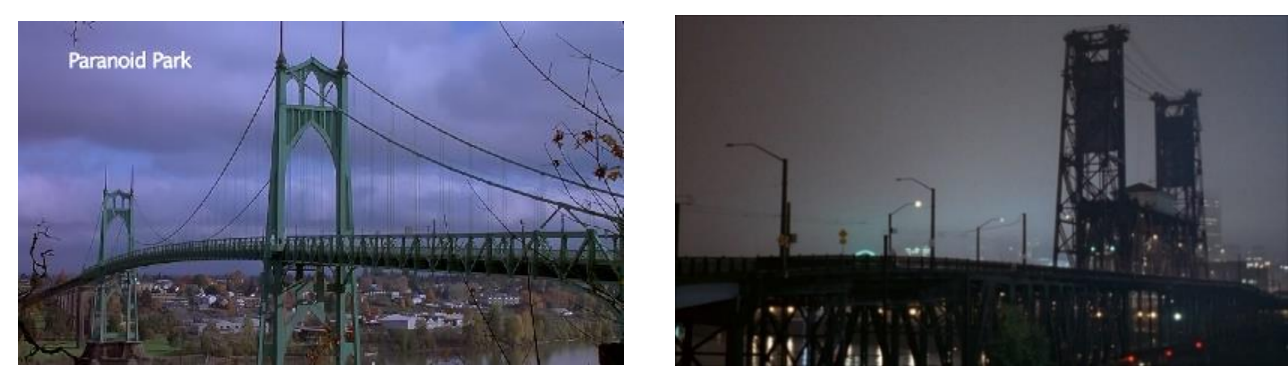

Vicari (2012) comenta que GVS utiliza o céu (que aparece em muitos de seus filmes) como elemento natural e secular, a representação de um espaço intangível, cuja observação aciona a mente, a consciência e a reflexão, lembrando ao homem sua finitude e solidão: o céu, que tudo vê e abrange, suspenso e separado do mundo dos homens e da terra, "chama a atenção para a fugacidade do tempo e a inconstante natureza antilinear da circunstância" (p.58). Na cena do acontecimento o céu, descrito a noite, revela qualidades elétricas, mudando de cor repentinamente e simbolizando o estado passional do ator. Em PP a imagem do céu vai além da representação do tempo e do destino e figura a próprio espaço interior.

Por sua vez, a terra é tanto descrita em relação ao céu, seu oposto semântico, sendo elemento essencial do espaço da pista de skate e do pátio de trens, onde tanto a manipulação como a luta entre o ator e o vigia acontecem:

Figura $152-$ A terra

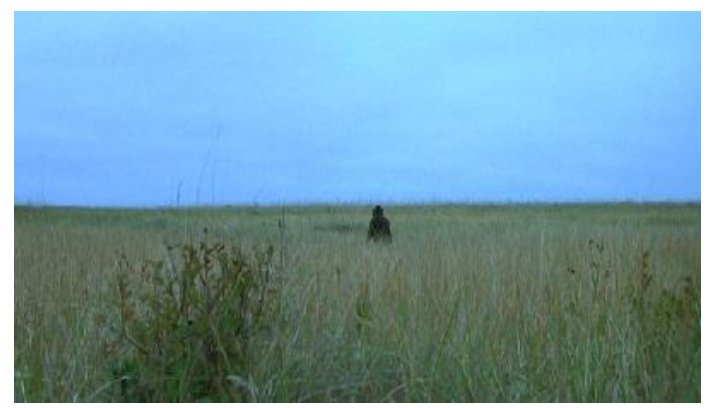



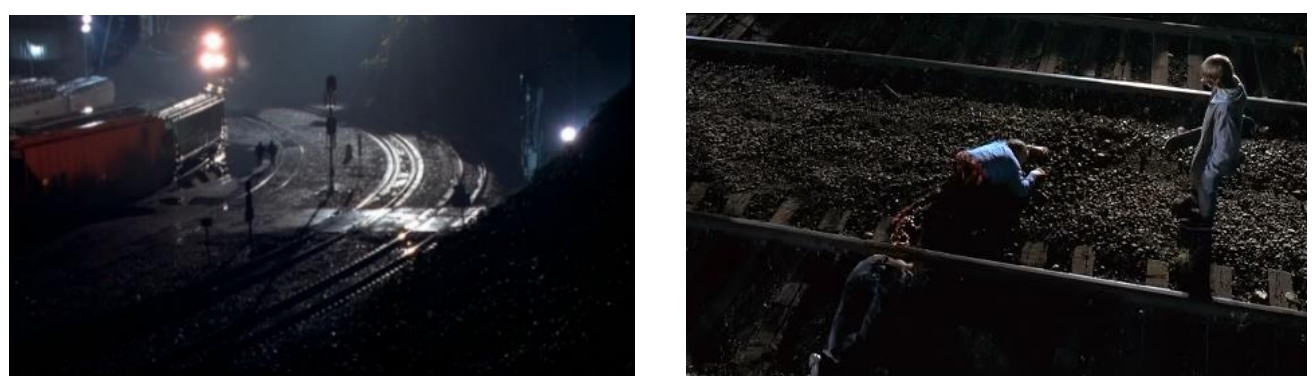

Percebemos na análise dos primeiros minutos de $P P$ e na figuração visual da oscilação entre o presente da narração e o passado do narrado, que o exterior da casa do tio do protagonista é tão importante quanto o seu interior. Enquanto no romance Alex parece escrever apenas dentro de casa, não citando nenhum passeio ou escrita ao ar livre, no filme as imagens da natureza, da praia e da água são constantes, sendo mais utilizadas que os espaços interiores. Se no romance as elipses entre os trechos das cartas são acompanhadas por desenhos de arame farpado, no filme a interrupção do passado e a volta ao presente é figurada muitas vezes pela imagem da praia e do mar. Vimos que Alex não apenas caminha por trilhas e pela areia, mas também se senta em um banco próximo ao mar, onde escreve suas lembranças, de modo que a água, relacionada, em chave psicanalítica, ao inconsciente, ao feminino e aos espaços interiores, é uma importante presença no filme:

Figura 153 - A água
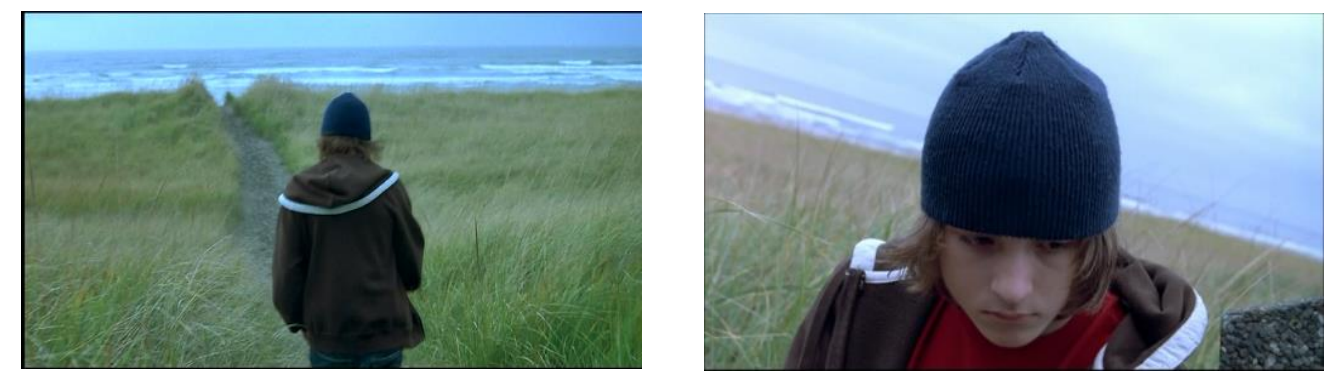

Outra mudança interessante na figuração da temática do relacionamento amoroso proposta no filme, que transpõe com fidelidade a relação de Alex com a namorada, descrevendo momentos íntimos (apenas um é mostrado), discussões na escola, inclusive o rompimento do namoro, é a adição de uma cena que não existe no romance, mas não trai o percurso figurativo de Jennifer, construída como jovem autoritária, igualmente em fase de tradição entre adolescente e mulher como Alex, e exigindo dele outro comportamento e valores. O momento mais tenso do casal é relatado na carta 7, ocorrendo quase no final do livro, e parece ser o gatilho de sua separação: Jennifer pede a Alex que ele seja um namorado melhor, ande menos de skate e compre um carro. Apesar dessa cena não ter sida adaptada, os desejos de Jennifer em 
relação ao namorado e o incômodo que ela lhe causa são construídos no filme de outra forma, mais leve, e traduzida menos como uma briga de casal do que como visita a uma loja de roupas de segunda mão, que acontece no fim de semana após o acontecimento, e substitui a primeira tentativa frustrada de sexo do casal.

No romance, quando Alex vai à escola na segunda-feira, após o sábado e o domingo trágicos, ele encontra a jovem, que lhe pergunta sobre o final de semana, reclama de seu sumiço, mas o convida à sua casa, depois da aula. Alex concorda e os jovens tentam fazer sexo, mas o adolescente, confuso em relação à nova namorada, e tomado pelo sobrevir, sente-se mal e desiste. $\mathrm{O}$ enunciador fílmico mantém a cena em que os jovens se encontram na escola logo após a morte do vigia, mas troca a tentativa frustrada de sexo por uma cena em um brechó. Alex vem andando pelos corredores da escola, absorto em pensamentos e passa por Jennifer, ignorando-a. A namorada, mostrada fora de foco e com voz dessincronizada, chama-o. Ele então se volta e vai ao seu encontro. Ela está irritada e reclama do comportamento do namorado, dizendo que ele prefere o amigo a ela, e lhe faz um convite para fazer algo depois da aula, não mencionando a sua casa:

Jennifer: Alex, Alex (o garoto aproxima-se) O que? Você vai me ignorar? Então, você se divertiu com Jared no sábado?

Alex: Na verdade, não.

Jennifer: O que vocês fizeram?

Alex: A gente só se encontrou.

Jennifer: Eu fui nadar na casa da Elizabeth. Você deveria ter vindo, mas, claro, eu acho que isso não te interessa, porque andar de skate com Jared é bem mais legal.

Alex: Mas..

Jennifer: Não interessa. Fica quieto. Então, o que você vai fazer depois da aula?

Alex: Nada.

Jennifer: A gente podia fazer algo se você quiser.

Alex: Tá legal.

Jennifer: Legal. Você me acompanha até a sala?

Alex: $\mathrm{Ok}^{191}$.

${ }^{191}$ Jennifer: Alex... Alex...What, you just gonna walk right past me? So, did you have fun with Jared on Saturday? Alex: Not really.

Jennifer: What'd you guys do?

Alex: Just hung out.

Jennifer: Well, I went swimming at Elizabeth's. You should have come. But, right, I guess that stuff doesn't interest you anymore because, skating with Jared is more fun.

Alex: But...

Jennifer: Whatever, shut up. So...What are you doing after school?

Alex: Nothing.

Jennifer: We could do something if you want.

Alex: Ok.

Jennifer: Cool. So, you gonna walk me to my class?

Alex: Ok. 
Figura 154 - A cena de sexo entre os jovens, depois da aula, é trocada por uma visita a uma loja de roupas, mas mantém a tensa relação entre eles, preservando suas personalidades.
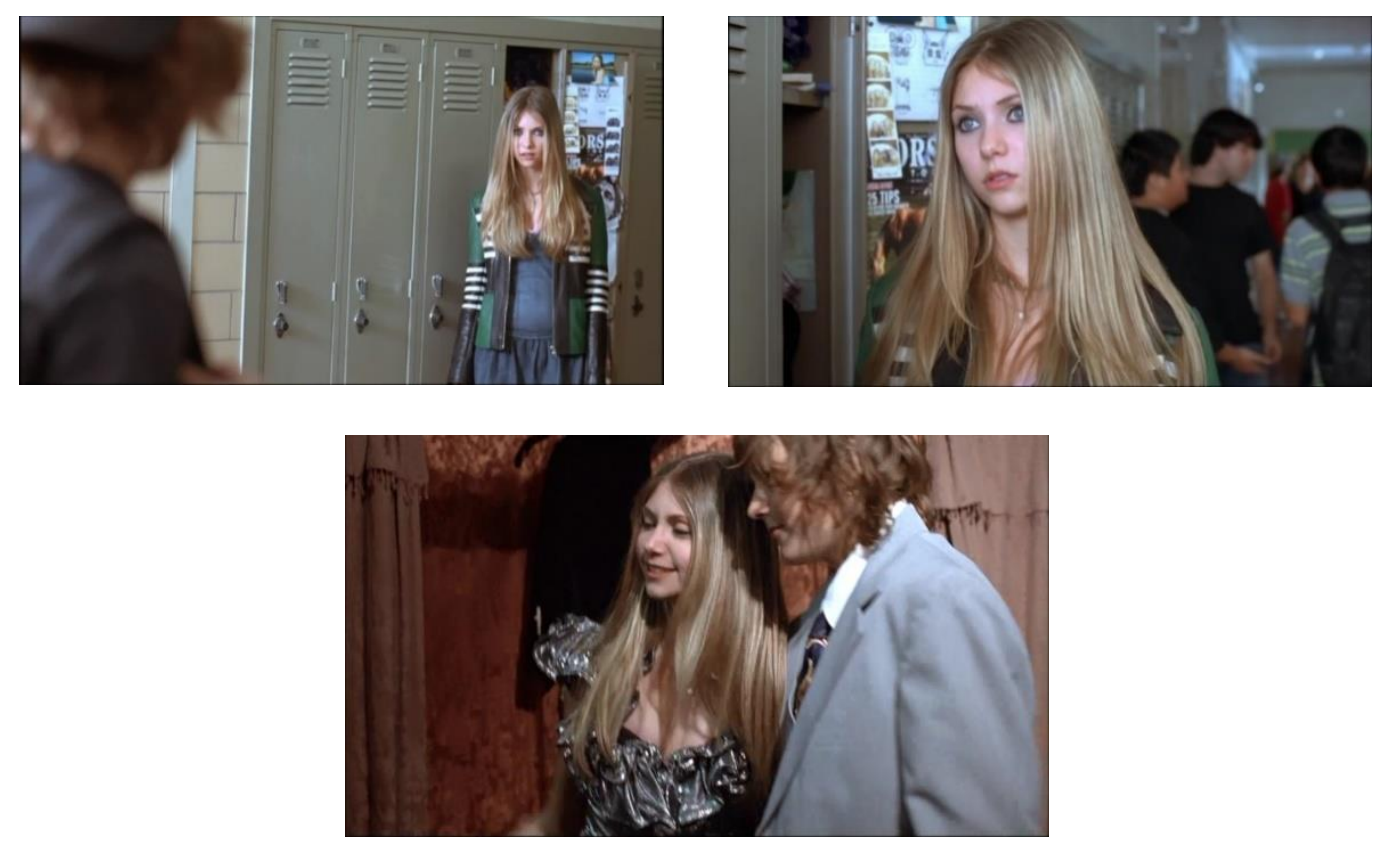

Tanto no romance como no filme Alex, perdido em pensamentos, passa por Jennifer e a ignora, mas o diálogo do romance é mantido quase na íntegra. Na cena e no diálogo do filme, as características de Jennifer são preservadas, revelando uma adolescente com personalidade forte e dominadora, e que expressa suas vontades francamente a ponto de intimidar Alex, que adota uma posição mais submissa e apologética, sendo quase monossilábico. Em relação ao filme, a alteração do diálogo e a sequência das cenas parece, a princípio, ser arbitrária, mas na verdade delineiam rapidamente não apenas a tensa relação entre os jovens (que no filme encontram-se pela primeira vez), mas Jennifer como antissujeito que ameaça os valores do jovem.

$\mathrm{Na}$ loja de roupas, percebe-se a atitude controladora da jovem que, sentada, observa o jovem em um terno, fazendo comentários sobre sua aparência, que ela agora julga mais atraente e sexy. A atitude da namorada de vestir o jovem em roupas mais adultas figura o seu desejo de ter um namorado mais maduro e adulto, e serve como atitude que adapta a ideia do romance da "compra do carro". Na cena anterior, na escola, percebe-se que Alex veste roupas típicas de adolescente, enquanto na loja ele traja uma roupa social. Jennifer veste um traje mais elegante e refinado que reflete o seu querer-ser mais adulta (ela ainda é virgem). Ao mesmo tempo, na comparação entre livro e filme, percebe-se o cuidado do enunciador em discutir certa inocência e pureza dos jovens, ao mesmo tempo em que cria uma cena que não altera os programas narrativos e temáticos dos atores. 
Outra mudança inesperada do romance é a nacionalidade do detetive que investiga o caso do vigia morto. Enquanto na obra literária o homem da lei é um investigador americano, Mathew Brady, no filme ele é um sino-americano: o detetive Richard Lu. Como já comentamos, a relação entre o jovem e o detetive é menos explorada no filme, mas a mudança brusca não é facilmente explicada, podendo ser vista tanto como citação bem-humorada e bricolada do famoso detetive Charlie Chan, personagem da TV e do cinema presente nas décadas de 30, 40 e 50; motivada racialmente, e dentro de um projeto enunciativo atento a minorias (há jovens negros no filme); ou até pelo mundo privado do ator da enunciação e do cenário artístico de Portland. De qualquer maneira, em relação ao romance, a mudança insere na narrativa um fator racial que quebra paradigmas e estereótipos de representação de agentes da lei, ou mesmo de atores centrais e importantes.

Além do céu, outro importante elemento simbólico para GVS, e sempre presente visualmente em seus filmes, inclusive em $P P$, é o da pietá, a Virgem Maria, ícone religioso universal de socorro e luto, mas redefinida pelo cineasta em contextos infundidos de energia sexual, de modo que mesmo os homens são associados a essa figura de proteção (VICARI, 2012, p.55). No filme, a pietá é mencionada tanto sonoramente, pela canção The white lady loves you more, sobre a Dama Branca, figura materna protetora que vela e protege os skatistas adolescentes e perdidos nas ruas, e também é sugerida nas imagens das mulheres: Jennifer, Macy e a amiga, que exalam certa qualidade religiosa de pureza e proteção:

Figura 155 - As pietás de Gus Van Sant
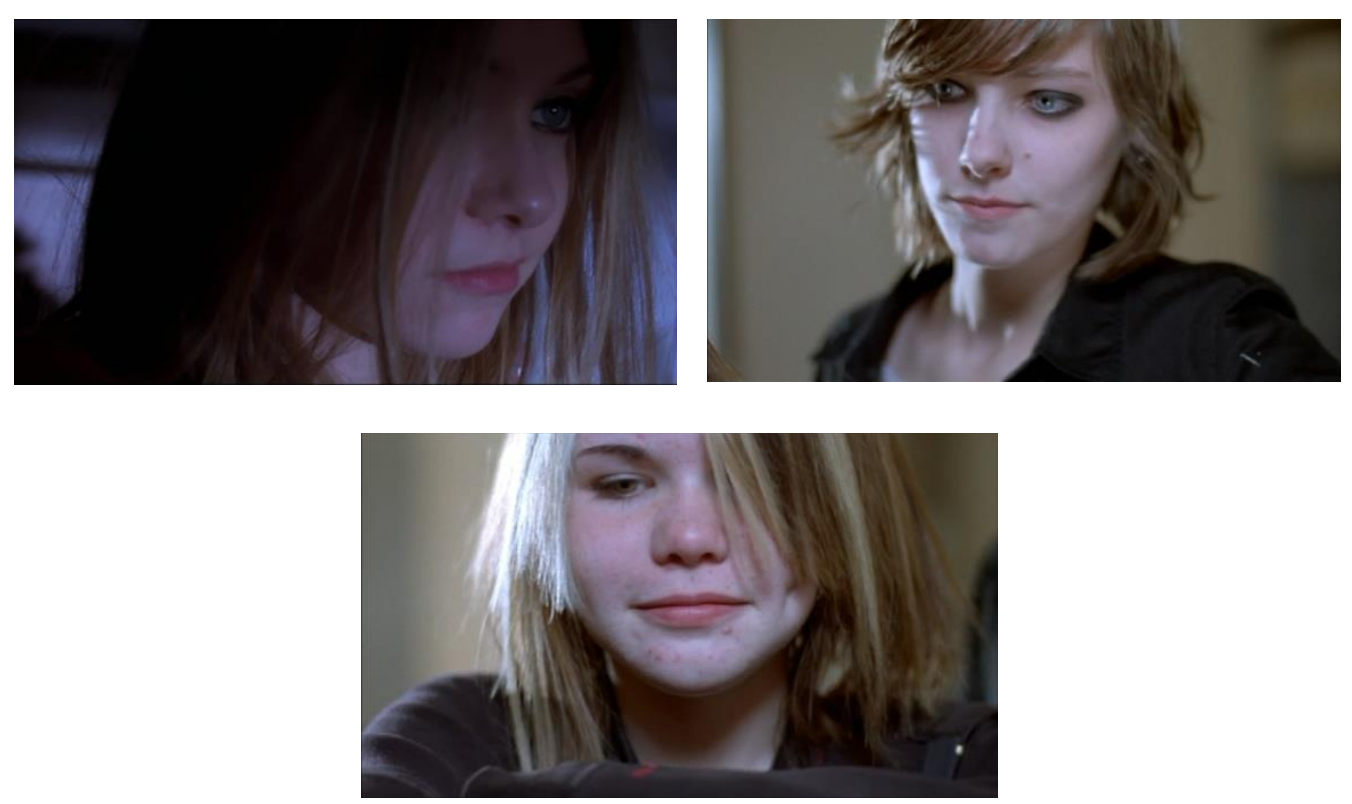
Vicari acredita que as pietàs van santianas tocam no que se pode chamar de "emoções culturais" e retraduzem a imagem de Cristo, que pode ser simbolizada como imigrante, usuários de drogas ou trapaceiro protegido por um amante, homossexual ou heterossexual (p. 57). Em uma das cenas finais do romance, Alex aparece deitado na calçada e Macy aproxima-se do jovem, perguntando-lhe se está morto:

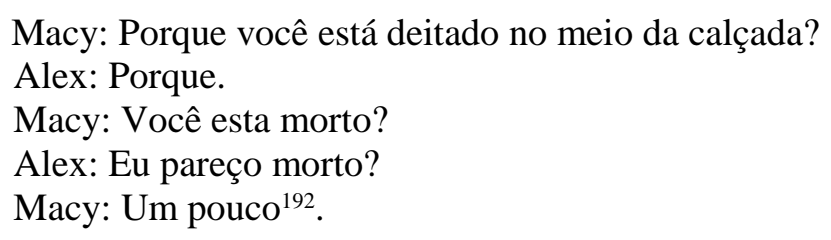

No filme, apenas a primeira pergunta é mantida, mas a amiga do protagonista aparece como um ser aéreo que vem de "cima", perguntando ao jovem prostrado: "O que você está fazendo aí, deitado no meio da calçada. É legal aí embaixo?” É nesse momento simbólico de morte que Macy "aproxima-se da terra" para auxiliar o jovem, sugerindo-lhe que escreva. No discurso de GVS, ela possui características do anjo protetor e redentor:

Figura 156 - Macy / pietá como entidade superior e salvadora

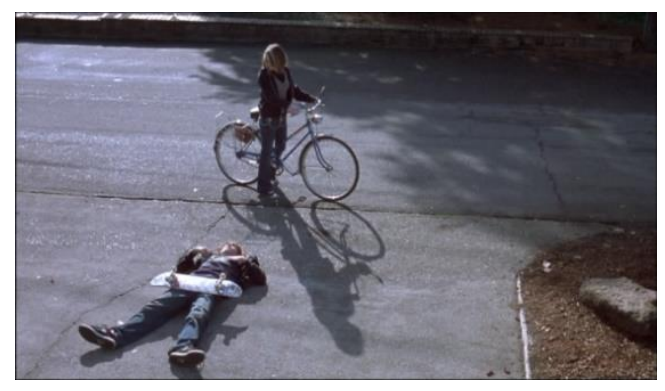

A simbologia da pietá, carregada também de noções de entrega e carinho, e de tensão sexual, engloba também a homossexualidade e a homoafetividade, outro importante tema do ator da enunciação. Observamos em relação à trilha musical do filme, que o gênero punk-rock foi utilizado na cena em que Jared, percebendo que Alex tem um novo skate, fica alterado e violento, dizendo que queria ser previamente avisado sobre a troca para não correr o risco de ter que andar ao lado de um "cara com skate de veado" (fag board $)^{193}$. Jared é mais velho que

\footnotetext{
192 No romance: Macy: "Why are you lying in the middle of your driveway?" Alex: "Because".

Macy: "Are you dead?"

Alex: "Do I look dead?"

Macy: "A little"

No filme: "Why are you lying in the middle of the driveway? Is it fun down there?

${ }^{193}$ No romance wuss board (prancha de covarde, maricas ou mulherzinha).
} 
Alex e tem uma vida sexual mais ativa que o adolescente de 16 anos, sendo claramente heterossexual. Lembramos que no romance, quando Jared avisa ao protagonista que não o acompanhará a Paranoid Park no sábado à noite, como haviam combinado, por causa de uma aventura sexual em outra cidade, este se sente "traído". Ao concordar em subir em um trem com Scratch, Alex pensa em Jared, imaginando que ele ficaria com ciúmes da aventura. No filme, a cena que em Jared comunica a Alex que ele vai abandoná-lo é escura e mostra o ator melancólico e carente, abraçado a um violão:

Figura 157 - Alex, pesaroso ao ser comunicado que ele e o amigo não ficarão juntos no fim de semana, por causa de uma aventura sexual do outro

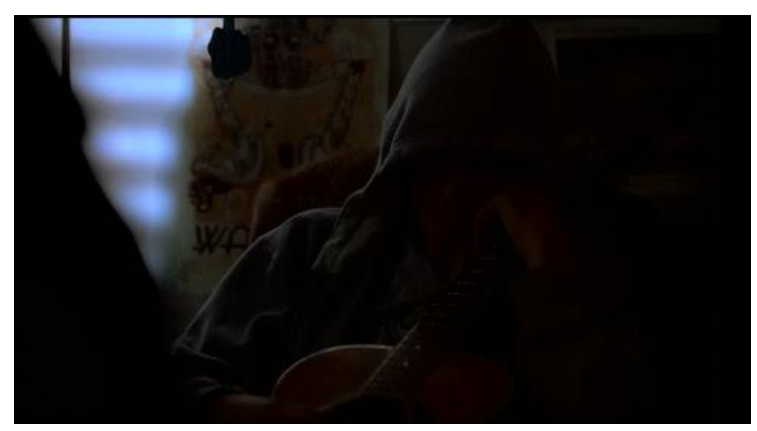

Ao mesmo tempo, por tratar-se de um texto visual e figurativo icônico, a construção visual dos personagens (pouco abordada no romance) parece intensificar certa representação andrógina de alguns adolescentes, entre eles Alex e Scratch. Os dois adolescentes, por exemplo, têm o cabelo mais comprido que Jared. Quando se sentam lado a lado na pista de skate para conversar, entreolham-se em câmera lenta, em um longo plano aproximado de suas faces, e sem cortes, de modo que o observador, a partir de um enquadramento próximo dos rostos dos adolescentes (PP), inicia um movimento suave e em câmera lenta, que vai de Alex a Scratch, e depois retorna, em um movimento sem cortes que os conecta.

Nesse momento, a expressão facial de Scratch assume um caráter nitidamente sedutor, e ele levemente sorri para Alex, com os lábios fechados. Na narração em voz-over o relato de Alex, que já tinha dito que simpatizara com Scratch, é alterado em relação ao romance, de modo que sobre a imagem dos dois adolescentes que se entreolham, Alex comenta: Ele me perguntou se eu queria cerveja. Eu não sabia, eu queria mesmo era andar de trem ${ }^{194}$. Segundo o Urban Dictionary expressões relacionadas à palavra "trem", como "ride a train", ou mesmo "freight

\footnotetext{
194 "He asked me if I wanted to get some beer. I didn't know about the beer, but I really wanted to ride a freight train". No romance esse diálogo não existe: "Hey", Scratch said to me: "Wanna hop a train?" I looked up at him. I kinda did. "What sort of train?" "The ten twenty. It comes right through here every night. We can ride it all the way to Safeway". ("Hey", Scratch me disse. "Quer subir num trem"? Eu olhei pra ele. Eu tipo queria. "Que tipo de trem?" "O das dez e vinte. Passa bem aqui toda a noite. Podemos ir até o Safeway").
} 
train", podem possuir conotação sexual ${ }^{195}$. No português brasileiro o equivalente seria "fazer um trenzinho".

Figura 158 - Homoafetividade entre Scratch e Alex na pista de skate
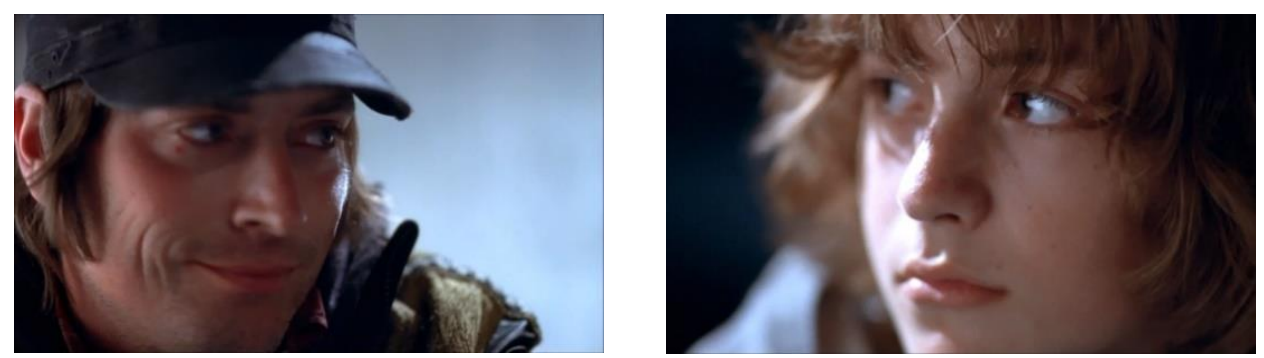

No filme, a relação de Alex com os personagens masculinos, por estar imbricada na busca da figura paterna, outro tema geralmente abordado por GVS, é utilizada mais ambiguamente, mas não se limita ao protagonista. O tio Tommy, com quem o pai de Alex fica por uns tempos, e também cuida do jovem, recebendo-a em sua casa, é também um ator ambíguo, que parece não estar relacionado profundamente à família do jovem, e fazendo-se presente na narrativa a partir do momento da separação dos pais de Alex. Vicari (2012) entende que esse ator poderia ser um amante homossexual, mas nem o filme ou o romance dão a entender que essa relação exista. Além dos problemas com a nova namorada, que acusa Alex de preferir ficar com Jared, o enunciador não cita a declaração final de amor por Macy e nem o agradecimento por seu carinho. Isso não quer dizer, no entanto, que Alex seja homossexual, ao contrário, pois mostra desejo por Macy e Jennifer: no filme a homoafetividade é sugerida, mas apenas como mais uma questão dentro da afetividade do jovem, e também ligada, como vimos, à figura protetora da pietà.

Além dessas questões, uma cena inexistente no romance, e que explora uma nova figura na narrativa é o uso de drogas. Enquanto Alex e Jared conversam em alguma sala, o observador abandona os dois amigos, movimenta-se para a esquerda e revela, por uma janela, a imagem de dois investigadores que escoltam um adolescente algemado. $\mathrm{O}$ diálogo entre os jovens sobre o incidente é rápido, pois enquanto Jared conta ao amigo suas aventuras eróticas no final de semana, Alex o interrompe e pergunta:

Alex: Sabe por que estão prendendo aquele cara?

Jared: Pegaram ele com maconha, acho... sei lá. Ele não vai ter um julgamento justo.

\footnotetext{
${ }^{195}$ Urban Dictionary. Disponivel em: <https://www.urbandictionary.com>. Acesso em 04 / 06 / 2019.
} 
Figura 159 - Jovem é escoltado na escola por posse de maconha

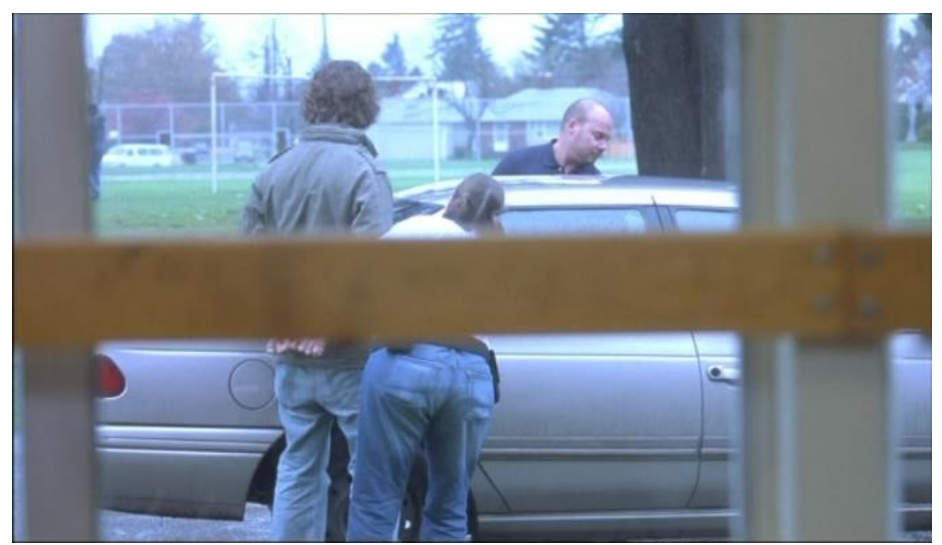

Apesar de existir apenas no filme, o sentido da cena insere-se nas isotopias temáticas do romance, que concernem o mundo adulto, a lei e a autoridade, figuradas tanto pelo vigia do pátio de trens e sua morte, quanto pelo detetive que investiga o assassinato. Nesse caso, porém, a cena da prisão e o comentário de Jared atualizam a temática mundo adulto, construindo uma figuração mais tônica da repressão e de uma divisão entre dois períodos de vida. No filme, a figuração da cena também remete a um discurso com valores de morte e não-liberdade. $\mathrm{O}$ comentário de Jared sobre o julgamento injusto revela um ponto de vista sobre a arbitrariedade da lei em relação a esse tipo de crime, e o tratamento repressivo aos jovens. Nota-se que a imagem é cortada por um pedaço de madeira que protege a janela da escola, figurando uma obstrução, e conota visualmente a ideia de proibição.

Outro importante investimento de sentido do enunciador é a operação de repetição, que se dá mais visualmente do que sonoramente. Observamos no capítulo sobre a sequência acontecimento, que antes de ser totalmente mostrado, ele é diversas vezes sugerido, de modo que algumas de suas imagens são repetidas duas vezes no filme, na forma de "lembranças desorganizadas e fora de lugar". Como $P P$ é um texto sobre a memória fragmentada, convém pontuar que outras cenas, e planos, são igualmente repetidos, de modo que possuem valor remissivo e intenso, confundindo a linearidade cronológica da narrativa e os fatos apresentados pelo narrador. Tais momentos que se repetem, nem sempre originam novas sequências, ficando à deriva na narrativa e frustrando mesmo a ideia de um discurso circular (que começa e termina no mesmo ponto). Assim: 
Figura 160 - Repetições de imagens durante o filme

Sequência 1: (Plano 13,14,15,16: 5'11') e Sequência 2 (Planos 58,59, 60 e 61: 16'05")
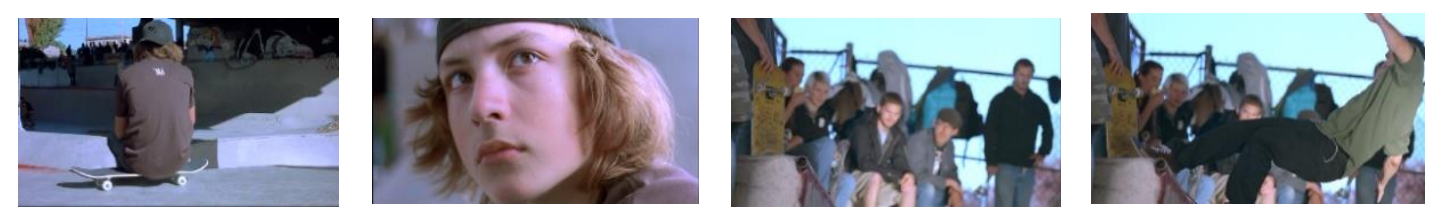

Plano 19 (7’) e Plano 90 (22’54”)
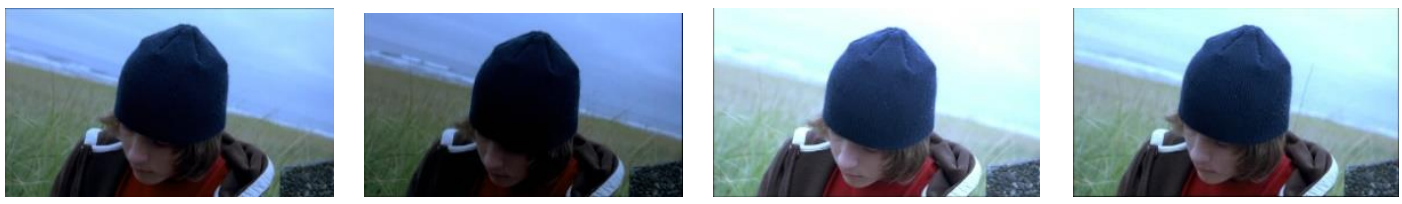

Plano 96 (24’20”) e Plano 158 (42’50”)
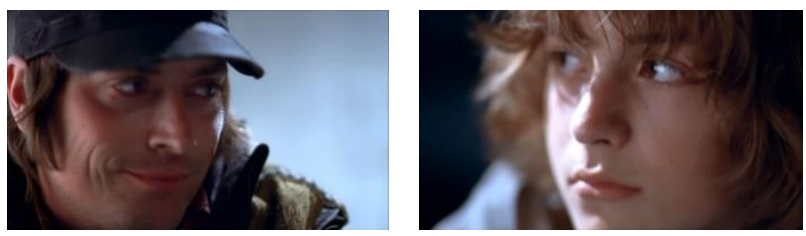

Plano 2 (1'15') e Plano 115 (31'47’)

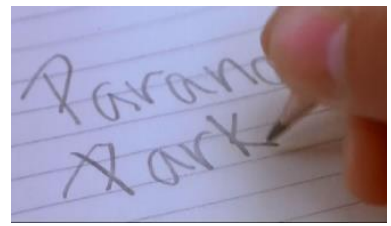

Plano 12 (4'55") e Plano 122 (33'39”)
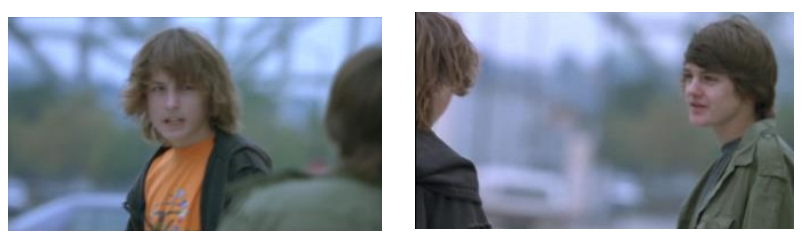

Plano 26 - 27 (12’34”) e Plano 181- 182 (46'59”)
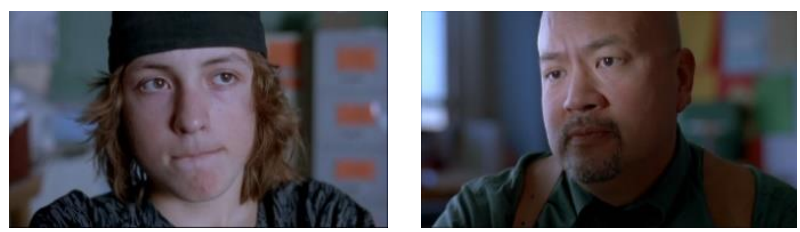
Finalmente, outra indicação de forte presença do enunciador no enunciado está associada a imagens que parecem não pertencer à narrativa, ou a tangenciam, e que observamos tanto na cena do ator com um cão na praia, que não existe no romance e não é desenvolvida na narrativa fílmica, pois o cão desaparece (uma imagem hápax), assim como as sequências da pista de skate com textura granulada, que não fazem parte das sequências narrativas do romance, não sendo relacionadas a seus atores. Tais cenas indicam uma ambiguidade no discurso, uma oscilação entre diegese e não diegese, e uma manipulação do ator da enunciação que, como na imagem do título, intromete-se nos conteúdos dos enunciados propostos pelo texto fonte.

Figura 161 - Elementos estranhos à narrativa proposta pelo romance
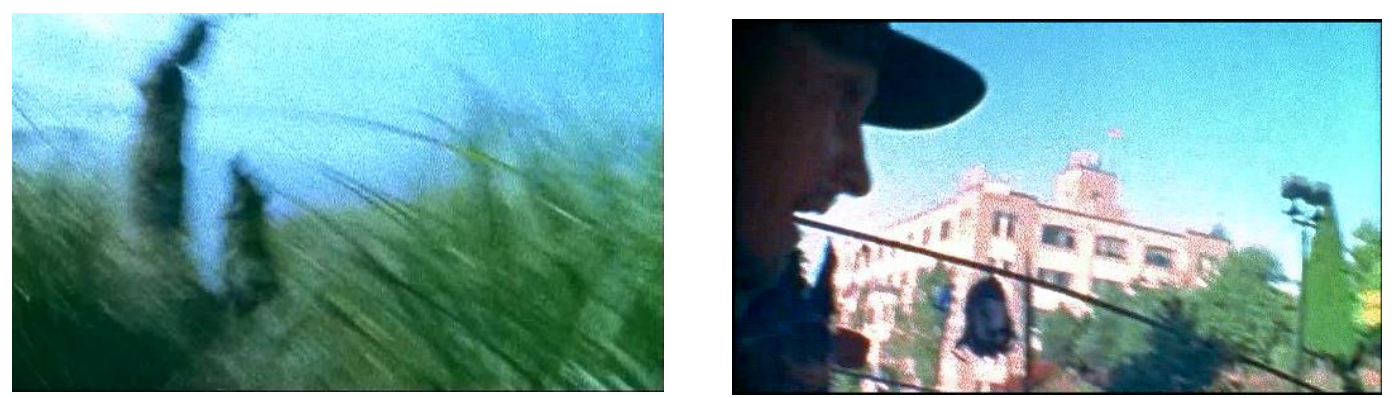

Sabe-se, no romance, que Jared grava vídeos de manobras de skate, e pode-se assumir que esse tipo de imagem é de sua câmera, mas nada é mencionado no filme sobre isso, além do que no romance Alex nunca faz relatos do amigo usando a câmera em sua presença, e nem após o acontecimento. Ademais, no filme, como as imagens de skate, que são granuladas, também são utilizadas nas cenas de Alex com o cão na praia, pode-se inferir que elas não pertençam à câmera de Jared, no presente, e não façam parte da diegese. Sendo utilizadas para o presente, as imagens granuladas não simbolizam apenas a memória e o passado. Assim, não considerando tais imagens como parte da narrativa, mas do discurso, podemos admiti-las como documentais, servindo à narrativa adaptada como paratexto, e existindo dentro de sua temática como um discurso figurativo independente, mas ajustando-se a ela de forma propositadamente ambígua e bricolada. Assim, tais "enxertos" existem entre enunciado e enunciação ${ }^{196}$, e causam um tipo de flutuação entre o real e fictício.

\footnotetext{
${ }^{196}$ Segundo Aumont e Marie (2006), o gênero documentário é uma montagem cinematográfica de imagens dadas como reais e não fictícias, tendo quase sempre um caráter didático e informativo que visa restituir as aparências da realidade, mostrar as coisas e o mundo como são, e tendo o mundo real como referência, o que postula que o mundo representado existe fora do filme. Como é um tipo de gênero, uma construção de sentido, concerne também às modalidades discursivas (p. 86).
} 
Dessa forma, o ator da enunciação é capaz de manter-se dentro de sua temática e figuração, relacionadas a jovens de rua e minorias, enquanto os documenta como atores do mundo "real", em uma atitude que propõe um olhar diferenciado a partir de dois gêneros fílmicos e sobrepostos. Vimos acima, que logo após a imagem de Alex dormindo na sala de aula, as últimas imagens do filme correspondem a uma longa sequência de jovens skatistas, dentre os quais Alex se encontra. $\mathrm{O}$ jovem olha para a câmera com uma gestualidade facial bem diferente da apresentada na diegese. Pode-se dizer que a estratégia enunciativa cria uma duplicidade entre o ator Alex e o seu intérprete, o adolescente Gabe Nevins, e causa ainda um novo e último tipo de corporificação, concretude e iconicidade, um último investimento figurativo intenso, pois é concessivo.

Figura 162 - Alex ou Gabe Nevins?

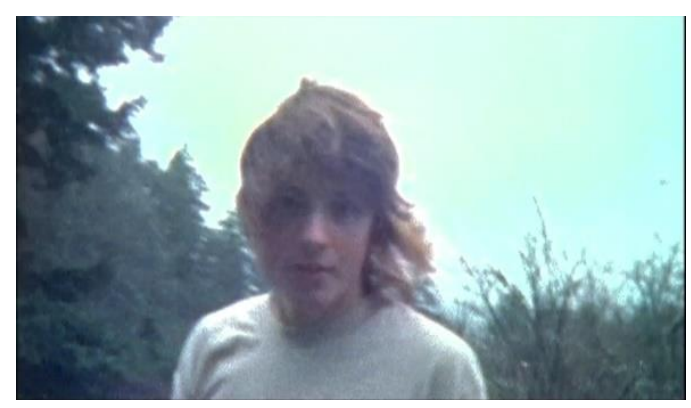

A pergunta se a imagem que vemos é referente à ficção ou à realidade, na verdade, não pode realmente ser respondida, e o intuito da abordagem de sentido do ator da enunciação fílmica é o de gerar complexidade semântica, acionada pelos subcontrários semânticos naõ-ser e não-parecer. De um lado, a imagem do jovem está inserida em um conjunto de outras imagens do mesmo tipo, relativas aos garotos das ruas de Portland, que podem ser reconhecidos como não pertencentes à ficção, ou paralelas a ela. De outro lado, e ao mesmo tempo, ao lado de Alex, esses sujeitos do nível narrativo são atualizados como atores fictícios no nível discursivo do enunciado, existindo como possíveis companheiros do novo cotidiano do protagonista, que começa após a queima das cartas, e passa a integrar os "valores da comunidade de skate".

Logicamente, a dúvida entre ficção e realidade interessa menos do que a construção de sentido da operação, que humaniza o ator fictício enquanto revela o ator "real", e faz uma homenagem carinhosa aos adolescentes, colocando-os em um espaço discursivo fictício e poético: ao problematizar o contrato de veridicção, o ator da enunciação chama a atenção para as várias aparências da adolescência. Olhando para a câmera, o ator Alex quebra a ilusão da ficção e revela o aparato cinematográfico; realiza-se, segundo Fiorin (2002), uma embreagem 
discursiva que pretende inserir o ator fictício dentro da realidade e, em nossa opinião, construílo como ator social "real". As cenas documentais, sendo inseridas em vários momentos do filme, podem ser vistas como um dos interesses temáticos mais recorrentes do ator da enunciação, relacionados à mescla entre ficção e realidade, e possuindo as categorias expressivas do "jornalismo / documentário", chamam a atenção para as operações da práxis enunciativa, a partir da qual o texto fílmico recicla e adota outros discursos filmicos.

\subsection{A práxis enunciativa e $P P$}

Após a extensa análise do filme, algumas observações de suas operações de sentido, e temas e figuras criadas pelo ator da enunciação, discutiremos o discurso fílmico como prática enunciativa, ou seja, uma composição inédita possibilitada a partir de outros enunciados anteriores a ele. De um lado, vimos que as estratégias audiovisuais para mimetizar o sujeito da falta, do sofrer e do sobrevir são extremamente ricas, envolvendo a exploração massiva de categorias cromáticas, sonoras e cinemáticas na composição de um discurso extremamente intenso e concessivo; de outro, percebe-se como o enunciador narra visualmente a partir de diferentes suportes e operações proxêmico-gestuais do observador, gerando sequências expressivas esteticamente diferentes (cor, textura, ângulo etc), e instaurando uma tensão entre meios e gêneros fílmicos.

Como o cinema é um conjunto significante que constrói os seus discursos e enunciados a partir de um sistema potencializado e virtualizado pela prática do sentido, acredita-se que $P P$ enquanto filme, ou seja, tex to significado por coerções de um conjunto significante audiovisual motivado, atualizará outros discursos fílmicos para fabricar o seu próprio discurso. Uma vez que desde o seu nascimento, o cinema constrói enunciados audiovisuais para representar estados passionais e somáticos do homem, e tenta estabelecer efeitos de ficção e verdade em seus discursos, $P P$ não escapa a essas práticas e figurações, estando intimamente e irremediavelmente envolvido nelas, como um recém-nascido dentro de uma língua. A partir daí, discutiremos alguns conceitos da práxis enunciativa, e observaremos como certos ideias e estilos discursivos criados pelo Expressionismo alemão, o Impressionismo francês, e o filme de arte, ou avant-garde, foram atualizados pelo sujeito da enunciação para compor o seu texto sobre a maioridade e o acontecimento.

Aproximando a práxis enunciativa da bricolagem, Floch (1995) entende que ela implica a convocação de certo número de formas já constituídas sem, no entanto, produzir discursos estereotipados, mas singulares, em enunciados com qualidades de entidade autônoma (p. 6). Do ponto de vista prático, o sentido é socializado, reciclado e reestruturado constantemente, de 
modo que o uso cria um sistema virtualizado ou potencializado de sentido, que será atualizado pelo enunciador, depois realizado. De um lado a práxis é cíclica e bidirecional, ou seja, ascendente e descendente, concebendo a produção de sentido diferentemente do percurso gerativo, isto é, não como um discurso formado a partir de semas mínimos aos quais estruturas maiores são adicionadas, em uma operação ascendente e unidirecional, mas como atualização de outros discursos. De outro lado, porém, pode-se pensar que as trocas de sentido se dão minimamente a partir de um dever / querer e um de crer / saber, possuem importância para o homem, são relacionadas a valores de vida, e estabelecem atores, tempos e espaços. Assim, dentro do escopo de nossa discussão, o percurso gerativo será compatível com a práxis, e o sentido será formado tanto narrativamente como discursivamente, a partir de semas mínimos abstratos e práticas concretas.

Fontanille e Zilberberg observam que a práxis, em chave tensiva, é determinada por zonas átonas e tônicas e conteúdos latentes e manifestos que podem ser relacionados ao sistema e ao processo. Assim:

Figura 163 - Dimensão tensiva da práxis enunciativa

\begin{tabular}{|l|l|l|}
\hline & Praxis tônica & Práxis átona \\
\hline $\begin{array}{l}\text { Estatuto do conteúdo } \\
\text { latente (sistema em potência) }\end{array}$ & Potencializado & Virtualizado \\
\hline $\begin{array}{l}\text { Estatuto do conteúdo } \\
\text { manifesto (processo em ato) }\end{array}$ & Atualizado & Realizado \\
\hline
\end{tabular}

Fonte: adaptado de Zilberberg; Fontanille (2001, p. 178)

As operações da práxis podem ser consideradas do ponto de vista do devir do objeto, que é o produto do ato significante, o enunciado, ou do ponto de vista do devir dos sujeitos, os parceiros da interação semiótica. No primeiro caso, as operações atuam sobre os modos de presença dos objetos. O percurso que explora a tensão entre o modo virtual e o realizado é ascendente, uma vez que ele sobe em direção à manifestação e almeja atingir o centro de referência do discurso, a instância realizante. O percurso que explora a tensão entre o modo realizado e o virtualizado denomina-se descendente, na medida em que ele volta em direção ao sistema, cristalizando as formas vivas em estereótipos, em praxemas, e alimenta a competência dos sujeitos da enunciação graças aos produtos dos usos mais típicos. 
O percurso ascendente é analisável como dois atos diferentes: a fase Virtualizado $\rightarrow$ Atualizado [Virt. $\rightarrow$ Atual.] representa a emergência de uma forma; a fase Atualizado $\rightarrow$ Realizado [Atual. $\rightarrow$ Real.] representa o aparecimento de uma forma, que recebe uma expressão e estatuto de realidade que lhe permite fazer referência. Nas operações descendentes, nas quais as formas significantes são implícitas, memorizadas, tipificadas ou ainda apagadas e esquecidas, há também duas fases: Realizado $\rightarrow$ Potencializado [Real. $\rightarrow$ Pot.], que é a condição de declínio de uma forma enquanto viva e inovadora, sua entrada no uso e sua fixação enquanto praxema potencialmente disponível para outras convocações; e a fase Potencializado $\rightarrow$ Virtualizado [Pot $\rightarrow$ Virt.], que representa o desaparecimento de uma forma, sua diluição nas estruturas subjacentes ao exercício de uma prática significante.

$\mathrm{Na}$ perspectiva retórica do discurso é preciso levar em conta a manipulação concomitante de ao menos duas grandezas ou dois enunciados, dos quais a práxis deriva modos de existência: "o ato semiótico rebaixa uma forma para promover outra; dois modos de existência concorrentes são modificados de forma solidária" (FONTANILLE, 2008, p. 278). Assim:

Figura 164 - Transformações da existência de enunciados dinamizados pela práxis

\begin{tabular}{|c|r|r|}
\hline Descendência & Emergência & Aparecimento \\
\hline Declínio & Distorção $[$ Virt. $\rightarrow$ Atual.] & Flutuação [Atual. $\rightarrow$ Real.] \\
& {$[$ [Real. $\rightarrow$ Pot.] } & [Real. $\rightarrow$ Pot.] \\
\hline Desaparecimento & Remanejamento [Virt. $\rightarrow$ Atual.] & $\begin{array}{r}\text { Revolução [Atual. } \rightarrow \text { Real.] } \\
{[\text { [Pot. } \rightarrow \text { Virt.] }}\end{array}$ \\
& {$[$ Pot. $\rightarrow$ Virt.] } \\
\hline
\end{tabular}

Fonte: quadro adaptado de Fontanille (2008, p. 279)

A distorção corresponde a uma emergência de uma forma correlacionada ao declínio de outra. Os tropos vivos, verbais ou visuais, que põem em concorrência uma forma atualizada (o conteúdo figurante e percebido) e uma forma potencializada (o conteúdo reconstituído, conceitual ou parafrásico); a flutuação corresponde ao aparecimento de uma forma combinada ao declíno de outra. Duas isotopias ligadas por uma metáfora são manifestadas alternadamente na superfície textual. A alternância supõe que a isotopia figurante oscile entre atualização e realização, e a isotopia figurada entre potencialização e realização; o remanejamento 
corresponde à emergência de uma forma combinada ao desaparecimento da outra, e afeta as relações entre os primitivos culturais e o sistema. Toda a operação que tem por objetivo reativar a combinatória virtual em um estereótipo deriva dessa transformação: alguém que afirme estar "matando cachorro a grito" enquanto vocifera com um cão, efetua um remanejamento semiótico; a revolução corresponde ao aparecimento de uma forma correlacionada ao desaparecimento de outra. A clássica comutação, que no domínio visual pode ser exemplificada como a figura do "pato-coelho", na qual o aparecimento do coelho acarreta o desaparecimento do pato e vice-versa (FONTANILLE, 2008, p. 278).

Do ponto de vista do devir dos sujeitos os modos de existência e as tensões existenciais advêm somente no campo de uma instância de discurso, subtendido pelo campo da presença de uma instância sensível e perceptiva, em relação com outras instâncias, pois os modos de existência “existem" para alguém. As duas principais dimensões do campo esquemático são a intensidade da assunção, modalizada pelo crer, pois obedece a lógicas das forças e caracteriza o elo empático que une o sujeito e sua produção; e a extensão do reconhecimento, ligada ao saber, pois obedece à lógica dos lugares, e concerne ao número dos actantes da enunciação (transformacionais e posicionais ${ }^{197}$ ) e à difusão das formas significantes implicadas.

O cruzamento das dimensões elementares da presença, a assunção intensa e o reconhecimento, extenso, possibilitam uma tipologia das operações da práxis do ponto de vista do devir das instâncias do discurso, a partir da qual a atitude da instância em relação aos enunciados que ela manipula é qualificada: a correlação direta entre intensidade e extensidade define as duas operações sobre o valor de troca, que são a amplificação e a atenuação. A primeira instaura uma forma no uso de modo que a força de assunção é fortalecida pela extensão do reconhecimento, sendo um percurso que conduz da adoção à integração de uma forma [adoção $\rightarrow$ integração]; a segunda descreve o processo inverso, e a enunciação não assume mais uma forma, que sai de uso [reconhecimento $\rightarrow$ obsolescência]. A correlação inversa define duas operações sobre o valor de uso: a somação e o desdobramento. A primeira impõe uma forma por meio de uma assunção forte, podendo conduzir da difusão à revivificação de uma forma

\footnotetext{
${ }^{197}$ Os actantes transformacionais são de dois tipos: os que dependem do desejo e da busca, que associam o sujeito e o objeto, e os que dependem da comunicação: destinador e destinatário. Os actantes posicionais são unidades sintáticas abstratas, definidos a partir de uma topologia. Podem ser de três tipos: actante-fonte, actante-alvo e actante-controle. Fontanille explica que ao utilizar uma teoria localista quer recorrer à percepção, pois se as estruturas sintáticas podem ocupar um lugar no espaço é porque são cenas percebidas vagamente, e conservam as propriedades do lugar e do movimento, sendo extraídas de toda a substância figurativa. Tais topologias são estruturas de campo, e têm o estatuto de imagens esquemáticas subjacentes à sintaxe do discurso (FONTANILLE, 2008, p. 159).
} 
[difusão $\rightarrow$ ressemantização]; a resolução (ou desdobramento) difunde um uso, fazendo-o perder sua força de assunção [formação $\rightarrow$ desgaste] (FONTANILLE, 2008, p. 182). Assim:

Figura 165 - Operações da práxis do ponto de vista do devir dos sujeitos

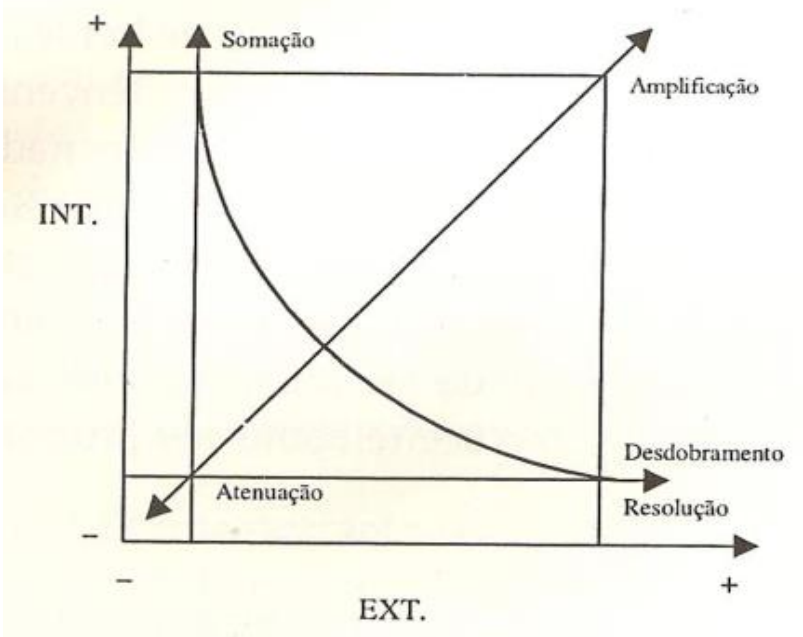

Fonte: Fontanille; Zilberberg (2001, p. 179)

De modo que:

\begin{tabular}{|c|c|c|}
\hline & Assunção forte & Assunção fraca \\
\hline $\begin{array}{c}\text { Reconhecimento } \\
\text { extenso }\end{array}$ & Amplificação & $\begin{array}{c}\text { Desdobramento ou } \\
\text { resolução }\end{array}$ \\
\hline $\begin{array}{c}\text { Reconhecimento } \\
\text { restrito }\end{array}$ & Somação & Atenuação \\
\hline
\end{tabular}

Fonte: Fontanille (2008, p. 282)

Para mostrar o funcionamento de cada dimensão, Fiorin utiliza os seguintes exemplos, retirados de textos literários e do discurso verbal de forma geral: para a amplificação, os bestsellers tipo $O$ código da Vinci ${ }^{198}$, que combina romance policial, histórias de sociedades secretas, religiosas e fanáticas e teorias da conspiração, em narrativas vertiginosas que abordam a destruição do mundo; para a atenuação, uma forma linguística que ainda pode ser reconhecida, mas já não tem impacto, tornando-se obsoleta, como uma gíria do passado: broto, pé na tábua etc.; para o desdobramento ou a resolução, uma forma que tem um abaixamento de intensidade, fato relacionado a uma grande extensão de uso, em uma operação de desgaste e cristalização de grandezas linguísticas e discursivas. É quando não já não se percebem todas as implicações do sentido de certas formas. Assim, apesar de existirem certos adjetivos masculinos

${ }^{198}$ Dan Brown (2004). 
no dicionário, tais como mal-acabado ou mal-agradecido, não existe mal-amado, apenas malamada, fato que esconde uma motivação ideológica; para a somação, que é um aumento de intensidade para um uso bem restrito, pouco extenso, opera-se uma ressemantização do que tinha perdido impacto pela grande difusão. Um anúncio de uma empresa de turismo publica "Fortaleza, 7 dias por semana: tomou, sarou" (FIORIN, 2010, p. 65; 66; 67).

Fontanille (2017), que pensa as práticas humanas como imanências do sentido presentes no texto, enfatiza o lado prático ou ativo da enunciação, explicando que "não se pode fundar uma enunciação coletiva, polifônica, multidimensional e evolutiva sobre o único plano de imanência da textualidade: ela é necessariamente de ordem processual e prática" (p. 987). A partir da práxis, o semioticista elenca quatro características da enunciação:

Toda enunciação pressupõe, explora e manifesta uma ou mais experiências, anteriores, posteriores ou concomitantes; essas experiências podem ser somáticas, práticas, textuais ou de outros tipos: midiáticas, científicas, sobretudo; elas podem ter sido assumidas explicitamente por outras enunciações cujos atos e autores são identificáveis (nesses casos há, no sentido estrito, enunciação depois re-enunciação), mas podem igualmente ter sido somente memorizadas, partilhadas ou transmitidas, no interior de uma experiência individual ou coletiva, sem enunciação identificável. Em todos os casos, essas experiências já produziram semioses textuais, práticas ou existenciais; a experiência em questão é acessível a uma exploração reflexiva, e suficientemente maleável para ser transposta em outra semiose (FONTANILLE, 2017, p. 999-1000).

Vimos, nos exemplos acima, que as dinâmicas da práxis não foram restringidas a apenas um tipo de conjunto significante. Porém percebe-se, pelos exemplos fornecidos, que ela foi discutida do ponto de vista intralinguístico, ou seja, de enunciados formados dentro de uma linguagem em particular, e não interlinguístico e nem sincréticos. Além disso, a grande maioria dos exemplos tratam de enunciados menores, a única exceção sendo a de Fiorin, que cita $\mathrm{O}$ Código da Vinci como exemplo de amplificação. Assim, percebe-se que a teoria está apenas em seu início, precisando ser mais aplicada e desenvolvida. A discussão é importante, no entanto, pois propõe ferramentas que possibilitam um ponto de vista semiótico sobre tipos diferentes de operações interdiscursivas na tradução.

Já comentamos como o romance utiliza a forma epistolar, e combina o drama existencial, o thriller psicológico e um pouco de romance policial de suspense em um molde infanto-juvenil. O discurso fílmico igualmente combina elementos de outros gêneros para compor sua narrativa, enunciados atualizados de outros discursos. De um ponto de vista geral, o enunciador do texto alvo utiliza, ou incorpora o texto fonte, reatualizando-o e realizando-o junto com o seu, de modo que o sentido seja uma mescla de enunciados complexos, e que em 
nosso caso se dá entre duas linguagens diferentes e com dois tipos diferentes de relação biplanar, arbitrária e motivada.

A retórica da práxis na adaptação do texto literário parece ser uma realização ligada a uma revolução semiótica, relacionada à comutação (transformação, metamorfose, alteração), pois pode-se entender que o sentido e conteúdo do discurso literário é transformado em discurso e conteúdo fílmico. Vimos que a linguagem verbal constrói imagens do mundo inteligível e sensível, figurando-o, que são refigurativizadas em figuras audiovisuais plásticas. Percebemos, por exemplo, na cena do acontecimento, como os verbos e advérbios do romance colocam os atores em deslocamento em um espaço profundo, cuja figuração de movimento produz possibilidades imagéticas que são permutadas em linguagem audiovisual figurativa.

Uma operação enunciativa muito recorrente no filme parece ser a da flutuação, que ocorre quando duas isotopias ligadas por uma metáfora são manifestadas alternadamente na superfície textual, em uma dinâmica que supõe que a isotopia figurante vá e venha entre atualização e realização e a isotopia figurada, entre potencialização e realização. Assim, na cena do chuveiro, na qual ruídos de pássaros são ouvidos enquanto Alex toma banho, oscila-se entre o mundo do banho e o mundo fora dele, um espaço interno e privado, e um espaço externo sugerido, que nunca é realizado visualmente no discurso: nessa imagem, o ladrilho do pássaro no banheiro torna-se uma imagem sonora dentro da imagem visual.

O som do grito no diálogo entre o jovem e o detetive causa a mesma impressão, criando um espaço realizado e outro potencializado. A flutuação pode também ser percebida na questão das imagens texturizadas, que propõem um espaço (ou imagem) "real" dentro de um espaço (ou imagem) fictício, que por sua vez utiliza esse "real documental" para figurar a memória na ficção, em uma oscilação entre enunciado e enunciação. De certa forma, todas essas existências no discurso possuem fundo metafórico ou simbólico, conotando estados patêmicos e o movimento da memória. Em todos esses casos há também a alternância entre enunciação e enunciado, que podem ser vistos como dois conjuntos figurativos.

A ideia de flutuação do sentido, que parece ser bem diferente da práxis do drama, por exemplo, ou do documentário, revela no discurso fílmico a utilização de práticas realizadas por outros discursos, como o filme de arte, por exemplo, ou o documentário poético, que acreditamos ser uma atualização de técnicas impressionistas e expressionistas de sentido, realizadas principalmente no início do século 20, mais precisamente entre 1920 e 1930.

Utilizando-se a tipologia narrativa fílmica de Bordwell (1985), que joga luz sobre o nosso objeto, $P P$ traz as marcas do gênero discursivo filme de arte, um estilo narrativo alternativo surgido na segunda metade do século XX com raízes no avant-garde, e propõe uma 
mescla de narrativa objetiva, subjetiva ou expressiva, e comentário narrativo (p. 205). Como características temáticas e formais desse tipo de narração, registram-se realidades diegéticas multifacetadas, personagens com problemas psicológicos contemporâneos, tais como como alienação ou falta de comunicação, e tentativa de verissimilitude de comportamentos subjetivos e espaços e tempos sentidos como "naturais", construídos através de atos naturais e "não atuados", luz natural, locais reais e não cenografados, tempos mortos onde nada ocorre etc. Nesse gênero, que pode abordar eventos paralelos e transitórios na vida de um personagem, imitando inconstâncias, acasos e causalidades desconhecidas, há também a despreocupação com a relação causa e efeito, ordem cronológica, ou a fórmula começo-meio-fim (da cena, ou filme). Bordwell entende que o filme de arte, menos preocupado com a ação do que com a emoção, mostra personagens que expressam, explicam, ou estão alheios de seus próprios estados mentais, em histórias que orbitam em eixos temáticos, tais como autobiografias ou biografias, fantasias, alucinações ou sonhos, de maneira que tal tipo de filme "desenvolveu uma gama de sinais para expressar o estado de espírito do personagem: posturas estáticas, olhares encobertos, sorrisos que desvanecem, caminhadas sem destino, cenários que revelam emoções, e objetos associados" (BORDWELL, 1985, p. 208). As convenções desse tipo de realismo artístico expressivo moldam o espaço e consequentemente o tempo da narrativa: no filme de arte o ponto de vista ótico (a câmera subjetiva), as imagens rápidas de uma lembrança ou de uma percepção visual, os padrões de edição, as modulações de luz, a cor ou o som figuram o estado psicológico do personagem. Como comentário narrativo observam-se dispositivos estilísticos que se contrapõem a normas clássicas: ângulos, movimentos de câmera e cortes pouco usuais, mudanças irrealistas de luz ou espaço, disjunção da trilha sonora, ou qualquer quebra de realismo objetivo não motivado e não relacionado à subjetividade construída na diegese (p. 209). Tais comentários, quando repetidos e reutilizados, suscitam a discriminação de um cinema de "autor". O filme de arte, assim, existiria entre diversas tendências: desvio de normas clássicas, aderência às normas do art-cinema, criação de normas intrínsecas inovativas, e desvios maiores ou menores dessas normas (p. 213).

De fato, $P P$ possui uma estética parecida ao estilo discriminado por Bordwell, adotando um tipo de discurso fílmico singular para mimetizar as lembranças na mente de um jovem perturbado emocionalmente e mergulhado em si próprio. Assim, quadros, imagens e sons são mesclados de maneira pouco usual, ou seja, mais poética e simbólica, para compor a ideia do sujeito sensível siderado. Como representação retórica, Alex possui qualidades tanto metonímicas como metafóricas: de um lado, tudo o que relata está diretamente relacionado à 
sua experiência pessoal, existindo como extensão de sua subjetividade e corpo sensível; de outro, o jovem é símbolo da juventude e da maioridade, realizando um rito de passagem.

A partir da ideia de filme de arte, que sem dúvida explica o nosso objeto, gostaríamos de retroceder mais um pouco na história do cinema, para argumentarmos como o estilo filme de arte é alicerçado em outros discursos fundadores, advindos de escolas de pensamento sobre a relação cinema / estética / realidade sensível, de modo que a práxis se revela também como atividade mítica de um grupo de artistas com crenças e valores de vida / morte e natureza /cultura. Sendo uma prática figurativa constante do cinema, a subjetividade foi expressa minimamente pela distância entre o observador e as coisas do mundo, em uma semiose proxêmica (de ator e câmera), e depois, com a evolução da linguagem fílmica, foi ainda mais desenvolvida. O cinema, através da construção de diversos pontos de vista, movimentos de câmera, truques óticos e efeitos visuais e sonoros aprende a expressar audiovisualmente o sujeito corporificado e sensível.

Traduzindo o espaço interior sensível do sujeito, $P P$ adota um estilo que traz as marcas do Expressionismo alemão, gênero textual que figura a ansiedade metafísica como condição existencial, e que pode servir de descrição não apenas ao movimento expressionista de 1905 a 1912, mas também ao desenvolvimento geral desse gênero, na Europa e nas Américas, em nosso século (BRILL, 2002, p. 392). Segundo Thomas ${ }^{199}$ (1944 apud Brill, 2002), o páthos que marca o Expressionismo como arte resulta menos de um conceito estilístico do que da coragem de colocar o indivíduo, e sua vivência emocional, no centro da expressão artística, em temáticas que apontam para uma realidade percebida pelos sentidos, e que são, para o expressionismo, "o impulso que gera a experiência íntima, ou um símbolo de um estado de alma específico" (p. 401), originado de um compromisso com o primado da verdade individual, encarando a subjetividade como comprovação do real (CARDINAL, 1988 apud CÁNEPA, 2006, p. 57) ${ }^{200}$. Rosenfeld (1993) 201 explica que as peças expressionistas, no teatro:

Faziam do mundo interno do personagem o único elo entre os diversos elementos da trama, abrindo mão das noções tradicionais de estruturação da cena segundo os princípios de unidade espaço-temporal. Encenava-se o próprio desenvolvimento psicológico dos personagens, num tipo de narrativa em que, com frequência, somente o personagem central realmente existia, sendos os outros, na maioria das vezes, projeções distorcidas da mente do herói (apud CÁNEPA, 2006, p. 61).

\footnotetext{
199 THOMAS, Karin. Bis Heute: Stilgeschichte der Bildenden Kunst im 20 Jahrhundert, neue.Ed ver. Köln, Dumont Buchverlag, 1944.

${ }^{200}$ CARDINAL Roger. O expressionismo. Rio de Janeiro: Jorge Zahar, 1988.

${ }^{201}$ ROSENFELD, Anatol. Historia da literatura e do teatro alemães. São Paulo: Perspectiva, 1993.
} 
$\mathrm{Na}$ literatura, a narrativa expressionista "buscava a destruição da sintaxe tradicional, num estilo que poderia ir da concentração telegráfica ao hino largo e extático, sempre à procura do confronto individual do artista coma realidade" (1993 apud CÁNEPA, 2006, p. 60). No entendimento de Nazário (2002), o Expressionismo cria uma atmosfera de excesso, demência e pesadelo (p. 509). A partir desses conceitos e exemplos, pode-se aproximar o romance e o filme desse tipo de estética, através de investimentos expressivos e semânticos verbais e audiovisuais: no texto literário, a forma epistolar, as divisões em "arame farpado", fontes góticas, itálicos, elipses, e a imagem de um "zumbi catatônico", constroem o efeito de um enunciador afetivo e psicologicamente perturbado que se projeta ao enunciatário através do afeto; da mesma maneira, no enunciado fílmico, as aproximações do rosto, os ângulos de câmera acentuados, texturas granuladas, sons eletroacústicos, jogos de claros e escuros ${ }^{202}$, e oscilações gradativas entre ícone e figura e exibição e inacessibilidade constroem os efeitos de "real sensível" e duração temporal vivida. A forma elíptica e fragmentada do romance, intensificada no filme, é também uma característica do estilo expressionista. No discurso fílmico podemos dizer que a sequência acontecimento é a que mais se aproxima do gênero, com seu apelo trágico, tons escuros, música clássica, tempo chuvoso e a imagem chocante de um homem, cortado ao meio, arrastando seu tronco decepado pelo chão.

Uma importante característica Expressionista no filme é sua autoconsciência, ou reflexividade, criada na estética da vanguarda modernista, pois ele se assume enquanto discurso não convencional e individualizado, que procura desvencilhar-se das construções mais prosaicas de sentido. Segundo Elsaesser ${ }^{203}$, o segredo do fascínio exercido pelos filmes expressionsitas alemães vem do fato de suas narrativas serem suficientemente oblíquas para encorajar todo tipo de especulação (1996 apud CÁNEPA, 2006, p. 77): o filme de GVS, apoiado na representação da memória, dá um tratamento onírico e não-linear ao reconhecimento, construindo uma narrativa que pretende a confusão.

Concomitantemente ao Expressionismo, outra corrente de pensamento relacionada à expressão da subjetividade que nos interessa com mais profundidade é o Impressionismo, que na verdade utiliza a mesma estética alemã (THOMPSON; BORDWELL, 2003, p.106), e

\footnotetext{
${ }^{202}$ Nazário (2002) comenta que no cinema expressionista, "os iluminadores recriavam em estúdio toda uma mascarada fantástica; manchas que deslizavam pelas paredes criando profundidades; focos direcionados que revelavam pouco a pouco elementos sinistros: o olhar podia acompanhar os contornos e os planos, os contrastes de claridade e sombra. Nos filmes de Fritz Lang, por exemplo, a inação é expressiva, e Cidadão Kane, inspirado no cinema mudo alemão, possui os mais diversos malabarismos cinematográficos - pan-focus, planos inclinados, big close-ups, longos travelings, montagem fragmentada (p. 520 e 522). Todos esses elementos estão presentes em Paranoid Park.

${ }^{203}$ ELSAESSER, T (org.). A second life: German cinema's first decades. Amsterdã: Amsterdan University Press, 1996.
} 
igualmente se insere dentro de práticas audiovisuais da construção das sensações e percepções do sujeito, em um estilo que deriva parcialmente da ideia de cinema como forma de arte. Ao mesmo tempo, do ponto de vista das coerções materiais do suporte, teorias impressionistas entendem o cinema como um meio puro, ou seja, um conjunto significante que apresenta possibilidades únicas para a expressão do artista, que passa a compor um "cinema puro", filmes abstratos concentrados em formas gráficas e temporais (THOMPSON; BORDWELL, 2003, p.90).

Mais intensamente do que o Expressionismo, no entanto, que representa a condição psicológica a partir de cenários deformados e distorcidos, e da maquiagem pesada no rosto dos atores, o Impressionismo no cinema, assim como na pintura, vai apostar na experimentação, na estética idealista ou irrealista, quase pomposa e rebuscada, de modo que esses tipos de filmes são caracterizados por um grande número de proezas técnico-estilísticas, abrangendo sobreimpressões, deformações óticas e planos subjetivos, e preocupando-se com a duração dos planos, enquadramento e ritmo da montagem (MARTINS, 2006, p. 91). Como para os Impressionistas o ritmo é central, eles procuram construir música visualmente, oferecendo um meio de enfatizar menos a ação do que as reações dos personagens a ela (THOMPSON; BORDWELL, 2003, p. 91). Diferentemente do Expressionismo, o Impressionismo fílmico queria evitar a teatralidade, procurando a naturalidade (p. 91). Schapiro (2002) entende que na literatura impressionista, os escritores descrevem paisagens em clima de transformação, em efeitos que "fornecem um contraponto dinâmico ao fluxo do sentimento, ao desejo, às respostas dos indivíduos aos estímulos mutáveis, aos efeitos difundidos de uma mudança súbita na consciência” (p. 307). Narrativas Impressionistas dependem de uma motivação psicológica: "como as narrativas clássicas, operam causa e efeito, mas as causas emergem de características e obsessões conflitantes do personagem" (THOMPSON; BORDWELL, 2003, p.97). Desse ponto de vista, $P P$ pode ser considerado um romance impressionista.

Thompson e Bordwell dividem o Impressionismo no cinema em três momentos distintos, ocorridos a partir do surgimento e da difusão de certos traços estilísticos: o pictórico, englobando os expedientes fílmicos mais diretamente ligados à manipulação da câmera (sobreimpressões, fora de foco, imagens deformadas), montagem rítmica acelerada, e finalmente a repetição e a difusão do estilo (p. 92). Segundo Martins (2006), ao buscar escrever com a câmera para instalar um olhar humano e mais natural, o Impressionismo francês consagra o reino da imagem, dando especial atenção ao tratamento do espaço, tais como enquadramento, profundidade de campo e ponto de vista, que somados a distorções plásticas, trabalha a 
materialidade não-figurativa da imagem, sua parte mais abstrata. No discurso fílmico de $P P$ todos esses elementos estilísticos podem ser discernidos.

$\mathrm{Na}$ mesma época, essas duas correntes estilísticas vão proporcionar enunciados discursivos para a composição de formas documentais poéticas, que procuram apenas registrar as imagens do mundo em um tipo de estética apoiada no ritmo e na diversidade das imagens: são os "filmes sinfônicos" sobre as metrópoles, cujo estilo baseia novas formas experimentais. Durante a década de 20, o documentário atinge o estatuto de cinema de arte (THOMPSON; BORDWELL, 2003, p.184). Em PP, as imagens textuturizadas e fluidas, cores oscilantes, dessincronias, inacessibilidades e obstruções de som e imagem, superposição de sons, câmera lenta etc, revelam a prática de atualização desses estilos discursivos e suas técnicas expressivas, e a oscilação entre o poético e o poético documental.

Depois da discussão sobre a incorporação de outros discursos fílmicos utilizados em $P P$, podemos voltar à discussão da práxis em relação ao sujeito da enunciação e ao seu devir. Desse ponto de vista, acredita-se que a existência de um ator da enunciação fortemente marcado no enunciado fílmico sugere a intensidade de assunção, caracterizada pela intensidade de um elo empático que une o sujeito à sua produção, e que se torna mais forte na medida em que ele se reconhece nele (FONTANILLE, p. 2008, p. 280). Como a somação impõe uma forma, por meio de uma assunção forte e reconhecimento restrito, conduzindo da difusão à revivificação de uma forma, o enunciador reinstala a textura, o fora de foco, a dessincronia, a imagem fluida e multidirecional, para o uso semissimbólico de estados mentais e afetos. A somação, relacionada à explosão do estranho, é o afeto intenso e concentrado, e sem extensão. O seu oposto, a difusão do familiar, é o que Alex busca. Em PP vimos como o ator da enunciação deixa suas marcas no enunciado, a partir do acúmulo de formas já utilizadas em diferentes estéticas, assim como adota e integra diferentes conteúdos musicais de gêneros diferentes para compor o seu discurso.

As operações enunciativas feitas a partir do devir do objeto, relativas à revolução da tradução intersemiótica e a flutuação de sentido entre o que se vê e o que se ouve, e as feitas a partir do devir da instância do discurso, baseadas na somação, ajustam-se ao projeto enunciativo do texto alvo: a flutuação causa não apenas um vaivém entre imagens, mas entre imagens e sons, que definem no conteúdo textual espaços internos e externos, e interiores e exteriores; a somação funda um texto repleto de enunciados discursivos expressivos e impressivos, adotados e integradas na enunciação a partir da atualização, contribuindo para a construção dos efeitos de subjetividade e estados mentais e psicológicos do narrador / ator. Nesse sentido, Alex possui marcas de construção de um novo realismo contemporâneo adotado pelo cinema, que utiliza e 
atualiza estéticas criadas a partir do início do século XX para dar conta do indivíduo sensível e da subjetividade.

A partir dessas constatações podemos voltar à questão do enunciatário projetado nos discursos literário e fílmico, e tirar algumas conclusões sobre sua construção: de um lado, em relação ao texto literário e suas isotopias temáticas e figurativas, ou seja, à semântica discursiva, a narrativa relata as ansiedades e angústias de um jovem norte-americano branco e de classe média, e que vive em um ambiente urbano que existe em um país ocidental e capitalista. Assim, o enunciatário projetado nesse texto deve ser capaz de se identificar com o mundo de Alex, seus desejos, anseios, hábitos e modos de ser e fazer, e possuir ou conhecer os mesmos valores sociais do protagonista, que poderíamos denominar cristãos, liberais e humanistas; deve também ser capaz de compreender as ansiedades pelas quais o ator passa, relacionadas à morte, à lei, à culpa, à sexualidade, aos vários problemas familiares, e as responsabilidades sociais sugeridas pelo destinador-produtor, que adota o ponto de vista desse jovem "siderado" e preocupado com o futuro.

Como a finalidade última de todo o ato de comunicação não é informar, mas persuadir o outro a aceitar o que está sendo comunicado, em um jogo de manipulação com vistas a fazer o enunciatário crer naquilo que se transmite (FIORIN, 2011, p. 75), do ponto de vista textual e linguístico, de sua sintaxe discursiva, o enunciatário do romance é construído como capaz de entender diferentes gêneros textuais e os vários tipos de meios de comunicação, como as correspondências (é interessante que mesmo sendo um jovem norte americano em 2006, Alex não tenha um celular), assim como certos procedimentos argumentativos, que consistem em um conjunto de procedimentos linguísticos e lógicos usados pelo enunciador para convencer o enunciatário: as formas do conteúdo e da expressão do romance, tais como a enunciação enunciada em primeira pessoa, projeções de tempo e espaço, e a utilização de itálicos, imagens, e operações retóricas.

Do ponto de vista fílmico, porém, no qual observamos formas artísticas expressivas e poéticas audiovisuais, o enunciatário parece ser um pouco diferente do projetado pelo romance. O discurso fílmico, que fragmenta o tempo e o espaço do enunciado, utiliza a voz-over, diferentes tipos de música, cria uma mise-en-scène bem menos convencional e esperada para o gênero drama teen (pensamos em filmes MTV), destruindo o realismo da narrativa visual e sonora standard, objetiva e fácil de acompanhar, aponta para a construção de um enunciatário mais "letrado" audiovisualmente, acostumado com a fragmentação das ideias e com o experimentalismo formal discutido acima. Tal estratégia focaliza um enunciatário conhecedor dos vários gêneros cinematográficos e até audiovisuais, mas não necessariamente jovem, e que 
possui certa maturidade para lidar com a narrativa lenta, elíptica, remissiva, e construída gradualmente dentro de uma estética que privilegia a falta de ação, a não-linearidade e a contemplação.

Vimos que do ponto de vista temático, o filme evita o romantismo e o coleguismo entre Macy e Alex, e a solidão e confusão do ator são mais enfatizadas do que a descoberta do amor. Em resumo, $P P$ não é um filme para adolescentes, e nem sua trilha sonora reflete esse mundo. Assim, se o romance projeta um leitor mais jovem e inexperiente, a partir de um texto verbal descomplicado, o filme sugere o contrário, um enunciatário diferenciado. Sendo elaborado como filme de arte e tons Expressionistas e Impressionistas, é esperado que o receptorinterpretante de $P P$ seja capaz de codificar a complexidade discursiva e narrativa proposta pelo enunciador.

\subsection{Resumo do projeto enunciativo: do texto $a b$ quo ao texto a quem}

A partir da ideia de que $P P$ é um texto sobre a passagem à maioridade e transformação de um adolescente que escreve sobre as causas e consequências de um evento inesquecível e traumático que muda a sua vida completamente, e dentro de uma temática mítica associada ao rito de passagem, delimitamos a narrativa dentro do percurso gerativo, da semiótica tensiva e da práxis enunciativa. Fundado sobre os valores semânticos fundamentais de vida e morte, e os tensivos continuação da continuação e continuação da parada. Privilegiando a ideia de mundo epifânico e de subjetividade fragmentada, o discurso literário é construído tensivamente pelos modos semióticos do acontecimento, do foco e do sobrevir, e uma sintaxe operada pela tonicidade, a triagem e a concessão: como o enunciador constrói o texto a partir da focalização do herói, é o seu ponto de vista que determina todas as estratégias discursivas da narrativa. Alex lembra e escreve sobre o acontecimento e o sobrevir para entrar em conjunção com um objetovalor relacionado, de um lado, à retirada de um "peso dos ombros" para continuar sua vida adolescente; e de outro, entender o que se passou pelo discurso, de maneira que ao relatar, tria e organiza lembranças sobre o trauma e suas consequências. Como é a partir do ator tudo é

relatado, conhecido e sentido, romance e filme estabelecem a primeira pessoa e ativam figurações corporais. Na pesquisa efetuada a partir da ferramenta Antconc percebeu-se que o verbo mais usado no texto literário é ver (see). Entre os verbos do sentido see / hear e watch / listen os primeiros, relacionados ao acidente, ao involuntário e à não-intencionaidade, foram mais utilizados que os primeiros, relacionados ao desejo e à intencionalidade, em uma estratégia 
que procura figurar o sujeito invadido por um mundo que não consegue controlar, sendo componentes da figuração do sobrevir: o mundo epifânico.

Além de buscar o sujeito "siderado", o romance adota a forma epistolar, criando um espaço flexível para tratar da subjetividade e suas aflições, de maneira mais direta e informal, e com forte registro de oralidade. Sendo modalizado tensivamente pela concessão, a narrativa é construída a partir de figuras retóricas relacionadas à intensidade e à aceleração, tais como a hipotipose, a hipérbole, o metaplasmo, a reticência, a interrogação, os metágrafos, elipses verbais e plásticas etc. As unidades narrativas do discurso, tais como os diálogos / cenas, os resumos, as digressões e descrições, não só contribuem para a construção da intensidade, mas controlam também a velocidade do discurso. Percebemos como a cena do acontecimento desacelera a narrativa, por justamente organizar o acontecimento e o início do sobrevir, de forma que o jovem revê lentamente o acidente para explicá-lo a si mesmo pela primeira vez. Além disso, notamos intensa exploração da expressividade tipográfica, os negritos, os itálicos, as maísculas etc, além do espaço planar da página, que sugere signos visuais, tais como cartões e cartazes. Do ponto de vista semissimbólico destacamos brevemente as categorias topológicas da página, e cromáticas e eidéticas das letras, para manifestarem gêneros textuais, tais como a carta, e estados passionais, qualidades sonoras, pensamentos sobre pensamentos, que também figuram um jovem dividido e confuso. Sendo um texto sincrético, o romance acolhe imagens, tais como o arame farpado, que marca as elipses tipológicas, o cartão do detetive e um pôster de "procura-se", imaginado pelo jovem quando ele foge do pátio de trens. Em relação à categoria topológica da página em branco, chamamos a atenção para o uso de espaços que fragmentam as ideias do narrador, formando o que denominamos elipses. Sugerimos que tais estratégias de sentido foram também acolhidas pelo enunciador fílmico, que realiza um discurso fragmentado.

O filme adapta os mesmos modos e sintaxes tensivas do romance, e constrói um discurso intenso, transpondo o seu conteúdo de maneira quase integral. Os conteúdos das estruturas semionarrativas e discursivas foram mantidos, o que caracteriza o texto a quem como bem fiel ao original. $\mathrm{O}$ mesmo acontece com a unidade discursiva do romance mais utilizado no filme, o diálogo, que apesar de ser retocado, mantém frases e sentidos do texto a quo. Assim, a narrativa fílmica mantém os mesmos atores, oscila entre passado e presente, possui a maioria das cenas do romance, transportando os mesmos espaços paratópicos e utópicos, familiares e não-familiares e tempos anteriores e posteriores. As características topológicas e geográficas foram igualmente preservadas, de modo que a pista de skate e o pátio de trens são locais ínferos, ligados ao elemento natural terra e à categoria cultura; e a casa do tio, espaço onde a principal 
performance do ator ocorre, é relacionada à natureza, sendo fortemente associada a água e ao fogo, elementos opostos que simbolizam à consciência, vida e nascimento, e também figuram no romance. O enunciador em segundo grau, narrador / ator, foi mantido no filme, expressandose em primeira pessoa e escrevendo textos cujo destinatário só será conhecido ao final de seus relatos. Isso posto, podemos dizer que todos os componentes da discursivização e tematização do romance foram transportados para o filme, não sem o auxílio das canções e músicas, que não apenas recriam os afetos do romance, como verbalmente produzem textos que se conectam a seus conteúdos. Assim:

Figura 166 - Transposição fiel de elementos do enunciado literário

\begin{tabular}{|c|c|}
\hline $\begin{array}{l}\text { Espaços, geografias, topologias e elementos } \\
\text { naturais }\end{array}$ & $\begin{array}{l}\text { Pista de skate e pátio de trem (subterrâneos: } \\
\text { terra), casa da família, casa do tio (mar: água } \\
\text { e fogo), escola, pista de patinação, cafeterias }\end{array}$ \\
\hline Tempo & Passado e presente \\
\hline Atores (destinatários e actantes sujeitos) & $\begin{array}{l}\text { Alex (o narrador em primeira pessoa), Jared, } \\
\text { Jennifer, Macy, tio Tommy, pai, mãe, irmão } \\
\text { menor, detetive de polícia e segurança. Alex } \\
\text { é um actante sincretizado em narrador e } \\
\text { narrado. }\end{array}$ \\
\hline Unidades discursivas & Diálogos e algumas descrições espaciais \\
\hline Cenas & $\begin{array}{l}\text { Escrita na casa da praia, brigas e sexo com } \\
\text { Jennifer, encontros com Macy, ir à pista duas } \\
\text { vezes, acontecimento, mentir à mãe, ir ao } \\
\text { shopping, comprar skate novo, falar com o } \\
\text { pai na garagem, encontros com o detetive na } \\
\text { escola. }\end{array}$ \\
\hline Breagem & Debragem enunciativa \\
\hline Temas & $\begin{array}{l}\text { Religiosos e espirituais, familiares, } \\
\text { interpessoais, psicológicos, afetivos, sociais, } \\
\text { meios de comunicação. }\end{array}$ \\
\hline
\end{tabular}


Apesar de ser intenso como o romance, e igualmente construindo um sujeito atônito pelo sobrevir, a intensidade fílmica é composta audiovisualmente por um forte contraponto entre tempo e espaço. Percebemos, de um modo geral, que o andamento do filme é desacelerado, sendo que a média temporal dos 281 planos, em um discurso de aproximadamente 1 h 21', descontado a duração dos créditos finais, é de 4 minutos, revelando um filme com poucos cortes e ritmo extremamente lento. Soma-se, a isso, a forte característica remissiva do discurso, com suas imagens lentas, repetições e longos planos. Ao mesmo tempo, e considerando um discurso que bebe do estilo impressionista e mais artístico e estético, ou gráfico, um vasto arsenal expressivo é utilizado para compor os enunciados audiovisuais, tais como ângulos acentuados, texturas de imagens, super / subexposições da luz, movimento fluido do quadro, dessincronização etc, fazendo com que eles tenham um ritmo interno próprio, que se torna acelerado por causa dos tipos e quantidades de contrastes que suportam para figurar a confusão e o sobrevir. Segundo Pietroforte (2012), que aproxima as acentuações tônicas de uma melodia, que é da ordem do tempo, às de uma pintura, que é da ordem do espaço, pode-se entender que quanto mais marcações na extensão da tela, mais o discurso plástico possui ritmo, ou andamento e aceleração, como nas duas gravuras de Mondrian, abaixo:

Figura 167: Ritmo plástico

Tela desacelerada Tela acelarada

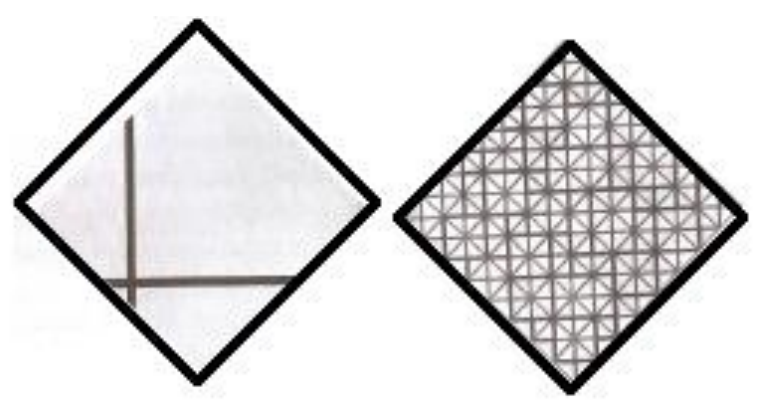

Fonte: Pietroforte (2012, p. 108)

Assim, pode-se dizer que o discurso fílmico cria um forte contraponto entre o ritmo temporal e plástico, o tempo cronológico e o tempo topológico, de modo que existe de um lado uma desaceleração na velocidade de duração do discurso em contraponto a uma aceleração de seu espaço planar imagético; de outro, imagens e sons desconectados, tanto figurativamente quanto em relação à sincronia entre vozes e lábios, também criam intensidades. Além disso, e apesar da enunciação de caráter lento, o discurso cria pontos de aceleração, ritmo compassado e dinamismo, como as imagens dos skatitas na rua, que denominamos documentais. A aceleração plástica, a desaceleração temporal e suas quebras, e as relações entre imagem e som 
são operações que, figurando o sobrevir e a passionalidade, revelam as operações concessivas da sintaxe fílmica tensiva. Se no discurso literário a sintaxe tensiva é gerenciada pela linguagem verbovisual tipográfica, no filme ela se dá por mudanças plásticas bruscas e inesperadas, sobreposições e figurações contrastantes entre imagem e som.

Dentro dessa estratégia significante, percebemos como o espaço cognitivo do enunciado, formado de imagem e sons, são figurados obstruídos, inacessíveis e acessíveis, e também contribuem para a construção do sobrevir, dos estados passionais e a ideia de lembrança fórica sugerida no romance. Os regimes intersubjetivos entre enunciador e enunciatário, o polêmico, não polêmico e não contratual (inacessibilidade, acessibilidade e obstrução respectivamente), são utilizados extensivamente, de modo que o enunciatário perde sua capacidade de observar elementos do texto audiovisual, em uma relação intersubjetiva disfórica, baseada tanto na negação do poder observar ou do saber visual, como do poder saber, através da remissividade e repetições elípticas. Enquanto o filme mantém os mesmos destinadores, sujeitos e objetos-valor do romance, observamos que sujeitos e antissujeitos são tratados plasticamente de maneira diferente, sendo mais e menos exibidos. A família de Alex, cujo papel narrativo é de não-destinador, é tratada visualmente como fora de quadro, de foco, com cabeças cortadas etc. As imagens de Jennifer são geralmente cobertas por Alex, ou estão obstruídas. De maneira geral, podemos dizer que o contrato que rege os regimes intersubjetivos entre o enunciador e o enunciatário é o polêmico.

As estratégias de construção de um discurso fílmico regido pela intensidade, aceleração e remissividade revelam forte investimento estilístico, ou seja, a presença de um enunciador que chama a atenção para si próprio, e que apesar de não revelar o aparato cinematográfico, utiliza-o de maneira mais intensa e reflexiva, explorando todas as suas potencialidades expressivas. Assim a partir da ideia de enunciador, enunciação e texto a quem, importantes diferenças entre os textos, ambos fortemente marcados pelo enunciador, podem ser delineadas. Vimos, por exemplo, que compondo um discurso fragmentado, mas menos linear e emissivo do que o literário, o enunciador fílmico posiciona o acontecimento no meio da narrativa, gerando suspense e a ideia de reinício, para depois arrematá-la. Nesse sentido, após a intensidade crescente, o filme, exatamente em sua metade, é modalizado tensivamente como mais menos, e o discurso desacelera brevemente para o início da resolução, na qual a presença de Macy cresce, até ela sugerir a escrita das cartas ao ator.

Outra importante diferença entre o texto fonte e o texto alvo, é que este não adapta o importante conteúdo da última carta e realiza a cena da queima das cartas, que simboliza a parada da parada do sofrer e do sobrevir. A omissão da última carta altera o caráter existencial 
do ator, que no filme parece menos ligado a Macy do que ao mundo do skate, proposta feita na última sequência do filme, e mais solitário. Além disso, além da cena retirada, outra é adicionada à narrativa fílmica: a dos jovens comprando roupas em um brechó, uma maneira criativa de mostrar o poder de Jennifer sobre Alex, sua personalidade autoritária e desejo de ser adulta. Do ponto de vista da práxis enunciativa, comentamos que cada discurso atualiza outros enunciados. De modo geral, podemos categorizar similaridades e diferenças importantes, ou tônicas, entre o romance e filme, da seguinte maneira:

Figura 168 - Características discursivas gerais da enunciação literária e fílmica

\begin{tabular}{|c|c|}
\hline $\begin{array}{l}\text { Romance } \\
\text { Modo: sobrevir, foco, acontecimento } \\
\text { Sintaxe: tônica, triagem, concessão }\end{array}$ & $\begin{array}{l}\text { Filme } \\
\text { Modo: sobrevir, foco, acontecimento } \\
\text { Sintaxe: tônica, triagem, concessão }\end{array}$ \\
\hline $\begin{array}{l}\text {-Marcas da enunciação no enunciado } \\
\text { •Discurso linear (emissividade) }\end{array}$ & $\begin{array}{l}\text {-Marcas da enunciação no enunciado } \\
\text { •Discurso não-linear (remissividade) }\end{array}$ \\
\hline $\begin{array}{l}\text {-Discurso marcado pela intensidade: } \\
\text { andamento acelerado e tônico a partir de } \\
\text { conteudo e expressão acelerados (retórica e } \\
\text { unidades discursivas intensas e aceleradas; } \\
\text { investimento na expressão tipográfica: } \\
\text { negritos, itálicos etc). }\end{array}$ & $\begin{array}{l}\text {-Discurso marcado pela intensidade: } \\
\text { andamento acelerado e tônico }{ }^{204} \text {, a partir de } \\
\text { uma expressão lenta (desacelerada), extensa, } \\
\text { e contrastante (sobreposições e choques entre } \\
\text { imagens e sons, assincronias, planos longos, } \\
\text { poucos cortes, câmeras lentas, ângulos } \\
\text { abruptos, imagens granuladas, falta de } \\
\text { nitidez, alterações bruscas de categorias } \\
\text { topológicas, cromáticas e eidéticas etc.); e de } \\
\text { um conteúdo intenso e acelerado (a morte de } \\
\text { um homem e o amadurecimento pessoal) } \\
\text { - Acontecimento no meio da narrativa } \\
\text { (suspense, resolução e reinício) } \\
\text { - Narrador em primeira pessoa apenas sonoro } \\
\text { (voz-over); uso de PP (debreagem } \\
\text { enunciativa) } \\
\text { - Fechamento da narrativa menos delineado: } \\
\text { corte dos conteúdos da última carta }\end{array}$ \\
\hline
\end{tabular}

${ }^{204} \mathrm{O}$ andamento desacelerado do discurso fílmico também aponta para outra leitura sobre os componentes da intensidade: desaceleração tônica temporal e aceleração espacial. Assim, pode-se propor também uma aceleração negativa ou uma desaceleração sobrecontrária. 


\begin{tabular}{|l|l|}
\hline $\begin{array}{l}\text { - Gêneros literários: romance epistolar, } \\
\text { drama / thriller psicológico (citação de de } \\
\text { Dostoievski), romance infanto-juvenil }\end{array}$ & $\begin{array}{l}\bullet \text { Gêneros fílmicos: expressionismo, } \\
\text { impressionismo e filme de arte }\end{array}$ \\
$\begin{array}{l}\text { - Regime intersubjetivo entre enunciador e } \\
\text { enunciatário é contratual }\end{array}$ & $\begin{array}{l}\text { - Regime intersubjetivo entre enunciador e } \\
\text { enunciatário é polêmico }\end{array}$ \\
& $\begin{array}{l}\text { Cenas adicionadas: queima das cartas na } \\
\text { praia; e jovens em uma loja de roupas }\end{array}$ \\
\hline
\end{tabular}

Fonte: autor

Enquanto no discurso literário as categorias expressivas eram relacionadas a imagens sonoras (fonético / fonológicas) e tipológicas, do ponto de vista tensivo do discurso fílmico, as categorias expressivas existem como igualmente plásticas, audiovisuais, mas também cinemáticas e sonoras, e dentro de células tensivas complexas e profundas, podendo ser mais ou menos breves ou aceleradas, criando ritmos mais pontuais (planos curtos) vs. durativos (planos longos), acentos tônicos plásticos (mais cortes) vs. acentos menos tônicos (menos cortes), velocidade normal vs. anormal da imagem, gradações plásticas (imagem / som) vs. saltos plásticos. A partir desses significantes, o plano da expressão do discurso fílmico manifesta signos visuais e sonoros mais ou menos icônicos, músicas mais ou menos rítmicas, imagens mais ou menos aceleradas, imagens e sons mais ou menos sincronizados e observadores e informantes mais e menos fluidos no espaço da diegese. Assim, a biplanaridade do texto fílmico de PP é construída da seguinte maneira:

Figura 169 - Elementos do plano da expressão e do conteudo fílmico

\begin{tabular}{|l|}
\hline \multicolumn{1}{|c|}{ Plano expressivo plástico audiovisual (considerando gradação mais / menos) } \\
\hline - Categorias eidéticas e cromáticas sem granulação vs. com granulação \\
- Cromatismo normal (cores vibrantes) vs. cromatismo anormal (cores apagadas); calros e \\
escuros acentuados \\
- Categorias plásticas contínuas (composição) vs. categorias plásticas descontínuas \\
(recomposição) \\
- Acentos tônicos musicais (ritmo, tonalidade, duração marcada, intensidade variada) vs. \\
acentos átonos musicais (timbre, atonalidade, duração difusa, intensidade estável ) \\
- Acentos tônicos plásticos no andamento temporal (cortes) vs. acentos âtonos plásticos no \\
andamento temporal (duração da imagem)
\end{tabular}


- direcionalidade uniforme $v s$. direcionalidade não-uniforme (multidirecional)

- Contrastes tônicos plásticos no andamento espacial (aceleração) vs. contrastes átonos plásticos no andamento espacial (desaceleração)

- Coerções materiais diferenciadas: suporte fotoquímico mais sensível à luz (35rmm) vs. suporte fotoquímico menos sensível à luz (18mm)

Plano do conteúdo audiovisual (considerando gradação mais / menos)

- Sincronia imagem / som vs. assincronia imagem / som

- Ícones visuais e sonoros $v s$. figuras visuais e sonoras

- Exibição vs. Inacessibilidade visual e sonora

- Músicas, canções (ritmo / altura: notas) vs. paisagens sonoras eletroacústicas (timbre / duração)

- Discurso ficcional (imagem não-granulada) vs. discurso não-ficcional (imagem granulada)

- Planos longos e fluidos vs. planos curtos

- Imagens exibidas na velocidade padrão vs. imagens lentas ou aceleradas

Fonte: autor

Dentro da proposta de um discurso expressivo que busca mimetizar o sensível, a questão semissimbólica é um desafio tanto para o texto literário como para o fílmico, uma vez que ambos são extensos e produzem diferentes relações simbólicas entre categorias de expressão e do conteúdo durante a enunciação. Observamos no filme, por exemplo, como as categorias topológicas, cromáticas e eidéticas das imagens da família de Alex simbolizam a distância afetiva entre o jovem e os pais, cortados da imagem, observados sem nitidez (fora de foco), ou distantes, assim como acontece com Jennifer, mas se relacionam ao percurso temático da "falta ou incerteza do amor". Da mesma maneira, as categorias plásticas e cinemáticas articulam os estados afetivos do jovem e sua solidão. Verificamos que muitas vezes ele é também mostrado com pouca nitidez, seu corpo é cortado pelo quadro, ou colocado na parte inferior da imagem, visto à distância e diminuído, ou seja, enunciado dentro do espaço como inacessível ou obstruído. Na sequência acontecimento, no pátio de trens, as cores escuras e frias predominam, assim como o andamento intenso e rítmico da música clássica se opõe ao andamento mais estável e durativo da paisagem sonora, de modo que o ritmo e o andamento da Nona Sinfonia se relacionam a categorias fundamentais, como a morte; da mesma maneira, na cena do chuveiro, timbres, durações difusas e sons do mundo natural da trilha sonora, assim 
como a oscilação cromática da imagem relacionam-se a categorias passionais e empáticas, como a entrada no mundo epifânico, o medo e o trauma.

As categorias expressivas das composições eletroacústicas, mais utilizadas em relação ao mundo do skate, igualmente relacionam seus timbres, alturas, durações e intensidades à categoria temática da lembrança e aos valores de vida. As imagens com textura, utilizadas apenas para o mundo do skate e para a cena de Alex na praia com um cão, igualmente alicerçam os valores de vida, e a conjunção do jovem com o mundo valorizado do skate; e de outro, são utilizadas para articularem a veridicação do discurso, oscilando entre "ficção e realidade", ser e parecer, produzindo dicotomias entre outros gêneros discursivos, como filme / documentário. $\mathrm{Na}$ última sequência do filme, na qual skatistas e Alex são mostrados tanto por imagens granuladas como por imagens normais, as categorias cromáticas e eidéticas relacionam-se ao tema da maioridade e à categoria fundamental vida. De modo geral, como toda a narrativa é a lembrança passionalizada e disfórica de um sujeito, as categorias expressivas literárias e fílmicas semissimbolizam paixões e o ator traumatizado. No filme, o conteúdo remissivo projetado por essas articulações de sentido simbolizam a própria continuação da parada do mundo epifânico.

Em relação à semiótica proxêmica e gestual, avaliamos que de um total de 281 planos, 83 eram relativos a distâncias aproximadas dos atores (PP e 1/2PP), 90 eram planos médios e 103 planos distantes (PA, PCj e PG), de maneira que a aproximação foi explorada em quase metade dos enquadramentos, construindo em relação ao ator, como no romance, debreagens enunciativas. O PM, plano mais utilizado, foi considerado um termo complexo composto de aproximação e distância, e utilizado como tensão entre interior e exterior. Dentro da discussão semissimbólica, a categoria aproximação e distância relaciona-se com os espaços exteriores e interiores, e valores fundamentais público / privado.

Finalmente, em relação à práxis enunciativa, ainda pouco explorada, além de concluirmos que o discurso fílmico bebe de fontes expressionistas, impressionistas, e do filme de arte / poético documental, consideramos que a adaptação poderia ser enquadrada dentro do tipo tensivo da revolução semiótica, na qual conjuntos significantes são comutados, e o aparecimento de um acarreta o desaparecimento do outro. Em relação ao texto fílmico como um discurso que incorpora outro discurso, consideramos que a transformação tensiva empregada pelo enunciador é a flutuação, uma vez que o discurso audiovisual concessivo se dá a partir da sobreposição de sons, ou oposição entre imagens e sons que funcionam metaforicamente, possuindo um valor duplo e oscilante, sugerindo um espaço e tempo que parecem estar além da diegese, ou paralela a ela. Como flutação discursiva, e dentro da tensão 
entre fidelidade e infidelidade do tradutor, o discurso fílmico aponta menos para a criação de outros sentidos do que de duplos sentidos, ou seja, de temas e imagens caros ao ator da enunciação, tais como a juventude perdida, a homoafetividade, a figura protetora da pietá e o céu, que são sobrepostos aos temas e figuras do romance de maneira sutil e metassimbólica.

Do ponto de vista do sujeito produtor do discurso localizamos operações de somação, que indicam o elo empático entre sujeito e produção. Assim, percebemos na narrativa um forte investimento enunciativo que busca metáforas e metonímias visuais sensíveis, ou seja, o mimetismo da memória afetiva, alterando a ordem das sequências, propondo sons e músicas diferentes e especiais, utilizando ângulos diferentes e imagens nem sempre nítidas, criando um discurso polêmico, contrapontual, concessivo etc. A operação discursiva da somação funda um texto repleto de enunciados discursivos oriundos de outros discursos fílmicos e audiovisuais, tais como o expressionista, o impressionista e o filme de arte, ou o avant-garde, que são atualizados, integrados e realizados com o discurso alvo, contribuindo para a construção dos efeitos de subjetividade e estados mentais do narrador / ator.

A somação revela o trabalho de um ator da enunciação preocupado em construir a intensidade psíquica do ator do enunciado, fundindo não apenas enunciação e enunciado, mas enunciador e enunciatário, que é mergulhado nas profundezas de um espaço interior subjetivo articulado por tensões concessivas da relação imagem e som e suas durações. Ao propor um filme apoiado menos na palavra e na narrativa organizada em ordem cronológica e emissiva, do que em imagens e sons nem sempre são sincronizados ou lógicos, na não-linearidade e na remissividade, GVS constrói um discurso fortemente paradigmático e pontual, feito em pedaços que precisam ser ordenados pelo enunciatário. Nesse quebra-cabeças expressivo, busca-se menos sua participação inteligível do que sensível. A velocidade lenta, poucos cortes sons eletroacústicos e planos longos sincronizam o tempo da enunciação do enunciado e do enunciatário e provocam o sentido de tempos vividos e compartilhados, fundindo espaços e tempos diferentes em dois tempos diferentes que se alinham: o do enunciador e o do enunciatário. Mergulhado na mente do ator e em seu mundo epifânico, o enunciatário vive a própria “sideração". Propondo um texto menos acessível e mais hermético, sensível e artístico, o enunciador de $P P$ exige um enunciatário paciente, maduro e sofisticado, que se depara com um discurso que minimiza a ação e a lógica das causas e consequências e pretende ser, antes de tudo, uma experiência sensível, durativa e intensa, um discurso-acontecimento. 


\section{CONCLUSÃO}

O objetivo da tese foi o de discutir e analisar o processo de adaptação de uma obra literária para o cinema a partir da semiótica narrativo-discursiva, que diferenciamos de uma semiótica comunicativa / informacional, observando como suas ferramentas analíticas, advindas da linguagem verbal e especulações sobre suas articulações, formas e conteúdos, podem contribuir para os estudos da tradução, entendida semioticamente como condição primordial da vida e sobrevivência humana. Como o nosso escopo foi de ordem discursiva e mitopoética, pois analisamos duas narrativas, utilizamos o percurso gerativo, a semiótica tensiva e as modalidades de existência da práxis enunciativa como base para as análises dos textos envolvidos na operação, observando algumas articulações inter e intratextuais entre plano de conteúdo e expressão, e similaridades e diferenças temáticas e figurativas relacionadas a um projeto enunciativo do enunciador e do ator da enunciação.

A diferenciação de um texto $a b$ quo e um ad quem, a mesma utilizada para descrever as estruturas semionarrativas e discursivas do percurso gerativo foi sugestiva, pois colocou o texto fonte em relação direta com o texto alvo, mas em um nível inferior do "percurso da adaptação", mais abstrato e profundo. Utilizando a mesma analogia para o texto alvo, a adaptação propriamente dita, estaria em um nível mais superficial, concreto e prático. O texto adaptado, amalgamado a um texto mais abstrato, como no percurso, existiria também em uma dinâmica prática. Posto isso, podemos dizer que vislumbramos duas direções básicas da análise da transposição intersemiótica, que podem ser do texto fonte ao texto alvo, ou vice-versa. Em nosso caso, uma vez que pensamos a partir da origem e não do destino da adaptação, fomos da fonte ao alvo, do ab quo ao a quem, em uma direção que também precisa ser discutida cientificamente, pois traz diferenças de análise. A ideia de tomar a iniciação do "início" foi a de tentar esgotar o texto fonte, para melhorar avaliar o texto alvo, e observar como os tropos intensos foram ressignficados audiovisualmente. Nesse sentido, subvertemos as práticas de análise da adaptação, que geralmente adotam outra direção: a do texto alvo ao texto fonte.

Observamos que a linguagem verbal adota novas características ao ser utilizada no texto literário impresso, que forma um conjunto significante diferente do oral, e se aproxima do filme de várias maneiras: ambos os textos são planares, estruturando o sentido em uma área ou campo delimitado, a página e o quadro, e expressos por categorias plásticas, de modo que o texto literário pode conter imagens e utilizar significantes tipográficos plásticos (ângulos e formas diferentes de letras e números, negritos, sublinhados, tachados etc.). Ademais, ambos os textos são produzidos tecnologicamente, sendo relacionados às línguas naturais, que existem como 
línguas de entrada ou de saída do sentido, sua criação ou interpretação. Finalmente, ambos os conjuntos significantes são narrativo-discursivos por natureza, semânticos, dinâmicos e tensivos. Partindo das considerações semióticas sobre linguagem verbal e audiovisual, das aproximações entre texto literário e fílmico, e do ponto de vista semio-discursivo, é possível obter um vasto arsenal para a análise da adaptação como operação inteligível e "sensível", de modo que a tensão é controlada por um enunciador em operações espaçotemporais de mais $e$ menos sobre os elementos de sentido, sejam do plano da expressão ou do conteúdo, do enunciado ou da enunciação.

Duas noções discursivas que nortearam a discussão foram a de figurativização e proxêmica. Como operação presente tanto no enunciado como na enunciação, entendeu-se a primeira como "fechamento" do sentido, término da produção do texto. Assim, de um lado, foi aproximada, na práxis enunciativa, ao discurso realizado, uma vez que não existe realização sem algum tipo de figuração, e de modo que só a partir da figurativização pode haver potencialização, virtualização e atualização de enunciados. Ao mesmo tempo, como sentido "recrudescido", ela também possui movimento e andamento, no tempo e no espaço, podendo ser tomado não apenas como categoria do comteudo do enunciado, mas da enunciação, que também utiliza atores, tempos, espaços e ideologias, deixando suas marcas e traços no enunciado: a partir daí, o percurso do sentido foi pensado como ferramenta que pode ser utilizada tanto para o enunciado, o "o que é narrado", como para a enunciação, o "como é narrado".

Partindo da ideia de construção do espaço cognitivo e do movimento, propostos por Fontanille, que detecta uma tensão entre observador enunciador e enunciatário, de modo que o primeiro é modalizado pelo fazer saber e o segundo pelo não poder não observar (semas que percorrem eixos contrários, contraditórios e subcontrários), também foram analisadas as figurações verbovisuais e audiovisuais do espaço cognitivo, e suas figurações como exposição, inacessibilidade, acessibilidade e obstrução. Do ponto de vista dos movimentos no espaço, trabalhou-se com a noção de espaço figurado aspectualmente e cinematicamente, e adotaramse as modalidades de movimento do ator no espaço, a distância, a ocupação, o cruzamento e a difusão também para o enunciador fílmico cinemático.

Por causa da ilusão de movimento, tanto do enunciado como da enunciação, achamos pertinente observar o cinema do ponto de vista da semiótica proxêmico-gestual, que trata da construção de sentido através de movimentos e gestos no espaço. Assim, como o cinema é comparado tanto ao teatro como à dança, a semiótica lembra que o sentido fílmico é, por causa da atividade de um observador plástico que se move no espaço bi e tridimensional motivado, 
um discurso coreográfico. A partir da noção greimasiana de gesto prático, mítico, e estético, lembramos que a câmera cinematográfica se torna uma ferramenta de extensão do corpo humano (e da visão), sendo operada pela gestualidade e gesticulando; de outro, cria o espaço cognitivo da narrativa, desdobrado em imagem e som. Apesar de o cinema ser uma linguagem sincrética, entendemos a imagem como superiormente hierárquica aos outros elementos visuais do filme, como a arquitetura, a gestualidade, a moda etc, pois suas categorias plásticas podem influenciar e alterar tudo que é observado. Além disso é a partir da edição, que fecha e encerra o sentido do texto fílmico, e faz parte da figurativização, que distâncias e gestos, e todos os elementos visuais e sonoros do texto fílmico ganham duração e vida. Observamos no texto alvo como a semiótica proxêmica e gestual do observador, que articula aspectualidades espaciais e sonoras opera os sentidos na narrativa.

Para a nossa análise, partimos do princípio que o romance tenta, antes de tudo, colocar um sujeito sensível e frágil no mundo, e em fase profunda de transformação, com angústias e buscas de caráter humano, construindo um discurso tenso que precisa dar conta das paixões, confusões, euforias e disforias desse sujeito, relacionadas a um evento traumático e suas consquencias psicoogicas, que são também sociais, morais e éticas. O filme de Gus Van Sant segue com fidelidade a proposta do romance, quebrando os paradigmas fílmicos mais comuns para mostrar o "estado de choque", sendo audacioso em suas escolhas narrativas e estilísticas, e bebendo de fontes discursivas fílmicas que ajudam a traduzir o ator do romance como espaço interior e profundo, dotado de um campo de presença figurado a partir de uma ressonância audiovisual, de velocidades temporais e espaciais: focalizado a partir desse sujeito da falta, o discurso fílmico, assim como o romance, procura fundir o enunciatário ao corpo e à mente atordoada desse jovem que passa por uma prova e uma transição de valores.

Apesar de ser fiel ao romance observamos que, eliminando a maioria da narrativa verbal, que contém uma série de comentários e divagações do jovem sobre o mundo, o filme busca ser menos sobre a maioridade do que sobre o próprio sobrevir. Como romance e filme existem a partir da ideia do concessivo, do improvável, do surpreendente, mostra-se a pertinência da questão dos modos e sintaxes tensivas, que Zilberberg acredita serem fundamentais para o estudo do sentido, pois possibilitam a inteligibilidade cognitiva do inesperado fórico. Os textos foram escolhidos como objetos de estudo por justamente não apenas figurarem a sensação intensa do trauma e do choque, mas estendê-la ao máximo no tempo. A semiótica tensiva, que entende o acontecimento e o sobrevir como modos discursivos que geram textos verbais e não verbais, calcula que ambos foram sempre figurados na existência do homem linguageiro, dentro 
de estéticas relacionadas a práticas e coerções, a bricolagens semióticas, confirmando uma práxis tambem figurativa e mitopoética.

Posto isso, e frente a um discurso literário que pretende a inserção do sobrevir na narrativa, relacionado ao sujeito "traumatizado" e transformado, e mergulhado em um mundo epifânico, tentamos observar como o filme elabora dinâmicas formais e estéticas que alicerçam esse tipo de figuração. De um lado, e mais naturalmente, observamos como os atores, espaços e tempos do romance são transpostos para o filme; do ponto de vista do percurso, porém, examinamos também transposições audiovisuais de semas fundamentais, manipulações, percursos narrativos, temáticos e figurativos, que foram figurados por imagens e sons em movimento, e por distâncias e gestos do observador cinemático. Além disso, consideramos a página do livro como quadro visual, uma vez que o romance trabalha com certas "imagens" e expressões plásticas tipográficas como investimentos de sentido para manifestar o sobrevir e o corpo do ator inserido no mundo, e de modo que tais potencialidades visuais podem interessar o enunciador do texto alvo. Vimos na sequência acontecimento do filme, como o espaço topológico construído pela língua natural auxilia a figuração do texto audiovisual, a partir das figurações topológicas verbais do espaço, que é um tipo de descrição do espaço.

A partir do que já discutimos no último subcapítulo da tese, algumas considerações merecem ser feitas sobre limitações da análise, e sugestões para encaminhamentos teóricos futuros. Primeiramente, não se pode afirmar com certeza se o tex to lido pelo enunciador fílmico é o mesmo analisado nessa tese. É capaz que, como ambos, escritor e cineasta, escreveram o roteiro do filme, o texto literário exista mais como manuscrito do que como trabalho tipográfico e visual acabado, e tenha sido publicado, ou publicado novamente depois do sucesso do filme. Posto isso, podemos supor que os investimentos de sentido discriminados aqui não existiam no manuscrito original, tendo sendo assimiladas posteriormente. A questão não é um empecilho para as nossas discussões pois: a análise foi quase inteiramente centrada no discurso verbal e menos nos elementos tipográficos da página. Assim, em caso de confirmação que a adaptação não ocorreu a partir do romance impresso, esse aspecto da análise pode ser desconsiderado, mas não invalida a pertinência da discussão, pois a página do livro é operada por categorias plásticas que podem motivar a adaptação (como acontece com traços e cores de gravuras de romances e graphic novels, e até tipos de letras). Ademais, mesmo no caso mais remoto da preexistência do filme em relação ao romance, então é possível que justamente o oposto tenha ocorrido, e o texto literário, entendido como conjunto significante parte não-natural e tecnológico, tenha adaptado o texto impressionista audiovisual do filme. Mais uma vez, a possibilidade não 
invalida as discussões e análises articuladas, oferecendo outros pontos de vista para a o estudo adaptação e da transposição semiótica.

Em relação ao programa Antconc, achamos interessante utilizá-lo além de suas aplicações mais costumeiras, verificando relações verbais inter e intratextuais, e observando como o texto verbal comporta-se no romance e no filme adaptado. Percebemos quantidades e tipos de palavras, pontuações e tempos verbais empregados no texto literário, que puderam ser relacionadas ao tipo de discurso e tema da narrativa proposta, apoiados na idea de maioridade a partir do sobrevir, e pudemos comparar as palavras empregadas na narrativa literária com as empregadas na narrativa fílmica, assim como observar a transformação do texto verbal escrito em texto verbo-audiovisual "encorpado" por voz e imagem. Com essa ferramenta, a velocidade da análise dos textos verbais foi também facilitadas. A partir daí, no entanto, sentimos que a comparação verbal dos textos foi apenas superficial, e poderia ter sido mais explorada, inclusive em relação aos textos verbais das canções. De qualquer maneira, a análise linguística computacional do texto verbal em adaptações pode ser considerada um horizonte de pesquisa profícuo para a área.

Em relação à própria teoria semiótica utilizada, as noções de intensidade e extensidade, sincretismo, práxis enunciativa e semissimbolismo ainda precisam ser mais aprofundadas tanto em relação ao cinema quanto a adaptação fílmica. Nesse trabalho, as contribuições para essas questões tiveram apenas caráter sugestivo e de encaminhamento epistemológico, e precisam de mais formulações e comparações. A práxis, que sugere relações com a bricolagem, interdiscurso, intertexto e gênero, provou ser útil para o estudo da transposição intersemiótica, mas suas categorias ainda geram dúvidas de aplicação. Do ponto de vista semissimbólico entre texto verbal e fílmico, a questão também provou ser árdua, pois suscitou indagações sobre uma aparente contradição na afirmação de que o primeiro poderia ser de ordem estética, ou poética, e utilitária, enquanto o segundo apenas estética. De outro lado, se é fato que o filme seja naturalmente semissimbólico, e nunca apenas simbólico, e tendo em vista a extenção e as transformações constantes de sua narrativa audiovisual em movimento, isso significa que para cada cena, ou sequência, novas operações serão construídas a partir das mesmas e poucas categorias do plano da expressão. O mesmo problema ocorre em relação ao romance. Assim, em nossa análise, apenas apontamos em ambos os textos construções semissimbólicas mais gerais, relacionadas ao acontecimento e ao sobrevir, e a figuração de suas consequências emocionais na vida do narrador. De qualquer maneira, pensamos que tanto a práxis como o semissimbolismo precisam ser tratados como tópicos independentes em relação ao cinema e à literatura, assim como sua pertinência para a adaptação deve ser explorada. 
Outros pontos que podem ser considerados problemáticos na discussão, e criticados, são as análises quantitativas e qualitativas do estudo, em relação tanto à duração temporal dos planos, como suas quantidades e tipos. De um lado, tanto a contagem de número de planos como suas durações foram feitas a partir de equipamentos caseiros e amadores, de modo que os dados numéricos ficam comprometidos. De outro, os tipos de planos arrolados para comporem as silabas proxêmicas tensivas, também podem ser questionados, uma vez que a diferença entre PPs, $1 / 2$ PPs, PM etc. são recortes de ordem um tanto subjetiva, não sendo equiparadas à discriminação de notas musicais ou sílabas, e podendo ser contestadas. A despeito desses problemas, sentimos que a análise quantitativa e qualitativa foi fundamental para nossas argumentações, e lembramos que mesmo podendo ser inexata, pretendeu registrar, de forma bem geral, descontinuidades maiores e menores no andamento enunciativo proxêmico e gestual. Mais uma vez, pensamos que, mesmo que as análises da decupagem sejam inexatas, tais problemas não interferem nas leituras do texto audiovisual, e nem alteram suas conclusões básicas. Em relação à semiótica tensiva, as sobreposições de diferentes ritmos da imagem, som e movimento provaram ser árduas para a análise, uma vez que o filme, do ponto de vista de seu andamento plástico e sonoro, parece ser um texto composto de diferentes andamentos plásticos, cinemáticos e sonoros: relacionamos minimamente a expressão à desaceleração e à extensidade; e o conteúdo à aceleração e intensidade. Concluímos que o texto fílmico, que possui expressão cinemática, opera diversas camadas de intensidade e extensidade, aceleração e desaceleração, que merecem maior investigação e discriminação.

Acreditamos, a partir dessas considerações, que a semiótica narrativo-discursiva se mostrou uma poderosa ferramenta para o tratamento da questão da tradução intersemiótica, sucitando novas questões, enfrentamentos e possibilidades científicas de abordagem dentro desse campo de estudo. A partir daí, só nos resta desejar que a tese sirva como inspiração para outras discussões desse tipo, mas que também extrapole os centros acadêmicos, pois pode ser entendida como o estudo de transposição do sentido entre os diferentes conjuntos significantes, uma questão importante em todas as áreas do conhecimento humano. 


\section{REFERÊNCIAS BIBLIOGRÁFICAS}

AUMONT, Jacques. El rostro en el cine. Barcelona, Buenos Aires, México: Paidós, 1998.

; MARIE, Michel. Dicionário teórico e crítico de cinema. Tradução: Eloisa Araújo Ribeiro. Campinas, SP: Papirus Editora, 2003.

O olho interminável: cinema e pintura. Tradução: Eloisa Araújo Ribeiro. São Paulo: Cosac Naify, 2004.

A imagem. Tradução: Estela dos Santos Abreu e Claudio C. Santoro. São Paulo. Papirus Editora. 11 $1^{\mathrm{a}}$ edição. 2006.

BARROS, Diana Luz de. De la perfection: duas reflexões. In: Semiótica, estesis, estética. Eds. Eric Landowski, Raul Dorra, ana Claudia de Oliveira. 1998. p. 119-133.

BARROS, Diana Luz de. Teoria do discurso: fundamentos semióticos. São Paulo: Humanistas. FFLCH-USP, 2002.

BEIVIDAS. Waldir. Semióticas sincréticas: posições (a linguagem no cinema). São Paulo: Annablume, 2015.

BERTRAND, Denis. Caminhos da semiótica literária. São Paulo: EDUSC, 2003.

BONITZER, Pascal. Le champ aveugle: essais sur le cinema. Col. Jean Narboni. Cahiers du cinéma. Gallimard. Éditions Gallimard, 1982.

BORDWELL, David. Narration in the fiction film. Great Britain: Methuen \& Co. Ltd.. 1985.

BORDWELL, David; THOMPSON, Karen. A arte no cinema: uma introdução. Trad. Roberta Gregoli. São Paulo: Editora Unicamp. Edusp, 2013a.

BORDWELL, David. Sobre a história do estilo cinematográfico. Trad. Luis Carlos Borges. Campinas, São Paulo: Editora Unicamp, 2013b.

BRANIGAN, Edward. Point of view in cinema: a theory of narration and subjectiviy in classical film. Berlin, New York, Amsterdam: Mouton Publishers, 1984.

BRILL, Alice. O Expressionismo na pintura. In: O Expressionismo. Org. J. Guinsburg. São Paulo: Perspectiva, p. 389-448. 2002.

BUCH, Esteban. Música e Política: a Nona de Beethoven. Tradução Maria Elena Ortiz Assumpção. Bauru, São Paulo: Edusc, 2001.

CÁNEPA, Laura Loguercio. Expressionismo alemão. In: História do cinema mundial. Org. Fernando Mascarello. Campinas, SP: Papirus, p. 55-88, 2006. 
CANTARELLA, Eva. Pandora's daughter: the role and status of women in Greek and Roman antiquity. Baltimore and London: Johns Hopkins University Press, 1986.

CASETTI, Francesco. Adaptation and Mis-adapttions. Film, Literature, and Social Discourses. In: A companion to literature and film. Edited by Robert Stam and Alessandra Raengo. Blackwell Companions in Cultural Studies (Book 20). Wiley-Blackwell, 2004. p. 81-91.

CHATMAN, Seymour. Story and Discourse: narrativve structure in fiction and film. Ithaca and London: Cornell University Press, 1978.

Coming to terms: the rhetoric of narrative in fiction and film. New York: Cornell University Press, 1990.

CHION, Michel. A audiovisão: som e imagem no cinema. Lisboa: Texto e Grafia, 2008.

COKER, Wilson. Music \& meaning: a theoretical introduction to musical aesthetics. New York: The Free Press, 1972.

COOK, Nicholas. Beethoven: symphony n 9. Cambridge music handbooks. Cambidge University Press, 1993.

DELEUZE, Gilles. Cinema 1: a imagem em movimento. Tradução: Stella Senra. São Paulo: Editora 34, 2018.

DOANE, Mary Ann. A voz no cinema: articulação de corpo e espaço. Tradução de Luciano Fiqueiredo. In: A experiencia no cinema. Org. Ismail Xavier. Rio de Janeiro: Grall, 1983.

DYER, Richard. Nino Rota: music, film, feeling. London: Palgrave Macmillan, 2010.

ELLIOT, Kamilla. Rethinking the novel /film debate. Cambridge University Press, 2003.

EISENSTEIN, Sergei. O sentido do filme. Rio de Janeiro: Jorge Zahar Editor, 1990.

A Forma do Filme. Tradução: Teresa Otoni. Rio de Janeiro: Jorge Zahar Editor, 1990.

FALSETTO, Mario. Conversations with Gus Van Sant. London: Rowman \& Littlefield, 2015.

FIORIN, José Luiz. Objeto artístico e experiência estética. In: Semiótica, estesis, estética. Eds. Eric Landowski, Raul Dorra, ana Claudia de Oliveira. 1998. p. 101-117.

Editora Ática, 2002.

As astúcias da enunciação: as categorias de pessoa, espaço e tempo. São Paulo:

Em busca do sentido: estudos discursivos. São Paulo. Editora Contexto. 2008.

Práxis Enunciativa. Coleção Mestrado em Linguística. v. 5. 2010. p. 53-73. Disponível em: http://publicacoes.unifran.br/index.php/colecaoMestradoEmLinguistica/ article/view/ 329. Acesso em: 25 / 04/ 2019. 
Elementos de Análise do Discurso. São Paulo: Editora Contexto, 2011.

. Figuras de retórica. São Paulo: Editora Contexto, 2016.

Novos caminhos da linguística. São Paulo: Editora Contexto, 2017a.

Two concepts of enunciation. Semiotica, 2017b (219), pp. 257-271. Disponível em https://www.degruyter.com. Acesso em 12 / 04/ 2019

FLOCH, Jean Marie. Petites mythologies de l'oel et de l'esprit: por une semiotique plastique. Edition Hadès-Benjamins, 1985.

Identitéles visuelles. Paris : PUF, 1995.

FONTANILLE, Jacques. Les espaces subjectives : introduction à la sémiotique de l'observateur. Hachette, 1989.

; ZILBERBERG Claude. Tensão e Significação. Tradução: Ivã Carlos Lopes, Luiz Tatit, Waldir Beividas. São Paulo : Humanistas / FFLCH/USP, 2001.

Significação e Visualidade: exercícios práticos. Porto Alegre: Sulina, 2005.

. Semiótica do Discurso. Tradução de Jean Cristtus Portela. São Paulo: Editora Contexto, 2008.

. Práxis e enunciação: Greimas herdeiro de Saussure. Gragoatá, [S.1.], v. 22, n. 44, p. 986-1004, dez. 2017. ISSN 23584114. Disponível em: http://www.gragoata.uff.br/index.php/gragoata/article/view/968>. Acesso em 04 / 06 / 2019.

GORBMAN, Claudia. Unheard Melodies : narrative film music. Bloomington \& Indianapolis: Indiana University Press, 1987.

GREIMAS. Algirdas Julius. Du sens: essais sémiotiques. Paris. Editions de Seuil. 1970.

. Sémiotique figurative et sémiotique plastique. Actes Semiotiques. VI, 60. 1984.

Da l’imperfection. França, Périgueux: Pierre Fanlac, 1987.

. Da imperfeição. Prefácio e tradução: Ana Claudia de Oliveira. Apres. Paolo Fabri, Raúl Dorra, Eric Landowski. São Paulo. Hacker Editores. 2002.

Semiótica figurativa e semiótica plástica. In: Semiótica Plástica. Tradução: Ignacio Assis Silva. Org. Ana Claudia de Oliveira. 2004. p. 75-96.

; COURTÉS, Joseph. Dicionário de semiótica. São Paulo: Editora Contexto, 2011.

JAKOBSON, Roman. On translation. Org. R. A Brower. Harvard University Press, 1959.

. Linguística e Comunicação. Tradução: Izidoro Blikstein e José Paulo Paes. São Paulo: Cultrix, 2010. 
JORDAN, Randolph. The Work of Hildegard Westerkamp in the Films of Gus Van Sant: An Interview with the Soundscape Composer (and some added thoughts of my own). Offscreen. Vol. 11, Nos. 8-9, Aug/Sept 2007 (p.1-17). Disponível em https://offscreen.com/view/jordan_westerkamp. Acesso em 07/11/2018.

The Ecology of Listening while Looking in the Cinema: Reflective audioviewing in Gus Van Sant's Elephant. Organised Sound, 17. 2012. p 248-256.

JOST, François. The look: from film to novel: an essay in comparative narratology. In: A companion to literature and film. Edited by Robert Stam and Alessandra Raengo. Blackwell Companions in Cultural Studies (Book 20). Wiley-Blackwell, 2004. p. 71-80

KANDINSKY, Wassily. Ponto e linha sobre plano. Tradução Eduardo Brandão. São Paulo : Martins Fontes, 2001.

LANDOWSKY, Eric. O livro que se fala. In: Da imperfeição. Trad. Ana Claudia de Oliveira. São Paulo: Hacker Editores, 2002.

LEITE, Ricardo Lopes. A complexidade na hipótese tensiva de Claude Zilberberg. Estudos Semióticos. Editores Responsáveis: Ivã Carlos Lopes, José Américo Bezerra Saraiva e Eliane Soares de Lima. Volume 15, Edição Especial, São Paulo, abril de 2019, p. 27-38. Disponível em: http//www.revistas.usp.br/esse. Acesso em 04/06/2019.

LEONE, Eduardo; MOURÃO, Maria Doria. Cinema e Montagem. São Paulo: Editora Ática, 1987

LEVY, Emanuel. Gay directors, gay films? Pedro Almodovar, Terence Davies, Todd Haynes, Gus Van Sant, John Waters. New York: Columbia University Press, 2015.

LIMA, Eliane Soares de. Entre compaixão e piedade: o estudo das paixões em semiótica. 2014. 224p. Tese (doutorado em Linguística). Faculdade de Filosofia, Ciências e Letras. Universidade de São Paulo. 2014.

MANCINI, Renata. Sem Greimas, com Greimas, após Greimas, cem Greimas. In: Estudos Semióticos. Volume 14, número 1. Editores responsáveis: Iva Carlos Lopes e José Américo Bezerra Saraiva. São Paulo, Julho de 2018. p. 22-27. Disponível em https://doi.org/10.11606/issn.1980-4016.esse.2018.144306. Acesso em 01/06/2019.

MARTINS, Fernanda Aguiar Carneiro. Impressionismo francês. In: História do cinema mundial. Fernando Mascarello (org.). Campinas, São Paulo: Papirus, p. 89-107. 2006.

MASSIA, F. The literary prestigie of the translated text: collod's re-writing of Perrault's Contes. In: Traduire: signes, textes, pratiques; Translating: Signs, Texts, Practices. Organização: J. Fontanille, M. Sonzogni e R. Troqe. Signata 7. Presses Universitaries de Liège, 2016, p. 127-154.

MCFARLANE, Brian. Novel to film: an introduction to the Theory of Adaptation. Oxford: Clarendon Press, 1996. 
MÉDOLA, Ana Silvia. Lógicas de articulação de linguagens no audiovisual. In: Linguagens na comunicação: desenvolvimentos da semiótica sincrética. São Paulo: Estação das letras e Cores, 2009. p. 401-419.

MENDES, C. M.; LARA G.M.P. Em torno do acontecimento: uma homenagem a Claude Zilberberb. Curitiba. Appris Editora. 2016.

MITRY, Jean. Esthétique e psychologie du cinema I e II. Editions universitaires, 1963.

MONELLE, Raymond. Linguistics and semiotics in music. London: Routledge, 2002.

NAZÁRIO, Luis. O Expressionismo e o cinema. In: O Expressionismo. Org. J. Guinsburg. São Paulo: Perspectiva, p. 505 - 541. 2002.

NELSON, Blake. Paranoid Park. USA. Speak, 2006.

OLIVEIRA, Ana Claudia; TEIXEIRA, Lucia. Linguagens na comunicação: desenvolvimentos de semiótica sincrética. São Paulo: Estação das Letras e Cores, 2009.

PARANOID PARK (DVD- 2007): Direção: Gus Van Sant. Produção: David Allen Cress, Neil Kopp. Elenco: Gabe Nevins, Daniel Liu, Taylor Momsen, Lauren McKinney, Christopher Doyle, Jake Miller. 85 min.

PETRILLI, Susan. Translation everywhere. In: Traduire: signes, textes, pratiques; Translating: Signs, Texts, Practices. Organização: J. Fontanille, M. Sonzogni e R. Troqe. Signata: annales des semiotiques; annals of semiotics 7. Presses Universitaries de Liège, 2016. p. 23-56.

PIETROFORTE, Antonio Vicente Tópicos de semiótica: modelos teóricos e aplicações. São Paulo: Annablume, 2008.

Semiótica Visual: os percursos do olhar. São Paulo: Editora Contexto, 2012.

PLAZA, Júlio. Tradução Intersemiótica. São Paulo: Perspectiva, 2010.

RALLO DITCHE, Elisabeth; FONTANILLE, Jacques; LOMBARDO, Patrizia. Dictionnaire des passions littéraires. Paris: Éditions Belin, 2005.

REIS, Carlos; LOPES, Ana Cristina M. Dicionário de teoria da narrativa. São Paulo: Ática, 1988.

RUTHVEN, Kenneth Knowles. O mito. Trad: Esther Eva Horivitz. São Paulo: Perspectiva, 2010.

SCHAPIRO, Meyer. O impressionismo: reflexões e percepções. Tradução: Ana Luiza Dantas Borges. São Paulo: Cosac e Naify, 2002.

SILVA, Ignácio Assis. Figurativização e Metamorfose: o mito de Narciso. São Paulo: Editora da Universidade Paulista, 1995 
SONNENSCHEIN, David. Sound Design: the expressive power of music, voice, and sound effects in cinema. Michael Wiese Productions, 2001.

STAM, Robert; RAENGO, Alessandra. A companion to literature and film. Edited by Robert Stam and Alessandra Raengo. Blackwell Companions in Cultural Studies (Book 20). WileyBlackwell, 2004.

TARASTI, Eero. Myth and Music: a Semiotic Approach to the Aesthetics of Myth in Music especially that of Wagner, Sibelius and Stravinsky. Series Approaches to Semiotic. 51. Mouton Publishers, 1979.

Signs of Music: a guide to musical semiotics. Mouton de Gruyter, 2002.

TATIT, Luiz. A duração estética. In: Semiótica, estésis, estética. Eds: Eric Landowski, Raúl Dorra, Ana Claudia de Oliveira. São Paulo: EDUC / Puebla: UAP, 1998.

$2007 \mathrm{a}$.

Hjelmslev e as Bases Tensivas do Semissimbolismo. São Paulo: Editora do CPS,

Semiótica à luz de Guimarães Rosa. São Paulo: Ateliê Editorial, 2010.

Claude Zilberberg e a prosodização da semiótiva. In: Em torno do acontecimento: uma homenagem a Claude Zilberberb. Org: Conrado Moreira mendes e Glaucia Muniz Proença Lara. Curitiba. Appris Editora. 2016.

THOMPSON, Kristin; BODWELL, David. Film History: an introduction. Second edition. 2003.

TURIM, Maureen. Flashbacks in film: memory \& history. New York: Routledge, 1989.

VICARI, Justin. The Gus Van Sant touch: a thematic study - Drugstore Cowboy, Milk and Beyond. Jefferson, North Carolina, and London: McFarland \& Company, Inc., Publishers, 2012. E-book.

VOGEL, Christina. La práxis énonciative: um stat d'entre-deux? (a partir de Valéry). In: Nouveaux actes sémiotiques. Limoges: PULIM, 1995, p. 61-76.

WATT, Ian. The Rise of the Novel: studies in Defoe, Richardson and Fielding. London: Pimlico, 2000.

Razão e Poética do Sentido. Trad. Ivã Carlos Lopes, Luiz Tatit e Waldir Beividas. São Paulo: Edusp, 2006.

Elementos de semiótica tensiva. Trad. Ivã Carlos Lopes, Luiz Tatit e Waldir Beividas. São Paulo: Ateliê Editorial, 2011.

La structure tensive: suivi de Note sur la strucuture des paradigmes et de Sur la dualité de la poétique, Press Univeritaires de Liège, 2012. 


\section{Website}

ANTHONY, Laurence. (2018). AntConc (Version 3.5.7) [Computer Software]. Tokyo, Japan: Waseda University. Available from https://www.laurenceanthony.net/software

BLAKE NELSON TEEN NOVELIST: News, information and random commentary by author Blake Nelson. General Print Interview. Disponível em: <http://blakenelsonteennovelist.blogspot.com/>. Acesso em 02 / 06 / 2019.

BLAKE NELSON. In: WIKIPÉDIA, a enciclopédia livre. Flórida: Wikimedia Foundation, 2019.

Disponível

em:

<https://en.wikipedia.org/w/index.php?title=Blake_Nelson\&oldid=904669111 > Acesso em: $06 / 07 / 2019$.

CAST KING. In: WIKIPÉDIA, a enciclopédia livre. Flórida: Wikimedia Foundation, 2019. Disponível em: <https://en.wikipedia.org/w/index.php?title=Cast_King\&oldid=903216032>. Acesso em $07 / 07 / 2019$.

CRACK. Celebrating Elliott Smith: his five most significant tracks. Gunseli Yalcinkaya Disponível em: <https://crackmagazine.net/article/lists/celebratingelliottsmith/> Acesso em 02 $\underline{106 / 2019 .}$

PIERO SCARUFFI. Elliot Smith. Disponível em: <https://www.scaruffi.com/vol5/smith.html >. Acesso em 02 / $06 / 2019$.

PROPORÇÃO DE TELA. In: WIKIPÉDIA, a enciclopédia livre. Flórida: Wikimedia Foundation, $2019 . \quad$ Disponível em: $<$ https://pt.wikipedia.org/w/index.php?title=Propor\%C3\%A7\%C3\%A3o_de tela\&oldid=539 84218>. Acesso em: 06 / 07/ 2019.

ROCK NYC. Elliott Smith Reviews Reposted. Alyson Camus, 2013. Disponível em: <http://rocknyc.live/elliott-smiths-roman-candle-elliott-smith-eitheror-xo-and-figure-8.html>. Acesso em 02/06/2019.

SAMUEL RICHARDSON. In: WIKIPÉDIA, a enciclopédia livre. Flórida: Wikimedia Foundation, 2018.2 Disponível em: <https://pt.wikipedia.org/w/index.php?title=Samuel_Richardson\&oldid=52352642 >. Acesso em: 07 / 07 / 2019.

SOUND ON SOUND. Billy Swan 'I Can Help. Richard Buskin. Disponível em: <https://www.soundonsound.com/people/billy-swan-i-can-help>. Acesso em 02 / 06 / 2018.

THE QUIETUS. Elliott Smith: an introduction to. John Calvert, November $15^{\text {th }}, 2010$. Disponível em: $\quad$ https://thequietus.com/articles/05286-elliott-smith-an-introduction-to$\underline{\text { review }>\text {. Acesso em } 02 / 06 / 2019 .}$

URBAN DICTIONARY. Disponivel em: <https://www.urbandictionary.com>. Acesso em 04 / 06 / 2019. 


\section{Referências bibliográficas de apoio}

ACTES SÉMIOTIQUES. La figurativité - Tome 2. Dir. Algirdas Julius Greimas. No 26. Juin. Pulim, 1983.

ACTES SÉMIOTIQUES. La subjecitivité au cinéma. Dir. Algirdas Julius Greimas. No 41. Mars. Pulim, 1987.

ADELMO, Luiz; MANZANO, Fernandes. Som-imagem no cinema: a experiência alemã de Fritz Lang. São Paulo: Perspectiva, 2014.

AGAWU, Kofi. Music as discourse: semiotic adventures in romantic music. Osford: Oxford University Press, 2009.

ALLOA, Emmanuel (org). Pensar a imagem. Belo Horizonte: Autêntica Editora, 2015.

ALVES DA SILVA, Cintia. O semissimbolismo na propaganda audiovisual: uma análise de Paint. Em: Estudos Semióticos. Volume 11, número 2. Editores responsáveis: Iva Carlos Lopes e José Américo Bezerra Saraiva. São Paulo, dezembro de 2015. p. 56-61. Disponível em: http//revistas.usp.br/esse. Acesso em 15/04/2019.

AMIEL, Vincent. Estética da montagem. Lisboa: Edições Texto e Grafia, 2007.

AUMONT, Jacques; MARIE, Michel. L'analyse des films. Série Cinéma (dir. Michael Marie) Nathan Université, 1998.

et al. A estética do filme. Tradução: Marina Appenzeller. $5^{\circ}$ edição. São Paulo: Papirus Editora, 2007.

BADIR, Semir. Les intersémiotiques. Estudos Semióticos. Editores Responsáveis: Ivã Carlos Lopes e José Américo Bezerra Saraiva. Volume 9, Número 1. São Paulo, julho de 2013. p. 112. Disponível em: http://revistas.usp.br/esse. Acesso: 25/04/2019.

BAL, Mieke. Narratology: introduction to the theory of narrative. Toronto: University of Toronto Press, 2007.

BARKER, Jennifer. The tactile eye: touch and cinematic experience. Berkeley, Los Angles, London: University of California Press, 2009.

BARROS, Mariana Luz Pessoa de. O discurso da memória: entre o sensível e o inteligível. 2011. 306p. Tese (doutorado em Linguística). Faculdade de Filosofia, Ciências e Letras. Universidade de São Paulo. 2011.

.Lembrar, esquecer, memorizar, rememorar: memória e modos de existência. Galáxia

(São Paulo), São Paulo, n. 33, p. 49-62, dez. 2016. Disponível em $<$ http://www.scielo.br/scielo.php?script=sci_arttext\&pid=S1982-532016000300049\&lng= pt\&nrm=iso>. Acesso: 23 / 04/ 2019. 
BARTHES, Roland. Image, music, text. Translated by Stephen Heath. New York: Noonday Press Edition. 1994.

A câmara clara: nota sobre a fotografia. Lisboa: Edições 70, 2017.

BASSO FOSSALI, Pierluigi. DONDERO, Maria Giulia. Sémiotique de la photogrhapie. Pulim, 2011.

BATEMAN, John; SCHIMIDT, Karl Heinrich. Multimodal film analysis: how films mean. New York, London: Routledge, 2012.

BELLOUR, Raymond. L'analyse du film. Collection ÇA cinema (dir. Joel Farges et François Barat) Paris: Editions Albatros, 1979.

BEJA, Morris. Film and literature: an introduction. New York: Longman, 1979.

BEYAERT, Anne. Texture, couleur, luimière et outres arrangemts de la perception. Protée. Direção: François Ouellet. Volume 31, n 3. 2003. p. 81-90. Disponível em: https://id.erudit.org/iderudit/008439ar. Acesso em 15/04/2019.

BOUQUET, Stéphane. Danse/cinema. Le cinématographe. Disponível em: https://www.lecinematographe.com/Danse-Cinema_a4452.html. Acesso em: 24/ 04/ 2019.

BRANIGAN, Edward. Narrative comphehension and film. London and new York: Routledge, 1992.

BRISELANCE, Marie-France; MORIN Jean-Claude. Gramática do cinema. Lisboa: Edições texto\&grafia, 2011.

BURCH, Noel. Práxis do cinema. Tradução Marcelle Pithon, Regina Machado. Coleção Debates. Direção J. Ginsburg. Perspectiva.São Paulo. 2006.

CAHIR, Linda Constanzo. Literature into film: theory and practical approaches. Jefferson, North Carolina: McFarland \& Co, 2006.

CARROLL, Noel. Mystifying movies: fads \& fallacies in contemporary film theory. New York: Columbia University Press, 1988.

CASSIRER, Ernst. Linguagem e Mito. Tradução: J. Guinsburg, Mirian Schnaiderman. Coleção Debates. São Paulo: Perspectiva, 2013.

CHION, Michel. Um art sonore, le cinéma: histoire, esthétique, poétique. Paris: Cahiers du Cinema, 2003.

La voz em e cine. Signo e imagem80. Madrid. Cátedra. 2004.

CORTINA, Arnaldo. Veridicção e paixão na práxis enunciativa. Gragoatá, [S.1.], v. 15, n. 29, dez. 2010. Disponível em: 〈http://www.gragoata.uff.br/index.php/gragoata/article/view/173>. Acesso em: 23 / 04/ 2019. 
CORTINA, Arnaldo; MORENO DA SILVA, Fernando (org.). Semiótica e Comunicação: Estudo sobre textos sincréticos. Séries linguísticas n. 25. São Paulo, Araraquara: Cultura Acadêmica Editora, 2014.

CRARY, Jonathan. Techniques of the observer: on vision and modernity in the nineteenth century. Cambridge, Massachusetts: MIT Press, 1992.

DARRAULT-HARRIS, Ivan. FONTANILLE Jacques. Les âges de la vie: sémiotique de la culture et du temps. Paris: PUF, 2008.

DELEUZE, Gilles. Cinema 2: a imagem tempo. Tradução: Stella Senra. São Paulo: Editora 34, 2018.

DROIN, Nicolas. Paranoid Park de Gus Van Sant: variations et répétitions. Coté films 28. Belgique: Editions Yellow Now, 2016.

DUBOIS, Jacques et al. Retórica Geral. São Paulo: Cultrix. 1974

DUDLEY ANDREW James. As principais teorias de cinema: uma introdução. Tradução: Teresa Ottoni. Rio de Janeiro: Jorge Zahar Editor, 2002.

DURAND, Jacques. Retórica e imagem publicitária. In: A análise das imagens (Christian Metz e outros). São Paulo: Editora Vozes, 1974. p. 19-59.

EDELINE, Francis. La sintaxis visual. In: Acta poética. Vol. 22, Núm. 1-2. 2002. p. 47-60. Disponível em: https://revistas-filologicas.unam.mx/acta-poetica/index.php/ap/article/view/66. Acesso em: 24/04/2019.

ELIADE, Mircea. Mito e realidade. São Paulo: Perspectiva, 2016.

FIORIN, José Luiz. Paixões, afetos, emoções e sentimentos. Revista Casa: Cadernos de semiótica aplicada. Vol. 5. n.2, dezembro de 2007. Disponível em: http://www.fclar.unesp.br/grupos/casa/CASA-home.html. Acesso em: 25 / 04 / 2019.

FONTANILLE, Jacques. Sémiotique du visible: des mondes de lumière. PUF, 1995.

. Sémiotique et littérature. Paris : PUF, 1999.

Soma \& Séma. Paris, França: Maisonneuve \& Larose, 2004.

Pratiques sémiotiques. Paris. PUF. 2008.

.Corps et Sens. France: Presses Universitires de France, 2011.

FLOCH, Jean Marie. Formes de l'empreinte: Brandt, Cartier-Bresson, Doisneau, Stieglitz, Stand. Pierre Fanlac, 1981.

FOSSALI BASSO, Pierlugi; DONDERO, Maria Giulia. Sémiotique de la photographie. Pulim, 2011. 
FOSSALI BASSO, Pierlugi; BORDRON, Jean François; DONDERO, Maria Giulia;

KLINKENBERG, Jean Marie; PROVENZANO, François. TORE, Gian Maria. Que peut le métalangage. Signata 4. Bélgica. PUF. 2014.

GARWOOD, Ian The sense of film narration. Scotland: Edinburgh University Press, 2015

GAUDREAULT, André; JOST, François. A narrativa cinematográfica. Tradução: Adalberto Miller, Ciro Inácio Marcondes, Rita Jover Faleiros. Brasília: Editora UNB, 2009.

GENETTE, Gerard. Narrative discourse: an essay in method. Translated by Jane. E. Lewin. New York: Cornell University Press. 1980.

2009.

Paratextos Editoriais. Tradução: Álvaro Faleiros. Cotia, São Paulo: Ateliê Editorial,

GIBSON, James. The ecological approach to visual perception. New Jersey, London : Cornell University, 1986.

GREIMAS, Algirdas Julius. Semântica Estrutural. Tradução: Haquira Osakape e Izidoro Blikstein, São Paulo: Cultrix, 1973.

. Maupassant: la sémiotique du texte. Exercises pratiques. Paris: Seuil, 1976.

Ensaios de semiótica poética: com estudos sobre Apollinaire, Bataille, Baudelaire, Hugo, Jarry, Mallarmé, Michaux, Nerval, Rimbaud, Roubaud. Tradução: Heloisa de Lima Dantas. São Paulo. Cultriz. 1976.

; FONTANILLE, Jacques. Sémiotique des passions: des états de choses aux états d'âme. Paris: Seuil, 1991.

; FONTANILLE, Jacques. O belo gesto. Tradução: Edna Maria Fernandes dos Santos Nascimento. In: NASCIMENTO, E.M.F.D.S; ABRIATA, V.L.R. (org). Formas de vida: rotina e acontecimento. Ribeirão Preto: Coruja, 2014. p. 55- 86.

Sobre o Sentido II: ensaios semióticos. São Paulo: Edusp, 2014.

GRODAL, Torben. Embodied visions: education, emotions, culture and film. Oxford University Press, 2009.

GROUPE $\mu$. Traité du signe visuel: pour une rhétorique de l'image. La coleur des idées. Seuil, 1992.

. Principia Semiótica. Aux sources du sens. Les Impresions Nouvelles, 2015.

HARKOT-de-LA-TAILLE, Elizabeth. Sentir, saber, tornar-se: estudo semiótico do percurso entre o sensorio e a identidade narraitva. São Paulo: Humanitas: FAPESP. 2016. 
HAWKES, Peter; DESMOND, John. Adaptation: studying film and literature. New York: McGraw-Hill. Kane, 2006.

HENDERSON, Brian. Tense, Mood, and Voice in Film (Notes after Genette). Film Quarterly. Vol. 36, No. 4 (Summer, 1983), p. 4-17. University of California Press. Disponível em: https://www.jstor.org/stable/3697090. Acesso em 25 / 04 / 2019.

HENAULT, Anne; BEYART, Anne. Ateliers de sémiotique visuelle. Paris: PUF, 2004.

HJELMSLEV, Louis. Prolegômenos a uma teoria da linguagem. Coleção Estudos. São Paulo: Perspectiva, 2003.

HUTCHEON, Laura. A theory of adaptation. New York, London: Routledge, 2006.

JOLY, Martine. Introdução à análise da imagem. Lisboa. Edições 70. 1994.

KAWIN, Bruce. Mindscreen: Bergman, Godard and first-person film. New Jersey: Princeton University Press, 1978.

KLINKENBERG, Jean Marie. A quelles conditions peut-on parler de négation dans l'image?. Aisthesis. Pratiche, linguaggi e saperi dell'estetico, [S.1.], v. 4, n. 2, May. 2012. Disponível em: http://www.fupress.net/index.php/aisthesis/article/view/10998/10446. Acesso em 24 / 04/ 2019.

KOZLOFF Sarah. Invisible storytellers: voice-over narration in American fiction film. London, England. University of California Press. 1988.

LANCIONI, Tarcisio. Figurativo, figural e plástico nos textos literários. Ainda a propósito de Pinóquio. In: Estudos Semióticos. Volume 13, número 2. Editores convidados: Waldir Beividas e Eliane Soares de Lima. São Paulo, dezembro de 2017. Disponível em: http//revistas.usp.br/esse. Acesso em 15/04/2019.

LANDOWSKY, Eric; DORRA, Raul; OLIVEIRA, Ana Claudia (eds). Semiótica, estesis, estética. São Paulo: EDUC/ Puebla. UAP, 1998.

LANDOWSKY, Eric. Passions sans nom: essais de socio-sémiotique III. Paris: PUF. 2004.

LEBORG, Christian. Gramática Visual. São Paulo: Gustavo Gili, 2015.

LEMOS, Carolina Lindenberg. Condições semióticas da repetição (tese de doutorado). São Paulo, 2015. 209p. Tese (doutorado em Linguística). Faculdade de Filosofia, Ciências e Letras. Universidade de São Paulo. 2015.

LOUBET-POETTE, Vanessa. L'énonciation cinématographique: caractéristiques et méthode(s) d'analyse d'une énonciation artistique audio-visuelle dans les longs métrages de Jean-Pierre Jeunet. Éditions universitaires européennes, 2010.

MAGALHAES, Marcela Borges; PRADO, Joao Batista Toledo. A estrutura da função poética. In: CASA Cadernos de semiótica aplicada. Disponível em: http//seer.fclar.unesp.br / casa. Volume 13, n.1. 2015. p. 121-150. 
MANCINI, Renata; CALIL, Lucas. Um olhar tensivo sobre o semissimbolismo em "O Senhor dos Anéis". Em: Estudos Semióticos. Volume 11, número 1. Editores responsáveis: Iva Carlos Lopes e José Américo Bezerra Saraiva. São Paulo, Julho de 2015. p. 11-20. Disponível em: http//revistas.usp.br/esse. Acesso em 15/04/2019.

MENDES, Conrado Mendes; LARA, Glaucia Muniz Proença (orgs). Em torno do acontecimento: uma homenagem a Claude Zilberberg. Curitiba, Paraná: Appris Editora, 2016.

METZ, Christian. Além da analogia da imagem. In: A análise das imagens (Christian Metz e outros). São Paulo: Editora Vozes, 1974. p. 7-18.

Linguagem e cinema. São Paulo. Coleção Debates. Direção: J. Guinsburg. São Paulo: Perspectiva, 1980.

.L’énonciation impersonnelle ou le site du film. Paris: Meridiens Klincksieck, 1991.

2012.

.A significação no cinema. Tradução: Jean Claude Bernadet. São Paulo: Perspectiva,

MILLER, Toby. STAM, Robert. A companion to film theory. Oxford: Blackwell, 1999.

NICHOLS, Bill. Movies and methods. Volume I: an anthology. California: University of California Press, 1976.

NICHOLS, Bill. Ideology and the image. Bloomington: Indiana University Press, 1981.

ODIN, Roger. Cinéma et production de sens. Paris: Armand Colin, 1990.

De la fiction. Belgique: De Boeck Université, 2000.

OLIVEIRA, Ana Claudia; LANDOWSKY, Eric. Do inteligível ao sensível: em torno da obra de Algirdas Julien Greimas. São Paulo: EDUC, 1995.

(org.). Semiótica plástica. São Paulo. Hacker Editores. 2004.

PARRET, Herman. La rhétorique de l'image: quand Alberti reencontre le Groupe $\mu$. In : Figures de la figure: sémiotique et rhétorique generale. Org. Semir Badir, Jean-Marie Klinkenberg. Limoges: Pulim, p. 143-154. 2008.

PEARLMAN, Karen. Cutting Rhythms: shaping the film edit. New York, London: Focal Press, 2013.

PIETROFORTE Antonio Vicente. Análise do texto visual: a construção da imagem. São Paulo: Editora Contexto, 2016a.

A significação na fotografia. São Paulo: Annablume, 2016 b.

PORTELA, Jean Cristtus, TOMASI, Carolina. Cronopoiese e cronotrofia na história em quadrinhos. Estudos Semióticos. Editores Responsáveis: Francisco E. S. Merçon e Mariana 
Luz P. de Barros. Volume 8, Número 2, São Paulo, Novembro de 2012, p. 21-27. Disponível em: http://www.fflch.usp.br/dl/semiotica/esse. Acesso em 24/ 04 / 2019.

PORTER ABBOTT Horace. The Cambridge introduction to narrative. Cambridge. New York: Cambridge Universituy Press, 2009.

RAMOS, Fernão Pessoa. A imagem-câmera. Campinas: Papirus Editora, 2012.

RENOUE, Marie. Lumière en noir et lumière tangible: le goût du paradoxe. Protée. Volume 31, n 3. 2003. p. 69-80. Disponível em: https://id.erudit.org/iderudit/008438ar. Acesso em $15 / 04 / 2019$.

SALT, Barry. Film style and technology: history and analysis. London: Starword, 1992.

SCHAFER, Murray. O ouvido pensante. Tradução: Marisa Trench de O. Fonterrada, Magda R. Gomes da Silva, Maria Lúcia Pascoal. São Paulo: Editora Unesp, 2011.

SIDER, Larry; FREEMAN, Diane; SIDER Jerry. Soundscape: the school of sound lectures 1998-2001. London and New York: Wallflower Press, 2003.

SIJLL, Jennifer Van. Narrativa cinematográfica: contando histórias com imagens em movimento. As 100 convenções mais importantes do mundo do cinema que todo cineasta precisa conhecer. São Paulo: Martins Fontes, 2017.

SOBCHACK, Vivian. The address of the eye: a phenonenology of film experience. Princeton, New Jersey: Princeton University Press, 1992.

Carnal Thoughts: embodiment and moving image culture. Berkeley: University of California Press, 2004.

STAM, Robert. Reflexivity in film and literature: from Don Quixote to Jean-Luc Godard. New York: Columbia University Press, 1992.

STAM, Robet; BURGOYNE, Robert; FLITTERMAN-LEWIS, Sandy. New vocabulary in film semiotics. London and New York: Routledge, 1992.

TÁPIA, Marcelo; MÉDICI, Thelma. Haroldo de Campos: transcriação. São Paulo: Perspectiva, 2015.

TATIT, Luiz. Tempo e tensividade na análise da canção. Cadernos de Estudos: Análise Musical, São Paulo, n. 3, p. 26-43, 1990.

A semiótica e Merleau-Ponty. In: Do inteligível ao sensível. Eds. Ana Cláudia de Oliveira, Erik Landowski. São Paulo: EDUC, 1995.

Musicando a semiótica: ensaios. São Paulo: Annablume, 1998.

Silêncio e luzes na apreensão estética. In: Silêncios e Luzes: sobre a experiência psíquica do vazio e da forma. Org. Luiz Carlos Uchoa Junqueira Filho. São Paulo: Casa do Psicólogo, 1998. p. 201-212. 
Semiótica da canção: melodia e letra. São Paulo: Editora Escuta, 1999.

Análise semiótica através das letras. São Paulo: Ateliê Editorial, 2001.

A abordagem do texto. In: Introdução à linguística: objetos teóricos. Organização:

José Luiz Fiorin. São Paulo: Editora Contexto, 2002.

O gr de Greimas: um estudo do destinador transcendente. Em: Perfiles Semióticos: Greimas en América Latina: Bifurcaciones. Mérida: Universidade de Los Andes, 2003. p. $327-$ 350 .

A escultura do tempo no desenho. Em: Disegno. Desenho. Desígnio. Org. Edith Derdyk. São Paulo: Editora Senac, 2007b. p. 117- 124.

; LOPES, Ivã Carlos Elos de melodia e letra: análise semiótica de seis canções. São Paulo: Ateliê Editorial, 2008.

TOMASI, Carolina. Elementos de semiótica. São Paulo: Atlas, 2012.

TSENG, Chiao. Cohesion in film: tracking film elements. UK: Palgrave Macmillan, 2013.

TURIM, Maureen. Flashbacks in film: memory and history. Routlege, 1989.

VANOYE, Francis. Récit écrit, récit filmique. Collection Armand Colin Cinéma: dir. Michel Marie. 2005.

VENUTI, Lawrence. The translation studies reader. Ed. Lawrence Venuti. London e New York: Routledge, 2012.

WALHBERG, Malin. Documentary time: film and phenomelogy. Visible Evidence. Vol. 21. Minneapolis and London: University of Minessota Press, 2008.

WELSH, James; LEV, Peter. The literature / film reader: issues of adaptation. Lanham, Maryland. Toronto. Plymouth, UK: The Scarecrow Press, Inc, 2007.

WHITTOCK, Trevor. Metaphor and film. Cambridge Universtiy Press, 1990.

XAVIER, Ismail. A experiência do cinema. Rio de Janeiro: Edições Graal: Embrafilme, 1983.

.O olhar e a cena: melodrama, Hollywood, Cienma Novo, Nelson Rodrigues. São Paulo: Cosac \& Naify, 2003.

ZILBERBERG, Claude. Ensayos sobre semiotica tensiva. Trad. Desiderio Blanco. Lima: Univerdidad de Lima y Fondo de Cultura Econômica, 2000.

As condições semióticas da mestiçagem. In: O olhar à deriva: mídia, significação e cultura. Org. Eduardo Peñuela Cañizal e Kati Eliana Caetano). São Paulo: Annablume, 2004.

- Pour saluer l'événement. Actes Sémiotiques, 111. 2008. Disponível em: https://www.unilim.fr/actes-semiotiques/1601. Acesso em: 24 / 04 / 2019. 
Des formes de vie aux valeurs. Formes sémiotiques. PUF, 2011. 


\begin{abstract}
ANEXOS
ANEXO A

JANUARY 8

SEASIDE, OREGON

(Later)

Dear

So I guess that's what these are. My letters to you, Macy McLaughlin. Or that's what they turned into. You sort of are the person I feel "most comfortable with," so I guess it makes sense.

You were so right, though. Every page I've written has felt like a weight off my shoulders. When you really get going, writing is like talking to your best friend, except they can't interrupt you or tell you what an idiot you are.

Anyway... what else can I tell you before I finish this? The ocean's pretty quiet tonight. (It's almost midnight now.) My uncle Tommy is downstairs cooking something. It was nice of him to invite me to come to his beach house for winter break. He's been super cool about everything. He's worried about me, I guess; he acts like I'm this fragile person now, with the divorce going on. He never pries or asks me what I do up here all night, scribbling away like some crazy person or whatever.

So anyway, the main thing I wanted to say to you before I end this is: thank you. I'm not sure for what, exactly. For being there, I guess. For riding the bus with me up Vista that night. And for occupying my brain, I sort of think about you now. Mostly because I've been writing you these endless letters. But at other times, too, like walking on the beach, or at night before I fall asleep. I always wondered what would replace those horrible pictures in my head. I never thought it would be the annoying sixth-grader who lived down the street.

As for what I'll do... who knows? I still have days when I expect Brady to show up at my door with handcuffs. Other times, I want to walk into a police station myself and confess everything. I wish I trusted people more. I wish I had more faith in things. On the other hand, why tempt fate? It's not like adults always do the right thing. They're more screwed up than teenagers. At least we know how full of crap we are.

That's the thing about hanging out with you these last couple months. You kinda saved my ass. The reason is: I trust you. I really do. And that's all it takes. Knowing there's one person out there on your side, one person who's got your back. That's enough to keep you sane.

Oh, yeah, and since I know this is the end, I guess I can say one thing: I sort of like you. I know. Isn't that ridiculous? And so typical. The minute you stop liking me, I start liking you. God messes with you that way. He totally does. It's all part of the great cosmic joke.

Okay Macy McLaughlin. It's late now and I'm gonna stop. Thanks for keeping me company. Thanks for a lot of things.

Now I'm going to find some matches....
\end{abstract}




\begin{abstract}
ANEXO B
Detetive: Hello there.

Alex: Hi.

Detetive: Have a seat. Sorry to take you out of class.

Alex: That's okay

Detetive So. Anyway. I talked to Jared and he says you almost went to the Eastside Skatepark the night of the seventeenth. Is that right?
\end{abstract}

Alex: Yes.

Detetive: So you...drove around that night?

Alex: Yes. I...well...we went there another time and I was...well. I thought it was cool ans evertything, but it was pretty hardcore. I'm not that good of a skater, so I didn't wasn't to go there by myself.

Detetive: Did you drive by there that night?

Alex: No.

Detetive: Where did you go?

Alex: That night? I...I drove around...downtown a little. And since I was downtown anyway, I got something to eat. And I...then I parked down near the waterfront. And walked around a little.

Detetive: Were you skateboarding?

Alex: Yeah. Well, actually, no, not really that night. I mean, I had my skateboard. Like I said, I'm not as good as the other guys. So I try to practice by myself.

Detetive: So can you give me some times for these things? Approximately?

Alex: Uh...I went to Jared's around seven or eight. Then we went to the bus station a little after that. And then I drove around. And then... oh, yeah...that was something I got confused about before. I didn't go home. I went to Jared's. Because we had originally planned to sleep over at his house that night."

Detetive: Where were his parents?

Alex: His mom was in Las Vegas. His dad doesn't live with them.

Detetive: No brothers or sisters? The house was totally empty?

Alex: Right. His sister lives in Seattle.

Detetive: And did your parents know this? That no one was home at Jared's?

Alex: Uh...

Detetive: So this is the old trick where you tell your parents you're sleeping at Jared's and your parents don't realize his parents are gone, and then you can do whatever you want?

Alex: Uh...well...

Detetive: No, I understand. We used to do that. It's an old one.

Alex: Yeah, I guess so.

Detetive: So what's your parental situation?

Alex: What do you mean?

Detetive: Your parents, they're together?

Alex: No. They're separated. Or they're...well, they'll probably get divorced.

Detetive: My parents got divorced. When I was about your age, actually. That's a tough thing to go through.

Alex: Yeah.

Detetive: Do you have brothers and sisters?

Alex: A brother. Younger. He's thirteen

Detetive: Do you have a sister?

Alex: No. 
Detetive: How about a girlfriend?

Alex: Uh...yeah, sort of.

Detetive: Where was she that night?

Alex: She was with her other friends.

Detetive: Did you call her at any point? Do you have a cell phone?

Alex: No, I didn't call her. We just started going out, actually.

Detetive: So she wasn't your girlfriend a couple weeks ago?

Alex: Right. I mean, we weren't totally hanging out yet. She's more of a girlfriend now.

Detetive: How's that going?

Alex: What?

Detetive: Having a girlfriend.

Alex: It's good, I guess.

Detetive: You sound unsure.

Alex: No, it's okay. She's kinda... I don't know. We just started going out, It hasn't really solidified. But it's okay. I mean, she's nice.

Detetive: So, getting back to this...I'm trying to think about this situation. This security guard. We find him, you know, deceased on these train tracks. We think, okay, he tripped, he fell. But then the autopsy says he was hit with a blunt object. My boss has this idea that some kids might have been riding that train, just for fun, which apparently happens a lot. They're riding along, the security guard sees them, and he tries to kick them off. There's some sort of confrontation, maybe a struggle, the guy ends up dead, and the kids take off. So what I'm trying to imagine is: what do these kids do then? Where do they go? What kind of kids are they?

Alex: Yeah, that's a good question.

Detetive: What would you do? If you were one of those kids.

Alex: I...I don't know. Call the police?

Detetive: What if the other kids were your friends? Would you call the police on your friends?

Alex: I think I would if someone got killed. Or if it was an accident or whatever.

Detetive: What if you were alone? What if you were by yourself and something like this happened?

Alex: Then I'd definitely call the police. Because, why not? Unless you wanted to kill the guy. I mean, myself, I don't have anything against security guards.

Detetive: Right. But what would you do if you didn't call the police? Like, what if you got scared and you didn't know what to do?

Alex: I'm not sure.

Detetive: You'd run probably, and you'd go back to the skatepark and tell your friends. Or if you were smart, you wouldn't go back to the skatepark; you'd head for the river and hope nobody saw you.

Alex: Yeah I guess so.

Detetive: And these kids, they're probably transients. Or runaways. They're probably in trouble already. If I was them, I think I'd hop the first train out of town. Get out of the state. Out of the country, even....

Alex: I heard someone got stabbed there once.

Detetive: Do you know any street kids? I mean, yourself personally.

Alex: No, I mean, I've seen them. "Streeters", ,people call them. Some of them skate. Most of them just beg for change and stuff.

Detetive: If I showed you photos, could you pick out people you've seen in the area?

Alex: I doubt it. It's not like I know any of them.

Detetive: All right, I'm going to cut this short.

Alex: So I can go back to class?

Detetive: Yeah. Hey, and thanks, I appreciate $\mathrm{it}^{205}$.

${ }^{205}$ NELSON, 2006, p. 121-127 